\title{
E-BOOK
}

\section{AMPLAMENTE EDUCAÇÃO NOVOS CAMINHOS PARA O ENSINO}

ORGANIZADORES

Dayana Lúcia Rodrigues de Freitas

Luciano Luan Gomes Paiva

Caroline Rodrigues de Freitas Fernandes
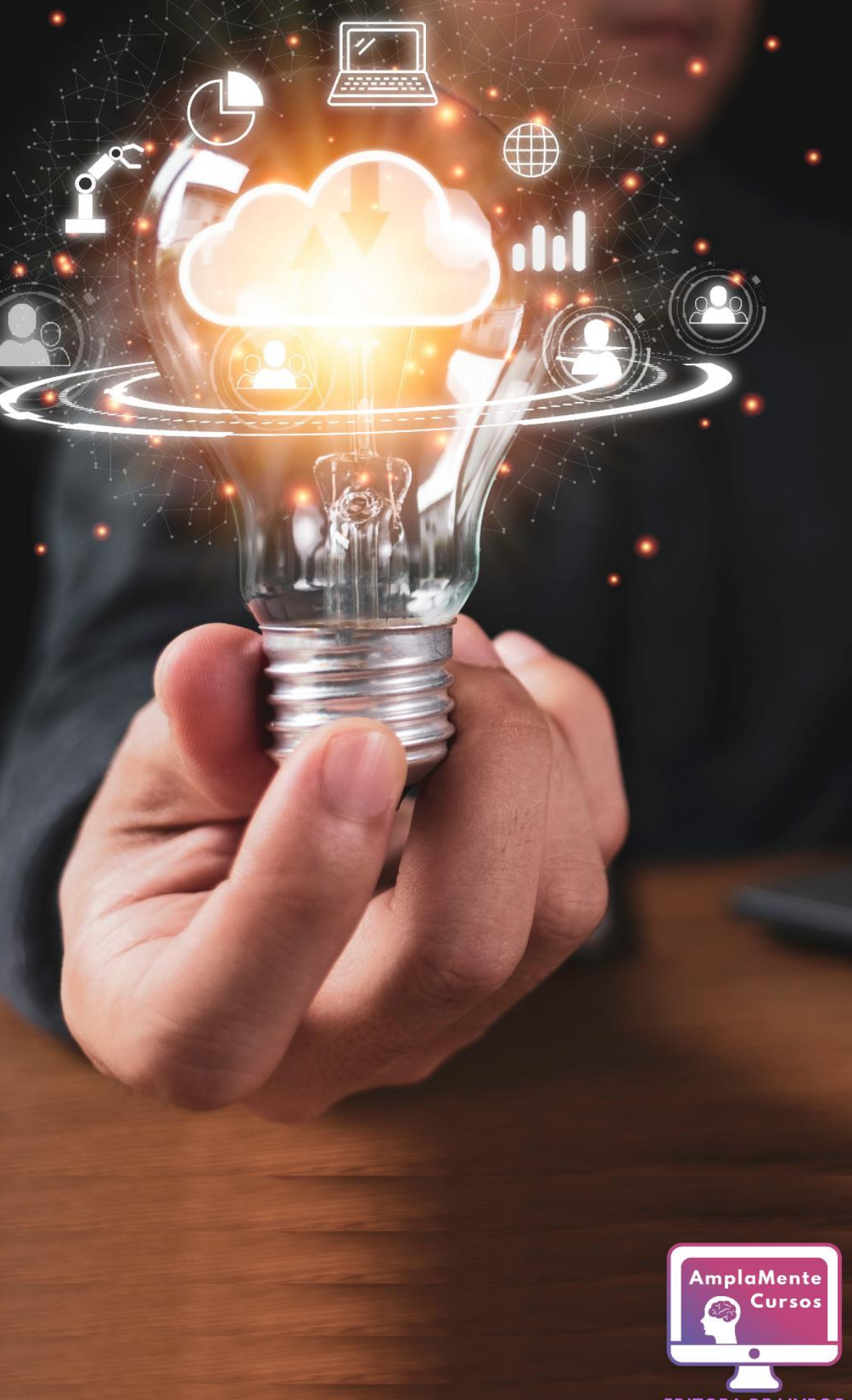


\section{E-BOOK}

\section{AMPLAMENTHE EDUCAÇÃO: NOVOS CAMINHOS PARA 0 FNSINO}

$1^{\text {a }}$ EDIÇÃO. VOLUME 01.

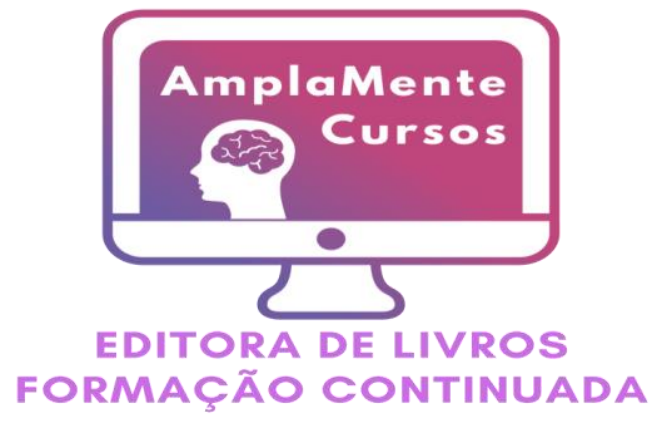

\section{ORGANIZADORES}

Dayana Lúcia Rodrigues de Freitas

Luciano Luan Gomes Paiva

Caroline Rodrigues de Freitas Fernandes

DOI: $10.47538 / A C-2021.14$
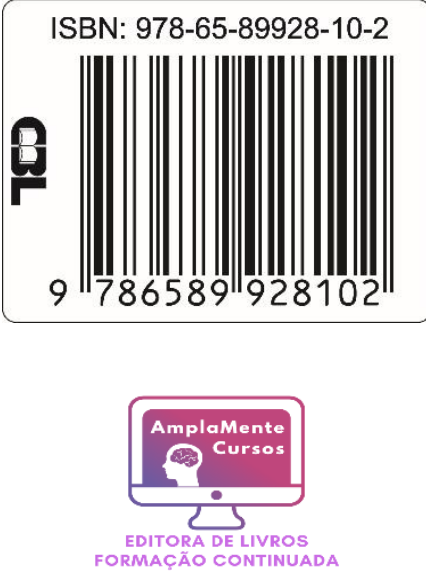

Ano 2021 


\section{E-BOOK \\ AMIPLAMINTISE FDUCAÇÃO: NOVOS CAMIINHOS PARA O MNSINO}

$1^{\text {a }}$ EDIÇÃO. VOLUME 01.

Dados Internacionais de Catalogação na Publicação (CIP)

(Câmara Brasileira do Livro, SP, Brasil)

Amplamente educação [livro eletrônico] : novos caminhos para o ensino : volume 1 / organizadoresDayana Lúcia Rodrigues de Freitas, Luciano Luan Gomes Paiva, Caroline Rodrigues de Freitas Fernandes. -- 1. ed. -- Natal, RN : Amplamente Cursos e Formação Continuada, 2021.PDF

Bibliografia

ISBN 978-65-89928-10-2

1. Educação 2. Educação - Finalidades e objetivos

3. Ensino 4. Interdisciplinaridade 5. Leitura

6. Pesquisa 7. Prática pedagógica I. Freitas, DayanaLúcia Rodrigues

de. II. Paiva, Luciano Luan Gomes.

III. Fernandes, Caroline Rodrigues de Freitas.

21-87911

CDD-370.1

Índices para catálogo sistemático:

1. Interdisciplinaridade : Educação 370.1

Maria Alice Ferreira - Bibliotecária - CRB-8/7964

Amplamente Cursos e Formação Continuada CNPJ: $35.719 .570 / 0001-10$

E-mail: publicacoes@editoraamplamente.com.br www.amplamentecursos.com Telefone: (84) 999707-2900

Caixa Postal: 3402 CEP: 59082-971

Natal- Rio Grande do Norte - Brasil

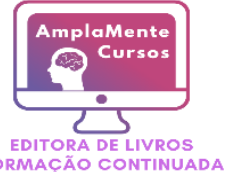




\section{Editora Chefe:}

Dayana Lúcia Rodrigues de Freitas

\section{Assistentes Editoriais:}

Caroline Rodrigues de F. Fernandes

Maria Pollyana Sales Vicente

Margarete Freitas Baptista

\section{Bibliotecária:}

Eliete Marques da Silva

\section{Projeto Gráfico e Diagramação: \\ Luciano Luan Gomes Paiva \\ Caroline Rodrigues de F. Fernandes}

Imagem da Capa: 2021 by Amplamente Cursos e Formação Continuada

Shutterstock Copyright (C) Amplamente Cursos e Formação Continuada

Edição de Arte: Copyright do Texto (C) 2021 Os autores

Luciano Luan Gomes Paiva Copyright da Edição (C) 2021 Amplamente Cursos e

Formação Continuada

Revisão: Direitos para esta edição cedidos pelos autores à

Os autores Amplamente Cursos e Formação Continuada.

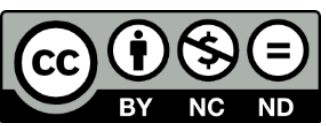

Todo o conteúdo deste livro está licenciado sob uma Licença de atribuição Creative Commons. Atribuição-NãoComercialSemDerivações 4.0 Internacional (CC-BY-NC-ND).

Este e-book contém textos escritos por autores de diversos lugares do Brasil e, possivelmente, de fora do país. Todo o conteúdo escrito nos capítulos, assim como correção e confiabilidade são de inteira responsabilidade dos autores, inclusive podem não representar a posição oficial da Editora Amplamente Cursos.

A Editora Amplamente Cursos é comprometida em garantir a integridade editorial em todas as etapas do processo de publicação. Todos os artigos foram previamente submetidos à avaliação cega pelos pares, membros do Conselho Editorial desta Editora, tendo sido aprovados para a publicação.

É permitido o download desta obra e o compartilhamento desde que sejam atribuídos créditos aos autores, mas sem a possibilidade de alterá-la de nenhuma forma ou utilizá-la para fins comerciais.

Situações de má conduta ética e acadêmica ou quaisquer outros problemas que possam vir a surgir serão encaminhados ao Conselho Editorial para avaliação sob o rigor científico e ético.

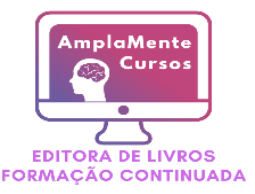




\section{CONSELHO EDITORIAL}

Dr. Damião Carlos Freires de Azevedo - Universidade Federal de Campina Grande Dra. Danyelle Andrade Mota - Universidade Federal de Sergipe

Dra. Débora Cristina Modesto Barbosa - Universidade de Ribeirão Preto

Dra. Elane da Silva Barbosa - Universidade Estadual do Ceará

Dra. Eliana Campêlo Lago - Universidade Estadual do Maranhão

Dr. Everaldo Nery de Andrade - Universidade Estadual do Sudoeste da Bahia

Dra. Fernanda Miguel de Andrade - Universidade Federal de Pernambuco

Dr. Izael Oliveira Silva - Universidade Federal de Alagoas

Dr. Jakson dos Santos Ribeiro - Universidade Estadual do Maranhão

Dra. Josefa Gomes Neta - Faculdade Sucesso

Dr. Maykon dos Santos Marinho - Faculdade Maurício de Nassau

Dr. Rafael Leal da Silva - Secretaria de Educação e da Ciência e Tecnologia da Paraíba

Dra. Ralydiana Joyce Formiga Moura - Universidade Federal da Paraíba

Dra. Roberta Lopes Augustin - Faculdade Murialdo

Dra. Smalyanna Sgren da Costa Andrade - Universidade Federal da Paraíba

Dra. Viviane Cristhyne Bini Conte - Universidade Tecnológica Federal do Paraná

Dr. Wanderley Azevedo de Brito - Instituto Federal de Educação, Ciência e Tecnologia de Goiás

\section{CONSELHO TÉCNICO CIENTÍFICO}

Ma. Ana Claudia Silva Lima - Centro Universitário Presidente Tancredo de Almeida Neves

Ma. Andreia Rodrigues de Andrade - Universidade Federal do Piauí

Esp. Bruna Coutinho Silva - Pontifícia Universidade Católica de Minas Gerais

Ma. Camila de Freitas Moraes - Universidade Católica de Pelotas

Me. Carlos Eduardo Krüger - Universidade Regional Integrada do Alto Uruguai e das Missões

Esp. Caroline Rodrigues de Freitas Fernandes - Escola Ressurreição Ltda.

Me. Clécio Danilo Dias da Silva - Universidade Federal do Rio Grande do Norte

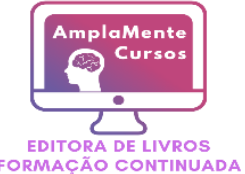


Me. Fabiano Eloy Atílio Batista - Universidade Federal de Viçosa

Me. Francisco Odécio Sales - Instituto Federal de Ciência e Tecnologia do Ceará

Me. Fydel Souza Santiago - Secretaria de Educação do Estado do Espírito Santo

Me. Giovane Silva Balbino - Universidade Estadual de Campinas

Ma. Heidy Cristina Boaventura Siqueira - Universidade Estadual de Montes Claros

Me. Jaiurte Gomes Martins da Silva - Universidade Federal Rural de Pernambuco

Me. João Antônio de Sousa Lira - Instituto Federal de Educação, Ciência e Tecnologia do Maranhão

Me. João Paulo Falavinha Marcon - Faculdade Campo Real

Me. José Henrique de Lacerda Furtado - Instituto Federal de Educação, Ciência e Tecnologia do Rio de Janeiro

Me. José Flôr de Medeiros Júnior - Universidade de Uberaba

Ma. Josicleide de Oliveira Freire - Universidade Federal de Alagoas

Me. Lucas Peres Guimarães - Instituto Federal de Educação, Ciência e Tecnologia do Rio de Janeiro

Ma. Luma Mirely de Souza Brandão - Universidade Tiradentes

Me. Marcel Alcleante Alexandre de Sousa - Universidade Federal da Paraíba

Me. Márcio Bonini Notari - Universidade Federal de Pelotas

Ma. Maria Antônia Ramos Costa - Instituto Federal de Educação Ciência e Tecnologia de Rondônia

Ma. Maria Inês Branquinho da Costa Neves - Universidade Católica Portuguesa

Me. Milson dos Santos Barbosa - Universidade Tiradentes

Ma. Náyra de Oliveira Frederico Pinto - Universidade Federal do Ceará

Me. Paulo Roberto Meloni Monteiro Bressan - Faculdade de Educação e Meio Ambiente

Ma. Rosiane Correa Guimarães - Universidade Federal de Jataí

Ma. Sirlei de Melo Milani - Universidade do Estado de Mato Grosso

Ma. Viviane Cordeiro de Queiroz - Universidade Federal da Paraíba

Me. Weberson Ferreira Dias - Instituto Federal de Educação, Ciência e Tecnologia do Tocantins

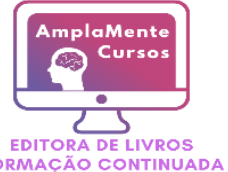




\section{DECLARAÇÃO DOS AUTORES}

Todos os autores desta obra declaram que trabalharam ativamente na produção dos seus trabalhos, desde o planejamento, organização, criação de plano de pesquisa, revisão de literatura, caracterização metodológica, até mesmo na construção dos dados, interpretações, análises, reflexões e conclusões. Assim como, atestam que seus artigos não possuem plágio acadêmico, nem tampouco dados e resultados fraudulentos. Os autores também declaram que não possuem interesse comercial com a publicação do artigo, objetivando apenas a divulgação científica por meio de coletâneas em temáticas específicas.

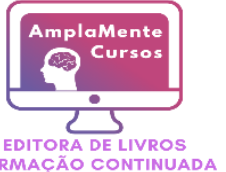




\section{APRESENTAÇÃO}

O E-book Amplamente Educação: novos caminhos para o ensino, consiste em uma coletânea de textos científicos, oriundos de práxis docentes nos diversos contextos de ensino e aprendizagem educacional, principalmente voltada às práticas pedagógicas inovadoras no ambiente escolar. Nesse sentido, este e-book direciona os diálogos às novas demandas educativas, que após todo um período de desconstrução e renovação dos hábitos escolares passa a almejar novos caminhos para a Educação.

Com as novas demandas sociais e educacionais, a ampliação dos cursos à distância, a difusão das formações e cursos online, a normalização da hibridização do ensino, além da própria experiência com as aulas emergenciais remotas, os professores estão cada vez mais preparados para direcionar os novos caminhos para o ensino. São rumos que primam pela organização, planejamento, estrutura mínima de troca de informações, diálogo e empatia, bem como uma série de aspectos importantes que corroboram com o debate educacional.

É nesse sentido que o E-book Amplamente Educação: novos caminhos para o ensino, traz diversos textos de professores pesquisadores em formato de artigos completos oriundos de Pesquisa Concluída, Pesquisa em Andamento, Ensaio Acadêmico, Revisão Bibliográfica e Relato de Experiência para suscitar um debate importante para os profissionais de diferentes áreas de ensino.

Assim, em nome da Editora Amplamente Cursos, convido a todas as pessoas para a leitura do E-book Amplamente Educação: novos caminhos para o ensino, com propostas, concepções, perspectivas, melhorias, apontamentos, análises entre outras questões importantes para o campo educacional.

Luciano Luan Gomes Paiva

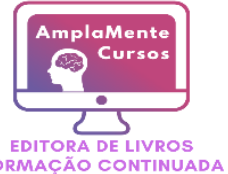




\section{SUMÁRIO}

CAPÍTULO I 15

A CONTRIBUIÇÃO DA ARTETERAPIA, NA EDUCAÇÃO INFANTIL

Maria Gardênia dos Santos Lima.

DOI-Capítulo: 10.47538/AC-2021.14-01

\section{CAPÍTULO II} 33

A CONTRIBUIÇÃO DA LITERATURA INFANTIL NOS ANOS INICIAIS DO ENSINO FUNDAMENTAL NUMA PERSPECTIVA DE ESTIMULAR A PRÁTICA LEITORA

Marcos Antônio Carlos dos Santos; Jaqueline Fonseca de Queiroz;

Aldejane Leandro de Araújo; Ingride Alane Cabral Câmara da Silva.

DOI-Capítulo: 10.47538/AC-2021.14-02

\section{CAPÍTULO III}

\section{A ESCRITA NA EDUCAÇÃO INFANTIL}

Mirtes Pereira do Nascimento Figueredo; Laura Nayara de Macêdo Pereira;

Rosa de Lima Martins; Raisa Corlet dos Santos.

DOI-Capítulo: 10.47538/AC-2021.14-03

\section{CAPÍTULO IV} 60

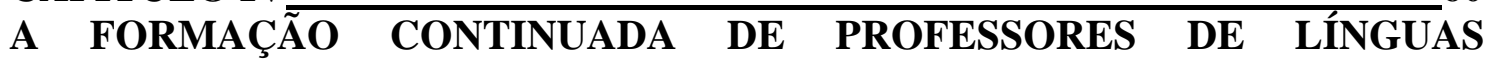
ESTRANGEIRAS DURANTE A PANDEMIA DO COVID-19

Ana Luisa Martinez Burguillo Mendonça Lucas.

DOI-Capítulo: 10.47538/AC-2021.14-04

\section{CAPÍTULO V}

A IMPORTÂNCIA DA LEITURA NA EDUCAÇÃO INFANTIL

Vanúsia Silva de Sousa; Liane Batista de Aquino;

Maria das dores Barbosa Soares; Daniele do Nascimento Luna

Josélia Isídio Rodrigues de Sousa.

DOI-Capítulo: 10.47538/AC-2021.14-05

\section{CAPÍTULO VI}

\section{A IMPORTÂNCIA DOS JOGOS COMO RECURSOS PEDAGÓGICOS NO} ENSINO DE MATEMÁTICA

Sara Gabriele Alves Monteiro; Maria Aparecida Teixeira;

Luana Teixeira Alves; Claudiane Teixeira;

Adriana Aparecida Gonçalves.

DOI-Capítulo: 10.47538/AC-2021.14-06 
A IMPORTÂNCIA DOS JOGOS PARA A APRENDIZAGEM NA EDUCAÇÃo INFANTIL

Alcione Sousa Dos Santos Almeida.

DOI-Capítulo: 10.47538/AC-2021.14-07

CAPÍTULO VIII

A PRESENÇA DO COMPLEXO DE DON JUAN NO PERSONAGEM MAURÍCIO VILAÇA NA OBRA REVOLTA DE MÁRCIO SOUZA

Elves França da Costa Júnior.

DOI-Capítulo: 10.47538/AC-2021.14-08

CAPÍTULO IX 126

A RELAÇÕES ENTRE JOGOS E A APRENDIZAGEM DAS CRIANÇAS

Alcione Sousa Dos Santos Almeida.

DOI-Capítulo: 10.47538/AC-2021.14-09

CAPÍTULO X 142

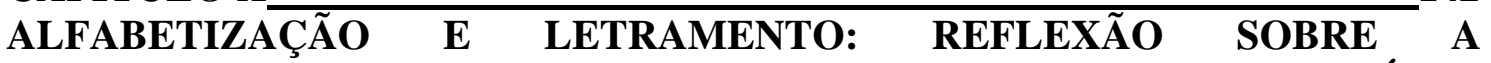
APRENDIZAGEM DAS CRIANÇAS NOS ANOS INICIAIS POR INTERMÉDIO DE LEITURAS

Alexandra Lemos Padre; Edna Maria de Lemos;

Elizabete Maria Lemos; Maria Goretti silva de Santana.

DOI-Capítulo: 10.47538/AC-2021.14-10

\section{CAPÍTULO XI}

AS MEDIDAS DE ENFRENTAMENTO AOS IMPACTOS DA PANDEMIA DO COVID-19 NA SEARA TRABALHISTA

Jorge Ribeiro Dias Dos Santos; Roberta Vasconcelos da Cunha.

DOI-Capítulo: 10.47538/AC-2021.14-11

\section{CAPÍTULO XII} 166

AS NOVAS COMPETENCIAS EM TEMPOS DE PANDEMIA: SABERES DESENVOLVIDOS POR UM DOCENTE

Elcimar de Oliveira Lima.

DOI-Capítulo: 10.47538/AC-2021.14-12

\section{CAPÍTULO XIII} 182

Raisa Corlet dos Santos; Tiêgo Gonçalo de Barros;

Luciana Ivete Maciel Bezerra; Mirtes Pereira do Nascimento Figueredo.

DOI-Capítulo: 10.47538/AC-2021.14-13

CAPÍTULO XIV 195 ATUAÇÃO DO PSICÓLOGO EDUCACIONAL NO ENSINO SUPERIOR: UMA BREVE REVISÃO DA LITERATURA

João Paulo Roberti Junior

DOI-Capítulo: 10.47538/AC-2021.14-14 
CAPÍTULO XV

\section{CONDIÇÕES ADVERSAS NA DOCÊNCIA}

Ramiro Dias de Oliveira.

DOI-Capítulo: 10.47538/AC-2021.14-15

\section{CAPÍTULO XVI} 225

COVID-19 E O IMPACTO PSICOLÓGICO EM DOCENTES E DISCENTES DA EDUCAÇÃO INFANTIL E ANOS INICIAIS

Caroline Rodrigues de Freitas Fernandes; Dayana Lúcia Rodrigues de Freitas;

Jaqueline Honorato de Souza; Wustania Gaspar Rodrigues;

Lígia Maria da Conceição Santos Silva; Nilsa Araújo Silva de Souza;

Rissa Soares Plácido; Elisama da Silva Araújo;

Francijânio Soares de Souza.

DOI-Capítulo: 10.47538/AC-2021.14-16

\section{CAPÍTULO XVII}

EDUCAÇÃO INCLUSIVA NA PERSPECTIVA DA EDUCAÇÃO A DISTÂNCIA

Caroline Rodrigues de Freitas Fernandes; Dayana Lúcia Rodrigues de Freitas;

Jaqueline Honorato de Souza; Wustania Gaspar Rodrigues;

Maria Damiana da Silva;Adriano Cézar Dantas Ferreira;

Francisco Antônio Vieira de Araújo; Josiane Guimarães dos Anjos;

Francisca da Conceição da Costa Melo.

DOI-Capítulo: 10.47538/AC-2021.14-17

\section{CAPÍTULO XVIII}

EDUCAÇÃO INCLUSIVA: UMA ABORDAGEM SOBRE O PROCESSO DE INCLUSÃO ESCOLAR

Ana Paula de Sousa Costa; Maria Aparecida Teixeira;

Luana Teixeira Alves; Claudiane Teixeira;

Adriana Aparecida Gonçalves.

DOI-Capítulo: 10.47538/AC-2021.14-18

\section{CAPÍTULO XIX}

FORMAÇÃO DOCENTE PARA O USO DAS TECNOLOGIAS DIGITAIS

Caroline Rodrigues de Freitas Fernandes; Dayana Lúcia Rodrigues de Freitas;

Tiago Santana de Souza; Jaqueline Honorato de Souza;

Wiziley de Queiroz Freire; Patrícia Lima do Nascimento;

Maria Zilma Batista da Silva; Ana Maria Fonseca de Araújo Medeiros;

Lígia Maria da Conceição Santos Silva; Sara Maria Tomaz de Souza Araújo.

DOI-Capítulo: 10.47538/AC-2021.14-19

\section{CAPÍTULO XX} 262

GIG ECONOMY E OS DIREITOS TRABALHISTAS NO BRASIL

Fernanda Aparecida Breder; Juarez Ribeiro de Araújo Júnior .

DOI-Capítulo: 10.47538/AC-2021.14-20 


\section{IMPLICAÇÕES DO DISTÚRBIO DE APRENDIZAGEM NO PROCESSO EDUCATIVO}

Ana Paula de Sousa Costa; Érica Xavier Machado Pereira;

Joyce Cristyane Pereira; Mayara da Silva Lopes;

Rosea Maria Silva.

DOI-Capítulo: 10.47538/AC-2021.14-21

\section{CAPÍTULO XXII}

INCLUSÃO ESCOLAR COMO UMA PRÁTICA CULTURAL

Caroline Rodrigues de Freitas Fernandes; Dayana Lúcia Rodrigues de Freitas;

Maria Damiana da Silva; Ewerton Cardoso da Silva;

Wustania Gaspar Rodrigues; Patrícia Lima do Nascimento;

Maria Zilma Batista da Silva; Ana Maria Fonseca de Araújo Medeiros;

Lígia Maria da Conceição Santos Silva.

DOI-Capítulo: 10.47538/AC-2021.14-22

\section{CAPÍTULO XXIII}

JOGOS E BRINCADEIRAS NA EDUCAÇÃO INFANTIL

Ana Paula de Sousa Costa; Érica Xavier Machado Pereira;

Joyce Cristyane Pereira; Mayara da Silva Lopes;

Rosenice Benedita Ferreira.

DOI-Capítulo: 10.47538/AC-2021.14-23

\section{CAPÍTULO XXIV}

\section{LUDICIDADE COMO REQUISITO PARA UMA APRENDIZAGEM} SIGNIFICATIVA NA EDUCAÇÃ̃O INFANTIL

Alcione Sousa Dos Santos Almeida.

DOI-Capítulo: 10.47538/AC-2021.14-24

\section{CAPÍTULO XXV}

O CURRÍCULO NA PERSPECTIVA DA INCLUSÃO E DA DIVERSIDADE

Juliane Claudia Rossi Silva; Lucilene Cardoso de Miranda;

Maria de Lourdes Reche Borges; Sonia Maria Reche.

DOI-Capítulo: 10.47538/AC-2021.14-25

\section{CAPÍTULO XXVI}

\section{O LÚDICO COMO FERRAMENTA PARA A EDUCAÇÃO INCLUSIVA}

Tamires Aline de Amorim; Maria Aparecida Teixeira;

Luana Teixeira Alves; Ana Paula de Sousa Xavier;

Claudiane Teixeira.

DOI-Capítulo: 10.47538/AC-2021.14-26 
CAPÍTULO XXVII 353

OS DESAFIOS DA EDUCAÇÃO FRENTE ÀS NOVAS TECNOLOGIAS

Maria Aldeni de Oliveira Andrade; Alyson Matheus da Silva Rodrigues;

Geonar do Nascimento Silva.

DOI-Capítulo: 10.47538/AC-2021.14-27

\section{CAPÍTULO XXVIII} 363

PERCEPÇÃO DOCENTE SOBRE OS ENTRAVES E OS DESAFIOS DA EDUCAÇÃO NO CONTEXTO DA PANDEMIA EM UMA ESCOLA DA ZONA OESTE DO MUNICÍPIO DE BOA VISTA- RR

Rosana Cléia de Carvalho Chaves; Cristiane Pereira Ferreira;

Paula Roberta dos Prazeres Santos; Lyres Luiza de Souza Cruz Silva;

Julio Roque de Oliveira.

DOI-Capítulo: 10.47538/AC-2021.14-28

\section{CAPÍTULO XXIX} 380

PONTOS CANTADOS DE UMBANDA E SEU POSSÍVEL USO COMO FERRAMENTA PEDAGÓGICA PARA O ENSINO DE HISTÓRIA DA ÁFRICA E CULTURA AFRO-BRASILEIRA

Paula Roberta Libanori Haenisch.

DOI-Capítulo: 10.47538/AC-2021.14-29

\section{CAPÍTULO XXX}

ENSINO DE CIÊNCIAS: ESTRATÉGIAS DIDÁTICAS PARA A PREVENÇÃo AO USO DE DROGAS

Dayana Lúcia Rodrigues de Freitas.

DOI -Capítulo: 10.47538/AC-2021.14-30

CAPÍTULO XXXI 409

\section{A UTILIZAÇÃO DAS TIC'S NO ENSINO DE HISTÓRIA}

Caroline Rodrigues de Freitas Fernandes.

DOI-Capítulo: 10.47538/AC-2021.14-31

\section{CAPÍTULO XXXII}

\section{A IMPORTÂNCIA DO SENSO COMUM PARA O ENSINO DE CIÊNCIAS}

Dayana Lúcia Rodrigues de Freitas.

DOI -Capítulo: 10.47538/AC-2021.14-32

\section{CAPÍTULO XXXIII} 430

DIREITO AO VOTO: A PARTICIPAÇÃO FEMININA NA VIDA POLÍTICA DO NOSSO PAÍS

Caroline Rodrigues de Freitas Fernandes.

DOI-Capítulo: 10.47538/AC-2021.14-33 
CAPÍTULO XXXIV 439

AULAS DE CIÊNCIAS NATURAIS: UTILIZAÇÃO DAS REDES SOCIAIS COMO ESPAÇO DE ENSINO-APRENDIZAGEM

Dayana Lúcia Rodrigues de Freitas.

DOI -Capítulo: 10.47538/AC-2021.14-34

CAPÍTULO XXXV 454

LITERATURA POTIGUAR EM AÇÃO: UMA VISÃO PERSCRUTADORA PARA A OBRA O HORTO DE AUTA DE SOUZA

Thatyane Santos e Silva da Penha.

DOI -Capítulo: 10.47538/AC-2021.14-35

SOBRE OS ORGANIZADORES 470

SOBRE OS AUTORES 472

ÍNDICE REMISSIVO 481 


\title{
CAPÍTULO I
}

\section{A CONTRIBUIÇÃO DA ARTETERAPIA, NA EDUCAÇÃO INFANTIL}

\author{
Maria Gardênia dos Santos Lima'. \\ DOI-Capítulo: 10.47538/AC-2021.14-01
}

RESUMO: O presente trabalho, é voltado para profissionais da área de ensino infantil, para que possam refletir na sua atuação pedagógica por meio da arteterapia. Nesse âmbito, poderá também, abordar seu alunado em sua complexidade e singularidade infantil, ensinando a estar preparado para atuar através de novas estratégias metodológicas, mediante uma formação continuada em arteterapia para possivelmente compreender melhor a subjetividade do seu aluno, e poder assim, ajudá-lo na constituição de sua aprendizagem, atrelado ao recurso da arte que configura-se de forma colaborativa, e assim, ressignificando na criança uma vida propícia e desenvolvida nas suas potencialidades, desencadeando o bem- estar, a autoestima na escola, na vida e no meio onde a criança está inserida. A família também tem papel indispensável na evolução do desenvolvimento da criança. Elencamos renomados autores nesta pesquisa. Ademais, abraçar a arteterapia poderá favorecer a criatividade. A criatividade, é uma faculdade psíquica de todo ser humano, é uma terapia que é obtida através da arte que envolve prazer por meio de vários materiais, materiais esses que são: modelagem, cores, fluídos de tintas e entre outros. Nesse contexto, pode-se acreditar na autotransformação através das artes, trabalhando para que as crianças se surpreendam com o fazer artístico, mediante suas expressões que representem: seus medos, seus estresses, seus valores e seus sofrimentos no mundo complexo em que as mesmas, possivelmente, estão vivenciando atualmente.

PALAVRAS-CHAVE: Arteterapia. Psicanálise. Educação Infantil. Formação Continuada. Aprendizagem.

\section{THE CONTRIBUTION OF ART THERAPY IN EARLY CHILDHOOD EDUCATION}

\begin{abstract}
The onta work is aimed at professionals in the field of early childhood education, so that they can reflect on their pedagogical performance through art therapy. In this onta, you will also be able to approach your students in their complexity and uniqueness for children, teaching them to be prepared to act through new methodological strategies, through a continuous training in art therapy to possibly better understand their student's subjectivity, and thus be able to help them. It in the constitution of their learning, linked to the resource of art that is configured in a collaborative way, and thus, giving a new meaning to the child a propitious life and developed in its potentialities, triggering the well-being, self- esteem in school, in life and in environment where the child is inserted. The onta also plays na indispensable role in the ontar of the child's development. We list renowned authors in this research. Furthermore, embracing art therapy may favor creativity. Creativity is a psychic faculty of every human being, it is a therapy that is
\end{abstract}

1Pedagoga. Especialista em Psicopedagogia Institucional e Clínica (ISEP). Professora De Artesanato. E-mail: gardenialima83@gmail.com 
obtained through art that involves pleasure through various materials, which are: modeling, colors, paint fluids and others. In this onta, self-transformation through the arts can be believed, working so that children are surprised with artistic practice, through their expressions that they represent: their fears, their stresses, their values and their suffering in the complex world in which they, possibly, they are currently experiencing.

KEYWORDS: Artetherapy. Psychoanalysis. Child Education. Continuing Training. Learning.

\section{INTRODUÇÃO}

O presente trabalho tem o intuito de explanar os conceitos de Winnicott, mediante a fase infantil contribuições para o estudo do comportamento da criança, sob a visão de Winnicott para o processo de educação, atrelado a participação da família e a necessidade primordial da integração do ambiente familiar, criança e escola. Tudo isso, através das atividades dinâmicas da arteterapia, como objeto de brinquedo, mediado pelo brincar na atividade artística que possivelmente favoreça o bem estar e a aprendizagem Winnicott psicanalista.

Nesse contexto, a arteterapia vai além do "fazer por fazer", ela é uma ferramenta educacional que busca a construção de futuros cidadãos críticos, ainda como crianças, e que possibilita o desenvolvimento de aprendizagem de alunos com ou sem problemas de dificuldades de aprendizagem. Nosso tema, foca oportunizar a superação inerente ao mundo social e dificuldades encontradas no contexto de sua realidade.

Diante do nosso tema, podemos conceituar primeiramente: o que é arteterapia em seu aspecto de duas palavras ligadas, muito poderosas? Por um lado, a arte representa a estética das expressões que o ser humano faz, contextualizada às suas emoções, ou ao seu meio, para qual são apropriadas, possivelmente as várias linguagens artísticas: música, dança, pintura e o artesanato.

Outrossim, a terapia constitui ideias e ações em prática que pode ser mobilizada para resoluções de separações de problemas, sejam eles mentais ou físicos.

Contudo, através da arteterapia, a possibilidade de desenvolvimento da inteligência e bem estar emocional, desenvolve as potencialidades de criação na sua amplitude fruída, sendo um excelente recurso na pré-escola. Ela é uma ferramenta para desenvolver a imaginação e a aprendizagem 
A criança em desenvolvimento é um futuro adulto cidadão em construção, protagonista do seu saber e interativo no meio social consigo e com o outro. Dessa forma, é nessa perspectiva que a presente pesquisa, vem dialogar de forma explícita a necessidade de uma visão eminente voltada a reflexão da importância do amadurecimento saudável da criança para um desenvolvimento bom na aprendizagem, mediante o bem estar no seu processo de desenvolvimento biológico e psicológico, atrelado ao posicionamento da família e o professor atualizado que poderá ampliar sua formação continuada como colaboração para amplitude de conhecimentos e saberes de como atuar diante das complexidades que possam surgir.

\section{OBJETIVO GERAL}

Diante da atualidade é relevante a formação do pedagogo apropriar-se de uma especialização de arteterapia, visto que um professor de educação é polivalente, tendo em mente a oportunização dos benefícios, e da transformação contagiante que a arte possivelmente poderá proporcionar às crianças da idade pré-escolas atrelada a arteterapia.

As experiências entre professor e alunos, adquiridas mediante de recursos artísticos em um espaço escolar ou fora, poderá desenvolver além do bem estar no fazer artístico, a autoestima e a abrangência de potencialidades e habilidades artísticas, como também aptidões para interpretar o mundo que o rodeia e resolução de problemas no contexto de sua realidade.

Segundo Corazza (2002):

A sala de aula ou os espaços alternativos, dentro da escola para o uso da arteterapia precisam ser ambientes que facilitem a autoexpressão, comunicação, o contato com os potenciais da personalidade e seus aspectos: cognitivo, emocional e sensorial. Isso irá favorecer também, a interação de conteúdos emocionais, despotencializando assim a tensão, e trazendo maior harmonia, equilíbrio e saúde (CORAZZA, 2002).

\section{OBJETIVOS ESPECÍFICOS}

Compreender a importância da arteterapia; Repensar a educação atual no ensino infantil, contextualizando a arteterapia; Possibilitar o desenvolvimento do 
autoconhecimento através da diversificação e da criatividade; Criar atividades artísticas que promovam transformações pessoais individual na sociedade.

\section{METODOLOGIA}

A presente pesquisa, realizou-se com embasamento teórico de autores renomados de várias áreas da psicanálise (Winnicott), arteterapia (Jung), Lúdica (BROGÊRE), e Decreto da formação continuada do educador. O trabalho em questão, foi dividido em quatro capítulos, tendo a finalidade de expressar o olhar da arteterapia no contexto préescolar no intuito de ser aplicada como ferramenta lúdica em contribuição à subjetividade infantil e a prática pedagógica do educador.

No primeiro capítulo explana a contribuição de Winnicott no contexto do amadurecimento da criança, e a visão psicanalista infantil para o desenvolvimento do verdadeiro "Self". Todavia, no segundo capítulo destacou-se a relevância da arteterapia, breve olhar dos pensadores teóricos, direcionado no embasamento do tema, a inserção no ambiente escolar, atividades artísticas e no lúdico. Ademais, no terceiro capítulo explana a importância da família. Já no quarto capítulo, se configura na reflexão da necessidade da formação continuada para o educador em sua prática na pré-escola, articulada à arteterapia.

\section{A CONTRIBUIÇÃO DE WINNICOTT}

Mediante a psicanálise, não podemos esquecer de destacar o psicanalista Winnicott e conhecer sua história e seus principais conceitos em relação ao desenvolvimento primitivo do bebê, qual a importância, as angústias catastróficas, objeto transicional, verdadeiro e falso self. A visão de Winnicott, a mãe, é como um elo auxiliar.

Donald Wood Winnicoot (1896 - 1971) pediatra e psicanalista nasceram numa próspera família de Plymouth na Grã-Bretanha em 07 de abril de 1896 e morreu em Londres (25 de janeiro de 1971).

Donald tinha duas irmãs mais velhas e aos 14 anos foi para o internato, posteriormente ingressou na universidade de Cambridge, onde estudou biologia e depois medicina. Entretanto, interrompeu a guerra de 1914-18 o que levou a servir como 
estagiário de cirurgia e oficial médico em Destroier. Em 1923, foi indicado para o Green Hospital for Children, onde permaneceu pelos 40 anos seguintes trabalhando como pediatra, psiquiatra infantil e psicanalista.

\section{PSICANÁLISE WINNICOTEANA}

O ser humano que se estabelece como total no seu "eu", atrelado a suas capacidades de relacionamento intenso e externo com seu meio em termos de excitação, possivelmente desencadeará uma postura de defesa configurado num inconsciente reprimido.

Nesse sentido, faz-se relevante a psicanálise atuante e necessária para a compreensão do ser humano, é um processo clínico que lida com a dicotomia de um ego sadio e os rompimentos das estruturas do ego. O paciente existe como pessoa, é uma pessoa total que estabelece objetos como totais, acha-se bem alojado em seu próprio corpo e a capacidade de relacionamentos objetais está bem-estabelecida.

Desde este ponto de vista, o paciente encontra-se em dificuldades, e estas surgem dos conflitos que resultam de experiências de relacionamentos objetais naturalmente. ${ }^{\text {e'Os }}$ conflitos mais graves, aparecem em conexão com a vida instintual, isto é, as variadas excitações com acompanhamentos corporais que tem como fonte a capacidade que o corpo possui de ficar excitado de modo geral e localizado" (WINNICOTT, 1955, p. 53).

\section{OS CONCEITOS DE WINNICOTT}

A psicanálise, conceitos de Winnicott e conceitos em relação ao desenvolvimento da criança e sua criatividade, vem sendo discutidos consideravelmente no progresso da psicanálise.

Todavia, segundo a afirmação de Winnicott „eé no brincar, e talvez apenas no brincar, que a criança e o adulto fluem na sua liberdade de criação ${ }^{\text {eeee }}$ e é no brincar e somente no brincar, que o indivíduo (criança ou adulto), pode ser criativo e utilizar sua personalidade integral. Somente sendo criativo que o indivíduo descobre o seu self (WINNICOTT, 1971/1975, p. 79-80). 
Mediante a postulação desse psicanalista podemos entender que o "brincar" está relacionado a "racionalidade" e a "afetividade", numa função que permeia a natureza humana.

Segundo Winnicott:

Se a dependência realmente significa dependência, então a história de um bebê individualmente não pode ser escrita apenas em termos do bebê, ou seja, tem que ser escrita também em termos de provisão ambiental que atende a dependência ou que nisso fracassa (WINNICOTT, 1975, p. 102).

Os conceitos de Winnicott descreve uma visão processual do desenvolvimento psíquico da criança desde bebê.

Na visão de Winnicott o primeiro conceito é o conceito de tendência inata para a integração, ou seja, temos uma tendência para nos constituirmos como pessoas.

Para esse autor é necessário um ambiente acolhedor que venha atender a criança. O amadurecimento só acontece plenamente se o ambiente favorecer uma sustentação naturalmente, por outro lado, se não for um ambiente que não facilite o processo de desenvolvimento. Os ambientes são os cuidadores primários, ou seja, que não respeitam o ritmo da criança, folha ambiental, por negligenciar ou invasão ao processo natural da criança.

Nesse intuito, a criança abandona o seu desenvolvimento e desenvolve o falso self, que obriga ele a defender-se num ambiente desfavorável, mediante a reação do ambiente.

É necessário um ambiente favorável para uma integração plena do indivíduo. Sempre o ambiente deve ser suficientemente bom para que ocorra o desenvolvimento natural da criança, para que não desencadeie e constitua o falso self (é nesse contexto que para Winnicott o ambiente se qualifica suficientemente bem).

A criança gradativamente vai se adaptando de acordo com seu meio, através das pautas objetivas de sua mãe, que nesses intervalos ocorre a diferenciação entre a fantasia e a realidade do seu meio, que está inserido sua mãe e o mundo que o rodeia.

\section{O AMBIENTE FAVORÁVEL À INDEPENDÊNCIA DO BEBÊ}


A maturidade para Winnicott é igual a saúde ligada ao desenvolvimento emocional, ou seja, é necessário de forma progressiva o ser humano estar amadurecido em sua idade, em seu tempo cronológico, e nesse contexto poderá construir uma relação responsável em meio ao ambiente que contribuirá para a sua aprendizagem afetiva.

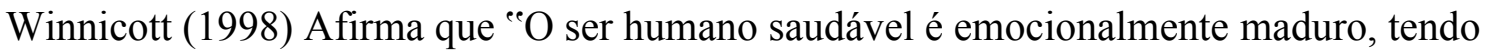
em vista a sua idade no momento. A maturidade envolve gradualmente o ser humano em uma relação de responsabilidade com o ambiente".

O desenvolvimento infantil percorre por um processo de experiências e descobertas permeadas pela complexidade de incertezas estabelecidas pelo meio em que a criança vive.

Outrossim, é relevante nesse contexto abrir um novo olhar em novas estratégias metodológicas, respeitando a singularidade da criança, atrelado a formas diversas de aprendizagem, por meio de estímulos do meio em que se encontra e no meio social. Sendo assim, as representações culturais e níveis de pensamento, constituem sua socialização psicomotora e afetiva.

Diante disso, faz sentido as afirmações de Winnicott em relação ao ambiente suficientemente bom para a criança que diz respeito ao seu bom desenvolvimento pleno e ao amadurecimento favorável. Por outro lado, a estimulação ambiental promoverá possivelmente aspectos maturacionais.

\section{ARTETERAPIA - BREVE OLHAR DOS PRESSUPOSTOS}

Epistemologicamente a arte já se faz desde tempos remotos, desde o período das cavernas na pré-história, a arte é tão antiga quanto a existência humana que pintava o seu cotidiano, seus acometimentos e suas emoções nas paredes das cavernas.

Nesse intuito, observa-se a arte presente na humanidade, uma importante representação primitiva é a arte rupestre que se expandiu de forma evolutiva em vários aspectos, atravessando gerações na história humana até os tempos atuais contemporâneos.

$\mathrm{Na}$ atualidade, a arte se configura nas mais diversas expressividades e linguagens artísticas em suas plasticidades, advindos de aspectos emocionais, permeado pela promoção de estímulos, criativa de ideias e sentimentos, interligados no eu humano. 
A arte é relevante na atualidade atrelada à arteterapia e para o trabalho de psicólogos e educadores que lidam com a saúde mental e com a educação.

Para Jung (1920) a arte transforma-se em imagens configurando-se em símbolos, libera a criatividade e a energia psíquica. Na visão junguiana, o consciente consegue captar sonhos submergidos no inconsciente e por meio da ação interativa do profissional, possivelmente desencadeará os significados simbólicos, permeado pelos aspectos psíquico, criativo e de expressão.

Nesse contexto, Jung (1920) aponta:

A energia psíquica consegue transformar-se em imagens, e através de símbolos, colocar seus conteúdos mais intensos e profundos. A arte é a expressão mais pura que há para a demonstração do ícone conte de cada um, e a liberdade de expressão e densibilidade criativa (JUNG, 1920, p. 78).

\section{A ARTETERAPIA COM CRIANÇAS NO AMBIENTE ESCOLAR}

O mundo está cada vez mais urgente, muito competitivo em necessidades básicas e que lidam com o raciocínio lógico, e deve dar oportunidade às crianças, por um mundo de sobrevivência em um mundo melhor. A psicologia deve estar presente na vida das crianças, devendo ter acompanhamentos. Dessa forma, a criança deve se sentir à vontade com a produção artística feita por ela, vindo do seu interior. Não existe o belo, bem o feio, qualquer forma de expressão vai trazer informações do processo interior da criança.

Mediante isso, podemos refletir sobre uma visão: O docente é a arte, uma reflexão, um caminho. A escola por um lado é o provedor sistemático de conhecimento para as crianças no âmbito social do seu meio.

A transformação social surge quando a educação faz valer as necessidades singulares e complexidades dos alunos. Entretanto, é imprescindível a formação continuada, mediante a carência das necessidades dos professores que precisam de uma abrangência de conhecimentos transformadores que possibilitam a reflexão através da arteterapia

O processo educativo gradativamente socializa continuamente em todas as instâncias fases da vida da criança, desde seu nascimento, sendo influenciado através do seu meio, que moldará sua forma de viver nas experiências interpessoais com o adulto. 
Posteriormente a interiorização dos conhecimentos adquiridos no seu cotidiano com o seu meio suficientemente bom, possibilitará a evolução do desenvolvimento de aprendizagem.

A escola, a família, ambos no compromisso de contribuição de atribuições de valores e saberes, atrelados de forma permeada entre arte e o conhecimento em construção, possibilitará passivamente uma criança em desenvolvimento, em um ser humano crítico consigo mesmo e com o mundo que está inserido.

Nesse intuito, poderá ser somatório relevante, a amplitude da valorização em relação do bem-estar da criança para seu desenvolvimento cognitivo e potencial como para as famílias, e o professor através de sua formação continuada e seu alto conhecimento em arteterapia.

A arteterapia atrelada a arte e a atividade pedagógica, permeada com várias formas do fazer no contexto artístico em várias linguagens, trabalha as atividades manuais, despertando possivelmente a sensibilidade, trabalha o ritmo de todas linguagens artística e todos elementos artísticos que podem através do corpo de forma integral conduzir a satisfação do bem-estar da interioridade da criança.

Para Urrutigaray, (2008), a materialização representativa artística expressa pelo sujeito e seu produto expressivo, advém de sua subjetividade e através das experiências das manipulações de materiais expressivos, promove através desses em sua percepção e sentido sensorial a realização do seu eu, e de sua própria ação.

A materialização resultante de uma ação modelar, sobre diferentes elementos plásticos viabiliza a estrutura de um campo psicológico diferenciado de modelos culturais que possam estar distanciados da realidade pessoal. A possibilidade da vivência de experiências sensoriais dadas pela percepção de formas, texturas, cores volumes, gerados pela materialização ou a concretização de si mesmo, torna possível a ação de plasmar a si mesmo, logrando a realização da individualização dada a atenção focalizada na sua própria ação (URRUTIGARAY, 2008, p. 52).

O ambiente no espaço escolar para a dinâmica da arteterapia, necessita de adequação que facilite às crianças o desenvolvimento de sua potencialidade ao seu desenvolvimento humano interiormente e exteriormente em suas características infantis, e nesse contexto possivelmente poderá contribuir as emoções integralmente. 
Nessa perspectiva, a relevância da pesquisa ancora-se na possibilidade da apropriação e reflexão do docente na sua abrangência do bem estar mental e do autoconhecimento e ambiente escolar para o ensino pré-escolar.

[...] o uso das práticas artísticas como função terapêutica em qualquer modalidade, busca a organização da vida psíquica com base nas simbolizações psíquicas possíveis. Desta forma, elas procuram uma maneira de dinamizar e organizar suas percepções, sentimentos, sensações, ou seja, os conteúdos internos da sua vida psíquica, transformando-os em imagens simbólicas (ANDRADE, 2000, p. 35).

Nesse sentido, para Andrade é imprescindível toda atenção na área que condiz à saúde mental, em que a preferível para a manutenção saudável mental "o cuidado do outro e consigo mesmo".

\section{ATIVIDADES ARTÍSTICAS PARA CRIANÇAS NO ENSINO INFANTIL}

Os recursos artísticos da arteterapia podem servir como disparadores para expressar plasticamente o que sentem. $O$ processo que sentem internamente podem expressar através de suas expressões artísticas de forma livre e significativa, as atividades devem ser prazerosas.

A Base Nacional Curricular de Educação Infantil, tem em sua essência a visão que as instituições tragam em seu projeto pedagógico: a atividade e a expressividade de linguagens artísticas. Entretanto, cabe ao educador promover mais atenção às crianças, experiências perceptivas, manipular com diversos materiais de sucata e da natureza, para contribuir nos benefícios focados na expressividade da criança com o intuito de desenvolver a sensibilidade da criança. Nesse contexto, a BNCC explicita os usos estruturantes das práticas pedagógicas. Em seu artigo afirma: os eixos estruturantes das práticas pedagógicas dessa etapa de Educação Básica são as interações e brincadeiras, experiências nas quais as crianças podem construir e apropriar-se de conhecimentos por meio de suas ações e interações com seus pares e com os adultos, o que possibilita a aprendizagem, o desenvolvimento e socialização.

Através dos eixos estruturantes das práticas pedagógicas e competências gerais da Educação Básica proposta pela BNCC, é assegurado seus direitos na educação infantil para que as crianças aprendam e desenvolvam plenamente, mediante desafios que possam 
motivar e ajudar nas experiências de resolução significativa consigo mesma e com o mundo em que estão inseridas.

Segundo a BNCC. Direitos de aprendizagem e desenvolvimento na educação infantil (BNCC, p. 38):

- Conviver com outras crianças e adultos em pequenos e grandes grupos, utilizando diferentes linguagens, ampliando o conhecimento de si e do outro, o respeito em relação à cultura e as diferenças entre as pessoas.

- Brincar cotidianamente de diversas formas em diferentes espaços e tempos com diferentes parceiros (crianças e adultos), ampliando e diversificando seu acesso a produções culturais, seus conhecimentos, sua imaginação, sua criatividade, experiências emocionais, corporais, sensoriais, expressivas, cognitivas, sociais e relacionais.

- Participar ativamente com adultos e outras crianças, tanto do planejamento da gestão da escola e das atividades propostas pelo educador quanto da realização das atividades da vida cotidiana, tais como: a escolha das brincadeiras dos materiais e dos ambientes, desenvolvendo diferentes linguagens e elaborando conhecimentos, decidindo e se posicionando.

-Explorar movimentos, gestos, sons, formas, texturas, cores, palavras, emoções, transformações, relacionamentos, histórias, objetos, elementos da natureza na escola e fora dela, ampliando seus saberes sobre a cultura em suas diversas modalidades: as artes, a escrita, a ciência e a tecnologia.

-Expressar, como sujeito dialógico, criativo e sensível, suas necessidades, emoções, sentimento, dúvidas, hipóteses, descobertas, opiniões, questionamentos, por meio de diferentes linguagens.

- Conhecer-se e construir sua identidade pessoal, social e cultural, constituindo uma imagem positiva de e de seus grupos de pertencimento nas diversas experiências de cuidados, interações, brincadeiras e linguagens vivenciadas na instituição escolas e em seu contexto familiar e comunitário.

- Nessa visão acima explanada pelo documento da BNCC, a proposta vem impor a intencionalidade educativa no ensino infantil, tanto pela creche, como pela pré-escola, a práticas pedagógicas e atividades devem ser pautadas nas necessidades da criança de 
forma que a convidem e seja favorável a motivá-las para seu bem-estar e aprendizagem e que promover a expansão positiva do seu interior e ser humano, numa educação globalizada.

Para Craidy (2007), as atividades para alguns autores são variadas de acordo com a necessidade de cada criança.

Não há uma maneira certa ou errada de trabalhar para que os projetos se concretizem, existe apenas o alegre, o agradável processo de experiência em si. Para que as crianças possam criar suas produções devem ser oferecidas oportunidades diversas para que elas se familiarizem com algum procedimento ligado aos materiais utilizados e os diversos tipos de suporte. Sendo assim, o trabalho deve ser organizado de forma a oferecer para as crianças a possibilidade de contato, uso e exploração dos materiais (CRAIDY, 2007, p. 74).

\section{O LÚDICO}

O Lúdico permeia as especificidades de valores na fase infantil. De acordo com pesquisas, direcionadas a esse tema é imprescindível a visão que expande muito mais seu lado criativo, e que por meio do lúdico possivelmente poderá ampliar sua atuação de ensino e aprendizagem, promovendo assim, sua autoestima.

O sujeito com sua criatividade se faz relevante para movimentar transformações na sociedade, embasada no desenvolvimento infantil e atrelada ao desempenho de um ensino que possivelmente formará alunos integrados. Entretanto, as crianças apresentam na maioria das vezes estresse, e entre outros fatores traumáticos, advindos de ocasiões negativas surgidas em seu meio social.

Nesse sentido, a arteterapia vem como reflexão nesta pesquisa, podendo ser administrada na escola que irá promover o bem-estar, a autoestima do aluno e educador, e assim, possibilita amenizar os sentimentos negativos, e venha favorecer as práticas pedagógicas em arteterapia de forma lúdica. Isso irá favorecer a aprendizagem infantil, e mais ainda, amplia a percepção do educador na sua percepção voltada às peculiaridades da crença motivando sua presença no ambiente pré-escolar.

Seja como for, a experiência lúdica aparece como um processo cultural, suficientemente em si mesmo sendo para merecer ser analisado, mesmo que não tivesse influência sobre outros processos culturais mais amplos (BROGÊRE, 2011, p. 32). 
De acordo com Brogêre (2011), a ação do lúdico relaciona-se a muitas dimensões, não somente culturalmente através das relações humanas, é uma atuação da criança ao qual ela pertence.

Outrossim, desenvolver o lúdico com outras estratégias de ferramenta de aprendizagem como a arteterapia, promoverá possivelmente no processo de formação futura da criança, a constituição de um adulto melhor como ser humano. Nesse contexto, é imprescindível a formação continuada do educador na sua prática pedagógica.

\section{A PARTICIPAÇÃO DA FAMÍLIA}

É de grande relevância a participação dos pais na formação psíquica da criança podendo assim contribuir na influência do seu amadurecimento e desenvolvimento humano.

Winnicott destaca que:

A família nunca deixa de ser importante e é responsável por muitas de nossas viagens, nós escapamos, emigramos, trocamos o Sul pelo Norte e o Leste pelo Oeste, devido à necessidade de nos libertarmos, e depois viajamos periodicamente de volta para casa renovar o contato com a família (WINNICOTT, 1993, p. 59).

Para Winnicott, sua visão relacionada à família embasava-se numa instituição inserida contextualizada, fundamentalmente como estrutura cultural desde o nosso nascimento.

Portanto, a participação da família é imprescindível na construção formativa da criança a partir do pensamento reflexivo, faz-se necessário que no âmbito familiar todas que constituem a família são como seres humanos heterogêneos, configuradas em suas singularidades, porém, que se permitam embasados no respeito, na convivência familiar e social, advindas das aprendizagens e do ensino, condutas positivas na forma de comportamento familiar.

(...) Se inicia o processo de aprendizado das habilidades, das competências e da aquisição dos primeiros conhecimentos, indicando que muito mais do que o conteúdo a ser ensinado está o modelo relacional que se imprime sobre a subjetividade de quem aprende. Isto confirma que o padrão de funcionamento interacional do indivíduo e seus familiares torna-se $\mathrm{o}$ aspecto fundamental para compreender como 
se dá a circulação de conhecimento e acesso à aprendizagem naquele dado contexto (MUNHOZ, 2006, p. 145).

\section{A FORMAÇÃO CONTINUADA DO PROFESSOR}

Diante da contemporaneidade, a relevante postura de uma formação continuada de professores é primordial que supra nas suas atitudes polivalentes defronte às necessidades como ser humano, favorecendo a construção cultural, estética e ética. Dessa forma, irá possibilitar o enriquecimento através do ensino a esses "alunos", um ambiente propício às potencialidades e capacidades das crianças que promove o bem-estar através de oficinas criativas (ministradas nas séries iniciais). A experiência do professor com as práticas artísticas poderá ampliar o ensino e a prática com os alunos.

O professor que atua com o aluno, promove a constituição do aprendizado do aluno, mediante suas complexidades singulares, necessita de uma postura flexível. Diante disso, é necessário ter uma visão atualizada, pois nesse contexto, o desenvolvimento de competências e capacitação poderá demonstrar de forma notória a teoria e a prática, em consonância permeada pelo conhecimento globalizado com excelência, mediante a formação continuada do professor.

A formação de qualidade inicial que o professor deve possuir, tem que ser aliar a necessidade da formação continuada, precisa se reinventar e participar dos contextos das crianças. O ambiente escolar possivelmente deve favorecer recursos baseados no cotidiano do aluno.

Não faz muito sentido buscar algo que não esteja aliado a prática, o planejamento deve estar ancorado em total contexto atrelado a realidade do aluno, assim, a formação continuada poderá fora e dentro da escola contribuir para uma boa atualização pedagógica do professor em seu ensino e assim, favorece o ensino mediante a complexidade de dificuldade de aprendizagem do aluno (criança), como também, o autoconhecimento do professor.

Nesse contexto, o decreto: 8.762, 9 de maio de 2017, afirma:

Art. 2: Para atender às especificidades do exercício de suas atividades e aos objetivos das diferentes etapas e modalidades da educação básica a formação dos professores da educação básica. 
- os projetos pedagógicos das instituições formadoras que reflitam a especificidade da formação dos profissionais da educação básica que assegurem a organicidade ao trabalho das diferentes unidades que concorram para essa formação e a sólida base-teórica e interdisciplinar, que efetiva integração entre teoria e práticas profissionais;

- A compreensão do espaço educativo na educação básica como espaço de aprendizagem, convívio cooperativo, seguro, criativo e adequadamente equipado para o pleno aproveitamento das potencialidades de estudantes e professores; XIV - A promoção continuada da melhoria da gestão educacional, escolar e o fortalecimento do controle social.

Seguindo a visão de Charlot (2005, p. 42): [...] Estudar a relação com o saber é estudar o próprio sujeito enquanto se constrói por apropriação do mundo, portanto, também como sujeito aprendiz [...].

A relação com o saber como sujeito que se constrói e se reconstrói, possibilitando a transformação de sua dinâmica na sua atuação produtiva e reflexão dos seus próprios saberes se constitui para uma melhoria de ensino e aprendizagem, através da formação continuada do educador. Entretanto, atualmente para atuar em sala de aula é necessária uma formação continuada por conta da emergente complexidade das crianças.

\section{CONSIDERAÇÕES FINAIS}

Criar a alegria de pensar, em tempos atuais é primordial como objetivo da escola atual. O professor, deve provocar a interação com a criança, convidando-a e tendo como missão provocar a curiosidade da criança através dos questionamentos e experimentos mediante ao mundo que o rodeia.

Nesse âmbito, o espaço escolar deve expandir o desenvolvimento em uma proposta criativa no cotidiano escolar. A proposta de uma oficina criativa deve abranger diferentes disciplinas que possibilitem promover a expressão artística, estimulando a criança através de uma visão global, a diversidade do certo ou errado, empoderando a conversa no espaço escolar. Toda a escola deve construir a experimentação criativa, todos podem criar o profissional levando um movimento diferente, capacitando os alunos a arte, como ferramenta primordial que mede o processo criativo.

É necessário trabalhar para expandir a ampliação da visão pedagógica e artística do aluno, adaptando vários materiais, retomando várias estratégias através de várias 
propostas diferentes, como: desenho, pinturas, colagem e entre outras possibilidades de atividades, que visem valorizar a individualidade. Tendo o professor como facilitador, o potencial criativo poderá fluir, e também, a livre expressão deve ter conexão com o interior singular de cada aluno.

Portanto, é primordial a visão de um pedagogo que não se entre e busque suprimentos às necessidades totais e artísticas desses alunos, que compreenda sua individualidade expressiva em relação ao seu meio e seus sentimentos.

Todavia, o pedagogo deve estar habilitado para exercer sua profissionalidade em arteterapia, e para isso, deverá ter uma formação nessa área para contribuir no desenvolvimento da aprendizagem da criança, estimulando e promovendo o desenvolvimento das suas expressões e potencialidades artísticas da criança.

Entretanto, o desenvolvimento psicossocial das crianças é importantíssimo para favorecer seu crescimento normal. A arteterapia nesse contexto é uma ferramenta que proporciona o positivamente o desenvolvimento variável da criança.

A arteterapia tem a possibilidade de favorecer inovações, despertar os potenciais do aluno, deliberar a subjetividade e o prazer, mediante o bem-estar com a ação da atividade espontânea.

A criança estará sempre inerente à ludicidade, e é através da vivência e experimentações na vida cotidiana do seu desenvolvimento total, continuamente em um ambiente favorável, contribuirá para que a criança interaja e explore seu meio.

Uma criança que necessita em sala de aula mais atenção, devido a sua dificuldade de aprendizagem, o professor pedagogo deve com sua formação continuada em arteterapia, ter uma visão ampliada para facilitar o ambiente de aprendizagem tornandose estimulante, mediante ao aluno de forma dinâmica.

Portanto, a reflexão em relação ao comportamento da criança deve ser considerada suas produções e significações simbólicas, respeitando as particularidades mais profundas da criança e seu universo. Para tanto, faz-se tão necessário através da aplicação da arte na nossa prática pedagógica, atrelar a arteterapia como ferramenta de melhoramento e desenvolvimento artístico, despertando a sensibilidade. 
Nesse linear, a arteterapia é riquíssima para a infância. Nela permeia-se a expressão livre do interior e universo da criança advindos do seu psicológico infantil. A importância dessa pesquisa para reflexão nasceu decorrente da óptica pedagógica que a estrutura permanente da personalidade humana da criança nos primeiros anos da infância.

\section{REFERÊNCIAS}

ANDRADE L. Q. Terapias expressivas, São Paulo: Vector, 2000. ANDRES, M ${ }^{\mathrm{a}}$ Helena, Vivência e Arte, Agir, RJ, 1966.

BROUGÊRE, G. A criança e a cultura Lúdica. In: Kishimoto, T.M (Org.). O brincar e suas teorias. 6ed, São Paulo com gage Learning, 2011.

CORAZZA. Sandra Mara. Infância e educação Era uma vez. Quer que conte outra vez? Petrópolis vozes 2002.

CHARLOT. B. Relação com o saber, formação de professores e globalização: questões para a educação hoje. Porto Alegre: Artmed, 2005.

CRAIDY, CARMEM MAIA, O educador de todos os dias. Convivendo com crianças de 0 à 6 anos, mediação, RS, 2007.

$\begin{array}{lccc}\text { DIREITOS DE APRENDIZAGEM E DESENVOLVIMENTO NA EDUCAÇÃO } & \text { E } \\ \text { INFANTIL CONFORME BNCC. } & \text { Documento disponível em: }\end{array}$ http://basenacionalcomum.mec.gov.br/wp-

content/uploads/2018/06/BNCC_EI_EF_110518 versaofinal_site.pdf Acessado em: 14.11.2020.

GOMES, M. M. Oficinas com recursos expressivos na formação de educadores: mãos que criam arte, reflexão e vida, Im ciornal, S. Percursos em arteterapia. Arteterapia e educação, arteterapia e saúde. São Paulo: Summus, editorial, 2005.

MUNHOZ, M. L. P. (2006). Família "'ócus" da aprendizagem humana. Im M. S. Andrade e M. L; P. B. Franco Corgs. Aprendizagem humana. São Paulo: Casa.

POLÍTICA NACIONAL DE FORMAÇÃO DOS PROFISSIONAIS DA EDUCAÇÃO BÁSICA. Disponível: https://presrepublica.jusbrasil.com.br/ontar/ 335563771/decreto8752-16 Acessado 29.12.2020 às 14:10.

URRUTIGARAY, M. C. 2008. A arteterapia humanizando os espaços de saúde. São Paulo Casa do Psicólogo.

WINNICOTT. D. W (1975). O brincar e a realidade. Trad J.O.A. Abreu e V. Nobre. Rio de janeiro: Imago.

WINNICOTT, D.W. A família e o desenvolvimento individual. São Paulo: Martins Fontes, 1993.

WINNICOTT, D. W. O ambiente e os processos de maturação: estudos sobre a teoria do desenvolvimento emocional. Trad. Irineo Constantino Schuch Ortiz, 1963/1982. 
WINNICOTT, D. W. Natureza humana. Trad. David Litman Bogomoletz. Rio de Janeiro: Imago, 1988/1990.

WINNICOTT, D. W. (1975). $O$ brincar \& a realidade. Rio de Janeiro: Imago

WINNICOTT, D. W. (1971/1975). $\boldsymbol{O}$ brincar e a realidade. Trad. José Octavio de Aguiar Abreu e Vanede Nobre. Rio de Janeiro: Imago.

WINNICOTT, D. W. (1955c). A posição depressiva no desenvolvimento emocional normal. In Da Pediatria à Psicanálise. Rio de Janeiro: Imago Biografia de Donald Woods Winnicott em PDF. Disponível em:

https://febrapsi.org/publicacoes/biografias/donald-woods- winnicott/\#: :text $=$ Pediatra $\% 20 \mathrm{e} \% 20$ psicanalista $\% 2 \mathrm{C} \% 20$ nasceu $\% 20$ numa, anos $\% 20$ foi $\% 20$ para $\% 20 \mathrm{um}$ \%20internato. Acessado em 11.11.2020 às 17:54 


\title{
CAPÍTULO II
}

\section{A CONTRIBUIÇÃO DA LITERATURA INFANTIL NOS ANOS INICIAIS DO ENSINO FUNDAMENTAL NUMA PERSPECTIVA DE ESTIMULAR A PRÁTICA LEITORA}

\author{
Marcos Antônio Carlos dos Santos²; Jaqueline Fonseca de Queiroz ${ }^{3}$; \\ Aldejane Leandro de Araújo ${ }^{4}$; Ingride Alane Cabral Câmara da Silva ${ }^{5}$. \\ DOI-Capítulo: 10.47538/AC-2021.14-02
}

RESUMO: O presente artigo busca entender os caminhos que se deve percorrer ao trabalhar a literatura infantil na escola, e suas contribuições, a partir dos anos iniciais do ensino fundamental. Compreendemos que o tratamento dado à Literatura Infantil, no que é visto na escola, é apenas o básico, e muitas das vezes trabalhado erroneamente. Sugerimos que ao trabalhar com essas novas práticas de aprendizagem, seja desperta no leitor sua interação com o universo literário. Propomos que o uso do livro infantil ilustrado seja uma ferramenta de aprendizagem constante no cotidiano da criança, entre outras fontes de gêneros textuais, e que incentive o interesse por leitura.

PALAVRAS-CHAVE: Literatura Infantil. Contação de História. Livro infantil ilustrado.

\section{THE CONTRIBUTION OF CHILDREN'S LITERATURE IN THE EARLY YEARS OF ELEMENTARY EDUCATION FROM A PERSPECTIVE OF STIMULATING READING PRACTICE}

\begin{abstract}
This article seeks to understand the paths that must be taken when working with Children's Literature at school, and their contributions, from the early years of ontar school. We understand that the treatment given to Children's Literature, which is seen at school, is just the basics, and often wrongly. We suggest that when working with these new learning practices, the reader's interaction with the literary universe is awakened. We propose that the use of illustrated children's books be a constant learning tool in the child's daily life, among other sources of textual genres, and that it encourages interest in onta.
\end{abstract}

KEYWORDS: Children's Literature. Storytelling. Illustrated Children's Book.

\section{INTRODUÇÃO}

\footnotetext{
2 Doutorando em Ciências da Educação pelo Instituto Superior de Educação do CECAP - Professor Me. em Ciências da Educação, Escritor-marquinhosgmr@gmail.com

3 Doutoranda em Ciências da Educação pelo Instituto Superior de Educação do CECAP - Professora Me. em Ciências da Educação - jacfqueiroz@ gmail.com

4 Doutoranda em Ciências da Educação pelo Instituto Superior de Educação do CECAP - Professora Me. em Ciências da Educação - al-de-jane@ @otmail.com

5 Técnica em Química - IFRN- Instituto Federal do Rio Grande do Norte. Graduanda em Licenciatura da Computação pela UFERSA-RN - ingridecamara@ hotmail.com
} 
A magia da Literatura Infantil surgiu para abrilhantar o universo infantil e para agradar a jovens e adultos. Ao longo dos anos, vários estudos sustentam que esse universo de fantasia, imaginação, graciosidade, palavras imaginárias despertou na criança uma nova prática de aprendizagem no processo de letramento. Neste trabalho nos dispomos a pesquisar sobre "A contribuição da Literatura Infantil nos anos iniciais do ensino fundamental numa perspectiva de estimular a prática leitora". Partimos de uma investigação histórica a partir das fontes bibliográficas analisadas que aumentou no autor a curiosidade de entender melhor a construção da leitura literária. Iniciamos com um levantamento do ensino nas antigas civilizações e a invenção do livro infantil, como também, da entrada deste discurso no Brasil. Analisamos os principais autores brasileiros e o apoio dado no desenvolvimento intelectual da criança.

Sendo assim, o objetivo geral procurou averiguar uma observação mais holística do tema que impulsionou a conhecer melhor a trajetória da cultura letrada durante o início da colonização no Brasil e na república. Diante de toda essa justificativa o presente artigo apresenta como objetivos específicos: a formação inicial do leitor a partir do colono português no Brasil; Literatura Infantil: alfabetizar através dos gêneros textuais; contação de história como prática pedagógica; livro ilustrado como ferramenta de aprendizagem. Sendo assim, nossa intencionalidade é contribuir com um novo olhar sobre a leitura literária e as contribuições no processo ensino aprendizagem.

Optamos por uma metodologia bibliográfica porque toda pesquisa tem a preocupação central de identificar os fatores que determinam ou que contribuem para ocorrência de resultados negativos no que se refere à leitura e escrita. A pesquisa desenvolvida fundamentou-se em teorias que apoiam a leitura como um processo importante, que possibilita ao educando participar melhor da escolarização a qual faz parte.

Todos têm direito de ter acesso a esses conhecimentos, mas sabemos que o direito à aprendizagem é insuficiente, provavelmente por ausência de políticas públicas educacionais no contexto da educação. Precisa-se minimizar ou erradicar o analfabetismo funcional das crianças com estratégias adequadas possibilitando a qualidade do ensino. Pretendemos com esse artigo ajudar as escolas a desenvolverem novas estratégias de leitura. Observou-se durante o desenvolvimento do texto que é inadmissível a criança 
chegar ao final do ensino fundamental anos iniciais sem ter as devidas competências de leitura e escrita. Relembrando que a pesquisa fundamentou-se em teorias que apoiam a alfabetização e letramento, pois as duas linhas de entendimento procuram caminhos diferentes na construção do processo ensino aprendizagem.

Concluímos a pesquisa sugerindo a disponibilização do material pesquisado na escola, e que possa ser consultado possivelmente no planejamento escolar. Além do mais, recomendamos à escola estruturar melhor o Projeto Político Pedagógico (PPP), revendo os princípios éticos, educacionais e políticos.

\section{A FORMAÇÃO DO LEITOR A PARTIR DA VINDA DO COLONO PORTUGUÊS AO BRASIL}

A cultura letrada no Brasil colônia teve início com a chegada dos portugueses em 1500. Na época havia uma população indígena, que obrigada pelos jesuítas (os mensageiros de Deus), impuseram aos nativos outra cultura, especificamente a europeia. Os indígenas brasileiros possuíam uma cultura que passava de geração a geração. Sabemos que havia várias tribos em cada aldeia, e os costumes desses povos eram diversificados. Com o receio de perder as novas terras recém-descobertas, a coroa portuguesa logo tratou de povoá-la implementando na colônia o sistema de Capitanias Hereditárias, em 1532. Devido ao fracasso das Capitanias Hereditárias, a coroa portuguesa procurou substituir criando um novo sistema de administração para a colônia, denominado de Governo Geral, em 1549. Tomé de Souza, o primeiro governador-geral aportou no Brasil, trazendo os primeiros jesuítas com a missão de converter os gentios. Os primeiros feitos no domínio foram: criar escolas, colégios e seminários. Com tudo isso, os jesuítas criaram a princípio a educação nos moldes da fé cristã, opondo os gentios a acreditarem que o que estava sendo ensinado era propício à aprendizagem dos cativos. Tradições, costumes, dos povos indígenas passaram a ser retirados em substituição à cultura europeia. A catequese foi a principal cartilha de aprendizagem na colônia portuguesa.

Segundo Saviani (2021) a educação colonial no Brasil compreende etapas diferentes: o período heróico de (1549-1570), o Ratio Studiorum (1599-1759) e a fase pombalina (1759-1808). 
Com a chegada do marquês de Pombal (1750-1777) na colônia portuguesa, adepto das ideias iluministas, tratou de priorizar a educação que precisava ser libertadora e desprender do vínculo do ensino jesuíta. Além disso, várias medidas administrativas foram tomadas: suprimiu as capitanias hereditárias; elevou o Brasil à categoria de vicereinado. A partir deste planejamento administrativo, o objetivo de Pombal era desenvolver uma política socioeconômica e cultural na colônia. O confronto entre jesuítas e o governo pombalino culminaram com a expulsão da Companhia de Jesus do Brasil, e por alvará restringiu o seu domínio. Por "Alvará” também estruturava o ensino público na colônia. Para Saviani (2021, p. 82), o objetivo do Alvará privilegiou os estudos de nível primário e secundário [...] e a importância da cultura das ciências.

A visão educacional pombalina era expandir o ensino à colônia que não fosse apenas o ensino religioso. Ele acreditava que o conhecimento deveria ser laico, e a ciência propícia para ajudar a humanidade. Portanto, o alvará determinava que todas as classes e escolas dirigidas pelos jesuítas fossem extintas. Por tornar-se um homem respeitado pelas suas ideias reformistas, Pombal foi destituído do cargo de ministro pela rainha D. Maria I, após a morte de D. José I, em 1777. Seu legado na colônia foi desprovido do pensamento de D. Maria I. A monarca tinha como objetivo o retorno dos religiosos ao magistério, como professores das aulas régias aproximando-os novamente do ensino na colônia. Após a doença de D. Maria I, D. João é nomeado príncipe regente de Portugal, em 1799. Adepto das aulas régias intensificou o ensino na colônia, onde mesmo com toda a precariedade manteve-se firme em dar continuidade às ideias educacionais deixadas pelo Marquês de Pombal.

Saviani (2021) argumenta que:

As reformas pombalinas da instrução pública perduraram de 1759 a 1834 que tiveram como características básicas: estatização e secularização da administração do ensino concentrando a gerência de todos os assuntos ligados à instrução na figura do diretor-geral de Estudos, criado pelo Alvará de 28 de junho de 1759, cuja ação se estendia a todo o reino por meio de diretores locais e comissionários; estatização e secularização do magistério, organizando exames de estado conduzidos por Diretoria-Geral dos Estados como mecanismo de controle e condições do exercício docente, ficando proibidos de ensinar aqueles que não fossem aprovados nesses exames; estatização e secularização do ensino que passou a ser controlado pela Real Mesa Censória mediante a censura de livros, antes exercida pelo Santo Ofício e obrigando os professores a encaminhar relatórios das atividades por 
eles realizadas, assim como do desempenho de seus alunos, à DiretoriaGeral dos Estudos; estatização e secularização da estrutura organizacional dos estudos mediante a criação de aulas régias de primeiras letras e de humanidade mantidas pelo Estado com recursos provenientes do "Subsídios Literário", criado especificamente para esse fim; estatização dos estudos superiores por meio de uma ampla e profunda reforma da Universidade de Coimbra (SAVIANI, 2021, p. 110).

Pela ordem indicada à reforma educacional que o governo do Marquês de Pombal pretendia realizar na colônia, o ensino deveria favorecer à população e, não apenas a um grupo elitista. Vimos que, mesmo com as ideias revolucionárias nos moldes da filosofia iluminista do século XVIII, Pombal não agradou à rainha, D. Maria I. As modificações apresentadas se tornaram um empecilho para concretizar-se, e diversos foram os motivos, entre os quais podemos destacar: a falta de professores, a escassez de material didático suficiente e o atraso cultural. Enfatizamos que, com a expulsão de Pombal da colônia, o Brasil passou também pela "fase joanina", com a chegada da família real em 1808, chefiada pelo príncipe regente, em 1816, rei com o título de Dom João VI.

De acordo com Saviani (2021, p. 113), nessa nova fase as ideias pedagógicas oriundas do pombalismo continuam inspirando as iniciativas de D. João VI, onde sua motivação principal tenha sido de caráter administrativo". Ou seja, a necessidade da formação de quadros para a administração e para a defesa militar do reino, cuja sede se transferiu para o Rio de Janeiro, conduziu à criação de cursos organizados nos moldes das aulas régias. Assim, em 1808 criou a Escola de Cirurgia na Bahia; de Cirurgia e Anatomia no Rio de Janeiro em 1809; a Imprensa Régia Real e a Academia Militar em 1810; o Jardim Botânico em 1808; o Banco do Brasil em 1808, a Biblioteca Real em 1810, que intensificou a cultura letrada, mas restrito à nobreza. Por Decreto, em 1814, a Biblioteca Real, depois de organizada e ampliada seu acervo de maneira significativa, passou a ser consultada de forma franqueada ao público, conforme Gomes (2015, p. 2009).

Portanto, o ensino na colônia teve caráter elitista, tudo que era visto como aprendizagem, apenas os filhos da elite desfrutavam desse privilégio, sendo bem tratados para exercerem profissões como de médico, advogado, almirante, entre outras. $\mathrm{O}$ investimento em educação naquela época chegava apenas na casta privilegiada do Brasil. 
Além disso, quando terminavam o ensino primário muitos desses jovens iam estudar na Europa.

\section{LITERATURA INFANTIL: ALFABETIZAR ATRAVÉS DOS GÊNEROS LITERÁRIOS}

A história da Literatura Infantil tem seu apogeu na Europa do século XVII, por Charles Perrault e os irmãos Grimm, no início do século XIX. Em 1697, Perrault publicou os famosos Contos da Mamãe Gansa que intensificaram a literatura infantil. $\mathrm{Na}$ época não se escrevia para crianças, pois a infância não passava de algo tão insignificante durante a Idade Média, período em que as crianças da casta subversiva eram tratadas como indivíduos desprovidos de qualquer direito à educação, o que impulsionou a trabalhar para sustentar a nobreza. Vale ressaltar que no princípio o ensino de literatura infantil foi direcionado aos filhos e filhas da realeza.

Com a Revolução Industrial, na metade do século XVIII, parte da população deslocou-se do campo para as cidades à procura de ofertas de emprego. Com a invenção das máquinas para fabricar mercadorias surgiram novas classes sociais, e a exploração do trabalho infantil fortaleceu culminando numa grande desigualdade social. No contexto pesquisado inicialmente, só as crianças abandonadas em orfanatos eram entregues aos patrões para trabalharem nas fábricas. Com o passar do tempo, as crianças que tinham famílias começaram a trilhar o mesmo caminho, trabalhando por longas e exaustivas horas, perdendo, assim, toda a sua infância.

Com as reformas políticas educacionais ocorridas em meados do século XVIII, as injustiças cometidas pelo desenvolvimento do sistema capitalista europeu ajustaram de modo significativo os direitos das crianças ao acesso à escola. A literatura infantil aparece no currículo escolar em que as preocupações sociais se voltam à criança. Era preciso incluir as crianças no processo educacional retirando-as das fábricas e preparando-as para se tornarem indivíduos plenos de direitos: a infância, a saúde, a educação, a cultura, o lazer. Era dever do Estado reparar o erro cometido pelo sistema opressor devolvendo a criança escolarizada à sociedade.

Segundo Zilberman (1985, p. 13): 
A nova valorização da infância gerou maior união familiar, mas igualmente os meios de controle do desenvolvimento intelectual da criança e a manipulação de suas emoções. Literatura Infantil e escola, inventada a primeira e reformada a segunda, são convocadas para cumprir esta missão (ZILBERMAN, 1985, p. 13).

Diante disso, a Igreja Católica controlava o ensino durante a Idade Média entre os séculos V ao XI, sendo o ensino ministrado à população da nobreza e do clero. Convém lembrar que os conteúdos ensinados estavam organizados numa estrutura curricular formada pela cultura erudita, e a pedagogia fundamentava-se na memorização, na acumulação de conhecimentos e na moralização da criança.

Com o legado que o ensino da literatura infantil deixou pelos seus precursores ao longo dos séculos, tentou-se reformular esse conceito à medida que os discursos intensificaram a importância de cuidar melhor da criança, preparando melhor o sujeito com as devidas competências de letramento.

Diante todo esse percurso, no Brasil, o ensino da literatura infantil surgiu no final do século XIX. Nossos escritores brasileiros utilizaram-se das histórias clássicas infantis europeias. Sendo assim, com base nos textos estrangeiros os escritores brasileiros tomaram como suporte os ensinamentos da literatura infantil de alguns países criando narrativas que pudessem ser trabalhadas na escola daquela época. Um detalhe: os textos eram controlados pelos educadores católicos que participaram da organização do ensino público.

No período compreendido entre os anos de 1920 e 1945 a emancipação da literatura infantil brasileira aos poucos dava espaço a outras manifestações culturais: o Barroco, o Parnasianismo, o Modernismo etc, que posteriormente entraram no currículo escolar. No que tange à literatura infantil, Monteiro Lobato foi o primeiro autor brasileiro que investiu no público infantil, criando uma nova estética de aprendizagem literária, fugindo aos padrões da pedagogia.

Já nas décadas de 1930 a 1945, durante o governo de Getúlio Vargas, a literatura infantil se acentua no discurso da escola pública, mas com pouca intensidade. Os textos impressos e as ilustrações deveriam passar por uma inspeção rígida que não ofendesse a imagem do governo. Após a redemocratização da política brasileira em 1945 a 1960, a literatura infantil ganhou mais autonomia nas escolas, surgiram novos autores com 
linguagem poética, questionadora, e ideias ousadas como as de Ana Maria Machado, Mário Quintana, Sylvia Orthof, Ziraldo e Ruth Rocha.

A presença da literatura infantil foi se concretizando a partir do momento que entraram em cena os gêneros literários: o conto, a poesia, o folclore, a fábula. Uma nova geração de autores literários tinha um propósito de formar leitores competentes utilizando métodos adequados na formação do leitor literário.

De outro ponto de vista, Abramovich (1997, p. 134) discute como desenvolver por intermédio da literatura o potencial crítico da criança. Sustenta que por meio de um material literário de qualidade, a criança é capaz de pensar criticamente e reformular o pensamento. Considerando aqui, como qualidade do material literário para o bom desempenho do processo da formação do leitor literário, textos que apresentam uma proposta ficcional que atenta o imaginário dos leitores e os exercita a compor novas possibilidades para perceber o mundo à sua volta. Contrariando, desta forma, os textos, por meio da história ficcional ou dos personagens, sobre determinado assunto.

É sabido que toda criança gosta de história e ainda mais se tratando de histórias infantis. Os textos literários infantis ajudam na compreensão da leitura e escrita. Como afirma Paiva e Oliveira (2010, p. 28), o livro infantil só será considerado literatura infantil legítima mediante a aprovação da criança. Para isso o livro precisa atender as necessidades da criança, que seriam: povoar a imaginação, estimular a curiosidade, divertir, e por último, sem imposições, educar e instruir. Por isso, escolher a obra adequada para a leitura faz parte da visão que o professor tenha. A postura do educador nesse contexto é primordial, pois familiarizar-se com a narrativa é poder se reinventar para agradar o público, não improvisar, porque a criança percebe quando algo a desagrada. Outro ponto pertinente é que o tempo e o espaço sejam significativos para a construção do conhecimento. Nem toda história lida tem o apreço do leitor. Lembrando que a criança bem acolhida transborda de alegria. Além do mais, incluir a criança dentro deste contexto possibilita a integração na tentativa de aproximá-la a gostar de ler.

De acordo com Kohan (2003, p. 10) "um livro infantil pode conter episódios divertidos tanto para crianças como para adultos [...]”. Lembrando que o texto infantil seja para a criança, a mesma ou outra história contada para adultos, deve seguir caminhos diferentes. No caso da criança, ela cria um mundo de fantasia, o adulto, não, recria a 
história com outra significação. Exemplo: a história “A Bela Adormecida”, um filme norte-americano de 1959, com roteiro baseado no conto de fada, criado por Charles Perrault e "Malévola", um filme estadunidense, de 2014, que narra a história a partir da principal vilã, a bruxa Malévola. Sendo assim, duas histórias passam a ter vários roteiros e compreensão diferente para agradar ao público infantil e adulto. Por isso, aproximar a criança do livro, logo cedo, é dever da família. Com isso, a criança ao longo do seu desenvolvimento cognitivo cria hábito pela leitura e aprimora a escrita, bem como, desenvolve competência, habilidade, compreensão entre outros.

\section{CONTAÇÃO DE HISTÓRIA COMO PRÁTICA PEDAGÓGICA}

A prática pedagógica tem nos revelado que as crianças que nascem e convivem em ambiente letrado, e têm acesso aos livros, desenvolvem interesses lúdicos mediante a leitura e a escrita. Sua inserção na escola é uma continuidade da prática exercida pelos pais. Vale reforçar que há crianças que por não terem pais leitores, e escola sem incentivo à leitura, acabam fadadas ao fracasso escolar e por toda a vida.

Escrever para crianças é contá-la num mundo de fantasias e poder sentir junto com elas a alegria, risos, curiosidade, questionamento, e valorizar o que a criança tem de melhor. A criança imatura é curiosa, busca respostas para diversas perguntas. É natural da criança, por isso, ao reformular um texto infantil ou contar a história original, temos que nos preocupar com a percepção crítica da criança, se ela está gostando ou não da leitura. Segundo Kohan (2003, p. 13), "é importante observar que muitas publicações da atual literatura infantil afundam as crianças na passividade e na banalidade". E este é um perigo real. No entanto, a criança deve ser capaz de escolher a história, e não ser imposta pelo professor.

Inserir a contação de história como metodologia no processo de aprendizagem da criança é pertinente, mas temos que observar que a história lida pelo contador precisa passar por uma leitura solitária antes da transmissão oral. Vale reforçar que o contador de história não pode abrir mão da qualidade literária dos textos que escolhe para narrar. Ele precisa dominar, como também, investigar o que é produzido na área de literatura e possuir uma bagagem pessoal de leitura. Por esse motivo, a escolha da história deve levar em consideração o seu público-alvo, para quem conta, onde conta é o que conta. Outra 
preocupação é a visão mais holística e detalhada da escrita para satisfazer o leitor. Além disso, o contador não deve esquecer que a leitura é o exercício de um diálogo. Para que a transmissão da oralidade seja eficiente é necessário que o contador narre suas histórias sempre performáticas, autêntico, o ímpeto vocal com desenvoltura, gracioso, envolvente, de modo que chame a atenção do leitor.

Segundo Kohan (2003, p. 19):

A literatura infantil abarca diferentes gêneros. Para todas as idades, podemos escrever poesia (poemas, cantigas de ninar, cantigas de Natal, cantigas de rodas, trava-língua, quadrinhas); conto (conto literário, conto popular, conto mítico); formar breves (fábulas, lendas, parlendas, adivinha, causos, provérbios); teatro (comédia, teatro de fantoches, teatro de marionetes) (KOHAN, 2003, p. 19).

Do ponto de vista da autora, existem vários tipos de gêneros literários que podem envolver a criança e despertar logo cedo o gosto pela leitura, então, a escola é o espaço adequado. A escola não pode ser omissa; deve incluir logo cedo a literatura infantil no currículo escolar. É importante frisar o uso metodológico da contação de história. Não deve acontecer quando as crianças estiverem agitadas e nem tão pouco no final da aula, porque não trará resultado satisfatório. Precisa ser bem planejada com o(a) professor(a) da turma, como também orientado pela coordenação pedagógica, não deve ser contada de qualquer maneira.

Tudo exige planejamento e preparo para desenvolver a prática. A Literatura, ou (os textos literários), deve fazer parte do cotidiano da criança. De nada adianta a criança gostar de ler se não fizer da leitura um hábito. Precisamos desenvolver práticas pedagógicas eficientes dentro desse contexto, como também, o professor necessita de formação continuada para ensinar de forma significativa o processo literário.

Conforme Maginani (2001, p. 63) alerta: "se propomos ao aluno que ele deve ler apenas o que gosta, não podemos nos esquecer de que esse gosto não é tão natural assim". Pelo contrário, é profundamente marcado pelas condições sociais e culturais de acesso aos códigos de leitura e escrita.

Bem lembrado pela autora, pois não é para o educador forçar o educando a gostar de todo tipo de texto literário. Ele pode mostrar a importância desse material no desenvolvimento cognitivo e no convívio social. Deixar a criança livre para escolher o 
que lhe atrai permitindo uma leitura livre. Supostamente essa decisão aproximará texto e leitor no processo ensino aprendizagem.

De acordo com Kohan (2003, p. 22) o que é adequado para cada criança:

\begin{tabular}{|l|l|}
\hline Aos 3 anos. & $\begin{array}{l}\text { As ilustrações devem predominar. As histórias para crianças } \\
\text { dessa idade devem possuir estruturas simples [...]. O } \\
\text { vocabulário deve ser simples, mas rico, e o enredo deve } \\
\text { provocar a curiosidade da criança, que não deve ser mais tratada } \\
\text { como um bebê, pois aos 3 anos ela experimenta sua primeira } \\
\text { crise de personalidade [...]. }\end{array}$ \\
\hline $\begin{array}{l}\text { Aos 5 ou } 6 \\
\text { anos. }\end{array}$ & $\begin{array}{l}\text { Esse público aprecia narrativas em etapas, nas quais um ou dois } \\
\text { heróis vivem suas aventuras no tempo e no espaço, superando } \\
\text { medos, experimentando surpresas, alimentando esperanças, até } \\
\text { o final feliz [...]. }\end{array}$ \\
\hline Aos 8 anos & $\begin{array}{l}\text { Aventuras, detetives, grupos de amigos e o medo são temáticas } \\
\text { que atraem as crianças dessa idade. Narrativas fantásticas e } \\
\text { mitológicas são apreciadas, bem como histórias da vida real que } \\
\text { abordam conflitos em família, na escola, no esporte, etc. }\end{array}$ \\
\hline Aos 12 anos. & $\begin{array}{l}\text { Romances sobre a amizade, o primeiro amor, os problemas do } \\
\text { entorno social (ecologia, pacifismo, convivência, etc). Cujo os } \\
\text { protagonistas sejam adolescentes como os leitores, vivendo essa } \\
\text { difícil fase de transição. Histórias de suspense, aventuras } \\
\text { arriscadas, ficção científica, poesia e teatro podem agradar a } \\
\text { leitores que estão saindo da infância e entrando na maturidade. }\end{array}$ \\
\hline
\end{tabular}

Com base nas definições sustentadas pela autora, salientamos a importância de ensinar os gêneros textuais obedecendo às fases de aprendizagem da criança. É importante destacar: quanto aos estudos na área de leitura e literatura, a literatura infantil seja efetivada com um propósito de atender o desenvolvimento intelectual da criança, que seja bem trabalhada.

O letramento é o objeto de ensino para a construção de alfabetizados, primordial instrumento de formação de leitores. Esta atividade iniciada na escola torna-se capaz de desenvolver práticas educativas possibilitando evoluir nas competências e habilidades necessárias da aprendizagem respeitando as fases de desenvolvimento cognitivo da criança. Por essa razão, ao trabalhar os textos literários, o contador de história necessita 
conhecer o público antes de operar um gênero literário, pois sem o diagnóstico da turma não haverá sintonia com os alunos.

A escola deve compreender que o que deve ser trabalhado tenha significado no processo ensino aprendizagem da criança. Esse entendimento possibilita a organização do currículo escolar na qualidade das práticas educativas de leitura e escrita. Formar leitores é algo que requer, portanto, condições favoráveis para a prática de leitura; não se restringe apenas aos recursos materiais disponíveis, pois, na verdade, o uso que se faz dos livros e demais materiais impressos é o aspecto mais determinante para o desenvolvimento da prática e do gosto pela leitura. Por isso, a escola precisa entender seu verdadeiro papel na vida da criança.

Uma escola que não desenvolve com eficácia seu processo de alfabetização e letramento deve rever esse conceito. Além do mais, a escola precisa desenvolver e assumir sua responsabilidade política, pois esta necessita desenvolver a alfabetização como forma de pensamento, processo de construção do saber e entender que a partir do momento que a criança é inserida no convívio escolar, passa a ter total responsabilidade no processo de ensino aprendizagem.

Dessa forma a Literatura é um processo gradativo que tem que ser discutido nas escolas, não deve ser vista como algo desprovido do currículo, e sim, um processo contínuo de aprendizagem, seja qualquer texto literário, que venha atender o propósito do leitor infantil. É preciso formar leitores que tenham um envolvimento integral com a leitura de maneira que esta desenvolva a reflexão e o espírito crítico.

\section{LIVRO ILUSTRADO FERRAMENTA DE APRENDIZAGEM}

Há milhões de anos, a comunicação entre os homens foi transformada em arte a partir do momento que resolveram pintar nas paredes das cavernas. Era uma espécie de linguagem imagética que facilitava o diálogo entre eles. A partir de 3500 A.C, surgiu a primeira escrita desenvolvida pelo homem, a "cuneiforme", na Mesopotâmia. Outras civilizações adaptaram sua escrita e com isso ocorreu o desenvolvimento das sociedades orientais. O legado deixado pelos orientais culminou nas antigas civilizações ocidentais ao aprimorar a capacidade de evolução humana, especificamente a grega e a romana. 
$\mathrm{Na}$ conjuntura deste trabalho a necessidade criada envolve todo um percurso histórico em que podemos entender sobre a importância do texto imagético no desenvolvimento intelectual da criança. Reordenar percursos para chegarmos a alguns focos teóricos e metodológicos contribuíram no sustento de que a partir das contribuições que vieram no movimento da História Cultural de Charlier (2001), que nos redimensiona a um olhar mais enfático entre o autor e a editora. Certau (2007) contribui para desenvolver a pesquisa. Scott e Nikolajeva (2011) trazem contribuições do livro ilustrado. Diante disso, o percurso histórico feito nos conduz a uma dimensão em que a história do livro ilustrado ganhou adeptos nos países da Europa e nos Estados Unidos. Destacamos a Alemanha, onde muitas pesquisas são dedicadas aos livros ilustrados, e que segundo Scott e Nikolajeva (2011), dito por Spitz - os livros ilustrados são examinados no contexto da psicologia do desenvolvimento e de seu efeito terapêutico sobre a criança leitora.

No Brasil os primeiros livros foram trazidos pelos portugueses colonizadores e a maioria era sobre religião e medicina. Enfatizamos que durante a maior parte do período colonial de 1500 a 1822, não era permitida a produção de livro na colônia e tudo era controlado pelos inspetores reais. A partir de 1808, D. João, príncipe regente, autorizou as impressões gráficas importando maquinário para isso. Com a Proclamação da República em 1889, as editoras e os ilustradores nacionais ganharam destaque; com restrições, as publicações em livros, revistas ou outros meios de comunicação na época tinham o controle do Estado. Foi com Hans Cristhan Andersen que o livro ilustrado infantil ganhou adeptos no Brasil com a história do "Patinho Feio", de 1843.

Quando pensamos no livro ilustrado para criança, ressaltamos que eles são uma ferramenta de aprendizagem e que podem despertar a imaginação da criança. Provavelmente as ilustrações são o primeiro contato que a criança tem com as artes visuais. Segundo Kohan (2003, p. 34) na literatura infantil, a imagem, o visual, adquire uma importância muito maior do que na literatura de adultos.

Quando o texto e imagem estão bem colocados no livro, a criança logo percebe que a narrativa faz menção entre a escrita e imagem, mas devemos entender que essa aguçada percepção deve acontecer quando a criança tem suas competências de leitura bem trabalhadas. 
A leitura do livro ilustrado é mais que ler um texto e imagem, é entender que há duas vias de entendimento; isso reforça a aprendizagem e complementa a graciosidade e nuances que compõem uma boa obra literária. Destacamos ainda que a capa do livro deve chamar a atenção do leitor infantil, o qual reforça o interesse da criança em apoderar-se da obra. Outro ponto a considerar são as ilustrações, uma vez que a criança adora contos de fadas com príncipes, princesas, fadas, duendes, bichos, enfim, tudo que for imaginário, a criança gosta de ouvir. A história deve agradar ao público infantil, e antes de montá-la é necessário que a criança seja participativa na escola da história.

Segundo Colomber (2011, p. 35), a imagem está presente na literatura infantil desde seu surgimento, mas agora se encontra enormemente potencializada por sua presença na comunicação social, nas novas possibilidades técnicas, nas estratégias de venda consumista e nas tendências a fusões de códigos da arte atual. Sendo assim, a literatura infantil contribui, inclusive, com uma forma artística inovadora nesse campo: o livro ilustrado. Esta conquista provocou o entusiasmo de todos os setores e, agora, há uma nova força referente aos usos da imagem, mas com a "tarefa" de sustentar o desafio apresentado à palavra.

Quando o professor leva um livro ao aluno, sua intenção é que o livro seja bem recebido pela criança, mas nem tudo acontece da forma como foi planejada. Muitas vezes o livro é rejeitado logo de cara, por não apresentar a capa que chame a atenção, o tipo de letra, as cores etc.

Assim, ler um livro ilustrado não se resume a ler texto e imagem. É isso, e muito mais. Ler um livro ilustrado é também apreciar o uso de um formato, de enquadramento, da relação entre a capa e guardas com o conteúdo; é também associar representações, optar por uma ordem de leitura no espaço da página, afinar a outra... Ler um livro ilustrado depende certamente da formação do leitor (LINDEN, 2011, p. 8-9).

Através desse entendimento, podemos analisar que a ilustração não faz parte apenas dos livros infantis ilustrados, as imagens tornaram-se interdisciplinares estendendo-se a outras áreas do conhecimento. O educador não deve apenas explorar as imagens num texto literário. Deve acontecer também na aula de História, Geografia, Matemática etc. A inserção da imagem numa aula faz com que o educando consiga desenvolver aptidões pela leitura e interpretação textual. Ao ler um livro ilustrado, seja 
didático ou infantil, o educador deve chamar o leitor para conhecer outro universo da leitura como os textos nos livros didáticos.

\section{Imagem 01}

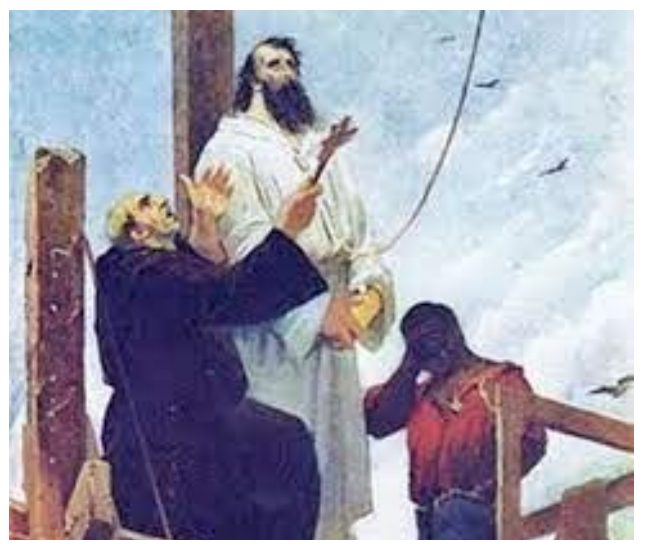

Joaquim José da Silva Xavier nasceu na fazenda de Pombal em 12 novembro de 1746, e faleceu em 21 de abril de 1792. Foi dentista, tropeiro, minerador, comerciante, militar e ativista político, que atuou nas capitanias de Minas Gerais e Rio de Janeiro. Foi líder do movimento da Inconfidência Mineira, 1789 onde denunciou os desmandos da coroa portuguesa na colônia.

Título: A condenação de Tiradentes.

Fonte: historiadetudo.com

Trabalhando com imagem

a) Qual o título da imagem?

b) Qual a fonte pesquisada?

c) O que aparece em primeiro plano? $\mathrm{E}$ ao fundo?

d) Faça uma descrição da imagem. Como as pessoas representadas estão vestidas? O que estão fazendo?

e) As pessoas representadas na imagem têm a mesma condição social? Estão desempenhando as mesmas atividades?

f) Qual o personagem principal da figura? Qual era sua função na época?

g) Escreva um resumo sobre a vida de Tiradentes.

Imagem 02

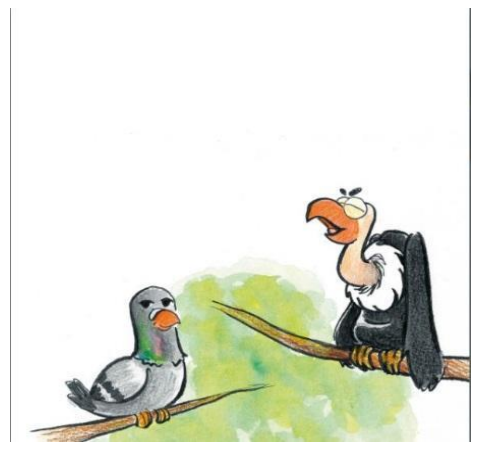

Fonte: Duarte
...O pombo Frederico, logo voou e dedurou o plano das aves ao urubu.

Frederico: - Senhor, os pássaros estão revoltados e estão preparando uma emboscada para prender o senhor.

Gaston: - Conte-me tudo.

Frederico: - Grou, grou! Gru, ru, gru ru! Ru lu!

Gaston: - Volte e me mantenha informado.

- Chem-chem! Chem-chem! Chem-chem!(risos).

De volta ao bando, o pombo fofoqueiro passou a observar tudo os que as aves planejavam. (SANTOS, 2019, p. 10). 
Assim, com o texto, as imagens estão presentes de forma diferente. Na imagem 1 retrata o personagem real de Joaquim José da Silva Xavier, mártir da Inconfidência Mineira de 1789. Enquanto a imagem 2 narra uma história ficcional criada pelo autor. Embora as ilustrações estejam presentes no texto, os roteiros têm sentidos opostos e, a criança precisa estar ajustada dentro do processo de letramento. Com isso, diferenciar o texto literário do texto em prosa possibilita ao educador desenvolver práticas leitoras diferenciadas contribuindo no sucesso educacional da criança. O educador tem de cumprir com suas responsabilidades enquanto formador desse processo literário.

Portanto, ninguém deve ser obrigado a gostar de ler, mas deve ser influenciado, estimulado, incentivado. Isso são iniciativas que devem partir da família, já mencionado anteriormente no texto. Ou seja, a escola é outro veículo de motivação que deve acolher a criança nesse universo letrado oferecendo o suporte necessário na trajetória educacional da criança.

\section{CONSIDERAÇÕES FINAIS}

Ao escrever esse artigo partimos de uma leitura a partir do processo histórico desde a chegada do colonizador português à Proclamação da República de 1889. Com os primeiros livros ilustrados no Brasil durante a era pombalina, o incentivo à educação e à cultura foi se alargando no desenvolvimento da colônia, porém, devido ao embate entre religiosos e o ministro Marquês de Pombal o atraso na educação foi ficando para trás. A educação na época voltou a ser controlada pelos educadores jesuítas com a autorização de D. Maria I. A partir da sua doença, impossibilitada de governar, o príncipe D. João VI assumiu o trono português. Após a invasão francesa em Portugal, a corte aportou no Brasil em 1808. No Brasil, D. João VI abriu os portos brasileiros às nações amigas, e no campo da educação foi simpatizante das ideias pombalinas, ponderado.

Com o advento da circulação do livro na colônia propagou-se o ensino da Literatura Infantil restrito às crianças da nobreza que se tornaram conhecedores das histórias infantis através dos autores estrangeiros e brasileiros. Com as reformas no campo da educação as crianças em vulnerabilidade adquiram seus direitos de frequentar as escolas. A Literatura Infantil ganhou novos gêneros textuais, como também o público para todos os gostos literários. Surgem o conto, a poesia, a fábula, o folclore, as cantigas 
de ninar etc, e novas metodologias surgiram no processo ensino aprendizagem para atender as crianças. A escola é construída pelo sujeito da aprendizagem, que é a criança, sendo que os direitos de aprendizagem devem ser assegurados e respeitados. Novas formas de comunicação e a construção de novas habilidades os levam a um novo caminho de aprendizagem, possibilitando à criança entender o universo das letras ao seu redor.

Buscamos enfatizar o papel da escola na formação dos educandos, numa perspectiva de interação constante da leitura onde as crianças sintam-se interligadas nas diferentes formas de aprender a ler.

Entendemos ainda, que o professor deve estar sempre revendo sua prática docente em sala de aula e modificando, consecutivamente, sua maneira de trabalhar com os discentes, dinamizando, satisfazendo curiosidades e inquietações numa perspectiva de alcançar resultados satisfatórios no decorrer do exercício do magistério.

Consciente da importância do hábito de ler, a escola, mesmo com as limitações relacionadas ao espaço físico, material didático e capacitação docente, entre outras, necessita utilizar outros repertórios que exaltem a leitura como algo imprescindível na escolaridade da criança e na sociedade letrada.

Sobre os diversos aspectos contidos no corpo deste trabalho, percebe-se que as tarefas foram direcionadas aos protagonistas da pesquisa, e possivelmente existam reais possibilidades da ação escolar tornar-se multiplicadora na aprendizagem de leitura, tornando-se significativa para o leitor.

Portanto, a parceria escola/família tem um papel importantíssimo na formação dos alunos. Além disso, faz com que os educandos sejam capazes de competir com as novas tecnologias educacionais existentes no mundo globalizado. Assim sendo, acreditamos que apesar das dificuldades existentes, podemos levar os alunos a subirem cada vez mais degraus no mundo letrado.

\section{REFERÊNCIAS}

ABRAMOVICH, Fanny. Literatura Infantil: Gostosuras e Bobices. São Paulo, 1997. COLOMBER, Teresa. Introdução à Literatura Infantil e Juvenil Atual. 1. Ed. São Paulo: Global, 2017. 
GOMES, Cristina.

Literatura

Infantil.

Disponível

em: http://www.infoescola.com/literatura-infantil/> Acesso em: 20/04/2009.

KOHAN, Sílvia Adela. Escrever para crianças: tudo o que é preciso saber para produzir texto de literatura infantil. São Paulo: Gutemberg, 2003.

MAGNANI, Cecília. Problemas da Literatura Infantil. 3. Ed. Rio de Janeiro: Nova Fronteira, 1984.

NICKOLAJEJA Maria; SCOTT Carole. Livro Ilustrado: Palavras e Imagens. São Paulo: Cosac Naify, 2011.

PAIVA, S. C. F.; OLIVEIRA, Ana C. F. A literatura infantil no processo de formação do leitor: Cadernos de Pedagogia. São Paulo, Ano 4v. 4n. 7, p. 22-36, jan./jun. 2010.

SANTOS, M. A. C. O mistério no reino dos pássaros. Natal: Editora Sul, p. 15, 2019.

SAVIANI, Dermeval. História das ideias pedagógicas no Brasil. 6. Ed. Ampl. Campinas/SP: Autores Associados, 2021.

ZILBERMAN, Regina. A Literatura Infantil na Escola. São Paulo: Global, 1985. 


\title{
CAPÍTULO III
}

\section{A ESCRITA NA EDUCAÇÃO INFANTIL}

\author{
Mirtes Pereira do Nascimento Figueredo6; Laura Nayara de Macêdo Pereira7; \\ Rosa de Lima Martins ${ }^{8}$; Raisa Corlet dos Santos9. \\ DOI-Capítulo: 10.47538/AC-2021.14-03
}

RESUMO: O presente artigo vem demonstrar que a escrita na Educação Infantil é de fundamental importância na interação da criança com o adulto. A fundamentação teórica faz considerações sobre a necessidade da escrita em diversas formas contextuais, pressuposta para o desenvolvimento intelectual em uma relação genuína do indivíduo com os diversos fenômenos com os quais entra em contato na dinâmica sociocultural em que está inserido. A análise comparativa entre o registro gráfico do som e a escrita alfabética destas crianças demonstrou que, da mesma forma que a criança se apropria das letras mais significativas para escrever o nome dos objetos, ela utiliza os símbolos musicais com os quais tem contato para grafar os sons que canta ou que faz parte do seu cotidiano. Com base nessas análises é possível concluir que, se a criança recebeu o mesmo estímulo nessas duas linguagens, às estratégias que ela busca para representar graficamente os fenômenos sonoros, apresentam características semelhantes. Tanto nos aspectos gráficos como nos processos construtivos da escrita. Tais conclusões suscitam a reflexão sobre a necessidade da alfabetização nas diversas formas de linguagem para uma relação mais consciente e real com o ambiente em que vivemos. A metodologia utilizada neste trabalho foi pesquisa bibliográfica e coleta de informações através de pesquisas pela internet. A fundamentação teórica é feita a partir de concepções de autores como Vygotsky (1991), Piaget (1948), Teberosky (1999), Emília Ferreiro (1999), Soares (1998), entre outros que contribuíram e muito para o desenvolvimento geral do estudo proposto.

PALAVRAS-CHAVE: Educação Infantil. Escrita. Aprendizagem.

\section{WRITING IN EARLY CHILDHOOD EDUCATION}

ABSTRACT: This article demonstrates that writing in Early Childhood Education is of fundamental importance in the interaction of children with adults. The theoretical foundation makes considerations about the need for writing in different contextual forms,

\footnotetext{
${ }^{6}$ Graduação em Pedagogia - UVA. Pós-graduação em Psicopedagogia Clínica E Institucional - ISEP. Pós-graduação em Educação Infantil E Anos Iniciais - FAVENI. Professora e responsável escolar no Município de Guamaré-RN. Email: Mirtes_gmr@hotmail.com

${ }^{7}$ Graduada em Pedagogia - Faculdade do Complexo Educacional Santo André. Pós-graduação em Educação Especial Inclusiva e Neuropsicopedagogia Institucional e Clínica (Cursando) - FAVENI. Professora no Município de Alto do Rodrigues-RN. E-mail: lauranayara17@gmail.com

${ }^{8}$ Graduação em Pedagogia UVA. Pós-graduação em Psicopedagogia Clínica E Institucional - FAIBRA. PósGraduação em Educação Infantil E Ensino Fundamental - Instituto Superior De Educação Elvira Dayrell. Professora no Município de Guamaré-RN. E-mail: rosalima87@gmail.com

${ }^{9}$ Graduação em educação física UFRN. Pós-graduação em Gestão De Programas E Projetos De Esporte E Lazer Na Escola - IFRN. Professora no Município de Macau-RN. E-mail: rayacorlet@gmail.com
} 
presupposed for intellectual development in a genuine relationship between the individual and the various phenomena with which he comes into contact in the sociocultural dynamics in which he is inserted. The comparative analysis between the graphic recording of sound and alphabetic writing of these children showed that, in the same way that the child appropriates the most significant letters to write the names of objects, he uses the musical symbols with which he has contact to write the sounds that you sing or that are part of your daily life. Based on these analyses, it is possible to conclude that, if the child received the same stimulus in these two languages, the strategies he seeks to graphically represent the sound phenomena present similar characteristics, both in graphic aspects and in the constructive processes of writing. Such conclusions raise reflection on the need for literacy in different forms of language for a more conscious and real relationship with the environment in which we live. The methodology used in this work was bibliographic research and information collection through internet searches. The theoretical foundation is based on the conceptions of authors such as Vygotsky (1991), Piaget (1948), Teberosky (1999), Emília Ferreiro (1999), Soares (1998), among others who contributed a lot to the general development of the study. proposed.

KEYWORDS: Early Childhood Education. Writing. Learning.

\section{INTRODUÇÃO}

O presente artigo tem como objetivo levantar algumas questões sobre a construção da Escrita Infantil, buscando compreender não só os fatores que têm contribuído para o fracasso escolar das crianças, como também verificar as possibilidades da escola garantir a todos, indistintamente, o direito de se tornarem leitores e escritores. Levando as mesmas a investigar as práticas de escrita, e como esta poderá contribuir na melhoria da habilidade de interpretação de textos e, consequentemente, na sua formação como escritor.

Quando a criança entra na escola ela passa a ter contato direto com um novo mundo; mundo esse onde elas serão preparadas para construir e transformar tudo ao seu redor. Ao darmos uma folha em branco e um lápis a criança que até então não teve contato com qualquer outro tipo de material parecido, ela começa a fazer vários rabiscos; hora ela escreve no interior da folha, hora na parte superior e em outras partes da folha. Sabemos que de alguma forma cada rabisco feito por elas tem significados.

Desse modo elas conseguem desenvolver ou representar graficamente o mundo que o cerca, por sua vez, a criança constrói e reconstrói o próprio mundo através dos desenhos e rabiscos representados na folha em branco. Diante das representações gráficas dos alunos representadas nas folhas em branco, o professor não precisa fazer correção da escrita da criança, porque não há nada errado com os desenhos ou rabiscos construídos pela as crianças no sentido comum da palavra. O que existe são separações distanciadas 
das produções gráficas atuais do que a própria criança fará em um futuro próximo. E um dos procedimentos significativos que a criança adota em uma determinada etapa de processo da aquisição da linguagem escrita é o de repetir várias vezes, com pausa e de forma que ouve uma palavra.

Ao observar os trabalhos infantis, pode-se verificar que cada criança tem um ritmo próprio para se adaptar à linguagem escrita, e essas características se refletem no seu desenvolvimento. Essa situação coopera entre si, por isso tem despertado grande interesse na análise da escrita infantil. Portanto, o objetivo principal deste trabalho é analisar o processo de aquisição da linguagem escrita na educação infantil, determinar o estágio de desenvolvimento da escrita e esclarecer os motivos pelos quais as crianças se comportam de forma diferente diante do processo de escrita. Portanto, a pesquisa realizada neste trabalho é fundamental para que cada criança possa identificar e analisar as etapas do seu desenvolvimento da escrita e quais as intervenções adequadas para promover o seu desenvolvimento integral. Por fim, a conclusão deste artigo retoma sinteticamente as principais ideias apresentadas neste trabalho. Nessa perspectiva, pode-se dizer que para haver a democratização da Educação Infantil não basta apenas à existência de leis, é preciso que haja compromisso dos órgãos públicos responsáveis; pois fica claro que tudo só dar certo se for trabalhado em conjunto como diz o velho ditado "uma andorinha só não faz verão" e todos deve das às mãos a um ensino de qualidade, com uma Educação voltada para todos.

Para atingir os objetivos desejados na realização deste artigo, utilizei pesquisa de diversos teóricos como: Vygotsky (1991), Piaget (1948), Teberosky (1999), Emília Ferreiro (1999), Soares (1998), e outros acervos para enriquecer este trabalho.

\section{DESENVOLVIMENTO}

A primeira tentativa de criar um sistema de escrita data por volta de $4.000 \mathrm{aC}$. O sistema mais básico apareceu na primeira carta há muito tempo (dois mil anos depois) foi formado. Na verdade, não podemos atribuir o surgimento da escrita a uma única sociedade. Recentemente, as civilizações dos Estados Unidos, Egito, China e Mesopotâmia começaram a desenvolver seus sistemas de representação gráfica. Entre eles, é necessário simplificar a sinalização escrita para tornar o sistema de revisão mais 
compacto e poderoso. Foi nessa época que surgiram as primeiras letras na antiguidade.

Diferentes civilizações começaram a trabalhar com sistemas mais simplificados e, ao mesmo tempo, capazes de identificar distintos conceitos, seres e objetos.

[...] A escrita diferencia-se do simples desenho quando este deixa de representar um objeto do mundo e passa a representar uma palavra de uma língua. Os sistemas de escrita começaram com caracteres na forma de desenhos de objetos que representavam palavras inteiras. Mas este sistema logo encontrou algumas dificuldades: por exemplo, como escrever os nomes das pessoas? Não bastava fazer o desenho de um homem ou de uma mulher! Então começaram a inventar combinações de caracteres (CAGLIARI, 1999, p. 165).

Segundo estudiosos, foram os gregos que inventaram o alfabeto. Isso porque os gregos precisavam de caracteres que representassem as vogais, pois não compreendiam uma escrita apenas consonantal. O objetivo do alfabeto era escrever as palavras pelos sons das consoantes e das vogais e isto era tido como uma tarefa fácil em que bastava observar os sons enquanto se falava.

A escrita é uma importante ferramenta de comunicação, e o seu surgimento se deve ao conhecimento desenvolvido e acumulado nas sociedades humanas no decorrer de milhares de anos, sendo de fundamental importância para a conservação de registros, pois garante a propagação de informações por gerações.

[...] usamos a leitura e a escrita de acordo com nossas necessidades, definidas por nós enquanto sujeitos, mas também de acordo com as demandas que o meio social nos impõe. Assim, usamos a leitura e a escrita de diferentes formas, em diferentes contextos no trabalho, na família, na escola e em outros espaços com os quais convivemos (SOARES, 1998, p. 16).

A melhor maneira de estudar a escrita e as várias tendências e fatores envolvidos nela consiste em descrever os estágios que nós observamos quando uma criança desenvolve sua habilidade para escrever e os fatores que a capacitam passar de um estágio para outro. Para uma criança ser capaz de escrever ou anotar alguma coisa, duas condições devem ser preenchidas.

Em primeiro lugar, as relações da criança com as coisas ao seu redor devem ser diferenciadas de forma que tudo o que ela encontra inclua-se em dois grupos principais: a) as coisas que representam algum interesse para a criança, coisas que gostaria de possuir ou com as quais brinca; b) são os objetos instrumentais, isto é, que desempenham apenas um papel instrumental ou utilitário, e só têm sentido enquanto auxílio na aquisição de 
alguns outros objetos ou para a obtenção de alguns objetivos. E por isso, possuem apenas um significado funcional para ela.

Em segundo lugar, a criança deve ser capaz de controlar seu próprio comportamento por meio desses subsídios, e nesse caso eles já funcionam como sugestões que ela mesma invoca. Só quando as relações da criança com o mundo que a cerca se tornaram diferenciadas dessa maneira, quando ela desenvolveu sua relação funcional com as coisas, é que podemos dizer que as complexas formas intelectuais do comportamento humano começaram a se desenvolver.

Cada criança passará por várias etapas no processo de aquisição da linguagem escrita, partindo do pressuposto de criar hipóteses a partir dos momentos que vivenciou, quando a etapa atual está em conflito, ela se desenvolverá para uma nova etapa evoluindo constantemente.

Segundo Colello (1995, p. 27) “o processo de construção da língua escrita é, na verdade, muito mais complexo do que supõem os educadores que insistem em ensinar o abecedário, as famílias silábicas e a associação de letras para a composição de palavras, sentenças e textos. A capacidade de ler e escrever não depende exclusivamente da habilidade do sujeito em "somar pedaços de escrita", mas, antes disso, de compreender como funciona a estrutura da língua e o modo como é usada em nossa sociedade".

O autor busca descrever e classificar as sucessivas etapas de produção da escrita, tentando compreender o motor que impulsiona esse processo de aprendizagem. Suas conclusões apontam quatro momentos básicos pelos quais passam a maioria das crianças, independentemente do processo de escolarização. A criança para chegar ao código de escrita alfabética, passa por quatro (4) hipóteses, as quais serão comentadas abaixo.

\section{NÍVEL I: HIPÓTESE PRÉ-SILÁBICO}

Nesse nível a criança não estabelece vínculo entre a fala e a escrita, demonstrando interação de escrever através de traços linear com formas diferentes, nesse nível elas também usam letras do próprio nome ou letras e números na mesma palavra, caracterizando uma palavra como letra inicial e tendo leitura global, individual e instável do que escreve, e só elas sabem o que quis escrever. 
Para Ferreiro (1999, p. 198):

"torna-se claro que a dificuldade de diferenciar as atividades de escrever e desenhar é apenas momentânea. Se quando solicitada, a escrever, a criança grafa sinais e desenhos, já se pode considerar que o conflito foi vencido. Ela já sabe que o desenho não é escrito. Que a escrita é representada por letras. Mas se ainda desenha e escreve é possível que esteja estabelecendo relações entre um ou outro".

Todas as escritas se assemelham muito entre si, o que não impede que a criança as considere diferente visto que a intenção que presidiu a sua realização era diferente. Com essas características, torna-se claro que a escrita não pode funcionar como veículo de transmissão de informação, pois cada um pode interpretar sua própria escrita, porém não as dos outros. Todavia a criança reconhece a intencionalidade comunicativa da linguagem escrita.

Segundo Ferreira e Teberosky (1999, p. 198), “A criança espera que a escrita dos nomes dos objetos seja proporcional ao tamanho e não ao comprimento do nome". A tendência da criança é refletir na escrita algumas características do objeto. "A escrita é uma escrita de nomes, mas os portadores desses nomes têm, além disso, outras propriedades que a escrita poderia refletir, já que a escrita do nome não é ainda a escrita de uma determinada forma sonora".

Pode ocorrer também o uso de números misturados às letras. Estas inversões são voluntárias e testemunham um desejo de exploração ativa dessa forma dificilmente assimiláveis. Neste nível, a leitura do escrito é sempre global, e as relações entre as partes e o todo estão muito longe de serem analisadas.

\section{NÍVEL II: HIPÓTESE SILÁBICA}

Nesse nível, as crianças percebem que, para serem capazes de ler palavras com diferentes significados, deve haver distinções objetivas na escrita. A melhoria mais óbvia nos gráficos é que a forma dos gráficos é mais definida e mais próxima das letras. No entanto, o fato conceitual mais interessante é o trabalho realizado após lidar com a hipótese de escrever coisas na menor figura e a hipótese de várias figuras.

Nesta hipótese a criança consegue superar um enorme problema, que é a decisão de quantas letras seriam necessárias para grafar uma palavra. A quantidade de letras 
utilizadas pela criança agora, passará a ser associada aos sons da fala produzida por ela, ou seja, cada emissão sonora será representada por uma única letra, o que tornará a escrita silábica. Podendo escrever uma letra para cada palavra; como por exemplo, cavalo, onde ela representará essa palavra com as letras, CVL, o C, representa a sílaba, CA, o V, que representa a sílaba, VA, e L, que representa a sílaba, LO. Esse avanço realizado pela criança em seu modelo de escrita ocorre inicialmente sem um valor sonoro. Todavia, conforme a criança for aumentando seu repertório sonoro e seu conhecimento sobre a escrita, ela começa a lançar escritas com valor sonoro.

\section{NÍVEL III: HIPÓTESE SILÁBICO-ALFABÉTICA}

Neste nível há um grande avanço da criança na construção da escrita, ela se sente mais confiante porque descobre que pode escrever com lógica. Apesar de todo esse avanço existe um momento de grande conflito, pois a criança precisa negar a lógica do nível silábico.

O valor sonoro torna-se imperioso e a criança começa a acrescentar mais letras, devido ao maior contato com materiais escritos e a sua percepção de que a quantidade de letras que utilizava anteriormente não é mais suficiente para a escrita das palavras. Neste nível a criança já consegue fazer a correspondência letra/som, usa o eixo qualitativo e quantitativo, e compreende que existe uma relação entre escrita e fala.

Aqui o papel do professor é essencial para ajudar essa criança a chegar ao nível alfabético através de atividades dirigidas, como a cruzadinha com banco de dados, Por exemplo. Nessa hipótese a mesma palavra no nível III, e no nível IV passa ater uma forma mais consistente, por exemplo, a palavra cavalo agora é representada de diversas formas: KVALO, CAVALU, CAVLO, e outras formas.

\section{NÍVEL IV: HIPÓTESE ALFABÉTICA}

Neste nível a criança consegue ler e expressar graficamente o que pensa ou fala, compreendendo a organização do código, conhece o valor sonoro convencional de todas ou de grande parte das letras, juntando-as para formar sílabas e palavras, faz distinção entre letras, símbolos, palavras ou frases. Ela é capaz de compreender que a escrita tem 
função social, compreendendo o modo de construção dos códigos da escrita, omite letras quando misturadas as hipóteses alfabética e silábica. Nesse nível ela não tem problemas de escrita no que se refere a conceito. Às vezes a criança ainda não consegue dividir as frases convencionalmente (gramaticalmente) e sim de acordo com o ritmo frasal. É importante destacar que, nesse momento, a criança escreve foneticamente, ou seja, faz relação entre som e letra, mas não domina as regras ortográficas.

Seguindo o mesmo raciocínio do exemplo da palavra CAVALO, nesse nível a criança consegue escrever corretamente a palavra CAVALO. Então podemos afirmar que a criança ao chegar a esse nível escrevendo corretamente as palavras, ela é considerada alfabetizada, concluindo assim a sua longa jornada na construção da escrita na Educação Infantil.

\section{CONCLUSÃO}

Diante de tudo que foi abordado nessa longa jornada deste trabalho, conclui-se que não existe um momento ou idade adequada para que as crianças iniciem um trabalho pedagógico com a linguagem escrita. Cada criança possui um ritmo no que diz respeito à alfabetização, portanto, é imprescindível que o professor tenha embasamento teórico adequado para enfrentar as dificuldades que surgiram durante esse processo de escrita.

Entretanto, como já foi dito, dependendo do contexto, esses desafios podem ocorrer de maneira muito diferenciada, em momentos diferentes de seu desenvolvimento e em locais distintos, em casa ou na escola.

Apontado em item precedente deste trabalho, as quais nos indicam que o trabalho em torno da linguagem escrita deve ser o aspecto a ser privilegiado nas propostas pedagógicas dessa primeira etapa da Educação Básica tanto quanto em outros aspectos, ou seja, é trabalho que precisa ser feito em uma inter-relação entre os conhecimentos de mundo a serem trabalhados na Educação Infantil. Portanto, as ações pedagógicas relacionadas à linguagem escrita deveriam ser consideradas como mais uma das múltiplas dimensões a serem levadas em conta na organização das rotinas diárias e dos planejamentos mensais e anuais das creches e pré-escolas. 
Desta maneira é fundamental a ação intencional do professor, possibilitando situações em que possam interagir em duplas, em trios, em grandes grupos e até mesmo individualmente, em alguns momentos, tendo em vista a apropriação por parte de cada um e as reflexões sobre o seu próprio processo de escrita. A criança da pré-escola tem necessidade de brincar, de se movimentar, de se relacionar umas com as outras para o seu desenvolvimento psicomotor. Como educadores e pedagogos que somos, temos que observar o estágio em que se encontra a criança, para que haja um desenvolvimento de acordo com as faixas etárias de cada uma. Esperamos que estudiosos e teóricos continuassem aprofundando cada vez mais os conhecimentos sobre a escrita na Educação Infantil para amenizar as dificuldades e melhorar os níveis de aprendizagem das nossas crianças.

\section{REFERÊNCIAS}

BRASIL. Referencial Curricular Nacional da Educação Infantil. MEC, 1998.

CAGLIARI, G; CAGLIARI, L. C. Diante das letras: a escrita na alfabetização. Campinas, SP: Mercado das Letras: Associação de Leitura do Brasil? ALB; São Paulo: FAPESP, 1999.

COLELLO, Silvia M. Gasparian. Alfabetização e Letramento: repensando o ensino da língua escrita. 1995. Disponível em: <http:// /videtur29/silvia.htm> Acesso em: 30 maio de 2013, às 14: $10 \mathrm{~h}$.

FERREIRO, Emília; TEBEROSKY, Ana. Psicogênese da língua escrita. Porto Alegre: Artes Médicas, 1999.

SOARES, Magda. Letramento: um tema em três gêneros. 2. Ed. Belo Horizonte: Autêntica Editora, 1998.

VYGOTSKY, L. S. Pensamento e linguagem. 3. Ed. São Paulo: M. Fontes, 1991

A Formação Social da Mente. São Paulo: Martins Fontes. 1988

FREITAS, M. T. A. Vygotsky e Bakhtin - psicologia e educação: um intertexto. São Paulo/Juiz de Fora: Ática/EDUFJF, 1994. MORAIS, 1996

PIAGET, J. A formação dos símbolos na criança. PUF, 1948.

WALLON, H. (1968). A evolução psicológica da criança. Lisboa: Edições 70. 


\title{
CAPÍTULO IV
}

\section{A FORMAÇÃO CONTINUADA DE PROFESSORES DE LÍNGUAS ESTRANGEIRAS DURANTE A PANDEMIA DO COVID-19}

\author{
Ana Luisa Martinez Burguillo Mendonça Lucas ${ }^{10}$. \\ DOI-Capítulo: 10.47538/AC-2021.14-04
}

RESUMO: A pandemia do Covid-19 transformou a forma como a educação acontece nos dias atuais não só no Brasil, mas no mundo. Dentro dos vários âmbitos educacionais e as várias disciplinas escolares, o ensino de línguas estrangeiras enfrentou grandes desafios na tentativa de transportar práticas antes realizadas presencialmente para as plataformas digitais, uma vez que ensino-aprendizagem de línguas estrangeiras é muito pautado na interação oral. Com isso, esta pesquisa investigou como a visão dos professores de línguas estrangeiras de um curso livre de idiomas acerca da preparação ofertada pela instituição para enfrentar o primeiro semestre de ensino remoto emergencial. Verificou-se que a necessidade de aulas online e do ensino remoto emergencial causou muita insegurança e incerteza nos professores e que a formação continuada oferecida não foi satisfatória. Por isso, com base em uma das perguntas norteadoras deste estudo, que tipo de formação gostariam de ter recebido, proponho ao final da análise tópicos de formação continuada de professores de línguas estrangeiras, sugeridos pelos professores participantes desta investigação, a serem desenvolvidos futuramente. Esta pesquisa é de natureza quanti qualitativa e caracteriza-se como um estudo de caso. Como referenciais norteadores para a pesquisa contamos com Libâneo (2013), Gatti (2009), Nóvoa (2009), Pimenta (2002), dentre outros.

PALAVRAS-CHAVE: Formação de professores. Línguas Estrangeiras. Ensino Remoto Emergencial. Pandemia Covid-19.

\section{THE CONTINUOUS TRAINING OF FOREIGN LANGUAGE TEACHERS DURING THE COVID-19 PANDEMY}

ABSTRACT: The Covid-19 pandemic transformed the way education takes place today, not only in Brazil, but in the world. Within the various educational spheres and the various school subjects, the teaching of foreign languages faced major challenges in an attempt to transfer practices previously carried out in person to digital platforms, since teachinglearning foreign languages is very much based on oral interaction. With that, this research investigated how the vision of foreign language teachers of a free language course about the preparation offered by the institution to face the first semester of emergency remote teaching. It was found that the need for online classes and emergency remote teaching caused a lot of insecurity and uncertainty for teachers and that the continuing education offered was not satisfactory. Therefore, based on one of the guiding questions of this study, what type of training would they like to have received, I propose, at the end of the

\footnotetext{
${ }^{10}$ Mestranda do curso de pós graduação em Letras e Linguística da Faculdade de Letras da UFG; currículo lattes: http://lattes.cnpq.br/0629402700233426. E-mail: analu.mbmlucas@gmail.com
} 
analysis, topics on the continuing education of foreign language teachers, suggested by the teachers participating in this investigation, to be developed in the future. This research is quantitative and qualitative in nature and is characterized as a case study. As guiding references for the research we have Libâneo (2013), Gatti (2009), Nóvoa (2009), Pimenta (2002), among others.

KEYWORDS: Teacher Training. Foreign Languages. Emergency Remote Teaching. Pandemic Covid -19.

\section{INTRODUÇÃO}

No início do ano de 2020 o mundo se deparou com um vírus que transformou a forma como as pessoas viviam até então. Devido ao seu alto índice de contaminação, e a pouca informação que os profissionais de saúde tinham sobre o tratamento e os sintomas da tal doença, o coronavírus (Sars-CoV-2) parou o mundo, e até então enfrentamos uma das maiores pandemias da história da humanidade. Como consequência desse cenário mundial, e sem previsão de retomada das atividades após alguns meses de isolamento social, professores e alunos foram obrigados a desenvolver um novo meio de ensinar e aprender a partir de suas próprias casas, e assim surgiu o ensino remoto emergencial.

A pandemia revelou lacunas acerca das metodologias de ensino das instituições que utilizam pouco as ferramentas digitais. Dentro dos vários âmbitos educacionais e as várias disciplinas escolares, o ensino de línguas estrangeiras enfrentou grandes desafios na tentativa de transportar práticas antes realizadas presencialmente para as plataformas digitais, uma vez que ensino-aprendizagem de línguas estrangeiras é muito pautado na interação oral entre professor - alunos, e alunos-alunos.

Entendo que por ser este um possível momento de reflexão, e com o intuito de contribuir para que as instituições de ensino entendam melhor as necessidades de formação continuada de seus professores colaboradores, esta pesquisa tem o objetivo de investigar como foi feita a preparação de professores de línguas estrangeiras de um curso livre de idiomas para enfrentar o primeiro semestre de ensino remoto emergencial. Destarte, as perguntas que guiaram este estudo foram: como o professor avalia a própria experiência/ habilidades com ferramentas digitais de ensino? Quais foram as dificuldades enfrentadas? Que tipo de formação continuada os professores receberam para atuar no ensino remoto? Que tipo de formação gostariam de ter recebido? 
Para tanto, esta investigação está dividida em quatro partes: fundamentação teórica, metodologia, análise de dados e considerações finais.

\section{FUNDAMENTAÇÃO TEÓRICA}

Um dos principais desafios da educação hoje está na preparação de professores que enfrentarão as peculiaridades do sistema educacional brasileiro que nem sempre contribui para que o professor desempenhe seu trabalho com excelência. Nos cursos de licenciatura, as discussões acerca da formação de professores são recorrentes. Sabe-se que independente da área de atuação, o professor precisa desenvolver certas competências e conhecimentos didático pedagógicos para além das teorias.

Apesar de existirem programas, como o PIBID (Programa Institucional de Bolsas de Iniciação à Docência) e o PROLICEN (Programa de Bolsas de Licenciatura) que buscam aproximar o professor em formação com a realidade prática do ser professor, Nóvoa (2009, p. 1) afirma que "a formação de professores está muito afastada da profissão docente, das suas rotinas e culturas profissionais".

Conforme a Lei de Diretrizes e Bases da Educação (LDB) (BRASIL, 1996) a formação docente engloba tanto a formação inicial, normalmente proporcionada pelas licenciaturas, quanto pela formação continuada que envolve tanto cursos de pósgraduação e cursos formais quanto capacitações ofertadas pela própria instituição e articulações com instituições acadêmicas, esportivas, culturais e comunitárias.

Da mesma maneira, o Plano Nacional de Educação (PNE) (BRASIL, 2014) tem, dentre outras diretrizes, tanto a melhoria da educação, quanto a valorização dos profissionais que nela atuam. Como metas para alcançar seus objetivos, o plano prevê o desenvolvimento docente em diversas facetas, dentre elas as formações: inicial, continuada, específica e especializada (para atendimento educacional especializado).

Educação de qualidade não é algo definido por um único fator: estrutura, metodologias, materiais didáticos, ambiente escolar, fatores sociais e a formação de professores fazem parte do escopo do que é ensinar/ aprender. Libâneo (2013, p. 27) define a formação de professores como "um processo pedagógico, intencional e organizado, de preparação teórico-científica e técnica do professor para dirigir competentemente o processo de ensino." 
Ainda para o autor, a formação docente se divide em grande duas esferas, a técnico-científica, que inclui todos os conhecimentos científicos acerca da disciplina que o futuro professor ministrará e toda sua formação acadêmica; e a esfera técnico-prática, que engloba os saberes acerca da didática e dos conhecimentos pedagógicos, incluindo metodologias específicas para cada disciplina.

Pimenta (2002, p. 30) afirma ainda que "a formação passa sempre pela mobilização de vários tipos de saberes: saberes de uma prática reflexiva, saberes de teoria especializada, saberes de uma militância pedagógica." Entretanto, podemos afirmar que os aspectos reflexivos, bem como os saberes teóricos e práticos não devem ser considerados separadamente, e sim como elementos entrelaçados constituintes da formação docente. Congruente ao exposto, Tardif (2002) reitera em seu livro que o saber docente não deve ser separado de outras dimensões de ensino.

Ao defender uma proposta de integração de teoria e prática, Gatti (1997, p.57) ressalta que uma visão "[...] globalizada da função social de cada ato de ensino, sempre confrontada e reconstruída pela própria prática e pelo trato com os problemas concretos dos contextos sociais em que se desenvolvem, poderia ser a chave de toque que acionaria uma nova postura metodológica".

Desse modo, Libâneo (2013, p. 27) concorda que
As disciplinas teórico-científicas são necessariamente referidas à prática escolar, de modo que os estudos específicos realizados no âmbito da formação acadêmica sejam relacionados com os de formação pedagógica que tratam das finalidades da educação e dos condicionantes históricos, sociais e políticos da escola. Do mesmo modo, os conteúdos das disciplinas específicas precisam ligar-se às suas exigências metodológicas. As disciplinas de formação técnico- prática não se reduzem ao mero domínio de técnicas e regras, mas implicam também os aspectos teóricos, ao mesmo tempo que fornecem à teoria os problemas e desafios da prática. A formação profissional do professor implica, pois, uma contínua interpenetração entre teoria e prática a teoria vinculada aos problemas reais postos pelas experiências prática e a ação prática orientada teoricamente.

Considerando as situações reais e desafios e problemas que surgem com a prática docente, como mencionado acima, podemos inferir que os conhecimentos teóricos e práticos da formação de professores nem sempre abarcam todas as situações presentes no contexto de ensino- aprendizagem, já que tal contexto é complexo e repleto de singularidades impossíveis de serem previstas. Desse modo, Pimenta (2002) propõe que 
pensemos em uma formação docente que engloba a formação inicial e continuada dentro de um mesmo projeto.

A formação continuada tem por objetivo acompanhar e atualizar o processo de desenvolvimento do professor que está em atuação. Chimentão (2009, p. 03) ressalta que

a formação continuada não descarta a necessidade de uma boa formação inicial, mas para aqueles profissionais que já estão atuando, há pouco ou muito tempo, ela se faz relevante, uma vez que o avanço dos conhecimentos, tecnologias e as novas exigências do meio social e político impõem ao profissional, à escola e às instituições formadoras, a continuidade, o aperfeiçoamento da formação profissional.

Desse modo, podemos afirmar que sem uma boa formação docente e sem uma formação contínua pouco adianta o acesso aos melhores materiais e ferramentas, pois é preciso saber usá-los e adequá-los a cada contexto e alunos, pois a sala de aula é um espaço vivo em constante transformação.

No âmbito do ensino aprendizagem de línguas a formação de professores tem um caráter particular, pois para ser professor de língua estrangeira é preciso tanto passar pelo processo de aprendizagem do idioma quanto o conhecimento de metodologias de ensino do mesmo.

Considerando a formação de professores de línguas estrangeiras, para Almeida Filho (1993, 1999) são cinco as competências básicas necessárias de um professor de línguas: 1. Competência linguístico-comunicativa; 2. Competência implícita; 3. Competência teórica; 4. Competência aplicada e 5. Competência profissional.

A Competência linguístico-comunicativa consiste no domínio que o professor tem da gramática da língua e na sua capacidade de uso considerando as regras socioculturais da língua estrangeira. A competência implícita refere-se às crenças e atitudes em relação ao que é ou não apropriado para as situações de ensino. A competência teórica se relaciona ao conhecimento que o professor tem de teorias e pesquisadores que estudam o processo de ensino e aprendizagem de línguas estrangeiras. A competência aplicada é a mistura da competência teórica com a prática usada a serviço do processo de ensino e aprendizagem. Finalmente, o termo competência profissional é atribuído a capacidade do professor de calcular o desenvolvimento das demais competências e ao refletir sua prática buscar o constante aprimoramento dessas competências de acordo com sua necessidade. 
Quanto ao ensino de línguas estrangeiras especificamente, Hall e Verplaetse (2000, p. 10, Apud CONSOLO, 2006, p. 34) ressaltam que a interação

na aprendizagem de línguas adicionais é especialmente importante. Isto é em suas interações entre si que os professores e os alunos trabalham juntos para criar o intelectual e atividades práticas que moldam a forma e o conteúdo do idioma de destino, bem como os processos e resultados de desenvolvimento individual.

Congruente a ideia de que professores e alunos trabalham juntos para desenvolver o conhecimento e as atividades práticas do idioma de destino, Freire (1996, p. 21) postula que "um primeiro saber inicialmente apontado como necessário à formação docente, numa perspectiva progressista", é o saber de que "ensinar não é transferir conhecimento, mas criar as possibilidades para a sua própria produção ou a sua construção.” Deste modo, podemos afirmar que ao ensinar, nós professores, aprendemos também.

Como vimos até aqui, a formação docente é uma questão fundamental quando tratamos de educação. O ensino de línguas estrangeiras, assim como as demais disciplinas, tem suas especificações, e exige do professor não somente um conhecimento amplo do que é ser professor, mas também um conhecimento abrangente da língua que ensina. Além disso, com base na interação oral entre professores e alunos, o professor deve propiciar um ambiente que possibilite a construção do conhecimento, ao mesmo tempo que administra duas línguas com backgrounds e realidades socioculturais diferentes, fazendo com que suas atribuições sejam ainda mais complexas.

\section{METODOLOGIA}

De acordo com Moreira e Caleffe (2006, p. 73)

a pesquisa qualitativa explora as características dos indivíduos e cenários que não podem ser facilmente descritos numericamente. [...] A pesquisa quantitativa, por outro lado, explora as características e situações de que dados numéricos podem ser obtidos e faz uso da mensuração e estatísticas.

Com base nessa definição, afirmo que esta investigação, por apresentar tanto dados estatísticos como cenários que não podem ser descritos numericamente, é um estudo de caso quanti qualitativo.

Bassey (2003, Apud André, 2013) considera três grandes metodologias de coleta de dados nas pesquisas de estudo de caso: fazer perguntas, observar eventos, e ler 
documentos. Destarte, nesta pesquisa escolhemos fazer perguntas através da aplicação de um questionário, via google forms, composto de oito perguntas mistas (fechadas e abertas) acerca das experiências profissionais de 14 professores de um curso livre de idiomas da cidade de Goiânia, no estado de Goiás, durante a pandemia do Covid-19, no ano de 2020.

\section{PARTICIPANTES}

Como mencionado acima, participaram deste estudo 14 professores formados e em formação de um curso livre de idiomas da cidade de Goiânia, no estado de Goiás que atuaram no ensino remoto emergencial. Os professores com média de idade entre 20 e 35 anos possuem diferentes backgrounds, formação e experiência docente. Entretanto, todos os participantes são graduados ou cursam graduação em Letras na Faculdade de Letras da Universidade Federal de Goiás, e atuam no ensino de línguas estrangeiras, sendo que, 1 é professora de alemão, 1 é professora de francês, 1 é professora de italiano, 3 são professores de espanhol, e 8 são professores de inglês.

\section{CONTEXTO - A PANDEMIA DO COVID-19}

Coronavírus é um grupo de vírus que causam infecções respiratórias que teve seu novo agente, o nCov-2019, descoberto depois de casos da infecção serem registrados na China em dezembro de 2019. Em fevereiro de 2020, de acordo com o Ministério da saúde, tivemos o primeiro caso da doença confirmado no Brasil. Devido a alta taxa de contaminação do vírus, do pouco que se sabia sobre os possíveis sintomas da doença, e do número de fatalidades crescentes, em 15 de março de 2020, foi anunciado no município de Goiânia, em Goiás, um decreto que anunciava o fechamento de todas instituições privadas e federais, bem como comércio e todos os serviços não essenciais por um período de 15 dias a se iniciar a partir do dia 16 de março de 2020, segunda-feira.

Pautado no distanciamento social, as medidas preventivas à propagação do vírus acarretaram o fechamento de todas as instituições de ensino por um período maior que 6 meses. Sem previsão de volta das atividades, e ainda com o risco de contaminação iminente, todo o sistema educacional foi obrigado a buscar meios de voltar com suas atividades a partir do serviço remoto. Com isso, foi criado o ensino remoto emergencial. 
Para tanto, pouco tempo foi dedicado à preparação dos professores frente a essa nova realidade, considerando que a pandemia surpreendeu a todos.

Após um longo e desafiador semestre de ensino online, e ainda sem previsão de retorno às atividades normais, o sistema educacional brasileiro opera hoje apenas com $30 \%$ de sua capacidade em todos os âmbitos, particular e privado.

\section{ANÁLISE DE DADOS}

Nesta seção, discuto os dados obtidos nos questionários respondidos pelos professores participantes. Como mencionado anteriormente, o questionário referia-se à formação continuada ofertada pela instituição de ensino para enfrentar o ensino remoto emergencial resultante da Covid-19, e era composto de 8 perguntas mistas (abertas e fechadas).

O ensino remoto da instituição de ensino à qual os professores atuam consistiu em aulas online através da plataforma de salas virtuais do google meet, em momentos síncronos. E em momentos assíncronos, foi utilizado a plataforma personalizada para a instituição, adquirida durante a pandemia. Com base nessas informações, a primeira pergunta do questionário pedia que a partir das aulas do primeiro semestre de ensino remoto os professores avaliassem suas experiências com base em 4 conceitos: ótima, boa, regular e ruim, considerando os seguintes critérios: sem dificuldades, consegui resolver as dificuldades, tive dificuldades que atrapalharam o processo, não consegui resolver meus problemas. As respostas com relação a essa pergunta são apresentadas no gráfico abaixo.

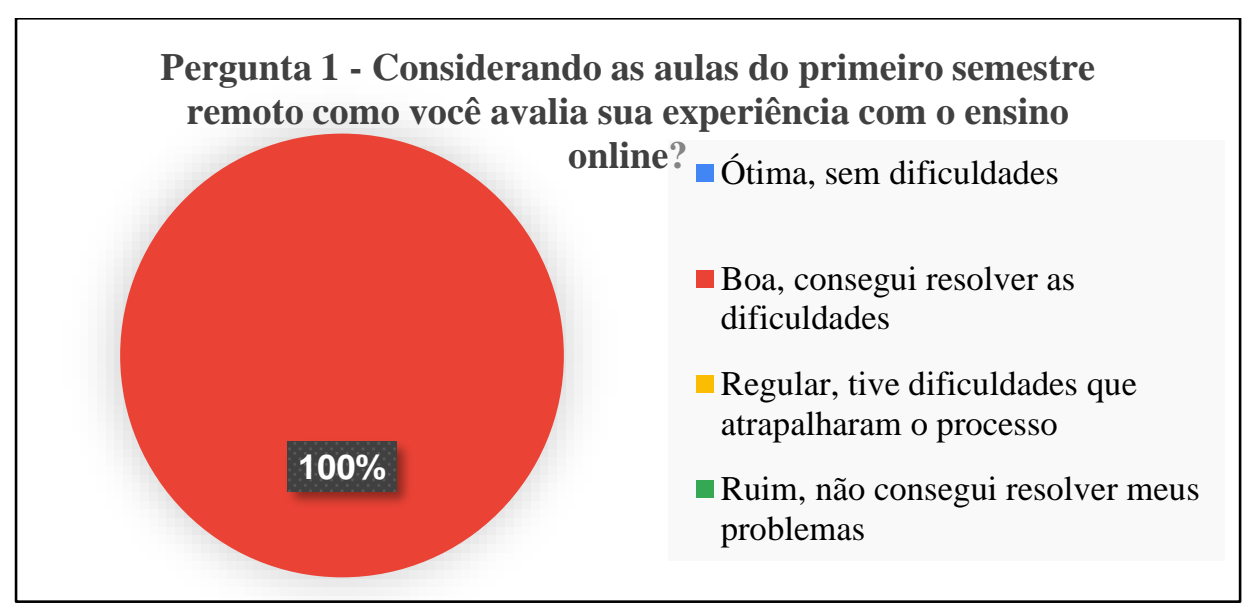


Fonte: Elaborado pela autora com base em material empírico coletado.

Como podemos ver, todos os professores relataram que apesar das intercorrências, conseguiram resolver suas dificuldades e avaliaram a experiência docente como boa. Como continuidade dessa primeira pergunta, prevendo a possibilidade de respostas que deixassem implícito possíveis dificuldades, pedi que relatasse as dificuldades enfrentadas durante todo o semestre. E para essa questão apresento as respostas.

[1] Excerto do questionário sobre as dificuldades enfrentadas no ensino online:

Minha maior dificuldade foi reduzir o meu ttt (tempo de fala de professor) e maximizar o tempo de fala de meus alunos. Também tive dificuldades em manter a atenção da turma em alguns momentos visto que as câmeras dos alunos poderiam ficar desligadas. Isso, ao meu ver, dificultou a aula porque muitas das vezes poucos alunos estavam presencialmente de fato. Outras vezes, tenho tido outras experiências com aula online e acredito que pedir para os alunos ligar a câmera cria outro ambiente virtual, um muito mais propício ao desenvolvimento de uma interação real necessária para o desenvolvimento de uma língua adicional. (Crisântemo)

Uma das maiores dificuldades que encontrei com relação ao ensino remoto, diz respeito à limitação da interação durantes as aulas síncronas. Muitos alunos não se sentiram seguros ou engajados o suficiente para participar das aulas de maneira efetiva. Muitas vezes, tive a sensação de que estávamos em um curso "conteudista" e televisionado, uma vez que, por mais que eu tentasse estimular a participação dos alunos, um número expressivo de estudantes permanecia com câmeras e microfones desligados. (Margarida)

Falta de alguns conhecimentos tecnológicos e acesso limitado a alguns dispositivos ou recursos para administrar aulas on-line. (Azaleia)

Percebemos pelos relatos de Crisântemo e Margarida que parte das dificuldades se deu pela dificuldade de interação com os alunos, hora por um TTT muito alto como menciona Crisântemo, e em outros momento pela própria limitação das plataformas digitais disponíveis para o ensino remoto. Tais relatos vão de encontro às reivindicações de Allwright (1984, p. 158) sobre a importância da interação em sala de aula na aprendizagem de línguas, que de acordo com o autor é "inerente à própria noção de pedagogia da sala de aula”. Já a resposta de Azaléia pode ser associada à proposta de Nóvoa (2009) que ressalta a importância da partilha, e da necessidade de práticas colaborativas, pois possivelmente através delas seriam sanadas as faltas de conhecimento tecnológico enfrentadas pela professora. Acredito que não professores e alunos, mas toda a humanidade enfrentou momentos de insegurança e incerteza, assim como Hortênsia, 
tendo em vista que enfrentamos uma realidade de pandemia de uma doença que ainda conhecemos muito pouco a respeito.

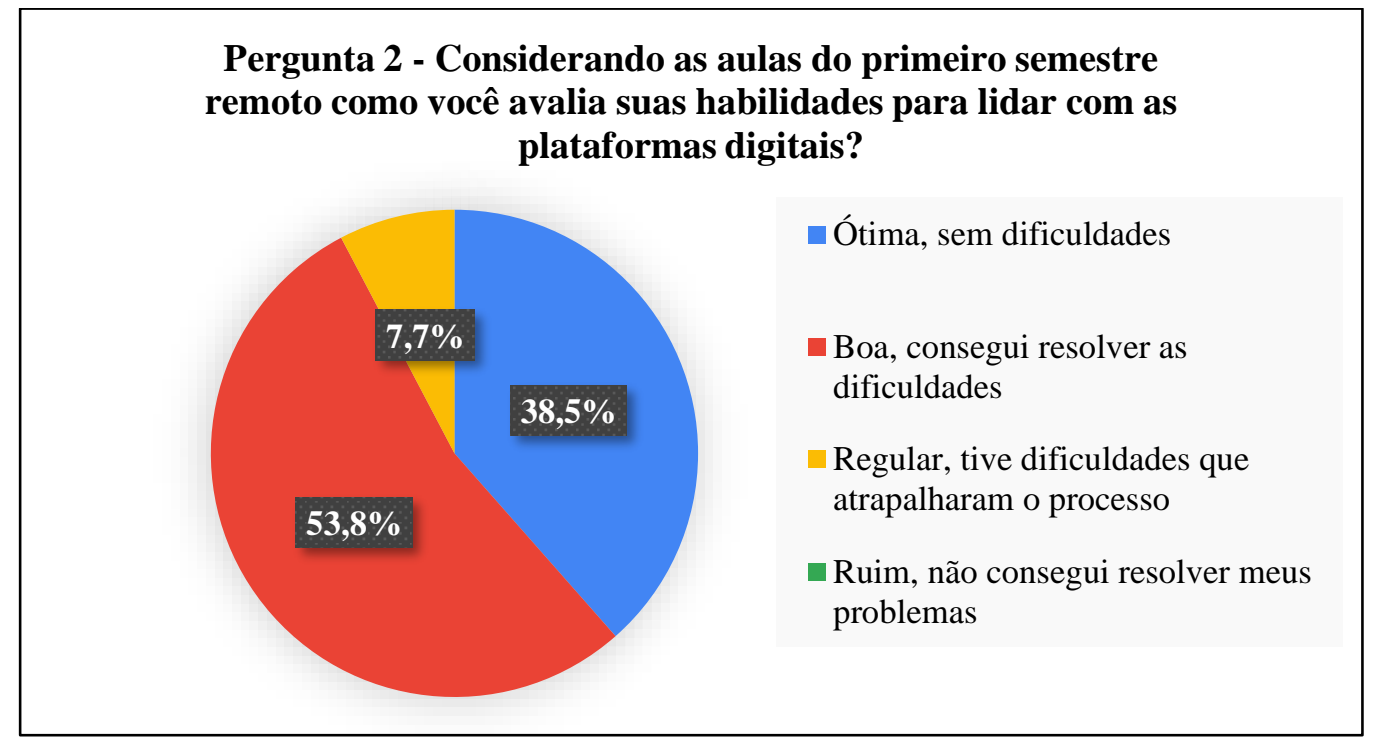

Fonte: Elaborado pela autora com base em material empírico coletado

Na segunda pergunta do questionário, pedi que os participantes relataram como avaliavam suas habilidades para lidar com as plataformas digitais, visto que todo o semestre aconteceu através do uso apenas de recursos online. Apresento as respostas por meio do gráfico acima.

Como mostram as porcentagens, em sua grande maioria os professores não relataram ter tido problemas com as plataformas digitais. Azaleia é a única que avalia suas habilidades com tecnologia como regular e reforça que teve dificuldades para aprender sobre recursos tecnológicos.

As perguntas 3 e 4 pedem que os professores marquem quais materiais didáticos e quais metodologias de ensino mais contribuíram para o ensino- aprendizagem de seus alunos de LE (Língua Estrangeira) dentro do contexto de sala de aula online. As respostas de ambas as questões podem ser vistas nos respectivos gráficos: 


\section{Pergunta 3 - Qual material didático que você utilizou contribuiu mais com suas turmas:}

Vídeos próprios gravados $7,7 \%$

Sites como wakelet, kahoot e mentimeter

Vídeos e links da internet

Livro didático

Textos disponibilizados nas plataformas digitais, Livro didático, Vídeos e links da..

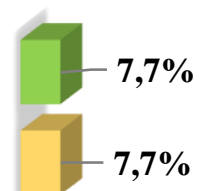

$7,7 \%$
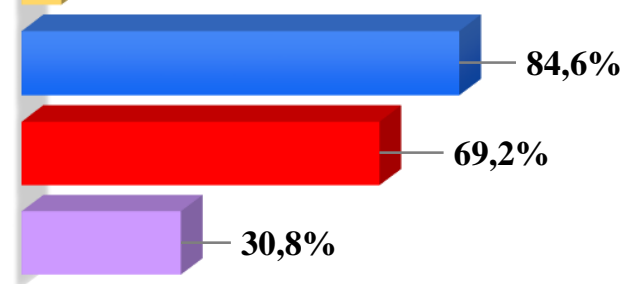

Fonte: Elaborado pela autora com base em material empírico coletado.

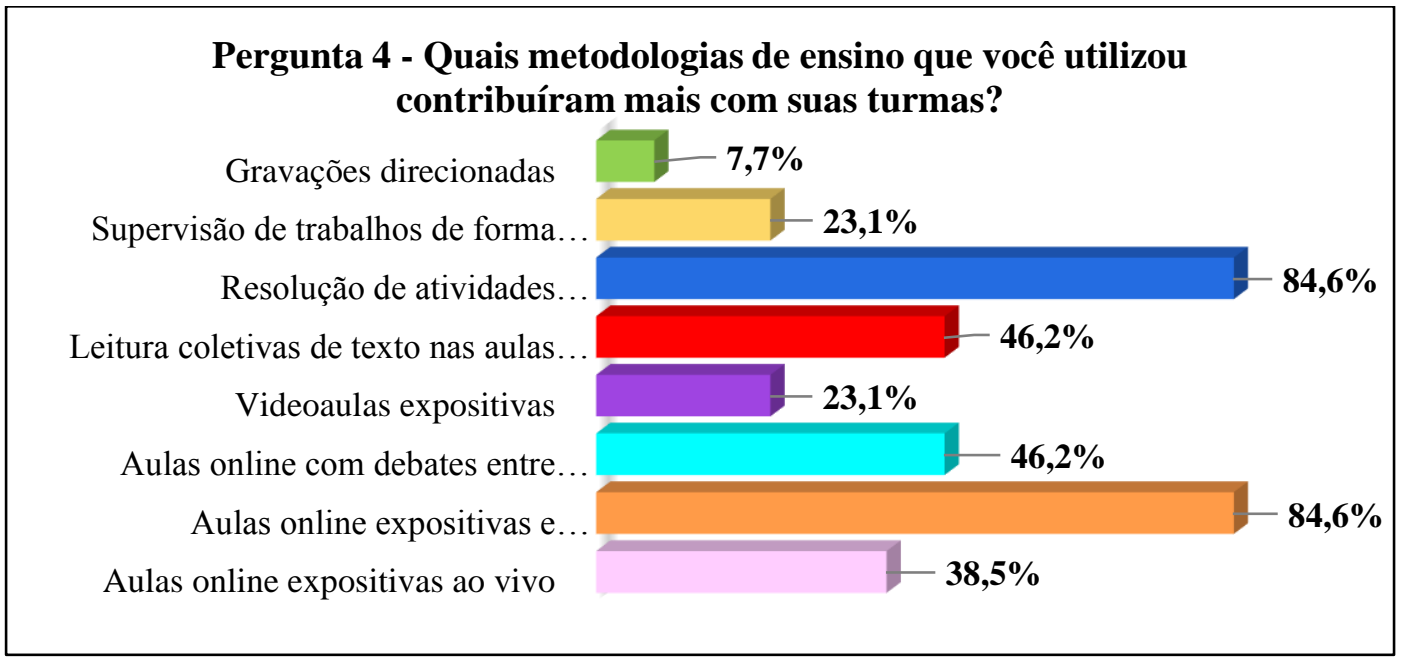

Fonte: Elaborado pela autora com base em material empírico coletado.

No gráfico da pergunta 3, referente ao uso de materiais didáticos utilizados nas aulas online, ainda vemos muito presente o uso do livro didático, 9 dos 14 professores afirmaram ter utilizado o livro, o que no contexto de pandemia em que nos encontramos, acredito propiciar uma certa segurança ao aluno que tem um material base para pesquisa e para estudo. Não obstante, percebe-se que houve uma diversificação dos materiais utilizados na sala de aula, o que de acordo com Moreira (2011, p. 229) "é um facilitador da aprendizagem significativa crítica."

Congruente, percebemos que os professores também procuram diversificar suas práticas pedagógicas utilizando diferentes metodologias de aula, com diferentes 
enfoques. Nóvoa (2009, p. 5) reitera a importância de "conceber a formação de professores num contexto de responsabilidade profissional", sugerindo uma atenção constante à necessidade de mudanças nas rotinas de trabalho, pessoais, coletivas ou organizacionais. A inovação é um elemento central do próprio processo de formação". E percebemos pelos relatos acima que o ato de inovar faz parte das práticas docentes dos professores participantes.

Pimenta (2002, p. 30) argumenta que

As investigações sobre o professor reflexivo, ao colocarem os nexos entre formação e profissão como constituintes dos saberes específicos da docência, bem como as condições materiais em que se realizam, valorizam o trabalho do professor como sujeitos das transformações que se fazem necessárias na escola e na sociedade. $\mathrm{O}$ que sugere $\mathrm{o}$ tratamento indissociado entre formação, condições de trabalho, salário, jornada, gestão, currículo.

Com base nisso, a quinta e sétima pergunta pede que os professores reflitam sobre sua formação profissional, suas experiências e respondam se no começo da pandemia se sentiam preparados para o ensino remoto emergencial e se a formação que haviam recebido tinha sido suficiente para enfrentar o semestre de ensino online.

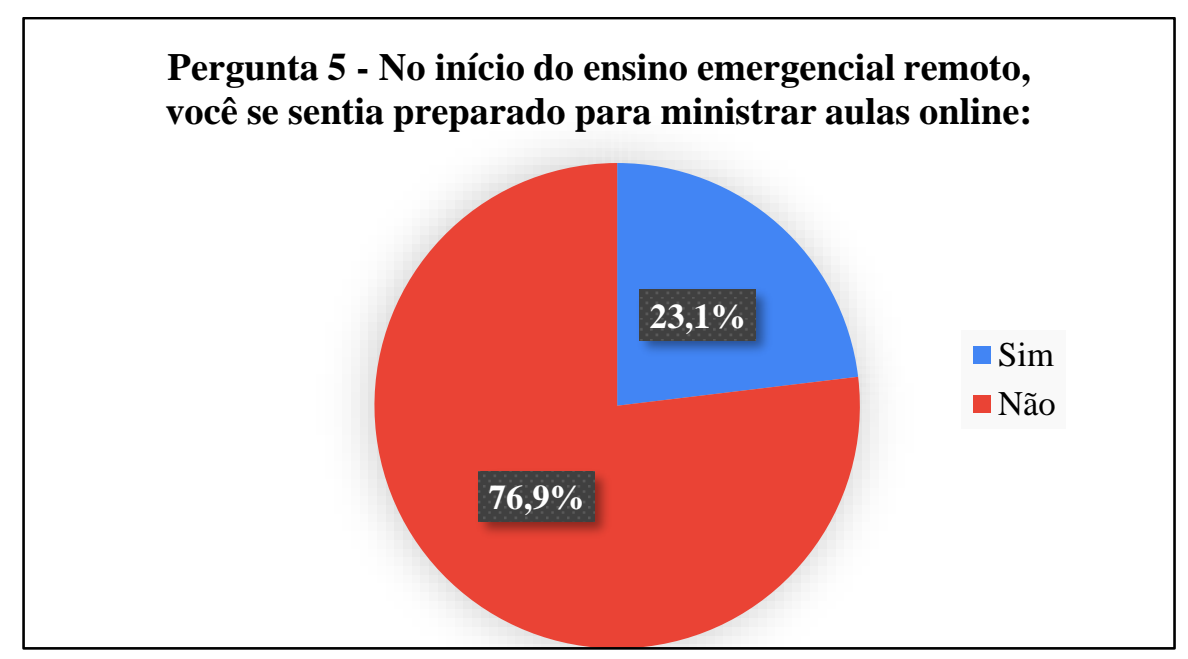

Fonte: Elaborado pela autora com base em material empírico coletado 


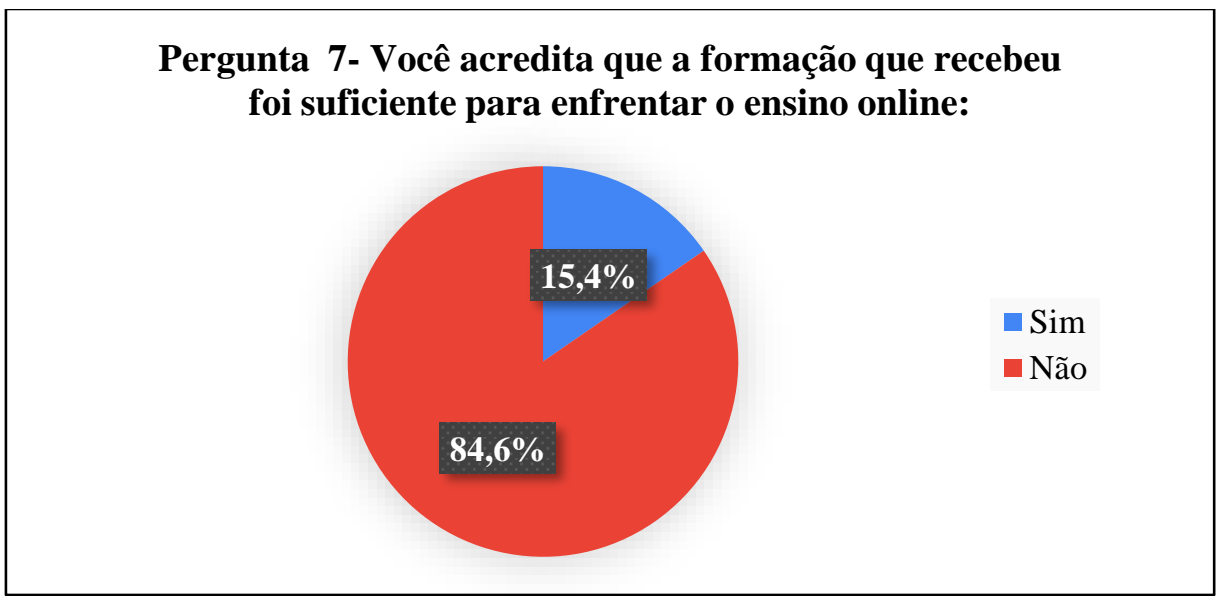

Fonte: Elaborado pela autora com base em material empírico coletado

Percebemos em ambos os gráficos acima, que a maioria dos participantes respondeu que não só não se sentia preparado para ministrar aulas online, como entendem que a formação que receberam não foi suficiente para enfrentar essa situação de Covid19, revelando uma lacuna deixada pela instituição de ensino que de acordo com as respostas dos professores à questão 6, forneceu apenas uma ferramenta de formação continuada acerca do uso das plataformas digitais.

Ressaltamos ainda, que com base no que Pimenta (2002) discorre sobre o tratamento indissociado entre formação, condições de trabalho, salário, jornada, gestão, currículo, as condições de trabalho foi outra lacuna apontada pelos professores participantes deste estudo, que na resposta em que apontam as dificuldades que enfrentaram durante esse semestre, mencionam que precisaram investir em equipamentos e ferramentas que antes da Covid-19 eram fornecidas pela instituição.

Garcez (2013, p. 216) aponta que

uma condição para contribuir para a formação de professores é ouvir esses professores, compreender a prática docente situadamente, isto é, no conjunto das contingências em que ela se dá, observar como os professores dão conta (ou não) das demandas complexas que se apresentam na sua rotina de trabalho e buscar com eles uma compreensão de como a prática docente satisfatória se dá, ou de como pode vir a se constituir. Nossas lentes de observação devem ter base sistemática, devem ser informadas pela reflexão pregressa, daí a necessidade de teorização, mas é importante privilegiar a perspectiva e o protagonismo dos atores, no nosso caso dos agentes educacionais. 
Com base nessa condição, a pergunta número 8 abre espaço para que os professores exponham as suas necessidades e relatem o que os faria sentir mais bem preparados para ministrar aulas online, e quais assuntos seriam pertinentes para serem abordados em cursos de formação continuada. Exibo abaixo as sugestões de Begônia, Antúrio, Flor, Margarida, Crisântemo e Ciclame.

[2] Excerto do questionário sobre as sugestões de tópicos para futuros cursos de formação continuada:

Como planejar online, como otimizar e possibilitar a interação online, haja vista os diferentes tipos de equipamentos e acesso a Internet de alunos e professores, como otimizar tempo online, warmers, uso melhor das opções gratuitas na Internet otimizando o trabalho e ensino. (Begônia)

A meu ver, precisamos dialogar e estudar sobre como manter o ensino descentralizado e dialogado no contexto on-line. A princípio, muitas professoras e professores abandonaram suas práticas habituais presenciais para adotar aulas mais expositivas dentro de um ensino bancário. Acredito que precisamos aprender e pesquisar o ensino remeto não só como algo a se conquistar, mas como conquistar esse desafio. (Antúrio)

Com relação à questão ${ }^{\circ} 7$ me refiro sobre o que a instituição de ensino onde trabalhou não me ofereceu. Mas antes das aulas online eu fiz um curso por conta própria que me fez sentir mais preparada para o ensino remoto. O curso abordava três temas: 1) Planejamento; 2) Ferramentas para elaborar atividades dinâmicas; e 3) Ambientes de aprendizagem e ferramentas de transmissão. Considero que esses três assuntos são muito relevantes para um curso de formação continuada no momento em que estamos. (Flor)

Acredito que no ensino remoto de línguas estrangeiras, um dos maiores desafios é estimular a participação dos alunos nas aulas síncronas e viabilizar atividades orais de maneira prática e efetiva. Nesse sentido, acredito que cursos de formação continuada devem considerar a discussão de temáticas relacionadas a possíveis meios de fomentar a participação dos alunos e viabilizar a prática oral. (Margarida)

Acho que eu gostaria de conhecer mais ferramentas para poder tornar as aulas online tão diversificadas quanto as aulas presenciais. Acredito que dar aula online seja melhor que dar aula presencialmente, por incrível que pareça. Entretanto, precisamos também de mais ferramentas para que as aulas não fiquem enjoativas ou caiam em uma rotina entediante. (Crisântemo)

Seria melhor se tivéssemos um material pensado e confeccionado especificamente para as aulas online. O que fizemos foi adaptar conteúdos e formatos de aulas presenciais para o contexto remoto e não funcionou bem em alguns momentos. (Ciclame) 
Compreendemos que o contexto da pandemia do Covid-19 desestabilizou as estruturas e desafiou todas as áreas a pensar em como desenvolver o 'novo normal', para que só assim pudéssemos seguir exercendo nossas funções. No âmbito da educação não foi diferente. O que enfrentamos foi e tem sido um período de novas descobertas, de incertezas e de constante aprendizado através de práticas e reflexões. Constatamos com base nas sugestões acima apresentadas pelos professores participantes, que, na área da educação, conforme Pimenta (2002, p. 31) argumenta

A formação de professores na tendência reflexiva se configura como uma política de valorização do desenvolvimento pessoal - profissional dos professores e das instituições escolares, uma vez que supõe condições de trabalho propiciadoras da formação como contínua dos professores, no local de trabalho, em redes de auto formação, e em parceria com outras instituições de formação.

Finalmente, encerro esta análise, ressaltando a importância da formação de professores como fator central no desenvolvimento do contexto educacional brasileiro, uma vez que o professor é um dos seus principais atores. Enfatizo também a necessidade de se discutir ambientes educacionais colaborativos por parte dos professores e dos outros funcionários das instituições para que se constitua uma competência coletiva que em conjunto enfrente os dilemas que surgirem. Friso ainda que, enquanto um dos protagonistas dos processos de ensino-aprendizagem, o professor deve sempre refletir sobre sua formação e prática e assim como os participantes desta investigação, deve propor tópicos que contribuam para uma formação continuada pautada na inovação sempre.

\section{CONSIDERAÇÕES FINAIS}

Este artigo apresentou os resultados de uma pesquisa que teve como objetivo investigar a visão dos professores de línguas estrangeiras de um curso livre de idiomas acerca da preparação e dos canais de formação continuada ofertados pelo curso livre para enfrentar o primeiro semestre de ensino remoto emergencial. Verificamos que dos 14 professores que tomaram parte desta investigação, todos classificaram seu desempenho no primeiro semestre de ensino remoto como bom, o que implica que as dificuldades foram superadas ao longo do semestre. 
No quesito experiência/ habilidades com ferramentas digitais de ensino, alguns professores relataram pouco conhecimento das tecnologias, resultando num processo de ensino online mais turbulento. Contudo, em sua grande maioria os professores já estavam habituados às plataformas e às mídias digitais. Quanto às dificuldades enfrentadas, destaco a questão da interação entre professor -alunos e alunos-alunos, visto que como mencionado durante o trabalho, o ensino de línguas estrangeiras tem como enfoque pedagógico principal, a interação oral entre os envolvidos no processo ensinoaprendizagem.

Acerca da formação continuada dos professores, mostramos que o que foi ofertado não foi suficiente para que os professores se sentissem seguros para enfrentar o ensino remoto emergencial. Esperamos que este trabalho tenha atingido as expectativas com relação ao que tange às sugestões de tópicos, realizadas pelos professores participantes, a serem desenvolvidos em cursos de formação continuada de professores nas instituições de ensino de línguas.

\section{REFERÊNCIAS}

ALMEIDA FILHO, J. C. Dimensões comunicativas no ensino de línguas. Campinas: Pontes, 1999.

O professor de língua estrangeira em formação. Campinas: Pontes, 1999.

ALLWRIGHT, R. The importance of interaction in classroom language learning. Applied Linguistics, v.5, n.2, p. 156-171, 1984

ANDRÉ, M. O que é um estudo de caso qualitativo em educação? Revista da FAEEBA - educação e contemporaneidade, Salvador, v.22, n.40, jul./dez.2013.

BASSEY, M. Case Study research in educational settings. Londres: Open University Press, 2003.

BRASIL. Lei no 9.394, de 20 de dezembro de 1996. Estabelece as diretrizes e bases da educação nacional (LDB). Disponível em: <http://www.planalto.gov.br/ccivil_03/leis/19394.htm.> Acesso em: janeiro de 2021.

BRASIL. Lei no 13.005, de 25 de junho de 2014. Aprova o Plano Nacional de Educação - 4654 PNE e dá outras providências. Publicado na Edição Extra do Diário Oficial da União, de 26 de junho de 2014, n¹20-A. Disponível em: <http://pne.mec.gov.br/18planos-subnacionais-de-educacao/543-plano-nacional-de-educacao-lei-n-13-005-2014> Acesso em: janeiro de 2021.

CHIMENTÃO, L. K. O significado da Formação Continuada Docente. $4^{\circ}$ CONPEF. Congresso Norte Paranaense de Educação Física Escolar. Londrina, Paraná, 2009. 
FREIRE, P. Pedagogia da autonomia: Saberes necessários à prática educativa. São Paulo: Paz e Terra, 1996.

GARCEZ, P. M. (2013). [Conversa com] Pedro de Moraes Garcez. In: SILVA, K. A.; ARAGÃO, R. (Orgs.). Conversas com formadores de professores de línguas. Campinas, SP: Pontes, p. 215-228.

GATTI, B. Formação de professores e carreira: problemas e movimentos de renovação. Campinas, SP: Editora Autores, 1997.

GATTI, B. Formação de professores no Brasil: características e problemas. Revista Educação \& Sociedade, vol.31, n.113, 2010. Disponível em: < https://www.scielo.br/pdf/es/v31n113/16.pdf> Acessado em janeiro de 2021.

LIBÂNEO, J. C. Didática. 2. ed. São Paulo, SP: Cortez, 2013.

MOREIRA, A. F. B. Formação de professores e currículo: questões em debate. Ensaio: aval.pol.públ.Educ., Rio de Janeiro, 2020 .

MOREIRA, H; CALEFFE, L. G. Metodologia da pesquisa para o professor pesquisador. Rio de Janeiro, Lamparina, 2006. 2 edição.

MOREIRA, M.A, Teorias de Aprendizagens, São Paulo, EPU, 2011.

NÓVOA, A. Para uma formação de professores construída dentro da profissão.

Revista de Educación, Madri, n. 350, p. 1-10, 2009.

PIMENTA, S. G. (Org.). Saberes pedagógicos e atividade docente. São paulo: Cortez, 2002.

TARDIF, M. Saberes docentes e formação profissional. Petrópolis, R.J.: Editora Vozes, 2002. 


\title{
CAPÍtTULO V
}

\section{A IMPORTÂNCIA DA LEITURA NA EDUCAÇÃO INFANTIL}

\author{
Vanúsia Silva de Sousa ${ }^{11}$; Liane Batista de Aquino ${ }^{12}$; \\ Maria das dores Barbosa Soares ${ }^{13}$; Daniele do Nascimento Luna ${ }^{14}$ \\ Josélia Isídio Rodrigues de Sousa ${ }^{15}$. \\ DOI-Capítulo: 10.47538/AC-2021.14-05
}

RESUMO: Este trabalho teve como objetivo principal mostrar a importância da leitura na educação infantil. Pois a leitura permite viagens a mundos internos e externos, ficção e realidade. Já se sabe que para que o hábito de leitura se estabeleça, as crianças necessitam estar em contato com os livros desde a infância.

Nesse sentido, cabe não só ao educador, mas também à família, nesse processo de realizar ações que possam fornecer à criança tal conscientização, bem como, o interesse e o prazer na leitura e, destacar a forma de desenvolver na criança todos os benefícios que envolvem o aprendizado da leitura. A mesma é cada vez mais necessária para a vivência social, uma vez que, ela ocorre quando há interação entre leitor e autor.

Para tanto, esse artigo mostra uma breve percepção histórica da leitura, como a leitura pode contribuir de forma positiva na formação da criança, e o papel do professor na aquisição da leitura na fase da educação infantil.

PALAVRAS-CHAVE: Leitura. Literatura Infantil. Professor.

\section{THE IMPORTANCE OF READING IN EARLY CHILDHOOD EDUCATION}

ABSTRACT: This paper has main objective to show the importance of the reading in the Childhood Education. Child's imagination is wided through of reading, taking this child daydreaming with imaginary and real worlds. For a child to like of the reading, they need to be incentive to read since childhood.

Thus, the obligation of educate is not just of the teacher, but the family has obligation to educate too. This process purposes to become a child more conscious, giving their a pleasure to read in order that they can develop all benefits that is inside of the reading. The reading is very necessary to social life and it happens when there is an interaction between reader and author.

\footnotetext{
${ }^{11}$ Pedagogia - UVA. Pós-graduada em Educação Infantil e Anos Iniciais - FMB. Professora celetista do Município de Macau.E-mail: vanusiassousa@gmail.com

${ }^{12}$ Pedagogia - ISEP. Pós-graduação em Educação Infantil E Ensino Fundamental -Faculdade de Maciço de Baturite. Pós-graduação em Neuropsicopedagogia - FAVED. E-mail: Liane.aquino123@gmail.com

${ }^{13}$ Pedagogia - ISEP. Pós-graduação em Educação Infantil e Ensino Fundamental - faculdade de Maciço de Baubaturité. E-mail: dorinhasoaresb@gmail.com

${ }^{14}$ Pedagogia - ISEP. Pós-graduação em AEE - IPEBRAS. Pós-graduação em Alfabetização e Letramento - Faveni (em andamento). Pós-graduação em Anos Iniciais - Faceminas (em andamento). E-mail: darvindanny @ gmail.com

${ }^{15}$ Pedagogia - UFRN. Pós-graduação em Educação e Sustentabilidade em Unidade de Conservação - UFRN. Pósgraduação em Educação Infantil e Anos Iniciais - Faculdade Futura. Pós-graduação em Alfabetização e Letramento FAVENI. E-mail: joseliaisidiorodrigues564@gmail.com
} 
Therefore this paper shows a short view historical of reading and the way that can to help in the child's develop, this research shows also the importance of teacher in the learning of reading for child.

KEYWORDS: Reading. Childhood Education. Teacher.

\section{INTRODUÇÃO}

A leitura na educação infantil é imprescindível, pois ela tem a capacidade de formar cidadãos ativos na organização de uma sociedade mais consciente, com uma visão mais ampla e crítica, promovendo aquisição de conhecimentos, possibilitando acesso às informações e interações, podendo aprimorar $\mathrm{o}$ vocabulário, bem como $\mathrm{o}$ desenvolvimento intelectual e social. Por isso, desenvolver o hábito da leitura desde a infância é fundamental, e a influência dos pais e professores nesse estágio é de suma importância.

Nesse contexto, cabe salientar que, a importância da leitura consiste em proporcionar às crianças condições de inserção para que as mesmas se sintam estimuladas a ler, adquirindo enriquecimento cultural, social e ao mesmo tempo descobrindo e vivenciando um mundo novo de conhecimentos, de informações e transformações.

Para tanto, o objetivo geral deste artigo é destacar a importância da leitura na educação infantil para a formação de futuros cidadãos leitores autênticos, críticos e reflexivos. Dentre os objetivos específicos estão estimular a leitura como forma de entretenimento e a aprendizagem; proporcionar a leitura de forma lúdica e prazerosa; desenvolver situações que ofereçam estímulos à prática da linguagem oral e escrita. Pensando nisso, cabe ao professor o compromisso e a responsabilidade de promover às crianças situações envolventes, condições favoráveis e prazerosas e que venha a despertálas para a prática de leitura.

Diante de tal situação entende-se que a leitura é favorecedora ao desenvolvimento global da criança. Partindo dessa realidade, o artigo será desenvolvido com base em pesquisas bibliográficas, que consiste no levantamento e análise do que já foi produzido em publicações, Livros didáticos, livros teórico, artigos científicos, revistas e blogs referentes ao tema e será concluída com o nosso conhecimento adquirido que nos leva acreditar que o trabalho acrescentará de forma positiva nas contribuições fundamentais 
para a informação dos educadores e para o desenvolvimento de metódicos de ensino na educação infantil.

Dessa forma, para a contribuição do mesmo, buscou-se fundamentar nas obras de autores como: Batista (2013), Fernandes (2010), Faria (2010), Coelho (2012), Fleck (2011), Soares (2000), Silva (1993), Cagliare (1098), Koch (2000), Antunes (2005), Dutra (2011), Brito (2010), Lois (2010) e Freire (2002) entre outros.

Neste contexto, vale salientar que pensar nas crianças e na sua relação com os livros de literatura é pensar no futuro, e pensar no futuro é ter a responsabilidade de construir um mundo de possibilidades, onde o sujeito- leitor é aquele que produz sua leitura a partir de sua inscrição, nessa dinâmica, como sujeito social, uma vez que os sentidos do texto são construídos nessa relação dialógica entre autor/texto/leitor.

\section{CONTEXTO HISTÓRICO DO PROCESSO DA LEITURA}

Buscando contribuir de forma mais efetiva com a formação do leitor e do professor comprometidos com a prática da leitura na formação dos alunos cidadãos, vimos a necessidade de contextualizar um pouco sobre a leitura.

Usamos de formas parafraseadas as concepções de Walda Antunes, Paulo Freire, Bastos, Santos, Morim além de outros, para contribuir com informações que serão valiosíssimas para que possamos compreender como vem acontecendo à prática da leitura e escrita ao longo dos tempos.

Ao falarmos de leitura devemos compreender que não é um ato novo e sim uma atividade desde o surgimento do homem no período da pré-histórica. Como afirma Antunes (2005), “[...] a própria natureza tem oferecido ao homem possibilidades e matérias em ambulância para fazer os seus registros como: pedra, areia, barro, madeira, casca e folhas de árvores, como também animais".

Nesse sentido, compreendeu-se que a escrita era feita em forma de figuras gravadas nas rochas das cavernas, que iam dando significados às palavras e aos sons, vindo proporcionar formas de expressão e tendo como evolução os diversos tipos de alfabetos. Sendo assim uma das formas utilizadas até hoje pelos povos para suas comunicações. 
Para Antunes (2005), [...] tudo que sabemos dos nossos antepassados é o resultado de forma diversas de comunicação que foram se estabelecendo, tanto baseadas na oralidade das gerações que se sucederam, como nos símbolos e mensagens gravadas e estruturadas de diversas maneiras e que serviram para testemunhar a existência do ser humano e transmitir muito do seu conhecimento. A partir da reflexão da autora faz-se necessário conhecermos um pouco sobre a nossa história, durante o Brasil colônia. É importante ressaltar que nos tempos de colônias, houve poucos desenvolvimentos teóricos no campo da educação.

Ao decorrer dos anos a leitura foi expandida, sendo que nesse período somente uma minoria da elite política e do clero tinha acesso à escola e não havia vontade política por parte da família real de Portugal no sentido de ampliar as oportunidades educacionais para o povo. Os privilegiados com acesso à leitura eram os senhores portugueses. Aqui se instalaram os senhores de engenhos e aos seus filhos, ou às pessoas que eram ligadas à administração da colônia, e ainda aos jesuítas e ao clero. Quanto às pessoas simples como os escravos e empregados dos senhores, esse direito era negado. Não só esse direito dentre outros, como a moradia, comida, qualidade, e principalmente a saúde.

Mas, a partir de meados do XIX o estado começa a exercer influência mais efetiva quanto à obrigatoriedade do ensino e a exigência de gratuidade. É de convir que nesse período quase não existia material didático. Partindo desse pressuposto, subtende-se que os recursos didáticos utilizados nas poucas escolas existentes, como manual de leitura eram relatados de viajantes, textos autobiográficos, textos escritos manualmente como cartas familiares, a bíblia, documentos de cartório, e a primeira constituição do império de 1.827 , específica sobre a instrução pública, o código criminal.

As escolas elementares quase inexistentes, dessa forma eram excluídos os escravos e, a mulher, no entanto submetida a uma educação geral na qual o objetivo maior era cumprir com as atividades domésticas.

Diante disso, Basto (1972), ressalta dizendo que durante a colonização, "as práticas escolares eram feitas nos engenhos e nos núcleos das fazendas por capelães, mestres-escolares e padres, que eram contratados para essa finalidade". 
Nos anos de 1800 a 1807 houve pouca mudança em vários setores do nosso país, e no ensino, permanecemos utilizando a tabuada como gramática de Reis Lobato. Porquanto era imposta por D. José I. Rei de Portugal que exigia não só nas metrópoles, mas em todas as colônias.

A partir de 1808, começaram as mudanças que se tornaram contínuas, até praticamente o fim do século, no entanto com a chegada da família real para o nosso país, para fugir da perseguição dos franceses comandado por Napoleão Bonaparte. Tal fato aparentemente comum trouxe modificações para a língua falada no Brasil e, também trouxe à tona o significado de nacionalidade de independência.

Com esses acontecimentos ocorreram transformações significativas nas relações sociais, econômicas e culturais, haja vista a necessidade de instrução para a capacitação trabalhista, pois outros países tinham grandes transformações.

Com essas mudanças sociais e políticas na Europa levaram a burguesia alcançar o poder na França, na Áustria, Rússia, Prússia, e na Inglaterra quase ao mesmo tempo acontecia a revolução industrial, pois o mundo inteiro passava por profundas mudanças tanto na sociedade quanto nas ideias.

Os homens mudaram seu ponto de vista sobre si, dessa forma tornam-se individualistas, mais fantasiosos, além de outros. Contudo, o Brasil aos poucos foi vivenciando essas transformações, havendo assim uma mudança na sociedade, a classe dos nobres e o clero passaram a exercer cada vez menor influência sobre o povo.

A educação Nacional, desde o século passado, se volta para a formação do cidadão. Porém, de maneira geral, as propostas educacionais do século XIX se intensificam neste século como escola pública, leiga, gratuita e obrigatória. Devido à explosão democrática e à ampliação das indústrias, o problema da escolarização assume níveis nunca vistos. Apesar da extensão dos programas de atendimento, ainda são influentes as medidas tomadas pelos governos, sobretudo nos países em desenvolvimento.

Apesar de tudo, não se pode negar que houve considerável ampliação da rede escolar. Podemos verificar que, desde o final do século XIX até a década de 40, aumentam 
as oportunidades de estudos. Mas, é a partir do final do século XIX e início do século XX que se configura, definitivamente, o movimento escola-nova.

Essas escolas devem ser compreendidas como tentativa de superação da tradicional excessivamente rígida e preocupada com a memorização dos conteúdos.

Tentando superar o viés intelectual da escola tradicional, as escolas novas têm como objetivo valorizar os jogos, os exercícios físicos, as práticas de desenvolvimento da motricidade e da percepção que estimulem as mais diversas habilidades. $\mathrm{O}$ ensino da leitura era feito tradicionalmente por meio de letras isoladas que depois seriam reunidas na formação de palavras e, após isso, na formação de frases.

No Brasil, a tendência tecnicista foi introduzida no início da ditadura militar e prejudicou sobretudo as escolas públicas. Uma das consequências funestas do tecnicismo é a excessiva burocratização do ensino, mergulhando os professores numa papelada inútil. Evidentemente, o que não foi compreendido nessa tendência é que o processo pedagógico tem sua própria especificidade e jamais poderá haver uma rígida separação entre concepção e execução do trabalho. Não tem sentido a existência de professores que apenas executam tarefas organizadas pelo setor de planejamento.

Com tudo, só a partir de 1980, no bojo do processo de redemocratização do país, que o campo da educação ganhou um grande impulso, em 1988, a Constituição Federal reconhece o dever do Estado e o direito da criança a ser atendida em creches e pré-escolas e vincula esse atendimento à área educacional, dando assim continuidade a essas mudanças em 1990 o Estatuto da criança e adolescente ratifica os dispositivos enunciados na constituição.

Hoje em pleno século XXI, a leitura é vista como uma atividade dialógica, um processo de interação que se realiza entre o leitor, mediado pelo texto, entendendo todos os elementos envolvidos em um determinado histórico-social.

\section{CONCEPÇÃO DE LEITURA NO ESPAÇO ESCOLAR}

A leitura nos traz hoje uma grande possibilidade de alcançar novos horizontes através do desenvolvimento de aptidões para construção do leitor enquanto ser socialmente construído. 
De acordo com esse conceito Dutra (2011) enfatiza, ler é uma das competências mais importantes a serem trabalhadas com o aluno, principalmente após recentes pesquisas que apontam ser esta uma das principais deficiências do estudante Brasileiro. Uma leitura de qualidade representa a oportunidade de ampliar a visão do mundo. Sabemos que é através da leitura que o homem pode tomar consciências das suas necessidades, promovendo assim a sua transformação e a do mundo. Diante do que o autor acima cita, faz se necessário criarmos o hábito da leitura, pois bem sabemos que é através da leitura que ampliamos os nossos conhecimentos sobre assuntos específicos, assim corno no geral. Pois, bem sabemos que quem ler e entender o que leu pode vir a tornar-se um sujeito conhecedor do mundo através da leitura.

Levando-se em conta o que nos representa o dicionário de língua portuguesa: "leitura é ato, arte ou hábito de ler", Aurélio (2001), Ou seja, aquilo que se lê é uma operação de percorrer em um meio físico, sequências de marcas codificadas que representam informações registradas, e convertê-las à forma anterior como imagens, sons, dados para processamento.

Sendo assim a leitura abre novos horizontes, nos faz viajar pelo mundo imaginário. É um rico passatempo. O exercício da leitura começa com o ato de narrar. Seguindo essa linha de raciocínio Ferreiro nos fala que:

O prazer da leitura leva a privilegiar um único tipo de texto: a narrativa ou literatura de ficção, esquecendo que uma das funções principais da leitura ao longo de toda a escolaridade é a obtenção de informações a partir de texto escrito (FERREIRO, 1992, p. 18).

A referida autora contribui com informações importantes no que diz respeito ao gosto que o indivíduo passa a ter quando descobre a leitura.

Segundo os Parâmetros Curriculares Nacionais de Língua Portuguesa:

A leitura é um processo no qual o leitor realiza um trabalho ativo de conhecimento do assunto, sobre o autor, de tudo que sabe sobre a linguagem etc. Não se trata de extrair informações, decodificando letra por letra, palavra por palavra. Trata-se de uma atividade que implica estratégias de seleção, antecipação, inferência, e verificação, sem as quais não é possível proficiências. É o uso desses procedimentos que possibilita controlar o que vai sendo lido, permitindo tomar decisões diante de dificuldades de compreensão, avançar, na busca de 
esclarecimentos, validar no texto suposições feitas etc. (BRASIL, 1998, p. 69-70).

Diante do que, os Parâmetros Curriculares nos mostram, faz-se necessário compreendermos que leitura não é tarefa simples, o sujeito precisa vencer etapas e construir procedimentos para bem desenvolver a capacidade de se tornar um leitor.

Nesse processo de leitura alguns questionamentos são inerentes e devem ser respondidos como: O que é leitura? Para que ler? Como ler?

Podemos ter várias respostas diferentes e isso é possível porque a concepção de leitura diverge entre os educadores que lidam com a construção de alunos leitores.

A concepção de leitura de língua como representação do pensamento corresponde a de sujeito psicológico, individual, dono de sua vontade e de suas ações, Koch (2002).

Nesse contexto, entende-se que essa concepção é vista como um ego construído mentalmente, sendo assim a língua como representação do pensamento e do sujeito. É visto também como um produto-lógico-do pensamento.

Para Soares (2000, p. 18), diz “a leitura não é esse ato solitário; é interação verbal entre indivíduos, e indivíduos socialmente determinados: leitor, seu universo, seu lugar na estrutura social, suas relações com o mundo e com os ostros".

Levando-se em conta as considerações de Soares, entende-se que a leitura é um processo dinâmico e social, tendo como resultado da interação, da informação que está presente no texto e o conhecimento do leitor, possibilitando assim a construção do sentido, ou seja, a compreensão textual.

Com base nisso, é importante ressaltar que, a leitura é uma atividade que se realiza individualmente, mas que se insere num contexto social, envolvendo disposições atitudinais e capacidades que vão desde a decodificação do sistema de escrita até a compreensão e a produção de sentido para o texto lido. abrange, depois, desde capacidades desenvolvidas no processo de alfabetização até capacidades que habilitam o aluno à participação ativa nas práticas sociais letradas que contribuem para o seu desenvolvimento. 
Dessa forma, nasce à motivação para leitura a partir da curiosidade, da abertura da cabeça para novos conceitos assim como para aquisição de novos conhecimentos e informações (COELHO, 2012).

Nesse sentido, devemos considerar que a aprendizagem da leitura é a base para a aprendizagem. Dessa forma, compreende-se que o desenvolvimento do interesse e da capacidade da leitura pode contribuir, automaticamente, para o processo da escolarização.

Para Cagliari (1998) "leitura é um dos aspectos mais importantes que a aquisição dos conhecimentos, como um meio de comunicação, socialização e expressão do pensamento. Sendo a leitura a forma mais usada para comunicação e por consequência, um veículo de socialização, esta será eficiente se for bem explorada e desenvolvida”.

Diante do que o autor expõe, é de suma importância, que todos venham conscientizar-se que a leitura é um fator importante em nossas vidas, tendo em vista que ela contribui na participação social e no exercício da cidadania que estão diretamente ligados à prática e uso da leitura. Para Lajolo destaca:

Numa sociedade como a nossa", em que a divisão de bens é tão desigual não se estranha que desigualdade similar presidia também à distribuição de bens culturais, já que a participação em boa parte destes últimos é medida pela leitura, habilidade que não está ao alcance de todos, nem mesmo de todos aqueles que foram escola (LAJOLO, 1994, p. 160).

Partindo desse pressuposto, o autor nos mostra que a leitura tem um valor positivo para todos, pois ela não só beneficia os indivíduos como também a sociedade, sendo assim uma das habilidades mais importantes para o nosso cotidiano. Evidencia-se a função social da leitura, presente nos diversos usos de cada indivíduo e sua grande influência no aprendizado do ler e escrever.

Não obstante o ato de ler oferece a possibilidade de uma livre participação social do homem na sociedade, transcendendo de forma reflexiva, crescendo progressivamente e ampliando o seu entendimento das coisas que o cercam. Nesse aspecto, a leitura representa um instrumento de grande poder nas mãos daqueles que a detêm. Numa sociedade letrada, cabe à escola o papel de ensinar a criança a ler e escrever com competência, formando cidadãos conscientes e críticos. Ler, portanto, significa colher 
conhecimentos e o que já está estabelecido, introduzindo no mundo em novas séries de relações e em um novo modo de perceber a quem nos cercam.

Cabe salientar que, com a leitura, o homem adquire conhecimentos e obtém vantagens pessoais. Ela é veículo de estudo e do saber, a verdadeira chave do êxito. Através da leitura, aprendemos a fixar valores e incluir o bom gosto; aprende-se também a viver e a triunfar na luta pela sobrevivência.

\section{A IMPORTÂNCIA DA LITERATURA NA EDUCAÇÃO INFANTIL}

A literatura infantil é, antes de tudo, literatura; ou melhor, é arte: fenômeno de criatividade que representa o mundo, o homem, a vida, através da palavra. Funde sonhos e a vida prática, o imaginário e o real, os ideais e sua possível/impossível realização.

Diante disso, pensar nas crianças e na sua relação com os livros de literatura é pensar no futuro, e pensar no futuro é ter a responsabilidade de construir um mundo com menos espaço para opressão das diferenças. Pensando nisso, a literatura infantil pode influenciar de maneira positiva nesse processo, Bakhtin (1992) expressa sobre a literatura abordando que por ser um instrumento motivador e desafiador, Ela é capaz de transformar o indivíduo em um sujeito ativo, responsável pela sua aprendizagem, que sabe compreender o contexto em que vive e modificá-lo de acordo com sua necessidade.

Para tanto, a literatura no caráter formador faz com que as crianças apreciem a essência da arte literária, possibilitando uma inter-relação com o cotidiano. Quanto mais oferecermos literaturas às crianças, mais elas estarão capacitadas a atender o texto, a interpretar, a valorizar e ativar os seus intertextos construídos para o desenvolvimento de uma competência literária.

Portanto, faz muito sentido pensarmos a literatura como porta de entrada para a leitura das crianças. As histórias abordam situações muito próximas de seu cotidiano, falam de famílias, diferentes culturas e épocas, dos sentimentos, das relações, alimentam a imaginação e a fantasia, e contribuem com a socialização. Além disso, durante parte da infância as crianças buscam saber o que faz da realidade e o que é ficção. Sem dúvida estes são conceitos difíceis, porém as histórias as ajudam a compreendê-los. 
As histórias alimentam as brincadeiras de faz de conta das crianças, pois ampliam enredos, conflitos, personagens, cenários e desfechos. E, como no passe de mágica, as crianças viram reis, rainhas, dragões, cavaleiros, animais falantes, fadas, magos, bruxas, heróis e heroínas entre outros. Personagens no vasto repertório do "era uma vez".

A convivência com a literatura possibilita que a criança conheça o uso especial da palavra que oferece oportunidade de o mundo real torna-se mágico, de poder brincar no mundo do faz de conta que relaciona a realidade e a imaginação.

Neste sentido, entende-se que a literatura infantil contribuirá para a assimilação no desenvolvimento integral da criança. Diante disso Abramovich relata que:

É importante para a formação de qualquer criança, ouvir muitas, muitas histórias... Escutá-las é o início da aprendizagem para ser um leitor, e ser leitor é ter um caminho absolutamente infinito de descoberta e de compreensão de mundo (...) (ABRAMOVICH, 1997, p. 16).

Diante do relato exposto pelo autor acima citado, é oportuno frisar que, a professora ou professor necessitam articular condições de organização dos espaços, tempos, materiais e das interações nas atividades para que as crianças possam expressar sua imaginação nos gestos, no corpo, na oralidade e/ou na língua de sinais, no faz de conta, no desenho e em suas primeiras tentativas de escrita. De modo a proporcionar às crianças diferentes experiências de interações que lhes possibilitem construir saberes, fazer amigos, aprender a cuidar de si e a conhecer suas próprias preferências e características, deve-se possibilitar que eles participem de diversas formas de agrupamento (grupos da mesma idade e grupos de diferentes idades), formados com base em critérios pedagógicos.

\section{O PAPEL DO PROFESSOR NA AQUISIÇÃO DA LEITURA}

Quando analisamos a prática pedagógica de qualquer professor vemos que, por trás de suas ações, há sempre um conjunto de ideias que as orienta. No entanto o papel do professor na construção do aluno leitor que visa à importância da leitura na educação infantil é delicado, pelo fato de não se conceber apenas a decodificação de palavras, mas a de um sujeito instigador em que promova seus alunos de modo a se tornarem seres ativos e autênticos. 
Dada a relevância que, é por meio da leitura que as pessoas podem ter acesso ao legado cultural da humanidade, construído ao longo dos anos.

Diante dessa compreensão, vale salientar que a formação das crianças, ocorre por meio de sua participação na rede de relações que constitui a dinâmica social. É convivendo com pessoas, seja com adultos, ou com jovens que os conhecimentos são assimilados e desenvolvem hábitos e atividades de convívio social, com cooperação e respeito humano. Daí a importância da interação professor-aluno e da relação alunoprofessor.

Refletindo sobre o papel da leitura e a importância da formação da criança como leitor, compreendemos que o professor deve ser o agente promissor nessa formação, buscando assim, estimular a capacidade da criança no ato de interagir com o conhecimento de forma autônoma, o que passa a beneficiar depois, no comprimento de seu papel de cidadão, conforme nos aponta Lena Loís:

Se a prática da leitura não está incorporada, o desenvolvimento da cidadania também fica comprometido. Se não lê, não se pode aumentar o repertório crítico, sem a crítica, o poder de julgamento fica limitado e a capacidade de intervenção e inserção cultural também (LOÍS, 2010, p. 19).

Diante da afirmação de LOIS, compreendemos que o professor de educação infantil tem um papel importantíssimo nessa fase da criança, em relação aos seus primeiros contatos com a leitura e a formação de hábitos leitores. Ele tem uma grande responsabilidade e precisa se preparar com o compromisso e profissionalismo. Segundo Freire (1999, p. 29),

Percebe-se, assim, a importância do papel do educador, o mérito da paz com que viva a certeza de que faz de sua tarefa docente, não apenas ensinar conteúdos, mas também ensinar a pensar certo. (FREIRE. 1999. p. 29).

A relevância do autor destaca a importância que o professor deve ter de criar possibilidades e condições estimuladoras e desafiadoras para que os discentes possam refletir e buscar alternativas para solucionar, de maneira criativa, os problemas que muitas vezes surgem.

Cabe aos mediadores, ainda, levar o sujeito leitor a perceber o texto, compreender, dialogar e discutir aquilo que leu. O leitor não deve ser um sujeito passivo diante da 
leitura, mas necessita estabelecer uma relação de troca, uma experiência que o leve a se questionar, duvidar, crer, e tecer novas concepções acerca do que leu.

Neste contexto, cabe ao professor criar oportunidade para que a criança, no processo de elaborar sentidos pessoais, se aproprie de elementos significativos de sua cultura não como verdades absolutas, mas como elaborações dinâmicas e provisórias. Trabalha-se com os saberes da prática que as crianças vão construindo ao mesmo tempo em que se garante a apropriação ou construção por elas de novos conhecimentos. Para tanto, a professora e o professor observam as ações infantis, individuais e coletivas, acolhe suas respostas, busca compreender o significado de sua conduta.

\section{CONSIDERAÇÕES FINAIS}

Conforme pode ser visto ao decorrer da construção deste artigo, a leitura infantil é o objeto promissor no desenvolvimento intelectual, cultural, social e pessoal do ser humano.

É por meio da leitura que podemos formar cidadãos críticos, uma condição indispensável para o indivíduo capaz de compreender o significado das inúmeras vezes que se manifesta no debate social e de pronunciar-se com sua própria voz, tornando consciente de todos os seus direitos e sabendo lutar por eles.

Para tanto, o presente trabalho deixa claro que o ato de ler é fundamental não apenas como mais uma habilidade que o aluno desenvolve para adquirir conhecimento, mas importante para sua formação como um todo porque a partir do momento que se torna um bom leitor, a compreensão da realidade que o cerca, atitudes no sentido de atuar de forma positiva na sociedade passam a ser inerentes à natureza do mesmo.

Por isso, a leitura precisa ser concebida como aquilo que vai em busca do ponto de vista, que leva ao questionamento, à investigação dos meios que permitiram elaborálo, ao confronto com seus próprios pontos de vistas, a sua relação com o instrumento que permite elaborá-las.

Partindo desse pressuposto, a compreensão dos textos pela criança é a meta principal do ensino da leitura. Ler com compreensão inclui, além da compreensão linear, a capacidade de fazer inferências. A compreensão linear depende da capacidade de 
construir um "fio da meada" que unifica e inter-relaciona os conteúdos lidos, compondo um todo coerente. Por exemplo, acabar de ler uma narrativa, ser capaz de dizer quem fez o quê, quando, como, onde e por quê. Já a capacidade de produzir inferências diz respeito ao "ler nas entrelinhas", compreender os submetidos, os ou 'não ditos', à realização de operações como associar elementos diversos, presentes no texto ou que fazem parte das vivências do leitor, para compreender informações que não estejam explicitadas no texto. Para tanto, a capacidade de compreensão não vem automaticamente, nem plenamente desenvolvida, precisa ser exercida e ampliada em diversas atividades, que podem ser realizadas antes mesmo que as crianças tenham aprendido a decodificar o sistema de escrita.

Nesse sentido o professor contribui para o desenvolvimento dessa capacidade dos alunos quando: lê em voz alta e comenta ou discute com eles os conteúdos e usos dos textos lidos; proporciona a eles familiaridade com gêneros textuais diversos (histórias, poemas, trovas, canções, parlendas, listas, agendas, propagandas, notícias, instruções de jogos, cartazes, diferentes gêneros entre outros). Saber reconhecer diferentes gêneros textuais e identificar suas características gerais favorece bastante o trabalho de compreensão, porque orienta adequadamente as expectativas do leitor diante do texto.

É pertinente dizer que, a leitura só é eficaz se houver compreensão da mesma. O indivíduo que não compreende o que lê, na verdade não leu. Ela é uma forma de se conhecer a realidade e de refletir sobre a mesma.

O trabalho com a leitura tem a finalidade de formação de leitores competentes; ou seja formar alguém que compreenda o que ler; que possa ler também o que não está escrito. Dessa forma a leitura é um processo de compreensão que se conclui a partir do momento em que o cérebro recebe a informação visual que está diante dos olhos e termina quando esta informação é integrada aos conhecimentos prévios que o leitor possui.

\section{REFERÊNCIAS}

ABRAMOVICH, Fanny. Literatura Infantil: gostosuras e bobices. São Paulo: Scpione, 1993.

ANTUNES, Walda de Andrade. Biblioteca escolar-curso para formação continuada do professor/leitor: manual. São Paulo: global, 20105. 
BASTOS, Silva A parecida. Leitura e escrita em pleno Brasil Colônia. São Paulo: Brasiliense, 1982.

BRASIL. Ministério da Educação Básica. Secretaria de Educação Fundamental. Parâmetros Curriculares Nacionais: língua portuguesa. 3. Ed. Brasília: MEC/SEF, 2001.

BAKHTIN, Mikhail V. Estética da criação verbal. São Paulo: Martins Fontes, 1992.

BRITO Daniele santos de. Importância da leitura na formação social do indivíduo. Revela, ano IV, n. 8, p. 1-35, junho 2010.

CAGLIARI, L. C. Alfabetizando sem o BÁ-BE-BI-BÓ-BU. São Pulo: Scipione, 1998. COELHO, Nelly Novaes. A literatura Infantil. São Paulo: Moderna, 2000. Paulo, 2012. Nelly Novaes. A literatura Infantil. Teoria-ANÁLISE-Didática. Quiron, São

DUTRA, Vânia L. R. Abordagem fundamental da gramática na Escola Básica. Anais do VII congresso Internacional da Abralih. 2011. Disponível em www.abralin.org.acesso em 06/05/2019.

BRASIL. Diretrizes Curriculares Nacionais Gerais da Educação Básica / Ministério da Educação. Secretaria de Educação Básica. Diretoria de Currículos e Educação Integral. Brasília: MEC, SEB, DICEI, 2013.

FERREIRA, Aurélio Buarque de Holanda, 1910-1989, Miniaurélio século XII Escolar: O minidicionário da língua portuguesa. 4. Ed. Rio de Janeiro: Nova fronteira, 2001.

FREIRE, Paulo. A pedagogia da autonomia. São Paulo. Paz e Terra, 1999.

FERREIRO, E; M. G. P. Os processos de Leitura e Escrita. 3. Ed. Porto Alegre, Artes Médiacas, 1990.

FONSECA, ed. Inteirações: com olhos de ler, apontamentos sobre a leitura para a prática do professor infantil/edi Fonseca; Josca Aline Barouk, coordenadora; Maria Cristina Carapeto Lavador Alves, organizadora. - São Paulo: Blucher, 2012. - (coleção interações).

KOCH, Ingedore V.; Vanda Maria. Ler compreender: os sentidos do texto. São Paulo CONTEXTO, 2006, p. 9-29.

LAJOLO, MARIA. Do mundo da leitura para a leitura do mundo. 3. Ed. São Paulo: Ática, 1994.

Loís, LENA. Teoria prática da formação do leitor: leitura e literatura na sala de aula. Porto Alegre: Artmed, 2010.

MOOR, A. M. COSTA, G. P. O ensino colaborativo na formação do professor de inglês instrumental. In: LEFFA, V. (org.). O professor de línguas estrangeiras construindo a profissão. Pelotas: Educat, 2001, p. 157-173.

SAVELI. Esméria de Lurdes. Por uma pedagogia da leitura=reflexão sobre a formação do leitor. In: CORREIA, Djane Antonucci. (org). Práticas de letramento no ensino: leitura, escrita, e discurso. São Paulo: parábola Editorial; ponta Grossa, PR: UEPG, 2007. 
SOARES, M. A. As condições sociais da leitura: uma reflexão em contra ponto. In: TERZI, B. A Construção da leitura. 3.de. Campinas: pontes, 2002.

SITES: https://www.pensador.com/frases_sobre_leitura/ Acesso em 14/04/2019 às 20h00minhrs 


\title{
CAPÍTULO VI
}

\section{A IMPORTÂNCIA DOS JOGOS COMO RECURSOS PEDAGÓGICOS NO ENSINO DE MATEMÁTICA}

\author{
Sara Gabriele Alves Monteiro ${ }^{16}$; Maria Aparecida Teixeira ${ }^{17}$; \\ Luana Teixeira Alves ${ }^{18}$; Claudiane Teixeira ${ }^{19}$; \\ Adriana Aparecida Gonçalves ${ }^{20}$. \\ DOI-Capítulo: 10.47538/AC-2021.14-06
}

\begin{abstract}
RESUMO: O presente artigo tem como objetivo debater a importância dos jogos para o ensino da matemática, onde serão apontados os principais benefícios que os jogos proporcionam a aprendizagem de alunos do ensino fundamental, anos iniciais. A linha de pesquisa principal é apresentar uma proposta de ensino que possa ser desenvolvida em sala de aula, utilizando os jogos como um recurso pedagógico que estimule a aprendizagem matemática de maneira significativa, mostrando como os jogos podem melhorar o processo de aprendizagem e aquisição de conhecimentos matemáticos. Com os jogos matemáticos, os alunos podem encontrar equilíbrio entre o real e o imaginário e com isso ampliarem seus conhecimentos e o raciocínio lógico-matemático, passando a usar conceitos matemáticos em situações cotidianas. Para elucidar os preceitos teóricos, utilizaremos teóricos de renome como Borin (1998) e Gandro (2000).
\end{abstract}

PALAVRAS-CHAVE: Jogos. Ensino de Matemática. Recursos Pedagógicos.

\section{THE IMPORTANCE OF GAMES AS PEDAGOGICAL RESOURCES IN MATHEMATICS TEACHING}

ABSTRACT: This article aims to discuss the importance of games for teaching mathematics, where the main benefits that games provide for the learning of elementary school students, early years will be pointed out. The main line of research is to present a teaching proposal that can be developed in the classroom, using games as a pedagogical resource that significantly encourages mathematical learning, showing how games can improve the process of learning and acquisition of knowledge mathematicians. With math games, students can find a balance between the real and the imaginary and thus expand their knowledge and logical-mathematical reasoning, starting to use mathematical concepts in everyday situations. To elucidate the theoretical precepts, we will use renowned theorists such as Borin (1998) and Gandro (2000).

KEYWORDS: Games. Teaching of Mathematics. Pedagogical Resources.

\section{INTRODUÇÃO}

\footnotetext{
${ }^{16}$ Graduada em Pedagogia. E-mail: sarapedagoga@gmail.com

${ }^{17}$ Graduada em Pedagogia. E-mail: maria.bbu18@gmail.com

${ }^{18}$ Graduada em Pedagogia. E-mail: luana.teixeira@gmail.com

${ }^{19}$ Graduada em Pedagogia. E-mail: claudiane.teixeira@gmail.com

${ }^{20}$ Graduada em Pedagogia. E-mail: adriana_ap01@hotmail.com
} 
Os jogos podem ser um recurso pedagógico com imensas e várias formas de uso no contexto escolar como um elemento que agrega a aprendizagem dos alunos. Os jogos no ensino da matemática têm uma importância singular, pois leva o aluno a descobrir e explorar diferentes vertentes dos problemas propostos até chegar a uma resposta correta.

Através dos jogos matemáticos a criança aprende a se relacionar consigo mesma e com o mundo. $\mathrm{O}$ uso planejado de jogos em atividades pedagógicas, voltadas para o ensino da matemática, tem o poder de encantar e favorecer o entendimento das propriedades matemáticas em suas diferentes nuances e contextos.

O planejamento da atividade serve à estruturação e o desenvolvimento do pensamento do aluno, e na conduta diante dos desafios que um jogo impõe se trabalha a formação básica da sua cidadania. A execução desse projeto leva pais, professores e acadêmicos a ter uma nova visão sobre o uso de jogos aliado ao ensino da matemática.

A organização desse projeto está dividida em tópicos, sendo os principais o tema, a justificativa, o referencial teórico, os objetivos e a metodologia, junto com outras informações importantes para a realização da proposta em sala de aula. Ao longo do projeto são dadas informações baseadas em estudos de autores renomados que abordam o tema e sua importância no contexto educacional.

\section{REFERENCIAL TEÓRICO}

A matemática faz parte da vida da maioria das pessoas desde muito cedo, estando presente direta ou indiretamente, em diversas situações cotidianas. Em quase todos os contextos da vida social em diferentes momentos, exercita- se os conhecimentos matemáticos. Mesmo sendo utilizada praticamente em todas as áreas do conhecimento, em momentos e contextos diversos, nem sempre é fácil ensinar aos alunos os conteúdos necessários e sua importância de maneira objetiva e significativa.

Isso acontece porque muitos alunos acham a aprendizagem da matemática algo difícil de ser aprendida de maneira contextualizada, e muitos acabam desmotivados na aprendizagem matemática passando a executar cálculos e resoluções de problemas de modo mecânico, descontextualizado do seu cotidiano. 
O ensino da matemática muitas vezes está pautado apenas na aquisição de conhecimentos voltados para a realização de problemas e cálculos, muitas vezes complexos, desconexos da realidade e necessidades dos alunos, isso torna a aprendizagem maçante e, por vezes, impossível de ser adquirida.

Segundo as Diretrizes para o Ensino da Matemática (2006), um dos principais desafios no ensino da matemática é a abordagem de conteúdos voltados para a resolução de problemas e cálculos simples. Isso acontece porque muitas vezes os assuntos relacionados a esses conteúdos são introduzidos aos alunos em sala de aula de maneira mecânica, sem qualquer interligação com a realidade em que ele se encontra, logo o aluno não ver sentido em aprender aquilo, pois julga que não vai precisar usar aqueles conhecimentos no futuro.

Para mudar essa realidade o professor de matemática necessita lançar mão de estratégias de ensino inovadoras que aproximem os conteúdos da realidade contextual dos alunos, usando metodologias adequadas de acordo com os interesses dos mesmos. Nesse sentido os jogos matemáticos constituem uma opção viável para o ensino aprendizagem de modo significativo, principalmente no ensino fundamental, uma vez que alunos que estão nessa etapa do ensino se interessam bem mais por jogos por remeterem ao caráter da ludicidade, competição e cooperação.

Na visão de Rêgo e Rêgo (2000) é de extrema importância a introdução de novas metodologias de ensino, onde o aluno seja ativo e participativo na construção de sua própria aprendizagem, respeitando- se o seu contexto e levando em consideração os aspectos recreativos e lúdicos das motivações próprias de sua idade, sua imensa curiosidade e desejo de realizar atividades em grupo.

No ensino dos conteúdos voltados a resolução de problemas e cálculos simples, a introdução de jogos como estratégia de ensino- aprendizagem na sala de aula se apresenta como um recurso pedagógico inovador e que motiva a aprendizagem significativa do aluno, pois cria situações que permitem ao aluno desenvolver métodos de resolução de problemas usando diferentes caminhos e possibilidades, estimula a sua criatividade a partir do desafio e ao mesmo tempo gerador de motivação para aprender sempre mais e superar suas próprias possibilidades. 
O uso de jogos para o ensino da matemática estimula o raciocínio lógico do aluno, sua imaginação e criatividade, o espírito coletivo e colaborativo, além da aprendizagem significativa onde o aluno internaliza os conteúdos e os leva para seu cotidiano efetivamente. Os jogos matemáticos também facilitam o trabalho do professor, que pode dispor de diferentes tipos de estratégias para introduzir os conteúdos matemáticos e com isso chamar a atenção dos alunos e estimular sua aprendizagem.

O jogo propicia o desenvolvimento de diversas habilidades, tais como raciocínio mais apurado, resolução de problemas de diferentes maneiras, comunicação, cálculos rápidos e assertivos, entre outros. Isso acontece porque ao jogar, o aluno tem a oportunidade de resolver problemas, investigar e descobrir a melhor jogada a ser feita, refletir e analisar as regras do jogo, estabelecendo relações entre os elementos do jogo e os conceitos matemáticos. Pode- se dizer que o jogo possibilita uma situação de prazer e aprendizagem significativa nas aulas de matemática (SMOLE; DINIZ; MILANI, 2007).

Segundo Gandro (2000) o jogo propicia o desenvolvimento de estratégias inovadoras para a resolução de problemas na medida em que também possibilita a investigação e a exploração do conceito através da estrutura matemática relacionada ao jogo e que pode ser vivenciada, pelo aluno, quando ele joga, elaborando estratégias e testando-as com o objetivo elucidar os desafios de vencer o jogo proposto. Nessa perspectiva, o jogo é um recurso pedagógico que estimula a aprendizagem de diferentes conceitos matemáticos, onde o aluno aprende efetivamente os conteúdos, deixando de lado a aprendizagem mecânica ao qual são submetidos nas aulas tradicionalmente executadas no dia a dia escolar.

O trabalho com jogos para o ensino da matemática é defendido por Smole, Diniz e Milani (2007), que ressaltam que os jogos se constituem em um dos recursos pedagógicos que mais favorece o desenvolvimento da linguagem e comunicação, de diferentes processos de raciocínio e de interação entre os alunos. Por meio dos jogos os alunos têm a possibilidade de acompanhar e interagir com as jogadas uns dos outros, desenvolvendo assim, o senso crítico, defendendo pontos de vista e aprendendo a ser mais confiante.

O uso de jogos no ensino da matemática contribui não só para a aprendizagem de conceitos matemáticos, mas reflete em outros campos da aprendizagem e do 
desenvolvimento do aluno. Sobre isso Borin (1998) corrobora que dentro das situações que envolvem o jogo, é impossível que os alunos fiquem passivos e isso gera uma grande motivação, é possível notar que, ao mesmo tempo em que estes alunos falam de matemática, apresentam também uma melhora significativa na construção de atitudes mais positivas frente a seus processos de aprendizagem nas diferentes áreas do conhecimento.

Trabalhar com jogos nas aulas de matemática possibilita a diminuição dos bloqueios apresentados por muitos dos alunos que têm medo da matemática e sentem- se incapazes de aprender os conteúdos relacionados a ela. Então o jogo matemático tem uma função educativa que influencia diretamente na autoestima do aluno, que se sente mais motivado a aprender significativamente.

Ao ensinar matemática por meio dos jogos, o professor proporciona ao aluno a possibilidade de aliar a aprendizagem a ludicidade, mas sem com isso deixar a aprendizagem de lado. Os próprios alunos encaram o jogo como um momento sério, onde eles querem superar os próprios desafios e mostrar que aprenderam um determinado conteúdo.

Segundo Borin (1998), os próprios alunos, à medida que vão jogando, percebem que o jogo não tem apenas o caráter lúdico e que precisa ser levado a sério e não encarado apenas como mais uma brincadeira. Ao jogar o aluno analisa as regras do jogo e desenvolve certas habilidades que os levam a relacionar aspectos deste jogo com determinados conceitos matemáticos. Isso serve de pressuposto para que os alunos interrelacionem o que já sabem para poder superar os desafios do jogo.

Os jogos podem ser usados para que os alunos que estão em fase de aprendizagem aprendam as regras matemáticas mais facilmente, os jogos também instigam a memorização de conceitos matemáticos que são difíceis de serem lembrados. Segundo as Diretrizes do MEC (2006), os jogos são um eficiente recurso para estimular a memorização de regras matemáticas e sugerem que há vários tipos de jogos que podem ser utilizados para instigar a memorização dos conteúdos de modo significativo, e não de forma mecânica. 
A utilização de jogos para o ensino da matemática leva o aluno a percorrer diferentes caminhos até chegar a resposta esperada, isso é de extrema importância pois o faz refletir sobre as várias possibilidades de aprendizagem. $\mathrm{O}$ erro também é uma forma de aprender, de ver onde é preciso melhorar. O jogo é um norteador tanto da aprendizagem do aluno, quanto da prática pedagógica do professor, pois através dos jogos o professor vai perceber em quando conteúdos precisa reforçar a aprendizagem do aluno, procurando metodologias inovadoras para dar o conteúdo novamente.

A resolução de problemas matemáticos em suas diferentes complexidades é uma das metodologias mais indicadas para o uso de jogos como recurso pedagógico. Na visão de Borin (1998) a resolução de problemas é a metodologia mais adequada para desenvolver uma postura crítica no aluno diante de qualquer situação que exija dele uma resposta mais completa. A cada hipótese formulada ou cada jogada feita pelo aluno desencadeia nele uma série de questionamentos sobre qual estratégia usar, que caminhos seguir para atingir a resposta correta e vencer o jogo. Ao efetuar as jogadas o aluno frequentemente se questiona sobre os erros que cometeu e porque escolheu esse caminho, isso o leva a testar diferentes meios de aprendizagem.

Essa metodologia representa, em sua essência, uma mudança de postura em relação ao que é ensinar matemática, ou seja, ao adotá-la, o professor será um espectador do processo de construção do saber pelo seu aluno, e só irá interferir ao final do mesmo, quando isso se fizer necessário através de questionamentos, por exemplo, que levem os alunos a mudanças de hipóteses, apresentando situações que forcem a reflexão ou para a socialização das descobertas dos grupos, mas nunca para dar a resposta certa. Ao aluno, de acordo com essa visão, caberá o papel daquele que busca e constrói o seu saber através da análise das situações que se apresentam no decorrer do processo (BORIN, 1998, p. 10-11).

É função do professor, ao preparar suas aulas com a utilização de jogos procurar escolher técnicas que explorem todos os potenciais de aprendizagem que o jogo oferece, devendo também analisar as metodologias mais adequadas aos tipos de objetivos que pretende alcançar. Nesse sentido (STAREPRAVO, 1999) diz que o trabalho com jogos requer do professor certas atitudes que o levem a considerar como uma atividade a ser realizada durante todo o ano letivo, e não de modo esporádico, relacionando o jogo como uma estratégia aliada à construção do conhecimento, devendo planejar cuidadosamente sua execução e os objetivos que pretende alcançar. 
Conforme os Parâmetros Curriculares Nacionais (1998) não há um caminho exclusivo para o ensino de qualquer disciplina, em particular, a matemática. As possibilidades de trabalho são diversas, na qual o educador poderá construir e estruturar sua própria prática pedagógica, com diferentes metodologias. Dessa forma, o jogo se apresenta como um recurso que fornece as informações do problema a ser resolvido e ao mesmo tempo, faz com que o aluno desenvolva estratégias para solucioná-lo.

O jogo deve ser visto como um instrumento pedagógico que favorece a aprendizagem do aluno, em especial a aprendizagem matemática, pois através dos jogos os alunos vão percebendo que é possível aprender de forma lúdica e divertida, passando assim, a compreender e utilizar regras que serão empregadas ao longo de todo o processo de ensino aprendizagem.

Ao aprender matemática por meio dos jogos o aluno tem um melhor aprendizado em relação aos conteúdos que precisam ser aprendidos e ainda compreendem que a escola não é o único local de realização de atividades matemáticas, podendo ser realizada e vivenciada nos diferentes espaços e momentos. Outro ponto importante a ser destacado é que os jogos tanto podem ser físicos quanto virtuais, uma vez que, na era tecnológica muitas crianças têm um contato frequente com aparelhos eletrônicos que podem ser aliados no processo de ensino aprendizagem.

Sendo assim, a utilização dos jogos no ensino da matemática leva os alunos se esforçam para superar obstáculos, tanto cognitivos quanto emocionais, sendo que se estão motivados, ficam mais dispostos mentalmente a aprender de maneira significativa.

Logo os jogos matemáticos, com seu caráter lúdico são um recurso indispensável para uma aprendizagem completa do aluno, que desenvolve diferentes habilidades de grande importância para a sua formação humana. Portanto, propiciar situações com jogos é investir no prazer, no desafio e numa melhora pontual do desempenho dos alunos na aprendizagem de conceitos matemáticos.

\section{CONSIDERAÇÕES FINAIS}

A realização deste projeto sobre a importância dos jogos para o ensino da matemática foi de extrema importância para aquisição de novas aprendizagens, pois 
permitiu uma reflexão mais profunda sobre a necessidade de inovação nas práticas pedagógicas tradicionais.

Após a realização dos estudos realizados sobre o tema abordado e a revisão bibliográfica com base nos estudos de diversos autores, fica evidente que os jogos exercem uma influência positiva no processo de ensino aprendizagem dos alunos que estão no ensino fundamental, pois através da metodologia de resolução de problemas eles são levados a adquirir novos conhecimentos que podem ser usados e vivenciados em seu cotidiano.

Os jogos são um elemento a mais que auxilia no desenvolvimento do aluno em diversos aspectos, proporcionando a aprendizagem significativa de modo lúdico, mas sem perder o caráter objetivo do ensino formal. O jogo leva o aluno a testar diferentes possibilidades e superar os desafios que se impõe, aprendendo os conceitos matemáticos de maneira mais objetiva e completa.

Com esse projeto espera-se que os resultados sejam positivos quando da sua aplicação, proporcionando novas formas de ver o uso dos jogos como estratégia de ensino da matemática. Neste sentido, com esse projeto professores e acadêmicos podem rever seus conceitos e inovar a prática pedagógica.

\section{REFERENCIAS}

BORIN, J. Jogos e resolução de problemas: uma estratégia para as aulas de matemática. 3.ed. São Paulo: IME/USP, 1998.

BRASIL. Ministério da Educação e do Desporto. Secretaria da Educação Fundamental. Parâmetros Curriculares Nacionais: matemática. Brasília: MEC/SEF, 1998.

GANDRO, R.C. O conhecimento matemático e o uso de jogos na sala de aula. Tese. Doutorado. Universidade de Campinas. Campinas: Unicamp, 2000.

BRASIL. Diretrizes Curriculares Nacionais. Resolução CNE/CP n 1, de 15/12/2006 para os cursos de Pedagogia. Brasília: MEC, 2006.

RÊGO, R.G.; RÊGO, R.M. Matemática ativa. João Pessoa: Universitária/UFPB, INEP, Comped: 2000.

SMOLE, K.S.; DINIZ, M.I.; MILANI, E. Jogos de matemática do $6^{\circ}$ ao $9^{\circ}$ ano. Cadernos do Mathema. Porto Alegre: Artmed 2007.

STAREPRAVO, A.R. Jogos, desafios e descobertas: o jogo e a matemática no ensino fundamental, séries iniciais. Curitiba: Renascer, 1999. 


\title{
CAPÍTULO VII
}

\section{A IMPORTÂNCIA DOS JOGOS PARA A APRENDIZAGEM NA EDUCAÇÃO INFANTIL}

\author{
Alcione Sousa Dos Santos Almeida ${ }^{21}$. \\ DOI-Capítulo: 10.47538/AC-2021.14-07
}

RESUMO: Ao analisar o panorama da educação mundial e brasileira e, em especial, da Educação Infantil e após a realização de estudos desenvolvidos por grandes pensadores, foi possível averiguar a importância que os jogos apresentam para o processo de ensino aprendizagem de crianças e, principalmente, daquelas que se encontram na faixa etária de zero a cinco ou seis anos de idade. A utilização de jogos e brincadeiras como procedimentos metodológicos no contexto das salas de aula de Educação Infantil, ajudam na formação de conhecimentos mais sólidos e significativos para as crianças. Diante de tal perspectiva, é que a pesquisa foi desenvolvida e tem como objetivo principal averiguar a realidade de uma turma da Educação Infantil, no sentido de identificar as principais estratégias metodológicas utilizadas pelo professor da sala utilizada como campo de pesquisa. $\mathrm{O}$ trabalho tem como estratégia metodológica a pesquisa bibliográfica e a pesquisa de campo o que, certamente, contribuirá para um melhor desenvolvimento, embasamento e credibilidade dos fatos verificados e constatados.

PALAVRAS-CHAVE: Ludicidade. Aprendizagem. Jogos. Brincadeiras. Conhecimento.

\section{THE IMPORTANCE OF GAMES FOR LEARNING IN EARLY CHILDHOOD EDUCATION}

ABSTRACT: By analyzing the panorama of global and Brazilian education and, in particular, Early Childhood Education and after conducting studies developed by great thinkers, it was possible to ascertain the importance that games have for the teachinglearning process of children, and especially, of those in the age group from zero to five or six years old. The use of games and games as methodological procedures in the context of Kindergarten classrooms help to form more solid and meaningful knowledge for children. Given this perspective, the research was developed and its main objective is to investigate the reality of an Early Childhood Education class, in order to identify the main methodological strategies used by the classroom teacher used as a research field. The work's methodological strategy is bibliographical research and field research, which will certainly contribute to a better development, foundation and credibility of the verified and verified facts.

KEYWORDS: Playfulness. Learning. Games. Jokes. Knowledge.

\section{INTRODUÇÃO}

21 Pedagoga. Professora da Educação Básica. E-mail: alcioneveronilson@gmail.com 
A criança é um ser em constante crescimento físico e psicológico, sendo assim, necessita de estratégias motivadoras que influenciam diretamente e positivamente nesse desenvolvimento. A escola por ser uma instituição voltada para o trabalho sistemático desse desenvolvimento deve buscar estratégias que potencializam tal crescimento, dessa forma, deve utilizar atividades lúdicas como ferramenta pedagógica, ou seja, deve criar ambientes prazerosos de aprendizagem utilizando como principal caminho as brincadeiras e os jogos infantis.

É importante ressaltar que, especialmente, os jogos na Educação Infantil é uma ou se não a principal forma de apresentar os conhecimentos para as crianças com significado, onde, consequentemente, os alunos aprenderão com maior prazer.

Diante de tal importância que os jogos têm para educação das crianças pequenas foi que decidimos desenvolver o presente trabalho que tem como objetivo principal analisar a realidade de uma turma da Educação Infantil e como objetivos específicos identificar as principais estratégias metodológicas utilizadas pelo professor do campo de pesquisa, descobrir os tipos de jogos e brincadeiras que fazem parte do ambiente educacional e averiguar se esse tipo de atividade está presente nos planejamentos do corpo docente como ferramenta indispensável ao desenvolvimento cognitivo das crianças.

Para realização da pesquisa foram utilizados os procedimentos metodológicos de análise bibliográfica, que ressaltam e enfatizam as ideias e pensamentos de autores renomados que tratam do tema, como também, o de estudo de campo. Esses procedimentos foram selecionados com o objetivo de oferecer maior credibilidade ao trabalho, pois, dessa forma, haverá um verdadeiro confronto entre teoria e prática.

Para desenvolvimento da pesquisa bibliográfica entraremos em diálogo com os pensamentos de autores como Vygotsky (1998), Piaget (1998), Gomes (2004), entre outros que ressaltam toda a importância que a ludicidade traz para o desenvolvimento psicológico e aprendizagem das crianças que estão na Educação Infantil.

\section{HISTÓRIA DOS JOGOS NA EDUCAÇÃO INFANTIL CONCEITO E HISTÓRIA DOS JOGOS}


O ato de brincar é inato da criança, ou seja, faz parte de suas atividades diárias e está diretamente ligado ao seu desenvolvimento psicológico e social, portanto, é quase que inadmissível falar em educação de crianças sem relacioná-las com o brincar. Conforme Antunes (2005, p. 33) "as implicações da necessidade lúdica extrapolaram as demarcações do brincar espontâneo”.

Mesmo diante dessa grande importância tanto para crianças, como para jovens, não é comum identificar nas escolas estratégias metodológicas planejadas e voltadas para o ato de brincar. De acordo com Neves (2009, p. 45), “a criança e mesmo o jovem opõem uma resistência à escola e ao ensino, porque acima de tudo ela não é lúdica, não costuma ser prazerosa".

A palavra "lúdico" tem sua origem na palavra latina "ludus" que significa "jogo", porém, essa definição deixou de ser simplesmente essa e passou, ao longo da história, a ser definido como traço essencial de psicofisiologia do comportamento humano, isto é, algo que faz parte do desenvolvimento humano. Nesse sentido, Carneiro (1995, p. 66) destaca que "todas as pessoas têm uma cultura lúdica, que é um conjunto de significações sobre o lúdico".

Nas comunidades primitivas o brincar se expressava através das danças, lutas e de todas as atividades recreativas desenvolvidas. Segundo Antunes (2005, p. 56) "na Grécia antiga, Platão afirmava que os primeiros anos de vida da criança deveriam ser ocupados por jogos"

Segundo Kishimoto (1995), Platão colocava a importância de a criança aprender brincando para combater a opressão e a violência, enquanto Aristóteles enfatizava a necessidade de se utilizar jogos "sérios" na educação de crianças pequenas, como forma de prepará-las para vida.

A importância do jogo na educação de crianças só surgiu a partir do século XVI, ou seja, foi a partir desse período que estudiosos começaram a perceber a valorizar atividades lúdicas no contexto de aprendizagem de crianças. Para o pensador norteamericano Dewey (1859- 1952), “o jogo faz o ambiente natural da criança, ao passo que as referências abstratas e remotas não correspondem ao interesse da criança." (2005, p. 23). 
Jean Piaget (apud ANTUNES, 2005, p. 25) "retrata que os jogos não são apenas uma forma de entretenimento para gastar a energia das crianças, mas meios que enriquecem o desenvolvimento intelectual”. Em outras palavras, são atividades que contribuem, diretamente e essencialmente, na aprendizagem cognitiva e social das pessoas.

\section{A INTRODUÇÃO DOS JOGOS NA EDUCAÇÃO INFANTIL}

Aprender por meio de atividades recreativas como jogos e brincadeiras provocam grandes contribuições para o desenvolvimento e assimilação de conhecimentos cognitivos tanto para crianças, quanto para jovens e adultos. Aprender através de atividades prazerosas faz com que esses sujeitos adquiram capacidades e habilidades que permitem o seu autoconhecimento, como também, conhecer e experimentar situações de aventura, exploração e ação.

Marcellino (1997, p. 44) destaca que "ao tratar do lúdico foca a abordagem que se busca, o lúdico não como algo isolado ou associado a uma determinada atividade", dessa forma, deve ser visto como algo imprescindível ao desenvolvimento das capacidades e habilidades da criança, como algo inseparável do crescimento cognitivo e psicológico desses indivíduos.

Atividades lúdicas podem ser consideradas todas aquelas que envolvem o ato de desenhar, brincar espontaneamente, jogar e utilizar brinquedos.

Cadermartori (1991, p. 58) ressalta que a criança vê o mundo a sua volta antes mesmo de detê-lo e escrevê-lo, sendo assim, afirma que:

A manipulação lúdica dos sons da língua pela criança, fruição do sonoro independente do significado, constitui-se em parte fundamental do desenvolvimento linguístico. Do modo que o conhecimento da realidade exterior não se dá sem a atividade de exploração dos objetos, o conhecimento linguístico não prescinde de uma atividade com a língua na qual está é tratada como objetivo material. Aceito este ponto de vista, o ludismo sonoro deixa de ser visto como uma inconsequente infantil, à qual se pode ser indiferente, para ser visto como parte específica da habilidade da espécie para aprender a língua.

Diante de tal afirmação fica notória a importância que os diversos tipos de jogos têm para se alcançar o pleno desenvolvimento das capacidades das crianças, sendo assim, 
deve ser atribuído valor a todas as atividades lúdicas sejam elas primárias que se restringem ao ato de falar e ouvir, sejam elas linguísticas fundamentais como é caso daquelas que tratam do ato de trabalhar jogos verbais, leituras, dramatizações, entre outras.

O brinquedo é outro elemento de grande importância para o desenvolvimento das crianças, isto é, o brinquedo, quando bem selecionado, o melhor atendimento às características e necessidades infantis, porém, é fundamental enfatizar que o brinquedo deve ser selecionado de acordo com a idade e com o objetivo ao qual se pretende alcançar com a sua utilização.

É brincando que os indivíduos desenvolvem sua imaginação e executam suas forças, além do mais, é brincando que a crianças exercita seus músculos e constrói, gradativamente, seu raciocínio lógico, tão importante para se viver em sociedade.

.Os estabelecimentos que atendem crianças na faixa etária de 0 a 6 anos de idade têm, na sua grande maioria, limitado as atividades infantis aos exercícios repetitivos, motora e, por meio dessa castração bloqueiam a organização independente das crianças para as brincadeiras, essas estratégias pedagógicas não estimulam a criatividade e o pensamento argumentativo e lógico dos educandos, tratam suas ações simbólicas como se servissem apenas para explorar e facilitar ao educador a transmissão de determinada visão do mundo, definida, a princípio, pela instituição infantil. Nessa perspectiva, Wajskop (1995) aponta que se as instituições fossem organizadas em torno do brincar infantil, elas poderiam cumprir suas funções pedagógicas, privilegiando a educação da criança em uma perspectiva criadora, voluntária e consciente.

Cabe à escola desenvolver atividades que concebem o trato com os valores humanos essenciais para se viver em sociedade, dessa forma, o trabalho realizado pelos estabelecimentos educacionais deve ter uma visão global e ir além dos conhecimentos técnicos proporcionados pelas disciplinas escolares. É aí que entra a importância da aplicabilidade de atividades lúdicas no contexto de uma sala de aula.

De acordo com Gomes (2004, p. 47), a ludicidade é uma dimensão da linguagem humana, que possibilita a "expressão do sujeito criador que se torna capaz de dar significado à sua existência, ressignificar e transformar o mundo". E mais na frente 
conclui: "Dessa forma, a ludicidade é uma possibilidade e uma capacidade de se brincar com a realidade, ressignificando o mundo".

Gomes (2004, p. 145) estabelece a premissa básica de nossa abordagem quando escreve:

Como expressão de significados que têm o brincar como referência, o lúdico representa uma oportunidade de (re) organizar a vivência e (re) elaborar valores, os quais se comprometem com determinado projeto de sociedade. Pode contribuir, por um lado, com a alienação das pessoas: reforçando estereótipos, instigando discriminações, incitando a evasão da realidade, estimulando a passividade, o conformismo e o consumismo; por outro, o lúdico pode colaborar com a emancipação dos sujeitos, por meio do diálogo, da reflexão crítica, da construção coletiva e da contestação e resistência à ordem social injusta e excludente que impera em nossa realidade (GOMES, 2004, p. 146).

De acordo com o pensamento do autor, jogar é uma necessidade humana que faz parte dos interesses dos indivíduos independentemente de sua idade e que o desenvolvimento do aspecto lúdico favorece, como citado anteriormente, ao desenvolvimento pessoal, social e psicológico das pessoas.

No processo educacional de pessoas, e principalmente, na modalidade de Educação Infantil, a execução de estratégias lúdicas pedagógicas deve ser tratada como essencial e prioritária, portanto, devem estar contidas no planejamento escolar realizado pelos professores e coordenadores. Essa inclusão visa, portanto, a flexibilização e dinamização das atividades realizadas ao longo de toda a prática docente, oportunizando a eficácia e significação da aprendizagem.

Segundo Rau (2012a), a utilização de jogos como método pedagógico pode contribuir para a formação integral da criança. A ludicidade no contexto educacional é composta por atividades significativas que estão de acordo com as necessidades das crianças de forma integrada, associando-se à sua realidade sociocultural no processo de construção de conhecimento. Para Piaget, por meio da ludicidade a criança incorpora a sua própria realidade.

Nesse contexto, é por meio do desenvolvimento de atividades lúdicas que a criança, considerada ser em formação, se prepara para a vida, ou seja, através de uma prática contínua de atividades que priorizem o dinamismo e o prazer pela aprendizagem, a criança consegue uma melhor assimilação da cultura do meio na qual está inserida, 
adaptando-se às condições que a vida lhe oferece e aprendendo a competir, cooperar com seus semelhantes e conviver como um ser social. Sendo assim, cabe aos educadores adquirirem a posição de facilitadores e mediadores dos conhecimentos sistematizados, e criarem um ambiente que proporcione essas atividades e que oportunize, a todos, as melhores condições para que possam construir de forma autônoma e integral o seu próprio conhecimento.

\section{CONSIDERAÇÕES FINAIS}

A Educação Infantil é uma etapa de suma importância para o desenvolvimento pleno do ser humano, isto é, é uma modalidade da educação básica que forma todo o alicerce da vida educacional dos indivíduos, sendo assim, cuidar dessa etapa é papel de toda instituição que prima pelo bom trabalho.

A proposta ora apresentada traz como uma de suas metodologias observarem a realidade de uma turma da Educação Infantil com o objetivo de averiguar a prática desenvolvida no referido contexto e comparar com as teorias pesquisadas ao longo do estudo desenvolvido.

A sala de aula selecionada para o desenvolvimento do trabalho trata de crianças de quatro anos de idade de uma escola pública municipal da cidade de Macau. A turma é formada por vinte e cinco crianças sendo onze do sexo masculino e quatorze do sexo feminino.

O processo de ensino ficava a cargo de uma professora com uma boa experiência pedagógica e com formação inicial e continuada na área e de uma auxiliar, com pouca experiência profissional, mas com formação adequada para atuar na turma.

O trabalho de observação foi desenvolvido durante cinco dias consecutivos, onde foi possível conhecer a prática pedagógica desenvolvida no âmbito da sala de aula que serviu como campo de pesquisa, ou seja, foi possível averiguar se os profissionais utilizavam ou não atividades lúdicas como ferramenta de trabalho em sala.

No primeiro dia de observação a professora regente da sala de aula em questão, iniciou seu trabalho com a rotina aplicada numa rodinha com os alunos, ou melhor, sentados no chão em forma de círculo, professoras instigaram uma conversação onde foi 
indagado sobre as novidades do final de semana, sobre a quantidade de alunos presentes no dia, chamada pelo nome com auxílio de uma fícha com o nome de cada criança e ainda sobre a escolha do ajudante do dia. É importante ressaltar que as atividades dessa rodinha foram desenvolvidas todos os dias da semana em que o trabalho de observação foi feito.

Após a realização da rodinha as professoras fizeram uma explanação verbal a respeito da importância dos hábitos de higiene e dramatizaram uma situação onde as duas enfatizaram ainda mais esse conhecimento. Após a realização da dramatização elas estimularam a oralidade das crianças questionando-as a respeito do conteúdo em pauta. A maioria dos alunos mostrou boa capacidade de expressão oral.

Terminada essa atividade os alunos iniciaram a pintura de desenhos que ressaltam imagens de materiais usados na higiene pessoal. Em seguida os alunos foram lavá-las para lanchar e posteriormente irem para o recreio. Nesse momento as crianças brincaram espontaneamente sob o monitoramento das referidas professoras.

Na ocasião foi possível perceber que algumas crianças imitavam e gesticulavam as próprias professoras, ou seja, elas brincavam de escolinha e demonstravam ter assimilado os conhecimentos trabalhados no âmbito da sala de aula. Após o intervalo houve o momento da escovação dos dentes e da realização de uma pequena atividade sobre as vogais presentes nas palavras encontradas no contexto da sala.

Ao concluírem essa segunda atividade chegou o fim do horário de aulas, pois, durante a semana em que aconteceram as observações as crianças estavam indo para casa mais cedo pela falta de água potável para consumo dos próprios alunos, sendo assim, estava indo para casa uma hora mais cedo.

Segunda, terça, quarta quinta basicamente as aulas seguiram essa mesma organização, formada por: momento da rodinha, explanação oral sobre os conhecimentos trabalhados, realização de uma atividade escrita, lanche, recreio e realização de uma segunda atividade, que poderia ser escrita, oral ou de leitura de livros.

Já na sexta-feira, houve uma rotina um pouco diferenciada, isto é, a segunda atividade foi desenvolvida através de um jogo planejado pelas professoras e que tinha como objetivo estimular a colaboração entre as crianças. $\mathrm{O}$ jogo consistia em dividir a turma em grupos, que tinham tarefas a cumprir, como achar brinquedos espalhados e 
escondidos pela escola e responder algumas perguntas baseadas nos conhecimentos trabalhados durante a semana. O grupo que concluísse sua tarefa primeiro, teria que ajudar aos que ainda não tinham conseguido, o que causava uma pontuação extra. Além de estimular a colaboração entre as crianças, houve um processo de avaliação a respeito do que tinha sido trabalhado em sala de aula durante a semana.

Ao concluir o trabalho de observação na sala de aula escolhida para ser campo de pesquisa, foi possível perceber alguns conhecimentos teóricos aplicados na prática, como também, a falta e a necessidade de alguns deles. De modo geral, a realização desse trabalho permitiu o confronto entre teoria e prática e, consequentemente, o enriquecimento de uma base de conhecimentos ora em formação.

\section{REFERÊNCIAS}

ANTUNES, C. Jogos para a estimulação das múltiplas inteligências: os jogos e os parâmetros curriculares nacionais. Campinas: Papirus, 2005.

ANTUNES, Celso. O jogo e o brinquedo na escola. In: SANTOS, Santa Marli Pires dos. (Org.). Brinquedoteca: a criança, o adulto e o lúdico. 6. ed. Petrópolis: Vozes, 2008. Cap. 4, p. 37-42.

BRASIL. Lei de Diretrizes e Bases da Educação infantil (LDBEN), n. 9.394, de 20 dezembro de 1996. Estabelece as diretrizes e bases da educação nacional. Brasília, Diário Oficial, 23 dez. 1996, p. 27833.

BRASIL/SEF/MEC. Referencial Curricular Nacional para Educação Infantil. Brasília, 1998.

BRUNER, J. A cultura da educação. Porto Alegre: Artmed, 2001.

CAMPOS, M. C. R. M. A importância do jogo no processo de aprendizagem. Disponívelem:<http://www.psicopedagogia.com.br/entrevistas/entrevista.asp?entrIDAc essono dia 11 de junho de 2017.

CANDERMARTORI., Ligia. O que é literatura infantil. 5 ed. São Paulo: Brasiliense, 1991.

CARNEIRO, M. A. B. Aprendendo através da brincadeira. Ande, Revista da Associação Nacional de Educação, ao 13, nº 21, Cortez Editores, 1995.

CUNHA, Nylse Helena Silva. Brinquedoteca: um mergulho no brincar. 2. ed. São Paulo: Maltese, 1994.

FRIEDMANN, A. A Importância de Brincar. Diário do Grande ABC, 26 de setembro de 2003, Santo André, SP.

GOMES, C. L. (org.). Dicionário Crítico do Lazer. Belo Horizonte: Autêntica, 2004.

KISHIMOTO, Tizuko M. O jogo e a Educação Infantil. São Paulo: Pioneira, 1994. 
MARCEllinO, N. C. Pedagogia da animação. 2. edição, Campinas, São PauloSP, Editora Papirus, 1997.

MOYLES, J. R. Só Brincar? O papel do Brincar na Educação Infantil. Porto Alegre: Artmed, 2002.

NEGRINE, A. Aprendizagem e desenvolvimento infantil. Porto Alegre: Propil, 1994.

OLIVEIRA, Vera Barros de. Brincar: caminho de saúde e felicidade. In: OLIVEIRA, Vera Barros de; SOLÉ, María Borja i, Fortuna, Tânia Ramos. Brincar com o outro: caminho de saúde e bem estar. Petrópolis: Vozes, 2010. Cap.1, p. 13-46

PIAGET, Jean. A formação do Símbolo na criança: imitação, jogo e sonho. Rio de Janeiro: Zanar, 1978.

PIAGET, J. A psicologia da criança. Ed. Rio de Janeiro. Bertrand Brasil, 1998.

RAU, Maria Cristina Trois Dorneles. A ludicidade na educação: uma atitude pedagógica. Curitiba: Inter Saberes, 2012a.

RICHTER, Sandra; FRONCKOWIAK, Ângela. A tensão lúdica entre brincar e aprender na infância. Revista Pátio Educação Infantil, ano IX, n. 27, p. 39-41, abr./jun. 2011.

RIZZI, Leonor e Haydt, Régina Célia. Atividades lúdicas na educação da criança. Ed. Ática, $6^{\mathrm{a}}$ edição, série educação, 1997.

RODRIGUES, Almir Sandro; SILVA, Ana Tereza Reis; PARIZ, Josiane Domingues Bertoja. Teorias da Aprendizagem. Curitiba: IESDE, 2003.

SANTOS, S. M. P. dos. Brinquedoteca: sucata vira brinquedo. 2.ed. Porto Alegre: Artmed, 2008.

TEIXEIRA, C. E. J. A ludicidade na escola. São Paulo: Loyola, 1995.

VYGOTSKY, L. S. O Papel do Brinquedo no Desenvolvimento. In: VYGOTSKY. A Formação Social da Mente. São Paulo>Icone-Editora da Universidade de São Paulo, 1991.

VYGOTSKY, L. S. Aprendizagem, desenvolvimento e linguagem. 2. ed. São Paulo: Ícone, 1998

WAJSKOP, G. Brincar na Pré-Escola. São Paulo: Cortez, 1995 


\title{
CAPÍTULO VIII
}

\section{A PRESENÇA DO COMPLEXO DE DON JUAN NO PERSONAGEM MAURÍCIO VILAÇA NA OBRA REVOLTA DE MÁRCIO SOUZA}

\author{
Elves França da Costa Júnior ${ }^{22}$. \\ DOI-Capítulo: 10.47538/AC-2021.14-08
}

RESUMO: O presente trabalho de conclusão de curso discute os traços do complexo de Don Juan por meio comportamento do personagem Maurício Vilaça, em meio a uma sociedade patriarcal que se encontra na Província do Grão-Pará, na qual acontecia a revolta da Cabanagem, que serviu de cenário para as aventuras amorosas de Maurício Vilaça. Tendo como embasamento teórico os pressupostos da psicanálise e do conceito do patriarcado, propomos uma análise do personagem na obra Revolta de Márcio Souza. Depois do levantamento de algumas ocorrências de Don Juan na literatura e das características do comportamento donjuanismo concluímos que Maurício Vilaça é uma espécie de Don Juan que age de acordo com os valores patriarcais da sociedade da época valendo-se tanto da sua classe social quanto de seus privilégios de gênero.

PALAVRAS-CHAVE: Revolta. Donjuanismo. Patriarcado.

\section{THE PRESENCE OF THE DON JUAN COMPLEX IN THE CHARACTER MAURÍCIO VILAÇA IN THE WORK REVOLTA BY MÁRCIO SOUZA}

ABSTRACT: This course conclusion work discusses the features of the Don Juan complex through the behavior of the character Maurício Vilaça, in the midst of a patriarchal society found in the Province of Grão-Pará, in which the Cabanagem revolt took place. served as the setting for the amorous adventures of Maurício Vilaça. Having as theoretical basis the presuppositions of psychoanalysis and the concept of patriarchy, we propose an analysis of the character in the work Revolta de Márcio Souza. After surveying some occurrences of Don Juan in the literature and the characteristics of Don Juanism behavior, we conclude that Maurício Vilaça is a kind of Don Juan who acts in accordance with the patriarchal values of society at the time, taking advantage of both his social class and his gender privileges.

KEYWORDS: Revolt. Donjuanism. Patriarchy.

\section{INTRODUÇÃO}

A imagem de Don Juan, apresentada simbolicamente desde os primórdios de 1600, a partir da peça El burlador de Sevilla y el convidado de piedra, estabelece certo modelo de comportamento masculino. Ao longo do tempo, Don Juan se tornou

\footnotetext{
${ }^{22}$ Universidade Federal do Amazonas; http://lattes.cnpq.brq6074335965277066; https://orcid.org/0000-0001-99967024. E-mail: Elvesjr18@gmail.com
} 
personagem arquetípico, ligado a atitudes de sedução que podem ser interpretadas por diferentes vieses de leitura: numa perspectiva romântica e social, se expressa como a busca de satisfazer os desejos mais íntimos, inclusive os de rebeldia contra o moralismo vigente na sociedade. Desse modo, este trabalho não só visa as características clássicas do personagem, como aponta outras que não restringem sua figura a uma leitura romantizada. Para tanto, propomos neste trabalho a leitura da obra Revolta, de Márcio Souza, na qual poderemos ver alguns desses traços no personagem principal, que se desenvolve em cenas onde a sedução e o ego andam lado a lado durante a narrativa.

Esta pesquisa torna-se relevante pelo fato que constitui o corpus da análise um livro ambientado no contexto amazônico, Revolta, de Márcio Souza, que se propõe questionar diversas mazelas de uma sociedade em crise. A obra Revolta é o terceiro livro da tetralogia Crônicas do Grão-Pará e Rio Negro. Neste volume, o povo do Grão-Pará decide tomar nas mãos o próprio destino e, em 1835, a população vai em busca de revolucionar a província.

Sob esse enfoque histórico da revolta da Cabanagem, Márcio Souza elege um personagem que desloca a narrativa para fatos periféricos que lançam luz sobre certas relações sociais. Assim, o personagem Maurício Vilaça, sobre o qual recai nosso enfoque neste trabalho, não estava diretamente ligado à organização política da província, mas presenciava fatos que permeiam toda a província do Grão-Pará. Entretanto, as atitudes do personagem revelam nos eventos cotidianos, aspectos da opressão contados pelo próprio opressor.

Analisaremos o personagem a partir de suas aventuras amorosas, a fim de rastrearmos traços que nos permite aproximá-lo da figura de Don Juan e compreendermos as relações de gêneros no contexto colonial que ambienta o enredo. Partiremos de leituras teóricas que nos permitam abordar essas relações contínuas que perpassam durante toda a obra.

\section{DON JUAN: LITERATURA, PSICANÁLISE E PATRIARCADO HISTÓRIA DO DON JUAN NA LITERATURA}

A primeira aparição do Don Juan na literatura dá-se por meio de uma peça de teatro, nos anos de 1630, na Espanha, desde então é perceptível a presença deste, que se 
tornou um certo arquétipo quando o assunto é voltado à sedução. A partir disso, não demorou muito para se expressar em outras obras literárias, como em Don Juan, ou le Festin de Pierre, de Molière, escrita em 1665, cuja obra apresenta um personagem infiel, sedutor, valente e hipócrita, colecionador de conquistas amorosas, seduzindo moças da nobreza e criadas sempre satisfazendo seus desejos. Como afirma Jorge de Souza Araújo:

Coube ao frade mercedário espanhol Gabriel Téllez (1584-1648) que, com o pseudônimo de Tirso de Molina, completa a trindade do século de ouro no teatro de Espanha (os outros dois são Lope de Vega e Calderón de La Barca) - trazer à luz do eterno debate uma das mais originais e permanentes criações da literatura universal: o Don Juan Tenório. O mito do eterno sedutor foi gerado por Tirso a partir de uma peça trágica, El burlador de Sevilla y el convidado de piedra, aí por volta de 1630. Desde então, o mito se consagrou no imaginário coletivo, passando-se a quase todas as literaturas conhecidas no mundo (2005, p. 17).

A partir daí, surgem muitas outras obras que retomam o tema, de autores como José Zorilla, Byron, Balzac entre outros. Assim, Don Juan ora apresenta-se como o sedutor envelhecido, mas insuperável (envolvendo-se em disputas de sedução e tramas de vingança); ora como seduzível pelas mulheres, na versão byroniana; ou ainda atrelando sedução ao desejo de poder (na obra de Balzac).

Na ocorrência talvez mais conhecida, na obra épica Don Juan, de Byron (18191824), que ficou incompleta, composta por dezesseis cantos, tendo ficado o décimo sétimo inacabado, antes de sua morte, em 1824, Don Juan é um homem facilmente seduzido pelas mulheres, lançado nos braços delas pela força das circunstâncias do destino. O poema inicia-se com a história do verdadeiro amor pela bela filha de um pirata, que o vende depois como escravo para a esposa de um sultão, a fim de satisfazer-lhe os desejos carnais. O Don Juan de Byron é menos sedutor e mais uma vítima dos desejos femininos e de seus infortúnios. O primeiro envolvimento amoroso de Don Juan byroniano foi com Donna Júlia, moça casada, de vinte e três anos, enquanto ele tinha apenas dezesseis. Outros estudos literários vêm se dedicando ao tema do tal sedutor. Assim, com o passar dos anos, surgiram muitas obras voltadas ao tema do donjuanismo, inclusive diferentes adaptações para o cinema.

As diversas versões do personagem em todas as ocorrências citadas e ainda em muitas outras evidencia cada vez mais os aspectos voltados à temática da sedução, da obra de Tirso de Molina, tornando-a conhecida universalmente, mesmo que ora se 
aproximem, ora se afastem da fonte. O conhecimento gerado a partir das obras seja das transgressões do modelo inicial, seja da continuidade do mesmo, proporciona a compreensão de diversas formas do personagem. Nesse estudo, pretendemos associar as características desse personagem ao protagonista, como já evidenciamos, da obra Revolta, de Márcio Souza.

\section{AS DISCUSSÕES NA PSICANÁLISE SOBRE O DONJUANISMO}

O aparecimento assíduo da temática de Don Juan, tema do personagem sedutor, seu repetido sucesso em literatura, e em diversas outras artes, sugere uma certa importância psicológica. Não ficando inerte no decorrer do tempo, foi desenvolvido com rapidez propagando cada vez mais o arquétipo de Don Juan, assim recaiu também na psicanálise, para entender os princípios do donjuanismo.

Desse modo, a psicanálise apropria-se do estereótipo da literatura para explicar certo traço do comportamento humano, cuja principal característica é a compulsão para sedução. O complexo de Don Juan não se caracteriza somente por esta compulsão, mas se faz evidente na personalidade da pessoa uma necessidade de seduzir que não vai além de si mesma, uma vez que, conquistado o alvo do desejo, este deixa de despertar o interesse e é abandonado.

Sobre o modo como é visto esse personagem, Mezan (2005, p. 65) que destaca “o personagem é a própria encarnação do desejo: por onde passa deixa seu rastro numa trajetória marcada por uma espécie de furacão libidinal”. Essas particularidades indicariam a forma que se mantém o seu desenvolvimento na sedução, que de maneira firme e romântica oferece às mulheres todo o seu amor, e quando consegue conquistá-las, desaparece instantaneamente, incapaz de continuar a se relacionar por longo prazo. Assim, procura sua nova donzela a ser conquistada, como se fosse uma necessidade de satisfazer seu próprio ego. Sua lista inacabada de pretendentes está sempre aberta para a próxima aventura. Conforme Jorge de Souza Araújo (p. 94, 2005), "Don Juan busca obsessivamente a completude, saciando-se no outro o que busca em si, num jogo de espelhos em que o Outro, uma vez conquistado (seduzido, burlado, abandonado), perde todo o interesse". Para Don Juan, é mais importante conquistar a mulher do que realmente o envolvimento romântico que terá com ela. 
No mito original de Don Juan, de Tirso de Molina, "El Burlador de Sevilla" (1630), sua estória traz sua virilidade e compulsão sexual não controlada, Mezan (2005) destaca que a postura de Don Juan, quando utiliza a sedução para realizar seus desejos com mulheres, é a forma que ele usa para fazê-las acreditarem que foram realmente amadas, quando de fato ama apenas a si mesmo.

Klein (1996), no texto Amor, culpa e reparação, faz algumas considerações sobre o personagem Don Juan em relação à manifestação de sua infidelidade, que em suas diversas formas de apresentação, tem um ponto em comum: "o frequente distanciamento de um objeto amado, proveniente em parte do medo da dependência [...] Don Juan é assolado inconscientemente pelo medo da morte dos objetos amados, e a manifestação desse medo se daria através de sentimentos depressivos e de grandes sofrimentos psíquicos, se não fosse essa defesa contra si próprio: sua infidelidade". Sempre se afasta de suas conquistas por mais intensa que seja a relação. Para corroborar, Klein diz:

Através desse recurso, ele prova a si mesmo que seu único grande objeto amado (originalmente a mãe, cuja morte era temida porque seu amor por ela era voraz e destrutivo) não é indispensável, pois sempre é possível encontrar outra mulher pela qual tem sentimentos ardentes, porém superficiais. Ao contrário dos indivíduos cujo pavor da morte da pessoa amada leva à sua rejeição ou à negação do amor, ele não consegue fazer isso, por vários motivos [...] Ao mesmo tempo, ao procurar outras mulheres, dando-lhes amor e prazer, mantém em seu inconsciente a mãe amada, ou a recria (1996, p. 364).

Por isso Don Juan segue de um objeto para outro, ou seja, cada mulher com quem se relaciona acaba recriando o papel de sua mãe, que acaba se fazendo em inúmeros objetos de conquista, assim, a representatividade de sua mãe está sempre consigo de forma consciente, para essa representação não ficar inerte, a infidelidade e não continuação de seus casos se fazem presentes em todas as suas relações. Embora válida e interessante a elucidação da causa da compulsão por sedução identificada pela psicanálise, não é este o foco de nossa abordagem. A origem psíquica desse comportamento, não nos interessa no âmbito desse trabalho, mas a descrição dos seus traços característicos é fundamental para estabelecer analogias entre o comportamento do Maurício Vilaça e do que se convencionou chamar de donjuanismo. 
$\mathrm{Na}$ abordagem proposta, entendemos que o comportamento do personagem pode ser explicado mais por fatores sociais e menos por elementos psíquicos, razão pela qual associamos o tema do donjuanismo a um modelo de organização social: o patriarcalismo.

\section{PATRIARCALISMO: ASPECTOS EM MAURÍCIO VILAÇA E SOCIEDADE}

Embora a constituição familiar seja histórica, um modelo de organização familiar e social tornou-se base para diversas formas de relações, o patriarcalismo. Compreendese que a família patriarcal é aquela que se estrutura em torno da figura do pai, o patriarca, que mantém sob seu jugo a mulher e os filhos (SAFFIOTI, 2004). Dessa forma, estabelece-se uma hierarquia a partir do poder masculino exercido pelo pai que acaba por se estender para as demais relações sociais e designar lugares de prestígio para o homem e lugares de subalternidade para a mulher.

Nessa perspectiva, Maria do Perpétuo Socorro Leite Barreto define:

O patriarcalismo pode ser definido como uma estrutura sobre as quais se assentam todas as sociedades contemporâneas. É caracterizado por uma autoridade imposta institucionalmente, do homem sobre mulheres e filhos no ambiente familiar, permeando toda organização da sociedade, da produção e do consumo, da política, à legislação e à cultura. Nesse sentido, o patriarcado funda a estrutura da sociedade e recebe reforço institucional, nesse contexto, relacionamentos interpessoais e personalidade, são marcados pela dominação e violência (2004, p. 64).

Assim, a sociedade que convive com um sistema patriarcal é refém de uma soberania masculina, onde o homem tem um papel de autoridade mediante a mulher, já que o patriarcalismo concebe o poder de decisão e direitos ao homem, não se torna mandante só dentro de sua casa, mas também exerce poder em cima dos menos favorecidos que se oprimem pelo poder, além das mulheres e crianças também serem submissos, até os religiosos eram subjugados pela dominação masculina.

\section{Como afirma, Roosenberg Rodrigues Alves:}

Percebe-se, então, que a família patriarcal era o mundo do homem por excelência. Crianças e mulheres não passavam de seres insignificantes e amedrontados, cuja maior aspiração eram as boas graças do patriarca. A situação de mando masculino era de tal natureza que os varões não reconheciam sequer a autoridade religiosa dos padres. Assistiam à missa, sem a menor manifestação daquela humildade cristã do crente (própria, aliás, das mulheres), assumindo sempre ares de proprietário 
da capela, protetor da religião, bom contribuinte da Igreja. Jamais um orgulhoso varão se dignaria a beijar as mãos de um clérigo. Não que o contrário não acontecesse, porém, se assim o fosse, seria exceção, diferentemente das esposas e filhas (ALVES, 2009, p. 05).

Nesse universo masculino, os homens em geral dispunham de infinitas regalias, pois as mulheres eram concebidas como objetos de satisfação masculina e, consequentemente, julgadas como inferiores. Considerando-se as relações interpessoais, é possível identificar no comportamento masculino uma moral sexual ambígua que permite ao homem uma liberdade que o autoriza a sedução das mulheres sucessivamente, sem a obrigatoriedade de ligar-se afetivamente a suas conquistas. Tal percepção nos permite situar a personagem de Don Juan como um estereótipo da sociedade patriarcal, ou mesmo como um modelo de certo padrão de comportamento desejável desta sociedade, para qual a masculinidade se inscreve no polo da positividade, da ação e racionalidade.

Por outro lado, a figura de Don Juan pode ser compreendida, também, como uma subversão ou ameaça da ordem patriarcal ${ }^{23}$ pela ótica masculina, uma vez que ameaça a honra do patriarca pela iminência da sedução da mulher e das filhas, pois, conforme explica Saffioti: "um dos elementos nucleares do patriarcalismo reside exatamente no controle da sexualidade feminina, a fim de assegurar a fidelidade da esposa ao seu marido" (2004, p. 49). Entretanto, se considerada a situação da mulher, Don Juan reforça a lógica da dominação masculina, pois a mulher ainda ocupa um lugar de objeto e de passividade em relação ao desejo do outro, tendo, inclusive de ratificar o discurso da vítima para eximir-se da culpa da relação considerada socialmente inadequada. Sobre a discussão sexual e os favorecimentos do homem em detrimento da mulher na sociedade, Pateman (1993), citado por Saffioti, afirma:

A dominação masculina dos homens sobre as mulheres e o direito masculino de acesso sexual regular a elas estão em questão na formulação do pacto original. O contrato social é uma história de liberdade; o contrato sexual é uma história de sujeição. O contrato original cria ambas, a liberdade e a dominação. A liberdade do homem e a sua sujeição da mulher derivam do contrato original e o sentido da liberdade civil não pode ser compreendido sem a metade perdida da história, que revela como o direito patriarcal dos homens sobre as

235 Conforme tese de Margarida Losa, Don Juan: ameaça do patriarcado. Disponível em:<https://repositorioaberto.up.pt/bitstream/10216/2015/2/mlosacoloquio2000084328.pdf>. Acesso em: 12.jun.2018. 
mulheres é criado pelo contrato (PATTERMAM apud SAFFIOTI, 2004, p. 53-54).

Nesta vertente, há uma espécie de contrato entre os homens, onde a mulher é símbolo de realização dos desejos masculinos, o que favorece integralmente o poder sobre o sexo feminino. O patriarcado tem uma relação direta com a política dos homens e também esses contratos estão diretamente ligados ao patriarcalismo, pois é por meio deles que ainda se torna presente na sociedade atual.

Interessa-nos, portanto, identificar esses traços de comportamento retratados na personagem Maurício Vilaça, no romance Revolta, de Márcio Souza, de maneira a evidenciar como o patriarcalismo se cruza com o comportamento donjuanesco desse personagem.

\section{MAURÍCIO VILAÇA E SUAS AVENTURAS AMOROSAS}

Em Revolta, as mulheres eram facilmente conduzidas a realizações sexuais dos homens, neste caso, Maurício Vilaça, às vezes em troca de favores, dinheiro ou até mesmo comida, já que que o estado em que se encontrava a província era de extrema miséria e pobreza, aproveitava-se para satisfazer seus instintos sexuais. Como aconteceu com Margarida, quando Vilaça decidiu fugir um pouco dos conflitos que estavam acontecendo na cidade e partir para se aventurar nas companhias femininas:

Daí que eu resolvi fugir, deixar para trás essa triste realidade, e com umas companhias femininas para mudar o foco da vida. Assim passei na casa de margarida, que é uma moça de Santarém, e a convidei para ir à Ilha Grande de Johanes, onde um amigo meu tem uma fazenda. Aliás, foi esse amigo que me apresentou Margarida, que estava procurando emprego e achou que eu pudesse arranjar algo para ela na minha loja. Pena que Margarida é muito despreparada e não sirva para balconista. Margarida só serve para um propósito, e nisso ela é mestra. [...] passamos a noite nos amando, acordamos para o pequeno almoço e logo a seguir mais amor, almoçamos e tome amor e mais um serão de puro amor" (SOUZA, 2005, p. 39-40).

Depois de ceder às suas necessidades sexuais, Maurício não vê mais a mulher como objeto sexual, já que seus prazeres foram realizados, e a forma de como a enxergava antes de se relacionar, desaparece:

Um oco na boca do estômago e vontade de sair correndo, de desaparecer para sempre. Tive raiva e frustração. Era sempre assim, o sexo só existe no presente, enquanto dura o desejo e a excitação nos 
ilude com a promessa do gozo, que depois se revela rápido e pífio" (SOUZA, 2005, p. 51).

Essa passagem aponta para a volubilidade do personagem e sua inconstância nas relações. Assim confirmando, a mudança repentina de relações amorosas, como Don Juan. Logo após ter se relacionado com Margarida, já sente atração pela irmã dela na primeira vez que a ver, uma tapuia mais jovem, recém entrado na adolescência, Maurício a descreve com um desejo explícito e voraz, e também sem pudor:

E lá estava a irmãzinha, estirada na rede, o camisão de algodão fino levantado quase até a cintura. Era um mulherão, muito mais provocante que Margarida, pois conseguiria se desvencilhar completamente de qualquer pudor. Os cabelos pretos se espalhavam sobre o branco meio encardido da rede que cheirava a fêmea, a urina e suor. [...] Era uma boca perfeita, capaz de fazer milagres, o que me fez sentir arrepios só de imaginar. A menina pulou da rede e a camisola cobriu-lhe as coxas fartas como uma cortina de teatro que cai fora de hora (SOUZA, 2005, p. 40).

Outro momento em que Maurício se aproveita de sua posição social para consumar seus desejos, ou seja ter suas realizações sexuais, é quando conheceu Matilde. Uma moça pobre que morava em uma casa velha, seu pai estava muito doente e seu noivo estava preso, estava completamente desesperada, pois até a comida já não tinha em sua despensa. Ao conversar com Maurício e explicar-lhe toda sua situação chega a chorar falando sobre suas necessidades, e ele se vê no papel de ajudar a pobre moça. A princípio sem nada em troca, porém, a mulher se excede em trocar carícias de agradecimento com ele, que não se importa mais com a situação, pois por dentro estava louco para consumir aquela pobre mulher:

Por favor, Matilde - pedi, tentando me livrar de suas carícias, mas ao mesmo tempo desejando continuar, pois a minha conquista se transformara numa farsa, a minha galanteia produzira mais uma vez uma resposta mercenária [...] deitou-se no chão e fizemos amor ligeiro ali mesmo (SOUZA, 2005, p. 82).

Com a pobreza e miséria tomando conta da província, era comum os pais negociam suas filhas por troca de dinheiro, ou porque não queriam trabalhar e usavam suas filhas para se sustentarem:

- Essas meninas chegaram ontem aqui - disse Sebastião. - Encontrei as duas perambulando com o pai na Rua de Todos os Santos. Estavam sem comer há uns três dias, coitadas. Almoçamos na banca do preto Nicácio, aquela ali da Rua da Ajuda, e depois elas deitaram comigo, cada uma na sua vez, no fundo de uma catraia no trapiche do Mercado. 
O pai delas se aborreceu comigo porque as garotas eram bem novas e tinham ficado com a roupa toda molhada, pois a catraia estava meio alagada (SOUZA, 2005, p. 92).

Maurício também participou deste envolvimento com as jovens tapuias ao ser convidado por seu amigo Sebastião, regados a bebida e ao som de viola, deitados no chão de seu quarto. Mas não saiu como o planejado, uma das meninas estava menstruada, logo quando perceberam a expulsaram da casa, a segunda não fez sexo como ele queria e a terceira não cedeu facilmente, até que Maurício tem uma crise de fúria e expulsa todas elas de sua casa.

- Ih! Ela sujou o tapete - apontou Sebastião.

- Eu não sabia que ela estava menstruada. [...].

- Sabe de uma coisa, Sabá?

- O quê?

- Essas tapuias são umas merdas

- É, eu também acho.

Empurrei a menina com os pés e virei para o lado.

- Agora já chega, Sabá. Leva essas meninas embora [...] ele foi saindo empurrando as tapuias, a cabeça balançando em sinal de reprovação.

(SOUZA, 2005, p. 95-96).

Esse comportamento agressivo, dá-se pela insatisfação de seu ego perante as realizações de seus desejos, as relações tinham que ser conforme o seu gosto, logo, contrariado, apresenta um ataque de fúria, que o faz perder todo desejo que sentia. Como diz Saffioti, "Qualquer que seja a razão do rompimento da relação, quando a iniciativa é da mulher, isto constitui uma afronta para ele. Na condição de macho dominador, não pode admitir tal ocorrência, podendo chegar a extremos de crueldade” (2004, p. 62). A interrupção de sua satisfação nesta cena, remete ao fato de não poder manusear o corpo feminino das tapuias como queria, como dominante, não aceitava isso facilmente.

O desejo e a atração não eram unilaterais, as mulheres também sentiam atração e desejos por ele, como se pode perceber no excerto que segue:

Quem te escreve é uma amiga secreta - a carta assim começava. - Não pretendo revelar meu nome antes que possas me dar uma demonstração de tua amizade, e de tua descrição. Sou um a mulher casada e infeliz, mas que aspira à felicidade. Hoje à noite, toma um escaler e vai a bordo da escuna Muiraquitã, que está fundeada na barra. Uma vez a bordo, espero abrir-te as portas do paraíso (SOUZA, 2005, p. 115). 
Maurício não sente tanta atração por ela, sente que deve ir embora, não ficou à vontade perante a madame, talvez pela falta de atrativo que ela apresentava. Ela se sentia rejeitada pelo desconforto que ele apresentava e pela recusa de suas investidas. Porém, ele sente-se culpado por ver aquela mulher chorando e passa a consolá-la com carícias em seu corpo, até que então surge um desejo repentino, mesmo que a princípio não corresponda às investidas da mulher, ele acaba por corresponder aos seus desejos e satisfazer as duas partes. Os dois queriam o mesmo propósito, satisfação de suas vontades.

Andando pela cidade em guerra e com medo de ser atacado, Maurício acaba parando em frente à Sede das Amazonas, onde sabia que Terezinha estava lá sozinha e pede para entrar alegando que estava com medos de ser morto, mesmo sendo proibido a presença masculina naquele ambiente, Terezinha cede ao pedido. Retomando sua linguagem de conquista, descreve-a como uma mulher extremamente atraente, apesar do modo como foi criada, mas também criticava sua maneira de pensar:

Era uma carola, uma sonsa que acreditava piamente que todo prazer era pecado, especialmente os prazeres da carne. Por isso mesmo ela me atraía, estimulava a minha crueldade, o meu desejo de chocar, de derrubar as barreiras morais que ela construíra em torno de si. Filha de portugueses do Alentejo, tinha olhos castanhos, corpo esbelto, pernas grossas e seios fartos, que ela escondia ciosamente com vestidos negros, longos e fechados, num eterno luto (SOUZA, 2005, p. 140).

A religiosidade e o pudor de Terezinha tornavam o desejo de Maurício ainda mais forte, justamente por ser um desafio a ser conquistado.

Ele não sentia que agia diferente dos outros homens que se encontravam na Província, comparava-se a seu padrinho coronel Fernando, que não podia ver mulher e já ia para cima, ou ao cônego Batista Campos, que vivia cercado por mulheres. Fica evidente que tais homens desfrutavam de seu poder perante uma sociedade em ruínas por conta da guerra, assim reflete os impactos da dominação masculina. Além disso, percebe-se que tal comportamento parece ser estruturador das relações sociais e é utilizado como certa justificativa das atitudes do personagem.

Dada a dificuldade da conquista de Terezinha, acentuada pela proteção que a mulher tinha da mãe e da madrinha de Maurício, o rapaz utiliza outros subterfúgios para conquistá-la. Passado um tempo, Maurício vai procurar Terezinha para pedir desculpas pelos assédios e ela o perdoa. Ele a convida para viajar até Barcarena por uns dias. Então, 
se torna mais confiante para prosseguir com sua conquista, pois ela já era um pouco flexível com as carícias dele. Bebiam e se divertiam, Terezinha parecia feliz por sair daquela rotina:

A viagem longa durou quase todo o dia, mas Terezinha nem parecia a mesma mulher. Retirara o luto fechado e usava um vestido leve de tons verdes, não muito na moda e bastante modesto que lhe deixava os ombros nus. Não era mulher de falar muito, mas parecia contente, de alma leve, a observar o rio e a saborear a aragem que afagava seu rosto e lhe lambia os cabelos negros (SOUZA, 2005, p. 150).

A descrição acima sugere que um relacionamento afetivo começava a se desenhar, entretanto, tal percepção parece limitar-se aos sentimentos da mulher que aos poucos se deixa seduzir por Maurício, acreditando no pedido de desculpas: “[...] muito sozinha, [...] dessa vez não vestiu a carapaça de viúva convicta e não resistiu aos meus apelos e juras de amor. Pediu-me desculpas por ter se queixado à minha mãe, e pelos desconfortos gerados [...]" (SOUZA, 2005, p. 149).

Maurício sempre armava a cela para Natalie ir cavalgar pela manhã, assim foram conversando e se conhecendo melhor, até que o esperado acontecesse e ele recebe um convite para ir visitá-la à noite, pois ela estaria sozinha:

Dei a volta e entrei na casa com o coração aos ulos. Fui caminhando com muito cuidado para não esbarrar em nada, norteando-me apenas pela tépida luz que vinha de seu quarto. Aproximei-me da cama, olhei para aquela menina adormecida, inocente e desprotegida, que nem de longe lembrava a camponesa rústica que comandara o cruzamento dos garanhões. Quando dei por mim, estava em seus braços. (SOUZA, 2005, p. 69)

Depois de um tempo, Maurício reencontra Natalie em Belém, que partiria para a Inglaterra nos próximos dias, e voltam a se relacionar antes de sua partida.

Foram para casa dele, ele foi logo tratando de acariciá-la e elogiando seu corpo, "Agarrei Maria Jacinta, fui beijando-lhe o pescoço e acariciando os seios maravilhosos. Ela desvencilhou-se de meus braços e retirou cuidadosamente as meias, apanhou o espartilho e o ajeitou no encosto (SOUZA, 2005, p. 178).

Uma figura feminina perpassa toda a obra: Joaninha, uma moça de família humilde que morava no Cacoalinho com a mãe, Dona Elvira. Era por essa moça que Maurício se dizia ser apaixonado: 
Eu vinha ruminando sobre o meu amor por Joaninha há vários dias. $\mathrm{O}$ que me atraía nela? A beleza? Os olhos castanhos? A pele morna da mão me deixava perturbado, o perfume dela me inebriava. Para dizer a verdade, o que eu sei da Joaninha? Quem é ela, como será ela? Tínhamos conversado pouco e apenas trocados olhares, entrelaçando os dedos (SOUZA, 2005, p. 102).

A mãe de Joaninha não permitia essa aproximação, pois temia pela integridade da filha, de ser só uma na vida de Maurício, como acontecia com as demais mulheres, com as quais ele se envolvia.

No decorrer das cenas, percebemos que mesmo Maurício se dizendo apaixonado por Joaninha, não nega em se relacionar com outras mulheres, o que contraria esse sentimento e comprova ainda mais as características de Don Juan, em não manter seus relacionamentos duradouros.

\section{CONSIDERAÇÕES FINAIS}

O homem como ser dominante na sociedade patriarcal, tem como ser dominado as mulheres, que devem obedecer e satisfazer todos os desejos do homem. Cabe ao homem o poder de tomar as decisões, seja na família ou na organização da sociedade. Não contrariado, pois esse direito é lhe dado institucionalmente.

Interpretamos o personagem Don Juan, nesse contexto no qual ele é um personagem arquétipo da sedução, que surgiu no início de 1600 por Tirso de Molina. Este, traz consigo o poder de seduzir a mulher que deseja no momento, usando todas as formas para alcançar o seu objetivo. Desde seu surgimento, vem sendo frequente o uso de sua temática como fonte para outras obras que se assemelham.

O patriarcado se relaciona de forma direta com o donjuanismo, já que nesses dois vieses o poder da dominação masculina está incluso. Tal poder, propõe o direito do homem sobre a mulher, porém o donjuanismo ultrapassa essa questão, além de desfrutar desse poder, usa também seu poder de sedução, que juntos colidem na ordem patriarcal, no momento que passa a conquistar as mulheres, ou filhas dos homens que estão inseridos no patriarcalismo.

Evidenciamos que Maurício Vilaça apresenta características do Don Juan em vários traços psicológicos durante toda a narrativa, como vimos nesta análise. A busca 
insaciada pela sedução, tornou-se frequente no decorrer das cenas, vimos que o prazer diverge com o sentimento emocional, para este os meios com que buscava conquistar as mulheres objetificadas, justificavam os fins. Sendo assim, seus envolvimentos eram pouco duradouros, na medida que sua vontade de conquista era realizada e o objetivo alcançado, partia em busca de novas relações. Não tinha nenhum tipo de envolvimento emocional com tais mulheres, somente a busca fugaz de seu prazer.

Portanto, o comportamento do personagem com as mulheres, deixou claro o alcance do objetivo buscado neste trabalho, não esgotando as possibilidades de leituras, uma vez que, no tema do patriarcado e suas relações de violência contra a mulher, ainda há muito o que se explorar na obra. Para além dessa perspectiva, os aspectos históricos, preteridos em nossa análise, também são significativos e merecedores de futuros trabalhos acadêmicos.

\section{REFERÊNCIAS}

ALVES, R.R. Família Patriarcal e Nuclear: Conceito, características e transformações, II Seminário de pesquisa da pós-graduação em história UFG/UCG.

ARAÚJO, Jorge de Souza. Do penhor à pena: estudos do mito de Don Juan, desdobramentos e equivalências - Ilhéus, Ba: Editus, 2005.

BARRETO, M.P.S.L., Patriarcalismo e o Feminismo: uma retrospectiva histórica, Revista Àrtemis, v.18, n. 1, p. 64-73, 2004.

BOURDIEU, Pierre. A dominação masculina. Rio de Janeiro: Bertrand Brasil, 1999.

CANDIDO, Antônio. A personagem de ficção. São Paulo: Perspectiva, 1998

GANCHO, Cândida Vilares. Como analisar narrativas. São Paulo: Ática, 1991.

GENETTE, Gérard. Discurso da narrativa. Lisboa: Edições 70, 1972.

JUNIOR, Benjamin Abdala. Introdução à análise da narrativa. São Paulo: Scipione, 1995.

KLEIN, M. Amor, culpa e reparação (1937). In: Amor, culpa e reparação e outros trabalhos. Rio de Janeiro: Imago, 1996. p. 363-364.

LOSA, Margarida. Don Juan: ameaça do patriarcado. Disponível em: $<$ https://repositorio-

aberto.up.pt/bitstream/10216/2015/2/mlosacoloquio2000084328.pdf $>$. Acesso em: 12.jun.2018.

MEZAN, R. A sombra de Don Juan e outros ensaios. 2. ed. São Paulo: Casa do Psicólogo, 2005. 
REIS, Carlos (dir.), Discursos - n⿳ 12 (Literatura e Cinema), Lisboa, Universidade Aberta,1996

SAFFIOTI, Heleieth I. B. O poder do macho. São Paulo: Moderna, 1987.

SOUZA, Márcio, Revolta. Rio de Janeiro: Record, 2005.

http://tvbrasil.ebc.com.br/impressoes-do-brasil/episodio/marcio-souza-um-escritor-quediscute-a-amazonia. Acesso em abril de 2018. 


\title{
CAPÍTULO IX
}

\section{A RELAÇÕES ENTRE JOGOS E A APRENDIZAGEM DAS CRIANÇAS}

\author{
Alcione Sousa Dos Santos Almeida ${ }^{24}$. \\ DOI-Capítulo: 10.47538/AC-2021.14-09
}

RESUMO: A Educação Infantil, considerada primeira etapa de educação básica, é o alicerce de toda trajetória educacional formal dos indivíduos que ingressam nas instituições de ensino, sejam elas públicas ou privadas de todo o território nacional brasileiro. O presente trabalho visa discutir sobre a relações entre jogos e a aprendizagem das crianças no ambiente escolar. Trata-se de uma revisão de literatura que tem como principais teóricos: Teixeira (1995); Friedmann (2003); Piaget (1975); Antunes (2008) dentre outros. Diante de tal importância, a aplicação de jogos no contexto escolar se apresenta como uma ferramenta imprescindível de aprendizagem para os educandos que fazem parte da Educação Infantil, ou seja, por meio dessa atividade lúdica as crianças aprendem de maneira mais eficaz e prazerosa, além de dar maior significado aos conhecimentos assimilados pelos pequenos aprendentes.

PALAVRAS-CHAVE: Jogos. Educação Infantil. Ludicidade.

\section{RELATIONSHIPS BETWEEN GAMES AND CHILDREN'S LEARNING}

ABSTRACT: Early Childhood Education, considered the first stage of basic education, is the foundation of the entire formal educational trajectory of individuals who enter educational institutions, whether public or private, throughout the entire Brazilian national territory. This work aims to discuss the relationship between games and children's learning in the school environment. This is a literature review whose main theorists: Teixeira (1995); Friedmann (2003); Piaget (1975); Antunes (2008) among others. Given this importance, the application of games in the school context is an essential learning tool for students who are part of Early Childhood Education, that is, through this playful activity, children learn more effectively and pleasantly, in addition to give greater meaning to the knowledge acquired by young learners.

KEYWORDS: Games. Child education. Playfulness.

\section{INTRODUÇÃO}

Desenvolver uma educação que esteja focada no pleno desenvolvimento das capacidades e habilidades dos educandos requer do professor um planejamento voltado para a prática de estratégias metodológicas baseada nas principais necessidades e interesse dos alunos.

24 Pedagoga. Professora da Educação Básica. E-mail: alcioneveronilson@gmail.com 
Outro ponto de fundamental importância é trabalhar esses conhecimentos de maneira que todos possam assimilá-los. É aí que está o maior desafio dos professores. A esse respeito, Friedmann (2003) expõe que no processo da Educação, o papel do educador é primordial, pois é ele quem cria espaços, oferece os materiais e participa das brincadeiras, ou seja, média a construção do conhecimento.

Dessa forma. Cabe ao professor selecionar e planejar atividades e materiais que estejam de acordo com a idade e, sobretudo, com os interesses que lhes são peculiares. Criar um ambiente dinâmico e prazeroso, onde a aprendizagem de conteúdos seja vista como algo atrativo aos alunos, é um grande desafio para os educadores.

Outro ponto que deve ser levado em consideração ao planejar atividades pedagógicas é a diversidade cultural, social e pessoal que se encontra numa sala de aula. Com isso, Teixeira (1995) menciona que cabe ao educador oferecer inúmeras oportunidades para que se torne prazerosa a aprendizagem por meio dos jogos e brincadeiras.

Oferecer um contexto onde a aprendizagem seja desenvolvida de maneira prazerosa é, indiscutivelmente, um grande desafio, no entanto, é fundamental enfatizar que esse desafio é possível de ser vencido, ou melhor, através da aplicabilidade de jogos no ambiente da sala de aula o professor consegue transformar o processo ensino aprendizagem em algo prazeroso.

\section{ESTRATÉGIAS LÚDICAS EM SALA DE AULA}

São muitas as estratégias que podem ser desenvolvidas numa sala de aula, principalmente, quando se refere à Educação Infantil. Os jogos e as brincadeiras são as principais formas onde o ludismo se manifesta.

Em se tratando dos jogos podem ser classificados de acordo com a idade e a área de interesse. Muitos pensadores focaram seus estudos na importância que o jogo tem para o desenvolvimento humano e, principalmente, o infantil, sendo assim, Piaget elaborou uma "classificação genética baseada na evolução das estruturas" (PIAGET apud RIZZI, 1997). 
De acordo com o pensamento de Piaget (1975) os jogos são classificados em três grandes categorias que corresponde a rês fazer do desenvolvimento infantil: fase sensório motora (do nascimento até os 2 anos, aproximadamente), fase pré operatória (dos 2 aos 5 ou 6 anos aproximadamente) e fase das operações concretas. Portanto são assim classificados: jogos de exercício sensório motor, jogos simbólicos e jogos de educativos computadorizados.

Nos jogos de exercício sensório motor a finalidade é o próprio prazer do funcionamento. Estes exercícios consistem na repetição de gestos e movimentos simples como agitar os braços, sacudir objetos, emitir sons, caminhar, pular, correr, etc. embora esses jogos comecem na fase maternal e durem predominantemente até os 2 anos, eles se mantém durante toda a infância e até na fase adulta. Por exemplo, andar de bicicleta, moto ou carro (PIAGET apud RIZZI, 1997).

Os jogos simbólicos aparecem, predominantemente, entre os 2 a 6 anos. A função desse tipo de atividade lúdica, de acordo com Piaget, "consiste em satisfazer o eu por meio de uma transformação do real em função dos desejos, ou seja, tem como função assimilar a realidade" (PIAGET apud RIZZI, 1997).

A criança tende a reproduzir nesses jogos as relações predominantes no seu meio ambiente e assimilar dessa maneira a realidade é uma maneira de se auto expressar. Esse jogo-de-faz-de-conta possibilita à criança a realização de sonhos e fantasia e revela conflitos, medos e angústias, aliviando tensões e frustrações (RIZZI, 1997).

Piaget afirma que: (...) é evidente que os jogos de construção não definem uma fase entre outras, mas ocupam, no segundo e, sobretudo no terceiro nível, uma posição situada a meio de caminho entre o jogo e o trabalho inteligente (PIAGET apud RIZZI 1997, p. 27).

Os jogos educativos computadorizados são criados com a finalidade dupla de entreter e possibilitar a aquisição de conhecimento. Nesse contexto, os jogos de computador educativos ou simplesmente jogos educativos devem tentar explorar o processo completo de ensino-aprendizagem. E eles são ótimas ferramentas de apoio ao professor na sua tarefa (PIAGET apud RIZZI, 1997). 
Para Antunes (2008), o jogo é um instrumento ideal para uma aprendizagem significativa, a partir dele estimula-se o interesse da criança. De acordo com o autor, muitos filósofos, sociólogos, teólogos e antropólogos concordam em:

Compreender o jogo como uma atividade que contém em si mesma o objetivo de decifrar os enigmas da vida e de construir um momento de entusiasmo e alegria na aridez da aprendizagem e da caminhada humana pela evolução biológica. [...] Em síntese, o jogo é o melhor caminho de iniciação ao prazer estético, à descoberta da individualidade e à meditação individual (ANTUNES, 2008, p. 38).

Segundo Rau (2012a), na perspectiva de Piaget sobre o lúdico, a criança brinca e descobre os objetos livremente e, portanto, desde cedo as crianças lidam com aspectos de prazer. Com isso, a aprendizagem não é um peso, mas um aspecto de satisfação e desenvolvimento. Para o autor (p. 110):

O lúdico como recurso pedagógico direcionado às áreas de desenvolvimento e aprendizagem pode ser muito significativo no sentido de encorajar as crianças a tomar consciência dos conhecimentos sociais que são desenvolvidos durante o jogo os quais podem ser usados para ajudá-las no desenvolvimento de compreensão positiva da sociedade e na aquisição de habilidades.

Já as brincadeiras podem ser desenvolvidas através da utilização de um brinquedo ou por meio da espontaneidade. Sejam elas dirigidas ou não devem ter o acompanhamento direto do professor, pois, ele deve considerar quais os objetivos a serem alcançados no momento de desenvolvimento dessas atividades.

É fundamental a criação de tempos espaços direcionado ao ato de brincar, uma vez que é por meio dessa metodologia que os professores da Educação Infantil alcançam melhores resultados de desenvolvimento cognitivo, cultural, social e até mesmo humano,

\section{A IMPORTÂNCIA DO BRINCAR PARA O DESENVOLVIMENTO DA APRENDIZAGEM}

$\mathrm{Na}$ infância o ser humano apresenta uma grande necessidade de brincar e é por meio dessa atividade que ele pode se desenvolver plenamente. Brincando, a criança desenvolve situação de interação social, "porque, brincando, a criança desenvolve a sociabilidade, faz amigos e aprende a conviver, respeitando o direito dos outros e as normas estabelecidas pelo grupo" (CUNHA, 1994, p. 11). 
Oliveira (2010, p. 26) afirma que: Brincadeiras e jogos podem ser vistos como um grande laboratório, em que crianças e adolescentes experimentam novas formas de agir, de sentir e de pensar. Brincando, a criança busca se adaptar de forma ativa à realidade onde vive, mas também emite juízos de valor, inclusive sobre o que considera passível de melhora.

A educação infantil é um período marcante no processo de formação do ser humano. Esta etapa da educação básica está dirigida para as crianças em fases iniciais, até aproximadamente cinco anos de idade (RODRIGUES; SILVA; PARIZ, 2003). Segundo a Lei de Diretrizes e Bases da Educação Nacional - LDBEN, n. ${ }^{\circ} 9.394$ de 20 de dezembro de 1996, artigo 29:

a educação infantil, primeira etapa da educação básica, tem como finalidade o desenvolvimento integral da criança até cinco anos de idade, em seus aspectos físicos, psicológicos, intelectuais e sociais, completando a ação da família e da comunidade (BRASIL, 1996, p. 27833).

É uma etapa de grande importância para o desenvolvimento do sujeito, o que requer dos profissionais que atuam com esse público toda uma atenção e dedicação para $\mathrm{o}$ atendimento com qualidade. A criança deve ter suas necessidades, particularidades e idades respeitadas, ou seja, o trabalho pedagógico na Educação Infantil deve ser voltado, impreterivelmente, para o ensinar e, consequentemente, o aprender com prazer.

As salas de aula que atendem o público infantil devem ser compostas por pessoas que compreendam as necessidades internas dos pequenos e proporcione um trabalho dinâmico por meio de jogos e brincadeiras.

A esse respeito, Fortuna (2011, p. 9) afirma que: A brincadeira é tão importante para o desenvolvimento humano que até mesmo quando ocorrem brigas ela contribui para o crescimento e a aprendizagem. Negociar perspectivas, convencer o opositor, conquistar adesões para uma causa, ceder, abrir mão, lutar por um ponto de vista - tudo isso ensina a viver

Huizinga (apud RICHTER; FRONCKOWIAK, 2011, p. 40) mostra que o jogo é uma "função significante isto é, encerra um determinado sentido [...] que transcende as necessidades da vida e confere um significado à ação”. Richter e Fronckowiak (2011) argumentam que esse significado e essa ação surgiram do próprio conhecimento. Quando 
a criança brinca nota-se a satisfação, os sentimentos de alegria e o prazer em realizar essa atividade, o que torna uma aprendizagem significativa que tem sentido e que está na realidade da criança.

Alcançar uma aprendizagem significativa em crianças pequenas requer do professor toda uma preparação técnica que se adquire através da formação acadêmica inicial e continuada, como também, por meio da identificação e compromisso com o trabalho a ser desenvolvido.

Na Educação Infantil o objetivo de alcançar uma aprendizagem significativa está atrelada diretamente com as estratégias metodológicas que os professores aplicam no contexto da sala de aula. A esse respeito, Friedmann(2003) expõe que no processo da Educação, o papel do educador é primordial, pois é ele quem cria espaços, oferece os materiais e participa das brincadeiras, ou seja, media a construção do conhecimento.

Dessa maneira, cabe ao professor selecionar e criar materiais pedagógicos adequados, como também, inserir em seu planejamento atividades lúdicas como jogos e brincadeiras que possam colaborar para uma aprendizagem prazerosa e significativa. Assim, na visão de Moyles (2002) as crianças sentem grande prazer em repetir jogos que conhecem bem, sentem-se seguros quando percebem que contam cada vez mais habilidades em responder ou executar o que é esperado pelos outros.

Teixeira (1995) menciona que cabe ao educador oferecer inúmeras oportunidades para que se torne prazerosa a aprendizagem por meio dos jogos e brincadeiras. Assim sendo, o educador deve assumir o papel de mediador do conhecimento para que a aprendizagem flua e se concretize de maneira eficiente e, sobretudo, prazerosa.

Brincar é um ato que faz parte da natureza da criança, ou seja, são atividades indispensáveis ao desenvolvimento físico, mental, intelectual e emocional da criança. Nesse sentido, Vygotsky (1998) ressalta que no brinquedo, a criança cria uma situação imaginária, isto é, é por meio do brinquedo que essa criança aprende a agir uma esfera cognitiva, é promove o seu próprio desenvolvimento no decorrer de todo o processo educativo.

Brincadeiras e jogos são atividades internas que fazem parte do cotidiano de todas as crianças de modo geral, sendo assim, o brinquedo assume um importante papel na vida 
delas, isto, contribui significativamente no desenvolvimento dos aspectos motor, nas habilidades do pensamento, imaginação, interpretação, criatividade, tomada de decisões, entre outros fatores de grande relevância para a criança.

Segundo Piaget (1998, p. 62), “o brinquedo não pode ser visto apenas como divertimento ou brincadeira para desgastar energia, pois ele favorece o desenvolvimento físico, cognitivo, afetivo e moral".

Nessa perspectiva, o brinquedo não é simplesmente um objeto usado para distrair os alunos, ao contrário, ele assume um papel de crucial importância no trabalho pedagógico, pois, corresponde a uma profunda exigência do organismo e ocupa lugar de extraordinária relevância na educação escolar.

Além do mais estimula o crescimento e o desenvolvimento, a coordenação muscular, as faculdades intelectuais, a iniciativa individual, favorecendo o advento e o progresso da palavra. Estimula a observar e conhecer as pessoas e as coisas do ambiente em que se vive. Através do brinquedo a criança pode brincar naturalmente, testar hipóteses, explorar toda a sua espontaneidade criativa.

Assim, Campos (2011) destaca que os professores precisam estar cientes de que a brincadeira é necessária e que traz enormes contribuições para o desenvolvimento da habilidade de aprender e pensar.

O jogo é considerado uma atividade espontânea ou não realizada pelos professores de maneira organizada e com um objetivo a ser alcançado. Para realização dos jogos no contexto escolar, se faz necessário um ambiente adequado com espaços e tempos de forma a garantir o alcance dos objetivos propostos.

Santos (2008) destaca que enriquecer e valorizar os jogos realizados pelas crianças é outra função do educador, uma observação atenta pode indicar os professores que sua participação seria interessante para enriquecer a atividade desenvolvida introduzindo novos personagens ou novas situações que torne o jogo mais rico e interessante para as crianças, interessando-se por elas, animando-as pelo esforço.

Negrini, (1994), ao se referir a jogos, acrescenta: o jogo se apresenta para a criança como uma atividade dinâmica, no sentido de satisfazer uma necessidade. Dessa forma, os jogos e brincadeiras ajudam as crianças na resolução dos seus próprios problemas. 
Segundo Antunes (2005, p. 11) “A palavra jogo provém de jogo, substantivo masculino de origem latina que significa gracejo. Em seu sentido etimológico, portanto, expressa um divertimento, uma brincadeira, um passatempo, sujeito a regras que devem ser observadas quando se joga. Significa também balanço, oscilação, astúcia, ardil, manobra. Não parece ser difícil concluir que todo jogo verdadeiro é uma metáfora da vida".

Ao unir as estratégias facilitadoras de ensino promovidas pelo professor mediador com a busca pelo conhecimento dos alunos surge o conhecimento, considerado o principal objetivo da educação. “Assim, brincar significa extrair da vida nenhuma outra finalidade que não seja ela mesma. Em síntese, o jogo é o melhor caminho de iniciação ao prazer estético, à descoberta da individualidade e à meditação individual". (ANTUNES, 2005, p. 36).

Vygotsky (1998) afirma que o brincar é um espaço de aprendizagem onde a criança age além do seu comportamento humano. No brincar, ela age como se fosse maior do que é na realidade, realizando simbolicamente, o que mais tarde realizará na vida real. Embora aparentemente expresse apenas o que mais gosta, a criança quando brinca, aprende a se subordinar às regras das situações que reconstrói.

De modo geral as brincadeiras e os jogos direcionados ou não, assumem um importante papel no desenvolvimento global das crianças. São atividades que facilitam o processo ensino, permitindo assim, uma aprendizagem significativa, prazerosa e eficiente para as crianças em geral.

\section{A MEDIAÇÃO DO PROFESSOR NA REALIZAÇÃO DAS BRINCADEIRAS}

A atuação do professor na Educação Infantil é um fator de suma importância para o desenvolvimento de um bom trabalho, como também, para o alcance dos objetivos propostos para essa etapa tão importante na vida educacional dos indivíduos de modo geral.

No entanto, a qualificação profissional de pessoas para atuarem nessa modalidade de ensino, ainda é um grande problema que as escolas enfrentam nos dias atuais. De acordo com a Lei de Diretrizes e Bases da Educação Brasileira - LDB - (BRASIL, 1996), 
para atuar nesta primeira etapa da educação básica, a formação mínima do professor é aquela oferecida em nível médio, na modalidade normal (Art. 62). A própria lei que ampara a educação brasileira reforça a ideia de uma qualificação baixa para o professor dessa modalidade de ensino.

Diante das grandes transformações e necessidades que a sociedade contemporânea exige às funções desse profissional, vem passando por determinadas reformulações. Nessa perspectiva, o Referencial Curricular (BRASIL, 1998, p. 41) ressalta que:

Faz-se necessário que os profissionais, nas instituições de Educação Infantil, tenham ou venham a ter uma formação inicial sólida e consistente, acompanhada de adequada e permanente atualização em serviço. Assim, o diálogo, no interior da categoria, tanto quanto os investimentos na carreira e formação do profissional pelas redes de ensino, são hoje, desafios presentes, com vistas a profissionalização do docente da educação infantil.

Essa afirmação demonstra a exigência que a realidade vem exigindo para que os profissionais que atuam na Educação Infantil, se atualizam continuamente e, sobretudo, tenham uma formação inicial sólida e adequada, demonstrando, dessa forma, que devem ingressar em cursos de nível superior, pois, esse tipo de formação só pode ser adquirido no âmbito das instituições de ensino superior, sejam elas públicas ou privadas. Diante de tal exigência o Referencial Curricular (BRASIL, 1998, p. 41) continua enfatizando que:

$\mathrm{O}$ trabalho direto com as crianças pequenas exige que o educador tenha uma competência polivalente. Ser polivalente significa que ao educador cabe trabalhar com conteúdos de matérias diversas que abrangem desde cuidados básicos essenciais até conhecimentos específicos provenientes das diversas áreas do conhecimento. Este caráter polivalente demanda, por sua vez, uma formação bastante ampla e profissional que deve tornar-se, ele também, um aprendiz, refletindo constantemente sobre sua prática, debatendo com seus pares, dialogando com as famílias e a comunidade e buscando informações necessárias para o trabalho que desenvolve. São instrumentos essenciais para reflexão sobre a prática direta com as crianças a observação, o registro, o planejamento e a avaliação.

Diante de tais necessidades impostas pela realidade é que surge a exigência de um profissional mais capacitado e preparado para atuar nas salas de aulas da Educação Infantil. Cabe a esse professor buscar uma formação mais consistente e acadêmica, uma vez que, essa formação só é alcançada através dos cursos de formação superior.

A atual sociedade exige um profissional mais preparado, sendo assim, o agir pedagógico do educador deve buscar alcançar as necessidades que essa sociedade impõe, 
portanto, deve ter uma postura criativa e flexível, a fim de, atender essas exigências, sejam elas coletivas ou individuais.

Pensar sobre essas questões implica na elaboração e execução de diferentes estratégias metodológicas para serem aplicadas nos contextos das salas de aula por todo o Brasil, ou seja, reinventar o ambiente, para neles possam ocorrer interações entre o mundo físico e o social, oportunizando vivências e situações de troca de experiências, promovendo assim, a autonomia e a cooperação, elementos fundamentais para formação do cidadão mais atuante na sociedade. Para o RCNEI (1998, p. 21):

Educar significa, portanto, propiciar situações de cuidado, brincadeiras e aprendizagens orientadas de forma integrada e que possam contribuir para o desenvolvimento das capacidades infantis de relação interpessoal, de ser e estar com os outros em uma atitude básica de aceitação, respeito e confiança, e o acesso, pelas crianças, ao conhecimento mais amplo da realidade social e cultural.

A capacitação profissional promove uma prática pedagógica que possibilita a ampliação dos conhecimentos dos educandos sobre as diversas esferas da sociedade. Além disso, permite ao próprio professor rever suas práticas no sentido de avaliar seu fazer e analisar os resultados obtidos com seu trabalho.

Aprende ainda a respeitar os estágios de desenvolvimento das crianças e compreendem que a aprendizagem é um processo que exige diferentes níveis de maturidade nas crianças. Por meio dessa formação, adquire a capacidade de perceber as dificuldades inerentes ao educando, como também, de buscar estratégias que possam superá-las da melhor forma possível.

Aprende a conhecer e respeitar a criança na sua realidade social, cultural, religiosa e pessoal. Esse fato, proporciona uma melhor interação entre as partes e possibilita o desenvolvimento através da exploração de objetos, atividades lúdicas, desenvolvimento motor, físico, psicológico, intelectual, social e emocional.

Para Vygotsky (1991, p. 7) a função do educador é:

[...] desenvolver não uma única capacidade de pensar, mas muitas capacidades particulares de pensar em campos diferentes, não em reforçar a nossa capacidade geral de prestar atenção, mas de desenvolver diferentes faculdades de concentra a atenção sobre diferentes matérias. 
O papel do profissional da Educação Infantil, e atualmente, desenvolver uma prática pedagógica que promova uma ampliação do conhecimento sobre as diversas esferas da sociedade. Sendo assim, o Referencial Curricular para Educação Infantil (1998, p. 33) afirma que:

É função do professor considerar, como ponto de partida para sua ação educativa, os conhecimentos que as crianças possuem, advindo das mais variadas experiências sociais, afetivas e cognitivas a que estão expostas. Detectar os conhecimentos prévios das crianças não é uma tarefa fácil, implica que o professor estabeleça didáticas para fazê-lo.

O professor deve ter a capacidade de ser um guia no atendimento, alguém que, segundo Bruner (2001), ajuda o aluno a descobrir por conta própria. Cabe ao professor ver na criança alguém com capacidade de aprendizagem e desenvolvimento, mesmo que não ocorra em tempos e níveis iguais em todas.

O bom professor deve respeitar as diferenças impostas pela realidade e descobrir diferentes estratégias para que todos os alunos aprendam e possam ter as mesmas oportunidades de atuação na sociedade.

\section{ESTRATÉGIA LÚDICA APLICADA NA EDUCAÇÃO INFANTIL}

A Educação Infantil, considerada primeira etapa de educação básica, é o alicerce de toda trajetória educacional formal dos indivíduos que ingressam nas instituições de ensino, sejam elas públicas ou privadas de todo o território nacional brasileiro.

Diante de tal importância, a aplicação de jogos no contexto escolar se apresenta como uma ferramenta imprescindível de aprendizagem para os educandos que fazem parte da Educação Infantil, ou seja, por meio dessa atividade lúdica as crianças aprendem de maneira mais eficaz e prazerosa, além de dar maior significado aos conhecimentos assimilados pelos pequenos aprendentes.

Diante de tal afirmação foi decidido realizar uma pesquisa de campo com o objetivo de conhecer a realidade de uma turma de Educação Infantil, dessa forma, o trabalho foi desenvolvido numa turma de uma escola pública municipal composta integralmente, por vinte e sete alunos na faixa etária de três a quatro anos de idade. A referida turma tinha duas pessoas como responsáveis, uma professora regente e uma auxiliar. 
Ambas apresentavam formação inicial e continuada na área, demonstrando grande habilidade e segurança para atuarem junto aos seus alunos na sala de aula selecionada para realização da pesquisa de campo.

A referida pesquisa se desenvolveu por meio de observações, que aconteceram durante dez dias letivos no mês de maio do corrente ano.

Muitos pontos foram observados, porém, o fator principal era analisar a prática pedagógica das professoras no sentido de verificar a utilização organizada de estratégias lúdicas de aprendizagem no contexto da sala de aula, ou melhor, verificar se os jogos, em especial, faziam parte da realidade e do ambiente de aprendizagem das crianças que formavam o campo de pesquisa como forma de atender as reais necessidades de aprendizagem das crianças..

No geral, as aulas eram organizadas por meio de uma rotina pré-estabelecida, isto é, cotidianamente se verificava a realização de atividades com o mesmo perfil, que era: momento da chamada, rodinha das informações, explanações verbais, intervalo e realização de uma atividade.

A chamada sempre era feita com auxílio do crachá, onde estavam registrados o primeiro e segundo nomes das crianças. Sempre em ordem alfabética, as professoras chamavam o nome da criança oralmente e a mesma se levantava, procurava seu crachá sob a mesa e colocava-o num quadro de pregas. Isso acontecia individualmente com todos. Quanto aos alunos que faltavam, as professoras questionavam e o mais interessante é que os pequenos identificavam tanto, através da análise visual quanto, por meio da identificação do nome do colega registrado no crachá que ficava sob a mesa.

A aula tinha continuidade com a formação de uma rodinha com as cadeiras dos alunos. Nesse momento as professoras estimulavam a oralidade questionando-os a respeito de informações trazidas de fora para dentro do contexto escolar, ou seja, eram indagados sobre novidades acontecidas em casa, na rua, na cidade ou em qualquer outro ambiente externo que a criança frequentasse. Durante essa atividade havia grande empolgação por parte dos pequenos para expor suas novidades.

Posteriormente, as professoras sempre faziam uma explanação verbal sobre os conhecimentos teóricos. Algumas dessas explanações tratavam de temas como 
alimentação saudável, nomes e sons das vogais, representação de quantidades, importância do cuidado com os materiais escolares, entre outros. É fundamental destacar que nos momentos dessas explicações se observava grande inquietação por parte de alguns educandos, como também, certa desmotivação.

Logo em seguida, os alunos eram dispensados para o horário do recreio, onde foi possível verificar o envolvimento de algumas brincadeiras e jogos organizados pelas próprias professoras. Todos os dias elas monitoram as crianças durante o intervalo e desenvolviam brincadeiras em equipes, tradicionais e até mesmo estimulavam o faz de conta, levavam para o momento fantasias, maquiagem e espelhos para que os mesmos usassem sua imaginação e brincarem à vontade.

Havia uma grande organização por parte das professoras para inserir a ludicidade na hora do recreio dos alunos. Além de organizarem jogos e brincadeiras, havia dias em que deixavam as crianças à vontade para decidirem o que e como brincarem.

Ao terminar o horário do recreio os alunos retornavam à sala, onde eram levados a desenvolverem algum tipo de atividade que, em sua grande maioria, eram impressas em folhas de ofício. Essas atividades eram sempre relacionadas com a aula expositiva desenvolvida antes do horário do recreio ou mesmo a aula do dia anterior. A grande maioria dos educandos realizava o trabalho, porém, com pouca empolgação e havia alguns que até se negavam a realizar, sendo necessária a intervenção direta da professora ou da auxiliar da sala de aula..

Ao analisar as estratégias metodológicas das professoras, foi constatado e, sobretudo, concluído que a aplicação de jogos não estava sendo utilizada como ferramenta didática de aprendizagem, pois, em nenhum momento foram realizados, ou seja, não foi averiguado a execução de jogos voltados diretamente para estimular a aprendizagem cognitiva, motora, social ou de qualquer outro tipo dentro do contexto da sala de aula e apresentavam sempre o mesmo perfil de desenvolvimento.

Apesar de organizarem algumas atividades lúdicas para serem desenvolvidos no horário do intervalo, especificamente, no recreio, não era o bastante, isto é, os jogos devem ser realizados também dentro do âmbito da sala de aula a fim de mediar, estimular, facilitar e estimular os conhecimentos dos educandos devem ser utilizadas como forma 
de deixar essas aprendizagens mais significativas e prazerosas para os pequenos aprendentes.

O dinamismo lúdico deve estar presente tanto fora, quanto dentro da sala de aula para que o processo ensino aprendizagem se realize de maneira espontânea e, sobretudo, contribua para um melhor desenvolvimento das capacidades, habilidades e conhecimentos dos alunos.

Muitas foram às contribuições da pesquisa para o crescimento acadêmico e profissional do pesquisador. Esse trabalho servirá para que futuros pesquisadores percebam a importância da ludicidade no processo ensino aprendizagem de crianças, como também, para que os professores da própria sala de aula possam fazer uma autoanálise de sua prática e perceber pontos positivos e negativos, a fim, de aprimorar cada vez mais as estratégias metodológicas aplicadas em sala..

\section{CONSIDERAÇÕES FINAIS}

Numa educação em que se busca uma preparação para a vida, deve-se levar em consideração as necessidades humanas, dessa forma, deve-se usar a ludicidade como estratégia metodológica.

Brincar é algo vital para o desenvolvimento do corpo e da mente, sendo assim, utilizar jogos no processo de ensino contribui para o desenvolvimento de uma educação integral que motive as crianças e leve-as a uma aprendizagem prazerosa e significativa. Os jogos, em especial, favorecem para que crianças se convertam em adultos maduros, com grande imaginação e autoconfiança, mesmo aqueles que apresentam alguma dificuldade na sua aprendizagem ou na aquisição do conhecimento.

É fundamental dar ênfase nas metodologias que se alicerçam no ato de brincar, no facilitar as coisas do aprender através do jogo, da brincadeira, da fantasia, do encantamento. A arte-magia do ensinar-aprender (ROJAS, 1997), permite que o outro construa por meio da alegria e do prazer de querer fazer. Os jogos estão presentes em todas as fases da vida dos seres humanos, tornando especial a sua existência. 
Além de proporcionar uma aprendizagem significativa e prazerosa, os jogos, também contribuem para reforçar as relações interpessoais, ou seja, permite que as pessoas se aproximem e mostrem o melhor de si.

As crianças aprendem enquanto brincam, sendo assim, é imprescindível estimular atividades como a dramatização, a contação de histórias formais e informais, a construção de brinquedos e a criação de um espaço lúdico. Quando se utiliza jogos no processo ensino aprendizagem se consegue, sem grandes esforços, encontrar respostas a várias indagações, podendo assim, sanar dificuldades, bem como interagir com os semelhantes.

Os jogos despertam o interesse para a aprendizagem, desenvolvem a mente, a sociabilidade, a coordenação motora e deixa qualquer criança ou adulto felizes, além do mais instiga as potencialidades, provoca o funcionamento da criatividade e cultiva a sensibilidade, portanto, ocorre o desenvolvimento intelectual, social e, sobretudo, emocional. Tudo isso num processo natural, sem estresse e sem medo.

Através do desenvolvimento dos jogos as crianças envolvem-se no dinamismo da atividade e sente a necessidade de partilhar com o outro, mesmo que em postura de adversário, a parceria é um estabelecimento de relação. Esta relação expõe as potencialidades dos participantes, afeta as emoções e põe à prova as aptidões testando limites.

Ao jogar, as crianças terão a oportunidade de desenvolver capacidades indispensáveis a sua futura atuação profissional, tais como atenção, afetividade, o hábito de permanecer concentrado e outras habilidades perceptuais psicomotoras.

\section{REFERÊNCIAS}

ANTUNES, C. Jogos para a estimulação das múltiplas inteligências: os jogos e os parâmetros curriculares nacionais. Campinas: Papirus, 2005.

ANTUNES, Celso. O jogo e o brinquedo na escola. In: SANTOS, Santa Marli Pires dos. (Org.). Brinquedoteca: a criança, o adulto e o lúdico. 6. ed. Petrópolis: Vozes, 2008. Cap. 4, p. 37-42.

BRASIL. Lei de Diretrizes e Bases da Educação infantil (LDBEN), n. 9.394, de 20 dezembro de 1996. Estabelece as diretrizes e bases da educação nacional. Brasília, Diário Oficial, 23 dez. 1996, p. 27833. 
BRASIL/SEF/MEC. Referencial Curricular Nacional para Educação Infantil. Brasília, 1998.

BRUNER, J. A cultura da educação. Porto Alegre: Artmed, 2001.

CAMPOS, M. C. R. M. A importância do jogo no processo de aprendizagem. Disponívelem: $<$ http://www.psicopedagogia.com.br/entrevistas/entrevista.asp?entrIDAc essono dia 11 de junho de 2017.

CUNHA, Nylse Helena Silva. Brinquedoteca: um mergulho no brincar. 2. ed. São Paulo: Maltese, 1994.

FRIEDMANN, A. A Importância de Brincar. Diário do Grande ABC, 26 de setembro de 2003, Santo André, SP.

MOYLES, J. R. Só Brincar? O papel do Brincar na Educação Infantil. Porto Alegre: Artmed, 2002.

OLIVEIRA, Vera Barros de. Brincar: caminho de saúde e felicidade. In: OLIVEIRA, Vera Barros de; SOLÉ, María Borja i, Fortuna, Tânia Ramos. Brincar com o outro: caminho de saúde e bem estar. Petrópolis: Vozes, 2010. Cap.1, p. 13-46

PIAGET, Jean. A formação do Símbolo na criança: imitação, jogo e sonho. Rio de Janeiro: Zanar, 1978.

PIAGET, J. A psicologia da criança. Ed. Rio de Janeiro. Bertrand Brasil, 1998.

RAU, Maria Cristina Trois Dorneles. A ludicidade na educação: uma atitude pedagógica. Curitiba: Inter Saberes, 2012a.

RICHTER, Sandra; FRONCKOWIAK, Ângela. A tensão lúdica entre brincar e aprender na infância. Revista Pátio Educação Infantil, ano IX, n. 27, p. 39-41, abr./jun. 2011.

RIZZI, Leonor e Haydt, Régina Célia. Atividades lúdicas na educação da criança. Ed. Ática, 6 $6^{\text {a }}$ edição, série educação, 1997.

RODRIGUES, Almir Sandro; SILVA, Ana Tereza Reis; PARIZ, Josiane Domingues Bertoja. Teorias da Aprendizagem. Curitiba: IESDE, 2003.

SANTOS, S. M. P. dos. Brinquedoteca: sucata vira brinquedo. 2.ed. Porto Alegre: Artmed, 2008.

TEIXEIRA, C. E. J. A ludicidade na escola. São Paulo: Loyola, 1995.

VYGOTSKY, L. S. O Papel do Brinquedo no Desenvolvimento. In: VYGOTSKY. A Formação Social da Mente. São Paulo>Icone-Editora da Universidade de São Paulo, 1991.

VYGOTSKY, L. S. Aprendizagem, desenvolvimento e linguagem. 2. ed. São Paulo: Ícone, 1998 


\title{
CAPÍTULO X
}

\section{ALFABETIZAÇÃO E LETRAMENTO: REFLEXÃO SOBRE A APRENDIZAGEM DAS CRIANÇAS NOS ANOS INICIAIS POR INTERMÉDIO}

DE LEITURAS

\author{
Alexandra Lemos Padre ${ }^{25}$; Edna Maria de Lemosº; \\ Elizabete Maria Lemos ${ }^{27}$; Maria Goretti silva de Santana ${ }^{28}$. \\ DOI-Capítulo: 10.47538/AC-2021.14-10
}

RESUMO: O presente artigo foi realizado na área da educação e o estudo realizado, precede um trabalho visando aos profissionais da educação, principalmente aos professores a repensarem sobre a temática ambos discutam a questão, referente à alfabetização e letramento: Reflexão sobre a aprendizagem das crianças nos anos iniciais por intermédio de leituras no intuito de incentivar as crianças o hábito de ler através da leitura na formação dos alunos nos anos iniciais, e os educadores despertar interesse eficazes dentro do ambiente escolar. Desta forma, Por tanto o trabalho trata-se, de uma pesquisa bibliográfica com estudos aprofundados possibilitando aspectos cognitivos e uma auto- reflexão sobre a importância do ensino da leitura constantemente na vida escolar de qualquer indivíduo, consequentemente o estudo está fundamentado juntamente com as contribuições dos autores tais como:, Solé, Silva, Libâneo, Rios Ferreiro, Teberosky, Soares , Martins , Parâmetros Curriculares Nacionais (PCNs), entre outros que deram dados informativos e científicos para a elaboração deste artigo. Todos esses autores destacam a leitura como um dos caminhos necessários para o sujeito assimilar e aprimorar seus conhecimentos no cotidiano, porém, é necessário que o professor nos anos iniciais reveja suas práticas didáticas e pedagógicas favorecendo o hábito da leitura em sala de aula. É fundamental incentivar as crianças a ler desde cedo, principalmente se ela for introduzida no mundo fantástico da leitura a partir de seus primeiros anos de vida, estudos comprovam que o aprendiz se ele tiver constantemente contato com diversas leituras ele se tornará um adulto leitor. Ao conduzir esta pesquisa pode-se observar também que os demais membros da escola poderão contribuir para que as crianças se alfabetizam na idade certa e desenvolvam sua imaginação e adquira cultura leitora por intermédio da diversidade das leituras trabalhadas em sala de aula. É dever da escola oferecer subsídios variados nos primeiros anos de escolaridade, para criar bons leitores, enfim, diversas características permitirão a todos os docentes reflexões e melhorias, no aprendizado dos educandos por meio de práticas de ensino qualitativo, de forma prazerosa porque a leitura permite aos sujeitos leitores vantagens de viajar e conhecer diversos mundo através da leitura.

PALAVRAS-CHAVE: Leitura. Alfabetização. Escola cidadã.

25 Pedagoga. Professora da Educação Básica. E-mail: alexandralemospadre@outlook.com

26 Pedagoga. Professora da Educação Básica. E-mail: edna11302@gmail.com

27 Pedagoga. Professora da Educação Básica. E-mail: elizabetelemos10@ outlook.com

28 Pedagoga. Professora da Educação Básica. E-mail: goretti.medeiros@hotmail.com 


\section{LITERACY AND LITERACY: REFLECTION ON THE LEARNING OF CHILDREN IN THE EARLY YEARS THROUGH READING}

ABSTRACT: This article was carried out in the area of education and the study carried out precedes a work aimed at education professionals, especially teachers to rethink the theme both discuss the issue, referring to literacy and literacy: Reflection on children's learning in years initial through readings in order to encourage children to the habit of reading through reading in the training of students in the early years, and educators arouse effective interest within the school environment. Therefore, the work is, therefore, a bibliographical research with in-depth studies enabling cognitive aspects and a selfreflection on the importance of teaching reading constantly in the school life of any individual, therefore the study is based along with the contributions authors such as:, Solé, Silva, Libâneo, Rios Ferreiro, Teberosky, Soares, Martins, National Curriculum Parameters (PCNs), among others that provided informative and scientific data for the preparation of this article. All these authors highlight reading as one of the necessary ways for the subject to assimilate and improve their daily knowledge, however, it is necessary for the teacher in the early years to review their didactic and pedagogical practices, favoring the habit of reading in the classroom. It is essential to encourage children to read from an early age, especially if they are introduced to the fantastic world of reading from their first years of life, studies show that the learner, if he is constantly in contact with various readings, he will become an adult reader. When conducting this research, it can also be observed that the other members of the school will be able to contribute so that children become literate at the right age and develop their imagination and acquire a reading culture through the diversity of readings worked on in the classroom. It is the school's duty to offer varied subsidies in the first years of schooling, to create good readers, in short, several characteristics will allow all teachers reflections and improvements, in the learning of students through qualitative teaching practices, in a pleasurable way because reading allows to the subject readers the advantages of traveling and discovering different worlds through reading.

KEYWORDS: Reading. Literacy. Citizen school.

\section{INTRODUÇÃO}

O presente artigo tem como tema principal a Alfabetização e letramento: Reflexão sobre a aprendizagem das crianças nos anos iniciais por intermédio de leituras, no intuito de enfatizar a temática como um dos meios de comunicação essencial na vida de qualquer indivíduo e para que isso aconteça é preciso que o meio social, familiar e escolar esteja engajado em prol de conscientizar sobre a importância da leitura desde a primeira infância. Os principais autores que contribuíram para a produção deste trabalho foram: Foucambert, Solé, Libâneo, Rios, Soares, Silva, Ferreiro, Teberosky, Martins, Zilberman, e os Parâmetros Curriculares Nacionais (PCNs).

O interesse pelo tema surgiu da minha própria necessidade enquanto educadora e de depoimentos de outros educandos que enfatizam a leitura de diversos gêneros textuais 
como fonte que proporciona mudanças extraordinárias na vida das crianças ao conhecerem o mundo encantado da leitura. Os autores pesquisados mostram diversas fontes proporcionando a nós educadores uma reflexão para fazermos análise baseada em estudos e teorias que defendem esse tema.

Este artigo bibliográfico está subdesenvolvido em três capítulos, além da introdução e considerações finais, cada capítulo enfoca a importância do ensino e faz uma análise baseado em informações obtidas da temática, contribuindo para a melhoria do ensino e da aprendizagem da criança dentro da sala de aula. Ao abordar os conceitos de letramento, alfabetização e os níveis de cada criança, os autores no primeiro capítulo, esclarece os métodos iniciais do tema frisando e aprimorando os ensinamentos deste ensino nas escolas, fazendo com que os educadores estudem e elaborem ações voltadas para que o alunado saiba diferenciar o que é leitura e como funciona nas diversas concepções da alfabetização. No segundo capítulo procuramos mostrar a importância da leitura no cotidiano escolar, desde que este ensino no ambiente sirva como um grande estímulo no contexto social e cultural da criança. O incentivo da leitura na escola é indispensável nos dias atuais.

O terceiro capítulo esclarece a seriedade da leitura no ensino, no intuito de despertar na criança a curiosidade de conhecer o mundo através das metodologias estratégicas em sala de aula, retrata também as contribuições que uma biblioteca efetivamente ativa possibilita ao processo de ensino-aprendizagem dentro da instituição escolar. Desta forma, o artigo bibliográfico está direcionado a todos os docentes das instituições, em especial aos professores, que além de mediadores os mesmos representam o instrumento importantíssimo que conduz as metodologias competentes para as crianças dos anos iniciais ao mundo encantado da leitura.

\section{CONCEITUANDO ALFABETIZAÇÃO E LETRAMENTO}

A alfabetização é um processo pelo qual as crianças aprendem a ler e escrever, porém esse aprendizado vai muito além de transcrever a linguagem oral para a escrita. E esse processo inicia-se com as crianças manuseando os objetos, ouvindo pessoas, falando ou narrando histórias, entre outros. Também a alfabetização é vista como um momento 
mágico de aquisição de um determinado conhecimento específico entre as crianças, para o qual de volta toda a ação pedagógica.

Mas, Solé (2008, p. 50) enfatiza que: A alfabetização é um processo através do qual as pessoas aprendem a ler e escrever. Estes procedimentos, porém, vão muito além de certas técnicas de translação da linguagem oral para a linguagem escrita.

A palavra letramento, de acordo com Soares, (2003) é de uso ainda recente e significa o processo de relação das pessoas com a cultura escrita. Nesse entendimento é correto afirmar que o indivíduo é iletrado, pois todas as pessoas diariamente estão em contato com o mundo escrito, ambos reconhecem que existem diferenças, níveis de letramento e que constantemente poderá ocorrer a variação conforme a realidade cultural de cada sujeito.

A relação entre alfabetização e letramento é bastante forte, uma exclusivamente dependerá do conceito da outra, as duas ações são distintas, mas, inseparáveis. O ideal é alfabetizar letrando, ensinar a ler e escrever, ou seja, a criança precisa ser alfabetizada e letrada dentro do ambiente escolar, só assim saberá interpretar o que lê. De acordo com Rios e Libâneo (2009, p. 33) “a alfabetização e o letramento são processos que se mesclam e coexistem na experiência de leitura e escrita nas práticas sociais, apesar de serem conceitos distintos".

Se as crianças crescem em comunidades iletradas e a escola não as introduz na linguagem escrita (em toda a sua complexidade), talvez cheguem a atingir esses "mínimos de alfabetização", que lhes permitam seguir instruções escritas e aumentar a sua produtividade em uma fábrica, contudo não teremos de formar cidadãos para este presente nem para o futuro próximo. Há que se alfabetizar para ler o que os outros produzem ou produziram, mas também para que a capacidade de "dizer por escrito" esteja mais democraticamente distribuída. Alguém que pode colocar no papel suas próprias palavras é alguém que não tem medo de falar em voz alta (FERREIRO, 2004, p. 54).

O professor alfabetizador, deve proporcionar estímulos para o desenvolvimento das competências e habilidades dos alunos, fazendo todos a refletir sobre as relações entre partes faladas e partes escritas no contexto das palavras. Mediante análises, os mediadores devem propor ações que possam ocorrer dentro da escola e que possam facilitar a compreensão por parte dos educandos, e que todos em seu cotidiano aprimorem a 
aprendizagem em relação à leitura e a escrita dentro do ciclo de alfabetização, compreendemos que isso é um direito de cidadania.

É importante que no cotidiano escolar nós professores atuante em sala de aula fiquemos atentos para o uso frequente de leituras, propondo o alcance a todas as crianças para que as mesmas no contexto escolar tenham acesso às palavras e as escritas por intermédio das leituras realizadas pelo professor, essa prática auxiliará o aluno a repensar e aprenderam de forma prazerosa no espaço escolar.

Esse processo inicia-se mesmo antes das crianças ingressarem na escola, porque diariamente e no convívio familiar elas passam a ouvir suas mães contando histórias e elas mesmas vão construindo suas próprias histórias e passa a ver as imagens das revistas em quadrinhos e dos livros infantis. A partir daí, elas vão construindo seu mundo letrado, por meio de algumas linhas escritas por si mesmas em casa, quando sua mãe propõe em alguns momentos atividades em família, utilizando compras entre outros meios que proporcionem aprendizagens entre a criança e seu meio.

\section{OS NÍVEIS DE APRENDIZAGEM E O PROCESSO DE ALFABETIZAÇÃO NO CONTEXTO ESCOLAR}

Ao ingressarem em uma instituição escolar, as crianças passam a conviver mais com outros mundos, outras realidades e a conhecer outros tipos de signos, outras histórias contadas por seus professores e colegas, nessa troca de linguagens e experiências, elas próprias passam a criar seus próprios textos imaginários, suas linhas, rabiscam os seus cadernos e passam a escrever as letras do seu jeito e a ler de sua maneira.

As pesquisas no livro psicogênese da língua escrita, de Ferreiro e Teberosky, (1999) descrevem a evolução em relação aos níveis do processo da aquisição da escrita. E desses níveis, os mais destacados foram:

1) Nível icônico: Neste nível, escrever é reproduzir os traços típicos da escrita que a criança identifica como forma básica da mesma, e está praticamente relacionado ao nível pré-escolar, onde neste ambiente as crianças se utilizam de seus desenhos para representar a sua escrita. Porém, a criança inserida neste ambiente ainda não consegue diferenciar totalmente o desenho da escrita. Entretanto as suas escritas se assemelham muito entre si, o que não impede que a criança as considere como diferentes, porque a 
criança espera que a escrita dos nomes seja proporcional ao tamanho ou idade. Partindo desse princípio, torna-se claro que a dificuldade de diferenciar as atividades de escrever e desenhar é apenas momentânea.

2) Nível Pré-silábico: Este nível refere-se a toda a escrita que não busca correspondência sonora de forma sistemática, onde neste espaço suas escritas são aleatórias. Mas que neste nível as crianças que conhecem as letras do alfabeto, conseguem juntar letras para escrever palavras mesmo faltando letras. No entanto, a sua escrita é sem controle e tudo que consegue escrever é da mesma maneira. E não se preocupa com as grafias convencionais onde neste nível predominam garatujas ou as pseudo-letras.

3) Nível silábico: Este nível está caracterizado pela tentativa de dar valor sonoro a cada uma das letras que compõem uma escrita. Nesta tentativa a criança passa por um período da maior importância evolutiva, porque cada letra vale por uma sílaba. No entanto, é o surgimento da hipótese silábica, com esta hipótese a criança dá um salto qualitativo na concepção infantil da escrita, demonstrando consciência de que os sons que falamos podem ser representados graficamente por determinadas letras, mesmo que ainda não perceba a presença de consoantes e vogais na composição das sílabas.

4) Nível silábico-alfabético: Refere-se ao progresso da criança, pois a mesma nesse nível começa a perceber que sobram ou faltam letras nas palavras que as mesmas escrevem. E as suas grafias representam sílabas e outros fonemas, conseguindo agregar as letras sem prejudicar a correspondência sonora. Esta correspondência compreende principalmente a passagem da hipótese silábica para a alfabética, estabelecendo, portanto, uma grafia para cada sílaba. Então a escrita silábico-alfabética dessas crianças é totalmente resolvida em favor da hipótese silábica e a criança neste nível consegue escrever uma palavra com um ou dois sinais gráficos, predominando o valor sonoro convencional.

5) Nível alfabético: Significa teoricamente que a criança ela já esteja totalmente alfabetizada, porque ela mesma consegue escrever palavras e as frases, além de ser capaz de expressar suas ideias por escrito, em textos, com certa coerência e coesão, embora não esteja segura da sua grafia ou da ortografia de toda e qualquer palavra que deseja escrever, ainda que escrevam alfabeticamente mais, porém apresenta inúmeros problemas relacionados à ortografia e morfossintáticas. Entretanto, a escrita alfabética consiste no 
final desta evolução e neste nível a criança sistematicamente realizou a análise sonora dos fonemas e grafemas e passou por vários processos e adquiriu mais conhecimentos. Portanto, o professor precisa assegurar o desenvolvimento do seu aluno com diversas atividades, proporcionando para que os mesmos superem suas dificuldades na escola neste sentido contribuir para a formação intelectual das crianças.

\section{O QUE É LEITURA E OS TIPOS QUE AUXILIAM A APRENDIZAGEM}

A leitura é um processo bastante complexo, na qual o indivíduo por meio da memória consegue compreender, decodificar diversas informações de diferentes signos no dia-a-dia, enfim, essa prática é um testemunho oral das palavras impressas em diversos idiomas e possibilita o homem civilizado a construir as suas próprias atividades em suas múltiplas finalidades, e esse processo de aquisição de conhecimento, e as suas próprias habilidades na qual os leva a inserir-se no mundo vasto da leitura, fazendo com que todos possam adquirir ainda mais conhecimentos do mundo.

Fundamentando-se nessa perspectiva, realizar no ambiente alfabetizador qualquer tipo de leitura é uma tarefa lúdica de inteira interação, onde o leitor e o texto interagem diante de suas necessidades de assimilação e também de seus próprios conhecimentos prévios e contínuos, esta atividade de experiências próprias dependendo do que as crianças em comum já conhecem, acontecem a partir do convívio com outras crianças do seu meio, porém, o indivíduo aprende a ler de fato desde o momento em que ele se relaciona com o que ele mesmo lê, diante de sua realidade ou não. Dessa forma concordamos, quando, Martins (2007, p. 33) afirma que:

A leitura se realiza a partir do diálogo do leitor como o objeto lido - seja escrito, sonoro, seja gesto, uma imagem, um acontecimento. Esse diálogo referenciado por um tempo e um espaço, uma situação, desenvolvido de acordo com os desafios e as respostas que o objeto apresenta em função de expectativas e necessidades, do prazer das atividades e do reconhecimento de vivências do leitor.

Mediante a essas informações, a instituição escolar em lugar privilegiado para que os alunos entrem em contato com diversos tipos de textos e aprendam a ler diferentes leituras, porque a leitura possibilita que o indivíduo atribua por meio da leitura, novos significados que os transportam para outros lugares quando estão lendo determinadas leituras, neste contexto escolar ou em outros lugares como praças, bibliotecas, ônibus, 
entre outros espaços que possibilita às crianças, jovens e adultos a apreciar qualquer tipo de leitura no seu dia-a-dia.

No âmbito das abordagens, cada tipo de leitura objetiva funções norteadoras no intuito de aprimorarmos nossos conhecimentos, as leituras diárias assumem e oferecem um papel fundamental na vida de qualquer leitor, que diariamente lê diversos livros. Entre, linhas, os tipos de leitura nos fascina tornando nosso universo mágico e encantador embora o indivíduo aprenda a ler qualquer tipo de leitura a partir de seu contexto pessoal e social. Diante da aptidão leitora, gradativamente o leitor transforma seu universo decifrando e dando ênfase a suas leituras diárias, compreendendo e compartilhando experiências, pois a leitura acontece a partir de diálogo do leitor ativo com o objeto lido e contextualizado, num espaço respeitoso entre ambas as partes. Assim, os diversos tipos de leitura ocorrem no sentido de desempenha funções altamente consistentes e necessário, pois esse instrumento dominador dos sujeitos que sabem ler e escrever é essencial para diversificar sua realidade diante da propagação da diversidade dos tipos de leitura exposta em nossa sociedade, as mais destacadas no ambiente escolar são:

- Leitura informativa: serve para auxiliar o conhecimento na formação funcional e também nas curiosidades e necessidades das crianças.

- Leitura compreensiva: a criança por meio desta cultura adquire a capacidade de ler textos curtos. Leitura silábica e de palavras, ilustrações de livros que são de extrema necessidade para que a mesma possa aprender.

- Leitura corretiva: é realizada para a correção de certas falhas nas atividades das crianças e também de certos erros ortográficos entre outros.

- Leitura interpretativa: a criança tem capacidade de ler e compreender textos curtos e de fácil leitura com menor dependência das ilustrações, possibilitando-os para o mundo da fantasia.

- Leitura literária: são as leituras de textos literários, romances, novelas, crônicas, contos e outros, analisando a forma, a narrativa, a descritiva.

- Leitura sensorial: de certa forma caracteriza a descoberta do universo adulto no qual todos nós precisamos aprender a viver para sobreviver, pois começa muito cedo e nos acompanha por toda a vida. 
- Leitura emocional: é lida com os sentimentos, o que necessariamente implicaria a falta de objetividade, subjetivismo e no terreno das emoções as coisas ficam ininteligíveis, escapam ao controle do leitor, que se vê envolvido por verdadeiras armadilhas traçadas no inconsciente das crianças.

- Leitura colaborativa: é uma atividade em que o professor lê um texto com a classe, e durante a leitura, questiona os alunos sobre as pistas linguísticas que possibilitam a atribuição de determinados sentidos. Pois se trata, portanto, de uma excelente estratégia didática para o trabalho de formação de leitores.

- Leitura pelo professor: é importante porque o professor cria situações em que os alunos possam ler vários textos de um mesmo gênero - textos informativos, textos instrucionais ou mesmo biográficos.

- Leitura compartilhada: é realizada entre professor e alunos por meio de textos conhecidos - alguns textos do caderno do aluno, ou que estejam copiados na lousa ou em um cartaz, podem ser lidos particularmente de forma coletiva.

\section{O ENSINO DA LEITURA NO COTIDIANO ESCOLAR}

Em todos os aspectos a escola tem por responsabilidade proporcionar aos seus alunos, condições para que estes tenham acesso ao conhecimento, porque é nesse ciclo de criação e recriação do conhecimento próprio da vida escolar que a leitura ocupa sem dúvida um lugar de destaque na vida das crianças. E é neste local que devemos incentivar as crianças para elas aprenderem a ler e gostar de ler, assim neste ambiente desempenha o papel fundamental o professor, por ser um parceiro bastante importante na aquisição de conhecimento entre as crianças inseridas nestes níveis de aprendizagem.

O ambiente escolar tem que promover aos seus alunos clima favorável como meio que possa permitir muitas leituras de um mesmo texto ou diferentes textos por sujeitos que têm histórias, interesses, crenças e valores diferenciados. A leitura de textos é uma ação cuja função é fazer por meio de diferentes leituras, as crianças aprendem realmente a ler o que está escrito em jornais, livros, enciclopédias, entre outros. Portanto, cabe ao professor sempre na sala de aula reconstruir com seus alunos a trajetória interpretativa de 
cada um, buscando compreender a construção de cada sentido apontado neste espaço escolar. Entretanto, Silva (2008, p. 57) em seu relato nos mostra que:

O texto, seja na escola ou em qualquer outro lugar, deve ser compreendido como um espaço em movimento, de possibilidades. Cada texto pode ser o portador da palavra pensada que fará o aluno impulsionar-se no caminho da leitura [...], cada texto pode ser chave que abre o mundo infinito da leitura.

Partindo deste princípio, a aprendizagem do sistema linguístico que é a leitura, se constitui como uma das experiências mais valorosas na aquisição dos conhecimentos dos indivíduos ao permitir diversas formas verbais entre os seres humanos. O acesso a essa aprendizagem da leitura na escola apresenta como um dos grandes desafios da escola por ser um modelo de educação exigido nas séries do ensino fundamental. A prática de leitura na sala de aula é capaz de despertar na criança o interesse para que ocorra a sua aprendizagem, assim ela irá se encarregar de amadurecer o intelecto, porque esse procedimento é a via de acesso para uma grande variedade de informações no cotidiano escolar e social da criança.

\section{O AMBIENTE ESCOLAR E O LEITOR}

Neste sentido, cabe à escola proporcionar aos alunos atividades relacionadas à leitura, em que os participantes possam compartilhar discutindo ideias de que o texto construído dentro deste ambiente depende da autonomia e objetividade do leitor, e das perguntas como também da superestrutura dos textos que elas mesmas têm na sala de aula e também da sua complexidade. Dentro do ambiente escolar é necessário que o aprendiz consiga ser um estrategista em leitura, mediado pelo leitor maduro, enfim, se torne neste ambiente o leitor formador de opiniões fundamentado em uma linguagem considerada eficiente para o nível em que o mesmo esteja matriculado. Ainda nesta linha Foucambert, (1994, p. 30) defende que:

[...] ser leitor é querer saber o que se passa na cabeça do outro, para compreender melhor o que se na nossa. Essa atitude, no entanto, implica a possibilidade de distanciar-se do fato, para ter dele uma visão de cima, evidenciando de um aumento do poder sobre o mundo e sobre si, por meio desse esforço teórico.

Nesta perspectiva, cabe à instituição de ensino promover discussões, relacionadas de pensar no processo de formação de professores e suas condições de como organizar o 
seu espaço dentro dessa escola, que possam contribuir para ajudar ainda mais os seus alunos, tornando o ensino da leitura como um dos principais alicerces nos aspectos e na concepção por parte destes profissionais como um dos recursos para que possam desenvolver o alunado para o mundo significativo e recheado de saberes.

A aquisição da aprendizagem da leitura, não se limita a um só reconhecimento, mas sim a um entendimento do que vamos ler, para entender, portanto ensinar os alunos a ler, por meio de leituras na sala de aula é bastante importante porque envolve somente aspectos conceituais que se articulam o conhecimento com o saber fazer, mas que é preciso problematizar a dimensão dos valores e das atitudes veiculadas por esse sistema, além de contribuir para a formação do intelecto do infante.

Nessa visão teórica, Zilberman (2003) com suas palavras descreve que: [...] a sala de aula é um espaço privilegiado para o desenvolvimento do gosto pela leitura, assim como um campo importante para o intercâmbio da cultura literária, não podendo ser ignorada muito menos desmentida sua utilidade. Por isso, o educador deve adotar uma postura criativa que estimule o desenvolvimento integral da criança, desta forma quando a criança aprende na escola, ela se torna um sujeito altamente questionador, por sentir firmeza nos seus questionamentos, indaga com os outros, descobre novos horizontes, reconstrói, inventa, ensina. Entretanto, a escola torna-se um fator fundamental na aquisição do hábito da leitura e formação do leitor.

\section{ESTRATÉGIAS DE LEITURA NA SALA DE AULA}

As estratégias servem como uma direção prática, que concede privilégios tanto para o professor como para os alunos e faz com que os alunos dependendo dos seus conhecimentos, objetivos dentro do nível de aprendizagem, possam compreender e chegue a uma opinião própria, isto é, coloque-se como parte da leitura ou sinta-se parte da leitura mediante as estratégias do mediador. Entretanto, Solé (1998) “As estratégias são procedimentos, metas, regras, técnicas, métodos, habilidades que podem ser entendidas como um conjunto de ações voltadas para a execução de uma meta. Enfim, são as capacidades cognitivas, elas permitem uma ação inteligente e planejada da atividade da leitura". 
A aquisição do conhecimento acontece quando a criança diariamente passa a conviver com uma variedade que possibilita a ela a fazer seus próprios questionamentos, enquanto ser atuante na sua trajetória escolar. Além disso, o ensino de estratégias de leitura, como Solé (1998), o entende, deve-se basear em três ideias básicas:

Primeiro - É o processo de construção do conhecimento entre professor e aluno onde neste ambiente compartilham juntos os conhecimentos e ambos têm um papel fundamental neste cenário tão importante que é a escola.

Segundo - É que o professor exerce uma função muito importante de guia e orientador. Ele deve neste estabelecimento favorecer e garantir o elo na construção individual, as quais são apresentadas pelos conteúdos escolares e objetivos específicos.

Terceiro - Que os desafios do ensino devem estar um pouco além do que a criança é capaz de assumir sozinha. Ou seja, mostrar competência autônoma do que foi aprendido neste contexto escolar.

Nesta exterioridade, o ensino de estratégias na leitura facilita em todos os aspectos a compreensão leitora das crianças, conforme sua perspectiva, o professor deve planejar atividades que possam despertar no aluno o gosto pela leitura, despertando o interesse das crianças por meio das brincadeiras, relatos pessoais, apresentação dos grupos e dos textos narrativos, das ilustrações, festivais de leituras, recitais, entre outros recursos impressos e digitais. Essas estratégias nas salas de aula proporcionam às crianças mecanismos como soluções para que ocorra a aprendizagem conforme as fases da criança, habilidades e capacidades, assim estando inserida no mundo da leitura, constrói significados combinando prévios conhecimentos adquiridos entre os textos lidos e relidos neste ambiente.

\section{CONTRIBUIÇÕES DA BIBLIOTECA ESCOLAR NA FORMAÇÃO DA CRIANÇA}

A biblioteca escolar deve proporcionar aos educandos oportunidades de conhecer e crescer no meio cultural, enriquecendo ainda mais o repertório bibliográfico através de histórias contadas e lidas neste ambiente gradativamente. 
Assim, entre um livro e outro e pela mediação do professor ou até mesmo do "bibliotecário", aprenderão a ler, a escrever e a enxergar sua própria realidade e a dos outros que participaram direto ou indiretamente do seu contexto social. Dessa forma, Silva (2008) relata que "Em que uma leitura prazerosa seja em qualquer espaço, atrai crianças para o contato com o livro e a própria leitura, estimula ainda o interesse dos alunos, principalmente para o livro que contém a história contada, bem como para o gênero, o assunto e a coleção da qual ao livro faz parte. Destaca-se também o desejo despertado no pequeno leitor de sempre ir à biblioteca, demonstrando que se torna um ambiente prazeroso consequentemente fazer com que a leitura ganhe espaço na vida da criança e assim aprimorarem suas habilidades leitoras e isso só é possível se a criança mergulhar nas páginas mágicas que os livros infantis oferecem para o seu crescimento intelectual.

Silva (2008, p. 35) ele afirma que:

A escola não é apenas um lugar onde se "desenvolve" a aprendizagem intelectual de um conjunto de conteúdos e habilidades. Ela é também um espaço de convívio social e cultural, no qual pela interação entre sujeitos em torno dos objetos e manifestações culturais se produzem e partilham-se a construção coletiva de conhecimentos. É que na escola, o "envolvimento" entre diferentes sujeitos e diversos aspectos da cultura constitui um elemento de fundamental importância ao "desenvolvimento" humano na perspectiva da formação escolar.

Nesse sentido Foucambert (1994) defende que a leitura é uma atividade para os olhos e não para os ouvidos, querendo dizer com isto que a leitura é uma atividade para os olhos e não para os ouvidos, querendo dizer com isto que a leitura não se restringe ao aprendizado das correspondências letra-som, mas que o extrapola, esta é, aliás, uma discussão complexa e incômoda que apesar das pesquisas e descobertas sobre atividade de leitura na escola.

\section{CONSIDERAÇÕES FINAIS}

Conclui-se que este trabalho de ensino e aprendizagem, tem Como objeto de estudo a leitura nos dias atuais e sua relevância para que ocorra dentro do contexto educacional um diferencial, assim priorizar a aprendizagem das crianças, pois a mesma é de grande importância para a atuação do educador e também do educando no contexto escolar. Nós educadores entendemos que o processo de formação do leitor está vinculado 
primeiramente ao contexto familiar, isto é, se há presença de livros, leitores e situação de leitura no lar, isso faz com que a aprendizagem da criança aconteça mais rápido.

Sabemos que a leitura é uma atividade capaz de mudar o indivíduo e suas relações com o mundo, favorecendo a possibilidade da transformação coletiva, porém faz-se necessário uma conscientização da sociedade em relação à importância do ensino na leitura inserido no contexto tanto familiar como escolar, o qual pode começar a partir de mudanças dentro da própria escola e também em relação às mudanças do projeto político pedagógico da escola e na concretização de uma proposta social voltada somente para a leitura neste ambiente escolar. Entretanto, este trabalho bibliográfico referente ao ensino e a aprendizagem apontou novos caminhos que busca por meios de estudos atrativos proporcionando ao aluno nos anos iniciais um ambiente inovador, nesse sentido, cabe aos professores inovarem suas práticas docentes buscando novos caminhos para melhorar o aprendizado do ensino no espaço escolar.

Entretanto, a importância desse ensino de qualidade na escola, refere-se à aprendizagem das crianças e que os educadores no cotidiano devem proporcionar caminhos favoráveis as experiências adquiridas foram proporcionadas por intermédio da leitura teórica construindo assim, o desempenho e a confiança da inovação do ensino e da prática pedagógica de qualidade, principalmente, quanto ao ato de leitura. Compreendemos que é necessário que os professores se atualizem incessantemente procurando metodologias de ensino e aprendizagem, as realidades das suas crianças e que esse trabalho pode ser aplicado, desde que as propostas dos educadores sejam reflexivas e seja adequada à realidade dos mesmos, fazendo com que todos se envolvam por inteiro neste aprendizado meio das leituras que é fundamental para o indivíduo crescer intelectualmente e poder exercer sua cidadania.

\section{REFERÊNCIAS}

FERREIRO e JEBEROSKY, Emília e Ana. Psicogênese de Língua Escrita. Porto Alegre - RS, Editora Artmed, 1999.

FOUCAMBERT, Jean. A Criança, O Professor e a leitura. Porto Alegre - RS, Editora Artes Médicas, 1997.

A Leitura em Questão. Porto Alegre - RS, Editora Artes Médicas, 1994.

MARTINS, Maria Helena. O Que é Leitura. São Paulo - SP, Editora Brasiliense, 2007. 
NACIONAIS, Parâmetros Curriculares. In Nova Escola, São Paulo - SP, Abril / Maio 2001.

SILVA, Ezequiel Theodoro da. Leitura na Escola. Global Editora, São Paulo - SP, 2008.

SOLÉ, I. Estratégias de Leitura. Trad. Cláudia Schilling, 6a Edição, Porto Alegre RS, Editora Artmed, 1998.

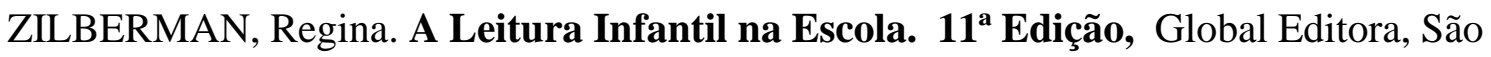
Paulo - SP, 2003.

CARVALHO, Marlene. Alfabetizar e letrar: um diálogo entre a teoria e a prática. 7. ed. Petrópolis, RJ: Vozes, 2010.

FERNANDES, Maria. Os segredos da alfabetização. 2. ed. São Paulo: Cortez, 2010

FERREIRO, Emília. Psicogênese da língua escrita. Porto Alegre: Artes médica sul, 1999.

Alfabetização e letramento. Construir Notícias. Recife, PE, v. 07 n.37, p. 5-29, nov/dez, 2007.

RIOS, Zoé; LIBÂNIO, Márcia. Da escola para casa: alfabetização. Belo Horizonte: RHJ, 2009.

SOARES, Magda. Alfabetização e letramento. 6. ed. São Paulo: Contexto, 2011. 


\section{CAPÍTULO XI}

\section{AS MEDIDAS DE ENFRENTAMENTO AOS IMPACTOS DA PANDEMIA DO COVID-19 NA SEARA TRABALHISTA}

\section{Jorge Ribeiro Dias Dos Santos ${ }^{29}$; Roberta Vasconcelos da Cunha ${ }^{30}$. DOI-Capítulo: 10.47538/AC-2021.14-11}

RESUMO: Este artigo retrata alguns conflitos enfrentados pela sociedade brasileira no período pandêmico e pós pandêmico, cujas incertezas, preocupações, agravamento da crise econômica, exigiram medidas para o enfrentamento dos impactos causados pela pandemia do covid-19 adotadas nas relações trabalhistas. Muitos trabalhadores se adequaram às mudanças de rotinas de trabalho, outros temiam pela perda ou rompimento da relação trabalhista, milhares de trabalhadores perderam seus empregos, assim como milhares de empresas fecharam as portas, causando conflitos econômicos, sociais, financeiros, emocionais e familiares. Quais as verbas a serem pagas para esses trabalhadores que tiveram seu contrato de trabalho ininterrupto? Quais as medidas adotadas pelas empresas para pagamentos das verbas rescisórias? Quais as medidas adotadas pelo legislador? Qual a posição do trabalhador diante de tais medidas? Essas são as indagações que surgiram ao longo desse período caótico e o artigo procura apresentar as algumas soluções para tais questionamentos, daí a considerável relevância jurídica do trabalho.

PALAVRAS-CHAVE: Relação trabalhista. Segurança jurídica. Enfrentamento da covid-19. Pagamento de verbas contratuais. Estabilidade.

\section{MEASURES TO ADDRESS THE IMPACTS OF THE COVID-19 PANDEMIC ON THE LABOR SEARA}

ABSTRACT: This article portrays some conflicts faced by Brazilian society in the pandemic and post-pandemic period, whose uncertainties, concerns, worsening of the economic crisis, demanded measures to face the impacts caused by the covid-19 pandemic adopted in labor relations. Many workers adapted to changes in work routines, others feared the loss or break of the labor relationship, thousands of workers lost their jobs, as well as thousands of companies closed their doors, causing economic, social, financial, emotional and family conflicts. What are the sums to be paid to these workers who had their employment contract interrupted? What measures are adopted by companies for payment of severance pay? What measures has the legislator adopted? What is the position of the worker regarding such measures? These are the questions that arise during this chaotic period and the article seeks to present some solutions to such questions, hence the considerable legal relevance of the work.

KEYWORDS: Labor relationship. Legal security. Coping with covid-19. Payment of contractual funds, Stability.

\footnotetext{
${ }^{29}$ Advogado. Especialista em Direito Imobiliário, Negócios, Administração e Direito. Pós - Graduando em Direito Material e Processual Civil e Especialista em Direito do Material e Processual do Trabalho.

${ }^{30}$ Advogada. Especialista em Direito do Consumidor com Ênfase nas relações de Consumo. Especialista em Direito Material e Processual Civil e Pós graduanda em Direito do Material e Processual do Trabalho.
} 


\section{INTRODUÇÃO}

Através desse artigo, elencamos as conquistas históricas dos direitos fundamentais e sociais tutelados pela Constituição Federal de 1988, bem como pontuamos interpretações e mudanças consideráveis ao longo do último século, reflexo da evolução das relações sociais, legislativas e trabalhistas.

As relações sociais se tornaram cada vez mais complexas, em decorrência da proteção de direitos fundamentais, em especial os direitos e garantias trabalhistas, o princípio norteador é o da proteção da parte mais frágil da relação - o empregado. Esse mesmo princípio anda de mãos dadas com o da dignidade humana (art. 1, III da Constituição Federal), norteador do ordenamento jurídico brasileiro.

O Direito do Trabalho possui vários direitos fundamentais regulamentados desde a Constituição Federal de 1988, tais como: carteira de trabalho assinada, $13^{\circ}$ (décimo terceiro) salário, férias, entre outras garantias e princípios protetivos específicos que norteiam as relações de trabalho e emprego.

O contexto econômico e pandêmico exigiu uma postura de flexibilidade por parte das empresas e dos trabalhadores, uma vez que o Brasil e o mundo vêm enfrentando uma crise econômica sem precedentes, em que milhares de empresas tiveram que fechar as portas e se deparar com o impacto das rescisões trabalhistas de vários funcionários, estes por sua vez, estão lutando com a crise e o desemprego, padecendo com sérias restrições financeiras.

Diante da crise mundial ocasionada pela pandemia do COVID-19, a qual afetou diversas áreas e ramos de atividades econômicas-financeiras, ocorreu uma fragilidade e reformulação que mitigaram os direitos fundamentais, em especial, os direitos sociais trabalhistas.

De acordo com o Professor Carlos Bezerra de Leite, com essa flexibilização de transacionar os direitos trabalhistas, houve um retrocesso jurídico, contudo, ao presente artigo cabe mostrar que houve sim a flexibilização de alguns direitos, porém, ocorreram para promover a segurança jurídica da localidade, evitando um colapso, ainda pior no sistema financeiro e econômico brasileiro. 


\section{OS DIREITOS TRABALHISTAS AFETADOS DURANTE A PANDEMIA DO COVID-19}

O décimo terceiro salário, também chamado de abono natalino, gratificação ou subsídio de Natal, é o salário devido ao trabalhador, empregado ou funcionário público, de aproximadamente 01 (um) salário mensal, que pode ser pago em uma ou mais prestações, de acordo com a legislação brasileira.

Segundo o professor e doutrinador Mauricio Godinho Delgado, o instituto legislativo do $13^{\circ}$ (décimo terceiro) salário foi recepcionado pelo governo de João Goulart em 1962, durante seu mandato ocorrido em 1961 a 1964, período que o país passava por uma enorme crise. As organizações sindicais se utilizavam das ameaças de greves para pressionar o governo, exigindo o sancionamento da lei, sem emendas.

A pressão não era apenas da classe trabalhadora, pois o governo de Goulart sofria com duras críticas e objeções dos patrões pela não aprovação da gratificação ao trabalhador.

Nesse contexto histórico, João Goulart assinou a Lei de nº 4.090, de 13.07.1962, que garantia o direito ou benefício ao trabalhador de receber o $13^{\text {a }}$ (décimo terceiro) salário, na época que foi estabelecido que metade do benefício era pago em fevereiro e novembro de cada ano.

A gratificação natalina foi assegurada pela Constituição Federal e tornou-se um direito importantíssimo e vital a todos os trabalhadores brasileiros, que fazem jus ao mesmo e já incorporaram no seu planejamento financeiro.

Depois desse apanhado histórico, cabe ressaltar de forma contemporânea os impactos sociais, econômicos e jurídicos relacionados à pandemia causada pelo coronavírus, que ceifou milhares de vidas, provocando um verdadeiro estado de calamidade pública vivida em nível mundial, fora os transtornos sociais e econômicos.

O ano de 2020 foi atípico em todos os sentidos, pois resultou em uma crise econômica global que levará anos para que os países e suas economias possam se reestruturar.

Os governos se viram na obrigação de tomar medidas de enfrentamento à crise $\mathrm{e}$ políticas públicas, assim, leis excepcionais foram criadas com o objetivo de enfrentar a 
crise econômica provocada pela pandemia do coronavírus no Brasil, afetando em especial os direitos perenes dos trabalhadores.

Foi sancionada a Medida Provisória n ${ }^{\circ} 936$ em 01.04.2020 e outros institutos de natureza emergencial que dispõem de medidas complementares de natureza trabalhista, para enfrentamento do estado de calamidade que assolou nosso país.

A medida provisória $\mathrm{n}^{\circ} 936$ foi transformada na Lei $\mathrm{n}^{\circ} 14.020$, a qual veio dirimir e autorizar a redução de jornada de trabalho, salários e a suspensão dos contratos de trabalhos até final do estado de pandemia.

Cabe citar que o ano de 2020 foi um ano de várias mudanças globais, sociais e econômicas. Assim, houve um impacto social, por conta desse período atípico vivenciado pela sociedade.

Em 13.07.2020 foi sancionado o Decreto de $\mathrm{n}^{\circ}$ 10.020, que trouxe em seu conteúdo a prorrogação de prazos para celebração de acordos no âmbito trabalhista, versava sobre a diminuição ou redução da jornada de trabalho e para efetuar os pagamentos de benefícios e programas governamentais.

Derradeiramente, o governo sancionou o decreto de $\mathrm{n}^{\circ} 10.070$, que estipulava mais uma vez a prorrogação dos prazos, entre empregado e empregador, para celebrarem acordos de redução proporcional da jornada de trabalho e salário, suspensão de contrato de trabalho, isso para aplicação do benefício governamental.

Em verdade, houve várias mudanças legislativas, principalmente na seara trabalhista, tudo isso para amoldar as partes a nova realidade social.

Diante dessa nova realidade mundial e sérios reflexos aos Direitos Sociais em nosso país, inclusive no campo tributário e econômico, a situação caótica abriu margem para diversos entendimentos e alternativas aos pagamentos das verbas e reflexos trabalhistas dos empregados.

Nessa linha de análise, entende-se que a legislação trabalhista foi omissa quanto à estipulação do $13^{\circ}$ salário e alguns reflexos.

Uma das medidas de enfrentamento aos impactos causados pela pandemia do coronavírus foi a interrupção do contrato de trabalho dos empregados. Assim, muitas 
empresas interromperam suas atividades, seja por motivos de prevenção da saúde do trabalhador, precaução de não contágio do vírus, pelo colapso sofrido em várias áreas de atividades comerciais em seus diversos setores, como: comércio, turismo, entretenimentos, prestação de serviços e muitas outras.

Nesse contexto social, o trabalhador teve seu contrato de trabalho interrompido, e após seu retorno às atividades laborais, o obreiro veio a ser amparado pelo legislador em gozar por um curto período de estabilidade no emprego, equivalente ao acordado pelo programa de benefício emergencial, após o restabelecimento da jornada de trabalho. Assim, se o contrato de trabalho foi suspenso no período de 90 (noventa) dias, sua estabilidade no emprego era de 180 (cento e oitenta) dias.

Salientando que o Governo Federal implantou medidas que ajudavam os pequenos empreendedores e empresários a custear as despesas e manutenção dos empregados na relação trabalhista, vez que os negócios foram severamente impactados.

As empresas de maior poder aquisitivo decidiram por cautela assegurar o pagamento integral do $13^{\mathrm{a}}$ salário de seus empregados, por razões legais, para evitar a cobrança dessas verbas em eventuais demandas trabalhistas. Outras, em consenso com seus empregados decidiram optar pela suspensão do contrato de trabalho e consequentemente o pagamento do benefício de forma proporcional ao tempo trabalhado.

Outra forma de garantir a ordem e segurança jurídica das relações trabalhistas, foi optar pela redução da jornada, em que os empregadores reduziram a jornada de trabalho e, consequentemente, a base para cálculo do $13^{\circ}$ (décimo terceiro) seria o salário reduzido, e não o integral.

Assim, restou uma margem para várias indagações, qual o valor do salário base de dezembro para fins de cálculos e pagamento do benefício citado?

É evidente que nesse contexto da pandemia e da crise econômica, a maior parte das empresas optaram pelos pagamentos das verbas trabalhistas que lhes causam menos impacto, sendo menos vantajoso ao empregado, pela redução do salário do trabalhador, com amparo nas medidas de enfrentamento à crise causada pelo coronavírus.

Otávio Calvet, Mestre e Doutor em Direito pela PUC/SP, Juiz do Trabalho do TRT-RJ, defende a tese que para fins de cálculos e pagamento do $13^{\circ}$ (décimo terceiro) 
salário ao empregado, deve ser calculado com base do salário nominal, sem levar em consideração, para fins de cálculo, a excepcional redução provisória, pois nesse parâmetro prevalece o Princípio da Dignidade do trabalhador, visando a maior proteção ao hipossuficiente da relação trabalhista.

A Constituição Federal de 1988, prevê e estipula, dentre os Direito Sociais dos trabalhadores rurais e urbanos, o pagamento do $13^{\circ}$ salário de forma integral e ainda de acordo com as normas trabalhistas, contudo, como a pandemia causada pelo coronavírus causou uma crise sem precedentes no mundo e o governo teve que adotar medidas econômicas, sociais e políticas públicas, que viessem a resguardar empregos, pois, uma trágica consequência será o desemprego em níveis ainda mais alarmantes.

Acordos extrajudiciais nas rescisões dos contratos de trabalho, redução da jornada trabalhada, salário proporcional, e o pagamento proporcional do $13^{\circ}$ salário, em função da suspensão do contrato de trabalho, foram algumas das medidas de enfrentamento dos impactos da pandemia, as quais tinham a função de evitar futuras ações em massa no âmbito trabalhista, além de oferecer condições mais justas ao empregado e sua família.

Algumas empresas optaram em pagar somente as verbas trabalhistas proporcionais, do $13^{\circ}$ (décimo terceiro) salário e férias do trabalhador, tendo com fundamento legal a Nota Técnica SEI n 51520 de 2020, que regulamentou sobre as obrigações contratuais na seara trabalhistas.

Algumas empresas em melhores condições financeiras não quiseram assumir o risco de demandas judiciais e pagaram a parcela integral do décimo terceiro salário.

\section{A IMPORTÂNCIA DOS MEIOS ADEQUADOS DE RESOLUÇÃO DE CONFLITOS NO CONTEXTO PANDÊMICO}

A Justiça do Trabalho sempre privilegiou a resolução das demandas através da conciliação, sendo um dos institutos mais antigos e importantes dessa justiça especializada, disciplinado pela Consolidação das Leis do Trabalho, em que o juiz deveria tentar a conciliação em dois momentos específicos, no início e final da instrução.

Com o advento da Lei de 13. 467/2017, conhecida como a Reforma trabalhista, houve uma mudança processual, estrutural, cultural e social quanto a adoção dos meios adequados de resolução de conflitos, estimulando a negociação, conciliação, arbitragem 
e mediação extrajudicial, em paralelo ao movimento de Tribunal Multiportas e as modificações legislativas ocorridas após a Resolução 125 do CNJ, o CPC e a Lei de Mediação.

A Reforma Trabalhista trouxe importantes alterações na relativização da disponibilidade dos direitos e a inserção do procedimento de jurisdição voluntária da transação extrajudicial, conforme previsão legal do art. 855-A da CLT, em que as partes alcançando o acordo na esfera extrajudicial, posteriormente podem só homologá-lo em Juízo, caso houvesse a necessidade e prezando pela segurança jurídica,

O panorama consensual e extrajudicial trazido pela reforma trabalhista foi precursor de suma importância para a fase crítica experienciada na pandemia, em que as negociações foram mais do que necessárias para enfrentar tantas controvérsias na relação empregatícia.

Diante desse cenário pandêmico, os meios de resolução de conflitos foram muito salutares para dirimir as controvérsias, através da arbitragem, conciliações e mediações trabalhistas, principalmente nas rescisões de trabalho, permitindo a possibilidade de o empregador negociar e pagar as verbas de forma parcelada.

Também existe a possibilidade de o empregado renunciar algumas verbas desse período não trabalhadas durante a suspensão do contrato de trabalho, em especial as férias e $13^{\circ}$ (décimo terceiro) salário no contexto pandêmico.

As negociações extrajudiciais trouxeram um cenário de colaboração, de mais diálogo, mais acessibilidade, mais informalidade, sem comprometer a eficácia e segurança jurídica, uma vez que os acordos extrajudiciais podem ser homologados e tornarem-se títulos executivos judiciais.

Por conseguinte, essa nova realidade das negociações, conciliações judiciais e extrajudiciais trabalhistas, é muito benéfica no contexto atual e pós-pandêmico, pois, empresas de todos os portes sofreram muito com a pandemia, muitas fecharam as portas por não serem de serviços essenciais, por não conseguirem manter as despesas, os empregados, aluguel, os impostos e todas as despesas que são de responsabilidade dos empregadores. 


\section{CONSIDERAÇÕES FINAIS}

O contexto econômico e pandêmico exigiu uma postura de flexibilidade por parte das empresas e dos trabalhadores, uma vez que o Brasil e o mundo vem enfrentando uma crise econômica sem precedentes, em que milhares de empresas tiveram que fechar as portas e se deparar com o impacto das rescisões trabalhistas de vários funcionários, estes por sua vez, lutam com a crise e o desemprego, padecendo com sérias restrições financeiras.

A crise econômica no Brasil foi potencializada pela pandemia causada pelo coronavírus e trouxe várias problemáticas às relações jurídicas no âmbito trabalhista, pois, a classe trabalhadora temerosa pelo desemprego em massa, e sem alternativas, veio a renunciar e relativizar direitos sociais garantidos desde a Constituição Federal de 1988, mesmo sendo a parte mais vulnerável dessa relação, sendo inegável nesse contexto, o confronto de Princípios Constitucionais e Sociais.

É inegável que a gratificação natalina é um direito garantido na Constituição Federal desde 1988, contudo, diante do cenário social e crise causada pela pandemia do coronavírus, surgiram outras formas de solucionar conflitos trabalhistas, nas quais tornou-se mais viável dirimir as problemáticas por meio da negociação e transação extrajudicial dos direitos trabalhistas.

A legislação que emergiu nesse período, em especial a Lei nº 14.020 de 2020, veio regulamentar alguns direitos trabalhistas diante desse contexto, como o período de suspensão contratual, o pagamento do $13^{\circ}$ (décimo terceiro) salário, permitindo que ele fosse de forma proporcional, pago de acordo com período trabalhado, ensejando várias discussões acerca do direito material, gerando assim reflexos nas demais verbas.

A aplicação da norma mais favorável ao trabalhador, como princípio basilar do Direito do Trabalho, deve ser mantida, sem que seja ignorado o panorama da atual crise econômica que assolou o país desde 2020, uma vez que ela atingiu todas as classes sociais, causando fechamento de pequenas e grandes empresas, agravamento no desemprego e desigualdade social.

Com a crise econômica, sem as medidas de enfrentamento e a flexibilidade nas negociações, o impacto negativo aos trabalhadores seria ainda mais drástico, pois eles 
precisam manter seus empregos, sendo o salário mais do que nunca vital à subsistência de suas famílias.

Os acordos extrajudiciais foram a forma mais célere e eficiente às partes, menos estressante e evitando a morosidade do Poder Judiciário, sem mencionar que são uma forma de contenção judicial, pois, são ações preventivas e pedagógicas que essas práticas são voltadas para evitar a judicialização.

Tanto na pandemia e no pós pandemia, a adoção dos métodos adequados de resolução de controvérsias representa uma forte tendência à desjudicialização, muito importante diante das crises econômicas e sociais, potencializadas pela pandemia do coronavírus.

Inobstante a ampliação das negociações individuais e coletivas, das conciliações e mediações extrajudiciais, o Tribunal Superior do Trabalho fixou entendimento que os acordos extrajudiciais e judiciais não podem suprimir direitos indisponíveis que amparam os trabalhadores e que não sejam maculados por fraudes que lesem os direitos e garantias irrenunciáveis.

\section{REFERÊNCIAS}

BUENO, Cassio Scarpinella. A nova etapa da reforma do Código de Processo Civil, volume 1: comentários sistêmicos à lei $\mathrm{N}^{\circ}$ 11.187, de 19.10.2005, Casio Scarpinella Bueno. - 2. Ed. rev., atual. e ampl. - São Paulo: Saraiva, 2006.

CESAR, Silvio, CLT - Principais Dúvidas Trabalhistas - Resumo. Salário

LEITE, Carlos Henrique Bezerra. Curso De Direito Processual Do Trabalho/Carlos Henrique Bezerra Leite. - 17. Ed. - São Paulo: Saraiva Educação, 2019.

BRASIL. Legislação trabalhista. 2. Trabalho doméstico, legislação, Brasil. 3. Trabalho rural, legislação, Brasil. I. Noleto, Eliezer de Queiroz. II. Título. III. Série.

MIESSA, ELISSON; Manual dos recursos trabalhistas: teoria e pratica/ Elison Miessa - 2 ed. rev. Atual e ampl. - Salvador: Ed. Juspodivm, 2016.

SARAIVA, RENATO; Processo do Trabalho/ Renato Saraiva, Arayanna Mafredini 12. Ed. rev., atual. e ampl. - Salvador: JusPODIVM; 2020.

www.conjur.com.br/2020-nov-24/trabalho-contemporaneo-todas-todos-magistraturaideologia

www.planalto.gov.br.decretofederal 10422 


\section{CAPÍTULO XII}

\section{AS NOVAS COMPETENCIAS EM TEMPOS DE PANDEMIA: SABERES DESENVOLVIDOS POR UM DOCENTE}

Elcimar de Oliveira Lima ${ }^{31}$.

DOI-Capítulo: 10.47538/AC-2021.14-12

RESUMO: O artigo pretende analisar os saberes, competências desenvolvidas por um Docente de Contabilidade, durante a pandemia da COVID-19. Como professores de Contabilidade têm enfrentado situações emergentes como a da pandemia e que novos saberes, competências e habilidades pedagógicas têm sido demandadas no desenvolvimento das suas habilidades docentes? A proposta é analisar como a pandemia interferiu no trabalho docente, quais foram as novas competências demandadas e como a tecnologia influenciou na reflexão do docente no processo de ensino e aprendizagem. Faz-se necessário um estudo sobre os conhecimentos pedagógicos dos docentes do Curso de Ciências Contábeis da UFBA. Pretende-se utilizar uma pesquisa-ação, de abordagem qualitativa, cuja investigação se dá acerca da própria prática do professor-pesquisador através de processos de reflexão sobre a ação. Trata-se de um método de pesquisa onde o pesquisador juntamente com participantes da situação estão envolvidos para buscar soluções aos problemas levantados.

PALAVRAS-CHAVE: Professor de Contabilidade. Pandemia da COVID-19. Saberes pedagógicos e Tecnológicos. Competências docentes.

\section{NEW SKILLS IN TIMES OF PANDEMIC: KNOWLEDGE DEVELOPED BY A TEACHER}

ABSTRACT: The article intends to analyze the knowledge, competences developed by an Accounting Professor during the COVID-19 pandemic. As Accounting teachers have faced emergent situations such as the pandemic and what new knowledge, skills and pedagogical skills have been demanded in the development of their teaching skills? The proposal is to analyze how the pandemic interfered in the teaching work, what were the new skills required and how technology influenced the reflection of teachers in the teaching and learning process. A study on the pedagogical knowledge of the professors of the Accounting Sciences Course at UFBA is necessary. It is intended to use an action research, with a qualitative approach, whose investigation takes place about the practice of the teacher-researcher through processes of reflection on the action. It is a research method where the researcher together with participants in the situation are involved to seek solutions to the problems raised.

KEYWORDS: Professor of Accounting. COVID-19 pandemic. Pedagogical and Technological knowledge. Teaching skills.

\footnotetext{
${ }^{31}$ Faculdade de Ciências Contábeis - FCC. Universidade Federal da Bahia - UFBA
} 


\section{INTRODUÇÃO}

O ensino superior representa um dos fatores básicos para o desenvolvimento de um país. A sua qualidade depende da formação e comprometimento dos professores, uma vez que contribui para a melhoria da competência técnica e profissional dos docentes. A universidade necessita de um docente que reflita sobre sua prática, planeje e avalie seu processo educativo, articule experiências pedagógicas e adote formas de intervenção didática inovadoras (BIANCHI, ENGEL, VENDRUSCOLO, 2015).

O docente de Contabilidade diante da situação de pandemia se viu comprometido em refletir sobre suas práticas pedagógicas. De que forma a situação de calamidade pública mundial impactou em mudanças mais efetivas nos docentes, a partir de uma prática reflexiva imposta pela realidade profissional, exigida para o enfrentamento de situações tais como: mudança de uma cultura instituída, normativa, mudança de um paradigma de ensino tradicional, presencial, cartesiano, centrado no docente, em detrimento do estudante, mudança de uma concepção de aprendizagem cognitiva e tecnicista, que pouco articula o pensar, o sentir e o agir, contemplando a subjetividade e a pessoa do estudante, enfim na mudança de uma reflexão sobre a prática de forma restrita, centrada numa perspectiva instrumental e acrítica.

Este trabalho tem por objetivo apresentar os saberes e competências desenvolvidas por um docente, durante as aulas remotas no Curso de Ciências Contábeis da UFBA - Universidade Federal da Bahia. A partir de uma abordagem qualitativa, utiliza-se a pesquisa-ação respaldada em Thiolent (1996), por meio da exploração dos planos de ensinos utilizados nas aulas remotas do $2^{\circ}$ semestre de 2020 ao $1^{\circ}$ semestre de 2021.

\section{CONHECENDO O PERFIL DO DOCENTE EM CONTABILIDADE}

A popularização do ensino superior, em virtude das políticas para a educação no país, tem causado alterações no sistema educacional. As regras, normas e padrões impostos aos docentes têm provocado impacto no perfil profissional desses educadores.

O perfil dos docentes no que tange ao período de trabalho, modalidade de contratação, o número de instituições que leciona e atividades extra docência influenciam, 
a qualidade do ensino, que, como se sabe historicamente, assenta basicamente na figura do professor, enquanto responsável pelo ato de educar (NASSIF; HANASHIRO, 2002).

Os professores de Contabilidade tiveram formação, voltada para o mercado de trabalho, para a busca de resultados organizacionais. Alguns desses profissionais foram introduzidos no universo docente, como forma de melhorar sua renda, sem, no entanto, se preocuparem com os fundamentos e princípios que norteiam o processo do ensinoaprendizagem. São professores, ou melhor dizendo, estão professores, por acreditarem que a experiência profissional é fator determinante para o sucesso da transmissão do conhecimento dentro de sala de aula, sem considerar as técnicas ou os saberes pedagógicos, que muitas vezes são deixados de lado, por desinteresse em mudar suas práticas educacionais ou por mero desconhecimento.

Existem também os professores profissionais, que buscaram formação pedagógica coerente com a proposta de trabalho, ou seja, a busca de cursos de especialização, mestrado e doutorado, para acrescentarem um conjunto de técnicas, princípios, fundamentos e saberes inerentes à formação do docente do ensino superior.

\section{PANDEMIA DA COVID-19 E O ENSINO SUPERIOR O ENSINO REMOTO E A COVID-19}

Em 11 de março de 2020, a Organização Mundial de Saúde declarou que vivíamos uma pandemia, em função do novo coronavírus, que provoca a COVID-19, doença cientificamente identificada por SARS-COV-2. Então, devido a sua alta taxa de contágio, os países adotaram ações para evitar a disseminação deste vírus, além da adoção de medidas para o cuidado daqueles infectados.

No dia 17 de março de 2020, o Ministério da Educação publicou a Portaria No 343/2020 autorizando a substituição das aulas presenciais em andamento "por aulas que utilizem os meios e tecnologias de informação e comunicação". (BRASIL, 2020). O Parecer No 5/2020 do Conselho Nacional de Educação - CNE/CP, orientou, que o papel dos adultos "mediadores familiares" seja delimitado na nova organização das atividades realizadas pelos estudantes para que eles e a família não percam o contato com a escola “e não tenham retrocessos na aprendizagem" (CNE, 2020). 
Em razão da pandemia, as instituições de ensino foram afetadas pelas medidas adotadas para contenção da COVID-19. Para evitar a disseminação entre os estudantes, foi necessário o fechamento de espaços sociais que reuniam um grande número de pessoas, ou seja, o fechamento das creches, escolas, faculdades e universidades, visto que nesses locais as rotinas favoreciam a aproximação, abraços, troca de objetos e afetos, entre outros comportamentos que são considerados nocivos a propagação do vírus.

Diante das incertezas quanto ao retorno às atividades presenciais, os sistemas de ensino adotaram o ensino remoto, seja no ensino superior e/ou na educação básica.

Afinal, o que é o ensino remoto? A característica principal são atividades mediadas pelas tecnologias digitais e suas diferentes interfaces, mas que são orientadas pelos princípios da educação presencial. Para Edméa Santos (2020, n.p.):

Todo currículo vem sendo praticado remotamente com mediações audiovisuais das modernas plataformas de webconferência. Muitas delas equipadas com outras interfaces que permitem projetar conteúdos, anotar digitalmente nos materiais, dialogar com chats acoplados numa mesma plataforma. Assim, os professores encontram seus alunos no dia e hora da agenda presencial, só que agora com mediação digital. $\mathrm{O}$ ciberespaço é subutilizado como lugar de encontro, cabendo ao recurso assíncrono apenas o acesso a conteúdo e material de estudo da disciplina. Alguns docentes abrem discos virtuais nas nuvens, outros postam em plataformas diversas. Mas ninguém conversa com ninguém fora da hora marcada.

O termo "ensino remoto" consagrou-se no Brasil para denominar a resposta educacional à impossibilidade das atividades pedagógicas presenciais. Fora do Brasil, o termo remote teaching já era usado no mês de março de 2020, empregado em oposição à aprendizagem on-line (HODGES et al., 2020) e também como sinônimo de aprendizagem on-line.

Além de "ensino remoto", outras expressões surgiram durante a pandemia: "aulas remotas", "ensino remoto emergencial", "educação remota", "atividades remotas", “aprendizagem remota", “aprendizado remoto", "estratégias de aprendizagem remota" e "sala de aula remota".

As expressões têm em comum a noção de alguma atividade educacional no espaço da residência do aluno e do professor manifestada pelo qualificativo "remoto", utilizando recursos tecnológicos ou à dimensão síncrona presentes nas atividades fora do espaço 
escolar durante a pandemia. Dessa forma os professores poderiam interagir com os alunos através de atividades síncronas e assíncronas dentro de uma plataforma virtual buscando desenvolver práticas de ensino e aprendizagem inovadoras diante do ambiente de pandemia e de isolamento social imposto pela COVID-19.

\section{O ENSINO SUPERIOR E A COVID-19}

A pandemia da COVID-19 tem ocasionado profundas mudanças na sociedade, na saúde, na economia e na educação, inclusive no processo de ensino e aprendizagem entre alunos e professores do Ensino Superior em âmbito mundial.

Além dos problemas psicológicos causados pela pandemia, houve a necessidade de criar mecanismos alternativos para a continuidade do ensino e consequentemente fazer a inserção da comunidade acadêmica em um ambiente relativamente novo, ou seja, o ensino remoto. A utilização de plataformas digitais no ensino superior passou a ser obrigatória no desenvolvimento das atividades de ensino, extensão e pesquisa.

Sobre o uso de tecnologias no processo de ensino e aprendizagem, Kenski (2012 apud BRANCHI, v.17, n. 46) destaca que o computador, quando bem utilizado pode levar a um melhor conhecimento e aprofundamento do conteúdo, e, inclui, novas mediações entre a abordagem do professor, a compreensão dos alunos e o conteúdo ensinado.

Para Mastroianni e Oliveira (2020), no momento em que os professores inserem a tecnologia em suas aulas, se deparam com uma nova forma de planejar suas atividades e avaliar a aprendizagem dos alunos. No início da suspensão das aulas presenciais por conta da COVID-19, houve a necessidade dos professores da utilização de ferramentas que auxiliassem no processo do ensino e aprendizagem de forma remota, dentre tais recursos podemos citar o AVA (Ambiente Virtual de Aprendizagem) - Moodle. Adicionalmente, outros recursos de interação entre aluno e professor, como o uso de páginas pessoais, grupos de WhatsApp, Canais do Youtube dentre outros também foram utilizados para sanar dúvidas dos alunos. Deve-se ressaltar que essas ferramentas desempenham um papel fundamental ao possibilitar o diálogo entre professor e alunos no enfrentamento do isolamento social. 
Outro ponto é a dificuldade de muitos alunos em acessar as plataformas digitais por falta de internet, equipamentos ou local adequado, que inviabiliza o acompanhamento das aulas remotas síncronas e assíncronas propostas pelos professores.

Nesse momento de dificuldade de adaptação às novas ferramentas tecnológicas, das limitações de recursos físicos e de equipamentos por parte dos alunos, é que o professor precisa refletir sobre suas ações e de que forma o processo de ensino e aprendizagem proposto pelo docente pode ser um diferencial para a transmissão de conhecimento eficiente ao discente.

\section{PROCEDIMENTOS METODOLÓGICOS}

O presente artigo compreende uma pesquisa-ação, de abordagem qualitativa, cuja investigação se dá acerca da própria prática do professor-pesquisador através de processos de reflexão sobre a ação. Trata-se de um método de pesquisa onde o pesquisador juntamente com participantes da situação estão envolvidos para buscar soluções aos problemas levantados. Conforme Thiolent (1996) "na pesquisa-ação os pesquisadores desempenham um papel ativo no equacionamento dos problemas encontrados, no acompanhamento e na avaliação das ações desencadeadas em função dos problemas" (THIOLENT, 1996, p. 15). Trata-se de um tipo de estratégia que não se resume à participação e, portanto, consiste na produção de conhecimentos que, a partir da experiência adquirida, colabora com a discussão sobre determinadas questões e propõe a divulgação dos resultados (THIOLENT, 1996).

Kemmis e Mc Taggart (1988, apud ELIA e SAMPAIO, 2001, p. 248), ampliam esta forma de entendimento do conceito de pesquisa-ação com as seguintes palavras:

Pesquisa-ação é uma forma de investigação baseada em uma autorreflexão coletiva empreendida pelos participantes de um grupo social de maneira a melhorar a racionalidade e a justiça de suas próprias práticas sociais e educacionais, como também o seu entendimento dessas práticas e de situações onde essas práticas acontecem. A abordagem é de uma pesquisa-ação apenas quando ela é colaborativa [...] (KEMMIS, MC TAGGART,1988, apud ELIA, SAMPAIO, 2001, p. 248).

A pesquisa-ação propõe alcançar os seus objetivos através do caráter participativo. Segundo Elliott (1997, p. 15), permite superar as lacunas existentes entre a pesquisa 
educativa e a prática docente, e os resultados ampliam as capacidades de compreensão dos professores e suas práticas, por isso favorecem amplamente as mudanças.

Este tipo de pesquisa se enquadra perfeitamente na proposta deste artigo que é apresentar os saberes e competências desenvolvidas por um docente, durante as aulas remotas de 5 turmas do Curso de Ciências Contábeis da UFBA - Universidade Federal da Bahia. A partir de uma abordagem qualitativa, utiliza-se a pesquisa-ação respaldada em Thiolent (1996), por meio da exploração dos planos de ensinos utilizados nas aulas no período do $2^{\circ}$ semestre de 2020 ao $1^{\circ}$ semestre de 2021.

Os procedimentos adotados corroboram a máxima do professor reflexivo, cuja prática deve estar permeada pela reflexão ativa, crítica, responsável e autônoma. Contudo, entendemos que os enunciados dispostos não encerram, de forma definitiva, as possibilidades de análise das realidades subjetivas e complexas acerca do ensino remoto.

\section{REFLEXOS DA PANDEMIA NO ENSINO REMOTO}

Atenta a realidade da pandemia do novo coronavírus, buscando proteger a vida de sua comunidade e seguindo as melhores orientações sanitárias, o Conselho Universitário da UFBA - Universidade Federal da Bahia, através da portaria no 103 de 19 de março de 2020 do Gabinete do Reitor, e portarias posteriores decidiu pela não retomada das atividades presenciais no ano civil de 2020 e 2021 , por entender que a plena realização da pesquisa, do ensino e da extensão, cerne da vida universitária, pressupõe a reunião e a circulação de grande quantidade de pessoas em espaços restritos, ritmo regular e fluxo intenso - condição que, infelizmente, torna escolas e universidades lugares particularmente sensíveis à disseminação em massa da Covid-19.

Diante desse cenário, a UFBA realizou, em caráter emergencial e excepcional, o Semestre Letivo Suplementar no ano de 2020 e 2021 de atividades online, com oferta de componentes curriculares e extracurriculares de ensino, pesquisa e extensão, adaptados ou especialmente concebidos para tal formato e que poderiam, inclusive, quando oportuno, ser ministrados conjuntamente por vários docentes, sendo ademais garantido aos estudantes adesão e desligamento facultativos, bem como posterior integralização de carga horária curricular. A expectativa era que essa ação mobilizasse todo o corpo docente e técnico-administrativo da UFBA, respeitadas as diferentes condições de trabalho em 
regime home office, acesso à internet e familiaridade com tecnologias e recursos de gestão pública e educação a distância.

A UFBA convocou a comunidade universitária a assumir mais um grande desafio. Para tanto, foram desenvolvidas ações para ampliar a capacitação do pessoal em tecnologias digitais, mesmo sabendo que nem todos os professores, técnicos e terceirizados conseguiriam reunir, em casa, as melhores condições para desempenhar seu trabalho. Era de conhecimento também que, infelizmente, grande parte dos estudantes da UFBA não dispunham de condições adequadas de estudo, equipamentos e acesso à internet nos locais onde moravam.

A realização do Semestre Letivo Suplementar foi cuidadosamente construída e resultou de intenso diálogo com as diversas instâncias da comunidade UFBA, com representantes de todas as unidades. Dessa forma foram definidas competências indispensáveis para a realização do trabalho docente, dentre elas podemos destacar:

- Participação de todos os docentes ativos e não afastados;

- Mínimo de 4 horas semanais em componentes curriculares ou atividades extracurriculares aprovadas pelo Departamento/equivalente;

- Possibilidade de realização de atividades compartilhadas por mais de um professor, com registro integral da carga horária da atividade desenvolvida;

- Capacitação para desenvolvimento de atividades remotas oferecida pela SEAD Superintendência de Educação a Distância;

- Suporte pedagógico e técnico para desenho metodológico das atividades e uso de ferramentas de TIC - Tecnologia da Informação e Comunicação;

- Apresentação de Plano de ensino do componente ou atividade a ser desenvolvido:

- Identificação do componente ou atividade;

○ Número de vagas;

- Metodologias (prever atividades síncronas e assíncronas).

- Cronograma das atividades síncronas e assíncrona;

- Métodos de avaliação;

- Ferramentas de TIC/AVA adotadas;

- Registro de frequência dos estudantes exclusivamente pela participação nas atividades assíncronas. 
Para o desenvolvimento dessas novas competências a UFBA, através da SEAD, ofereceu capacitação básica aos professores para melhor acesso e utilização do ambiente AVA - Moodle. Foi adicionado também outros cursos abertos para os docentes que tivessem interesse em aprofundar sua formação: uso de plataformas, inovações das práticas pedagógicas, requisitos da docência online, uso e produção de mídias na internet como recursos didáticos. Adicionalmente foi disponibilizado um curso de formação docente em mídias digitais para inclusão e acessibilidade no ambiente educacional.

\section{DIFICULDADES DA PRÁTICA DOCENTE DURANTE A PANDEMIA}

No decorrer do ano de 2020, foram ministrados vários cursos voltados para a capacitação do professor, diante da necessidade de aprimorar essas novas competências docentes, ou seja, a utilização de ferramentas de TIC - Tecnologia de Informação e Comunicação para o desenvolvimento das aulas remotas.

Como já foi comentado, a UFBA ofereceu cursos para orientar os docentes na utilização de ferramentas e plataformas online para o desenvolvimento das práticas pedagógicas. Dentre os cursos mais importantes oferecidos podemos citar o "Curso Moodle Instrumental para Professores" e "Estruturando Disciplinas no Moodle", onde foi possível parametrizar a plataforma online de acordo com as necessidades de cada disciplina do docente, como também o gerenciamento e utilização das ferramentas e atividades disponíveis no Moodle.

A dificuldade encontrada foi adequar o conteúdo das disciplinas, algumas $100 \%$ teóricas, outras teórico-práticas, outras totalmente práticas. No geral, as aulas exigiam o contato direto com o aluno, a arguição diária, o questionamento, o debate, uma dinâmica criativa para a condução das aulas, mudando a concepção de aula tradicional, da noite para o dia, para uma proposta de aula nunca utilizada, pelo menos para os professores do ensino superior convencional. Aulas num formato onde o distanciamento entre professor e aluno era o ponto chave, a falta de contato visual, a dificuldade na percepção do nível de aprendizagem do aluno, a inexistência de interação, participação, debate, indagação nas aulas. O simples cumprimento, ou a troca de olhares entre o professor e o aluno deixou de existir, pelo fato de muitos estudantes não disporem de equipamentos adequados para o compartilhamento de suas imagens, de recurso de internet ou simplesmente o desejo 
pessoal do aluno em não compartilhar sua câmera do celular ou computador, dificultou ainda mais o trabalho do docente.

Diante dos fatos apresentados, foi necessário desenvolver estratégias metodológicas para minimizar os impactos da pandemia no ensino remoto. No caso da UFBA, foi desenvolvido pela PROGRAD - Pró-reitoria de Ensino e Graduação um modelo de Plano de Ensino onde pudesse ser discriminado detalhadamente todas as estratégias a serem utilizadas pelo docente para o desenvolvimento de suas aulas remotas. Acrescentado a essa proposta, a FCC - Faculdade de Ciências Contábeis da UFBA criou uma comissão de professores do próprio departamento para auxiliar os demais docentes da unidade no preparo de seus planos de ensino. A comissão constituiu grupos de trabalhos para oferecer cursos, treinamentos, lives, instruções e como resultado foi confeccionada uma cartilha com sugestões práticas e objetivas para o planejamento e operacionalização dos componentes curriculares a serem oferecidos nos semestres suplementares, em consonância com as diretrizes estabelecidas pela UFBA.

A proposta da criação de uma cartilha para orientar os docentes foi interessante, mas era apenas um modelo genérico para todas as disciplinas. Cada professor tem uma forma de ministrar suas aulas, tem sua dinâmica de ensino. Cada disciplina tem uma forma de ser ensinada, tem conteúdo específicos que requerem estratégias metodológicas diferentes e é neste momento que se encontra a dificuldade do professor no ensino remoto, ou seja, como adequar suas disciplinas num formato completamente novo, sem perder sua essência, suas características próprias, seu jeito de ministrar as aulas, enfim como se adequar, o docente, a um ambiente totalmente tecnológico e novo.

\section{COLOCANDO EM PRÁTICA AS COMPETÊNCIAS DOCENTES}

As aulas remotas no ensino superior se tornaram uma realidade, logo os docentes se viram obrigados a se adequarem a uma nova demanda, um novo jeito de ensinar. $\mathrm{O}$ conteúdo das disciplinas eram os mesmos, mas foi necessária uma nova roupagem, um upgrade no processo de ensino e aprendizagem por parte dos docentes para a continuidade de suas atividades. Foi essencial a criação de planos de ensino específicos, para cada disciplina ministrada, com estratégias que contemplassem os requisitos indispensáveis no processo de ensino e aprendizagem, num formato remoto, ou seja, online. O docente, 
diante desses novos desafios, precisou repensar sua forma de ensinar, precisou refletir sobre suas práticas pedagógicas, enfim, precisou refletir sobre si mesmo, o ser docente.

Mas antes de iniciarmos a discussão sobre os saberes e competências docentes, façamo-nos algumas perguntas: "O que precisa saber um professor? "O que deveria saber todo aquele que planeja exercer esse ofício?" (GAUTHIER, 1998, p. 18). Vários pesquisadores juntam esforços para encontrar respostas a essas perguntas.

Para TARDIF (2006, p. 60), "a noção de "saber" remete a um sentido amplo que engloba os conhecimentos, as habilidades (ou aptidões) e as atitudes dos docentes, ou seja, aquilo que foi muitas vezes chamado de saber, de saber-fazer e de saber-ser".

Pimenta (1999, p. 8) entende que:

O saber do professor se fundamenta na tríade de saberes das áreas específicas, saberes pedagógicos e saberes da experiência. É na mobilização dessa tríade que os professores desenvolvem a capacidade de investigar a própria atividade e, a partir dela, constituírem e transformarem seus saberes-fazeres docentes.

Alguns autores como Freire (2018), Cunha (2004), Masetto (1998), apresentam suas considerações a respeito dos saberes e competências docentes, relatadas através das experiências coletadas dos professores do ensino fundamental, médio, técnico e superior, mas independentemente do tipo de instituição de ensino que o docente atua, ou a classificação dada aos saberes docentes, todos compartilham basicamente da mesma ideia a respeito das práticas e características necessárias para o exercício da profissão docente, ou seja, o professor precisa "saber", "saber-ser" e "saber-fazer", e esse é o ponto de partida que deve ser estudado, analisado e entendido por cada docente no exercício da sua profissão com qualidade.

Diante da realidade da pandemia mundial, do ensino remoto, foi necessário que o docente se reinventasse, refletisse sobre seus saberes e competências, buscando aprimorar-se e conhecer novos mecanismos, ferramentas, novos formatos e recursos tecnológicos para a desenvolvimento da atividade docente $100 \%$ online.

Para contemplar esse novo modelo de aula, os planos de ensino foram direcionados a um formato totalmente remoto, onde os docentes passaram a conhecer e inevitavelmente a utilizar recursos tecnológicos no seu processo de ensino e aprendizagem. Mas quais seriam e como utilizar essas novas ferramentas pelos docentes 
tradicionalmente inseridos num contexto de aula $100 \%$ presencial, muitas vezes utilizando apenas um pincel e uma lousa branca.

\section{TECNOLOGIA E AS NOVAS COMPETÊNCIAS DOCENTES}

Antes de iniciarmos a discussão sobre as tecnologias no processo do ensino e aprendizagem é importante diferenciarmos as TIC - Tecnologia da Informação e Comunicação e TDIC - Tecnologia Digital da Informação e Comunicação.

O termo Tecnologias da Informação e Comunicação - TIC - é o mais comum para se referir aos dispositivos eletrônicos e tecnológicos, incluindo-se computador, internet, tablet e smartphone. Como o termo TIC abrange tecnologias mais antigas como a televisão, o jornal e o mimeógrafo, pesquisadores têm utilizado o termo Novas Tecnologias para se referir às tecnologias digitais (KENSKI, 1998) ou Tecnologias Digitais da Informação e Comunicação - TDIC - (BARANAUSKAS, VALENTE, 2013).

De forma objetiva podemos apresentar as TICs como os processos informacionais e comunicativos das pessoas, como, por exemplo, o Jornal, Rádio ou TV. Já as TDICs englobam equipamentos digitais, tais quais computadores, lousa digital e principalmente a internet dentre outros.

No decorrer da pandemia os professores passaram obrigatoriamente a utilizar as TDICs como forma de transmitir o conteúdo das disciplinas. Moreira, Henrique \& Barros, (2020), relatam que os professores se transformaram em youtubers compulsoriamente, pois passaram a realizar aulas por meio de videoaulas, videoconferências e lives, com aplicativos tais como: Skype, WhatsApp, Google Meet, Zoom, Instagram, entre outros. As salas de aulas foram substituídas por plataformas de aprendizagem como: Moodle, Microsoft Teams e Google Classroom. Foi notado no início da implantação do ensino remoto, com a utilização das TDICs que muitos professores tiveram dificuldades na transposição didática de suas aulas tradicionalmente presenciais para um ambiente tecnológico, sendo sua utilização de forma meramente instrumental, o que além de causar danos a aprendizagem dos estudantes, poderia provocar estafa laboral aos docentes.

Após esse primeiro momento de adaptação das aulas tradicionais para o ensino remoto, período esse de muitas dificuldades e consequentemente aprendizagem, os docentes foram conduzidos a repensar suas práticas de ensino, sua maneira de ensinar, 
sua forma de transmitir conhecimento. As ferramentas tecnológicas que inicialmente eram vistas como meros modismos de internet, passaram a protagonista da vez. Mas como ministrar aulas remotas que garantisse o protagonismo e o engajamento de todos os estudantes e professores? Como oferecer estratégias de aprendizagem remotas que possibilitasse a aquisição de conhecimento por meio da participação efetiva do estudante? Esse era o desafio, os professores passaram a refletir muito mais ativamente sobre suas práticas de ensino e aprendizagem, buscando formas, mecanismos, ferramentas, estratégias que fossem eficientes para o atual momento onde a educação estava inserida.

Os planos de aula, que antes eram meras cópias de períodos anteriores, sem qualquer atualização de métodos ou ferramentas de ensino, passaram por uma grande transformação de conteúdo e forma. Agora, planos de ensino mais elaborados e detalhados, mesclando aulas síncronas com atividades assíncronas, utilizando metodologias ativas adaptadas ao ensino remoto, como por exemplo a Aprendizagem Baseada em Projetos - ABProj, Aprendizagem baseada em equipes/times - TBL, Problematização com o Arco de Maguerez, Aprendizagem entre Pares, Sala de Aula Invertida (SAI), Aprendizagem baseada em Games e Gamificação, ou Game-Based Learning (GBL), Estudo de Caso, Simulações, Portfólios, Webquest, Webgincana, Padlet. Enfim, ferramentas que poderiam ser utilizadas pelo docente de acordo com as características de sua disciplina, de seu componente curricular. Essa foi a principal inovação é o grande desafio imposto pela pandemia, ao docente, no processo de ensino/aprendizagem, ou seja, repensar tecnologicamente as estratégias de ensino num ambiente completamente remoto.

\section{CONSIDERAÇÕES FINAIS}

Diante do que foi apresentado, é possível concluir que os saberes e competências docentes e o processo de ensino e aprendizagem passou por uma grande transformação, ou melhor dizendo, uma grande atualização. Os fundamentos, as competências, os saberes, ou seja, "o saber", "o saber-ser", "o saber-fazer" continuou sendo utilizado na sua concepção histórica, mas numa nova roupagem tecnológica, onde foi preciso rediscutir, repensar, reanalisar, enfim, refletir sobre o processo de ensino e aprendizagem utilizando como base recursos digitais de informação e comunicação. 
Os docentes foram desafiados a repensar sua forma de ensinar, numa perspectiva de completo distanciamento do aluno. O processo do ensino que num primeiro momento foi adaptado para atender uma demanda emergencial de paralisação acadêmica, evoluiu para um ambiente novo, desafiador, mas cheio de oportunidades, com muitas ferramentas e estratégias inovadoras que poderiam ser exploradas. O papel do docente conteudista, de um mero intermediário, de um simples mediador entre o conteúdo a ser ministrado e o aluno, passou a ser de um grande protagonista, pois diante das dificuldades causadas pela pandemia, pelo isolamento social, pelo fechamento das escolas e universidades, pode se reinventar, pode desenvolver seu senso crítico, pode refletir sobre suas ações, pode criar, inventar, propor, testar novas estratégias de ensino, enfim, o docente pode compreender que naquele momento, era preciso reinventar o seu trabalho de forma eficiente, buscando sempre atender da melhor maneira possível o seu público, o seu aluno.

A pandemia foi e está sendo um grande desafio para a educação, para alunos e professores. $\mathrm{O}$ ensino remoto trouxe grandes desafios para o processo de ensino e aprendizagem, testou as competências e saberes docentes, mas trouxe também grandes contribuições para educação, pois foi possível refletir, repensar, criar e inovar. Os docentes foram desafiados a mudar sua forma de ensinar, numa perspectiva tecnológica e inovadoras e a prova está aí, escolas, faculdades e universidades voltando a abrir as portas, mesmo que de forma tímida, mas numa concepção nova do processo do ensino e aprendizagem.

\section{REFERÊNCIAS}

BARAnAuSKaS, M. C. C.; VALENTE, J. A. (2013). Editorial. Tecnologias, Sociedade e Conhecimento, 1(1), 1-5. Disponível: https://econtents.bc.unicamp.br/inpec/index.php/tsc/article/view/14436. Acesso em: 02 set. 2021.

BIANCHI, Márcia; ENGEL, Cristina I.; VENDRUSCOLO, Maria I. Formação Docente do Curso de Ciências Contábeis: um Estudo da Base Pedagógica nos Programas Stricto Sensu. In: Congresso de Contabilidade 2015, UFRGS. Disponível em: http://dvl.ccn.ufsc.br/congresso_internacional/anais/6CCF/52_15.pdf. Acesso em: 15 mai. 2021.

BRANCHI, B. A.; FERREIRA, D. H. L.; SUGAHARA, C.R. O impacto da COVID-19 no ensino superior: desenvolvimento de atividades remotas em matemática e estatística. Revista Tecnologia e Sociedade. ISSN: 1984-3526, v.17, n.46, jan./mar. 2021. Disponível em: https://periodicos.utfpr.edu.br/rts. Acesso em: 24 abr. 2021. 
BRASIL. Conselho Nacional de Educação. Parecer $\mathbf{n}^{\mathbf{0} 5}$, de 28 de abril de 2020. Disponível em: http://portal.mec.gov.br/index.php?option=com_docman\&view =download\&alias=145011 pcp005-20\&category_slug=marco-2020 pdf\&Itemid=30192. Acesso em: 17 ago. 2021.

BRASIL. Ministério da Educação. Portaria no 343, de 17 de março de 2020. Disponível em: $\quad$ http://www.in.gov.br/en/web/dou/-/portaria-n-343-de-17-de-marco-de-2020248564376. Acesso em: 17 ago. 2021.

CUNHA, M. I. A Docência como Ação Complexa: O Papel da Didática na Formação de Professores. In Romnowski, J. P., MARTINS, P. L. O \& Junqueira. S. R. A. Conhecimento Local e Conhecimento Universal: Pesquisa, Didática e Ação Docente. Curitiba: Champagnat, 2004.

ELIA, M.F., SAMPAIO, F.F. Plataforma Interativa para Internet: Uma proposta de PesquisaAção a Distância para professores. Anais do XII Simpósio Brasileiro de Informática na Educação, 102-109, 2001.

FREIRE, Paulo. Pedagogia da autonomia: saberes necessários à prática educativa. São Paulo: Paz e Terra, 2018.

GAUTHIER, C. Por uma Teoria da Pedagogia: pesquisas contemporâneas sobre o saber docente. Ijuí (RS): Unijuí, 1998.

HODGES, Charles et al. The difference between emergency remote teaching and online learning. Educause Review, 27 mar. 2020. Disponível em: https://er.educause.edu/articles/2020/3/the-difference-between-emergency-remoteteaching-and-online-learning. Acesso em: 17 ago. 2021.

Kenski, V. M. (1998). Novas Tecnologias: o redimensionamento do espaço e do tempo e os impactos no trabalho docente. Revista Brasileira de Educação, nº8, 58-71. Disponível: https://anped.org.br/sites/default/files/rbe/files/rbe_08.pdf. Acesso em: 02 set. 2021.

MASETTO, M.T. Professor universitário: um profissional da educação na atividade docente. In: (org.) Docência na universidade. Campinas-SP: Papirus, 1998, p. 926.

MASTROIANNI, M. T. M. R.; OLIVEIRA, G. P. de. A inserção da tecnologia nas aulas de Matemática e seu processo avaliativo: um estudo preliminar sobre as percepções de professores polivalentes. Revista Eletrônica de Educação Matemática REVEMAT, Florianópolis, v. 15, n. 1, p. 01-22, 2020.

MINISTÉRIO DA SAÚDE. Disponível em: https://coronavirus.saude.gov.br/sobre-adoenca\#to-que-e-covid. Acesso em: 24 abr. 2021.

MOREIRA, J. A. M.; HENRIQUES, S.; BARROS, D. Transitando de um ensino remoto emergencial para uma educação digital em rede, em tempos de pandemia. Dialogia, n. 34, p. 351-364, jan./abr. 2020.

NASSIF, V. M. J.; HANASHIRO, D. M. M. A competitividade das universidades particulares à luz de uma visão baseada em recursos. Revista de Administração Mackenzie, São Paulo, v. 3, n. 1, p. 95-114, jan./jun. 2002. Disponível em: http://www.mackenzie.br/fileadmin/Graduacao/CCSA/Publicacoes/volume_3_numero_ 
1/A_Competitividade_das_Universidades_Particulares_a_Luz_de_uma_Visao_baseada _em_Recursos.pdf. Acesso em 15 mai. 17.

PIMENTA, S. G. (Org.) Saberes pedagógicos e atividade docente. São Paulo (SP): Cortez, 1999.

SANTOS, Edméa. EAD, Palavra proibida. Educação online, pouca gente sabe o que é. Ensino remoto, o que temos para hoje. Mas qual é mesmo a diferença? \#livesdejunho... Disponível em: https://www.e-publicacoes.uerj.br/index.php/redoc/announcement/view/1119 . Acesso em: 17 ago. 2021.

TARDIF, M. Saberes Docentes e Formação Profissional. 7 ed. Petrópolis (RJ): Vozes, 2006.

THIOLLENT, Michel. Metodologia da pesquisa-ação. 7. ed. São Paulo: Cortez, 1996.

UFBA. UFBA em Movimento. https://ufbaemmovimento.ufba.br/semestre-letivosuplementar. Acesso em: 19 ago. 2021. 


\title{
CAPÍTULO XIII
}

\section{AS PRÁTICAS CORPORAIS E O BRINCAR NA EDUCAÇÃO INFANTIL: RELATO DE UMA EXPERIÊNCIA PEDAGÓGICA}

\author{
Raisa Corlet dos Santos ${ }^{32}$; Tiêgo Gonçalo de Barros ${ }^{33}$; \\ Luciana Ivete Maciel Bezerra $^{34}$; Mirtes Pereira do Nascimento Figueredo ${ }^{35}$. \\ DOI-Capítulo: 10.47538/AC-2021.14-13
}

RESUMO: Este artigo nos mostra que a dinâmica de vida da criança é diversificada, e a escola constitui um lugar social privilegiado para desenvolver com qualidade a aquisição e problematização dos conhecimentos adquiridos ao longo da vida. Nesse sentido, o presente estudo constitui um relato de experiência pedagógica na qual observamos em sala de aula o desenvolvimento de crianças entre 4 e 5 anos de idade, a partir das experiências vividas com as práticas corporais e o brincar. Nosso objetivo consiste em descrever a relação entre a educação infantil e as práticas corporais e o brincar. Para tanto, utilizamos como instrumento metodológico a observação direta de momentos pedagógicos de uma turma de educação infantil. A partir deste relato concluímos que as práticas corporais e o brincar na educação infantil permitem em grau elevado e significativo o desenvolvimento espontâneo, a criatividade e a autonomia da criança.

PALAVRAS-CHAVE: Práticas corporais. Lúdico. Educação infantil.

\section{SIGNIFICANCE OF CORPORATE PRACTICES IN THEORY OF LEISURE IN CHILD EDUCATION}

ABSTRACT: This article shows us that we have observed the dynamics experienced with children of children's education in order to try to understand how some activities that demand movements favor positively in the evolution of the learning processes of the child, considering the transitory phase through which they pass, Daycare centers and preschools in the search for an integrated action that incorporates educational activities and essential care and their games. The objective of this study is to understand the need to question and reflect on the importance of analyzing the body movements, as well as the consequences of play activities with the children, in order to evaluate the meanings and mainly regarding the re-significances of the students during the lessons.

KEYWORDS: Body practices. Entertainment. Children's education.

\section{INTRODUÇÃO}

\footnotetext{
${ }^{32}$ Graduação em educação física UFRN. Pós-graduação em Gestão de Programas E Projetos De Esporte E Lazer Na Escola - IFRN. Professora no Município de Macau-RN. E-mail: rayacorlet@gmail.com

${ }^{33}$ Educação Física Licenciatura - UFRN. Professor Município de Pendência/RN. E-mail: tiegobarros@ @otmail.com

${ }^{34}$ Graduação em Pedagogia - UVA. Professora Especialista em Psicopedagogia -Faculdade Integrada de Patos. Pósgraduada em Educação Infantil e Educação Especial - FAVENI. Pós-graduação em Gestão e Supervisão Escolar Instituto Século XXI (em andamento). Professora Efetiva do Município de Guamaré/RN. E-mail: lucianaivete80573@gmail.com

${ }^{35}$ Licenciatura Plena em Pedagogia -UVA. Pós-graduação em Psicopedagogia Institucional e Clínica -ISEP. Pósgraduação em Educação Infantil e Anos Iniciais - FAVENI. Professora Município de Guamaré. Email:mirtes_gmr@hotmail.com
} 
O presente estudo retrata por meio de relato de experiência pedagógica a relação entre a educação infantil e as práticas corporais e o brincar na escola. Sabemos que na atualidade a escola constitui um dos ambientes mais propícios, senão o mais privilegiado, para que os alunos possam desenvolver suas capacidades tanto cognitivas quanto humanas e sociais, e é através das práticas corporais que observamos e podemos identificar se as interações sociais acontecem, e se elas têm êxito, dentro do ambiente escolar.

A lógica motora conquistada nos primeiros anos de vida, garante à criança mecanismo de percepção do mundo. É só observar os movimentos de uma criança que está dando seus primeiros passos, no seu primeiro ano de vida, podemos perceber movimentos como: engatinhar, ficar de pé, cair, dançar, manusear brinquedos, pegar objetos dentre outras formas.

Compreendemos que é assim que as crianças nos primeiros anos de vida se comunicam com o mundo e tudo que as rodeia. Entendemos esse momento como sendo o "pontapé" inicial para que ela passe a apreender e vivenciar o acervo de práticas corporais por meio do movimento humano.

Entendemos que quando a criança chega à escola carrega consigo conhecimentos, hábitos, linguagens e um acervo de gestos e códigos motores que refletem o seu contexto sociocultural anterior. No âmbito escolar, outras ações e intenções serão contextualizadas e vivenciadas, estimulando a criança a desenvolver diferentes capacidades necessárias à sua formação: habilidades motoras diversas, controle emocional, inter-relações pessoais, compreensão de regras, atitudes disciplinares, percepção temporal e espacial, não só relacionados ao desenvolvimento de técnicas corporais, mas também social e cognitivo.

Sabemos que o brincar para a criança não constitui apenas um ato/momento divertido, gratuito, irreal, passatempo. Para ela, brincar significa viver a própria vida, tal como ela é. Quando brinca a criança aprende, aprende regras, constrói ideias, cria situações de vida, soluciona conflitos, em outras palavras, desenvolve plenamente suas capacidades.

Para promovermos o desenvolvimento de atividades lúdicas dentro das instituições infantis educativas nos compete à importantíssima tarefa de promover a 
reflexão sobre a realidade e proporcionar experiências de intervenção garantindo uma boa formação e capacitação dos professores, bem como a provisão de excelentes condições para que os mesmos possam atuar no fazer pedagógico. Somente assim será possível o resgate do espaço de brincar da criança no dia a dia da escola na Educação Infantil.

Diante desse contexto, questionamos qual o papel das práticas corporais e do brincar durante a educação infantil? Com a indagação não pretendemos encontrar deliberadamente uma resposta que se constitua um modelo de receituário para a educação infantil, haja visto a diversidade de contextos educacionais em que convivem as crianças. Contudo, apontamos possibilidades pedagógicas que contribuam para o desenvolvimento de uma realidade específica, sem que neutralize as demais.

Nesse sentido, o objetivo do presente estudo é compreender a realidade da educação infantil a partir do desenvolvimento das práticas corporais e do brincar na escola. Partimos do entendimento de que as práticas corporais, no âmbito da ludicidade, do brincar, permitem reflexões acerca do processo ensino-aprendizagem na educação infantil, que vão além da compreensão metodológica de instrumentalização do brinquedo, do jogo, da dança.

\section{A CRIANÇA E O BRINCAR NA ESCOLA}

$\mathrm{Na}$ atualidade é comum ouvirmos diversas compreensões e entendimentos sobre o tempo e o espaço do brincar, as diferenças entre as brincadeiras de antigamente e as de hoje, a "liberdade" de antes e o "confinamento" atual, entre outros. Nesse sentido, concordamos com Almeida (1997, p. 133), quando afirma que: "Era portanto na rua que as crianças brincavam, corriam, brigavam, jogavam, rolavam e aprendiam (Lima). É importante colocar que a realidade das cidades passadas não era perfeita, nem para os adultos, quanto mais para as crianças".

Analisando o relato acima e a realidade atual da nossa sociedade, nos faz pensar sobre qual espaço e tempo as crianças de hoje possuem para se desenvolver. Onde elas brincam? Em que momento elas se encontram para brincar? Elas se encontram? Quem participa das suas atividades? Tais inquietações nos levam a pensar e apontar que a escola tem se mostrado atualmente em muitos contextos o único espaço propício, onde as crianças se encontram e realizam atividades juntas. 
Diante de tal realidade, inúmeros pesquisadores e estudiosos da infância e do brincar têm se debruçado sobre as questões relativas ao papel da escola no processo de educação infantil. Compreendemos que a escola possui grande importância neste novo cenário social em que a criança e o brincar se encontram. Entendemos também que, independente do contexto de origem, a criança, através do conhecimento do seu corpo e por meio do movimento, traz consigo conhecimentos e experiências corporais prévias, adquiridos junto a pessoas do seu âmbito familiar e outras referências do seu convívio. E ao chegar na escola, irá se deparar com outras intencionalidades e formalidades, iniciando uma etapa da vida a qual denominamos educação formal.

Nosso corpo é o registro vivo da nossa história de vida. Nele encontramos impregnações sociais que ditam o nosso modo de agir, e muitas vezes o de pensar, pois cada vez que nos olhamos no espelho, surgem novas percepções, que variam de acordo com o estado de espírito de cada um, como nos afirma Bertherat (2001, p. 1):

Sem perceber, desde os primeiros meses de vida, você reagiu a pressões familiares, sociais, morais "ande assim, não se mexa, fique quieto, faça alguma coisa, vá depressa, aonde você vai com tanta pressa...?" Atrapalhado, você dobrou-se como pode. Para conformar-se você se deformou. Seu corpo de verdade foi substituído por um corpo estranho que você aceita com dificuldade, que no fundo você rejeita.

Percebemos com o pensamento de Bertherat (2001) que a própria sociedade em que estamos inseridos, nos impõe desde o início comportamentos, valores, regras, que nos moldam, nos (de)formam, cujas implicações se apresentarão em menor ou maior grau no convívio das relações sociais, na família, na escola. Diante do exposto, somos convidados a refletir sobre o corpo, sobre o movimento e suas implicações na criança e no processo de educação infantil escolar.

Em se tratando de infância, pesquisas realizadas em diferentes áreas como a filosofia, psicologia, antropologia tem exaltado o papel do brincar no desenvolvimento infantil, apesar das divergências teóricas em relação ao seu desenvolvimento e à sua função, é consenso entre os pesquisadores, que nas situações de brincadeiras, a criança conhece mais de si e do seu entorno, à medida que age e interage com o outro, experimenta, emociona-se, se expressa, deseja, escolhe, recria os acontecimentos e os e os ressignifica (VIEIRA et.al, 2005). 
Brincando a criança aprende a representar e apresentar algo, gesticulando, desenhando, cantando, contando histórias, dançando, modelando, ou seja, vivenciando em seu espaço escolar desafios/problemas que demandam soluções corporais por meio do movimento, sabendo que por meio das atividades lúdicas, motricidade, imitação, imaginação, percepção, oralidade, o brincante se envolve por completo, facilitando assim a percepção do educador, no sentido de avaliar o potencial de aprendizado de um determinado grupo de crianças (VIEIRA et.al, 2005).

É relevante destacar que quando a criança desenvolve as atividades de modo autônomo, por meio de sua imaginação e do seu conhecimento corpóreo, sendo estimulada a expressar seus conhecimentos e saberes espontaneamente, a escola se torna para a criança um lugar de pertencimento, espaço de acolhimento e divertimento. A esse respeito, vejamos o que diz Freire (1989):

[...] sabemos ser a criança dotada de um grande dinamismo, sendo o movimento inerente a sua própria vida. Movimentar-se é uma necessidade básica de todo o ser humano, e na criança esta necessidade apresenta-se de forma mais explícita, por ser esta não apenas dotada de movimento, mas ser o próprio movimento.

Tendo-se como referência o pensamento do autor, compreendemos que a educação infantil na escola deve promover ações pedagógicas que privilegiem o corpo e o movimento da criança, em busca de uma aproximação mais fidedigna da sua realidade, no sentido de tornar mais atrativo possível o processo ensino-aprendizagem, o qual terá mais sentido e significado para a criança, quando esta tiver oportunidade de expressão, de imaginação, de criatividade, em outras palavras, quando ela espontaneamente vivenciar as ações.

Dessa forma, a escola deve propor situações pedagógicas as quais permitam à criança exercitar seu caráter eminentemente lúdico e espontâneo, por meio da construção de gestos e técnicas do corpo em movimento. Essa espontaneidade trata das diversas possibilidades de criação e recriação e principalmente de utilização com o que é transmitido por ela, trata-se de uma aproximação de significados com o mundo que a rodeia e vice-versa. Piccolo (1993, p. 64) corrobora com essa ideia dizendo que:

Na primeira infância, a atividade mental é mais rápida e é através da exploração de movimentos variados que se pode aperfeiçoar o sucesso da criança em tarefas intelectuais. É o autoconhecimento que vai levála às capacidades de lidar com os problemas e isso se consegue nas 
propostas motoras que fazem com que a criança conheça suas potencialidades.

Se o autoconhecimento se desenvolve por experiências vividas corporalmente, às quais impregnamos de sentidos e significados, para a criança, as experiências necessitam ser desenvolvidas por meio do brincar, da criatividade, da alegria e da espontaneidade, que estimule o seu interesse por novas experiências.

\section{AS PRÁTICAS CORPORAIS NA ESCOLA}

Sabemos o quanto é relevante o movimento para a criança, no sentido de que é por meio dele que as experiências ocorrem e a aprendizagem se processa. Quando falamos de movimento e de experiência, estamos tratando do corpo e das suas diversas possibilidades de uso, em diferentes contextos e situações de vida. Nesse sentido, entendemos que o conceito de práticas corporais constitui parte dessa dimensão da vida, uma vez que,

[...] entendem-se práticas corporais como fenômenos que se mostram, prioritariamente, em âmbito corporal e que se constituem como manifestações culturais. Essas manifestações são compostas por técnicas corporais e é uma forma de linguagem, como expressão corporal [...] (SILVA et.al, 2009, p. 20).

As práticas corporais tal como entendida acima, constituem o acervo do que muitos estudiosos denominam de Cultura Corporal, Cultura Corporal de movimento ou Cultura de movimento (Idem). Tema de discussão que não faz parte do presente momento neste relato, mas que contribui significativamente para entendermos que as diversas formas de movimento e suas manifestações tradicionais, tal como, o jogo, a dança, a brincadeira, o esporte, fazem parte dessa cultura, que possui sentido e significado, que gera experiência e aprendizagem de conhecimentos sobre o corpo.

Compreendemos que a relação entre práticas corporais e cultura é significativa porque privilegia o sujeito que se movimenta, que vive a experiência, levando em consideração seus sentidos e significados impregnado na ação. Tal como esclarece Thompson (apud SILVA, 2009, p. 14): “[...] experiência como a reflexão sobre o vivido e a percepção do lugar social dos sujeitos, que se constrói nas práticas cotidianas, dentre as quais incluem-se as práticas corporais". Nesse sentido, tais práticas têm como fundamento o desenvolvimento humano, uma vez que liga o praticante ao seu próprio 
corpo, numa perspectiva de autoconhecimento, privilegiando o sujeito, neste caso, a criança, em detrimento do objeto, seja ele o jogo, a brincadeira, a dança.

É importante ressaltar que, nessa perspectiva, novas formas de manifestações ainda podem ser criadas e incorporadas a esse acervo. Em tal contexto, precisam ser transmitidas e apropriadas pelos alunos e professores. Segundo Castellani Filho (1998, p. 54):

A cultura corporal constitui-se uma totalidade formada pela interação de distintas práticas sociais tais como a danças, o jogo, a ginástica, o esporte, que por sua vez materializam-se, ganham forma, através das práticas corporais. Enquanto práticas sociais, refletem a atividade produtiva humana de buscar respostas às suas necessidades. (grifo do autor).

Ao refletir o pensamento do autor, podemos entender que os aspectos da cultura corporal são de vital importância para o fazer pedagógico; necessitamos reafirmar e explicitar melhor as responsabilidades que estamos assumindo, como orientadores e docentes e, para tanto, planejarmos ações pedagógicas que contribuam, para que as crianças tenham acesso ao conhecimento do mundo circundante, que as envolve, à medida que favoreça a criação e recriação da cultura, sobretudo por meio das práticas corporais, vislumbrando um ambiente escolar onde haja espaço para a vivência do lúdico, que caracteriza fundamentalmente a criança.

\section{METODOLOGIA}

O presente estudo se caracteriza como sendo uma pesquisa do tipo qualitativa, de caráter descritivo, no qual descrevemos uma experiência pedagógica com crianças na escola. Optamos por este caminho metodológico porque este possibilita compreendermos melhor os dados a serem coletados e discutidos, que dizem respeito às subjetividades dos sujeitos que participam da pesquisa, suas atitudes e expressões.

Compõe a metodologia deste estudo a descrição das observações das aulas práticas vivenciadas com as crianças de 4 a 5 anos de idade, de uma turma da educação infantil, da Escola Municipal Lions Clube, cidade de Macau/RN.

A observação direta se deu no período de três semanas de aula, cujas atividades tinham como finalidade envolver o corpo das crianças, facilitando a socialização e a 
comunicação entre elas, tendo como objetivo trabalhar a coordenação motora e a percepção do corpo das crianças em movimento.

Nesta perspectiva metodológica, a preocupação com o processo é muito maior do que com o produto; as situações e os problemas e como os envolvidos lidam, constituem os dados a serem observados cuidadosamente. Como esclarece Lüdke e André (1986), “[...] a observação possibilita um contato estreito do pesquisador com o fenômeno pesquisado, o que apresenta uma série de vantagens [...]”. Assim, por meio da observação direta o observador (pesquisador) "ver" o que está ocorrendo em tempo real, bem como, pode se aproximar mais de perto da "perspectiva dos sujeitos" envolvidos. Essas condições permitem que a pesquisa qualitativa/descritiva enumere, relacione, descreva, classifique ou reflita sobre diversos fenômenos ocorridos durante a pesquisa, o que garante maior compreensão acerca dos fenômenos estudados e os fatores que os influenciam.

No intuito de aplicar o planejamento das aulas a serem observadas na presente pesquisa, elencamos no planejamento mensal da turma, os diversos tipos de brinquedos pedagógicos, contidos no ambiente escolar, tais como, fantoches, livros, leitura de imagens, Jogos de quebra-cabeça com figuras, jogo da memória, boliche de garrafas pet, assim como os demais recursos materiais disponíveis na escola: aparelho de som, Cartolina, papelão, canetas, tinta guache, cola, farinha de trigo, palitos de sorvete, folhas de revista e jornal.

No que tange às práticas corporais e o brincar desenvolvidos junto à turma de educação infantil, destacamos as brincadeiras dirigidas com regras simples: "cobra-cega", "andar de trem", "corre cotia", "batata quente". Em relação às atividades rítmicas, vivenciamos a atividade "põe a mão na cabeça" (música boneca de lata), dança da cadeira e dança com bexigas (balão).

\section{RESULTADOS E DISCUSSÕES}

As práticas corporais e atividades lúdicas descritas anteriormente foram planejadas e desenvolvidas ao longo do ano letivo, procurando estimular a percepção do corpo da criança, do espaço e do tempo, a interação com o grupo. As aulas transformaram- 
se em momentos significativos, que permitiram às crianças construírem e conhecerem cada vez mais a si, a seus colegas, e ao meio no qual estão inseridas.

A presença do lúdico na escola, por meio dos jogos, brinquedos e brincadeiras, da dança, é fundamental na construção do processo de aprendizagem na educação infantil. Para a criança, isso implica mais que o simples ato de brincar, é através dos jogos que ela se expressa e consequentemente se comunica com o mundo; ao jogar a criança aprende e investiga o mundo que a cerca, por isso, toda e qualquer atividade lúdica deve ser respeitada. Nosso papel, enquanto educadores, durante o processo didático-pedagógico foi o de provocar a participação coletiva e desafiar cada aluno a buscar soluções.

A criança exerce suas leituras especialmente através do corpo, usando a brincadeira como forma de organizar o que sente e percebe do mundo ao seu redor. Ao vivenciar estes momentos junto aos alunos, verificamos que a escola ainda é um espaço de socialização para a criança, e é através do relacionamento com os outros que há crescimento nos aspectos sociais e culturais de cada indivíduo. São nesses momentos de socialização e de conhecimento que possibilitam uma maior ampliação do universo que cerca a criança, favorecendo com isso novas oportunidades de enriquecimento em seu diálogo com o mundo e com outras pessoas.

Gallardo (2004) defende que os jogos e brincadeiras são os principais meios para que as crianças da educação infantil e das séries iniciais do ensino fundamental possam ter essas experiências, desenvolvendo habilidades tais como: responsabilidade e independência, fazendo com que aprendam a socializar-se.

Observamos o que denominamos o momento de brincar e aprender, por meio de um jogo chamado "batata quente". Por se tratar de um jogo com regras, pretendeu-se com essa experiência desenvolver atitudes de cunho perceptivo nas crianças, ligados à tomada de decisões, agilidade, construção e respeito às regras.

Através do jogo pode-se despertar na criança um espírito de companheirismo, cooperação e autonomia. A criança precisa interagir de forma coletiva, ou seja, precisa apresentar seu ponto de vista, discordar, apresentar suas soluções. É necessário também criar ambiente propício e incentivar as crianças a terem pensamento crítico e participativo, fazendo parte das decisões do grupo. Os jogos, segundo Piaget, tornam-se 
mais significativos à medida que a criança se desenvolve, pois, a partir da livre manipulação de materiais variados, ela passa a reconstruir objetos e reinventar as coisas, o que exige uma adaptação mais completa. Essa adaptação deve ser realizada ao longo da infância e consiste numa síntese progressiva da assimilação com a acomodação.

O jogo representa sempre uma situação-problema a ser resolvida pela criança e a solução deve ser construída pela mesma, sendo, portanto, uma boa proposta e, na sala de aula, propicia a relação entre parceiros e grupos e nestas relações, observamos a diversidade de comportamento das crianças para construir estratégias para a vitória e as relações diante das derrotas.

Podemos entender que a relação homem/mundo se faz necessariamente pela condição corporal, e é a partir da ação e interação da criança com o mundo à sua volta, medida por outros fatores, que ela amplia sua forma de pensar, sentir e atuar. Nesta experiência, percebemos que as crianças ao se movimentar de forma ritmada e compassada ou descompassada, ela se expressa com intencionalidade, e analisando comportamentos, descobrimos que as atividades com dança são as mais aceitas pelas crianças, e esse momento é vivido com muita alegria, sorrisos e manifestação corporal.

É importante destacar o que diz os Parâmetros Nacionais Curriculares (BRASIL, 1997), sobre a expressão corporal, oriunda de movimentos como a dança:

As atividades de caráter expressivo constituem um outro recurso para atender a diversidade de competências no processo de ensino e aprendizagem. Incluir as experiências e conhecimentos que as crianças têm de dança é extremamente interessante por se tratar de um contexto em que a ênfase não está na competição.

$\mathrm{Na}$ imagem 04, observamos crianças que jogam o jogo da memória. Um dos principais objetivos da atividade desenvolvida foi que essas crianças pudessem experimentar e desenvolver algumas habilidades necessárias no campo cognitivo, como por exemplo: percepção, visual, sensorial, auditiva. Salientamos também a importância do cunho social, pois estando realizando tarefas em grupo, o aluno participa ativamente do ambiente social em que está inserido, sendo uma forma bastante proveitosa de fazer ou refazer amizades e testar as compatibilidades. Essa ideia está contida nos objetivos da educação escolar, destacadas pelos Parâmetros Curriculares Nacionais (BRASIL, 1997), afirmando que: 
Se um dos objetivos da educação é ajudar as crianças a conviverem em grupo de maneira produtiva, de modo cooperativo, é preciso proporcionar situações em que aprender a dialogar, a ouvir o outro, ajudá-lo, pedir ajuda, trocar ideias e experiências, aproveitar críticas e sugestões sejam atitudes possíveis de serem exercidas.

A experiência relatada acima nos faz perceber o quanto é significativo, perceber crianças expandindo seus conhecimentos e descobertas, participando de jogos, que as levam a pensar/refletir, e pôr em prática suas tomadas de decisões, caracterizando um processo de troca de experiências com o outro.

\section{CONSIDERAÇÕES FINAIS}

O presente trabalho contribui para pensarmos a educação infantil como uma fase rica de sentidos e significados para as crianças que estão na escola. Neste espaço, percebemos a educação escolar como elemento fundamental para a formação dos sujeitos sociais, enfrentando o desafio da busca por uma escola mais justa, que valorize diferenças e construa novas formas de ser e de atuar na sociedade contemporânea. Compreendemos que a escola constitui um espaço privilegiado para a difusão e problematização da herança cultural acumulada pela humanidade ao longo de sua trajetória.

A partir deste relato de experiência pedagógica identificamos que a escola e sua equipe pedagógica deve, no planejamento das atividades teórico-metodológicas, levar em consideração a relação entre as manifestações da cultura corporal, das quais fazem parte as práticas corporais, e o contexto do desenvolvimento social, cognitivo da criança. Em suma, deve-se pensar a criança, acreditando que esta é um sujeito com características individuais e que precisa ser estimulada para o seu crescimento e desenvolvimento, de maneira a possibilitar-lhes o espaço para usar a sua criatividade, a capacidade inventiva, e acima de tudo, o desenvolvimento do seu senso crítico, objetivando o favorecimento da aprendizagem infantil, bem como do seu espaço como ser social.

É nesse sentido, que compreendemos que as práticas corporais e atividades lúdicas, constituem significativas manifestações culturais, que geram possibilidades de exploração das necessidades corporais, visto que, os conteúdos de ensino como a ginástica, jogos, esportes, dança e lutas são tematizados na escola para aprofundar conhecimentos e transformar realidades. 
No presente relato, identificamos que as práticas corporais e brincadeiras mais vivenciadas pelas crianças na escola são dançar, pular, correr, brincadeiras de expressão corporal, como fazer "careta". Concluímos que estas práticas vivenciadas na escola desempenham um papel fundamental no processo de educação infantil, uma vez que por meio destas, as crianças se expressam, representam e aprendem com o corpo e pelo movimento, de forma espontânea, demonstrando autonomia e participação social satisfatória na sala de aula.

Destacamos, finalmente, que estudos desta natureza na escola necessitam de mais aprofundamentos e novas investigações acerca dos temas que envolvem a criança, o brincar e as práticas corporais, no sentido de identificar, mapear, classificar, descrever os fenômenos ocorridos nesse processo ensino-aprendizagem e os fatores que influenciam, determinam o desenvolvimento de crianças na educação escolar.

\section{REFERÊNCIAS}

BRASIL, Secretaria de Educação Fundamental. RCNEE. Educação Física. Brasília: MEC/SEF, 1997.___.Secretária de Educação Fundamental. Parâmetros Curriculares Nacionais. Educação Física. Brasília: MEC / SEF, 1997.

BERTHERAT, Thérèse \& BERNESTEIN, Carol. O corpo tem suas razões: antiginástica e consciência de si. São Paulo: Martins Fontes, 2001.

CASTELLANI Filho, Lino. Educação Física no Brasil: A história que não se conta.Campinas, SP: Papirus, 1998.

FREIRE, João Batista. Educação Física de corpo inteiro: teoria e prática da educação física. 3. ed. São Paulo: Scipione, 1989.

GALLARDO, Jorge Sérgio Perez, Educação Física: contribuições à formação profissional, São Paulo: Ed. Unijuí, 2004.

LÜDKE, Menga. Pesquisa em educação: abordagens qualitativas/ Menga Lüdke, Marli E. D. A. André. - São Paulo: EPU, 1986.

MURCIA, J. A. M. Aprendizagem através dos jogos. Porto Alegre, RS: Artmed, 2005. SAVIANI, Demerval. Filosofia da educação brasileira. $6^{a}$ ed. Rio de Janeiro: Civilização Brasileira, 1998.

SILVA, Ana Márcia et al.. Corpo e experiência: para pensar as práticas corporais. IN: Práticas corporais no contexto contemporâneo: (in) tensas experiências/ Organizadores José Luiz Cirqueira Falcão, Maria do Carmo Saraiva. - Florianópolis: Copiart, 2009. 
VIEIRA, Ana Lúcia. Xavier. MELO, José pereira de. PONTES, Gilvânia Maurício Dias de. CAPISTRANO, Naire Jane. (Orgs.) O ensino de artes e educação física na infância. Natal: Paidéia, 2005. 


\title{
CAPÍTULO XIV
}

\section{ATUAÇÃO DO PSICÓLOGO EDUCACIONAL NO ENSINO SUPERIOR: UMA BREVE REVISÃO DA LITERATURA}

\author{
João Paulo Roberti Junior ${ }^{36}$ \\ DOI-Capítulo: 10.47538/AC-2021.14-14
}

RESUMO: Trata-se de uma revisão integrativa da literatura que teve como objetivo buscar artigos que exemplifica-se e descrevessem ações e intervenções do psicólogo educacional no ensino superior e como foram realizadas tais intervenções neste âmbito. Para a coleta de dados foram utilizadas as bases SCIELO e a PEPSIC (Periódicos eletrônicos em Psicologia). Inicialmente foram encontrados 62 artigos científicos. Desses, apenas 28 abordavam aspectos relacionados à atuação psicólogo educacional no ensino superior e estavam de acordo com os critérios de inclusão. Porém, dentre os 28 apenas 15 apresentaram alguma contribuição efetiva das práticas realizadas pelo psicólogo educacional neste âmbito e se encaixaram nos critérios de inclusão e exclusão. Os resultados apontaram que atualmente existem diferentes concepções e intervenções possíveis para atuação do psicólogo educacional no ensino superior. Além disso, demonstraram que existe um campo de atuação rico, necessário e possível de intervenção e atuação do psicólogo educacional no ensino superior.

PALAVRAS-CHAVE: Psicologia Educacional. Ensino superior. Atuação.

\section{EDUCATIONAL PSYCHOLOGIST'S PERFORMANCE IN HIGHER EDUCATION: A BRIEF LITERATURE REVIEW}

\begin{abstract}
This is an integrative literature review that aimed to seek articles that exemplify and describe actions and interventions of educational psychologists in higher education and how such interventions were carried out in this area. For data collection, the SCIELO and PEPSIC (Electronic Journals in Psychology) databases were used. Initially, 62 scientific articles were found. Of these, only 28 addressed aspects related to the role of educational psychologist in higher education and were in accordance with the inclusion criteria. However, among the 28 , only 15 had any effective contribution from the practices carried out by the educational psychologist in this area and met the inclusion and exclusion criteria. The results showed that currently there are different conceptions and possible interventions for the role of educational psychologists in higher education. Furthermore, they demonstrated that there is a rich, necessary and possible field of action for educational psychologist intervention and performance in higher education.
\end{abstract}

KEYWORDS: Educational Psychology. University education. Acting.

\section{INTRODUÇÃO}

\footnotetext{
${ }^{36}$ Professor substituto da Universidade Federal de Roraima. Lattes: http://lattes.cnpq.br/2469361629650438. Orcid: https://orcid.org/0000-0002-1489-5330. E-mail: joao.roberti@ufrr.br
} 
Nas últimas décadas, estudiosos da área de Psicologia Educacional têm questionado a afirmação de que o desempenho acadêmico estaria relacionado somente às capacidades cognitivas dos estudantes (MARTINS; SANTOS, 2019; MOURA; FACCI, 2016). O contexto universitário é um importante ambiente para o desenvolvimento e promove mudanças na trajetória e na perspectiva de vida (SANTOS et. al., 2015). Dentro deste contexto, fenômenos multifatoriais estão presentes e nos últimos anos complexificase na medida que o ensino superior tem sido pautado por diferentes percepções sobre produção de conhecimentos. Por isto, o ambiente acadêmico tem atualmente a emergência de utilizar estratégias que vão além da sala de aula a fim de desarticular paradigmas tradicionais. A função do psicólogo escolar e educacional no ensino superior diante deste cenário, é entre outras a de tornar o processo de aprendizagem mais significativo, pensar e problematizar estratégias amplas relacionadas à dimensão do ensino e da aprendizagem e combater percepções reducionistas que condicionam o problema no "indivíduo".

Neste sentido, pensar a atuação do psicólogo educacional no ensino superior é pensar de modo amplo, todas as complexidades que estão envolvidas nessa atuação. Complexidades que envolvem diversos fatores dado que o contexto universitário é um importante ambiente para o desenvolvimento dos jovens (BARDAGI, HUTZ, 2012) e apresenta um impacto nas trajetórias de vida daqueles que nele ingressam. Apresenta um impacto, pois, em grande medida o ensino superior apresenta e coloca em cena questões envolvendo a profissionalização, mudança de cidade, distanciamento do núcleo familiar, transformação das relações presentes no ambiente de aprendizagem tanto com professores quanto com colegas, e cultivando uma maior autonomia do aluno no seu processo de aprender, dentre outros inúmeros fatores.

Muitos destes fatores se deslocam de demandas existentes na atuação do psicólogo no ensino básico. Atuação esta que é resultante da própria história de criação da atuação do psicólogo educacional. Inicialmente pensado para modelos escolares, a atuação do psicólogo educacional esteve pautada durante muito tempo na "redução das taxas de reprovação e evasão e também a de melhorar o desempenho dos estudantes" (MOURA; FACCI, 2016, p. 506). Apesar de não se configurar como o único campo, constantemente "assume-se que a escola é o contexto principal de atuação do psicólogo" (OLIVEIRA; 
MARINHO-ARAÚJO, 2009, p. 653). Como um ambiente emergente de práticas e com necessidades de atuação específicas, o contexto do ensino superior aparece na arena como um desafio para a atuação do psicólogo educacional, dado que ele majoritariamente esteve voltado em sua atuação para os níveis básicos do ensino.

Neste sentido, existem ainda poucos referenciais teóricos e modelos de atuação neste âmbito (GEBRIM, 2014). Como resultado, suas práticas ainda são vistas como imediatistas e reducionistas do processo de ensino e aprendizagem no ensino superior e o psicólogo é chamado para atuar apenas quando existem conflitos, dificuldades e desavenças no âmbito educacional. Os psicólogos educacionais no ensino superior têm, portanto, o desafio de aliar as demandas que a eles são instituídas - baseada no ajustamento e na tutela de discentes - e promover neste ambiente "interstícios das relações de poder instituídas" a fim de gerar "um espaço para a afirmação de novos possíveis" (MELSERT; BICALHO, 2012, p. 159).

Considerando o exposto, essa revisão de literatura justifica-se pela necessidade de conhecer as atuais atuações do psicólogo educacional no ensino superior. A fim de entender quis são as práticas de atuação profissional do psicólogo educacional no ensino superior, busca-se aqui compreender quais e como estão sendo realizadas as intervenções mais recentes neste âmbito. Entendendo que igualmente a demanda pelo psicólogo educacional no ensino superior tem aumentado (GEBRIM, 2014), explanar sobre as atuações mais recentes é um campo rico e potente de contribuição de conhecimento neste âmbito.

\section{PSICOLOGIA EDUCACIONAL, ENSINO SUPERIOR E ATUAÇÕES POSSÍVEIS}

A emergência do ensino superior como campo de atuação do psicólogo educacional é recente e trouxe mudanças na perspectiva que historicamente foi construída em torno da atuação do psicólogo educacional. Neste sentido, "é difícil relatar quando o psicólogo se insere na Educação Superior no Brasil” (MOURA; FACCI, 2016, p. 505) e que historicamente a intervenção do psicólogo neste âmbito é marcada por perspectivas limitantes (CHIARATI, 2016). A sua intervenção e atuação foi e talvez ainda esteja sendo 
marcada pela ideia que a atuação deve ser exercida somente quando existem "problemas" no ambiente educacional, retificando os saberes científicos disciplinares.

A ideia de que a psicologia educacional intervém na realidade educacional favorecendo a atuação crítica e comprometida com tal realidade (GEBRIM, 2014) incita muitas questões. O psicólogo deve atuar de forma proativa para que a sua intervenção não se atenha apenas na resolução de problemas, mas antes, busque a prevenção e otimização do espaço acadêmico como promotor de bem-estar na dinâmica de ensino e aprendizagem.

Segundo Santos et. al. (2015), a carência de conhecimentos por parte dos psicólogos, acarretou em uma "atrofia de atuação" (p. 517). Essa carência é derivada da atuação historicamente situada no âmbito clínico e para atuar no contexto educacional "é imprescindível analisar e compreender as relações complexas que são estabelecidas entre a psicologia e a educação" (Ibid., p. 517).

No âmbito universitário é necessário que a atuação seja abrangente e inserida em diversos campos e não apenas no contexto acadêmico. Mas sim tudo o que este contexto desperta na vida daqueles que nele estão inseridos. É necessário que ele atue na tentativa de auxiliar a implementar ações que minimizem os obstáculos que se colocam entre os sujeitos e o conhecimento (Ibid., 2015). Esses obstáculos podem ser os mais diversos, desde o vínculo e manejo com docentes e gestores até o acompanhamento de demandas espontâneas surgidas pelos acadêmicos. Além disso, suas ações necessitam estar descentralizadas de aspectos estigmatizados e apenas voltadas para a relação ensino/aprendizagem, mas antes, todos os aspectos que esse processo coloca em evidência, como os processos políticos, econômicos, sociais e interseccionais do mundo acadêmico.

O princípio fundamental da inserção da psicologia escolar deve ser pautado também no ensino superior. É o princípio de que os aspectos particulares e as demandas surgidas no âmbito educacional, não devem ser desconsideradas dos aspectos sociais (BOCK, 2003) e, portanto, é necessário que sua atuação seja mais ampla do que apenas um atendimento individual específico. 
O ambiente universitário é idealmente pensado como aquele onde os alunos estão atentos, questionam, se envolvem, fazem as tarefas propostas, trocam ideias com seus pares e com o professor, compartilham o conteúdo e mostram interesse no aprendizado. Mas, no atual cenário, muitos alunos convivem, frequentemente, com dificuldades para permanência no ambiente acadêmico (GEBRIM, 2014). A fim de acompanhar e entender quais são as intervenções atuais possíveis do psicólogo educacional neste âmbito e como o profissional pode contribuir para todas essas questões, este estudo buscou conhecer quais são as ações e intervenções atuais existentes do psicólogo educacional no ensino superior.

\section{METODOLOGIA}

Este estudo constitui-se em uma revisão integrativa de literatura a respeito das atuações recentes dos psicólogos educacionais no ensino superior. A coleta de dados foi realizada em dois bancos de dados de difusão científica, que foi a Scielo (Biblioteca Eletrônica Científica Online) e a Pepsic (Período eletrônico em Psicologia). Como critérios de inclusão foram considerados artigos publicados nos últimos cinco anos. $\mathrm{Ou}$ seja, a partir de 2015 até 2020. Vale enfatizar que, no período anterior a 2015, identificouse uma escassez de produções sobre a atuação dos psicólogos educacionais no ensino superior. Optou-se pelo período estipulado para entender as atuações mais recentes, que foram desenvolvidas pelo psicólogo educacional no ensino superior, conjuntamente à estagnação da expansão e consolidação do ensino superior no Brasil, nos últimos anos, quando se complexificam as dinâmicas existentes neste âmbito.

Para o mapeamento dos artigos, foram incluídos os seguintes descritores, "psicologia educacional" and "ensino superior"; "psicólogo educacional" and "ensino superior" e "educational psychology" and "University". Inicialmente, foram encontrados 62 artigos científicos (17 na SCIELO e 45 no PEPSIC); desses, apenas 28 abordavam aspectos relacionados a possíveis atuações do psicólogo educacional no ensino superior e estavam de acordo com os critérios de inclusão. Porém, após a realização do critério de exclusão (produção dos últimos cinco anos), dentre os 28 apenas 15 permaneceram.

Após a seleção do material, foi realizada uma leitura seletiva e, posteriormente, exploratória dos artigos para adequar e identificar a contribuição do artigo levantado para 
o tema aqui investigado. Em seguida, foi elaborada uma tabela (Tabela 1) categorizando a definição da atuação e/ou as possibilidades de atuação do psicólogo educacional no ensino superior e as metodologias que estão sendo realizadas neste campo. Vale destacar, por fim, que os artigos mapeados e selecionados não são necessariamente artigos que narram algum relato de experiência específico realizado, mas que também versavam sobre alguma atuação possível do psicólogo no ensino superior.

\section{RESULTADOS}

Os resultados estão descritos na tabela abaixo e foram mapeados e construídos a partir de duas categorias: "Definição da atuação realizada ou da possibilidade de atuação" e "Metodologias possíveis de serem utilizadas para a atuação". Embora os 15 artigos selecionados nesta pesquisa abordassem aspectos relativos à atuação do psicólogo educacional no ensino superior, somente os artigos 1-3-4-6-8-10-11-15 se referiam a descrições específicas de práticas de atuação do psicólogo educacional no ensino superior. Os demais referem-se a pesquisas realizadas/implementadas que possuem também potencial analítico para pensar as atuações possíveis do psicólogo educacional na esfera universitária.

Tabela 1. Atuações realizadas pelo Psicólogo Educacional no ensino superior

\begin{tabular}{|c|c|c|c|}
\hline & $\begin{array}{c}\text { DEFINIÇÃO DA } \\
\text { ATUAÇÃO REALIZADA } \\
\text { OU DA POSSIBILIDADE } \\
\text { DE ATUAÇÃO }\end{array}$ & $\begin{array}{c}\text { METODOLOGIAS POSSÍVEIS } \\
\text { DE SEREM UTILIZADAS PARA } \\
\text { A ATUAÇÃO }\end{array}$ & REFERÊNCIAS \\
\hline 1 & $\begin{array}{l}\text { Intervenção psicológica } \\
\text { aliada à pesquisa e voltada } \\
\text { para estudantes } \\
\text { universitários que cogitavam } \\
\text { evadir do curso em que } \\
\text { estavam matriculados. }\end{array}$ & $\begin{array}{l}\text { Roda de conversa realizada com } \\
\text { quatro discentes da Universidade } \\
\text { Federal de Uberlândia (UFU). Essa } \\
\text { prática grupal pode ser dividida em } \\
\text { seis momentos: 1) contrato; 2) } \\
\text { apresentação; 3) escrita de } \\
\text { expressões vinculadas ao âmbito } \\
\text { acadêmico e pessoal; 4) elaboração } \\
\text { e leitura de uma carta; 5) } \\
\text { compartilhamento de ideias; 6) } \\
\text { encerramento }\end{array}$ & $\begin{array}{l}\text { PERETTA, A. A. C. e S.; } \\
\text { OLIVEIRA, I. W. M. de; } \\
\text { LIMA, L. M. de. Roda de } \\
\text { conversa sobre evasão: a } \\
\text { psicologia escolar no } \\
\text { ensino superior. Psicol. } \\
\text { Esc. Educ., Maringá, v. } \\
\text { 23, e186484, 2019 } \\
\text {. Available from <http:// } \\
\text { www.scielo.br/scielo.php } \\
\text { ?script=sci_arttext\&pid= } \\
\text { S1413- } \\
\text { 85572019000100321\&ln } \\
\text { g=en \&nrm=iso>. access } \\
\text { on 18 June 2020. Epub } \\
\text { Dec 09,2019. https://doi } \\
\text { org/10.1590/2175- } \\
\text { 35392019016484. }\end{array}$ \\
\hline
\end{tabular}




\begin{tabular}{|c|c|c|c|}
\hline 2 & $\begin{array}{l}\text { Conhecer e analisar a } \\
\text { atuação do psicólogo escolar } \\
\text { na Assistência Estudantil a } \\
\text { partir de um levantamento } \\
\text { documental e entrevistas } \\
\text { semiestruturadas } \\
\text { gestores, com } \\
\text { professores, uma mãe e } \\
\text { estudantes }\end{array}$ & $\begin{array}{l}\text { Transcrição das entrevistas, análise } \\
\text { de conteúdo e organização em eixos } \\
\text { temáticos. }\end{array}$ & $\begin{array}{l}\text { SILVA, A. de M.; } \\
\text { SILVA, S. M. C. da. } \\
\text { Psicologia Escolar na } \\
\text { Assistencia Estudantil: } \\
\text { estudo de caso no Cefet - } \\
\text { MG Araxá. Psicol. Esc. } \\
\text { Educ., Maringá , v. } \\
\text { 23, e207708, } 2019 \\
\text { Available from } \\
\text { <http://www.scielo. br/ } \\
\text { scielo.php? } \\
\text { script=sci_arttext } \\
\text { \&pid=S1413- } \\
\text { 85572019000100332\&ln } \\
\text { g=en \&nrm=iso>. access } \\
\text { on 18 June 2020. Epub } \\
\text { Dec 09, } \\
\text { 2019. https://doi.org/10. } \\
\text { 159 0/2175- } \\
\text { 35392019017708. }\end{array}$ \\
\hline 3 & $\begin{array}{l}\text { Acessibilidade na Educação } \\
\text { Superior para o } \\
\text { desenvolvimento de políticas } \\
\text { institucionais de } \\
\text { acessibilidade, buscando o } \\
\text { desenvolvimento acadêmico } \\
\text { de estudantes com } \\
\text { deficiência e/ou mobilidade } \\
\text { reduzida. } \\
\text { Criação e consolidação dos } \\
\text { núcleos de acessibilidade. }\end{array}$ & $\begin{array}{l}\text { Identificar e discutir as ações da } \\
\text { Psicologia nesses núcleos, em } \\
\text { especial averiguar como seus } \\
\text { coordenadores se manifestam diante } \\
\text { desse processo }\end{array}$ & 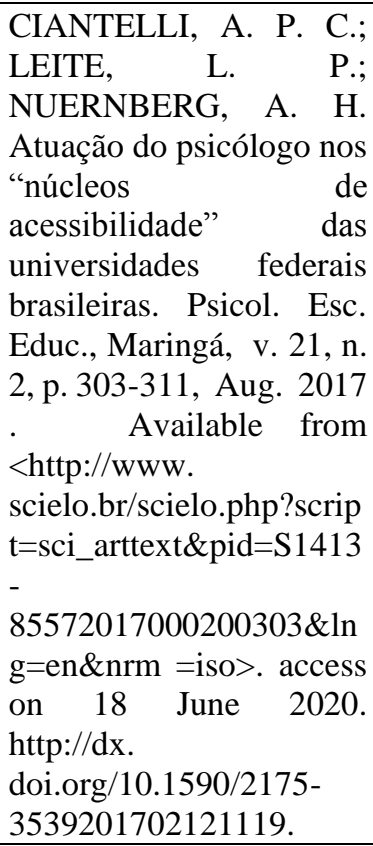 \\
\hline 4 & $\begin{array}{l}\text { Analisar a consciência de } \\
\text { bolsistas do Programa } \\
\text { Universidade para Todos } \\
\text { (ProUni), partindo da } \\
\text { compreensão apresentada } \\
\text { por eles sobre sua inserção e } \\
\text { vivência na graduação. }\end{array}$ & $\begin{array}{l}\text { Descrição histórica do Ensino } \\
\text { Superior brasileiro, focando na } \\
\text { política educacional do ProUni, em } \\
\text { seguida uma leitura da Psicologia } \\
\text { Crítica e do papel do psicólogo no } \\
\text { Ensino Superior. Foram } \\
\text { sistematizadas cinco categorias de } \\
\text { análise a partir da etnografia virtual } \\
\text { e, além dessas, mais uma } \\
\text { (totalizando seis) categoria de } \\
\text { análise pelos quatro diários de } \\
\text { campo. São elas: Assistência e } \\
\text { Permanência } \\
\text { Comprovação destudantil, } \\
\text { Organização do grupo, Preconceito, }\end{array}$ & 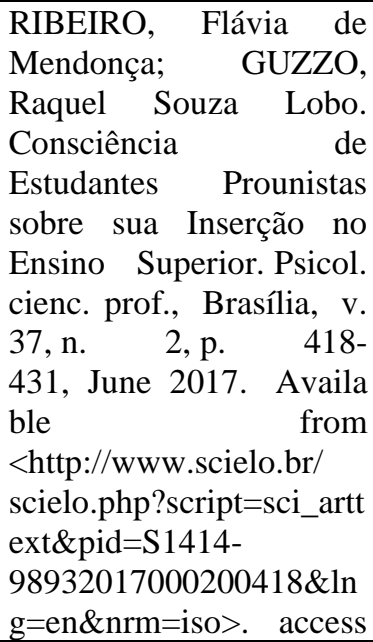 \\
\hline
\end{tabular}




\begin{tabular}{|c|c|c|c|}
\hline & & $\begin{array}{l}\text { Visão do ProUni e Solidariedade } \\
\text { entre prounistas. }\end{array}$ & $\begin{array}{l}\text { on } 18 \text { June } 2020 \text {. http:/ } \\
\text { /dx.doi. } \\
\text { org/10.1590/1982- } \\
3703001472016 \text {. }\end{array}$ \\
\hline 5 & $\begin{array}{l}\text { Analisar a atuação do } \\
\text { psicólogo escolar no Ensino } \\
\text { Superior e o posicionamento } \\
\text { que este profissional assume } \\
\text { diante do fracasso escolar. }\end{array}$ & 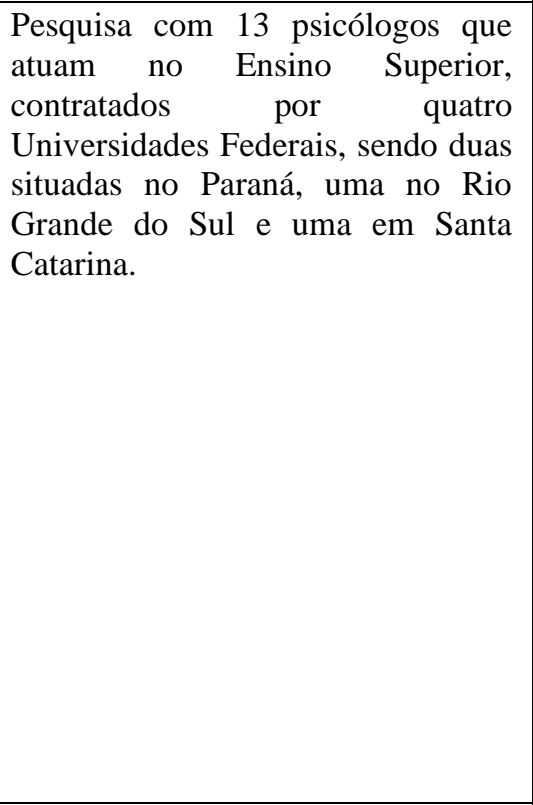 & 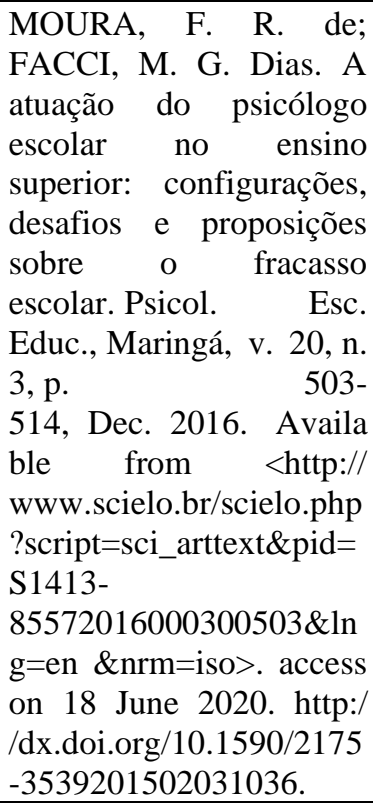 \\
\hline 6 & $\begin{array}{l}\text { Inserindo ações voltadas à } \\
\text { adaptação acadêmica, ao } \\
\text { aconselhamento de carreira e } \\
\text { a qualificação do processo } \\
\text { ensino-aprendizagem dos } \\
\text { estudantes em seu conjunto } \\
\text { de possíveis atuações. } \\
\text { Também há maior ênfase em } \\
\text { práticas a serem executadas } \\
\text { com docentes e funcionários, } \\
\text { como contribuir para a } \\
\text { ambientação de novos } \\
\text { colaboradores, assessorar a } \\
\text { definição e formulação dos } \\
\text { perfis docentes e técnicos, e } \\
\text { apoiar o desenvolvimento de } \\
\text { competências discentes. }\end{array}$ & $\begin{array}{l}\text { Acompanhamento individual, a } \\
\text { realização de encaminhamentos } \\
\text { externos e internos e o } \\
\text { desenvolvimento de orientações em } \\
\text { grupos, sendo a maioria com foco } \\
\text { nos discentes [...] realização de } \\
\text { encaminhamentos dos acadêmicos, } \\
\text { é essencial que as Clínicas-Escola } \\
\text { de psicologia e os serviços de saúde } \\
\text { [...] avaliação da instituição e dos } \\
\text { professores e o aperfeiçoamento da } \\
\text { prática docente por meio do } \\
\text { planejamento e desenvolvimento de } \\
\text { metodologias diferenciadas [...] } \\
\text { desenvolve-se com base em } \\
\text { diversos modelos, os quais podem } \\
\text { ser organizados em dois grupos. De } \\
\text { um lado, existem intervenções que } \\
\text { são essencialmente centradas nos } \\
\text { estudantes, as quais podem ser } \\
\text { executadas em diferentes níveis, a } \\
\text { saber, remediativo, preventivo e de } \\
\text { promoção do desenvolvimento. De } \\
\text { outro lado, encontram-se propostas } \\
\text { mais abrangentes, desenvolvidas } \\
\text { com toda a comunidade acadêmica, } \\
\text { ou seja, alunos, professores e } \\
\text { funcionários. }\end{array}$ & $\begin{array}{l}\text { SANTOS, } \\
\text { Schaurich dos et al . } \\
\text { Atuação do Psicólogo } \\
\text { Escolar e Educacional no } \\
\text { ensino superior: reflexões } \\
\text { sobre práticas. Psicol. } \\
\text { Esc. Educ., Maringá, v. } \\
\text { 19, n. 3, p. 515- } \\
\text { 524, Dec. } \quad 2015 \\
\text { Available from } \\
\text { <http://www.scielo.br/sci } \\
\text { elo. } \\
\text { php?script=sci_arttext\&p } \\
\text { id=S1413- } \\
\text { 85572015000300515\&ln } \\
\text { g=en\&nrm=iso>. access } \\
\text { on 18 June 2020. https: } \\
\text { //doi.org/ 10.1590/2175- } \\
\text { 3539/2015/0193888. }\end{array}$ \\
\hline 7 & $\begin{array}{l}\text { Apresentar a importância do } \\
\text { trabalho da Psicologia } \\
\text { acompanhando estudantes } \\
\text { cotistas frente às suas } \\
\text { aspirações e contradições }\end{array}$ & $\begin{array}{l}\text { Identificar estudantes cotistas por } \\
\text { meio de um questionário online. As } \\
\text { respostas do participante foram } \\
\text { categorizadas em contradições } \\
\text { cotidianas e aspirações pequeno- }\end{array}$ & $\begin{array}{l}\text { RIBEIRO, Flávia de } \\
\text { Mendonça; } \text { GUZZO, } \\
\text { Raquel Souza Lobo. } \\
\text { Psicologia e ensino } \\
\text { superior: }\end{array}$ \\
\hline
\end{tabular}




\begin{tabular}{|c|c|c|c|}
\hline & $\begin{array}{l}\text { cotidianas no } \quad \text { Ensino } \\
\text { Superior }\end{array}$ & $\begin{array}{l}\text { burguesas, e nos permitiu concluir } \\
\text { sobre a importância da Psicologia } \\
\text { para apoio e suporte às políticas de } \\
\text { ações afirmativas existentes } \\
\text { integrando essas estudantes na } \\
\text { comunidade universitária, além de } \\
\text { auxiliá-las no enfrentamento ao } \\
\text { sofrimento psíquico nas vivências } \\
\text { universitárias cotidianas e processo } \\
\text { de tomada de consciência. }\end{array}$ & $\begin{array}{l}\text { pequeno-burguesas e } \\
\text { contradições cotidianas } \\
\text { em cotistas. Rev. Psicol. } \\
\text { IMED, Passo Fundo , v. } \\
\text { 11, n. 1, p. } 2019 \\
\text { 45, jun. } \\
\text { - Disponível em } \\
\text { <http://pepsic.bvsalud.or } \\
\text { g/scielo.php?script=sci_a } \\
\text { rttext\&pid=S2175- } \\
\text { 50272019000100003\&ln } \\
\text { g=pt\&nrm=iso>. acessos } \\
\text { em 18 jun. 2020. http:/ } \\
\text { /dx.doi.org/10.18256/217 } \\
\text { 5-5027.2019.v11i1.3004. }\end{array}$ \\
\hline 8 & $\begin{array}{l}\text { Investigar a forma em que a } \\
\text { rotina acadêmica interfere } \\
\text { nos níveis de estresse de } \\
\text { alunos de graduação, } \\
\text { explorando as situações } \\
\text { geradoras e/ou mantenedoras } \\
\text { das situações vivenciadas. }\end{array}$ & $\begin{array}{l}\text { Foram aplicados questionários } \\
\text { abertos e o Inventário de Sintomas } \\
\text { de Stress (ISS) para adultos. }\end{array}$ & $\begin{array}{l}\text { MORETTI, F. A.; } \\
\text { HUBNER, M. M. Costa. } \\
\text { O estresse e a máquina de } \\
\text { moer alunos do ensino } \\
\text { superior: vamos repensar } \\
\text { nossa política } \\
\text { educacional?. Rev. } \\
\text { psicopedag., São Paulo } \\
\text { v. 34, n. 105, p. 258- } \\
\text { 267, 2017. Disponível } \\
\text { em } \\
\text { <http://pepsic.bvsalud. } \\
\text { org/scielo.php?script=sci } \\
\text { arttext\&pid=S0103- } \\
\text { 8486201700030000 } \\
\text { 3\&lng=pt\&nrm=iso>. } \\
\text { acessos } \\
\text { em } 18 \text { jun. 2020. }\end{array}$ \\
\hline 9 & $\begin{array}{l}\text { Problematizar as } \\
\text { experiências de indígenas no } \\
\text { contexto universitário }\end{array}$ & $\begin{array}{l}\text { A partir da ideia de campo-tema, a } \\
\text { produção das informações deu-se no } \\
\text { cotidiano universitário em } \\
\text { diferentes ocasiões e em distintas } \\
\text { atividades junto a estudantes } \\
\text { indígenas, finalizando com uma } \\
\text { roda de conversa em torno da } \\
\text { experiência na universidade. }\end{array}$ & $\begin{array}{l}\text { VIANA, Iclicia et al } \\
\text { Colonialidade, } \\
\text { invisibilização } \\
\text { potencialidades: } \\
\text { experiências de indígenas } \\
\text { no ensino superior. Rev. } \\
\text { psicol. polít., São Paulo } \\
\text { v. 19, n. 46, p. 602- } \\
\text { 614, dez. } 2019 \\
\text { Disponível em } \\
\text { <http://pepsic.bvsalud.or } \\
\text { g/ scielo.php?script=sci_artt } \\
\text { ext\&pid=S1519- } \\
\text { 549X2019000300016\&ln } \\
\text { g=pt\&nrm=iso>. acessos } \\
\text { em } 18 \text { jun. 2020. }\end{array}$ \\
\hline 10 & $\begin{array}{l}\text { Oferecer programas que } \\
\text { promovam a saúde mental do } \\
\text { universitário e o preparem } \\
\text { para a realidade profissional } \\
\text { e para os desafios da carreira. }\end{array}$ & $\begin{array}{l}\text { Intervenções psicológicas com } \\
\text { universitários desenvolvidas nos } \\
\text { anos de } 2015 \text { a 2017, por } 86 \\
\text { graduandos em Psicologia, e que } \\
\text { beneficiaram } 705 \text { universitários: } 1 . \\
\text { acolhimento e triagem psicológica; } \\
\text { 2. oficinas: de preparação para a }\end{array}$ & $\begin{array}{l}\text { RAMOS, Fabiana } \\
\text { Pinheiro et al . } \\
\text { Intervenções psicológicas } \\
\text { com universitários em } \\
\text { serviços de apoio ao } \\
\text { estudante. Rev. bras. } \\
\text { orientac. }\end{array}$ \\
\hline
\end{tabular}




\begin{tabular}{|c|c|c|c|}
\hline & & $\begin{array}{l}\text { vida acadêmica, de habilidades } \\
\text { sociais, de controle da ansiedade e } \\
\text { enfrentamento do estresse, de } \\
\text { orientação aos estudos, e de } \\
\text { temática específica; } 3 \text {. psicoterapia } \\
\text { individual; e 4. educação para a } \\
\text { carreira. }\end{array}$ & $\begin{array}{l}\text { prof, Florianópolis , v. } \\
\text { 19, n. 2, p. 221- } \\
\text { 232, dez. } \\
\text { \& Disponível em } \\
\text { <http://pepsic.bvsalud.or } \\
\text { g/ } \\
\text { scielo.php?script=sci_artt } \\
\text { ext\&pid=S1679- } \\
\text { 33902018000200010\&ln } \\
\text { g=pt\&nrm=iso>. acessos } \\
\text { em 18 jun. 2020. http:/ } \\
\text { /dx.doi.org/ } \\
\text { 1026707/1984- } \\
\text { 7270/2019v19n2p221. }\end{array}$ \\
\hline 11 & $\begin{array}{l}\text { Conhecer a opinião de } \\
\text { estudantes universitários } \\
\text { sobre as características das } \\
\text { relações estabelecidas com } \\
\text { seus pares, além de como } \\
\text { estas se modificam ao longo } \\
\text { da graduação e como } \\
\text { influenciam na adaptação } \\
\text { acadêmica na percepção de } \\
\text { calouros e formandos. }\end{array}$ & $\begin{array}{l}\text { Foram realizadas entrevistas } \\
\text { semiestruturadas individuais com } \\
24 \text { acadêmicos dos cursos de } \\
\text { Economia e Psicologia de uma } \\
\text { universidade do Sul do Brasil. As } \\
\text { respostas foram submetidas à } \\
\text { análise de conteúdo. }\end{array}$ & 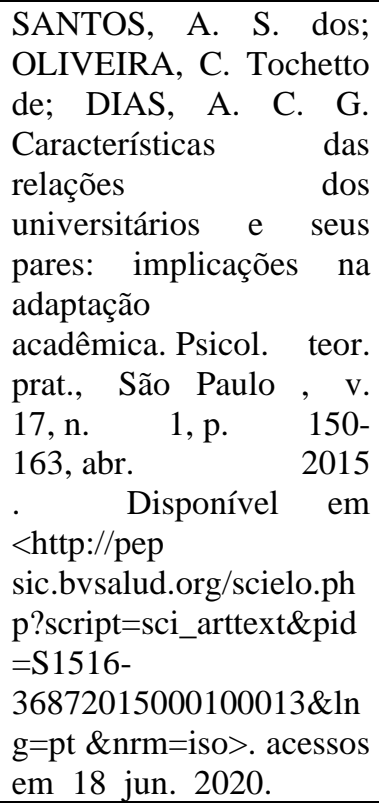 \\
\hline 12 & $\begin{array}{l}\text { Apreender e compreender os } \\
\text { sentidos que os jovens } \\
\text { pobres, bolsistas do } \\
\text { Programa Universidade para } \\
\text { Todos (Prouni) constroem } \\
\text { para a longevidade escolar }\end{array}$ & $\begin{array}{l}\text { Estudo qualitativo ancorado nos } \\
\text { princípios teórico-metodológicos da } \\
\text { Psicologia Sócio-Histórica, que } \\
\text { enfatiza a constituição do sujeito no } \\
\text { contexto sócio-histórico, bem como } \\
\text { a atividade do sujeito como } \\
\text { potencialmente transformadora do } \\
\text { próprio contexto. }\end{array}$ & $\begin{array}{l}\text { SOUSA, M. do C.; } \\
\text { MOREIRA, M. I. C. } \\
\text { Low-income youth and } \\
\text { long-term school } \\
\text { permanence: the senses } \\
\text { built up by Prouni } \\
\text { scholarship holders in } \\
\text { Belo Horizonte } \\
\text { (MG). Pesqui. prát. } \\
\text { psicossociais, São João } \\
\text { del-Rei, v. 12, n. 4, p. 1- } \\
\text { 16, 2017.Disponível em } \\
\text { <http:// } \\
\text { pepsic.bvsalud.org/ } \\
\text { scielo.php?script=sci_artt } \\
\text { ext\&pid=S1809- } \\
\text { 89082017000400008\&ln } \\
\text { g= pt\&nrm=iso>. acessos } \\
\text { em 18 jun. 2020. }\end{array}$ \\
\hline 13 & $\begin{array}{l}\text { Serviços de Psicologia das } \\
\text { Instituições de Educação } \\
\text { Superior brasileiras e o }\end{array}$ & $\begin{array}{l}\text { Junto ao tradicional trabalho de } \\
\text { orientação e encaminhamento dos } \\
\text { alunos, há também práticas } \\
\text { emergentes, como recepção aos }\end{array}$ & $\begin{array}{lr}\text { BISINOTO, } & \text { Cynthia; } \\
\text { MARINHO-ARAUJO, } \\
\text { Claisy. } & \text { Psicologia } \\
\text { Escolar na } & \text { Educação } \\
\end{array}$ \\
\hline
\end{tabular}




\begin{tabular}{|c|c|c|c|}
\hline & $\begin{array}{l}\text { trabalho realizado pelos } \\
\text { psicólogos escolares. }\end{array}$ & $\begin{array}{l}\text { calouros, apoio a coordenadores de } \\
\text { curso, realização de workshops } \\
\text { formativos, acompanhamento aos } \\
\text { egressos e avaliação institucional. O } \\
\text { conjunto diversificado de ações } \\
\text { evidencia que o trabalho dos } \\
\text { psicólogos escolares está se } \\
\text { deslocando de um modelo clínico- } \\
\text { terapêutico para um mais } \\
\text { preventivo-institucional }\end{array}$ & $\begin{array}{l}\text { Superior: panorama da } \\
\text { atuação no Brasil. Arq. } \\
\text { bras. psicol., Rio de } \\
\text { Janeiro, v. 67, n. 2, p. } \\
\text { 33-46, } \\
\text { Disponível em } \\
\text { <http://pepsic.bvsalud.or } \\
\text { g/scielo.php?script=sci_a } \\
\text { rttext\&pid=S1809- } \\
\text { 52672015000200004\&ln } \\
\text { g=pt\&nrm=iso>. acessos } \\
\text { em 18 jun. 2020. }\end{array}$ \\
\hline 14 & $\begin{array}{l}\text { Se reporta que los y las } \\
\text { docentes universitarios } \\
\text { consideran la escritura como } \\
\text { una habilidad transversal que } \\
\text { consistiría en el dominio de } \\
\text { técnicas y habilidades } \\
\text { generales que los y las } \\
\text { estudiantes debieran } \\
\text { aprender en la educación } \\
\text { escolar, rechazando como } \\
\text { tarea propia su enseñanza. La } \\
\text { escritura con fines } \\
\text { académicos es una actividad } \\
\text { ampliamente extendida en la } \\
\text { formación universitaria }\end{array}$ & $\begin{array}{l}\text { Lo/as participantes del estudio } \\
\text { fueron estudiantes } 543 \text { estudiantes } \\
\text { (355 mujeres) de la Carrera de } \\
\text { Psicología de la Universidad } \\
\text { Alberto Hurtado, institución privada } \\
\text { perteneciente al Consejo de } \\
\text { Rectores de Chile que atiende a } \\
\text { estudiantes de sectores vulnerables } \\
\text { del país. Estos estudiantes } \\
\text { participaron en el estudio porque: } \\
\text { cursaron entre los años } 2012 \text { y } 2018 \\
\text { el curso de Psicología Educacional, } \\
\text { y rindieron el ensayo argumentativo } \\
1 \text {, que es parte del esquema de } \\
\text { evaluación de aprendizajes del curso }\end{array}$ & $\begin{array}{l}\text { LARRAIN, Antonia; } \\
\text { BURROWS, Felipe. Las } \\
\text { pautas sí importan. Efecto } \\
\text { del uso de pautas sobre la } \\
\text { calidad de la escritura } \\
\text { argumentativa en la } \\
\text { universidad. Form. } \\
\text { Univ., La Serena , v. } \\
\text { 13, n. 1, p. } \\
\text { 126, feb. } \\
\text { <https://scielo. } \\
\text { conicyt.cl/scielo.php?scri } \\
\text { pt=sci_arttext\&pid=S071 } \\
\text { 8- } \\
\text { 50062020000100115\&ln } \\
\text { g=es\& nrm=iso>. } \\
\text { accedido } \\
\text { en 18 jun. 2020. http:// } \\
\text { dx.doi.org/10.4067/S071 } \\
\text { 8-50062020000100115. }\end{array}$ \\
\hline 15 & $\begin{array}{l}\text { Identificó las estrategias } \\
\text { disposicionales empleadas } \\
\text { por tutores en el diseño y la } \\
\text { implementación de clases a } \\
\text { nivel universitario, para } \\
\text { promover aprendizajes } \\
\text { significativos en un entorno } \\
\text { virtual de aprendizaje en } \\
\text { ocho diseños instruccionales } \\
\text { analizados }\end{array}$ & $\begin{array}{l}\text { Se tuvieron en cuenta los siguientes } \\
\text { aspectos: (1) la necesidad de } \\
\text { motivación del estudiantado como } \\
\text { elemento relacionado con el } \\
\text { desempeño académico; (2) la } \\
\text { observación de las prácticas } \\
\text { docentes en cuanto a su rol; (3) y las } \\
\text { prácticas docentes dispares, } \\
\text { especialmente en lo que refiere a los } \\
\text { medios para promover motivación } \\
\text { al aprendizaje. }\end{array}$ & $\begin{array}{l}\text { DUARTE-HERRERA, } \\
\text { M.; MONTALVO } \\
\text { APOLIN, D. E.; } \\
\text { VALDES LOZANO, D. } \\
\text { E. Estrategias } \\
\text { disposicionales } \\
\text { aprendizajes } \\
\text { significativos en el aula } \\
\text { virtual. Educación, San } \\
\text { José, San Pedro, Montes } \\
\text { de Oca, v. 43, n. 2,p. } \\
\text { 468-483, Dec. 2019 } \\
\text { Available from } \\
\text { <http://www.scielo.sa.cr/ } \\
\text { scielo.php?script=sci_artt } \\
\text { ext\&pid=S2215- } \\
\text { 26442019000200 } \\
\text { 468\&lng=en\&nrm=iso>. } \\
\text { access } \\
\text { on 18 June 2020. http:/ } \\
\text { /dx.doi.org/ 10.15517/rev } \\
\text { edu.v43i2.34038. }\end{array}$ \\
\hline
\end{tabular}


Conforme a tabela acima, são inúmeras as possibilidades de atuação do psicólogo educacional no ensino superior. Mesmo que tradicionalmente as atividades desenvolvidas nas universidades estiveram pautadas apenas pelo acompanhamento individual e na realização de encaminhamentos (SERPA; SANTOS, 2001), atualmente o campo de atuação e as atividades realizadas pelo psicólogo educacional são diversas.

As inúmeras possibilidades de atuação talvez sejam resultadas de dois aspectos. O primeiro de expansão do ensino superior no país e consequentemente das demandas inerentes a este nível de ensino que complexificou e se ampliaram. E o segundo, das problematizações pertinentes ao ofício/profissão do psicólogo no ambiente educacional que tradicionalmente esteve circunscrito à sua área dividida no binômio, psicologia escolar e psicologia educacional. Mas visto que o psicólogo atuante no ensino superior é tanto produtor de conhecimento (Psicólogo Educacional) quanto executor de uma prática neste ambiente educativo (Psicólogo Escolar), ele pode ser chamado de Psicólogo Escolar e Educacional (SANTOS, et. al. 2015). Mesmo que a atuação durante muito tempo esteve voltada a modelos engessados e limitantes de atuação, resultados de uma formação proeminentemente clínica da Psicologia, atualmente como podemos perceber, as intervenções são diversas e ricas em termos de ação do psicólogo escolar e educacional no ensino superior.

Um primeiro aspecto a se destacar, como resultado desta pesquisa, é que ainda existem poucas publicações atuais sobre as atuações do psicólogo escolar e educacional no ensino superior. Ainda há um lapso sobre como está se construindo a atuação neste âmbito e muitas pesquisas e explanações e problematizações precisam ser feitas para embasar outros profissionais que atuam no ensino superior. Isso auxiliaria também na construção e na reivindicação da presença do psicólogo atuando no ensino superior.

A realidade do ambiente universitário é muito diferente da realidade escolar/ensino básico, por isso as intervenções realizadas são distintas e com objetivos diferentes. O psicólogo escolar e educacional necessita estar atento para os aspectos que visam ajudar a superar o descompasso existente entre a forma com que foram construídas e legitimadas as intervenções do psicólogo no ambiente escolar/educacional. Nos artigos acima levantados, foi possível identificar seis amplas categorias de atuação e intervenção 
que estão sendo realizadas atualmente pelo psicólogo escolar e educacional no ensino superior. São elas:

1) Ações coletivas de demandas mais instrumentais e formativas como, formação sobre a atuação no EAD e o uso de tecnologias e otimização e desenvolvimento da escrita acadêmica.

2) Ações coletivas de demandas específicas e reflexivas existentes no ensino superior e na vida dos discentes como, a adaptação ao ambiente acadêmico e questões envolvendo a permanência e a evasão constante na universidade. Desafios sobre a carreira profissional e escolha da profissão. Problematizações sobre a importância da rotina acadêmica.

3) Atendimentos individualizados e encaminhamentos como o encaminhamento para os serviços de psicologia existentes, em especial às clínicas-escola existentes dentro da universidade. Encaminhamento para outros órgãos como a assistência estudantil existente na universidade.

4) Acompanhamento de políticas de inclusão e intervenções destinadas públicos específicos - e historicamente marginalizados no ambiente acadêmico -, como jovens pobres advindos do programa PROUNI, indígenas, estudantes cotistas e acessibilidade dos estudantes com deficiência

5) Avaliação e pesquisa tanto dos serviços oferecidos pela universidade, por meio de pesquisas com outros profissionais como, por exemplo, aos próprios estudantes sobre questões pertinentes que os atravessam, na demanda do ambiente acadêmico.

Tais categorias de intervenção demonstram que a atuação do psicólogo escolar e educacional é permeada por inúmeras possibilidades e que atualmente não se limitam apenas a um modelo centrado única e exclusivamente ao estudante - de modelo imediatista e clínico - como historicamente foi pautada às intervenções do psicólogo no âmbito educacional. Mas estão sendo realizadas propostas mais abrangentes, desenvolvidas com toda a comunidade acadêmica ou alguma parcela específica dela, como alunos com deficiência ou indígenas. Além disso, as ações não são realizadas apenas isoladamente, mas sim desempenhadas junto a instâncias da própria universidade como órgãos de assistência estudantil. $\mathrm{O}$ trabalho tem, se pautado, na articulação e não 
na individualização das ações, remetendo assim a uma atribuição propositiva e compromissada do seu papel neste âmbito institucional.

É positivo perceber também que nenhuma das ações realizadas atualmente esteve pautada no exame ou avaliação de doenças para um possível diagnóstico, prognóstico ou para algum tratamento específico, remontando a origem da clínica psicológica. Este é um serviço que não deve ser valorizado atualmente e que desqualifica a atuação do psicólogo neste âmbito, pois o seu intuito é otimizar e articular demandas para que estas não sejam personalizadas aos próprios alunos.

Além disso, é preciso destacar que o ambiente universitário traz questões não restritas apenas ao processo de ensino e aprendizagem, mas também questões mais largas dessa relação. Por isso, ele não deve desconsiderar aspectos contextuais, institucionais, políticos, éticos, sociais, econômicos e interseccionais que interferem nas vivências acadêmicas dos discentes (BISINOTO; MARINHO-ARAÚJO, 2011). A sua intervenção deve estar pautada e aliada na seguinte aliança "ensino superior-sociedade-psicologiaensino-aprendizagem", estes talvez sejam os elementos que resumem a pauta de ação do psicólogo escolar e educacional no ensino superior.

Os artigos levantados também demonstraram a importância da realização por parte do psicólogo, de pesquisas educacionais que auxiliem a mapear demandas, desafios e realidades existentes dentro da universidade. Isso implica na mudança de postura na atuação do psicólogo neste ambiente. Se inicialmente a postura era mais vertical - de cima para baixo, do psicólogo identificando e diagnosticando sujeitos e demandas - agora com o advento de pesquisas e mapeamento de demandas, a ordem no ambiente acadêmico se torna mais horizontal e equaliza níveis de poder na atuação e retira parcialmente do psicólogo o seu próprio saber disciplinador e transfere o protagonismo das ações e intervenções para todos os envolvidos ao ambiente acadêmico. Isso é o que Bleger (1980) também já assinalou na década de 80 sobre a importância da participação de todos em qualquer intervenção no ambiente educacional, pois sem esse pressuposto não há intervenção possível. Além disso, tal pressuposto pressupõe também um compromisso dos sujeitos com a existência do grupo do qual fazem parte.

São caminhos como estes que demonstram como a atuação do psicólogo no ensino superior pode ser promissora quando caminha com o intuito de produzir subjetividades 
críticas dentro da universidade e que as intervenções não sejam pautadas nos modelos canônicos de "totalização ou centralização no indivíduo, mas de um entrecruzamento de atravessamentos coletivos” (MELSERT; BICALHO, 2012, p. 155). Isso implica em uma atuação potencializadora de subjetividades críticas dentro da universidade, que não se associa apenas a um "mercado educativo" que enuncia classificações hierárquicas e de produção de desigualdade na produção do conhecimento.

Sugere-se por fim, o incentivo da política editorial voltar-se cada vez mais para publicações de relatos de experiência, pois tais trabalhos também contribuem para a atuação do psicólogo escolar e educacional. Isso ajuda a delinear os caminhos futuros para a atuação nessa área, garantindo também a visibilidade de propostas que promovam o bom desempenho educacional, o desenvolvimento humano integral e a responsabilidade social.

\section{CONSIDERAÇÕES FINAIS}

O objetivo deste artigo foi refletir e problematizar sobre a atuação recente do psicólogo escolar e educacional no ensino superior. Identificou-se que nos últimos 05 anos são poucos os trabalhos existentes que problematizam essa atuação. Contudo, os trabalhos encontrados demonstram que as atuações têm se ampliado e as perspectivas de atuação tem mudado. É preciso que o profissional no ensino superior esteja atento e resgate questões sociais mais amplas e que não veja sua prática dissociada dos contextos onde a universidade está inserida e os contornos sociais que ela produz.

Neste sentido, atualmente privilegia-se uma atuação menos vinculada ao aspecto individualista de atenção ao estudante e mais a uma compreensão sistêmica e ampla dos processos envolvendo o ensino e a aprendizagem no ensino superior. A atuação não deve se pautar apenas nas demandas existentes, mas sim buscar estratégias preventivas aos problemas que são comuns dentro do ambiente universitário. Problemas estes que até pouco tempo eram impensáveis na formação do psicólogo, pois o ensino superior ainda não era uma realidade hegemônica até pouco tempo. Mas hoje, com a disseminação das políticas de incentivo ao ensino superior, tornaram-se latente e consequentemente a atuação do psicólogo escolar e educacional nas universidades é cada vez mais necessário. 
Notou-se também que todas as pesquisas e intervenções realizadas foram executadas no âmbito do ensino superior público, à exceção das intervenções realizadas em outros países. Intervenções recentes realizadas no Brasil e no âmbito do ensino superior privado não foram encontradas e isso talvez aponte para dois aspectos já demonstrados no estudo de Santos et. al. (2015). Segundo os autores, provavelmente nas IES particulares não há contratação de profissionais que atuam única e exclusivamente neste âmbito ou que as ações de assistência estudantil ainda não estão sendo pesquisadas e consequentemente relatadas. Considera-se por fim, ser importante "conhecer quais programas de apoio aos discentes de ensino superior têm sido efetivados no âmbito da educação superior privada, o que pode ser sistematizado por meio de pesquisas em IES particulares" (Ibid., 2015, p. 521). É importante também que tais estudos sejam realizados a fim de avaliar como o contexto superior brasileiro tem sido intensificado na esfera privada em função da massificação e da privatização, com ensino voltado às ideias mercadológicas que massificam a formação e priorizam este nível de ensino (CHAUÍ, 2003). É nesse contexto, que o psicólogo escolar também está inserido, por isso a superação de modelos dicotômicos ainda é um grande empecilho.

Compreender os aspectos mais amplos de atuação é "perseguir o contentamento de conviver na universidade. Eis aí um ideal futuro para o psicólogo escolar e educacional" (GEBRIM, 2014, p. 120), pois o ensino superior é um ambiente complexo que necessita da criação de espaços de integração do estudante à vida acadêmica (TEIXEIRA, CASTRO, PICCOLO, 2007).

\section{REFERÊNCIAS}

BISINOTO, Cynthia; MARINHO-ARAUJO, Claisy. Psicologia Escolar na Educação Superior: panorama da atuação no Brasil. Arq. bras. psicol., Rio de Janeiro, v. 67, n. 2, p. 33-46, $2015 \quad$ Disponível em <http://pepsic.bvsalud.org/scielo.php?script=sci_arttext\& pid=S180952672015000200004\&lng=pt\&nrm=iso>. acessos em 18 jun. 2020.

BLEGER, J. Temas em psicologia - entrevistas e grupos. São Paulo: Martins Fontes, 1980.

BOCK, A. M. B. Psicologia da educação: cumplicidade ideológica. In: Meira, M. E. M.; Antunes, M. A. M. (Org.). Psicologia Escolar: Teorias Críticas. 2003; 1 ed. São Paulo: Casa do Psicólogo, p. 79-103. 
CHAUI, Marilena. A universidade pública sob nova perspectiva. Rev. Bras. Educ., Rio de Janeiro, n. 24, p. 5-15, Dec. 2003. Disponível em <http://www.scielo.br/scielo. php?script=sci_arttext\&pid=S1413-24782003000300002\&lng=en\&nrm=iso>. Acesso em 21 Dec. 2020. https://doi.org/10.1590/S1413-24782003000300002.

CHIARATTI, Fernanda Germiani de Oliveira. Psicologia Educacional e suas Contribuições para o Ensino e Aprendizagem. Indaial: UNIASSELVI, 2016.

CIANTELLI, A. P. C.; LEITE, L. P.; NUERNBERG, A. H. Atuação do psicólogo nos "núcleos de acessibilidade" das universidades federais brasileiras. Psicol. Esc. Educ., Maringá, v. 21, n. 2, p. 303-311, Aug. 2017. Available from <http://www.scielo. br/scielo.php?script=sci_arttext\&pid=S1413-85572017000200303\&lng=en\&nrm=iso >. access on 18 June 2020. http://dx.doi.org/10.1590/2175-353920170 2121119.

\section{DUARTE- HERRERA, M.; MONTALVO APOLIN, D. E.; VALDES LOZANO, D. E.} Estrategias disposicionales y aprendizajes significativos en el aula virtual. Educación, San José, San Pedro, Montes de Oca , v. 43, n. 2, p. 468483, Dec. 2019. Available from $<$ http://www.scielo.sa.cr/scielo.php?script=sci_arttext\&pid=S2215-

26442019000200468\&lng =en\&nrm=iso>.

access on 18 June 2020. http://dx.doi.org/10.155 17/revedu.v43i2.34038.

GEBRIM, Leilane Bernardes. Psicologia escolar e educacional no ensino superior: demandas e desafios na história do serviço de atendimento ao estudante da Universidade Federal de Uberlândia. Dissertação (mestrado). Programa de Pós-Graduação em Psicologia, Universidade Federal de Uberlândia, 2014.

LARRAIN, Antonia; BURROWS, Felipe. Las pautas sí importan. Efecto del uso de pautas sobre la calidad de la escritura argumentativa en la universidad. Form. Univ., La Serena , v. 13, n. 1, p. 115-126, feb. 2020. Disponible en $<$ https://scielo.conicyt.cl/scielo.php? script $=\quad$ sci_arttext\&pid=S0718$50062020000100115 \& \operatorname{lng}=\mathrm{es} \& \mathrm{nrm}=\mathrm{iso}>$. accedido en 18 jun. 2020. http://dx.doi.org/10.4067/S0718-50062020000100115.

OLIVEIRA, Cynthia Bisinoto Evangelista de; MARINHO-ARAUJO, Claisy Maria. Psicologia escolar: cenários atuais. Estud. pesqui. psicol., Rio de Janeiro , v. 9, n. 3, dez. 2009 Disponível <http://pepsic.bvsalud.org/scielo.php?script=sci_arttext\&pid=S1808$42812009000300007 \& \operatorname{lng}=$ pt\&nrm=iso $>$. acessos em 18 jun. 2020.

MARTINS, Rosana Maria Mohallem; SANTOS, Acácia Aparecida Angeli dos. Estratégias de aprendizagem e autoeficácia acadêmica em universitários ingressantes: estudo correlacional. Psicol. Esc. Educ., Maringá, v. 23, e176346, 2019. Disponível em <http://www.scielo.br/ scielo.php?script=sci_arttext\&pid=S1413$85572019000100301 \& \operatorname{lng}=$ pt\&nrm=iso $>$. Acesso em 10 jan. 2020. Epub 25-Abr-2019. http://dx.doi.org/10.1590/2175-35392019016346.

MELSERT, Ana Luísa de Marsillac; BICALHO, Pedro Paulo Gastalho de. Desencontros entre uma prática crítica em psicologia e concepções tradicionais em educação. Psicol. 
Esc. Educ., Maringá , v. 16, n. 1, p. 153-160, June 2012 . Disponível em $<$ http://www.scielo. br/scielo.php?script=sci_arttext\&pid=S141385572012000100016\&lng=en\&nrm=iso>. Acesso em 21 Dez. 2020. https://doi.org/10.1590/S1413-85572012000100016.

MORETTI, F. A.; HUBNER, M. M. C.. O estresse e a máquina de moer alunos do ensino superior: vamos repensar nossa política educacional?. Rev. psicopedag., São Paulo, v. 34, n. 105, p. 258-267, 2017. Disponível em <http://pepsic.bvsalud.org/scielo.php? script=sci_ arttext\&pid=S0103-84862017000300003\&lng=pt\&nrm=iso $>. \quad$ Acesso em 18 jun. 2020.

MOURA, F. R. de; FACCI, M. G. D. A atuação do psicólogo escolar no ensino superior: configurações, desafios e proposições sobre o fracasso escolar. Psicol. Esc. Educ., Maringá, v. 20, n. 3, p. 503-514, Dec. 2016. Disponível em $<$ http://www.scielo.br/scielo.php?script= sci_arttext\&pid $=$ S1413-85572016000300503 \&lng=en\&nrm=iso>. access on 18 June 2020. http://dx.doi.org/10.1590/21753539201502031036.

PERETTA, A. A. C. e S.; OLIVEIRA, Í. W. M. de; LIMA, L. M. de. Roda de conversa sobre evasão: a psicologia escolar no ensino superior. Psicol. Esc. Educ., Maringá, v. 23, e186484, $2019 . \quad$ Disponível

<http://www.scielo.br/scielo.php?script=sci_arttext\&pid=S1413-

$85572019000100321 \& \operatorname{lng}=$ en\&nrm=iso $>$. access on 18 June 2020. Epub Dec 09, 2019. https://doi.org/10.1590/2175-35392019016484.

RAMOS, Fabiana Pinheiro et al . Intervenções psicológicas com universitários em serviços de apoio ao estudante. Rev. bras. orientac. prof, Florianópolis , v. 19, n. 2, p. 221-232, dez. $2018 \quad$ Disponível em $<$ http://pepsic.bvsalud.org/scielo.php?script=sci_arttext\&pid=S1679-

33902018000200010\&lng=pt\&nrm=iso>. acessos em 18 jun. 2020. http://dx.doi.org/10 26707/1984-7270/2019v19n2p221.

RIBEIRO, D. C., \& BOLSONI-SILVA, A. T. Potencialidades e dificuldades interpessoais de universitários: estudo de caracterização. Acta Comportamentalia, 19(2), 205-224, 2010.

RIBEIRO, F. de Mendonça; GUZZO, Raquel Souza Lobo. Consciência de Estudantes Prounistas sobre sua Inserção no Ensino Superior. Psicol. cienc. prof., Brasília, v. 37 , n. 2, p. 418-431, June 2017. Disponível em <http://www.scielo.br/scielo.php?script=sci_arttext\& pid=S141498932017000200418\&lng=en\&nrm=iso>. access on 18 June 2020. http://dx.doi.org/10.1590/1982-3703001472016.

RIBEIRO, Flávia de Mendonça; GUZZO, Raquel Souza Lobo. Psicologia e ensino superior: aspirações pequeno-burguesas e contradições cotidianas em cotistas. Rev. Psicol. IMED, Passo Fundo, v. 11, n. 1, p. 27-45, jun. 2019. Disponível em $<$ http://pepsic.bvsalud.org/ scielo.php?script $=$ sci_arttext\&pid=S217550272019000100003\&lng=pt\&nrm=iso>. acessos em 18 jun. 2020. http://dx.doi.org/10.18256/2175-5027.2019.v11i1.3004. 
SAMPAIO, S. M. R. A psicologia na educação superior: ausências e percalços. Em Aberto, 23, 95-105, 2010.

SANTOS, Anelise Schaurich dos et al . Atuação do Psicólogo Escolar e Educacional no ensino superior: reflexões sobre práticas. Psicol. Esc. Educ., Maringá , v. 19, n. 3, p. 515-524, Dez. 2015. Disponível em <http://www.scielo.br/scielo.php?script=sci_arttext\& pid=S141385572015000300515\&lng=en\&nrm=iso>. Acesso em $10 \quad$ Jan. 2020. http://dx.doi.org/10.1590/2175-3539/2015/0193888.

Atuação do Psicólogo Escolar e Educacional no ensino superior: reflexões sobre práticas. Psicol. Esc. Educ., Maringá , v. 19, n. 3, p. 515-524, Dec. 2015. Disponível em <http://www.scielo.br/scielo.php?script=sci_arttext\&pid=S141385572015000300515\&lng =en\&nrm=iso $>$ access on 18 June 2020. https://doi.org/10.1590/2175-3539/2015/0193888.

SERPA, M. N. F., \& SANTOS, A. A. A. Atuação no ensino superior: um novo campo para o psicólogo escolar. Psicologia Escolar e Educacional, 5(1), 27-35, 2001.

SOUSA, Maria do Carmo; MOREIRA, Maria Ignez Costa. Low-income youth and longterm school permanence: the senses built up by Prouni scholarship holders in Belo Horizonte (MG). Pesqui. prát. psicossociais, São João del-Rei , v. 12, n. 4, p. 116, 2017 Disponível em $<$ http://pepsic.bvsalud.org/scielo.php?script=sci_arttext\&pid=S1809$89082017000400008 \& \operatorname{lng}=$ pt\&nrm=iso>. acessos em 18 jun. 2020.

SILVA, Alessandra de Moraes; SILVA, Silvia Maria Cintra da. Psicologia Escolar na Assistência Estudantil: estudo de caso no Cefet - MG Araxá. Psicol. Esc. Educ., Maringá, v. 23, e207708, 2019. Disponível em $<$ http://www.scielo.br/scielo.php?script=sci_arttext \&pid=S1413-85572019000100332 \&lng=en\&nrm=iso>. access on 18 June 2020. Epub Dec 09, 2019. https://doi.org/10. $1590 / 2175-35392019017708$.

TEIXEIRA, M. A. P., CASTRO, G. D., \& PICCOLO, L. R. Adaptação à universidade em estudantes universitários: um estudo correlacional. Interação em Psicologia, 11(2), 211-220, 2007.

VIANA, Iclicia et al . Colonialidade, invisibilização e potencialidades: experiências de indígenas no ensino superior. Rev. psicol. polít., São Paulo , v. 19, n. 46, p. 602614, dez. 2019 Disponível em <http://pepsic.bvsalud.org/scielo.php?script=sci_arttext\&pid=S1519549X2019000300016\&lng=pt\&nrm=iso >. acessos em 18 jun. 2020. 


\section{CAPÍTULO XV}

\section{CONDIÇÕES ADVERSAS NA DOCÊNCIA}

\section{Ramiro Dias de Oliveira ${ }^{37}$.}

DOI-Capítulo: 10.47538/AC-2021.14-15

RESUMO: A educação no Brasil há tempos tem passado por certas adversidades em seu ambiente, seja ela ligada a violência ao preconceito ou a falta de recursos, o que torna a vida profissional de um professor cada dia mais difícil, segundo esta pesquisa feita com 180 professores de todas as regiões do Brasil, mais de $80 \%$ dos professores já presenciaram algum caso de preconceito em sala de aula. $65 \%$ dos professores já sofreram algum tipo de violência no ambiente escolar. E mais de $80 \%$ já passaram por dificuldades ligadas à falta de recursos. Com todas essas adversidades fica difícil não dizer que o ambiente escolar no Brasil se encontra cada dia mais deplorável.

PALAVRAS-CHAVE: Educação. Adversidade. Professor. Violência. Preconceito.

\section{ADVERSE CONDITIONS IN TEACHING}

ABSTRACT: Education in Brazil has been going through certain adversities in its environment for some time, whether it is linked to violence, prejudice or lack of resources, which makes the professional life of a teacher increasingly difficult, according to this survey carried out with 180 teachers from all regions of Brazil, more than $80 \%$ of teachers have witnessed some case of prejudice in the classroom. $65 \%$ of teachers have already suffered some type of violence in the school environment. And more than $80 \%$ have already gone through difficulties related to lack of resources. With all these adversities, it is difficult not to say that the school environment in Brazil is increasingly deplorable.

KEYWORDS: Education. Adversity. Teacher. Violence. Prejudice.

\section{INTRODUÇÃO}

Desde a década de oitenta e noventa o Brasil passou por diversas reformas educativas e alterações nas condições de trabalho, formas de avaliação, novas tecnologias, tudo isso trouxe uma reestruturação no trabalho docente apresentando um novo mundo ao professor com vantagens, porém, evidenciando cada vez mais uma desigualdade entre as escolas principalmente públicas e particulares e tornando por vezes mais ímprobo a vida profissional de muitos professores. Dito isso, essa pesquisa tem

\footnotetext{
${ }^{37}$ Universidade de Caxias do Sul. E-mail: Rdoliveira5@ucs.br
} 
como objetivo esclarecer a seguinte questão. Como os professores brasileiros de ensino fundamental e médio consideram o ambiente profissional nas escolas atualmente?

Para isso vamos abordar alguns aspectos bem específicos como a violência nas escolas, casos de preconceitos, falta de recursos e principalmente o quanto isso afeta a vida profissional de um professor. A metodologia a ser utilizada contará com um questionário fechado de 5 perguntas a ser respondido por 180 professores espalhados pelo Brasil. Essa pesquisa será feita no segundo semestre de 2021 e deverá ser divulgada em grupos particulares de professores de diversos estados utilizando o Facebook e outras redes sociais.

Portanto, fica evidente que a escolha desse tema esta relacionada à constante preocupação que essa situação tem trazido a instituições e professores. Esse arcabouço precisa ser debatido no processo de formação dos educadores.

\section{CONDIÇÕES DE ADVERSIDADES NA DOCÊNCIA}

Em meio ao ambiente escolar brasileiro as adversidades têm ganhado cada vez mais notoriedade um dos principais problemas esta ligado a violência tanto Aluno/Aluno quanto Aluno/Professor. É indiscutível a gravidade deste problema, especialmente no Brasil, um dos países com maior índice de violência contra o professor (OCDE, 2013; SAEB/Prova Brasil, 2017). "Mesmo diante da importância do professor no processo de aprendizado, das altas taxas de relatos de violência sobre eles e das possíveis consequências que essa violência pode acarretar as rotinas desses profissionais" (PLASSA et al, 2020, p. 2).

É possível também analisarmos que o problema não está somente na violência Aluno/Professor e sim Aluno/Aluno. "Diante do agravamento da crise social e da escalada de violência, várias dimensões do cotidiano do trabalho docente estão, hoje, envolvidas com cenas de violência" (VILELA, 2006, p. 6). A violência que ocorre na escola e no seu entorno, situações como bulling, racismo, homofobia e machismo estão presentes diariamente na vida do estudante gerando um ambiente cada vez mais desagradável para o trabalho a ser realizado pelos professores. 
"Os desafios que se colocam diante dos professores quando se encontram nas condições de adversidade, considerando aqui os aspectos de violência e as precárias condições sociais da maioria dos alunos de escolas públicas e de seus familiares, associadas às condições de degradação do trabalho do professor" (VILELA, 2006). Não é nenhum absurdo afirmar que a um desgaste na profissão docente, desgaste esse relacionado com diversos fatores como número excessivo de alunos na sala de aula, condições gerais de trabalho, bem como a resposta dos professores às condições sociais e condições econômicas. tais como desprestígio da profissão e a exposição a situações da vida social moderna, consideradas estressantes.

As deficiências do sistema educacional brasileiro são, sem dúvida obstáculos, portanto, é necessário tomar como nota que a maioria das instituições a qualidade do ensino público e até privado em todos os níveis de ensino estão em completa precariedade, um dos fatores que levam a isso é a falta de recursos, por exemplo, ausência de biblioteca, não ter um ginásio para educação física, ou não ter um laboratório científico ou de informática. Com esta grande escassez de recursos é inevitável a influência negativa relacionada a educação brasileira, diversas instituições de ensino primário e secundário encontram-se em condições deploráveis, muitas possuem uma estrutura precária tendo dificuldade até para atender turmas com uma grande quantidade de alunos, são diversos elementos desses até os mais básicos como banheiros em boa qualidade acesso dos professores a itens de suma importância como Datashow e acesso à internet (PEREIRA, 2014). A falta de todos esses recursos contribui para a desvalorização tanto da profisssão docente quanto para o próprio sistema educacional brasileiro.

É claro que não podemos deixar de falar de uma das principais adversidades na docência, estamos falando da baixa remuneração recebida pelos professores que é, sem dúvida, uma das maiores fontes de descontentamento da categoria. De acordo com Alves e Pinto (apud, LOURENCETTI, 2012, p. 3).

A remuneração é um aspecto fundamental em qualquer profissão, principalmente na sociedade capitalista. Implícitos na discussão da remuneração docente estão aspectos decisivos para a garantia de uma escola pública de qualidade, tais como: atratividade de bons profissionais para a carreira e de alunos bem preparados para os cursos de licenciatura, valorização social e financeira do professor num contexto de precarização, complexidade e intensificação. 
Todo o profissional se exposto a uma remuneração tão baixa como a do professor teria dificuldade de executar o seu trabalho com excelência, o profissional exposto a esse cenário corre o risco de ter que lecionar pensando nas contas a vencer e se terá condições de ter o básico no seu mês. De acordo com pesquisa feita pela Organização para Cooperação e Desenvolvimento Econômico (OCDE, 2021) o Brasil se encontra na liderança do ranking de pior salário pago a professores do ensino médio no mundo.

Gráfico 1 - Salários legais anuais de professores em instituições públicas.

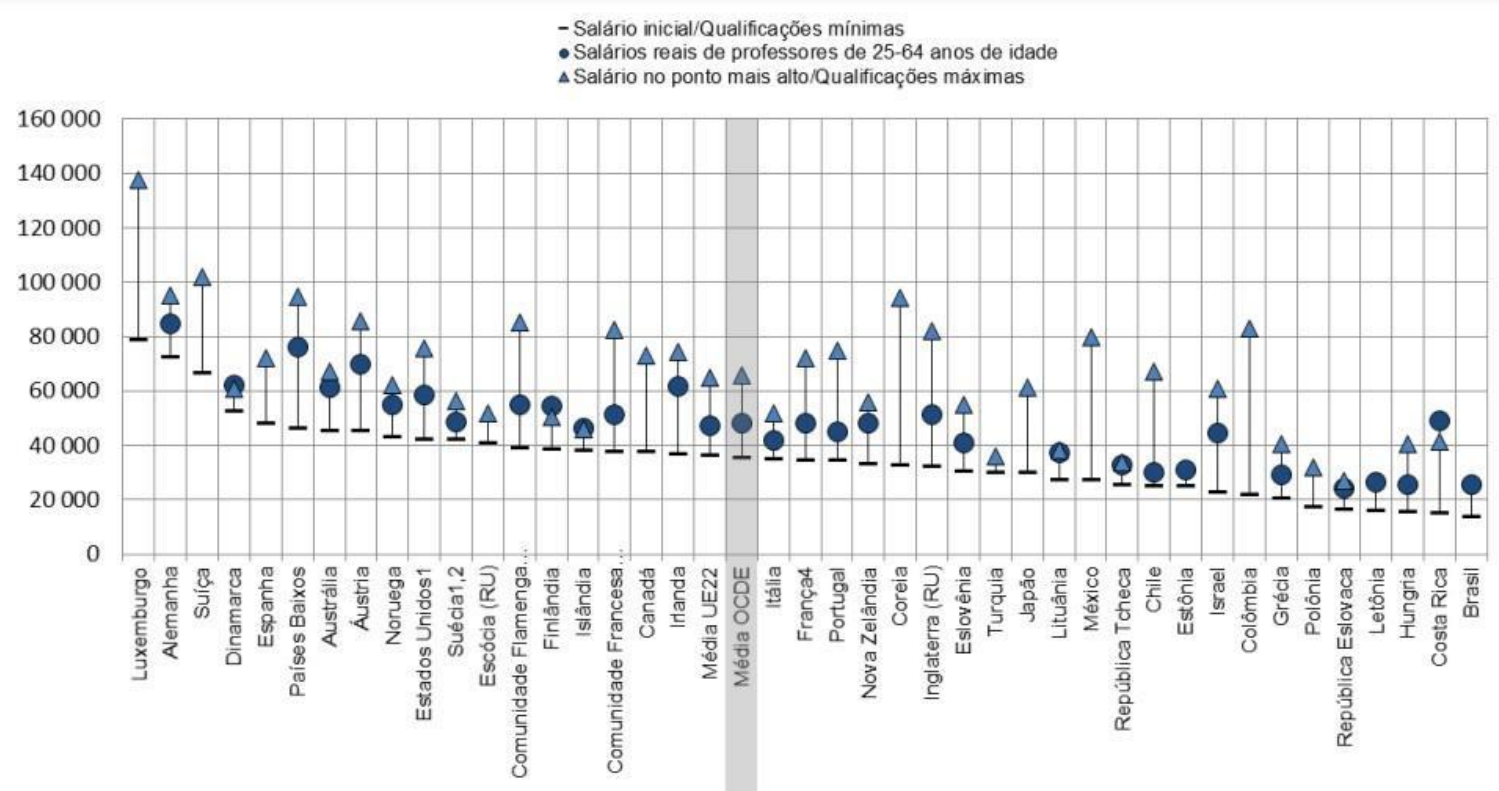

Fonte: OCDE (2021), Tabela D3.3 e Banco de Dados Education at a Glance, http://stats.oecd.org

\section{INVESTIGAÇÃO E RESULTADOS}

Como dito anteriormente essa pesquisa tende a abordar diversas adversidades, presente no ambiente escolar, portanto, como podemos ver no gráfico abaixo foi coletada a opinião de 180 professores de diversas regiões do Brasil, sendo $43 \%$ da região Sul, $31,7 \%$ do Sudeste, $15,6 \%$ do Nordeste, $5,6 \%$ do Centro Oeste e 3,3\% da região Norte. 
Gráfico 2 - Distribuição geográfica da pesquisa.

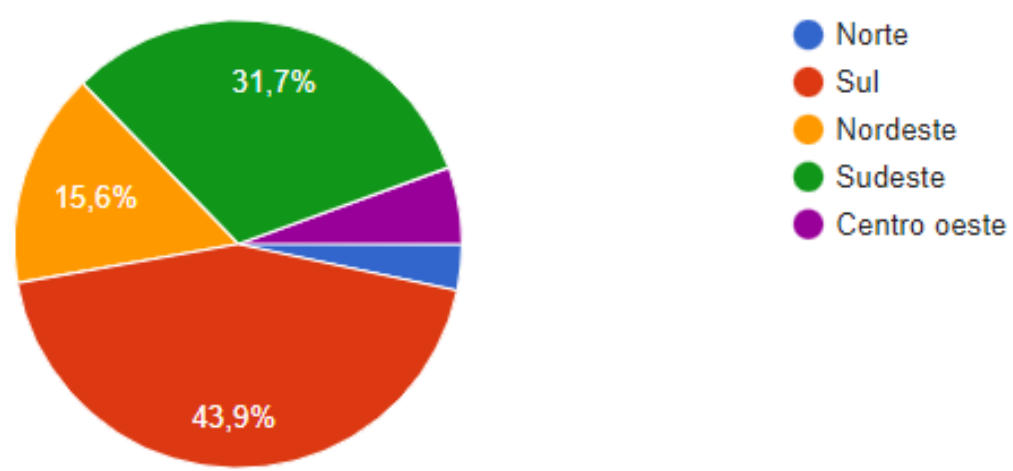

Fonte: Google formulários; Pesquisa de autoria própria.

Os resultados obtidos relacionados à distribuição geográfica da pesquisa foram considerados satisfatórios, pois, se obteve de um professor, pelo menos uma opinião em cada região do Brasil.

\section{VIOLÊNCIA NO AMBIENTE ESCOLAR}

Um dos principais casos de violência no ambiente escolar aconteceu em 13 de março de 2019 na escola estadual de Suzano no estado de São Paulo, onde dois adolescentes ex alunos da mesma escola deixaram 11 feridos e 8 mortos sendo esses estudantes, professores e coordenadores da escola como podemos ver na reportagem do (G1 Mogi das Cruzes e Suzano em 2019). Porém, infelizmente este não foi um acontecimento isolado em 2011, um caso que ficou conhecido como massacre de Realengo chocou o Rio de Janeiro onde um ex-aluno da Escola Municipal Tasso da Silveira atirou em 12 estudantes que, infelizmente, morreram no local, (reportagem da BBC de 2021). Em 2017 outro caso que também ficou bastante conhecido e sendo batizado como o massacre de Janaúba aterrorizou a pequena cidade do interior de Minas Gerais, onde um homem que trabalhava em uma creche incendiou a mesma atingindo crianças e professores e causando ao todo, 13 mortes além de deixar diversas vítimas com ferimentos graves, (reportagem da revista Hoje em dia em 2017). No mesmo ano aconteceu o que venho a ser conhecido como o massacre de Goyases onde um adolescente entrou armado em uma escola e desferiu diversos tiros deixando muitos alunos feridos e infelizmente levando dois colegas a morte (reportagem do G1 GO em 2017). 
Na pesquisa proposta por este artigo a seguinte pergunta foi feita, "Você já sofreu algum tipo de violência no ambiente escolar? Como podemos ver no gráfico abaixo, $35 \%$ dos 180 professores não sofreram nenhum tipo de violência, 52,2\% afirmam que sofreram apenas violência verbal e 12,8\% sofreram violência física e verbal.

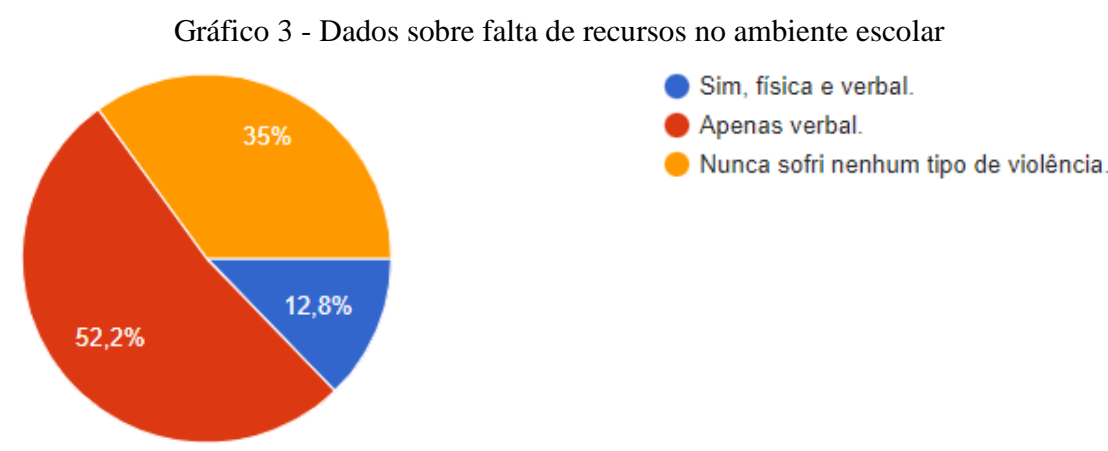

Fonte: Google formulários; Pesquisa de autoria própria.

Se levarmos em consideração apenas esta pesquisa, fica evidente que a violência esta sim muito presente no dia a dia das escolas, o que torna a mesma uma das adversidades mais preocupantes.

Preconceito nas escolas:

Adolescente morreu durante "brincadeira de luta" na escola; pai disse a uma reportagem para a TV jornal que o filho já tinha dito a ele que sofria bullying na escola por ser muito magro.

Infelizmente além do bullying nas escolas a homofobia também se faz presente dados que podemos ver na reportagem do site (Terra 2009). Cerca de $20 \%$ dos alunos que a partir do momento que se assumem homossexuais acabam por abandonar os estudos no decorrer do ano letivo.

De forma lamentável além do bullying e da homofobia outro preconceito infelizmente está presente nas escolas, um caso de uma adolescente, de apenas 14 anos, chocou a cidade de Curitiba a adolescente infelizmente ao olhar o seu caderno encontrou alguns rabiscos feitos por seus próprios colegas nesses rabiscos as duas frases que mais chocaram foram: 'Onde já se viu ter um preto nesse colégio' e 'preta desgraçada'. Este 
caso de injúria racial foi registrado em um colégio estadual cívico-militar. A Polícia Civil abriu uma investigação após a família registrar um boletim de ocorrência (reportagem do G1 PR e RPC Curitiba em 2021).

Ao elaborar este artigo a seguinte pergunta foi feita, "Você já presenciou algum caso de bulling, racismo, homofobia e machismo em sala de aula?" Como podemos ver no gráfico abaixo $82,8 \%$ dos 180 professores já presenciaram algum tipo de preconceito no ambiente escolar, e apenas $17,2 \%$ nunca presenciaram.

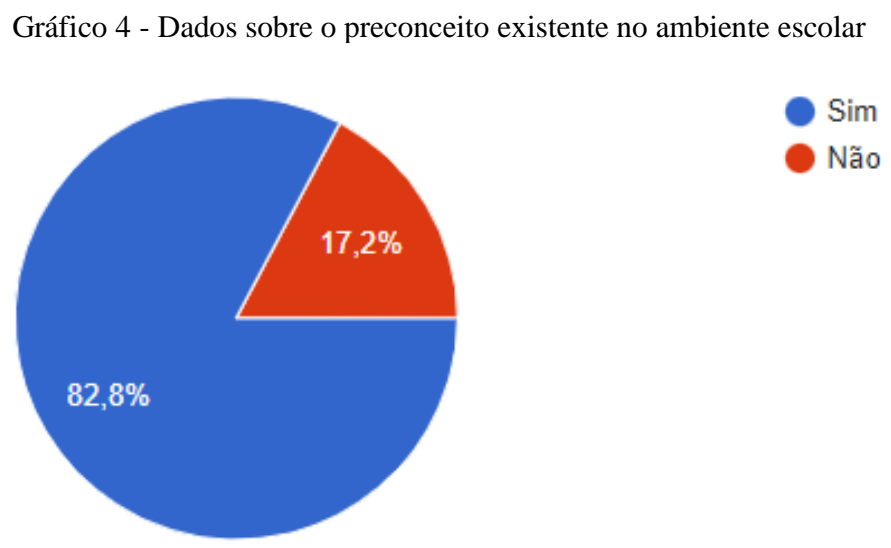

Fonte: Google formulários; Pesquisa de autoria própria.

Como podemos ver no gráfico acima o número de professores que já presenciaram casos de preconceito em suas escolas é muito alto, o que ajuda a embasar as notícias que encabeçam este capítulo.

Falta de recursos no ambiente escolar:

Segundo o boletim da comissão externa elaborada no primeiro semestre de 2021, destinada a acompanhar o desenvolvimento dos trabalhos do Ministério da educação. Cerca de 4,3 mil escolas públicas não possuem banheiros e mais de 3 mil não são abastecidas com água potável e cerca de $28,4 \%$ das escolas públicas no Brasil não possuem salas de aulas com um tamanho adequado.

Na pesquisa proposta por este artigo a seguinte pergunta foi feita, "Você já passou alguma dificuldade com falta de recurso na sua escola? tipo ausência de biblioteca, não ter um ginásio para educação física, ou não ter um laboratório científico ou de informática". Como podemos ver no gráfico abaixo 84,4\% dos 180 professores que 
responderam a pesquisa já passaram por dificuldade com falta de recursos e apenas $15,6 \%$ não.

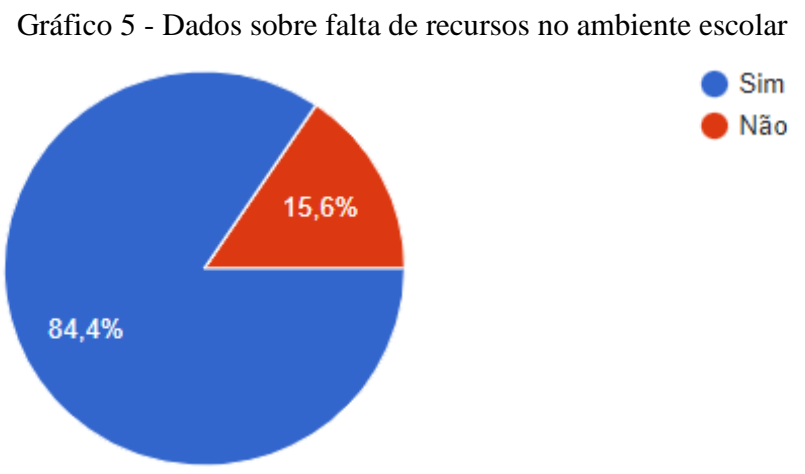

Fonte: Google formulários; Pesquisa de autoria própria.

Fica evidente, que os dados obtidos nesta pesquisa fazem uma anuência aos dados do Conselho externo, apresentado no início deste capítulo sendo assim mesmo que nesta pesquisa se tenha levado em consideração a opinião de apenas 180 professores é difícil dizer que atualmente no Brasil o problema com a falta de recursos em salas de aulas não exista ou seja algo supérfluo

A forma com que todas essas adversidades afetam os profissionais da docência:

$\mathrm{Na}$ pesquisa proposta por este artigo a seguinte pergunta foi feita, "Algumas dessas adversidades fizeram com que você em algum momento pensasse o fato de ser professor?" Como podemos ver no gráfico abaixo 46,1\% dos 180 professores que responderam a pesquisa afirmam que sim repensam o fato de terem se tornado professores em meio a tanta adversidade e 53,9\% dos entrevistados afirmam que não, nunca repensaram o fato de ser professor.

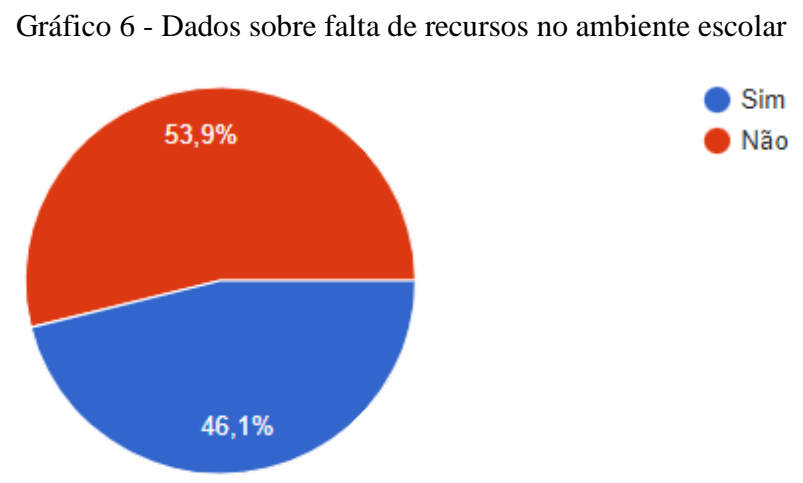

Fonte: Google formulários; Pesquisa de autoria própria. 
Dados divulgados pelo Inep informam que em 2019 o tipo de graduação mais procurada foi a de Bacharelado com 66\% dados do (Censo 2019). E o tipo de curso que mais vem crescendo é o de Tecnólogo 14,5\% e com um aumento em relação aos anos anteriores de $11,5 \%$, infelizmente os números relacionados a licenciatura permanecem no decorrer dos anos de 2009 a 2019 quase idênticos. E podemos retomar o início deste artigo quando falado que o Brasil hoje quando se fala de violência nas escolas esta no topo e infelizmente com todas essas informações não seria nenhuma surpresa um professor ser agredido ou até pior, ou seja é justificável o número de 46,1\% de professores que em algum momento repensaram o fato de ser professor por inúmeros motivos, não só a violência mas a desvalorização e o ambiente precário tornam a profissão docente cada vez mais em uma situação deplorável.

\section{CONCLUSÃO}

Sendo o Brasil um país gigante e com uma diversidade cultural imensa, foi de suma importância para a pesquisa que se obtivesse resultados de todas as regiões do pais, pois, julgasse difícil concluir algo levando em consideração apenas uma ou outra região, devido à diversidade cultural é claro, mas, também pela desigualdade social. Em relação a violência podemos concluir que dos entrevistados pelo menos $65 \%$ já sofreram algum tipo de violência seja ela física ou verbal, um número alto e triste para a educação no Brasil levando em consideração apenas essa pesquisa. Além da violência outro ponto abordado nesta pesquisa foi o de preconceito nas escolas, 82,8\% dos professores afirmam que já presenciaram algum tipo de caso de preconceito em sala de aula, este número alto, por vezes pode ajudar a explicar o grande número de casos de violência, pois, por muitas vezes o preconceito é um dos principais causadores de violência no ambiente escolar.

Todavia, outra dificuldade permeia este ambiente e esta relacionada a falta de recursos, levando em consideração apenas essa pesquisa $84,4 \%$ dos professores já passaram por problemas relacionados a falta de materiais para as suas aulas, número que assusta e evidencia que o professor atualmente no Brasil precisa "se virar nos trinta" para aplicar uma aula de qualidade. Levando em consideração todas essas adversidades a última pergunta feita para os professores foi, "se de alguma forma essas adversidades faziam com que os mesmos pensasse o fato de ser professor", desta pergunta $53,9 \%$ dos 
professores responderam que não o que nos indica que mesmo com tanta adversidade ainda assim a classe permanece intrépida. Por outro lado 46,1\% dos professores responderam que sim, o que pode indicar levando em consideração apenas esta pesquisa um desgaste na profissão o que pode acarretar em um futuro próximo um baixo índice de profissionais, levando em conta que com tantas adversidades cada vez menos alunos queiram se tornar professores. Ou seja, podemos concluir que o ambiente escolar segundo os professores e levando em consideração apenas essa pesquisa, se encontra de forma deplorável.

\section{REFERÊNCIAS}

OCDE. TALIS 2013 Results: An International Perspective on Teaching and Learning. TALIS, OECD Publishing. Paris, 2014. Disponível em: https://www.oecd.org/education/school/TALIS-technical-report-2013.pdf. Acesso em: 19 Set. 2021.

LOURENCETTI, Gisela C. A baixa remuneração dos professores: algumas repercussões no cotidiano da sala de aula. R. Educ. Públ. Cuiabá, v. 23, n. 52, p. 13-32, jan./abr. 2014

OECD (2021), "Brasil", em Education at a Glance 2021: OECD Indicators , OECD Publishing, Paris, https://doi.org/10.1787/85737d68-pt .

PLASSA, W.; PASCHOALINO, P. A. T.; BERNARDELLI, L. V. Violência contra professores nas escolas brasileiras. Nova Economia v.31 n.1, p. 2, 2020.

VILELA, Rita. A. T. O trabalho do professor nas condições de adversidade: Escola, violência e profissão docente. Tese (Mestrado em Pedagogia) - Pontifícia Universidade Católica de Minas Gerais, p. 6. 2006.

PEREIRA, Lucicléia Aparecida dos Santos. Os desafios enfrentados pelos professores na atualidade. (Monografia) - Universidade estadual da Paraíba, 65 p. 2014.

DUPLA ATACA ESCOLA EM SUZANO, MATA OITO PESSOAS E SE SUICIDA. G1 Mogi das Cruzes e Suzano, 2019. Disponível em: < https://g1.globo.com/sp/mogi-das-cruzes-suzano/noticia/2019/03/13/tiros-deixamferidos-em-escola-de-suzano.ghtml> . Acesso em: 21, Novembro e 2021.

BERNARDO, André. Massacre de Realengo: os 10 anos do ataque a escola que deixou 12 mortos e chocou o Brasil. BBC Brasil, 2021. Disponível em: <https://www.bbc.com/portuguese/brasil-56657419>. Acesso em: 21, Novembro de 2021.

TRAGEDIA EM CRECHE DE JANAUBA. Hoje em dia, 2017. Disponível em: <http://hoje.vc/1p2hv>. Acesso em: 21, Novembro e 2021.

\section{ALUNO ATIRA EM COLEGAS DENTRO DE ESCOLA EM GOIÂNIA, MATA DOIS E FERE QUATRO. G1 GO, 2017. Disponível em:}


<https://g1.globo.com/goias/noticia/escola-tem-tiroteio-em-goiania.ghtml>. Acesso em: 21, Novembro e 2021.

HOMOFOBIA AFASTA ESTUDANTES DAS ESCOLAS NO RIO. Terra, 2009. Disponível em: < https://www.terra.com.br/noticias/educacao/homofobia-afastaestudantes-das-escolas-norio,dbe837dabd9ea310VgnCLD200000bbcceb0aR CRD.html>. Acesso em: 21, Novembro e 2021.

ADOLESCENTE NEGRA É AMEAÇADA DE MORTE E SOFRE INJÚRIA RACIAL EM ESCOLA CÍVICO-MILITAR DE CURITIBA. G1 PR e RPC Curitiba, 2021. Disponível em: < https://g1.globo.com/pr/parana/noticia/2021/11/19/adolescentenegra-e-ameacada-de-morte-e-sofre-injuria-racial-em-escola-civico-militar-decuritiba.ghtml>. Acesso em: 21, Novembro e 2021.

MINISTÉRIO DA EDUCAÇÃO. Comissão Externa destinada a acompanhar o desenvolvimento dos trabalhos do Ministério da Educação (MEC), bem como da apresentação do seu Planejamento Estratégico (CEXMEC). Relatório Semestral 01/2021. Disponível em: <https://www.camara.leg.br/proposicoesWeb/prop _mostrarintegra? codteor $=2039292 \&$ filename $=$ REL+1/2021+CEXMEC $>$. Acesso em: 21, Novembro. 2021.

BRASIL. Instituto Nacional de Estudos e Pesquisas Educacionais Anísio Teixeira (Inep). Censo da Educação Básica 2019: notas estatísticas. Brasília, DF: Inep, 2020. Acesso em: 21, Novembro. 2021. 


\title{
CAPÍTULO XVI
}

\section{COVID-19 E O IMPACTO PSICOLÓGICO EM DOCENTES E DISCENTES DA EDUCAÇÃO INFANTIL E ANOS INICIAIS}

\author{
Caroline Rodrigues de Freitas Fernandes ${ }^{38}$; Dayana Lúcia Rodrigues de Freitas ${ }^{39}$; \\ Jaqueline Honorato de Souza ${ }^{40}$; Wustania Gaspar Rodrigues ${ }^{41}$; \\ Lígia Maria da Conceição Santos Silva ${ }^{42}$; Nilsa Araújo Silva de Souza ${ }^{43}$; \\ Rissa Soares Plácido ${ }^{44}$; Elisama da Silva Araújo ${ }^{45}$; \\ Francijânio Soares de Souza ${ }^{46}$. \\ DOI-Capítulo: 10.47538/AC-2021.14-16
}

RESUMO: O novo coronavírus, responsável pela difusão da pandemia da COVID-19, alterou as relações sociais, principalmente no campo da Educação. Novas formas de organização pedagógica surgiram impondo ao sistema educacional muitos ajustes e alterações e, isso trouxe aos educadores novas formas de adaptação, gerando sofrimento mental e físico. Diante desta realidade é possível notar uma série de impactos da pandemia na saúde mental dos professores. O professor, em seu trabalho, enfrenta inúmeros desafios e assume grandes responsabilidades, constituindo uma das categorias profissionais mais sujeitas a apresentar sofrimento mental. Além disso, essas mudanças trouxeram resultados negativos também para a vida dos alunos, que tiveram suas rotinas duramente modificadas. A pesquisa busca compreender a partir da literatura existente e pesquisas já realizadas neste aspecto os impactos da pandemia na saúde mental de professores e alunos da educação infantil e anos iniciais.

38Pós-Graduada em Mídias na Educação (UERN). Docente no Município de Macau/RN. Orcid: https://orcid.org/00000002-9198-6746. Lattes: http://lattes.cnpq.br/5956672837215695. E-mail: caroline_brum2005@ hotmail.com. 39Doutoranda em Educação (CECAP). Docente nos Município de Macau/RN e Guamaré/RN. Orcid: https://orcid.org/0000-0001-5355-3547. Lattes: http://lattes.cnpq.br/5122671799874415. E-mail: dayannaproducoes@gmail.com.

40 Graduada em Pedagogia pela faculdade UNINTA - Centro Universitário.E-mail: jaquehonorato2016@gmail.com 41 Graduação em pedagogia - UVA. Pós-graduação em Educação infantil e anos iniciais - FIAVEC. Pós-graduação em Alfabetização e Letramento - Faculdade do Vale Elvira Dayrell. Pós-graduação em Educação Especial e Inclusiva - Faculdade do Vale Elvira Dayrell. Pós-graduação em Língua Brasileira de Sinais-LIBRAS - Faculdade do Vale Elvira Dayrell. Professora no município de Guamaré/RN. E-mail: wustaniaprofessora@ hotmail.com

42 Graduada em pedagogia - UVA. Pós-graduação em psicopedagogia -FIP. Pós-graduada em Serviço Social no Campo (em andamento) - Universidade Dom Alberto. Professora do município de Guamaré rede privada. E-mail: mariaa.ligia@gmail.com

43 Graduação em normal superior - Fundação Universidade do Tocantins. Pós-graduação em Psicopedagogo - UVA. Pós-graduação em Educação Infantil - UFRN. Professora do município do Alto do Rodrigues. E-mail: nilsaaraujo2020@Outlook.com

44 Graduada em Pedagogia - UEA. Licenciada Em Letras - Língua Portuguesa e Libras - UFRN. Pós-Graduada Em Educação Infantil - FACEL. Pós-Graduada Em Gestão Escolar e Coordenação Pedagógica - FAEL. Mestranda em Ciências da Educação - CECAP. E-mail: rissaplacido@ hotmail.com

45 Graduação em pedagogia - ISEP, Pós-graduação em educação infantil e anos iniciais pela faculdade de Maciço de Baturité, Pós-graduação em gestão escolar e coordenação pedagógica - IPEBRAS, Pós-graduação em alfabetização e letramento - IPEBRAS, Pós-graduação em psicopedagogia institucional e clínica - IPEBRAS. Professora do município de Macau pela escola CEIMH, Professora do município de Guamaré.E-mail: elisama_alohayne@ @otmail.com 46 Graduação em educação física pela faculdade estadual do Rio Grande do Norte. Pós-graduação em exercícios físicos aplicados aos grupos especiais pela faculdade excelência. Professor do município de Guamaré.E-mail: janioyanne@gmail.com 
PALAVRAS-CHAVE: Covid-19. Docentes. Discentes. Educação Infantil. Anos iniciais.

\section{COVID-19 AND THE PSYCHOLOGICAL IMPACT ON TEACHERS AND STUDENTS OF EARLY CHILDHOOD EDUCATION AND EARLY YEARS}

ABSTRACT: The new coronavirus, responsible for the spread of the COVID-19 pandemic, changed social relations, especially in the field of Education. New forms of pedagogical organization emerged, imposing many adjustments and alterations to the educational system, which brought educators new forms of adaptation, generating mental and physical suffering. Given this reality, it is possible to notice a series of impacts of the pandemic on the mental health of teachers. The teacher, in his work, faces numerous challenges and assumes great responsibilities, constituting one of the professional categories most likely to present mental suffering. In addition, these changes also brought negative results to the lives of students, who had their routines heavily modified. The research seeks to understand from the existing literature and research already carried out in this aspect the impacts of the pandemic on the health of teachers and students in early childhood education and early years.

KEYWORDS: Covid-19. Teachers. Students. Child education. Early years.

\section{INTRODUÇÃO}

Nas últimas décadas o campo do trabalho tem sofrido várias modificações, principalmente com a fragilização dos vínculos empregatícios, a flexibilização dos contratos de trabalho e o favorecimento aos empregadores nos acordos trabalhistas, entre outras medidas estabelecidas nos últimos governos. Essas mudanças causam repercussões, direta ou indiretamente, em toda a organização social e geram impactos significativos na saúde do trabalhador.

Com a entrada do quadro de pandemia do COVID-19 causada pelo novo coronavírus que foi notificada no final de dezembro de 2019 na China, e que em pouco tempo se espalhou pelo mundo, esse quadro se agravou ainda mais, pois a pandemia trouxe consigo uma série de mudanças sociais, como as medidas de isolamento, a fim de conter a contaminação e impedir o contágio em larga escala.

Durante a difusão do surto da pandemia do COVID-19, os países afetados praticam diferentes estratégias de isolamento social que impactam no fechamento dos ambientes escolares em todos os níveis (creches, escolas, colégios, faculdades e universidades) objetivando evitar aglomerações e coibir a disseminação do novo vírus e esse fator atingiu diretamente as relações sociais tanto de docentes quantos dos alunos, 
mudando profundamente suas rotinas e afetando o psicológico e o emocional desses grupos.

Diante desse cenário, tanto docentes como estudantes tiveram as suas rotinas alteradas, precisando ajustar-se a um novo modelo de ensino-aprendizagem e concomitantemente precisaram realizar ajustes necessários no âmbito familiar, trabalhista e social, para atenuar a repercussão negativa da pandemia na saúde e na qualidade de vida de um modo geral.

\section{O IMPACTO PSICOLÓGICO DA PANDEMIA EM DOCENTES DA EDUCAÇÃO INFANTIL E ANOS INICIAIS}

Não é novidade que o trabalho docente é algo que traz consigo uma grande carga emocional, ainda mais quando se trabalha com o ensino infantil e os anos iniciais. A Organização Internacional do Trabalho (OIT) indica que desde 1983 a classe docente é a segunda categoria profissional, em nível mundial, a portar doenças de caráter ocupacional, incluindo desde reações alérgicas a giz, distúrbios vocais, gastrite e até esquizofrenia. $\mathrm{O}$ estresse que acomete os professores é considerado pela OIT não somente como um fenômeno isolado, mas um risco ocupacional significativo da profissão (TOSTES et al., 2018).

Um dos principais fatores que contribuem para esse resultado é que a jornada de trabalho de um professor não acaba junto ao término do expediente. Além disso, o docente precisa ainda preparar materiais, corrigir provas e organizar os conteúdos das disciplinas e estas são apenas algumas das atividades realizadas além do espaço físico da sala de aula.

Além disso, outros fatores comuns que cooperam para ocorrência dessas doenças são os baixos salários, os parcelamentos, a carga horária excessiva e os ataques verbais, físicos, psicológicos, que afetam tanto a vida pessoal, quanto a saúde mental dos profissionais da educação, em qualquer nível de atuação, do ensino infantil ao superior.

Segundo Zaidan e Galvão:

Professoras e professores experimentaram uma mudança brusca em suas rotinas, que se caracteriza pela penetração insidiosa do trabalho em todos os espaços e momentos de seu cotidiano, não importando que seus empregadores (o governo ou os donos de escola) não lhes tenham 
garantido estrutura para o teletrabalho (ZAIDAN; GALVÃO, 2020, p. 264).

Além desses fatores já conhecidos e registrados anteriormente, soma-se os impactos psicológicos diretamente relacionadas à pandemia do COVID-19, gerando simultaneamente abalos biopsicossociais causados pelas medidas preventivas de contenção da pandemia, como por exemplo, os efeitos da quarentena e do isolamento social, que limitam não somente as interações presenciais e relações sociais, como também, restringem a realização de atividades de lazer e entretenimento, sendo estes, também considerados como potenciais fatores de risco à saúde mental e bem-estar emocional.

Com o distanciamento social, as adversidades que já eram vivenciadas pelos docentes aumentaram, pois além dos elementos que já ocorriam em seu cotidiano foram acrescentados outros fatores como a falta de recursos tecnológicos para ministrar as aulas remotas; a sobrecarga de trabalho ainda maior devido a necessidade de auxiliar os alunos nas redes sociais ou aplicativos após o fim do horário; o uso excessivo de aparelhos tecnológicos, e, em alguns casos, a dificuldade para utilizar as plataformas digitais, devido à falta de capacitação e formação continuada.

Além de todos esses fatores mencionados, os períodos de lazer tornaram-se ainda mais raros na rotina dos profissionais da educação. Primeiramente porque houve a transformação do local de descanso em sua residência por um espaço de trabalho, juntando-se a isto o uso excessivo de computadores e de celulares, o que contribui para o aumento do esgotamento mental e indisposição para realização de atividades recreativas.

A preocupação de perder o emprego por despreparo tecnológico, ou por se sentir incapaz de corresponder às exigências dessas mudanças, além dos problemas financeiros e familiares decorrentes da pandemia agravam a situação psicológica dos docentes que têm se esforçado para atuar mesmo em meio ao turbilhão de emoções que têm vivido. No mais, destaca-se a necessidade de constante planejamento e reformulação das práticas pedagógicas, fato este que contribui para o grande montante de tempo a ser dispensado à sua atividade profissional (RODRIGUES, et al, 2021)

Os docentes, em condições de mudanças, são impulsionados ou obrigados a se adequarem às atribuições de um novo perfil profissional e, consequentemente, às 
exigências de novas performances para que as demandas sejam atendidas. Isso é ainda mais sentido na educação infantil e anos iniciais, onde é preciso inovar muito mais e buscar métodos mais criativos que possam atender a demanda de ensino para a faixa etária em questão.

Segundo Ball (2014), tudo isso pode produzir incertezas quanto a forma de como o trabalho pode ser organizado e gerar dúvidas na capacidade do profissional. $\mathrm{O}$ autor ainda aponta os movimentos de autovalorização e inadequação, além do sentimento de culpa, situações essas, que podem gerar um sofrimento mental nos docentes, como os efeitos já explanados ao longo da narrativa do presente estudo.

É importante considerar que as condições tanto sociais quanto de trabalho impostas pela pandemia vem se estendendo por mais de um ano na vida dos docentes, o que caracteriza um fator de estresse adicional, que pode agravar o quadro apresentado, com a evolução do estresse para a fase de exaustão, comprometendo tanto a saúde física quanto psíquica dos docentes (LIPP, 2015). Jacomini e Penna (2016) ponderam que o estresse patológico compromete, além da saúde dos docentes, seu exercício profissional e a qualidade da educação, fatos estes que precisam ser levados em consideração no planejamento das instituições de ensino.

O Instituto Península realizou uma pesquisa entre os docentes onde ouviu 2.400 professores da educação básica, das redes pública e privada, para entender como estavam se sentindo desde o início da pandemia. O quadro emocional constatado pelo instituto chama a atenção pois a maioria dos docentes pedem apoio para lidar com questões emocionais e demonstravam fatores como ansiedade (67\%), cansaço (38\%) e tédio (36\%). Compilados em maio, esses números podem ter aumentado, uma vez que o período de aulas remotas tem sido maior do que o inicialmente previsto. Dar aulas a partir de casa era situação inédita para a maioria dos professores entrevistados (88\%), tanto é que $83,4 \%$ não se sentiam preparados para isto, fator que também gerava ansiedade e preocupação.

Diante do cenário de retomada às aulas presenciais na maior parte do país, vale ressaltar que as preocupações apresentadas pelos docentes são em relação aos descumprimentos dos cuidados sanitários por parte dos alunos: falta de distanciamento, uso incorreto da máscara e a não utilização de álcool em gel. Os estudantes, em sua grande 
maioria, ainda não receberam nenhuma das doses da vacina, assim estão mais suscetíveis a contaminar-se e, por consequência, transmitir o vírus.

\section{O IMPACTO PSICOLÓGICO DA PANDEMIA NOS DISCENTES}

Com o isolamento social, as crianças também foram submetidas a uma mudança drástica no seu cotidiano, o que se pode qualificar como algo estranho. As repercussões psicológicas causadas pela pandemia podem impactar negativamente na saúde mental delas, causando estresse pós-traumático e raiva, dentre outros sintomas. Podemos citar fatores como: o medo de adquirir a doença, frustração, tédio, redução do convívio social, perda da rotina usual, sensação de isolamento do resto do mundo, dentre outras situações (Brooks et al. 2020).

Dentre as reações emocionais e alterações comportamentais frequentemente apresentadas pelas crianças durante a pandemia, destacam-se: dificuldades de concentração, irritabilidade, medo, inquietação, tédio, sensação de solidão, alterações no padrão de sono e alimentação (BRASIL, 2020).

O isolamento social, principal medida contra o coronavírus, significa para muitas crianças um pesadelo. No entanto, para algumas crianças, o lar não se configura o local mais seguro e o aumento de tempo de permanência em casa, aliado ao estresse parental por conta das novas demandas após pandemia, podem desencadear tensões, conflitos e situações de violência (BRASIL, 2020).

Ao mesmo tempo, no cenário de pandemia, as crianças também podem estar mais estressadas diante das restrições de mobilidade e de contato com seus pares e outros adultos significativos em suas vidas e, portanto, podem reagir de forma mais agressiva às demandas externas e às solicitações dos familiares. Gritos, xingamentos, insultos, desatenção a necessidades básicas de cuidado ou isolamento da criança no ambiente familiar podem acabar ocupando um espaço importante nas relações familiares, dando lugar à violência psicológica (BRASIL, 2020).

Outro fator a ser considerado é o alto índice de aumento do uso da Internet para a realização de atividades e tarefas escolares também levanta um alerta pois o tempo que as crianças e adolescentes têm passado em frente às telas podem causar prejuízos à saúde por conta dessa alta exposição. Além disso, o distanciamento social e o fechamento de escolas afetaram um período vital de desenvolvimento e de afirmação da identidade infanto-juvenil, podendo gerar sérias sequelas psicológicas neste público. 
Mesmo com a retomada para o presencial, a pandemia ainda não acabou. Os efeitos dela na saúde mental das crianças vão continuar presentes, pois envolvem tanto fatores da vida pessoal, quanto fatores externos, como aqueles relacionados à situação socioeconômica e sanitária do país.

O relatório Situação Mundial da Infância 2021 feito pela Unicef pede que governos e parceiros dos setores público e privado se comprometam, se comuniquem e ajam em conjunto para promover a melhoria e a permanência da saúde mental de todas as crianças, adolescentes e cuidadores, a fim de proteger os que precisam de ajuda e cuidar principalmente dos mais vulneráveis.

Será preciso um grande esforço de todos os atores envolvidos com a educação para eliminar ou minimizar os efeitos da pandemia na saúde mental e no bem-estar dos estudantes, principalmente da educação infantil e anos iniciais, bem como no processo de aprendizagem e participação destes, evitando o aumento da reprovação e da evasão escolar que poderão ampliar ainda mais as desigualdades educacionais já existentes em nosso país.

\section{CONSIDERAÇÕES FINAIS}

Sabemos que a educação e os educadores atravessam atualmente dias obscuros, tanto no que diz respeito a ausência de protocolos, diretrizes, políticas, formações e destinação de recursos públicos capazes de suprir as novas demandas inerentes a este contexto pandêmico, quanto pela inexistência de estrutura adequada à implementação de novas metodologias de ensino.

Tais complicadores ressoam diretamente na saúde dos docentes, que apresentam problemas como estresse, entre outros sintomas psicológicos associados. Além dos impactos psicológicos diretamente relacionadas à COVID-19, coexistem conjuntamente, os abalos biopsicossociais causados pelas medidas preventivas de contenção da pandemia, como por exemplo, os efeitos da quarentena e do isolamento social, que limitam não somente nossas interações presenciais e relações sociais, como também, restringem a realização de atividades de lazer e entretenimento, sendo estes, também considerados como potenciais fatores de risco à saúde mental e bem-estar emocional. 
Nesse contexto de pandemia, é necessário entender que a problemática relacionada à saúde mental não é uma questão simplesmente pessoal, mas sim um problema de caráter social que demanda ações coletivas. É primordial, por exemplo, que as instituições de ensino busquem estratégias coletivas de promoção à saúde, em especial a mental, com vistas a reduzir o impacto da pandemia para os docentes. Estratégias essas que visem a redução da sobrecarga intelectual, física e social não somente dos docentes que são tão importantes para o processo de desenvolvimento dos alunos, bem como a promoção de ações que beneficiem os próprios alunos.

\section{REFERÊNCIAS}

BALL, S. J. Fazendo neoliberalismo: mercados, estados e amigos com dinheiro. In: BALL, S. J. Educação Global SA: novas redes políticas e o imaginário neoliberal. Ponta Grossa: UEPG, 2014.

BRASIL. Crianças na pandemia Covid-19. CEPEDES/Fiocruz. 2020. Disponível em https://www.fiocruzbrasilia.fiocruz.br/wp-content/uploads/2020/05/crianc\%CC\% A7as_pandemia.pdf Acesso em 05/11/2021

INSTITUTO PENÍNSULA. Pesquisa de sentimento e percepção dos professores brasileiros nos diferentes estágios do Coronavírus no Brasil. Disponível em https://www.institutopeninsula.org.br/wp-content/uploads/2020/05/Pulso-Covid-19_Instituto-Peni\%CC\%81nsula.pdf Acesso em 05/11/2021

OIT - ORGANIZAÇÃO INTERNACIONAL DO TRABALHO. A condição dos professores: recomendação Internacional de 1966, um instrumento para a melhoria da condição dos professores. Genebra: OIT/UNESCO, 1984.

RODRIGUES, N. P. A., SILVA, D. R., GARCIA Jr, E.A., SILVA Jr., E. F., GOMES, R. S., FERNANDES, K. F. D., \& OLIVEIRA, K. Á. R. (2021). Disclosure of information on hygiene and changing habits during the Covid-19 pandemic. Research, Society and Development, 10(1), e 30910111739.https://www.rsdjournal.org /index.php/rsd/article/view/11739 doi: https://doi.org/10.33448/rsd-v10i1.11739.

TOSTES, M. V. et al. Sofrimento mental de professores do ensino público. Saúde em Debate, vol. 42, n. 116, 2018.

UNICEF. Impacto da covid-19 na saúde mental de crianças, adolescentes e jovens é significativo, mas somente a ponta do iceberg. Disponível em

https://www.unicef.org/brazil/comunicados-de-imprensa/impacto-da-covid-19-nasaude-mental-de-criancas-adolescentes-e-jovens. Acesso 05/11/2021

ZAIDAN, J. M.; GALVÃO, A. C. "COVID19 e os abutres do setor educacional: a superexploração da força de trabalho escancarada". In: AUGUSTO, C. B.; SANTOS, R. D. (orgs.). Pandemias e pandemônio no Brasil. São Paulo: Instituto Defesa da Classe Trabalhadora, 2020. 


\title{
CAPÍTULO XVII
}

\section{EDUCAÇÃO INCLUSIVA NA PERSPECTIVA DA EDUCAÇÃO A DISTÂNCIA}

\author{
Caroline Rodrigues de Freitas Fernandes ${ }^{47}$; Dayana Lúcia Rodrigues de Freitas ${ }^{48}$; \\ Jaqueline Honorato de Souza ${ }^{49}$; Wustania Gaspar Rodrigues $^{50}$; \\ Maria Damiana da Silva ${ }^{51}$; Adriano Cézar Dantas Ferreira ${ }^{52}$; \\ Francisco Antônio Vieira de Araújo ${ }^{53}$; Josiane Guimarães dos Anjos ${ }^{54}$; \\ Francisca da Conceição da Costa Melo ${ }^{55}$. \\ DOI-Capítulo: 10.47538/AC-2021.14-17
}

RESUMO: A inclusão educacional é um dos grandes e atuais desafios para o ensino no Brasil em todos os níveis de educação, desde a educação infantil até o ensino superior, incluindo a estes a modalidade de Educação a distância. Percebe-se que há ainda poucos estudos sobre a Educação à Distância como ferramenta para a inclusão de estudantes com necessidades educacionais especiais. Contudo, a $\mathrm{EaD}$ pode constituir-se como uma modalidade educacional favorável à inclusão destes estudantes, se observado as especificidades e necessidades individuais de cada aluno e se feita escolha adequada dos recursos tecnológicos que serão utilizados para auxiliar no processo de ensinoaprendizagem. A pesquisa busca apresentar fatores que influenciam na garantia de um sistema educacional inclusivo, com enfoque na Educação a Distância, apresentando recursos que podem ser utilizados para garantir essa inclusão e derrubar os potenciais barreiras de acesso no meio virtual.

PALAVRAS-CHAVE: Educação Inclusiva. Educação a distância. Acessibilidade.

47Pós-Graduada em Mídias na Educação (UERN). Docente no Município de Macau/RN. Orcid: https://orcid.org/00000002-9198-6746. Lattes: http://lattes.cnpq.br/5956672837215695. E-mail: caroline_brum2005@ hotmail.com. 48Doutoranda em Educação (CECAP). Docente nos Município de Macau/RN e Guamaré/RN. Orcid: https://orcid.org/0000-0001-5355-3547. Lattes: http://lattes.cnpq.br/5122671799874415. E-mail: dayannaproducoes@gmail.com.

49 Graduada em Pedagogia pela faculdade UNINTA - Centro Universitário.E-mail: jaquehonorato2016@gmail.com 50 Graduação em pedagogia - UVA. Pós-graduação em Educação infantil e anos iniciais - FIAVEC. Pós-graduação em Alfabetização e Letramento - Faculdade do Vale Elvira Dayrell. Pós-graduação em Educação Especial e Inclusiva - Faculdade do Vale Elvira Dayrell. Pós-graduação em Língua Brasileira de Sinais-LIBRAS - Faculdade do Vale Elvira Dayrell. Professora no município de Guamaré/RN. E-mail: wustaniaprofessora@ @otmail.com

51 Graduação em Pedagogia. Docente no Município de Guamaré/RN. E-mail: damianasilva1818@gmail.com

52 Graduação em Letras com habilitação em Língua Portuguesa UERN. Pós-graduação em Libras - FACESA. Pósgraduação em Metodologia do Ensino de Língua Portuguesa, Literatura e Artes -Faculdade Futura. Pós-graduação em Educação Especial e EJA e Linguística e Formação de Leitores - FACUMINAS. Professor do município de Guamaré/RN. E-mail: ferreira.adriano-ufrn@ outlook.com

53 Pós-Graduando em Educação Ambiental e Desenvolvimento Sustentável - FAVENI. Professor do município de Macau/RN. E-mail: totusant@outlook.com

54 Graduação em pedagogia - UVA. Pós-graduação em Atendimento Educacional especializado (AEE) - Ipebras. Pósgraduação Educação Especial Inclusiva - Facuminas. E-mail: guimaraesjosi87@ gmail.com

55 Graduação em Pedagogia - UFRN. Pós-Graduação em Psicopedagogia -ISEP. Pós-graduação em Ludopedagogia na Educação Infantil - FETREMIS. Pós-graduação em Educação Infantil e Anos Iniciais Do Ensino Fundamental FETREMIS. Professora no município de Guamaré/RN. E-mail: Franciscacostamello@ hotmail.com 


\section{INCLUSIVE EDUCATION FROM THE PERSPECTIVE OF DISTANCE EDUCATION}

ABSTRACT: Educational inclusion is one of the great and current challenges for teaching in Brazil at all levels of education, from early childhood education to higher education, including distance education. It is noticed that there are still few studies on Distance Education as a tool for the inclusion of students with special educational needs. However, $\mathrm{EaD}$ can be constituted as an educational modality that favors the inclusion of these students, if the specificities and individual needs of each student are observed and the appropriate choice of technological resources that will be used to assist in the teaching-learning process is made. The research seeks to present factors that influence the guarantee of an inclusive educational system, with a focus on Distance Education, presenting resources that can be used to guarantee this inclusion and to break down potential access barriers in the virtual environment.

KEYWORDS: Inclusive Education. Distance education. Accessibility.

\section{INTRODUÇÃO}

A educação é vista como um processo constante de aprendizagem e como fator responsável pelo desenvolvimento humano. Desde o nascimento até os últimos instantes de vida, esse processo está acontecendo e são as possibilidades de aprendizagens constantes que permitem a transformação individual ou social de cada pessoa. $\mathrm{O}$ acesso à educação, como muitos aspectos da sociedade atual, sofreu grande impacto com os avanços tecnológicos. Agora, o conhecimento pode ser acessado a qualquer hora e local e é possível realizar cursos em diferentes níveis educacionais parcial ou totalmente a distância.

A evolução histórica da EaD no Brasil, assim como em outros países, é marcada pelo surgimento e ampliação dos meios de comunicação e informação. As rápidas mudanças sociais e culturais ocorridas nas últimas décadas têm ampliado em nossa sociedade as possibilidades de acesso a esses recursos modificando e alterando os espaços educacionais, permitindo grandes avanços na educação em suas várias modalidades, entre elas, a educação a distância.

Diante dessa realidade é evidente o crescimento da educação a distância, proporcionando o acesso ao conhecimento a pessoas que até então, por algum motivo não podiam estar presentes em um espaço físico, formalizando sua aprendizagem em um sistema presencial. Assim a EAD traz a possibilidade de inclusão que vai além do social, levando a inserção de pessoas com necessidades especiais que buscam esse tipo de ensino 
para superar as barreiras de um sistema educacional ainda excludente e tradicional presente em muitas regiões do nosso país.

O ensino a distância remonta a ideia de um ensino voltado à superação de limites, não só territorial ou geográfico, mas pessoal e social, onde cada indivíduo pode se adaptar as suas condições físicas, cognitivas e relacionais. Essa adaptação é hoje o principal motivo de crescimento da EAD pois segue a perspectiva de uma educação especial à distância, moldada pelo próprio indivíduo para atender suas demandas.

Vale considerar que a educação à distância pode ser utilizada por indivíduos com diferentes tipos de necessidades especiais, visto que as tecnologias podem trazer atividades e estratégias pedagógicas que contemplam os diversos estilos de aprendizagem, possibilitando diferentes recursos tecnológicos que permitem ao cidadão, independentemente de sua condição, o acesso ao conhecimento.

Dessa maneira, a Educação à Distância é vista como um sistema gerador de uma nova formação educacional e cultural em muitos lugares do e apresenta um cenário atual de expansão, que pode ser expandido para todos os níveis e modalidades do ensino.

\section{EDUCAÇÃO A DISTÂNCIA}

A educação à distância é conhecida desde o século XIX, porém somente nas últimas décadas começou a chamar a atenção e assumir um papel importante no contexto educacional no nosso país.

No paradigma atual, a Educação a Distância é caracterizada pela legislação brasileira, segundo o Decreto 5.622 como

modalidade educacional na qual a mediação didático-pedagógica nos processos de ensino e aprendizagem ocorre com a utilização de meios e tecnologias de informação e comunicação, com estudantes e professores desenvolvendo atividades educativas em lugares ou tempos diversos (BRASIL, 2005).

Entende-se com isso que a Educação à distância (EAD), tem como características aprendizagem mediada pelo uso de tecnologias de informação e comunicação, havendo separação física entre alunos e professores, com suportes realizados por tutores, permitindo ao aluno desenvolver o aprendizado de forma independente e flexível. A conexão entre as duas partes envolvidas no processo de aprendizagem se dá por meio de 
várias tecnologias, como internet, correio, rádio, televisão, vídeo, telefone, fax, celular, computador, entre outras.

De acordo com Moore e Kearsley (2011), a partir do ano 2000, considera-se que teve início a quinta geração da Educação a Distância, na qual as aulas são virtuais, baseadas no uso do computador e da Internet, utilizando-se das potencialidades da Web 2.0, que pode ser compreendida como uma segunda geração ou uma forma aprimorada da Web. No contexto da EAD, a Web 2.0 transforma métodos pedagógicos tradicionais, oferecendo novas alternativas para uma sociedade marcada pela pluralidade das fontes de informação e por acesso cada vez mais facilitado.

Para muitas pessoas, a modalidade de ensino Educação a Distância (EAD) é uma educação de mais facilidades, que requer menos esforço para os estudantes. Outro grupo considera como uma das opções mais acessíveis para melhorar o nível de escolaridade da população, além, é claro, de ser uma forma nítida de promover a inclusão em todos os sentidos.

Outra característica intrínseca à educação a distância é a personalização do ensino, possibilitando uma ação inclusiva, pois o ensino pode ser adaptado às necessidades especiais de cada estudante, sendo elas tanto de ordem física quanto cognitiva. Contudo para que isso seja possível é necessário que seja percebido, analisado e respeitado o ritmo de cada aluno visto que a tecnologia na área educacional, acentua as possibilidades de individualização do ensino tornando-o mais inclusivo.

A EAD aliada à tecnologia vem suprir e amenizar as necessidades e os entraves da educação tradicional, criando novos caminhos para as pessoas, com ou sem deficiência ter acesso ao conhecimento. É certo que a acessibilidade no ensino e a flexibilidade de horários são benefícios bastante óbvios e muito desejados quando se busca a EAD. No entanto, é importante perceber que além desses benefícios a EAD traz ao aluno especial a oportunidade da inclusão social, pois além do aprendizado, gera no indivíduo o desenvolvimento de uma maior autonomia é algo extremamente benéfico não apenas para esse público, mas para todos os estudantes.

\section{EDUCAÇÃO A DISTÂNCIA: CAMINHO PARA INCLUSÃO}


Na Educação a Distância, o aluno precisa desenvolver a autonomia no gerenciamento de seus estudos oportunizando a quebra de paradigmas e permitindo o desenvolvimento de novas habilidades e competências. Para que este processo de adequação seja bem-sucedido é preciso de um acompanhamento sistemático de todo o processo.

Nesse contexto educativo, é imprescindível a adoção de estruturas curriculares flexíveis permitindo uma maior adaptação às possibilidades e necessidades individuais, favorecendo o processo inclusivo na educação e, consequentemente, nos diversos âmbitos sociais.

A Educação a Distância permite acesso à educação a pessoas antes excluídas, seja pela questão geográfica, financeira, temporal ou por dificuldades ou barreiras de acesso impostas pela educação presencial. A EAD oferece flexibilidade, admitindo que o aluno acesse os recursos em local e horário desejados, pelo tempo e da maneira que lhe for mais oportuna, utilizando tecnologias de sua preferência e que se adaptem às suas necessidades.

O desenvolvimento, que é parte essencial de qualquer aprendizado, tem gerado uma maior autonomia para o público do EAD. Essa modalidade tem contribuído muito para a Educação como um todo e tem sido deveras importante para inúmeros indivíduos em todo o país.

Ainda tratando sobre os benefícios da EAD, ela pode possibilitar, por exemplo, que pessoas com dificuldade para locomover-se possam estudar de sua própria casa, que pessoas cegas possam ser mais autônomas na busca pelo conhecimento, que pessoas com deficiência auditiva possam comunicar-se mais facilmente, entre muitas outras possibilidades que podem ser intermediadas a partir do uso de tecnologias e metodologias adequadas.

Assim, a Educação a Distância deve ser flexível, respeitando as individualidades do aluno, seu estilo de aprendizagem, seu ritmo, suas potencialidades e, também, suas dificuldades. Nesse contexto, o Decreto no 5.622, que regulamenta a Educação a Distância no Brasil, deixa claro, em seu Artigo 13, que os projetos pedagógicos de cursos 
e programas na modalidade a distância deverão, entre outros pontos, prever atendimento apropriado a estudantes portadores de necessidades especiais (BRASIL, 2005).

Percebe-se que a acessibilidade na Educação a Distância está alicerçada pela legislação e reconhece a importância da acessibilidade também no meio virtual, passando pela premissa de que a educação especial na perspectiva inclusiva, significa acima de tudo garantir acesso e utilização, com autonomia, do ambiente virtual, dos materiais e dos recursos utilizados na Educação a distância por qualquer outro aluno.

\section{RECURSOS PARA INCLUSÃO NA EaD}

Ainda segundo o Decreto 5.622, os projetos pedagógicos de cursos e programas na modalidade a distância deverão, entre outros aspectos, "prever atendimento apropriado a estudantes portadores de necessidades especiais" (BRASIL, 2005).

São vários os fatores que podem influenciar para que um ambiente seja mais ou menos acessível, mas segundo a legislação o mais característico é que o ambiente tenha uma boa interação com os recursos tecnológicos que minimizem as barreiras de acesso, interação e compreensão.

Amparando-se nesses conceitos, foram desenvolvidas estratégias e práticas que podem ser aplicadas em cursos à distância, visando a garantia de acesso ao maior número possível de usuários, gerando acessibilidade independente das limitações.

\section{TECNOLOGIA ASSISTIVA}

A Tecnologia Assistiva pode ser entendida como um mecanismo de auxílio que promove a ampliação de uma habilidade funcional deficitária ou a realização de uma função desejada que se encontra impedida por circunstância de deficiência ou envelhecimento. De acordo com CAT (2007), Tecnologia Assistiva é uma área do conhecimento, de característica interdisciplinar, que engloba produtos, recursos, metodologias, estratégias, práticas e serviços que objetivam promover a funcionalidade, relacionada à atividade e participação, de pessoas com deficiência, incapacidades ou mobilidade reduzida. 
A Tecnologia Assistiva (TA) é uma área do conhecimento que engloba recursos e serviços com o objetivo de proporcionar ou ampliar habilidades funcionais de uma pessoa com deficiência ou com incapacidades advindas do envelhecimento. O objetivo da TA é o de promover qualidade de vida e inclusão social de seus usuários (BERSCH; PELOSI, 2006, p. 7).

Para Bersch, o objetivo primordial da Tecnologia Assistiva é proporcionar à pessoa com deficiência maior independência, qualidade de vida e inclusão social através da ampliação de sua comunicação, mobilidade, controle de seu ambiente, habilidades de seu aprendizado e trabalho. Os recursos de Tecnologia Assistiva, no âmbito na EAD, possibilitam e facilitam o acesso ao computador e à Web para pessoas com deficiência ou determinadas limitações.

\section{RECURSOS DE ACESSO AO COMPUTADOR PARA PESSOAS COM LIMITAÇÕES MOTORAS}

Os recursos de acesso ao computador para limitação motora representam recursos de hardware ou software utilizados por pessoas com deficiência física ou mobilidade reduzida, que proporcionam uma maneira alternativa de utilizar as teclas ou o mouse (BERSCH; PELOSI, 2006). Tem-se como exemplos desses recursos:

- Alternativas para teclado: incluem teclados de todos os tipos: ampliado, reduzido, de conceitos, para uma mão, ergonômico, virtual, dentre outros.

- Alternativas para mouse: existem diversos tipos de mouses, que buscam atender às mais variadas necessidades dos usuários. Isso inclui mouses onde os movimentos são realizados através de rolos ou através de botões, mouses onde há um botão para cada função, mouse que utiliza o movimento dos olhos, entre outros.

\section{RECURSOS DE ACESSO AO COMPUTADOR PARA PESSOAS COM LIMITAÇÕES VISUAIS}

Os recursos de acesso ao computador para limitações visuais permitem que pessoas cegas ou com baixa visão utilizem o computador de maneira efetiva e dividemse, basicamente, em duas categorias: leitores de tela e ampliadores de tela. 


\section{LEITORES DE TELA}

O leitor de tela é um software utilizado principalmente por pessoas cegas, que fornece informações através de síntese de voz sobre os elementos exibidos na tela do computador. Esse tipo de software interage com o sistema operacional, capturando as informações apresentadas na forma de texto e transformando-as em resposta falada através de um sintetizador de voz. Pessoas com baixa visão e pessoas com dislexia também podem fazer uso dos leitores de tela.

\section{AMPLIADORES DE TELA}

Os ampliadores de tela são softwares utilizados por pessoas com baixa visão que ampliam toda ou uma parte da tela para que seu conteúdo seja mais facilmente visualizado. No caso de ampliação de uma parte da tela, o que aparece é ampliado em uma janela, como se fosse uma lupa. Além dos softwares ampliadores de tela, muitos programas oferecem recursos de zoom, inclusive os navegadores, permitindo ampliação ao navegar na Web.

\section{RECURSOS DE ACESSO AO COMPUTADOR PARA PESSOAS COM LIMITAÇÕES AUDITIVAS}

As pessoas com deficiência auditiva, geralmente, não encontram barreiras tão graves de acesso ao computador. Se a deficiência auditiva for leve, as barreiras quase não existem. No entanto, para pessoas surdas ou com deficiência auditiva severa, há a barreira da comunicação, especialmente se a pessoa surda não for oralizada, tendo como primeira língua (sua língua materna) a Língua Brasileira de Sinais (Libras) e não a língua portuguesa. Dessa forma, os recursos de Tecnologia Assistiva mais importantes são os softwares que transformam texto ou fala para Libras, como: Hand Talk, Rybená, ProDeaf, entre outros.

\section{CONCLUSÃO}

A garantia de acessibilidade na Educação a Distância sugere que o ambiente e o conteúdo de um curso online possam ser acessados e utilizados, de maneira efetiva, por todos, inclusive pelos alunos com deficiência ou limitações de alguma espécie. 
O uso de recursos da informática por pessoas com deficiência, como no caso de cursos à distância, gera independência e autonomia, sendo muito mais do que simples conveniência ou facilidade. Se para pessoas sem deficiência ou limitações, a tecnologia torna as coisas convenientes, para as pessoas com deficiência, torna as coisas possíveis.

Por fim, é preciso considerar que, mesmo que sejam feitos todos os esforços para garantir a acessibilidade na $\mathrm{EAD}$, não é possível criar um ambiente que seja completamente acessível a todas as pessoas em todas as situações. No entanto, muito pode ser feito para incluir o maior número possível de alunos da $\mathrm{EAD}$, a partir do momento em que a promoção da acessibilidade se torne algo comum e sempre presente nos ambientes educacionais e fora dele. Assim, seja na confecção de materiais, na preparação de ambientes virtuais, na estruturação de cursos, até chegar o dia em que garantir a acessibilidade será parte essencial do processo educativo e social dentro da nossa sociedade.

As pessoas com deficiência que até então tinham mais dificuldades de acesso à educação e às informações, graças à tecnologia e a EAD podem estudar mais facilmente, conquistar maior independência por meio do computador, ganhar mais autonomia e contar menos com o auxílio de terceiros.

Apesar disso, percebe-se ainda a ausência de políticas públicas ou mesmo a não aplicação de algumas existentes, que viabilizem a aquisição de computadores e recursos necessários para que as pessoas com deficiência possam realizar os cursos na modalidade EaD e assim conquistar sua independência e mudar de vida a partir da educação.

\section{REFERÊNCIAS}

BERSCH, Rita. Introdução à Tecnologia Assistiva. Porto Alegre, 2013. Disponível em: http://www.assistiva.com.br/Introducao_Tecnologia_Assistiva.pdf. Acesso em: $22 / 10 / 2021$

BERSCH, Rita de Cássia Reckziegel; PELOSI, Miryam Bonadiu. Portal de Ajudas Técnicas para educação: equipamentos e material pedagógico para educação, capacitação e recreação da pessoa com deficiência física: tecnologia assistiva: recursos de acessibilidade ao computador II. Brasília: ABPEE-MEC: SEESP, 2006. Disponível em: http://www.educadores.diaadia.pr.gov.br/arquivos/File/pdf/tecnologia_assistiva.pdf Acesso 22/10/2021 
BRASIL. Decreto 5.622, de 19 de dezembro de 2005. Regulamenta o art. 80 da Lei no 9.394, de 20 de dezembro de 1996, que estabelece as diretrizes e

bases da educação nacional. Disponível em: <http://www.planalto.gov.br/ccivil_03/_ato20042006/2005/Decreto/D5622.htm>.

Acesso em 22/10/2021.

CAT - Comitê de Ajudas Técnicas. Ata da Reunião VII, de dezembro de 2007. Secretaria Especial dos Direitos Humanos da Presidência da República (CORDE/SEDH/PR): $2007 . \quad$ Disponível em: <http://www.infoesp.net/CAT_Reuniao_VII.pdf>. Acesso em:

MOORE, Michael G.; KEARSLEY, Greg. Distance Education: A Systems View of Online Learning. $3^{\text {a }}$ Ed. Beltmont, CA: Cengage Learning, 2011. 


\title{
CAPÍTULO XVIII
}

\section{EDUCAÇÃO INCLUSIVA: UMA ABORDAGEM SOBRE O PROCESSO DE INCLUSÃO ESCOLAR}

\author{
Ana Paula de Sousa Costa ${ }^{56}$; Maria Aparecida Teixeira ${ }^{57}$; \\ Luana Teixeira Alves ${ }^{58}$; Claudiane Teixeira ${ }^{59}$; \\ Adriana Aparecida Gonçalves ${ }^{60}$. \\ DOI-Capítulo: 10.47538/AC-2021.14-18
}

RESUMO: O presente artigo tem por finalidade analisar os recursos e abordagens sobre o processo de inclusão escolar ocorrido nas escolas. Desse modo, buscamos elucidar alguns pontos e discorrer sobre a inclusão de alunos com necessidades especiais na rede regular de ensino. A linha de pesquisa principal é apresentar uma proposta que possa ser desenvolvida em sala de aula, visando a inclusão de modo efetivo de alunos com necessidades especiais nas atividades propostas durante as aulas, para que os mesmos se sintam de fato incluídos no processo de ensino aprendizagem. Para isso, utilizamos de teóricos como Aranha (2006), Mantoan (2005) e Gazin (2005).

PALAVRAS-CHAVE: Educação Inclusiva. Processos de inclusão. Escola.

\section{INCLUSIVE EDUCATION: AN APPROACH TO THE SCHOOL INCLUSION PROCESS}

ABSTRACT: This article aims to analyze the resources and approaches to the process of school inclusion that took place in schools. Thus, we seek to elucidate some points and discuss the inclusion of students with special needs in the regular school system. The main line of research is to present a proposal that can be developed in the classroom, aiming at the effective inclusion of students with special needs in the activities proposed during classes, so that they really feel included in the teaching-learning process. . For this, we use theorists such as Aranha (2006), Mantoan (2005) and Gazin (2005).

KEYWORDS: Inclusive Education. Inclusion processes. School.

\section{INTRODUÇÃO}

A inclusão de alunos com necessidades especiais na rede regular de ensino, muitas vezes se configura como um desafio para muitos docentes, em razão dos poucos ou inexistentes recursos apropriados disponíveis nas escolas para promover uma aprendizagem significativa e ao mesmo tempo inclusiva.

\footnotetext{
${ }^{56}$ Graduada em Pedagogia. E-mail: aniinhaxavier@homail.com

${ }^{57}$ Graduada em Pedagogia. E-mail: maria.bbu18@gmail.com

${ }^{58}$ Graduada em Pedagogia. E-mail: luana.teixeira@gmail.com

${ }^{59}$ Graduada em Pedagogia. E-mail: claudiane.teixeira@gmail.com

${ }^{60}$ Graduada em Pedagogia. E-mail: adriana_ap01@ @otmail.com
} 
O tema inclusão é relativamente recente no contexto educacional brasileiro, visto que anteriormente os alunos com algum tipo de necessidade especial de aprendizagem não frequentavam salas específicas separadas das salas regulares de ensino. Propostas de inclusão de alunos com necessidades especiais são cada vez mais frequentes no cenário educacional, com projetos direcionados à promoção da igualdade de aprendizagem de todos, respeitando as necessidades de cada um.

Esse projeto de ensino nos leva a pensar a educação inclusiva no contexto atual, levando a uma reflexão sobre os diversos processos de inserção dos diferentes grupos sociais nas instituições de ensino e os impactos que a inclusão tem na construção de suas identidades.

A inclusão vem para contemplar a todos em suas especificidades, sem distinção de qualquer natureza, uma vez que a educação é direito de todos, independentemente de sua condição física, mental, intelectual e social. A inclusão de alunos com necessidades especiais, muitas vezes se configura como um desafio a ser superado diariamente, tanto pelos docentes quanto pelos próprios alunos. Mesmo com todas as políticas e práticas sociais que garantem a inclusão como direito, a realidade se apresenta em desacordo com as leis impostas, isso acontece em razão da falta de recursos materiais e humanos adequados à promoção da inclusão de modo efetivo.

A organização desse projeto de ensino está dividida em tema, justificativa, participantes, objetivos, problematização, referencial teórico, metodologia, cronograma, recursos, avaliação, e por fim, as considerações finais. Cada parte do projeto é explicada detalhadamente como introduzir práticas de inclusão na educação regular e sua importância para a formação cidadã do aluno com necessidades especiais, levando docentes e acadêmicos a fazer uma reflexão mais profunda sobre o tema apresentado e como introduzi-lo no contexto escolar.

\section{REFERENCIAL TEÓRICO}

Para podermos desenvolver esta pesquisa é necessário compreender e refletir criticamente sobre a temática aqui abordada, sendo fundamental explorar diferentes conceitos relacionados a políticas públicas, formação e perfil dos docentes que atuam na 
educação básica, importância da inclusão para o desenvolvimento e aprendizagem dos alunos, entre outros.

A temática da inclusão de alunos com necessidades especiais está diretamente vinculada a diversos setores da sociedade, principalmente à educação, e é por isso que o foco maior é a relação da inclusão do contexto escolar, percebendo até onde a inclusão é de fato inclusiva para esses alunos.

A Educação Inclusiva é um direito garantido e assegurado na forma lei dentro da Constituição Federal (1988), do Estatuto da Criança e do Adolescente (1990), na Declaração Mundial de Educação para Todos (1990), na Declaração de Salamanca (1994) e LDB (1996). Todos esses documentos e legislações destacam que o acesso à educação e direitos das crianças com deficiências e necessidades especiais de ensino, esse direito também é assegurado pela Lei $\mathrm{N}^{\mathrm{0}} 7.853$, de 24 de outubro de 1989, que afirma em seu art. $8^{\circ}$,

Constitui crime punível com reclusão de 1 (um) a 4 (quatro) anos, e multa: I - recusar, suspender, procrastinar, cancelar ou fazer cessar, sem justa causa, a inscrição de aluno em estabelecimento de ensino de qualquer curso ou grau, público ou privado, por motivos derivados da deficiência que porta. [...]

Por muitos séculos as pessoas que tinham algum tipo de deficiência ou necessidade educacional especial foram segregadas e discriminadas, não tendo o direito de frequentar a escola juntos com os alunos ditos "normais", e por conta disso ficou um estigma muito grande em relação a inclusão dessas pessoas na rede regular de ensino. Mesmo com todas as leis existentes que asseguram o acesso e permanência delas na escola, muitos ainda são vítimas de preconceitos e discriminação, justamente por não haver metodologias voltadas para a inclusão coletiva de todos no âmbito escolar.

Nesse sentido, a escola configura-se como sendo o espaço primordial e fundamental da manifestação da diversidade, com isso decorre a necessidade de repensar e defender a escolarização como meio principal para promover a inclusão, reconhecendo a possibilidade e o direito de todos de aprender e desenvolver-se integralmente dentro de suas possibilidades. Sendo assim, o movimento de inclusão traz como premissa central, propiciar a uma educação de qualidade e igualitária para todos, uma vez que, o direito do 
aluno com necessidades educacionais especiais e de todos os cidadãos é ter acesso a uma educação que promova se crescimento e formação cidadã, pois:

Pressupõe, conceitualmente, que todos, sem exceção, devem participar da vida acadêmica, em escolas ditas comuns e nas classes ditas regulares onde deve ser desenvolvido o trabalho pedagógico que sirva a todos, indiscriminadamente (EDLER CARVALHO, 1998).

Mesmo com todos os pressupostos legais, a realidade ainda se apresenta bem diferente da almejada nas leis, as dificuldades são muitas e os desafios a serem superados ainda maiores. Muitos empecilhos impedem que a inclusão dos alunos com necessidades especiais se der de maneira prática, efetiva e de qualidade.

O que se percebe é que há uma grande disparidade entre a legislação e a realidade educacional, uma vez que a inclusão dos alunos que apresentam necessidades educacionais especiais no ensino regular não foi consolidada da forma desejada. A proposta de educação atual vigente ainda não oferece nem garante condições satisfatórias para ser considerada efetivamente inclusiva, ainda, se faz necessária uma maior competência profissional, projetos educacionais mais elaborados, uma maior gama de possibilidades de recursos educacionais à disposição para que a inclusão aconteça na prática.

A Resolução n.2/2001 que instituiu as Diretrizes Nacionais para a Educação Especial na Educação Básica, significou um avanço na perspectiva da universalização e atenção à diversidade existente na sociedade. No que se refere a educação brasileira essa resolução faz a seguinte recomendação, em seu Art. $2^{\circ}$,

Os sistemas de ensino devem matricular todos os alunos, cabendo às escolas organizar-se para o atendimento aos educandos com necessidades educacionais especiais, assegurando as condições necessárias para a educação de qualidade para todos.

Na visão de Mantoan (2003), a Inclusão de alunos com necessidades educacionais especiais é um movimento que tem sido muito discutido por diferentes segmentos da sociedade. Destacando ainda que a inserção desses alunos no sistema regular de ensino nada mais é do que garantir o direito constitucional que todos, independentes de suas necessidades, têm a uma educação de qualidade, e que a Inclusão vai depender da capacidade de saber lidar com a diversidade e as diferenças existentes. 
No tocante a educação inclusiva e inclusão de alunos com necessidades especiais de ensino, a escola se apresenta como sendo a principal instituição que promove essa reformulação de conceitos e concepções. Junto com a escola, o professor é a figura central nesse processo, mas que muitas vezes por falta de uma formação adequada acaba desempenhando esse papel de maneira secundária, o que leva a uma perda muito grande para o aluno no desenvolvimento de sua aprendizagem.

A Educação Inclusiva, em suas diferentes interpretações e modalidades existentes, se constitui hoje como foco principal das políticas públicas educacionais em nível federal, estadual e municipal (FERREIRA; GLAT, 2003). Nessa perspectiva de educação inclusiva, a escola deve se adaptar para atender a todos os alunos, independentemente de suas condições sociais, culturais, comportamentais ou biológicas (UNESCO, 1994).

O debate sobre inclusão escolar de alunos com necessidades educacionais na rede regular de ensino vem tomando proporções significativas e influenciando diretamente o ambiente escolar em todos os seus aspectos. Para compreender o que é inclusão e educação inclusiva, e sua importância é necessária uma conceituação sobre esses termos. Segundo Mantoan, inclusão e educação inclusiva são, respectivamente,

Inclusão é a nossa capacidade de entender e reconhecer o outro e, assim, ter o privilégio de conviver e compartilhar com pessoas diferentes de nós. A educação inclusiva acolhe todas as pessoas, sem exceção. É para o estudante com deficiência física, para os que têm comprometimento mental, para os superdotados, para todas as minorias e para a criança que é discriminada por qualquer outro motivo. Costumo dizer que estar junto é se aglomerar no cinema, no ônibus e até na sala de aula com pessoas que não conhecemos. Já inclusão é estar com, é interagir com o outro (MANTOAN, 2005, p. 24).

Sendo assim, a escola é um o espaço mais importante para o avanço da inclusão social das pessoas com necessidades especiais. Isso porque a diversidade existente no ambiente escolar é fundamental para o enriquecimento das trocas que ocorrem entre os sujeitos ali presentes, pois a interação constante nesse ambiente proporciona trocas sociais, culturais e intelectuais que contribuem para a formação de modo pontual. Todos os tipos de interação imprimem diferentes tipos de aprendizagem na formação dos indivíduos, principalmente das crianças, uma vez que elas se encontram em pleno processo de desenvolvimento e formação. 
A inclusão escolar é a oportunidade para que de fato a criança com necessidades especiais não fique à parte no processo de ensino aprendizagem, realizando atividades meramente condicionadas e sem sentido, apenas para mantê-las na escola. Para que haja a inclusão das crianças com necessidades especiais no processo educativo se faz necessário criar estratégias educativas que possam contemplar as necessidades apresentadas por elas, buscando meios de interligar e alcançar os objetivos traçados, tanto para as crianças com necessidades especiais, como para as sem necessidades. Por isso a importância de uma preparação e motivação dos educadores para se realizar uma educação inclusiva de qualidade voltada para o atendimento e promoção de valores que levem a inclusão de modo efetivo.

O papel do professor é de suma importância na educação inclusiva, visto que o professor é a "autoridade competente, que direciona o processo pedagógico, interfere e cria condições necessárias à apropriação do conhecimento" (GAZIM et. al, 2005, p. 51). Nessa perspectiva, o professor é o mediador entre o aluno, o conhecimento e sua integração a partir de suas especificidades, logo cabe a ele promover situações pedagógicas em que os alunos com necessidades educacionais especiais superem o senso comum e avance em seu potencial humano afetivo, social e intelectual, quebrando as barreiras que se impõem diariamente, superando os desafios que se apresentam dentro e fora da escola.

Um dos fatores primordiais para que a educação inclusiva de alunos com necessidades especiais em salas de aulas regulares dê certo, é que os professores mudem a visão que tem sobre a aprendizagem desses alunos, reconhecendo que eles são capazes de aprender tanto quanto os demais. Para tal, é necessário o constante planejamento e elaboração de atividades que dêem ênfase ao respeito às diferenças e as múltiplas possibilidades de aprendizagem, reconhecendo e estimulando as diferentes inteligências existentes.

Para que isso seja possível de se concretizar na sala de aula, com alunos heterogêneos em suas especificidades, Minetto destaca que,

O professor precisa organizar-se com antecedência, planejar com detalhes as atividades e registrar o que deu certo e depois rever de que modo as coisas poderiam ter sido melhores. É preciso olhar para o 
resultado alcançado e perceber o quanto "todos" os alunos estão se beneficiando das ações educativas (MINETTO, 2008, p. 101).

Dessa forma, os docentes que buscam uma ação educativa de fato inclusiva, devem sempre estar atentos a diversidade existente entre seus alunos, procurando exercer seu papel de maneira justa e solidária, pautado no respeito mútuo, eliminando todo e qualquer tipo de discriminação, visando formar cidadãos conscientes para o convívio com as diferenças que existem na sociedade.

Mesmo com todos os pressupostos expressando a importância de se trabalhar de forma inclusiva, muitos professores ainda encontram enormes desafios e dificuldades para trabalhar atividades nesse viés da educação inclusiva, principalmente em decorrência da necessidade de se trabalhar muitos conteúdos com alunos na rede regular, o que em muitos casos, dificulta a inclusão de todos de maneira igualitária. Isso os obriga a repensar sua maneira de ensinar, sua cultura, sua política e suas estratégias pedagógicas, passando assim, a adotar uma postura reflexiva diante da singularidade e diversidade encontrada na sala de aula. Ao repensar sua postura enquanto docente, o professor interliga conhecimentos e procura desenvolver ações pedagógicas que contemplem a todos em suas potencialidades e especificidades.

Para que a educação Inclusiva aconteça efetivamente é preciso o envolvimento de todos os profissionais da escola, numa tentativa conjunta de promover ações e práticas educativas inclusivas. Possibilitando os alunos com necessidades especiais, práticas educativas voltadas para a inclusão, eles passam a se sentir parte daquele ambiente educacional, percebendo que aceitos e apoiados por seus colegas, professores e demais profissionais da escola.

Dessa forma, os recursos físicos, estruturas e toda a materialidade que auxiliam para o desenvolvimento de um trabalho pedagógico de qualidade, embora muito importantes para a efetivação da inclusão, dão lugar ao desenvolvimento de atitudes inovadoras, de novas formas de atuação e de interação entre alunos, professores e demais funcionários da escola.

Para que isso seja possível é necessário que todos os profissionais diretamente ou indiretamente ligados à educação tenham um novo olhar, buscando construir uma pedagogia centrada no aluno, que por sua vez, suscita a construção de uma sociedade que 
respeite a dignidade e as diferenças existentes entre os indivíduos (STAINBACK \& STAINBACK, 1999).

Por essa e tantas outras razões a educação inclusiva é de extrema relevância de ser prática na contemporaneidade, pois leva os alunos com necessidades especiais a construir uma identidade livre de estigmas e preconceitos, desenvolvendo sua capacidade de aprendizagem baseada no respeito às suas singularidades.

\section{CONSIDERAÇÕES FINAIS}

Com os estudos aqui abordados sobre a Inclusão de alunos com necessidades especiais, foi possível refletir enquanto futuros educadores temos o compromisso e responsabilidade de promover ações com vistas à inclusão. Após realizar estudos sobre a inclusão pude perceber que o processo de inclusão está garantido por lei para todas as crianças, mas que ainda precisa ser realmente efetivado nas instituições através de recursos financeiros e investimentos nessa área seja através dos profissionais que atuam diretamente com as crianças, seja por projetos pedagógicos inclusivos.

Com os autores citados ao longo do projeto, compreendi que nós educadores temos que conhecer a importância da inclusão de crianças com necessidades especiais de maneira efetiva, dando a importância a cada uma delas respeitando as suas especificidades. Compreende também que as crianças em suas diversidades aprendem na interação com as outras e que o educador possui um papel importante para o desenvolvimento do seu potencial, auxiliando em sua formação integral.

Percebi ainda, as importâncias do conhecimento de cada criança que estamos trabalhando para poder trabalhar dentro de suas limitações devem garantir o desenvolvimento de cada criança dentro do seu potencial físico, cognitivo afetivo, garantindo uma inclusão de qualidade de forma que o aluno participe efetivamente das atividades.

\section{REFERÊNCIAS}

ARANHA, Maria Salete Fabio (org.). Educação Inclusiva: a escola. Brasília. Ministério da Educação, Secretaria da Educação Especial, 2006. 
BRASIL. Lei $\mathbf{N}^{\mathbf{0}} \mathbf{7 . 8 5 3}$, de 24 de outubro de 1989. Dispõe sobre o apoio às pessoas portadoras de deficiência, sua integração social, sobre a Coordenadoria Nacional para Integração da Pessoa Portadora de Deficiência (CORDE), institui a tutela jurisdicional de interesses coletivos ou difusos dessas pessoas, disciplina a atuação do Ministério Público, define crimes, e dá outras providências. Diário Oficial da União. 24 out 1989.

EDLER CARVALHO, R. Temas em Educação Especial. Rio de Janeiro: WVA Ed., 1998.

FERREIRA, J. R. e GLAT, R. Reformas educacionais pós-LDB: a inclusão do aluno com necessidades especiais no contexto da municipalização. In: Souza, D. B. \& Faria, L.C.M. (Orgs.). Descentralização, municipalização e financiamento da Educação no Brasil pós-LDB. Rio de Janeiro: DP\&A, 2003. p. 372-390.

GAZIM, E. et al. Tendências pedagógicas brasileiras: contribuições para o debate. Revista Chão da Escola. Curitiba, n. 4, p. 41-52, out. 2005.

MANTOAN, Maria Teresa Égler. "Inclusão é o privilégio de conviver com as diferenças" In: Nova Escola OnLine: o site de quem educa. Edição 182, Maio/2005.

MANTOAN, Maria Teresa Égler. Inclusão escolar: O que é? Por quê? Como se faz? São Paulo: Moderna, 2003.

MINETTO, M. F. O currículo na educação inclusiva: entendendo esse desafio. $2^{\mathrm{a}}$ ed. Curitiba: IBPEX, 2008.

STAINBACk, Susan e Stainback, William (organizadores). Inclusão: um guia para educadores. ARTMED: Porto Alegre, 1999.

UNESCO/Ministério da Educação e Ciência (1994). Relatório Final sobre a Conferência Mundial sobre Necessidades Educativas Especiais: Acesso e Qualidade. Salamanca, Espanha, 7-10, Junho, 1994. 


\title{
CAPÍTULO XIX
}

\section{FORMAÇÃO DOCENTE PARA O USO DAS TECNOLOGIAS DIGITAIS}

\author{
Caroline Rodrigues de Freitas Fernandes ${ }^{61}$; Dayana Lúcia Rodrigues de Freitas ${ }^{62}$; \\ Tiago Santana de Souza ${ }^{63}$; Jaqueline Honorato de Souza ${ }^{64}$; \\ Wiziley de Queiroz Freire ${ }^{65}$; Patrícia Lima do Nascimento ${ }^{66}$; \\ Maria Zilma Batista da Silva ${ }^{67}$; Ana Maria Fonseca de Araújo Medeiros ${ }^{68}$; \\ Lígia Maria da Conceição Santos Silva ${ }^{69}$; Sara Maria Tomaz de Souza Araújo ${ }^{70}$. \\ DOI-Capítulo: 10.47538/AC-2021.14-19
}

RESUMO: A sociedade contemporânea é marcada pelas profundas transformações devido à eclosão das tecnologias digitais. A partir disso, a atividade docente também vem se modificando para atender a essas modificações que atingem principalmente o ambiente escolar, suas concepções e suas formas de construção do saber. O presente artigo trata de uma pesquisa bibliográfica que envolve a formação inicial e continuada do professor para o uso das tecnologias digitais, reconhecendo as novas tecnologias digitais como importante ferramenta para o desenvolvimento da prática docente. Contudo, as ferramentas tecnológicas só produzirão o efeito desejado se os professores se apropriarem dela com intencionalidade pedagógica, tornando-as recursos a favor da aprendizagem e integrando-as aos outros recursos disponíveis e para isso os docentes devem estar conscientes e preparados para este fim, sendo necessário que a formação seja algo constante na vida do professor.

PALAVRAS-CHAVE: Formação de professores. Tecnologias digitais. Avanços tecnológicos.

\section{TEACHER TRAINING FOR THE USE OF DIGITAL TECHNOLOGIES}

ABSTRACT: Contemporary society is marked by profound changes due to the emergence of digital technologies. From this, the teaching activity has also been changing

61Pós-Graduada em Mídias na Educação (UERN). Docente no Município de Macau/RN. Orcid: https://orcid.org/00000002-9198-6746. Lattes: http://lattes.cnpq.br/5956672837215695. E-mail: caroline_brum2005@ hotmail.com. 62Doutoranda em Educação (CECAP). Docente nos Município de Macau/RN e Guamaré/RN. Orcid: https://orcid.org/0000-0001-5355-3547. Lattes: http://lattes.cnpq.br/5122671799874415. E-mail: dayannaproducoes@gmail.com.

63 Graduado em pedagogia -FACESA. Pós-graduando em Alfabetização e Letramento - FAVENI. Mestrando em Ciências da Educação pela FACEM. E-mail: tdetrabalho@ hotmail.com

64 Graduada em Pedagogia pela faculdade UNINTA - Centro Universitário.E-mail: jaquehonorato2016@gmail.com 65 Pedagogo. Professor da Educação Básica. E-mail: wizileyk003@gmail.com

66 Pedagoga. Professora da Educação Básica. E-mail: patricialimapatricia3226@gmail.com

67 Pedagoga. Professora da Educação Básica. E-mail: mariazilmagm@ gmail.com

68 Pedagoga. Professora da Educação Básica. E-mail: Ana.medeirosgmr@gmail.com

69 Graduada em pedagogia - UVA. Pós-graduação em psicopedagogia -FIP. Pós-graduada em Serviço Social no Campo (em andamento) - Universidade Dom Alberto. Professora do município de Guamaré rede privada. E-mail: mariaa.ligia@gmail.com

70 Graduação em Letras-Língua - UERN. Pós-graduação em Metodologia De Ensino Da Língua Portuguesa E Inglesa - Faculdade Futura. Pós-graduação em Metodologia Do Ensino Da Língua Inglesa -Faculdade Futura. Pós-graduação Em Literatura Em Língua Inglesa - FAEL. 2॰ Graduação em Pedagogia - Faculdade Futura (Cursando).E-mail: saratomaz20@hotmail.com 
to meet these changes that affect mainly the school environment, its conceptions and its forms of knowledge construction. This article deals with a bibliographical research that involves the initial and continuing education of teachers for the use of digital technologies, recognizing new digital technologies as an important tool for the development of teaching practice. However, technological tools will only produce the desired effect if teachers appropriate them with pedagogical intentions, making them resources in favor of learning and integrating them with other available resources, and for this, teachers must be aware and prepared for this purpose, it is necessary that training is something constant in the teacher's life.

KEYWORDS: Teacher training. Digital technologies. Technological advancements.

\section{INTRODUÇÃO}

A sociedade contemporânea tem passado por constantes processos de mudanças, sendo uma das marcas mais notáveis dessas mudanças a utilização das tecnologias digitais, presente nas mais diversas áreas da sociedade e da atividade humana, principalmente na área educacional, por ser responsável pela formação dos indivíduos em sua plenitude.

Diante disso, podemos dizer que o uso das tecnologias digitais no ambiente escolar traz como objetivo a possibilidade de integrar os alunos, de contextualizar os conteúdos escolares, permitindo que o aluno perceba as ligações, relações e conexões existentes entre um conteúdo e outro, aumentando a produção do conhecimento.

Esse pensamento nos remete a necessidade da formação de professores para o uso das tecnologias digitais, de modo a contribuir nesses processos de produção do conhecimento e no desenvolvimento intelectual e cultural dos alunos. É preciso compreender que o movimento da formação inicial voltado para o uso das tecnologias digitais deve ter prosseguimento com a formação continuada, uma vez que as tecnologias estão em constante avanço e é preciso estar atualizado quanto às novidades e melhorias que podem ser proporcionadas pelas novidades propostas pela tecnologia.

Com essas novas tecnologias, são exigidas novas formas de aprender, novas competências, novas formas de se realizar o trabalho pedagógico, por tanto, é necessário formar continuamente o professor para atuar neste ambiente telemático, em que a tecnologia serve como mediador do processo ensino-aprendizagem. Deste modo, investir na formação inicial e continuada do professor, representa o fortalecimento da educação, 
permitindo ao professor maior autonomia a partir do uso das tecnologias digitais implementadas em suas práticas pedagógicas.

\section{A FORMAÇÃO INICIAL DO PROFESSOR PARA O USO DAS TECNOLOGIAS DIGITAIS}

Ponderando que as tecnologias digitais têm provocado tantas mudanças na sociedade de modo geral, é necessário que a escola seja redimensionada para atender as demandas atuais. Esse redimensionamento passa primordialmente pela reavaliação do papel do professor, e consequentemente pela formação inicial dos futuros professores.

Os cursos superiores de licenciatura que são o recurso de formação inicial precisam preparar os futuros docentes para o uso eficaz das tecnologias digitais, contribuindo para o desenvolvimento de suas capacidades cognitivas e das aptidões que são requeridas para que se concretize os processos de ensino e de aprendizagem.

A Resolução CNE/CP n ${ }^{\circ}$, de 18 de fevereiro de 2002, que institui as Diretrizes Curriculares Nacionais para a Formação de Professores da Educação Básica, em nível superior, curso de licenciatura, de graduação plena, em suas orientações preconiza no Art. $2^{\circ}$, inciso VI "o uso de tecnologias da informação e da comunicação e de metodologias, estratégias e materiais de apoio inovadores" (BRASIL, 2002).

Complementando, temos nas Diretrizes Curriculares Nacionais para a Formação de Professores da Educação Básica o registro da importância da utilização das tecnologias digitais nos processos de ensino e de aprendizagem. Para tanto, apresenta-se a necessidade de se investir na formação do professor para que este mobilize seus conhecimentos e utilize as tecnologias digitais num processo dialógico, que proporcione a promoção da interação, exploração, colaboração e investigação do conhecimento.

Urge, pois, inserir as diversas tecnologias da informação e das comunicações no desenvolvimento dos cursos de formação de professores, preparando-os para a finalidade mais nobre da educação escolar: a gestão e a definição de referências éticas, científicas e estéticas para a troca e negociação de sentido, que acontece especialmente na interação e no trabalho escolar coletivo. Gerir e referir o sentido será o mais importante e o professor precisará aprender a fazêlo em ambientes reais e virtuais (BRASIL, 2001). 
A formação inicial do professor necessita urgentemente de uma revisão curricular que apresente disciplinas atualizadas, voltadas para o uso das tecnologias da informação e comunicação; um projeto político de curso que contemple o uso das tecnologias, ultrapassando questões operacionais e instrucionais, que visam apenas a aquisição de competências e habilidades para questões que visem a produção de situações pedagógicas que contribuam de fato para melhorar intelectual e culturalmente a formação dos indivíduos e a capacidade de instruí-los e capacitá-los a formar outros.

As tecnologias são tão importantes no processo de formação de professores, quanto a língua materna, as metodologias, a psicologia, a sociologia, e todas as demais áreas que compõem o currículo de uma licenciatura em qualquer área do conhecimento, ou de um curso de formação continuada (BONILLA, 2005, p. 203).

Partindo da compreensão exposta pelo autor, as tecnologias são fundamentais para o pleno exercício do trabalho docente. Portanto, constitui-se o conhecimento nesta área parte fundamental de sua formação, não podendo ser deixada de lado pelas instituições de ensino que tem como missão a formação dos educadores.

Mesmo considerando que a formação inicial é muito importante, ela por si só não é suficiente para atender a demanda educacional que se apresenta em constante mudança diante dos avanços tecnológicos, é preciso que esse processo seja contínuo. Nesta perspectiva, a formação inicial se caracteriza como a obtenção de princípios indispensáveis para a função e a atuação inicial que o futuro professor terá que desempenhar. Em seguida, a formação continuada de professores permitirá ao docente dar continuidade a aquisição de conhecimentos específicos para o desenvolvimento de sua profissão.

\section{A FORMAÇÃO CONTINUADA DO PROFESSOR PARA O USO DAS TECNOLOGIAS DIGITAIS}

As Diretrizes Curriculares Nacionais para a Formação Continuada de Professores da Educação Básica (BRASIL, 2020), afirmam que o professor deve agregar um conjunto de habilidades que somente podem ser estruturadas na vivência e na ação pedagógica cotidiana.

Art. $7^{\circ}$ A Formação Continuada, para que tenha impacto positivo quanto à sua eficácia na melhoria da prática docente, deve atender às 
características de: foco no conhecimento pedagógico do conteúdo; uso de metodologias ativas de aprendizagem; trabalho colaborativo entre pares; duração prolongada da formação e coerência sistêmica (BRASIL, 2020).

Além disso, o documento cita entre as competências gerais necessárias ao docente para exercício pleno de suas atribuições:

5. Compreender, utilizar e criar tecnologias digitais de informação e comunicação de forma crítica, significativa, reflexiva e ética nas diversas práticas docentes, como recurso pedagógico e como ferramenta de formação, para comunicar, acessar e disseminar informações, produzir conhecimentos, resolver problemas e potencializar as aprendizagens (BRASIL, 2020).

Confirmando esse pensamento Nóvoa (2002) diz que a formação continuada está alicerçada na dinamização de projetos de investigação nas escolas, na consolidação do trabalho coletivo e na partilha entre os diversos atores educativos, investindo nas escolas como lugares de formação. Para o autor, a formação não se constrói pelo simples acúmulo de cursos, conhecimentos ou de técnicas, mas a partir de um trabalho reflexivo e crítico sobre as práticas pedagógicas e na reconstrução permanente da identidade docente.

A formação continuada de professores deve ir além da formação técnica e operacional, e assegurar que o professor reflita acerca do uso das tecnologias digitais na e para a democratização da educação. A formação docente nessa perspectiva se torna muito mais abrangente e tende a romper com o modelo instrumentalista difundido pelas políticas públicas.

A formação continuada do professor deve visar alcançar um ambiente inovador e de qualidade, através da inserção das tecnologias digitais nos processos educativos. Segundo Libâneo (2001, p. 10) é preciso uma formação "que o auxilie a ajustar sua didática às novas realidades da sociedade, do conhecimento, do aluno, dos diversos universos culturais". Corroborando com esse pensamento Demo (2008, p. 17) afirma que

Toda proposta que investe na introdução das TICs na escola só pode dar certo passando pelas mãos dos professores. O que transforma tecnologia em aprendizagem, não é a máquina, o programa eletrônico, o software, mas o professor, em especial em sua condição socrática.

Para isso, faz-se necessário que a formação do professor para o uso pedagógico das tecnologias digitais ocorra na ação docente, de forma reflexiva, crítica. Logo, o professor ao se apropriar didática e conscientemente acerca do uso das tecnologias 
digitais na educação estará em condições de propor mudanças nos processos de ensino e de aprendizagem capazes de produzir resultados reais nos alunos, contribuindo para melhorar a qualidade do ensino e formar cidadãos aptos a atuar na sociedade contemporânea de forma ativa e participativa.

A formação de professores constitui-se em um mecanismo para a superação dos desafios educacionais contemporâneos. Desse modo, políticas públicas de formação de professores são fundamentais para se alcançar esse objetivo. Não somente a existência de políticas, mas o incentivo das instituições escolares e o apoio dos gestores em qualificar sua equipe e deixá-los aptos às demandas da atualidade.

Neste contexto, o papel do professor, certamente, terá que passar por um processo de ressignificação, tendo como centro o desenvolvimento cognitivo e cultural do aluno. Isso somente será possível à medida que o professor buscar capacitação visando a melhoria dos processos de ensino e de aprendizagem, modificando sua prática pedagógica com a integração do uso das novas tecnologias digitais ao currículo e a prática diária.

O processo de formação continuada gera condições para o professor construir conhecimento sobre as novas tecnologias, entender por que e como integrar estas ferramentas na sua prática pedagógica, tornando-se capaz de superar limitações administrativas e pedagógicas, possibilitando a transição de um sistema de ensino ultrapassado para uma abordagem integradora voltada para a resolução de problemas específicos do interesse de cada aluno e atualizada com a realidade por eles vivida.

A formação continuada deve ainda criar condições para que o professor saiba recontextualizar o aprendizado e as experiências vividas durante sua formação para aplicar a realidade da sala de aula, compatibilizando com as necessidades de seus alunos e com os objetos pedagógicos que se pretende atingir.

\section{O USO DE TECNOLOGIAS DIGITAIS NA DOCÊNCIA}

Com as Novas Tecnologias da Comunicação e Informação abrem-se novas e infinitas possibilidades à educação, exigindo com isso uma nova postura da educação e do educador. No atual contexto, tanto no âmbito social quanto educacional, já não é mais possível pensar a formação de professores sem a presença das tecnologias digitais, que 
desempenham importante papel no ensino-aprendizagem, uma vez que nossos alunos fazem parte de uma geração que já nasceu conectada à internet.

Deste modo, é importante que o papel do professor no contexto escolar seja revisto, bem como sua formação e sua prática pedagógica para que este perceba a necessidade de melhorar sua prática, transformando-se em agente de mudança e desenvolvimento.

Na formação de professores, é exigido dos professores que saibam incorporar e utilizar as novas tecnologias no processo de aprendizagem, exigindo-se uma nova configuração do processo didático e metodológico tradicionalmente usado em nossas escolas nas quais a função do aluno é a de mero receptor de informações e uma inserção crítica dos envolvidos, formação adequada e propostas de projetos inovadores (MERCADO, 1999, p. 20).

Como se pode perceber, as tecnologias digitais estão cada vez mais presentes na sala de aula, exigindo tanto dos professores quanto dos alunos uma nova relação com o saber e com a aprendizagem. Assim, é imprescindível uma maior atenção para as atuais demandas trazidas pelos alunos, refletindo constantemente sobre a sua ação pedagógica, tendo as tecnologias digitais como uma das possibilidades para a conexão dos processos educativos.

O professor pós-moderno deve estar em sincronia com a contemporaneidade, saber utilizar as tecnologias em prol de um ensino mais eficiente e eficaz, trabalhar em parceria com o aluno e, além de tudo isso, ser consciente de que não é o detentor de todo o conhecimento. Hoje, é necessário ensinar nossos alunos a refletir, questionar, raciocinar e compreender a nossa realidade, para que possam contribuir com a sociedade e construir opiniões próprias. (SILVEIRA, 2012, p. 3).

As tecnologias, portanto, devem fazer parte ativa da vida docente na sociedade contemporânea, gerando a necessidade de ressignificar suas práticas pedagógicas, alinhando-as ao sistema educacional, o que trará inúmeras vantagens, pois o próprio docente terá seus conhecimentos aprimorados e poderá agregá-los construindo uma formação tecnológica atualizada.

As novas tecnologias têm um significativo impacto sobre o papel dos professores, sendo responsável pela reciclagem constante recebida via rede, em termos de conteúdos, métodos e uso da tecnologia, apoiando de um modelo geral no ensino, além disso, torna 
os estudantes participantes ativos do processo de aprendizagem deixando de ser receptores passivos de informações ou conhecimento.

Assim, é urgente que os professores sintam-se coagidos a utilizarem as tecnologias e começarem a reformular suas aulas, encorajando seus alunos a participarem de novas experiências que produzirão maior conhecimento e trarão melhores resultados.

O grande desafio do docente é organizar os processos de forma que seus alunos adquiram as competências necessárias para viver e trabalhar na sociedade da aprendizagem. Para isto é necessário que tenhamos estratégias de formação que impliquem revisão das percepções e sentimentos do professor. E, não se trata apenas de motivação para uso de tecnologias e sim de atuar a partir de um conjunto de crenças adquiridas acerca do potencial destas tecnologias como elemento de diferenciação ou qualificação da sua prática docente e, da certeza que poderá utilizar os recursos de forma customizada às suas necessidades e planejamento (GIRAFFA, 2010, p. 34).

Como descrito, é preciso compreender que o papel da docência é propiciar uma profundidade científico-pedagógica que capacite o educando a enfrentar questões fundamentais da sociedade, portanto, sua prática social deve ser baseada na reflexão e crítica, que resultará em uma aprendizagem significativa.

Partindo desse pressuposto, ao ter acesso às tecnologias da comunicação e informação e sua transformação em conhecimento durante o período escolar, os alunos ao influir naturalmente no uso destas serão posteriormente agentes de mudança. $\mathrm{O}$ uso adequado destas tecnologias estimula a capacidade de desenvolver nesses alunos estratégias de buscas, critérios de seleção e habilidades de processamento de informação. Além disso, em relação à comunicação, as tecnologias estimulam o desenvolvimento de habilidades sociais, a capacidade de comunicação efetiva e coerente, a qualidade da apresentação escrita das ideias, permitindo uma maior autonomia e criatividade.

\section{CONSIDERAÇÕES FINAIS}

No atual contexto educacional, entende-se que já não é mais possível pensar a formação docente sem que seja debatida a utilização das tecnologias digitais a favor do ensino e da aprendizagem, uma vez que os alunos fazem parte de uma geração que já nasceu conectada à internet. Diante disso, evidenciamos que a formação inicial e continuada de professores é de fundamental importância para que este possa acompanhar 
as mudanças que estão ocorrendo na sociedade de modo geral, evitando que a escola não se torne obsoleta e que seu papel como agente de transformação seja inalcançado.

Se espera do professor no século XXI que ele seja ajude a tecer a contextura do desenvolvimento individual e coletivo dos alunos e que saiba manejar os instrumentos que a cultura irá indicar como representativos dos modos de viver e de pensar civilizados, específicos dos novos tempos, no nosso caso, todos os aparatos tecnológicos presentes no dia a dia.

Para isso, ainda são necessárias muitas pesquisas em novas tecnologias da informação, modelos cognitivos, interações entre pares, aprendizagem cooperativa, adequados ao modelo baseado em tecnologia, que oriente a formação de professores no seu desenvolvimento e ofereça parâmetros para a tarefa docente nesta perspectiva seja plenamente desenvolvida e alcance os resultados desejados.

\section{REFERÊNCIAS}

BRASIL. Conselho Nacional de Educação. Parecer CEB n. 09/2001. Diretrizes Curriculares Nacionais a Formação de Professores da Educação Básica, em nível superior, curso de licenciatura, de graduação plena. Brasília, 2001. Disponível em http://portal.mec.gov.br/cne/arquivos/pdf/009.pdf acesso: 15/11/2021

BRASIL. Conselho Nacional de Educação. Resolução CNE/CP No 1, DE 27 DE Outubro de 2020. Diretrizes Curriculares Nacionais para a Formação Continuada de Professores da Educação Básica e institui a Base Nacional Comum para a Formação Continuada de Professores da Educação Básica (BNC-Formação Continuada). Brasília, 2020. Disponível em https://www.in.gov.br/web/dou/-/resolucao-cne/cp-n-1-de-27-deoutubro-de-2020-285609724 acesso: 15/11/2021

BRASIL. Ministério de Educação e do Desporto. Conselho Nacional de Educação/ Conselho Pleno. Resolução CNE/CP 1, de 18 de fevereiro de 2002. Institui diretrizes curriculares 10205 nacionais para a formação de professores da educação básica, em nível superior, curso de licenciatura, de graduação plena. Brasília, DF, 18 fev. 2002. Disponível em: http://portal.mec.gov.br/cne/arquivos/pdf/rcp01_02.pdf . Acesso em: 10/11/2021

BONILLA, Maria Helena Silveira. Escola aprendente: para além da sociedade da informação. Rio de Janeiro: Quartet, 2005

DEMO, Pedro. Educar pela pesquisa. Campinas: Autores Associados, 2002.

GIRAFFA, Lucia. M. M. A Formação de professores para trabalhar com Educação à Distância: requisitos e implicações. Disponível em: <http://www.pucrs.br/edipucrs/erematsul/mesaredonda/resumo_LuciaGiraffax.p df> Acesso em: 10/11/2021 
LIBANEO, J. C. (2001). Buscando a qualidade social do ensino. Libâneo, JC Organização e Gestão da Escola-Teoria e Prática, (p. 53-60).

MERCADO, Luiz Paulo Leopoldo. Formação continuada de professores e novas tecnologias. Maceió: EDUFAL, 1999.

NÓVOA, Antonio. (Coord.). Os professores e sua formação. Lisboa-Portugal: Dom Quixote, 2002.

SILVEIRA, Ada Lúcia. Tecnologias, novos alunos, novos professores? Refletindo sobre o papel do professor na contemporaneidade. In: SEMINÁRIO INTERNACIONAL DE LETRAS - INLETRAS, 12., 2012, Santa Maria, RS. Anais... Pelotas: Unifras, 2012. Disponível em: https://www.unifra.br/eventos/inletras2012/Trabalhos/4668.pdf. Acesso em: 08/11/2021 


\title{
CAPÍTULO XX
}

\section{GIG ECONOMY E OS DIREITOS TRABALHISTAS NO BRASIL}

\author{
Fernanda Aparecida Breder ${ }^{71}$; Juarez Ribeiro de Araújo Júnior ${ }^{72}$. \\ DOI-Capítulo: 10.47538/AC-2021.14-20
}

RESUMO: A falta de proteção para o trabalhador na gig economy se mostra um desafio contemporâneo no Brasil e no mundo, assim o presente estudo objetiva analisar a "economia de bicos", no cenário da Quarta Revolução Industrial. Este trabalho apresenta novos entendimentos acerca do problema da falta de regulação dos trabalhadores por aplicativo, bem como pretende conceituar a gig economy e os direitos trabalhistas, além de investigar a divisão do trabalho e seu conceito histórico. A pesquisa foi realizada através de revisão de literatura, foi buscado no ordenamento jurídico nacional e em legislações internacionais, correntes doutrinárias, jurisprudências e julgados acerca do tema. Verificou-se que os ordenamentos jurídicos internacionais da Itália e Espanha não reconhecem o vínculo empregatício dos trabalhadores na gig economy, o que acontece de maneira análoga no Brasil, porém, a jurisprudência nacional e internacional desses países já reconheceu em alguns casos concretos o vínculo empregatício de alguns trabalhadores nessa modalidade. Entretanto, no Reino Unido, os motoristas de aplicativo Uber, são enquadrados na categoria workers possuindo acesso ao pagamento de saláriomínimo por hora, férias remuneradas e contribuições à previdência. A partir desses resultados conclui-se que, não há no Brasil um entendimento consolidado acerca do vínculo empregatício dos trabalhadores na gig economy, o que demonstra ser um grande desafio em escala global, pois esses trabalhadores ficam sem acesso aos principais Direitos Trabalhistas.

PALAVRAS-CHAVE: Gig economy. Direitos Trabalhistas. Vínculo empregatício.

\section{GIG ECONOMY AND LABOR RIGHTS IN BRAZIL}

ABSTRACT: The lack of protection for workers in the gig economy is a contemporary challenge in Brazil and in the world, so this study aims to analyze the "economy of nozzles", in the scenario of the Fourth Industrial Revolution. This paper presents new understandings about the problem of the lack of regulation of workers per application, as well as intends to conceptualize the gig economy and labor rights, in addition to investigating the division of labor and its historical concept. It was found that the international legal systems of Italy and Spain do not recognize the employment link of workers in the gig economy, which happens in a similar way in Brazil, however, the national and international jurisprudence of these countries has already recognized in some concrete cases the employment relationship of some workers in this modality. However, in the UK, Uber app drivers fall into the workers category with access to minimum wage pay per hour, paid leave and pension contributions. From these results, it is concluded that there is no consolidated understanding in Brazil about the employment relationship

\footnotetext{
${ }^{71}$ Graduada em Direito pela Faculdades Associadas de Ariquemes FAAR. nandabreder7@ gmail.com

${ }^{72}$ Pós-Graduado em Direito Tributário pela Faculdade de educação à distância de Coronel Fabriciano, Minas Gerais. juarezribeiroadv@gmail.com
} 
of workers in the gig economy, which proves to be a great challenge on a global scale, because these workers are without access to the main Labor Rights.

KEYWORDS: Gig economy. Labor rights. Employment relationship.

\section{INTRODUÇÃO}

A gig economy surge no século XXI, após a crise econômica mundial de 2008, com o nome de sharing economy ou economia de compartilhamento, que se configurava pela troca informal de produtos e tarefas, sendo mediadas por tecnologia digital. Outrossim, a essência primordial da economia de compartilhamento era a solidariedade entre os mais vulneráveis e a redução do consumismo (SLEE, 2017).

Entretanto, a economia de compartilhamento se transforma, cedendo lugar a busca exacerbada pelo lucro e irresponsabilidade social. Dessa forma, emerge a gig economy ou economia de bicos como é popularmente conhecida no Brasil, podendo ser entendida como o trabalho sob demanda ou temporário que é mediado por plataformas digitais. Nota-se que há uma tendência de flexibilização do trabalho na era digital (SLEE, 2017).

A gig economy, inicialmente, demonstrou-se como solução para a crise econômica e o desemprego, mas verdadeiramente acarretou trabalhos informais, violação de direitos trabalhistas, trabalho precário, barato e inseguro, o que aumentou ainda mais as desigualdades sociais. Além disso, as empresas por trás das plataformas alegam que são apenas empresas de tecnologia, sendo apenas intermediárias dos serviços oferecidos, dessa maneira transferem todo risco do empreendimento para o trabalhador, o que viola princípio da teoria do risco do empreendimento (SLEE, 2017).

Consequentemente, no Brasil, no ano de 2021, constatou-se que 40,8\% da população economicamente ativa, encontra-se na informalidade, segundo o Instituto Brasileiro de Geografia e Estatística (IBGE), em Pesquisa Nacional por Amostra de Domicílios Contínua (PNAD Contínua). Logo, a pesquisa retrata um grave problema social e econômico que se contrapõe aos direitos sociais trabalhistas, amparados pela Constituição Federal de 1988.

Ademais, as crises sanitária, econômica e política ocasionadas pela pandemia do Covid-19, de acordo com Organização Mundial do Trabalho (OIT), trouxeram um cenário alarmante para os países advindos da América Latina, especialmente para o Brasil, uma vez que, segundo noticiado pela OIT, em maio de 2020, $80 \%$ dos 
trabalhadores informais sofreram redução em sua renda. Em decorrência disso, entregadores e motoristas informais de aplicativos foram uma das categorias que mais se afligiam com a pandemia, em virtude da insegurança, do risco de contaminação, da redução dos ganhos e da ausência de legislação protetiva.

Portanto, entendendo a importância do trabalho para os indivíduos e o quanto o trabalho informal por aplicativo constitui um desafio contemporâneo em nível global para a sociedade e para o Direito do Trabalho, pela ausência de regulação, foi decidido realizar o presente trabalho.

\section{DIVISÃO DO TRABALHO E EVOLUÇÃO HISTÓRICA}

É necessário um exame sobre a evolução histórica da divisão do trabalho para um melhor entendimento acerca de sua influência sobre os direitos trabalhistas, bem como sobre a gig economy.

Em primeiro lugar, é importante destacar que a história da humanidade é fortemente marcada pelas mudanças na organização do trabalho, como por exemplo: a antiguidade é evidenciada pela escravidão; a idade média, caracterizada pela servidão; a idade moderna, sendo sinalizada pela transição do feudalismo para o capitalismo, assim como pelo "trabalho livre e independente"; a idade contemporânea, evidenciada pelo capitalismo e pelo trabalho assalariado (MAIOR, 2017).

De acordo com Francisco de Assis Barbosa Júnior, juiz do trabalho e professor de Direito, a Primeira Revolução Industrial se iniciou na Inglaterra, em 1760, nessa época, a forma de produção deixou de ser manual e passou a ser industrial com a utilização de máquinas a vapor. Ademais, nessa fase ocorreram mudanças significativas, a saber: nos meios de comunicação, nas estradas, na navegação, o que impulsionou o comércio. Além disso, a fase marcou o período de êxodo rural, ou seja, os camponeses deixaram o campo rumo às cidades (BARBOSA JÚNIOR, 2019).

Segundo Hobsbawm (1977) apud Proni (2006), a Revolução Industrial ocorrida nos séculos XVIII e XIX, transformou a organização do trabalho. Assim, na nova organização, a máquina substitui o trabalho manual, bem como no novo regime, foi utilizada mão de obra infantil e de mulheres. Ademais, as jornadas de trabalho 
aumentaram e passaram a ser exaustivas; os salários se mostraram insuficientes para o pagamento das despesas com alimentação, moradia e os ambientes de trabalho insalubres e perigosos.

Nota-se que mesmo com a industrialização, ainda não existia a regulamentação do trabalho e nem sequer o estabelecimento de condições mínimas para realizá-lo. Sendo assim, foi nessa fase que o Direito do Trabalho começou a ser formado com a edição da Lei de Peel, na Inglaterra, que proibia a admissão de menores de 10 (dez) anos e visava reduzir a exploração do trabalho de crianças e mulheres (CASTRO, 2013).

Na Segunda Revolução Industrial, iniciada na metade do século XIX, destaca-se a utilização do aço e eletricidade, também nessa fase se evidenciou o avanço da química e comunicação, bem como a utilização do petróleo (DATHEIN, 2004 apud CARA, 2019).

No mesmo sentido, é importante ressaltar que foi durante a Segunda Revolução Industrial que surgiu o modelo de gestão taylorismo, no século XIX, através de observações em uma fábrica, Frederick Winslow Taylor propôs a adoção de um método de organização através de linha de montagem. Com efeito, havia a especialização do trabalho, uma vez que o trabalhador era encarregado de uma única tarefa específica (VIDAL, 2002).

Outrossim, o modelo do taylorismo, demonstrou ser um causador de adoecimento dos trabalhadores pela própria organização do trabalho, sendo extremamente automático, monitorador, rotineiro e com movimentos repetitivos em uma linha de montagem. De acordo com Beynon (1995) apud Lapis e Merlo (2007), os operários nas fábricas viviam um sofrimento psíquico e físico.

Na fábrica 'taylorista', mesmo enriquecida com o conhecimento toda complexidade expressa pela abordagem sistêmica, o ser humano entrou 'caricaturizado' porque não foi assumido como pessoa (sujeito), mas como um conjunto de atributos articulados de modo complexo, a serem manipulados em função de valores oriundos de sua relação direta com as tarefas a ele designadas ou ao nível hierárquico do poder. Esta concepção predominou até os anos 70 (MOTTA, 1995 apud CARDOSO et al, 2007, p. 3).

Para Klaus Martin Schwab, economista alemão, a Terceira Revolução Industrial é conhecida como revolução digital ou do computador, tendo surgido no início da década 
de 60, com a computação mainframe. Além disso, as décadas de 70 e 80 , foram marcadas pelo computador pessoal, já na década de 90, pela internet (SCHWAB, 2019).

Ainda, de acordo com Singer (1999), algumas das consequências da Terceira Revolução Industrial foram: desemprego; a substituição da mão de obra humana pelo computador; redução no número de trabalhadores, embora tenha aumentado a produção e consumo de bens e serviços; propagação no autosserviço, em decorrência do avanço tecnológico, o que possibilitou alguns serviços serem executados pelo próprio cliente.

Enfim, a Quarta Revolução Industrial ou Indústria 4.0, é caracterizada pela internet que está presente em quase todos cantos do planeta pelas inúmeras transformações tecnológicas e inovações. Igualmente, pela integração do mundo físico e virtual, onde trabalhadores e robôs executam tarefas paralelamente. Dessa forma, os mecanismos tecnológicos alteram a organização do trabalho e reduzem a demanda de trabalhadores (PIRES, 2018; SCHWAB, 2019).

Para Magalhães e Vendramini (2018), estudos futuros apontam que os efeitos da Quarta Revolução Industrial ocasionaram queda de 35\% (trinta e cinco) por cento a 47\% (quarenta e sete) por cento, dos empregos em duas décadas. Além disso, a tecnologia substituirá não somente a mão de obra industrial, mas atingirá também setores, por exemplo: "escritórios de advocacia, instituições financeiras, corretoras de imóveis e agências de viagem', o que afetará diretamente a classe média. Entretanto, o trabalho criativo, a inovação e o empreendedorismo, servirão por algum tempo para englobar os trabalhadores sem emprego.

\section{CONCEITO DE GIG ECONOMY}

A gig economy ou economia de compartilhamento, é um modelo de negócio que utiliza a internet como meio para interligar consumidores e fornecedores, tendo como exemplo: a Uber, Airbnb, iFood, Rappi e Lifty.

De acordo com Ricardo Abramovay, professor da USP, no Brasil, a gig economy é mais conhecida como a "economia de bicos" (SLEE, 2017).

Para Adrian John Hawley, doutorando da Universidade de Londres, não há uma definição precisa na literatura para definir a gig economy, mas pode ser entendida como 
o trabalho realizado por trabalhadores individuais, sendo conectados por um smartphone ou aplicativo ou por meio de plataformas digitais. As atividades na gig economy vão desde as tarefas mais simples e repetitivas, como também, tarefas mais complexas e ainda serviços de entrega ou transporte (HAWLEY, 2018).

Segundo Tom Slee, a gig economy ganhou força no ano de 2008, após a crise econômica mundial, assim, em meio a altas taxas de desemprego surgiu a econômica de compartilhamento. Ainda, observa-se que foi marcada pela restrição de direitos assegurados pela Consolidação das Leis Trabalhistas (CLT) e por grande contrataste com os direitos trabalhistas (SLEE, 2017).

A Uber, por exemplo, foi criada por Travis Kalanick e é considerada, atualmente, uma das maiores referências no segmento de plataforma digital, gerenciada por uma empresa de tecnologia. Diferentemente dos táxis que necessitam respeitar a legislação e cumprirem com seus deveres legais, a Uber atua numa atmosfera informal (SLEE, 2017).

Na visão do professor de Direito do Trabalho na Bélgica, Valerio De Stefano, as plataformas na gig economy tem o poder de interligar várias organizações e indivíduos por meio da internet. Assim, na gig economy, a oferta e demanda de trabalhos são acordadas online ou por meio das plataformas digitais (STEFANO, 2015).

No entanto, de acordo com Burtch, Carnahan e Greenwood (2016), a gig economy se tornou uma opção para os desempregados e subempregados se recolocarem no mercado de trabalho. Além disso, a atividade por meio de plataforma possibilitou que indivíduos tivessem uma atividade empreendedora.

Ainda, segundo Hawley (2018), os trabalhadores na gig economy não possuem acesso aos direitos trabalhistas oferecidos pelo Estado, geralmente não recebem sequer o salário mínimo nacional. Ademais, os trabalhadores podem ser "desativados" a qualquer instante pelo próprio meio digital.

Portanto, faz-se necessário conhecer os direitos trabalhistas no Brasil, bem como os impactos exercidos pela gig economy sobre estes.

\section{DOS DIREITOS TRABALHISTAS}


O Direito ao trabalho é considerado um “direito mínimo indispensável”, sendo elencado na Declaração dos Direitos Humanos, de 1948, com status de direito social. Do mesmo modo, está disposto na Constituição da República Federativa do Brasil de 1988, em seu artigo $1^{\circ}$, inciso IV, sendo consagrado como princípio fundamental da República Federativa. Outrossim, é definido como direito social com previsão no artigo $6^{\circ}$, da CRF/1988 (MAIOR, 2017).

A Constituição Cidadã de 1988 , no artigo $7^{\circ}$, traz um rol exemplificativo de direitos trabalhistas, assim, podendo ser estendido a fim de trazer "melhoria da condição social” do trabalhador (BRASIL, 1988).

Dessa forma, dentre o rol de direitos trabalhistas previstos na Constituição Federal de 1988, destacam-se como mais relevantes para os trabalhadores na gig economy:

Art. $7^{\circ}$ São direitos dos trabalhadores urbanos e rurais, além de outros que visem à melhoria de sua condição social:

I - relação de emprego protegida contra despedida arbitrária ou sem justa causa, nos termos de lei complementar, que preverá indenização compensatória, dentre outros direitos;

II - seguro-desemprego, em caso de desemprego involuntário;

III - fundo de garantia do tempo de serviço;

IV - salário mínimo, fixado em lei, nacionalmente unificado, capaz de atender a suas necessidades vitais básicas e às de sua família com moradia, alimentação, educação, saúde, lazer, vestuário, higiene, transporte e previdência social, com reajustes periódicos que the preservem o poder aquisitivo, sendo vedada sua vinculação para qualquer fim;

VI - irredutibilidade do salário, salvo o disposto em convenção ou acordo coletivo;

VII - garantia de salário, nunca inferior ao mínimo, para os que percebem remuneração variável;

VIII - décimo terceiro salário com base na remuneração integral ou no valor da aposentadoria;

IX - remuneração do trabalho noturno superior à do diurno;

XIII - duração do trabalho normal não superior a oito horas diárias e quarenta e quatro semanais, facultada a compensação de horários e a redução da jornada, mediante acordo ou convenção coletiva de trabalho;

$\mathrm{XV}$ - repouso semanal remunerado, preferencialmente aos domingos;

XVI - remuneração do serviço extraordinário superior, no mínimo, em cinqüenta por cento à do normal; 
XVII - gozo de férias anuais remuneradas com, pelo menos, um terço a mais do que o salário normal;

XVIII - licença à gestante, sem prejuízo do emprego e do salário, com a duração de cento e vinte dias;

XIX - licença-paternidade, nos termos fixados em lei;

XXI - aviso prévio proporcional ao tempo de serviço, sendo no mínimo de trinta dias, nos termos da lei;

XXII - redução dos riscos inerentes ao trabalho, por meio de normas de saúde, higiene e segurança;

XXIII - adicional de remuneração para as atividades penosas, insalubres ou perigosas, na forma da lei;

XXIV - aposentadoria;

XXVIII - seguro contra acidentes de trabalho, a cargo do empregador, sem excluir a indenização a que este está obrigado, quando incorrer em dolo ou culpa; (BRASIL, 1988, p. 6-8).

Outrossim, observa-se que os trabalhadores em nível internacional contam também com a Organização Internacional do Trabalho (OIT), fundada em 1919, que visa a promoção de oportunidades para que homens e mulheres tenham acesso ao trabalho "em condições de liberdade, equidade, segurança e dignidade". Além disso, a OIT objetiva promover o seguinte: estabelecer normas e princípios, bem como direitos fundamentais trabalhistas; criar mais oportunidades de emprego e renda; "melhorar a cobertura e a eficácia da proteção social para todos" e também fortalecer o diálogo entre Estado, empregador e trabalhador (ORGANIZAÇÃO INTERNACIONAL DO TRABALHO, 1919).

Entretanto, para Guy Standing, professor da Universidade de Londres, existe um grande número de indivíduos que não possuem sequer direitos trabalhistas, sendo considerados não-cidadãos pelos países que os empregam. Portanto, estando englobados nesse grupo os empregados temporários; os trabalhadores que possuem baixa renda e os que não possuem oportunidades mínimas (STANDING, 2013).

\section{GIG ECONOMY E O ENTENDIMENTO JURISPRUDENCIAL COMPARADO}

A gig economy é um fenômeno novo e, assim como no Brasil, muitos países não possuem regulação, por este motivo pretende-se verificar a legislação e jurisprudência de outros países. 
De acordo com Pitas e Bellon (2021) apud Vaclavik, Oltramari e Oliveira (2021), No Reino Unido, em 2021, os trabalhadores do Uber alcançaram uma grande conquista, pois a empresa reclassificou os mais de 70 (setenta) mil motoristas que operam pela plataforma como workers (uma categoria intermediária de trabalhadores que ficam entre empregado e autônomo). Além disso, os trabalhadores terão como garantia "pagamento de salário-mínimo por hora, férias remuneradas e contribuições à previdência”.

No entanto, esse direito conquistado pelos trabalhadores do Uber, no Reino Unido, demorou cerca de 5 (cinco) anos para ser efetivado, tendo em vista que dois motoristas ingressaram judicialmente, pleiteando o reconhecimento do vínculo e demais direitos trabalhistas, no ano de 2016 (VACLAVIK; OLTRAMARI; OLIVEIRA, 2021). Contudo, a Uber alegava em sua defesa que esses indivíduos eram autônomos, bem como que a empresa atuava no ramo de tecnologia e não de transporte. Porém, a Uber perdeu em todas as instâncias (BARBOSA JUNIOR, 2021).

Na Itália, também não há regulamentação para os trabalhadores na gig economy, mas ocorre que em novembro de 2020, o ordenamento jurídico italiano reconheceu o vínculo empregatício de um entregador de comida da plataforma Glovo, que foi demitido por meio digital. De acordo com a juíza do trabalho Paola Marino, o trabalhador tinha um emprego permanente, portanto deveria receber a diferença de remuneração de um trabalhador autônomo para o de um trabalhador por prazo indeterminado, bem como os demais direitos estabelecidos em lei (BARBOSA JUNIOR, 2021).

Para Oliveira (2021), as legislações italianas, espanhola e portuguesa, reconhecem os trabalhadores na gig economy como autônomos. Dessa forma, encontram grandes desafios para oferecer-lhes melhores condições de trabalho, o que leva a refletir sobre a necessidade de criação de uma legislação protetiva, tendo em conta as péssimas condições de trabalho oferecidas como: "ausência de água, ausência de local para descanso, ausência de local para refeição, exposição ao risco de acidente e de contágio à diversos vírus".

Entretanto, em 23 de setembro de 2020, segundo Tecundo (2020) apud Barbosa Junior (2021), a plataforma Glovo, na Espanha, foi compelida a reconhecer o vínculo empregatício de todos os trabalhadores da plataforma. Segundo a Suprema Corte 
Espanhola, a empresa não pode ser considerada apenas mera intermediadora, uma vez que tem o controle absoluto sobre o aplicativo e é quem estipula as condições de trabalho.

\section{A GIG ECONOMY NO ORDENAMENTO JURÍDICO BRASILEIRO}

Ao analisar a jurisprudência dos Tribunais Regionais do Trabalho e julgados, no Brasil, observa-se que não há entendimento consolidado acerca do reconhecimento de vínculo empregatício entre os trabalhadores na gig economy. Entretanto, o Superior Tribunal de Justiça (STJ), já determinou que ações envolvendo motoristas de aplicativos Uber devem ser ajuizadas na Justiça Estadual, pois a relação entre os motoristas e a plataforma não configura uma relação de emprego (BRASIL, 2019).

No mesmo sentido, a Quarta Turma do Tribunal Superior do Trabalho (TST), no acórdão referente ao Agravo De Instrumento em Recurso De Revista, No TST-RR-1055554.2019.5.03.0179, publicado 05 de março de 2021, decidiu que não há vínculo empregatício entre o motorista do aplicativo e a Uber, pois carece do requisito subordinação, assim, falta um dos requisitos ensejadores da relação de emprego (BRASIL, 2021).

Contudo, a $2^{\mathrm{a}}$ Vara do Trabalho de Pìracicaba/SP, prolatou sentença no processo 0010669-19.2020.5.15.0051, reconhecendo o vínculo de emprego de um motorista com a Uber. Além disso, na fundamentação a juíza Bruna Muller Stravinski alegou que a Uber somente existe em virtude dos seus trabalhadores, ainda não podendo ser definida como mera intermediária entre o motorista e o usuário dos serviços, tais como as plataformas "Airbnb e Hoteis.com.". Ademais, foi argumentado que a empresa utiliza sua tecnologia em prol de desenvolvimento da sua atividade econômica de forma unilateral e é quem controla a escolha do motorista; estabelece as tarifas cobradas; emite nota fiscal, e quem faz a ligação entre motorista e o usuário do serviço. Portanto, não há que se falar em simples intermediação, uma vez que a Uber exerce o controle exclusivo (BRASIL, 2020).

De acordo com Ricardo Senra da BBC News Brasil, com o reconhecimento dos trabalhadores do Uber como workers, no Reino Unido, como observado no tópico 5, a empresa transformou sua derrota judicial em uma estratégia de marketing, pois passou a divulgar outdoors informando que a Uber ofereceria "salário mínimo, férias remuneradas, aposentadoria, licenças maternidade e paternidade". Entretanto, de acordo com o Ministro 
Guilherme Caputo, no Brasil, essa decisão não deve repercutir, tendo em vista se tratarem de ordenamentos jurídicos distintos (SENRA, 2021).

\section{CONSIDERAÇÕES FINAIS}

O desenvolvimento do presente estudo possibilitou uma análise de como a gig economy afeta os direitos trabalhistas dos indivíduos nas novas formas de trabalho, no contexto da Quarta Revolução Industrial ou Indústria 4.0.

Além disso, considera-se que o presente estudo apresenta a tentativa de compreender o fenômeno da gig economy no Brasil e suas implicações para o Direito do Trabalho, bem como para a sociedade. Nesse sentido, foi estudada a divisão do trabalho e evolução histórica, conceituada a gig economy e direitos trabalhistas, bem como foram pesquisadas jurisprudências, julgados e correntes doutrinárias acerca do assunto no Brasil e no mundo. Entende-se que o presente artigo apresentou algumas lacunas, mas que os objetivos do estudo, assim como a pergunta norteadora, foram esclarecidos, porém, não há pretensão de se esgotar a temática.

Ademais, no decorrer do artigo constatou-se que no Brasil, assim como em diversos países, não há um entendimento consolidado acerca dos trabalhadores na "economia de bicos", o que afeta diretamente esses indivíduos, pois esses deixam de acessar os direitos trabalhistas sociais fundamentais, promulgados no artigo $7^{\circ}$ da Constituição Federal de 1988, bem como ficam sem acesso às demais proteções trabalhistas em âmbito nacional e internacional.

Entretanto, como solução ao enfrentamento do problema da falta de regulação dos trabalhadores na gig economy, ao examinar o direito comparado, no Reino Unido, foi criado uma nova modalidade de trabalhador que fica entre autônomo e empregado, os "workers", a fim de garantir as condições mínimas de proteção trabalhista. Ainda, mesmo que seja um ordenamento jurídico diferente, foi encontrada uma nova forma de se pensar o fenômeno da gig economy.

Por fim, em virtude da relevância do Direito do Trabalho para sociedade, bem como pela intensificação do fenômeno da gig economy no país e em todo globo, sugere- 
se que estudos posteriores sejam realizados a fim de enfrentar o problema da falta de regulação e das condições precarizadas dos trabalhadores na gig economy.

\section{REFERÊNCIAS}

BARBOSA JÚNIOR, Francisco de Assis. Gig Economy e Contrato de Emprego. São Paulo: LTr, 2019. Disponível em: <https://www.amazon.com.br/Economy-ContratoEmprego-Francisco-Barbosa/dp/8536199946/ref=asc_df_8536199946/?tag=googl eshopp00-0\&linkCode $=$ df0\&hvadid=379749322006\&hvpos $=\&$ hvnetw $=$ g \&hvrand $=15181196253694368335 \&$ hvpone $=\&$ hvptwo $=\&$ hvqmt $=\&$ hvdev $=\mathrm{c} \&$ hvdvcmdl $=\&$ hvlo cint $=\&$ hvlocphy $=1031452 \&$ hvtargid $=$ pla-812340615783\&psc $=1>$ Acesso em: $10 \mathrm{de}$ ago. 2020.

BARBOSA JÚNIOR, Francisco de Assis. Gig Economy e Contrato de Emprego. 2.ed. São Paulo: LTr, 2021.

BRASIL. Constituição da República Federativa do Brasil, de 5 de outubro de 1988. Institui a Constituição da República Federativa do Brasil. Diário Oficial da União, Brasília, 5 out. 1988. Disponível em: < http://www.planalto.gov.br/ccivil _03/constituicao/constituicao.htm> Acesso em: 09 de ago. 2020.

Superior Tribunal de Justiça. Conflito de competência. CC 0079952. Rel. Ministro Moura Ribeiro. Jusbrasil, Salvador, Ano 2019. Disponível em: < https://stj.jusbrasil.com.br/jurisprudencia/859430549/conflito-de-competencia-cc164544-mg-2019-0079952-0/inteiro-teor-859430559?ref=serp> Acesso em: 20 de out. 2021.

Tribunal Regional do Trabalho (15. Região). Sentença do juízo a quo da $2^{\mathbf{a}}$ Vara de Piracicaba/SP, processo no 0010669-19.2020.5.15.005. Juíza Bruna Muller Stravinski. Jusbrasil, Salvador, Ano 2020. Disponível em: $<$ https://www.jusbrasil.com.br/diarios/1153955478/trt-15-judiciario-28-10-2021-pg15265>. Acesso em: 20 de out. 2021.

Tribunal Superior do Trabalho (8. Turma). Acordão do AIRR do processo 10555-54.2019.5.03.0179. Rel. Ministra Dora Maria da Costa. Jusbrasil, Salvador, Ano 2021. Disponível em: < https://www.jusbrasil.com.br/processos/211958462/processo-n0011199-4720175030185-do-tst>. Acesso em: 20 de out. 2021.

BURTCH, G.; CARNAHAN, S.; GREENWOOD, B. N. Can You Gig It? Na Empirical Examination of the Gig-Economy and Entrepreneurial Activity. Ross School of Business Paper, Minneapolis, n. 1308, março 2016. Disponível em:< https://papers.ssrn.com/sol3/papers.cfm?abstract_id=2744352> Acesso em: 20 de out. 2020.

CARA, Marcelo Henrique Martins. Quarta Revolução Industrial: Um estudo bibliográfico da indústria 4.0 e suas principais tecnologias inseridas. 2019. 47f. Monografia (Graduação) - Universidade Federal de Juiz de Fora, Curso de Graduação em Engenharia de Produção. Disponível em: < https://www.ufjf.br/engenhariadeproducao/files/2017/11/marcelohenriquemartinscara.p df> Acesso em: 10 de ago. 2020. 
CARDOSO, Marco Antônio Fernandes et al. Taylorismo Globalizado: Um estudo do setor industrial de telecomunicações. In: I ENCONTRO DE GESTÃO DE PESSOAS E RELAÇÕES DE TRABALHO, 13 a 15 de jun., 2007, Natal - RN. Anais... Natal: Associação Nacional de Pós-Graduação e Pesquisa em Administração, 2007. Disponível em: < http://www.anpad.org.br/admin/pdf/ENGPR435.pdf> Acesso em: 15 de ago. 2020.

CASTRO, Bruna Rafaely Lotife. A Evolução histórica do Direito do Trabalho no Mundo e no Brasil. JUSBRASIL, Fortaleza. 2013. Disponível em: $<$ https://brunnalotife.jusbrasil.com.br/artigos/111925458/a-evolucao-historica-dodireito-do-trabalho-no-mundo-e-no-brasil> Acesso em: 10 de ago. 2020.

HAWLEY, Adrian John. Regulating labour platforms. European Journal of Government and Economics, Londres, abril/mai. 2018. Disponível em: < https://revistas.udc.es/index.php/ejge/article/view/ejge.2018.7.1.4330/pdf> Acesso em: 20 de ago. 2020.

INSTITUTO BRASILEIRO DE GEOGRAFIA E ESTATÍSTICA. Desemprego cai para $11,8 \%$ com informalidade atingindo maior nível da série histórica: apresentação. Rio de Janeiro, 2019. Disponível em: <https://censo2021.ibge.gov.br/2012-agencia-de-noticias/noticias/25534-desempregocai-para-11-8-com-informalidade-atingindo-maior-nivel-da-serie historica.html > Acesso em: 10 de ago. 2020.

LAPIS, Naira Lima; MERLO, Álvaro Roberto Crespo. A saúde e os processos de trabalho no capitalismo: reflexões na interface da psicodinâmica do trabalho e da sociologia do trabalho. Psicologia \& Sociedade, Porto Alegre, v.19, n.1, janeiro/abr. 2007. Disponível em: <https://www.scielo.br/scielo.php?script=sci_arttext\&pid=S0102-718220070001 00009> Acesso em: 15 de ago. 2020.

MAGALHÃES, Regina; VENDRAMINI, Annelise. Os impactos da Quarta Revolução Industrial: $O$ Brasil será uma potência sustentável com condições de capturar as oportunidades que surgem com as mudanças econômicas, ambientais, sociais e éticas provocadas pelas novas tecnologias?, São Paulo, v.17, n.1, janeiro/fev. 2018. Disponível em: < https://bibliotecadigital.fgv.br/dspace/bitstream/handle/10438/26904/ 74093-153852-1-PB.pdf> Acesso em: 20 de ago. 2020.

MAIOR, Jorge Luiz Souto. História do Direito do Trabalho no Brasil. São Paulo: LTr, 2017. Disponível em: <https://www.amazon.com.br/dp/B06XXYGJHK/ref=rdr_ kindle_ext_tmb> Acesso em: 20 de ago. 2020.

MARINGONI, Gilberto. A longa jornada dos direitos trabalhistas. Revista de Informações e Debates do Instituto de Pesquisa Econômica Aplicada, São Paulo, ano 10, ed. 76, fevereiro 2013. Disponível em: < https://www.ipea.gov.br/desafios/index.php ?option=com_content $\&$ view=article $\&$ id=2909: catid=28\&Itemid=23> Acesso em: 20 de ago. 2020.

MATTOS, Miguel Ragone de. Trabalhadores urbanos e domésticos: a constituição federal e sua assimetria. Revista Estudos Feministas, Florianópolis, v.17, n.3, setembro/out. 2009. Disponível em: <https://www.scielo.br/scielo.php?pid=S0104026X2009000300015\&script=sci_arttext\&tlng=pt> Acesso em: 01 de nov. 2020. 
OLIVEIRA, Flora. A atividade legislativa sobre Gig Economy e sua importância para o mundo do Trabalho pós pandemia. Revista Espaço Acadêmico, Recife, ano 20, ed. Especial, abril 2021. Disponível em: <https://periodicos.uem.br/ojs/index.php/Espaco Academico/ article/ view/58124/751375151849>. Acesso em: 19 de out. 2021.

ORGANIZAÇÃO INTERNACIONAL DO TRABALHO. Conheça a OIT: apresentação. Brasília, 1919. Disponível em: < https://www.ilo.org/brasilia/conheca-aoit/lang--pt/index.htm> Acesso em: 22 de nov. 2020.

ORGANIZAÇÃO INTERNACIONAL DO TRABALHO. Perda maciça de renda afeta 90\% dos trabalhadores informais na América Latina e no Caribe: apresentação. Brasília, 2020. Disponível em: < https://www.ilo.org/brasilia/noticias/WCMS_744304/ lang--pt/index.htm> Acesso em: 10 de ago. 2020.

PIRES, Marcos Cordeiro. O Brasil, o Mundo e a Quarta Revolução Industrial: reflexões sobre os impactos econômicos e sociais. Revista de Economia Política e História Econômica, São Paulo, ano 14, n.40, julho 2018. Disponível em: < https://www.researchgate.net/profile/Manjula-Jain/publication/327052389_ An_Ana lytical_Study_on_the_Effects_of_WTO_on_India's_Foreign_Trade_performance/links/ 5b7 54e6fa6fdcc87df809ca9/An-Analytical-Study-on-the-Effects-of-WTO-on-IndiasForeign-Trade-performance.pdf\#page=5> Acesso em: 20 de nov. 2020.

PRONI, Marcelo Weishaupt. Duas teses sobre o trabalho no capitalismo. Ciência e Cultura, São Paulo, v.58, n.4, outubro/dez. 2006. Disponível em: $<$ http://cienciaecultura.bvs.br/scielo.php?script=sci_arttext\&pid=S0009-6725200600 0400013> Acesso em: 22 de set. 2020.

STANDING, Guy. O precariado: A nova classe perigosa. Tradução de Cristina Antunes. São Paulo: Autêntica, 2013. Disponível em: < https://monoskop.org/ images/e/ef/Standing_Guy_O_Precariado_A_nova_classe_perigosa_2013.pdf > Acesso em: 21 ago. 2020.

SCHWAB, Klaus Martin. A Quarta Revolução Industrial. Tradução de Daniel Moreira Miranda. São Paulo: Edipro, 2019. Disponível em: < https://www.amazon.com.br/Quarta-Revolu\%C3\%A7\%C3\%A3o-Industrial-KlausSchwab/dp/857283978X/ref=asc_df_857283978X/?tag=googleshopp00-

20\&linkCode $=$ df0\&hvadid $=379715709336 \&$ hvpos $=\&$ hvnetw $=g \&$ hvrand $=1120085601$ $3448384322 \&$ hvpone $=\&$ hvptwo $=\&$ hvqmt $=\&$ hvdev $=\mathrm{c} \&$ hvdvcmdl $=\&$ hvlocint $=\&$ hvlocp hy=1031452\&hvtargid=pla-809970231506\&psc=1> Acesso em: 28 de ago. 2020.

SINGER, Paul. Globalização e Desemprego: Diagnóstico e alternativas. 3.ed. São Paulo: Contexto, $1999 . \quad$ Disponível em: https://edisciplinas.usp.br/pluginfile.php/868786/mod_resource/content/0/Paul\%20Sing er.\%20Globaliza\%C3\%A7\%C3\%A3o\%20e\%20desemprego.\%20Diagn\%C3\%B3sticos $\% 20 \mathrm{e} \% 20$ alternativas.pdf $>$ Acesso em: 20 de ago. 2020.

SENRA, Ricardo. Uber transforma derrota judicial em marketing com oferta de férias e salário mínimo, mas não no Brasil. BBC NEWS BRASIL, São Paulo, 29 jul. 2021. Disponível em: < https://www.bbc.com/portuguese/internacional-57990721>. Acesso em: 20 de out. 2021.

SLEE, Tom. Uberização: A nova onda do trabalho precarizado. Tradução de João Peres. São Paulo: $2017 . \quad$ Elefante, Disponível em: 
<https://www.amazon.com.br/Uberiza\%C3\%A7\%C3\%A3o-Nova-Onda-TrabalhoPrecarizado/dp/8593115071> Acesso em: 10 de ago. 2020.

STEFANO, Valerio de. The rise of the "just-in-time workforce": on-demand work, crowd work and labour protection in the "gig-economy". In: Seminário Crowd-Sourcing the Gig Economy and the Law, 7 nov., 2015, Filadélfia - Pensilvânia. Comparative Labour Law \& Policy Journal. Geneva: Universidade de Milão, 2016. Disponível em: <file:///C:/Users/PC/Downloads/SSRN-id2682602..pdf> Acesso em: 20 de ago. 2020.

VACLAVIK, M. C.; OLTRAMARI, A. P.; OLIVEIRA S. R. Empresariando a informalidade: um debate teórico à luz da gig economy. Cadernos EBAPE.BR., Rio de Janeiro, outubro 2021.

Disponível em:

https://bibliotecadigital.fgv.br/ojs/index.php/cadernosebape/article/view/84834> Acesso em: 20 de out. 2021.

VIDAL, Mauricélia Bezerra. Taylorismo, Fordismo e Toyotismo: uma análise do sistema de trabalho. 2002. 87f. Dissertação (Mestrado) - Universidade Federal da Paraíba, Programa de Pós-Graduação em Economia Rural e Regional. Disponível em: <http://dspace.sti.ufcg.edu.br:8080/jspui/bitstream/riufcg/9327/1/MAURICELIA\%20B EZERRA\%20VIDAL\%20\%20DISSERTA\%C3\%87\%C3\%830\%20PPGERR\%20\%202002.pdf> Acesso em: 10 de ago. 2020. 


\title{
CAPÍTULO XXI
}

\section{IMPLICAÇÕES DO DISTÚRBIO DE APRENDIZAGEM NO PROCESSO EDUCATIVO}

\author{
Ana Paula de Sousa Costa ${ }^{73}$; Érica Xavier Machado Pereira ${ }^{74}$; \\ Joyce Cristyane Pereira ${ }^{75}$; Mayara da Silva Lopes ${ }^{76}$; \\ Rosea Maria Silva ${ }^{77}$. \\ DOI-Capítulo: 10.47538/AC-2021.14-21
}

RESUMO: Os distúrbios de aprendizagem são problemas que afetam a capacidade da criança de receber, processar, analisar e armazenar informações. Podem dificultar a aquisição de habilidades de leitura, escrita, soletração e resolução de problemas matemáticos. De modo geral, referem-se aos problemas relacionados à deficiências sensoriais e intelectuais que dificultam o processo de aprendizagem do indivíduo. Mediante tal relevância no processo educacional, este artigo tem por objetivo contextualizar as implicações dos distúrbios específicos de aprendizagem no processo de ensino-aprendizagem no contexto educacional. Na intenção de viabilizar a construção do artigo, utilizou-se a revisão bibliográfica como recurso metodológico, apresentando a fundamentação científica de alguns autores renomados no campo de estudo relacionados à temática. De modo geral, o tema deste artigo mostra-se relevante uma vez que é imprescindível que se conheça os principais entraves na trajetória educacional do aluno, sendo um destes dos distúrbios de aprendizagem. Ao final da pesquisa, é possível afirmar que os direcionamentos pedagógicos condizentes às necessidades do aluno podem evitar diversos problemas associados que afetam a autoestima e o bem estar emocional da criança, e ainda, possibilitar a otimização do processo educativo.

PALAVRAS-CHAVE: Distúrbio de aprendizagem. Processo de ensino-aprendizagem. Desenvolvimento.

\section{IMPLICATIONS OF LEARNING DISORDERS IN THE EDUCATIONAL PROCESS}

ABSTRACT: Learning disabilities are problems that affect a child's ability to receive, process, analyze or store information. They can make it difficult to acquire reading, writing, spelling, and math problem solving skills. In general, they refer to problems related to sensory and intellectual deficiencies that hinder the individual's learning process. Given such relevance in the educational process, this article aims to contextualize the implications of specific learning disorders in the teaching-learning process in the educational context. In order to facilitate the construction of the article, the literature review was used as a methodological resource, presenting the scientific foundation of some renowned authors in the field of study related to the theme. In general, the theme of

\footnotetext{
${ }^{73}$ Graduada em Pedagogia. E-mail: aniinhaxaviier@ hotmail.com

${ }^{74}$ Graduada em Pedagogia. E-mail: ericaxmp@hotmail.com

${ }^{75}$ Graduada em Pedagogia. E-mail: mj.joyce@ hotmail.com

${ }^{76}$ Graduada em Pedagogia. E-mail: mayara_lopes_may@ hotmail.com

${ }^{77}$ Graduada em Pedagogia. E-mail:silvaroseamaria@gmail.com
} 
this article is relevant since it is essential to know the main obstacles in the educational trajectory of the student, one of these being learning disorders. At the end of the research, it is possible to state that the pedagogical guidelines consistent with the student's needs can avoid several associated problems that affect the child's self-esteem and emotional well-being, and also enable the optimization of the educational process.

KEYWORDS: Learning Disorder. Teaching-learning process. Development.

\section{INTRODUÇÃO}

$\mathrm{Na}$ infância é imprescindível proporcionar o maior número possível de experiências à criança, pois isso as ajudarão a adquirir e descobrir um mundo completamente novo e explorar todas as possibilidades de aprendizagem possível. A educação pautada na particularidade de cada aluno deve, assim, ser inserida no conjunto de ações pedagógicas que ajudem o desenvolvimento infantil, tendo enfoque no contexto pedagógico, porém sem desconsiderar todo o contexto que promove o processo de ensinoaprendizagem. Por isso, analisar a imersão do sujeito com distúrbio de aprendizagem no meio social é um processo desafiador, principalmente porque isso requer uma mediação que pressupõe a interação entre todas as crianças.

Sendo assim, este artigo científico traz uma breve discussão acerca das implicações dos distúrbios específicos de aprendizagem no processo de ensinoaprendizagem no contexto educacional, proporcionando uma reflexão acerca da relevância das propostas pedagógicas para o desenvolvimento e a aprendizagem cognitiva e intelectual das crianças com distúrbios específicos de aprendizagem. Dessa forma, as práticas educacionais direcionadas possibilitam a construção do conhecimento da criança com distúrbio, estimulando aspectos relacionados à consciência e ao pleno uso dos sentidos para o desempenho de ações direcionadas.

Assim, percebe-se a importância de considerar os possíveis distúrbios identificados na vivência escolar, tendo como base ser tal identificação requerida de apoio pedagógico, a fim de se oferecer o desenvolvimento e exploração de habilidades, de se realizar um trabalho em prol de se atender as necessidades de cada estudante, e de oportunizar a exploração de recursos que estimulam a aprendizagem conforme a individualidade de cada criança.

Na intenção de viabilizar a construção do artigo, utilizou-se a revisão bibliográfica como recurso metodológico, apresentando a fundamentação científica de alguns autores 
renomados no campo de estudo relacionados aos distúrbios de aprendizagem. De modo geral, o tema deste artigo mostra-se relevante uma vez que é imprescindível que se conheça os principais entraves na trajetória educacional do aluno.

\section{DISTÚRBIOS DE APRENDIZAGEM}

Para fins de compreensão, os distúrbios de aprendizagem são problemas que afetam a capacidade da criança de receber, processar, analisar e armazenar informações. Ou seja, os distúrbios de aprendizagem referem-se aos problemas relacionados à deficiências sensoriais e intelectuais que dificultam o processo de aprendizagem. Em certos casos, podem ser acompanhados de problemas comportamentais, como distúrbios emocionais.

Distúrbio de aprendizagem é um termo genérico que se refere ao grupo heterogêneo de alterações manifestas por dificuldades significativas na aquisição e no uso da audição, fala, leitura, escrita, raciocínio ou habilidades matemáticas. Estas alterações são intrínsecas ao indivíduo e presumivelmente devidas à disfunção do sistema nervoso central (COLLARES; MOYSÉS, 1992, p. 32).

Desse modo, os transtornos de aprendizagem são caracterizados por terem origem de disfunções do sistema nervoso central e relacionados a problemas da cognição e processamento das informações. Para Siqueira e Gurgel-Giannetti (2011), o transtorno de aprendizagem possui uma relação direta com problemas na aquisição e desenvolvimento de funções cerebrais as quais envolvem o ato de aprender. Assim, o transtorno de aprendizado é caracterizado por problemas relacionados a distúrbios de ordem interna e/ou externa do aluno (CIASCA; CAPELLINI; TONELOTTO, 2003).

Não existe uma classificação padrão para os alunos com distúrbios de aprendizagem. De acordo com as definições, são indivíduos com inteligência provavelmente normal, mas que não alcançam rendimento escolar nos níveis esperados nas áreas da leitura, expressão escrita e/ou matemática. Outros apresentam problemas mais abrangentes, que afetam todas as áreas educacionais e sociais.

Nesse contexto, Carvalho, Crenitte e Ciasca (2007) ressaltam que o distúrbio de aprendizagem é como uma perturbação no ato de aprender, isto é, uma modificação nos padrões de aquisição, assimilação e transformação. Sendo assim, um distúrbio de aprendizagem se diferencia da dificuldade de aprendizagem, uma vez que esta se 
relaciona a um problema exclusivamente pedagógico e intimamente relacionada a fatores internos e emocionais, já o distúrbio envolve fatores orgânicos que, de fato, impedem o processo de aprendizagem por parte do aluno. Portanto, nos transtornos da aprendizagem, os padrões normais de aquisição de habilidades estão perturbados desde os estágios iniciais do desenvolvimento, não sendo adquiridos em decorrência de falta de estímulo ou de qualquer forma de traumatismo ou doença cerebral.

\section{DISTÚRBIOS ESPECÍFICOS DE APRENDIZAGEM DISCALCULIA}

Segundo a Enciclopédia sobre o Desenvolvimento na Primeira Infância (2017), a discalculia, ou incapacidade em matemática, consiste em uma dificuldade persistente para aprender ou entender conceitos numéricos, princípios de contagem e aritmética. Essas dificuldades são frequentemente chamadas de incapacidade matemática. Entre 3\% e 8\% das crianças em idade escolar apresentam dificuldades persistentes para a aprendizagem desses conceitos matemáticos, que as acompanham de uma série para outra no ensino fundamental. A discalculia trata- se trata de "uma desordem neurológica específica que afeta a habilidade de uma pessoa compreender e manipular números” (FILHO, 2007, p. $38)$.

Esse distúrbio pode se manifestar em alunos considerados inteligentes, que podem ser dotados de habilidades em várias diferentes áreas do conhecimento, mas ter uma deficiência para realizar uma ou mais operações matemáticas. Assim, pessoas com discalculia não são capazes de identificar e/ou classificar plenamente os números, os sinais matemáticos, compreender os princípios básicos e secundários de métodos de mensurações, de análise de sequências, contabilizar valores monetários, entre outros (GOMES; LIMA, 2019, p. 21-22).

Portanto, acredita-se que esse transtorno que atinge, exclusivamente, a aprendizagem da matemática apresenta características que são muito peculiares ao desenvolvimento de cada sujeito. "Dessa forma, a discalculia pode se configurar por uma desordem estrutural da maturação das capacidades matemáticas” (BERNARDI, 2014, p. 122). Isso denota que a discalculia acarreta prejuízos em diferentes habilidades matemáticas. 


\section{DISLEXIA}

A dislexia pode ser compreendida como uma grande dificuldade em aprender a ler e a escrever, fazendo com que a criança não consiga relacionar os sons da fala com a grafia da escrita e troque letras que possuem aspectos espaciais semelhantes. Também é muito comum que invertam letras nas palavras ou palavras nas frases, ou ainda aglutinem palavras ou separem as sílabas de forma inadequada quando escrevem (ALVES; MOUSINHO; CAPELLINI, 2011, p. 11). Desse modo, a dislexia expõe que a leitura não é algo natural para a criança, é adquirida e precisa ser progressiva e continuamente ensinada.

A dislexia, ou incapacidade em leitura, consiste em uma dificuldade inesperada de ler, sendo que "inesperada" significa que todos os fatores necessários para a leitura parecem estar presentes (inteligência, motivação e uma instrução em leitura pelo menos adequada) e, no entanto, a criança ainda não consegue ler (Enciclopédia sobre o Desenvolvimento na Primeira Infância, 2017, p. 4).

Logo, compreende-se a dislexia como um distúrbio que causa dificuldades para o indivíduo ler e escrever. Dessa forma, embora a criança com dislexia tenha inteligência normal, o aprendizado das habilidades de leitura e escrita é prejudicado, afetando assim seu desempenho escolar. Nesse sentido, é possível afirmar que a capacidade de compreensão da leitura, o reconhecimento das palavras, a leitura oral e o desempenho de tarefas que necessitam da leitura são comprometidos.

[A dislexia é] uma deficiência específica e distinta na aprendizagem da leitura, evidenciada por dificuldades persistentes em aprender essa habilidade, muitas vezes acompanhada por dificuldades de soletração. Mostra falta de precisão e/ou velocidade na leitura e/ou de compreensão de textos. Estas dificuldades não podem ser atribuídas simplesmente a baixa idade mental, limitações na acuidade visual ou auditiva, ou escolaridade insuficiente (DYSLEXIA INTERNATIONAL, 2010, p. $18)$.

Mediante o exposto, afirma-se então que a dislexia é um transtorno de origem neurobiológica, que se caracteriza pela dificuldade de decodificar o estímulo escrito ou o símbolo gráfico. Esse distúrbio compromete a capacidade do indivíduo em aprender a ler e escrever com correção e fluência e de compreender um texto. Em diferentes graus, quem possui esse distúrbio não consegue estabelecer a memória fonêmica, isto é, associar os fonemas às letras. Todavia, cabe ressaltar que o diagnóstico de dislexia não significa que 
a criança seja menos inteligente; significa apenas que é portadora de um distúrbio na capacidade de leitura, mas que pode ser corrigido ou atenuado.

\section{DISGRAFIA}

De acordo com Magalhães (2015), a disgrafia é o distúrbio da palavra escrita que se define por uma suave incordenação motora, expondo a própria letra com movimentos distintos e escrita desordenada, assim sendo caracterizada por letra feia. Isso ocorre em virtude de uma incapacidade de relembrar a grafia da letra. Na tentativa de recordar este grafismo escreve com lentidão e por isso acaba unindo incorretamente as letras, fazendo com que a mesma se torne ilegível. A disgrafia, entretanto, não está relacionada a nenhum tipo de comprometimento mental.

Para Garcia (1998), a disgrafia consiste em uma dificuldade na elaboração da escrita, porém só se considera desse modo quando, por exemplo, a qualidade de como se produz a escrita se demonstra abaixo do nível intelectual daquele que a produz. De modo geral, a disgrafia se apresenta com outras variações superpostas como transtornos no desenvolvimento matemático, transtornos do desenvolvimento na leitura, transtornos de condutas de tipo desorganizado e transtornos de habilidades motoras, por exemplo.

A disgrafia é caracterizada por problemas com a linguagem escrita, que dificulta a comunicação de ideias e de conhecimentos através desse específico canal de comunicação. Os disgráficos, com frequência, experimentam, em diferentes graus, sensações de insegurança e desequilíbrio com relação à gravidade desde a infância (MAGALHÃES, 2015, p. 14).

Portanto, a disgrafia é uma adversidade que afeta a qualidade da escrita, por não recordar a grafia das letras ao escrever. Essa disfunção modifica a escrita e prejudica o significado e/ou a forma da grafia. "A pessoa disgráfica acaba por ter dificuldade no ato de escrever, provocando uma grafia confusa e cansaço muscular, que, por sua vez, são responsáveis por uma caligrafia deficiente, com letras pouco diferenciadas, mal elaboradas e mal proporcionadas" (CORDEIRO, 2018, p. 2).

\section{DISORTOGRAFIA}


“Disortografia, é uma alteração na planificação da linguagem escrita, que causa transtornos na aprendizagem da ortografia, gramática e redação, apesar de o potencial intelectual e a escolaridade do indivíduo estarem adequados para a idade" (FERNÁNDEZ et al, 2010, p. 3). Assim, a disortografia compreende um padrão de escrita que foge às regras ortográficas estabelecidas convencionalmente, que regem determinada língua. Logo, o sujeito disortográfico é aquele que não consegue apresentar a escrita ortográfica adequadamente, ou seja, com os símbolos gráficos necessários, juntando palavras, omitindo sílabas e palavras, entre outros elementos.

Cabe ressaltar que, a disortografia é diferente da disgrafia, pois ela está relacionada a uma deficiência que afeta as aptidões da escrita. Em outras palavras, "a disortografia é uma dificuldade centrada na estruturação, organização e produção de textos escritos. Além disso, as crianças mostram uma construção frasal aquém do esperado, com o vocabulário pobre e curto, além de erros ortográficos" (BRITES, 2018 p. 3). Diante disso, afirma-se que a disortografia é a escrita incorreta, com erros e substituições de grafemas, alteração atribuída às dificuldades no mecanismo de conversão letra-som que interferem nas funções auditivas superiores e nas habilidades linguísticoperceptivas.

Em suam, no que se refere ao distúrbio da disortografia é possível compreender que ele apresenta fenômenos como, a dificuldade de aprendizagem relacionada à linguagem e transtorno na hora de escrever um texto. Apresenta uma escrita com omissões de letras, alternância de palavras e desordem na estrutura da frase. Além disso, a criança pode juntar palavras, que ao final perdem a acentuação, o fonema e o sentido lógico. Sem dúvida, tais erros estruturais e organizacionais comprometem de maneira significativa a aprendizagem dos alunos.

\section{TRANSTORNO DE DÉFICIT DE ATENÇÃO E HIPERATIVIDADE}

O Transtorno do Déficit de Atenção com Hiperatividade (TDAH) é um transtorno neurobiológico, de causas genéticas, que aparece na infância e frequentemente acompanha o indivíduo por toda a sua vida. Ele se caracteriza por sintomas de desatenção, inquietude e impulsividade. Andrade e Vasconcelos (2018) comentam que esse transtorno é uma síndrome neurocomportamental que se caracteriza pela presença persistente de 
desatenção, hiperatividade e impulsividade, interfere no desenvolvimento do indivíduo, podendo gerar distúrbios motores, perceptivos, cognitivos e comportamentais.

"Este transtorno se caracteriza por comportamentos inadequados, impulsivos e hiperativos, associados a dificuldades em manter a atenção e a concentração" (SEABRA, 2020, p. 20). Em outras palavras, o Transtorno do Déficit de Atenção com Hiperatividade compreende os aspectos cognitivos e comportamentais dos alunos, o que influencia em sua capacidade de aprender, construir conhecimento e interagir com o meio. Para Ramirez (2021), o TDAH costuma se manifestar na infância, mas os sintomas mais evidentes começam a aparecer na fase escolar. Isso porque é o momento que esses sujeitos são estimulados à interação e à utilização do raciocínio para resolução de problemas.

\section{IMPLICAÇÕES DOS DISTÚRBIOS DE APRENDIZAGEM NO PROCESSO DE ENSINO-APRENDIZAGEM}

Conforme a contextualização realizada, os distúrbios de aprendizagem estão relacionados a problemas que não decorrem de causas educativas. Isso significa que, mesmo após uma mudança na abordagem educacional, o aluno continua apresentando os mesmos sintomas. Contudo, se faz necessário que a escola exerça o papel de identificar indivíduos que apresentam as características primárias dos distúrbios específicos de aprendizagem. Para isso, o papel do professor em sala de aula é fundamental, uma vez que esse profissional tem contato constante com os alunos, e familiares, e poderá perceber precocemente a manifestação de algum sintoma de um distúrbio de aprendizagem.

Sem dúvida, incluir a família do estudante no processo de ensino-aprendizagem, permite que ela compreenda quais as dificuldades dos estudantes, a fim de que eles recebam também o apoio familiar. Para facilitar essa comunicação com os pais e responsáveis, é importante que a escola mantenha um relacionamento próximo e aberto com as famílias e com a comunidade escolar, sendo clara ao abordar a temática dos distúrbios de aprendizagem.

Sobre isso, França (2021) comenta que a rotina da escola é muito propícia para identificar queixas dos alunos que podem apontar, ou não, para casos de distúrbios de aprendizagem. Além do mais, o estabelecimento de ensino tem por compromisso promover maior integração do aluno com o restante da comunidade escolar, e partir dessa 
integração torna-se possível conhecer com afinco o meio em que o aluno está exposto, e se esse fator se relaciona com o seu rendimento ao longo da trajetória escolar.

Nesse contexto, cabe trazer à discussão que antes de lançar qualquer possibilidade de diagnóstico de distúrbio de aprendizagem, é preciso que o aluno passe por uma avaliação especializada com profissionais da área de saúde. França (2021) pontua que essa equipe deve incluir médicos, especialmente neurologistas, além de psiquiatras, psicólogos, psicopedagogos e até mesmo fonoaudiólogos. Essa é uma medida indispensável, pois a realização de avaliações superficiais pode causar um aumento no número de crianças e adolescentes submetidos a tratamentos medicamentosos desnecessariamente.

A partir do momento em que o estudante é devidamente diagnosticado com distúrbio específico de aprendizagem, é imprescindível que seja realizado um trabalho pedagógico direcionado. Para isso, é importante encontrar metodologias que se encaixem com o perfil de cada um dos alunos. Nesse sentido, o art. 208, inciso III da Constituição Federal de $1988(\mathrm{CF} / 88)$ determina o direito das pessoas com necessidades especiais receberem educação, preferencialmente na rede regular de ensino. A diretriz atual é a da plena integração dessas pessoas em todas as áreas da sociedade. Trata-se, portanto, de dois direcionamentos principais: o direito à educação, comum a todas as pessoas, e o direito de receber essa educação, sempre que possível na escola regular, na intenção de possibilitar a integração.

A Lei de Diretrizes e Bases da Educação Nacional (Lei 9.394/96) determina que os sistemas de ensino devem assegurar aos educandos com necessidades especiais: I. currículos, métodos, técnicas, recursos educativos e organização específicos, para atender às suas necessidades; II. terminalidade específica para aqueles que não puderem atingir o nível exigido para a conclusão do ensino fundamental, em virtude de suas deficiências, e aceleração para concluir em menor tempo o programa escolar para os superdotados; III. professores com especialização adequada em nível médio ou superior, para atendimento especializado, bem como professores do ensino regular capacitados para a integração desses educandos nas classes comuns; IV. educação especial para o trabalho, visando à sua efetiva integração na vida em sociedade, inclusive condições adequadas para os que não revelarem capacidade de inserção no trabalho competitivo, mediante articulação com os órgão oficiais afins, bem como para aqueles que apresentam uma habilidade superior nas áreas artística, intelectual ou psicomotora; V. acesso igualitário aos benefícios dos 
programas sociais suplementares disponíveis para o respectivo nível do ensino regular (BRASIL, 2006, p. 155-156).

A relevância do processo de ensino-aprendizagem direcionado se justifica porque na falta de tratamento, os distúrbios de aprendizagem comprometem a aquisição de conhecimentos, expõem a criança a experiências repetidas de insucesso e podem reduzir a motivação para a aprendizagem em geral. Por isso, o diagnóstico precoce e o direcionamento pedagógico condizente podem evitar diversos problemas associados que afetam a autoestima e o bem estar emocional da criança em idade escolar.

Considerando as situações ao entorno da aprendizagem da criança com distúrbio de aprendizagem, Vygotsky (2001) afirma que é fundamental focar nas potencialidades destes sujeitos e não na reabilitação dos defeitos. Por isso, o aluno deve ser estimulado a explorar o mundo, a interagir com o outro e a expor sua opinião e desejos. No entanto, na aprendizagem do aluno com distúrbio de aprendizagem, a disposição para aprender não depende somente dele, mas demanda que a prática pedagógica propicie condições para que essa atitude favorável se manifeste e prevaleça.

É nesse cenário que surge a importância da educação inclusiva, isso porque é por meio dela que se o profissional docente atuará de maneira a contemplar maior parte das necessidades dos alunos, sem desconsiderar as particularidades do processo educativo. $\mathrm{O}$ Instituto Rodrigo Mendes (2016) pontua a importância da educação que compreenda os distúrbios de aprendizagem, uma vez que ela pressupõe a igualdade de oportunidades e a valorização das diferenças humanas, contemplando todas as múltiplas diversidades, de modo a garantir o acesso, a participação e a aprendizagem de todos, sem exceção.

\section{CONSIDERAÇÕES FINAIS}

Sem dúvida, para que a aprendizagem seja significativa ao aluno portador de distúrbio de aprendizagem, se faz imprescindível conhecer e investir em ações pedagógicas que potencializam o interesse do indivíduo em aprender. E, a partir de então, o processo de ensino-aprendizagem terá sentido e se fará de modo pleno e integral. É preciso que se considere as vulnerabilidades do aluno com distúrbio de aprendizagem e propor metodologias educacionais que amenizam essas carências. 
Assim, é possível afirmar que uma das maiores implicações do distúrbio de aprendizagem no processo educativo se dá pela etapa de compreender o comportamento do aluno, traçar metodologias diferenciadas e estratégicas e realizar um trabalho colaborativo entre os meios que compõe o universo do aluno. Todavia, esse processo precisa contar com uma rede de apoio que possibilite que o trabalho pedagógico seja desenvolvido de maneira efetiva. Ou seja, a interação da instituição escolar com a família e profissionais da área da saúde são fundamentais.

\section{REFERÊNCIAS}

ANDRADE, Paula Faria Souza Mussi de; VASCONCELOS, Marcio Moacyr. Transtorno do déficit de atenção com hiperatividade. (2018). Disponível em: $<$ https://cdn.publisher.gn1.link/residenciapediatrica.com.br/pdf/v8s1a11.pdf >. Acesso em: 08, nov, 2021.

BERNARDI, Jussara. Discalculia: O que é? Como intervir?. Jundiaí, Paco Editorial: 2014.

BRASIL. Constituição da República Federativa do Brasil. Brasília, DF: Senado Federal: Centro Gráfico, 1988.

Ministério da Educação. Lei de Diretrizes e Bases da Educação Nacional. Disponível em: <http://www.planalto.gov.br/ccivil_03/Leis/L9394.htm>. Acesso em: 29, out, 2021.

BRITES, Luciana. Disortografia e Disgrafia. (2018). Disponível em: $<$ https://institutoneurosaber.com.br/como-entender-a-disortografia-e-disgrafia/>. Acesso em: 08, nov, 2021.

CARVALHO, Fabrícia Bignotto de; CRENITTE, Patrícia Abreu Pinheiro; CIASCA, Sylvia Maria. Distúrbios de Aprendizagem na Visão do Professor. (2007). Disponível em: <https://cdn.publisher.gn1.link/revistapsicopedagogia.com.br/pdf/v24n75a03.pdf>. Acesso em 07, nov, 2021.

CIASCA, S. M.; CAPELLINI, S. A.; TONELOTTO, J. M. F. Distúrbios específicos de aprendizagem. Distúrbios de aprendizagem: proposta de avaliação interdisciplinar. São Paulo: Casa do Psicólogo, 2003.

COLLARES, C. A. L. e MOYSÉS, M. A. A. A história não contada dos distúrbios de aprendizagem. Cadernos CEDES nº 28, Campinas: Papirus, 1992.

CORDEIRO, Ana Helena Soares. "Letra feia" é disgrafia: como o professor deve atuar diante desse transtorno de aprendizagem. Disponível em: <https://editorarealize.com.br/editora/anais/conedu/2018/TRABALHO_EV117_MD4_S A8_ID778_01082018222601.pdf>. Acesso em 08, nov, 2021. 
ENCICLOPÉDIA SOBRE O DESENVOLVIMENTO NA PRIMEIRA INFÂNCIA. Distúrbios de Aprendizagem. (2017). Disponível em: <https://www.enciclopediacrianca.com/pdf/complet/disturbios-de-aprendizagem>. Acesso em: 07, nov, 2021.

FERNÁNDEZ, Amparo Ygual. et al. Avaliação e intervenção da disortografia baseada na semiologia dos erros: revisão da literatura. Disponível em: <https://www.scielo.br/j/rcefac/a/3DRZb4rrSgpwmyJGfgg68fC/?lang=pt>. Acesso em: 08, nov, 2021.

FILHO, C. R. C. Jogos Matemáticos para estimulação da inteligência nos distúrbios de Discalculia. (2007). Disponível em: <https://www.webartigos.com/articles/2067/1/Jogos-MatemaacuteticosPara\%20Estimulaccedilatildeo-Da-Inteligecircncia-Nos-Distuacuterbios-DeDiscalculia/pagina1.html\#ixzz1JnDUXM53>. Acesso em: 07, nov, 2021.

FRANÇA, Luísa. O que é dificuldade de aprendizagem e como contorná-la? (2021). Disponível em: <https://www.somospar.com.br/dificuldade-de-aprendizagem/>. Acesso em 08, nov, 2021.

GOMES, Michelly Amarante da Silva; LIMA, Neuza Rejane Wille. A discalculia em escolas: como resolver esse problema? (2019). Disponível em: $<$ https://www.researchgate.net/profile/Neuza-Wille-

Lima/publication/348187755_A_DISCALCULIA_EM_ESCOLAS_COMO_RESOLV ER_ESSE_PROBLEMA/links/5ff31a22299bf140886fd308/A-DISCALCULIA-EMESCOLAS-COMO-RESOLVER-ESSE-PROBLEMA.pdf>. Acesso em: 07, nov, 2021.

INSTITUTO RODRIGO MENDES. O que é educação inclusiva? Disponível em: <https://diversa.org.br/educacao-inclusiva/o-que-e-educacao-inclusiva/>. Acesso em: 24, out, 2021.

MAGAlHÃES, Aniuzo. Disgrafia: Causas e estratégias de correção no ensino/aprendizagem. (2015). Disponível em: <https://bdm.unb.br/bitstream/10483/17172/1/2015_AniuzoMagalhaes_tcc.pdf >.

Acesso em 07, nov, 2011.

RAMIREZ, Gonzalo. TDAH (Déficit de Atenção e Hiperatividade): o que é, sintomas e o que fazer? (2021). Disponível em: <https://www.tuasaude.com/sintomas-dehiperatividade/>. Acesso em: 08, nov, 2021.

SEABRA, Magno Alexon Bezerra. Distúrbios e Transtornos da Aprendizagem: aspectos teóricos, metodológicos e educacionais. 1. ed. Curitiba/PR: Bagai, 2020.

SIQUEIRA, Cláudia Machado; GURGEL-GIANNETTI, Juliana. Mau desempenho escolar: uma visão atual. Revista da Associação Médica Brasileira, 2011.

VYGOTSKI, L. S. A construção do pensamento e da linguagem. São Paulo: Martins Fontes, 2001. 


\title{
CAPÍTULO XXII
}

\section{INCLUSÃO ESCOLAR COMO UMA PRÁTICA CULTURAL}

\author{
Caroline Rodrigues de Freitas Fernandes ${ }^{78}$; Dayana Lúcia Rodrigues de Freitas ${ }^{79}$; \\ Maria Damiana da Silva ${ }^{80}$; Ewerton Cardoso da Silva ${ }^{81}$; \\ Wustania Gaspar Rodrigues ${ }^{82}$; Patrícia Lima do Nascimento ${ }^{83}$; \\ Maria Zilma Batista da Silva ${ }^{84}$; Ana Maria Fonseca de Araújo Medeiros ${ }^{85}$; \\ Lígia Maria da Conceição Santos Silva ${ }^{86}$. \\ DOI-Capítulo: 10.47538/AC-2021.14-22
}

RESUMO: Para se tornar realidade a Educação Inclusiva exige das escolas transformações não apenas em sua estrutura e funcionamento, mas principalmente deve envolver mudanças no modelo de atendimento que se constitua por meio de ações interdependentes que, para se efetivarem e se perpetuarem, devem resultar em mudanças culturais. Partindo desse pressuposto, a aprendizagem representa o produto agregado oferecido pelas escolas. Para este fim, é necessário que o comportamento dos profissionais neste ambiente seja congruente e interdependente e os procedimentos por eles executados reforcem este resultado, para que assim a cultura da Educação Inclusiva seja mantida e propagada através do tempo.

PALAVRAS-CHAVE: Educação inclusiva. Prática cultural. Mudança social.

\section{SCHOOL INCLUSION AS A CULTURAL PRACTICE}

ABSTRACT: In order to become a reality, Inclusive Education requires transformations from schools not only in their structure and functioning, but mainly must involve changes in the service model that is constituted through interdependent actions that, in order to be effective and perpetuated, must result in cultural changes . Based on this assumption, learning represents the aggregate product offered by schools. To this end, it is necessary that the behavior of professionals in this environment is congruent and interdependent

\footnotetext{
78Pós-Graduada em Mídias na Educação (UERN). Docente no Município de Macau/RN. Orcid: https://orcid.org/00000002-9198-6746. Lattes: http://lattes.cnpq.br/5956672837215695. E-mail: caroline_brum2005@ hotmail.com. 79Doutoranda em Educação (CECAP). Docente nos Município de Macau/RN e Guamaré/RN. Orcid: https://orcid.org/0000-0001-5355-3547. Lattes: http://lattes.cnpq.br/5122671799874415. E-mail: dayannaproducoes@gmail.com.

80 Graduação em Pedagogia. Docente no Município de Guamaré/RN. E-mail: damianasilva1818@gmail.com 81 Graduação em Pedagogia - UVA. Pós-graduação em Formação de Docentes; Educação Infantil; Alfabetização e Educação Especial- FAVENI. Professor da Educação Básica. E-mail: ewertoncardosold@ hotmail.com 82 Graduação em pedagogia - UVA. Pós-graduação em Educação infantil e anos iniciais - FIAVEC. Pós-graduação em Alfabetização e Letramento - Faculdade do Vale Elvira Dayrell. Pós-graduação em Educação Especial e Inclusiva - Faculdade do Vale Elvira Dayrell. Pós-graduação em Língua Brasileira de Sinais-LIBRAS - Faculdade do Vale Elvira Dayrell. Professora no município de Guamaré/RN. E-mail: wustaniaprofessora@ hotmail.com 83 Pedagoga. Professora da Educação Básica. E-mail: patricialimapatricia3226@ gmail.com 84 Pedagoga. Professora da Educação Básica. E-mail: mariazilmagm@ gmail.com 85 Pedagoga. Professora da Educação Básica. E-mail: Ana.medeirosgmr@gmail.com 86 Graduada em pedagogia - UVA. Pós-graduação em psicopedagogia -FIP. Pós-graduada em Serviço Social no Campo (em andamento) - Universidade Dom Alberto. Professora do município de Guamaré rede privada. E-mail: mariaa.ligia@gmail.com
} 
and the procedures performed by them reinforce this result, so that the culture of Inclusive Education is maintained and propagated over time.

KEYWORDS: Inclusive Education. Cultural practice. Social change.

\section{INTRODUÇÃO}

No plano educacional, o princípio da Educação Inclusiva tem avançado no que diz respeito à exigência da qualidade do atendimento prestado aos alunos com problemas na aprendizagem, seja por deficiência, ou por dificuldades ocasionadas por repetências, defasagem de idade/série ou fatores econômicos e sociais. Para demonstrar que a Educação Inclusiva pode se tornar uma prática cultural é preciso uma análise sobre os efeitos dos comportamentos das pessoas ligadas à educação no ambiente educacional, ou seja, aqueles que trabalham nesta área e aqueles que se beneficiam deste serviço.

Para provocar efeitos inclusivos a partir das ações dos profissionais de ensino sobre o comportamento e a forma de aprender dos alunos, é preciso realizar comportamentos que sejam condizentes com o princípio inclusivo e que resultem na aprendizagem e repetição por parte dos alunos. Esses comportamentos podem tornar-se um padrão que, pelas suas consequências reforçadoras, repete-se através do tempo provocando mudanças culturais nas próximas gerações.

Uma questão básica de grande importância e normalmente ausente nas discussões de Educação Inclusiva refere-se à instalação da cultura de inclusão na comunidade escolar. Se o educando que tem uma deficiência for rejeitado pelos seus colegas de classe e visto pelas outras famílias como uma ameaça ao avanço do desenvolvimento ou um fator de insegurança para os seus filhos, não adiantará de nada ter profissionais qualificados e comprometidos, criar projetos inovadores, realizar adaptações curriculares, metodológicas e avaliativas que atendam à diversidade. Todo o esforço pedagógico de inclusão pode ir por água abaixo, se a cultura da inclusão não estiver firmemente plantada na comunidade escolar como um todo.

Entende-se por cultura de inclusão um conjunto de valores e atitudes acerca de como as pessoas com deficiências devem ser acolhidas e tratadas na escola e na sociedade; além de valores e atitudes que devem ser compartilhados e vivenciados por todos quer sejam educadores, funcionários, como demais crianças e principalmente pelas famílias destes indivíduos. 


\section{EDUCAÇÃO INCLUSIVA: PRINCÍPIOS E PERSPECTIVAS}

A educação é um processo social, cuja função, em síntese, é ensinar aos indivíduos comportamentos que serão adequados para garantir, a cada um, as melhores chances de sobrevivência no mundo, isto é, uma vida pessoal e social de boa qualidade. É por meio do processo formal de educação que devemos ensinar aos indivíduos comportamentos que possibilitem uma atuação com competência e autonomia quando já não estiverem mais participando deste processo.

A Política de Educação Inclusiva refere-se à responsabilidade dos governos e dos sistemas escolares de cada país com a qualificação de todas as crianças e jovens no que se refere aos conteúdos, conceitos, valores e experiências materializadas no processo de ensino-aprendizagem escolar, tendo como pressuposto o reconhecimento das diferenças individuais de qualquer origem (GLAT; BLANCO, 2007, p. 16).

Atualmente, o foco da escola mudou, visando não apenas transmitir conhecimentos, mas também atender aos quatro pilares da educação recomendados pela UNESCO: aprender a aprender, ensinando aos alunos como chegar à informação e ao conhecimento; aprender a fazer, o saber implica fazer, melhorando as condições de vida das pessoas; aprender a viver com os outros, trabalhando a aprendizagem da convivência, da compreensão mútua, de intercâmbios pacíficos e de harmonia; e aprender a ser, a ser cidadão ativo e viver com dignidade. Assim, a sociedade está exigindo das pessoas uma grande capacidade de autonomia e responsabilidade pessoal em relação à realização do destino coletivo (DELORS, 1999).

As necessidades educacionais especiais (NEE) passaram a ocupar lugar de destaque a partir da Conferência Mundial sobre Necessidades Educacionais Especiais: Acesso e Qualidade, realizada em Salamanca, Espanha, em 1994. A conferência foi planejada para atender a duas preocupações essenciais: garantir a todas as crianças, particularmente aquelas com necessidades especiais, acesso às oportunidades da educação; promover educação de qualidade com introdução de ideias inovadoras sobre a relação entre os serviços de Educação Especial e a reforma do sistema educativo.

Após isso alguns países começaram a se inspirar nesses ideais e elaborar suas próprias legislações. No Brasil, a Resolução no 2/01 (BRASIL, 2001), institui as Diretrizes Nacionais para a Educação Especial na Educação Básica, onde educandos com 
necessidades educacionais especiais representam aqueles que durante a vida escolar apresentam:

I - dificuldades acentuadas de aprendizagem ou limitações no processo de desenvolvimento que dificultem o acompanhamento das atividades curriculares, compreendidas em dois grupos:

a) aquelas não vinculadas a uma causa orgânica específica;

b) aquelas relacionadas a condições, disfunções, limitações ou deficiências;

II - dificuldades de comunicação e sinalização diferenciadas dos demais alunos, demandando a utilização de linguagens e códigos aplicáveis;

III - altas habilidades/superdotação, grande facilidade de aprendizagem que os leve a dominar rapidamente conceitos.

Infelizmente, embora esteja estabelecido em lei, o direito constitucional de acesso ao ensino para todos não tem sido garantido para grande parte destas pessoas citadas. Uma das principais causas para isso é que a escola encontra dificuldade em lidar com a diversidade de estilos de aprendizagem, independentemente de se tratar ou não de alunos com deficiência. Isto se verifica pelo alto índice de reprovação e evasão constatados principalmente na $1^{a}$ série no Ensino Fundamental no Brasil, onde apenas 53,7\% do total de alunos são promovidos, enquanto 46,3\% são reprovados, reproduzindo assim o ciclo de retenção que acaba expulsando os alunos ditos "normais" da escola (UNICEF, 2009).

De acordo com o Instituto Nacional de Estudos e Pesquisas Educacionais Anísio Teixeira (INEP, 2008), do total de alunos matriculados na educação básica em 2008, cerca de $0,60 \%$ corresponde a alunos da Educação Especial de escolas exclusivamente especializadas e/ou em classes especiais. O mais preocupante dos dados do INEP (2008) é a constatação de que apenas $0,11 \%$ dos alunos com deficiência matriculados na educação básica frequentam classes comuns no ensino fundamental. Portanto, a oferta de serviços para os alunos da Educação Especial ainda é muito inexpressiva, o que confirma que o princípio de que todos têm direito à educação ainda está distante de ser cumprido.

A escola inclusiva constitui um passo decisivo para eliminar atitudes discriminatórias, para criar comunidades escolares que acolham todos sem distinção e para conscientizar a sociedade sobre a importância de acolher e ajudar esses indivíduos. Essas ações implicam, portanto, em um processo de mudança que exige tempo para as 
adaptações necessárias e requer providências essenciais para o bom funcionamento do ensino inclusivo.

A inclusão representa um movimento social em defesa de todas as pessoas excluídas e marginalizadas. Sua efetivação depende da adesão de todos os cidadãos e de iniciativas do poder público.

Dentro dos pressupostos de uma sociedade inclusiva está prevista a garantia do direito coletivo de exercício da cidadania indiferentemente de gênero, origem socioeconômica, escolaridade, opção sexual, religião, cor, idade, raça e deficiência. Nela também está prevista a eliminação de qualquer forma de discriminação e segregação. Assim como estão previstos os princípios da aceitação das diferenças individuais, a valorização de cada pessoa, a convivência dentro da diversidade humana (MURTA, 2004, p. 43).

Sassaki (1997, p. 41) esclarece ainda que a inclusão social é um processo no qual as pessoas excluídas e o restante da sociedade, num esforço bilateral, devem buscar soluções para os problemas que dificultam a equiparação de oportunidades possam ser minimizados ou completamente sanados. Portanto, a inclusão social constitui um "(...) processo pelo qual a sociedade se adapta para poder incluir, em seus sistemas sociais gerais, pessoas com necessidades especiais e, simultaneamente, estas se preparam para assumir seus papéis na sociedade".

\section{TRANSFORMAÇÃO DA EDUCAÇÃO INCLUSIVA EM PRÁTICA CULTURAL}

Este processo de mudança e adequação social que surge a partir da educação inclusiva implica na construção de um novo modelo de atendimento, que se constitui por meio de ações interdependentes que, para se efetivarem e se perpetuarem, devem resultar em mudanças culturais.

Quando se fala de instalação de uma cultura, fica evidente, que não se está falando sobre um processo que acontece de imediato. Ao contrário, culturas envolvem padrões atitudinais e comportamentais extremamente complexos, cuja modificação é gradual, ainda mais quando se pensa a nível coletivo.

Para Sassaki (2002, p. 42) a inclusão social

[...] é um processo que contribui para a construção de um novo tipo de sociedade através de transformações, pequenas e grandes, nos ambientes físicos (espaços internos e externos, equipamentos, 
aparelhos e utensílios, mobiliários e meios de transportes) e na mentalidade de todas as pessoas, portanto também do próprio portador de necessidades especiais.

No entanto, é perceptível que a hegemonia da cultura escolar atualmente promove o domínio das consciências e a reprodução da ideologia dominante que ainda exclui os considerados improdutivos e favorece a subordinação das minorias. Porém, “[...] para superar essa hegemonia, seria necessário desenvolver uma contra hegemonia, [...] a criação e o desenvolvimento de uma nova cultura, tanto no que se refere aos valores e normas quanto à visão de homem e de mundo" (SILVA; CARVALHO, 2006, p. 48).

Bueno (2001) chama atenção para o cuidado ao implantar sistemas inclusivos como se fosse possível transformar todas as escolas em instituições inclusivas a partir de um documento normativo, afinal a realidade é totalmente diferente daquilo que vemos no papel. A legislação internacional, como a citada Declaração de Salamanca (1994), deve constituir-se num norte, pois as políticas de Educação Inclusiva devem considerar as peculiaridades de cada região, e estipular metas de curto, médio e longo prazo para que as transformações necessárias aconteçam de forma gradual e eficiente.

No Brasil, no caso dos alunos favorecidos com os serviços especiais, sua evolução na escola inclusiva depende do intercâmbio entre os profissionais dos serviços especiais e os profissionais do ensino comum. É necessário, para isso, um esforço conjunto entre aluno e professor, pois o aluno deve demonstrar suas necessidades e dificuldades e o professor adequá-las a seu método de trabalho, buscando eliminar as barreiras que dificultem a aprendizagem. Assim, o atendimento dispensado ao aluno vai garantir a permanência dele na escola.

Para que uma escola se torne inclusiva, deverá haver o reconhecimento de que alguns alunos necessitam de ajuda e apoio mais do que outros para poder alcançar o sucesso em sua escolarização. Essa postura representa mudança na cultura escolar, pois, sem a organização de um ambiente mais favorável ao atendimento das necessidades dos alunos que precisam de estratégias e técnicas diferenciadas para aprender, qualquer proposta de Educação Inclusiva não passa de retórica ou discurso político (GLAT; BLANCO, 2007, p. 28).

De acordo com Silva (2006, p. 202) 
Os principais elementos que desenhariam essa cultura seriam os atores (famílias, professores, gestores e alunos), os discursos e as linguagens (modos de conversação e comunicação), as instituições (organização escolar e o sistema educativo) e as práticas (pautas de comportamento que chegam a se consolidar durante um tempo).

Portanto, a evolução do aluno depende do efeito que as relações estabelecidas entre todos os sujeitos que compõem o ambiente escolar têm sobre ele, dando condições para a continuidade do processo de aprendizagem do aluno. A escola deve dispor ainda de espaço físico acessível, mobiliário adequado, material adaptado, recursos pedagógicos, além de trabalhar com os alunos para que desenvolvam atitudes de aceitação e cooperação entre os colegas. A inclusão torna-se com isso um modelo de atendimento que deve permear todas as ações voltadas para os alunos com necessidades educacionais especiais, desenvolvendo um padrão de comportamento, de acolhimento e respeito às diferenças individuais.

Toda comunidade escolar reúne uma matriz riquíssima de experiências sócio históricas, que se manifestam nos diversos aspetos das relações interpessoais presentes no ambiente escolar. Por isso, a assimilação de modificações nos padrões culturais constitui um processo complexo e progressivo. Contudo, quando essa mudança é almejada pela maioria e a proposta parte do grupo, o prenúncio de sucesso é mais seguro. Assim, cada comunidade escolar deve desenvolver a sua própria cultura de inclusão e, para isso, não há receitas prontas.

Uma escola só pode considerar-se inclusiva se todas as pessoas que ali convivem, seja trabalhando, aprendendo ou acompanhando seus filhos, assumirem esta missão. Pouco adianta a direção da escola decretar normas inclusivas, se houver falta de adesão e comprometimento, seja por parte das outras crianças, das suas famílias, dos funcionários ou, até mesmo, de alguns educadores.

Portanto, não basta pensar somente no fazer pedagógico para se oferecer uma educação realmente inclusiva. Há considerações que extrapolam a dimensão pedagógica. Pois, uma cultura de inclusão não se instala de uma hora para a outra, nem tampouco por decreto. Deve ser estrategicamente planejada, com o envolvimento de toda a comunidade, a qual deve estar disposta a fazer um significativo investimento de tempo para efetivar a sua instalação. 
É preciso não perder de vista que o impacto da inclusão ocorre tanto em quem é incluído como nos demais. Assim sendo, algumas estratégias podem ser efetivas para uma criança incluída e, no entanto, repercutirem-se, em todo o grupo.

\section{CONSIDERAÇÕES FINAIS}

No que diz respeito à Educação, a aprendizagem representa o produto final oferecido pelas instituições de ensino. Para que este fim seja alcançado, é necessário que os comportamentos dos profissionais, naquele ambiente, sejam reforcem a ideia de inclusão pregada pela educação.

A Política de Educação Inclusiva defende o direito de todas as pessoas terem acesso às escolas, e terem um ensino de qualidade que atenda às suas necessidades específicas. A incorporação deste princípio pode promover a instalação e a propagação de comportamentos que estejam de acordo com o princípio inclusivo, promovendo mudanças culturais favorecendo o surgimento de uma sociedade mais inclusiva.

A inclusão abrangendo ações como respeito mútuo, compreensão, apoio, equidade e autorização não é apenas uma tendência ou um conjunto de procedimentos educacionais a serem implementados. Pelo contrário, a inclusão é um desafio no sentido de determinar modos de conduzir o processo educacional para promovê-la. Não haverá um conjunto de práticas estáticas, e sim uma interação dinâmica entre educadores, pais, membros da comunidade e alunos para desenvolver e manter ambientes e oportunidades educacionais que serão orientadas pelo tipo de sociedade na qual queremos viver. (STAINBACK, 2002, p. 17).

Deste modo, podemos concluir que a educação na atualidade adquiriu uma dupla função: propiciar a aprendizagem dos indivíduos e desenvolver práticas que favoreçam a propagação de comportamentos exequíveis para o desenvolvimento de uma sociedade verdadeiramente inclusiva que permita o cumprimento do direito de educação para todos.

\section{REFERÊNCIAS}

BRASIL. (2001). Conselho Nacional de Educação - Câmara de Educação Básica (CNE/CEB). Resolução $\mathbf{n}^{\mathbf{0}} 2$ de 11 de setembro de 2001. Diretrizes Nacionais para a Educação Especial na Educação Básica. Brasília. Disponível em: 
<http://portal.mec.gov.br/index.php?option=content\&task=view\&id=329\&Itemid=460> Acesso em: 08/11/2021.

BUENO, J. G. S. (2001). A inclusão de alunos deficientes nas classes comuns do ensino regular. Temas sobre Desenvolvimento, São Paulo, n. 54, vol. 9, p. 21-27.

DELORS, J. (1999). Educação: um tesouro a descobrir. 2a ed. São Paulo, Cortez.

GLAT, R.; BLANCO, L. M. V. (2007). Educação Especial no Contexto de uma Educação Inclusiva. In: Glat, R. (org.). Educação Inclusiva: cultura e cotidiano escolar. Rio de Janeiro, 7 Letras, p. 15-35.

INEP - Instituto Nacional de Estudos e Pesquisas Educacionais Anísio Teixeira. (2008). Sinopse estatística da educação básica: censo escolar 2008. Brasília, MEC/INEP.

MURTA, A. M. G. (2004). Contribuições da psicologia sócio-histórica para a Educação Inclusiva: os sentidos produzidos por professores da educação infantil de uma cidade do Vale do Jequitinhonha acerca da inclusão escolar. Dissertação (Mestrado em Educação: Psicologia da Educação). São Paulo, Pontifícia Universidade Católica de São Paulo.

SASSAKI, R. K. Inclusão: construindo uma sociedade para todos. Rio de Janeiro, WVA. 1997.

SASSAKI, Romeu. Inclusão: Construindo uma sociedade para todos. 4 ed. Rio de Janeiro: WVA, 2002.

SILVA, F. C. T. Cultura escolar: quadro conceitual e possibilidades de pesquisa. Educar, Curitiba, n. 28, p. 201-216, 2006.

SKINNER, B. F. (2003). Ciência e comportamento humano. Trad. João Carlos Todorov, Rodolfo Azzi. São Paulo, Martins Fontes. Tradução de: Science and human behavior.

STAINBACK, S. (2002). As raízes do movimento de inclusão. Pátio, Porto Alegre, a. 5, n. 20. p. 15-17. UNESCO - Organização das nações unidas para a educação, a ciência e a cultura. (1990). Declaração Mundial Sobre Educação para Todos e Plano de Ação para Satisfazer as Necessidades Básicas de Aprendizagem. Tailândia. Disponível em: <http://unesdoc.unesco.org/images/0008/000862/086291por.pdf> Acesso em: $18 / 11 / 2021$

UNESCO. Declaração de Salamanca: sobre princípios, política e práticas na área das necessidades educativas especiais. Conferência Mundial de Educação Especial. 7 a 10 de junho de 1994.

UNICEF - Fundo das nações unidas para a infância. (2009). O direito de aprender: potencializar avanços e reduzir desigualdades. Brasília: UNICEF. Disponível em: <http://www.unicef.org/sitan/files/Brazil_SitAn_2009_The_Right_to_Learn.pdf> Acess o em: $18 / 11 / 2021$ 


\title{
CAPÍTULO XXIII
}

\section{JOGOS E BRINCADEIRAS NA EDUCAÇÃO INFANTIL}

\author{
Ana Paula de Sousa Costa ${ }^{87}$; Érica Xavier Machado Pereira ${ }^{88}$; \\ Joyce Cristyane Pereira ${ }^{89}$; Mayara da Silva Lopes ${ }^{90}$; \\ Rosenice Benedita Ferreira' ${ }^{91}$ \\ DOI-Capítulo: 10.47538/AC-2021.14-23
}

\begin{abstract}
RESUMO: Este artigo expõe uma reflexão a importância do lúdico no ambiente escolar, e proporciona relutância de uma investigação qualitativa, na qual a finalidade foi discutir relativamente o valor dos jogos e do brincar no método de ensino e aprendizagem no desenvolvimento da criança, alcançando uma estrutura na educação por meio de jogos, brincadeiras e brinquedos. Na construção dos jogos e na ação de brincar possibilitam o método de ensino aprendizagem da criança, porque promove a edificação da imaginação, da criatividade e da autonomia, colocando, desta forma uma afinidade que aproxima os jogos e brincadeiras ao desenvolvimento deles. Foi feito uma ressalva que a brincadeira instiga na percepção e restauração dos conhecimentos, contribuindo para erguer os auxílios da ludicidade no método de ensino e aprendizagem. Destaca-se que é de extremo valor ter o entrosamento sobre o comando das atividades sugeridas, e é o educador quem deve direcionar a criança e as atividades a serem desenvolvidas. O lúdico cede novos modos de educar, relacionado a fatores como: qualificação dos professores comprometidos pode-se conquistar uma educação de competência, capaz de ir de encontro com as preferências essenciais da criança, pois as atividades lúdicas não são somatórias, mas fazem parte do método de aprendizagem.
\end{abstract}

PALAVRAS-CHAVE: Jogos. Brincadeiras. Ludicidade.

\section{GAMES AND PLAY IN EARLY CHILDHOOD EDUCATION}

ABSTRACT: This article presents a reflection on the importance of playfulness in the school environment, and provides reluctance to carry out a qualitative investigation, in which the purpose was to discuss the relative value of games and playing in the teaching and learning method in child development, achieving a structure in education through games, games and toys. In the construction of games and in the action of playing, they enable the child's teaching-learning method, because it promotes the building of imagination, creativity and autonomy, thus placing an affinity that brings games and games closer to their development. A caveat was made that playing instigates the perception and restoration of knowledge, contributing to raising the aids of playfulness in the teaching and learning method. It is noteworthy that it is extremely valuable to have rapport on the command of the suggested activities, and it is the educator who should direct the child and the activities to be developed. The playful offers new ways of

\footnotetext{
${ }^{87}$ Graduada em Pedagogia. E-mail: aniinhaxaviier@ hotmail.com

${ }^{88}$ Graduada em Pedagogia. E-mail: ericaxmp@hotmail.com

${ }^{89}$ Graduada em Pedagogia. E-mail: mj.joyce@ hotmail.com

${ }^{90}$ Graduada em Pedagogia. E-mail: mayara_lopes_may@ hotmail.com

${ }^{91}$ Graduada em Pedagogia. E-mail: rosenice2415@ gmail.com
} 
educating, related to factors such as: qualification of committed teachers, it is possible to achieve a competent education, capable of meeting the essential preferences of the child, as the playful activities are not summation, but are part of the learning method.

KEYWORDS: Games. Jokes. Playfulness.

\section{INTRODUÇÃO}

O presente artigo tem a finalidade de contrapor a respeito da importância do brincar no método de desenvolvimento da criança na Educação Infantil, objetivando a ludicidade como adereço para a aprendizagem e a compreensão do conhecimento por meio de brincadeiras, jogos e brinquedos.

É muito importante destacar que os pais, professores e a sociedade em geral fiquem conscientizados sobre a importância da ludicidade, que precisa estar sendo vivenciada na infância, ou seja, de que o brincar é componente de uma aprendizagem prazerosa não ficando só lazer.

Analisa-se que, por meio do brinquedo, a criança forma o seu mundo, arrastando para a sua realidade casos incomuns do seu universo imaginário. $\mathrm{O}$ brincar possibilita $\mathrm{o}$ progresso, não ficando apenas um dispositivo didático adepto para o aprendizado, já que as brincadeiras, jogos e brinquedos excitam em áreas do desenvolvimento infantil como: inteligência, afetividade, mobilidade, criatividade e civilidade. Dessa maneira, o brinquedo contribui para que a criança possa manifestar-se sua competência de ser um ser criativo.

É importante lembrar que a função do adulto e do professor é de extrema importância em todas as fases da infância, pois o próprio vai estar conduzindo o seu conhecimento e autoconsciência, desta forma estará preparado para intervir na brincadeira e jogo de modo adequado destacando o avanço e proporcionando mais desenvolvimento.

Nosso trabalho foi elaborado refletindo sobre a importância das brincadeiras e jogos no método de ensino-aprendizagem na educação infantil, onde procuramos entender qual a importância das brincadeiras e jogos no método de ensino-aprendizagem.

Identificamos no transcorrer do nosso trabalho a contribuição das brincadeiras e jogos no desenvolvimento da criança, onde reconhecemos o função das brincadeiras e 
jogos no método de ensino-aprendizagem, procurando sobre conscientizar a importância da ludicidade, destacando a função do educador no trabalho com brincadeiras e jogos.

\section{JOGOS E BRINCADEIRAS}

Analisar o jogo talvez configure uma tarefa simples num primeiro momento. Ao falar da origem do jogo, Huizinga (1971, p. 03) mostra que "o jogo é fato mais antigo que a cultura, pois esta, mesmo em suas definições menos rigorosas, pressupõe sempre a sociedade humana; mas, os animais não esperaram que os homens os iniciassem na atividade lúdica."

Seguindo o pressuposto Huizinga examina o jogo como um efeito comum, definido pelo lúdico, remetendo que seria compreensível pensar no jogo como uma íntegra e absoluta atividade humana. $\mathrm{O}$ autor se mostra convicto de que é através do jogo que a sociedade se desenvolve.

Em tempos passados a cultura do brincar eram passadas dos mais velhos para os mais novos, onde se divertiram com brincadeiras que eram trazidas de geração em geração, porém com o passar dos anos, ocorreram alterações nos modos de brincar, assim como nos próprios brinquedos. As brincadeiras que eram criadas com o auxílio deles, nos dias atuais foram modificadas como a grande parte dos brinquedos, que são produzidos em fábricas.

Segundo Kishimoto (1993, p. 45) "brincar é uma atividade fundamental para o desenvolvimento da identidade e da autonomia". A ação do brincar facilita o aprendizado da criança, visto que auxilia na construção da reflexão, da criatividade e da autonomia, determinando, desse modo, uma relação modesta entre aprendizagem e jogo.

A Declaração Universal dos Direitos da Criança prevê em seu princípio VII, que “a criança deve desfrutar plenamente de jogos e brincadeiras os quais deverão estar dirigidos para educação, sociedade, e as autoridades públicas se esforçaram para promover o exercício desse direito".

É notório que brincar tornou-se um direito das crianças, sendo garantido por Leis e assegurado em quase todos os lugares. Embora compreendam que independente de sua condição social, física, financeira, a criança será capaz de brincar em qualquer situação, 
com os objetos que ela tem disponíveis. As crianças se adequam em diversos ambientes e dão a eles novos sentidos, seja inventando novas brincadeiras, brinquedo, oferecendo sentido a diferentes objetos, designando soluções e até mesmo imaginando diversas maneiras, além do que o adulto recomenda.

O direito ao brincar além de ser reconhecido pela CF de 1988 é previsto no ECA em seu artigo 16, IV, onde cita: "o direito à liberdade compreende os aspectos dentre eles: brincar, praticar esportes e divertir-se". (BRASIL, 1988).

Estudiosos afirmam que "a condição educacional do brincar é notada como uma ação construtiva, que prevê o avanço total do indivíduo quer seja na sua habilidade física, intelectual e moral, inclusive a formação da personalidade, a construção do caráter e do perfil de cada um” (PIAGET apud SANTOS, 2001, p. 173).

A brincadeira é algo específico à criança e, no que lhe diz respeito, à infância visto que, por meio do brincar, a criança prova, ordena-se, estabelece-se, produz regras para si e para o outro. Ela produz e reproduz, a toda nova brincadeira, o âmbito no qual coabita, criando no brincar um modo de linguagem que utiliza para assimilar e comunicar-se consigo mesmo, com as outras pessoas, com o mundo. Desde muito cedo as crianças se comunicam por gestos, sons e mais tarde a imaginação.

Podemos dizer que brincar é uma atividade natural, espontânea e necessária para sua formação. Assim, o brinquedo se faz muito importante como um elemento da criança distinguir seu próprio mundo, permitindo novas descobertas, visto que, quando a criança vai se desenvolvendo fisicamente e mentalmente, ela começa a escolher seus próprios brinquedos, na maioria das vezes ligados a seu sexo, e sempre acaba existindo um brinquedo preferido.

Quando as crianças brincam criam características próprias, pois através das brincadeiras que elas compreendem e se relacionam com o mundo a sua volta. As brincadeiras se evidenciam por alguma formação e pela aplicação de suas normas e regras não determinando o limite para a ação lúdica, sendo assim as crianças podem alterá-las e se retirar quando quiser, podendo colocar novos colegas, cumprindo as próprias regras, e possibilitando maior liberdade de ação para as crianças. 
Para Vygotsky (1998, p. 127), “a brincadeira possui uma função essencial no desenvolvimento da criança." Uma vez que a ideia de jogo está adaptada tanto ao brinquedo quanto às brincadeiras, sendo uma ação organizada e definida por uma base de regras mais definidas.

Seguindo o conceito de que o conhecimento vem através das interações, o jogo lúdico e o jogo de papéis, possibilita que ocorra uma atuação na área de desenvolvimento proximal do sujeito, isto é, produz situações para que determinados entendimentos e/ou princípios estejam garantidos ao exercer na proposta imaginativa possibilidade de criar casos, demonstrar papéis, seguir normas de conduta de sua cultura.

O brincar possui um papel protagonista no desenvolvimento das crianças, constatar as ligações entre jogos distintos facilita a execução na área dos processos de desenvolvimento proximal.

Diz Santos (2000, p. 11) "[...] o jogo com a brincadeira representa recursos auxiliares para promover o desenvolvimento físico, mental e sócio emocional da criança”.

Vale ressaltar que toda essa nova definição não se dá antes da prática da brincadeira, e nem quando se encerra a mesma, mas sim, se dá no momento da atividade, onde o uso da imaginação é fundamental. Ampliando essa ideia de que esta ruptura entre definição e sentido de um objeto no brinquedo não se antecede a brincadeira, e sim ocorre durante o ato do brincar. Como defende Vygotsky e Leontiev: "O jogo e a brincadeira permitem ao aluno criar, imaginar, fazer de conta, funciona como laboratório de aprendizagem, permitem ao aluno experimentar, medir, utilizar, equivocar-se e fundamentalmente aprender" (VYGOTSKY e LEONTIEV, 1998 p. 23).

Destacando melhor esta ação, temos Leontiev onde salienta que:

A relação particular entre o sentido e o significado do brinquedo não é, portanto, dada antecipadamente nas condições do jogo; ela surge ao longo do jogo. Precisamos acrescentar também que a relação do sentido e do significado real das condições do jogo não permanece imutável durante os movimentos do processo do brinquedo, mas é dinâmica e móvel (LEONTIEV, 1988, p. 129).

Quando Leontiev, descreve sobre o jogo e a brincadeira, ele mostra o mundo objetivo a qual a criança identifica, constantemente está se ampliando, e num certo ponto a criança não se agrada mais com os objetos que tem a seu dispor, como seus brinquedos, 
apetrechos, objetos e instrumentos que é de uso dos adultos, mas ela pode manusear. Manusear os objetos é fundamental para que a criança se envolva e compreenda a realidade.

Huizinga também expõe sobre a condição "não sério" do jogo, declarando que,

em nossa maneira de pensar, o jogo é diametralmente oposto à seriedade. A primeira vista, esta oposição parece tão irredutível a outras categorias como o próprio conceito do jogo. Todavia, caso o examinemos mais de perto, verificaremos que o contraste entre jogo e seriedade não é decisivo. (HUIZINGA, 1971, p. 08).

Uma característica essencial do jogo é a sua aplicação pelas crianças e pelos adultos, todavia o brinquedo tem uma integração única com o espaço das crianças. Vygotsky diz que:

A brincadeira tem um papel fundamental no desenvolvimento do próprio pensamento da criança. É por meio dela que a criança aprende a operar com o significado das coisas e dá um passo importante em direção ao pensamento conceitual que se baseia nos significados das coisas e não dos objetos. A criança não realiza a transformação de significados de uma hora para outra (VYGOTSKY, 1994, p. 54).

Portanto, os professores devem estimular e inovar nos jogos e brincadeiras, ampliando atividades onde todos possam inventar, por meio da fala, dos sinais, das letras e do próprio corpo, buscando continuamente valorizar a fórmula individual de cada um, por meio das interações que acontecem dentre as crianças.

Para Santos (2000, p. 161), “ao conceituar jogos e brincadeiras, percebe-se que eles completam a ideia um do outro justificando o desenvolvimento em vários aspectos como: cognitivo, motores, afetivo e social no processo educativo".

Nas brincadeiras ou nos jogos, o educador deve avaliar cada criança, através do seu desempenho, sua influência mútua com os colegas, reconhecer cada uma, e ainda mesmo constatar e avaliar se os seus alvos estão sendo adquiridos.

Com este sentido, Santos afirma que:

Se direcionados e conduzidos de maneira adequada, favorecem momentos de confraternização, participação e integração, aliviando o cansaço físico e mental. Proporciona aos participantes entendimentos das expressões como jogar, busca pela vitória, cooperação, aceitação da derrota e equilíbrio durante a realização das atividades, com os adversários de jogo ou companheiros (SANTOS, 2000, p. 161). 
Assim, para que isso ocorra, o educador necessita ficar cauteloso à sala de aula, mostrando motivação e ao mesmo tempo inovando suas sugestões pedagógicas, verificando desse formato as atividades que deram certo e o que devem aprimorar.

Segundo Leontiev (2001, p. 121) "a brincadeira se caracteriza como a atividade principal da criança”.

Dessa forma, a Educação Infantil como ambiente escolar da criança, precisa ter o foco nessa atividade que se torna a principal que é o brincar, com isso, é indispensável que fique à acomodação da criança, um infinito de objetos, brinquedos, materiais reais instrucionais, livros de histórias infantis, materiais como (papel, tinta, lápis, massinha entre outros), e que a afinidade que elas formam com esses materiais, seja da brincadeira livre.

As brincadeiras não podem ser desperdiçadas como simples momentos de distração, elas tem que ser absorvidas pelo professor, e serem planejadas com o intuito de desenvolvimento, de objetivo de aprendizagem.

Vygotsky (1984, 1994, 1998) "para aprofundar os estudos relativos aos jogos e brincadeiras e sua relação com o processo de aprendizagem de crianças em idade préescolar buscou-se os referenciais teóricos" e Kishimoto (1993) "os quais tem em comum o estudo sobre a importância dos jogos e brincadeiras na Educação Infantil”.

O jogo admite um espaço principal no desenvolvimento e aprendizagem da criança. Portanto, uma criança que atira uma bola para cair num cesto, frequentemente, vai admitindo a si própria, suas fronteiras e possibilidades, distribuindo ações físicas, motoras e cognitivas, anexa à coragem, movimento, sentido, comando entre outros.

Kishimoto fala:

[...] que esse tipo de jogo recebe várias denominações: jogos imaginários, jogos de faz de conta, jogos de papeis ou jogos sociodramático. A ênfase é dada á "simulação" ou faz de conta, cuja importância é ressaltar por pesquisas que mostram sua eficácia para promover o desenvolvimento cognitivo e afetivo-social da criança (KISHIMOTO, 2011, p. 64).

Pode-se analisar o valor dos jogos dentro do ensino não perdendo de que eles oferecem numerosos melhoramentos, como o jogo de quebra-cabeça, propicia às crianças interação com as peças, encarando distintos enigmas e confusões para armar o mapa. 
Para Smole (2000, p. 17), “o educador ao propor brincadeiras com intenção pedagógica, deve possibilitar à criança o planejamento e o uso de estratégias para solucionar problemas nas diversas situações criadas por ele".

É essencial que a criança participe, se envolva para que ela possa aprender. $\mathrm{Na}$ fase orientada existem brincadeiras que são exercícios da qual o propósito específico é o de proporcionar o conhecimento de um conceito definido, isto é, além de serem definidos pela intencionalidade do educador.

Kishimoto nos mostra que sim as brincadeiras trazem vastas oportunidades de conhecimento, porém, o professor não pode estar convicto de que o conhecimento adquirido pela criança, seja propriamente a que ele deseja.

Desse modo, ele precisa desempenhar seu papel de orientador, fazendo com que os pensamentos dos alunos cheguem onde ele deseja, além disso, precisa expor os erros para ficar claro quais assertivas não foram ponderados para a solução do problema oferecido.

A utilização do jogo potencializa a exploração e a construção do conhecimento, por contar com a motivação interna, típica do lúdico, mas o trabalho pedagógico requer a oferta de estímulos externos e a influência de parceiros bem como a sistematização de conceitos em outras situações que não jogos. Ao utilizar, de modo metafórico, a forma lúdica (objeto suporte de brincadeira) para estimular a construção de conhecimento, o brinquedo educativo conquistou um espaço definitivo na educação infantil (KISHIMOTO, 1996, p. 37-38).

Através da brincadeira, a criança faz uma leitura do mundo, ela observa reações diferentes das pessoas, vai aprendendo e conceituando tudo que está a sua volta. Na brincadeira ela consegue ser o protagonista, vivenciando como algo verdadeiro, não apenas uma brincadeira qualquer, a criança fantasia, e vive aquele momento com intensidade.

O Referencial Curricular Nacional para a Educação Infantil vem-nos a afirmar que, "O brinquedo e as brincadeiras favorecem o desenvolvimento da linguagem, pois a criança amplia o repertório de novas palavras ao manusear objetos diversificados e diferentes situações" (BRASIL, 1998, p. 23).

O educador que atua neste processo o tempo todo, precisa ser muito preciso, considerando que o brinquedo seja a grande razão para o desenvolvimento, conforme as 
crianças se envolvam em níveis mais elevados de compreensão das regras que o conduzem e nas atitudes esperadas na perspectiva planejada, eles precisam se atentar, referente, às disposições comuns habituais as ações pensadas ou exercidas nas ocasiões que se mostram praticamente diante de si.

\section{LUDICIDADE NA EDUCAÇÃO INFANTIL}

Kishimoto (1998) defende que: "O lúdico deve ser visto como uma ferramenta contributiva para o melhor desenvolvimento das crianças e não ser visto como algo fora do contexto educacional".

Compreende-se que a ludicidade é uma precisão em qualquer período e as crianças com suas brincadeiras tem a probabilidade de se abranger melhor no seu espaço, ela amplia uma afetividade de espalhar suas emoções e vontades.

Na educação lúdica Almeida fala que: "[...] é uma ação inerente na criança e aparece sempre como uma forma de conhecimento, que se redefine na elaboração constante do pensamento individual constantes com o pensamento coletivo. [...]" (ALMEIDA, 1995, p. 11).

Portanto, a atividade lúdica não está limitada ao público infantil, o simples fato das crianças brincar provoca a aprendizagem, porque estabelece centralização nas brincadeiras que está sendo concretizada.

E ainda sendo afirmada pela autora que diz:

a educação lúdica colabora no desenvolvimento da criança, permitindo um crescimento sadio, um enriquecimento permanente, integrando-se ao mais alto espírito democrático enquanto investe em uma séria produção do conhecimento. A sua prática demanda a participação criativa, franca, critica, livre, promovendo a interação social e tendo em vista o intenso compromisso da transformação e modificação do ambiente (ALMEIDA, 1995, p. 41).

Juntos praticamos atividades lúdicas em períodos de lazer, quando tocamos, cantamos e dançamos uma música, deciframos e anotamos poesias, narramos histórias, praticamos esportes entre outros. 
Santos (1999, p. 12) diz, "para a criança, brincar é viver. Esta é uma afirmativa bastante usada e aceita, pois a própria história da humanidade mostra que as crianças sempre brincam, certamente continuarão brincando".

Na educação infantil há três atividades lúdicas atuais: brincadeira, jogo e contação de histórias. O brincar para a criança é reverenciar aos desejos inconscientes e conscientes que entusiasmam nos atos físicos e mentais, e pelo anseio da criança ao brincar, adéqua concentração e cuidado, levando-a a produzir, idealizar, e vivenciar novas fórmulas, condições e aptidões, quando a criança brinca abre nelas as capacidades mentais, orais ou físicas.

Almeida (1995, p. 41) afirma que "a ludicidade nos permite trabalhar de várias formas para todos estarem interagindo em forma de igualdade e sabendo que cada qual tem sua habilidade e seu limite".

Deste modo, precisa-se usar a ludicidade como ferramenta de ensino, buscando resultados no desenvolvimento da criança que de outras formas de certo modo não seriam alcançadas.

Segundo Carvalho (1992, p. 14) “o brincar se torna importante no desenvolvimento da criança de maneira que as brincadeiras e jogos que vão surgindo gradativamente na vida da criança, desde os mais simples até os de regras”. Assim “(...) o ensino absorvido de modo lúdico, passa a alcançar um aspecto significativo e afetivo no curso do desenvolvimento da inteligência da criança (...)" (CARVALHO, 1992, p. 28).

Adotando esta ala de pensamentos os autores nos permitem abertura de como é admirável cogitar de forma lúdica as atividades sobrepostas em salas de aula, adaptando para as crianças a probabilidade de aprendizagem distinta das que são habituadas não abandonando de educar, mas ensinando-as com brincadeiras e atributos no procedimento de educação e aprendizagem.

Desse modo, compreendendo o crescimento potencial da criança, o educador conseguirá mediar os próximos passos da criança e no processo do seu desenvolvimento, analisando não só o que já construiu, mas também o que o desenvolvimento construirá no exercício de maturação. 
Assim, está claro que as atividades que abrangem jogos e brincadeiras na educação infantil apresenta para as crianças alguma aprendizagem mais acelerada, porque elas interagem com o outro de forma que assimila mais perfeitamente o teor existido. Por isso o professor é o instrumento básico nesse procedimento, precisando ser um membro efetivo.

Ensinar não se restringe em perder dados e documentos ou revelar-se exclusivamente um caminho, mas auxiliar as crianças a tomarem consciência de si próprias, e da coletividade, aparecendo as oportunidades para que fulano possa sugerir seu adequado caminho, tendo uma visão de planeta distintos com as distintas situações que cada um irá deparar.

Assim ensinar não é só passar os conteúdos que estão planejados em sua grade curricular, e sim nomear situações de cuidados, harmonizando jogos, brincadeiras e direcionando para a aprendizagem.

Piaget (1978, p. 119) "fala que é obrigatório o desenvolvimento das atividades lúdicas para todas as crianças porque brincando as crianças gasta energia e melhora seu conhecimento intelectual, quando a criança está brincando ela se envolve por completo na brincadeira, e com a mediação do professor as atividades lúdicas passam a serem agradáveis e significativas para as crianças, e as desenvolvem com mais prazer".

No Brasil a educação infantil passa a ser considerada em seus documentos oficiais a originalidade pelo: o Referencial Curricular Nacional para a Educação Infantil (RCNEI, 1998), as Diretrizes Curriculares Nacionais para a Educação Infantil (DCNEI, 1999/2009) e a Base Nacional Curricular Comum (BNCC), instaurando no setor educativo a responsabilidade de garantir o direito às crianças uma educação que solicite o desenvolvimento de suas distintas linguagens e potencialidades.

Conforme o Referencial Curricular Nacional da Educação Infantil, “É preciso que o professor tenha conhecimento que na brincadeira as crianças reformulam e estabilizam aquilo que sabem a respeito das mais distintas esferas do conhecimento, em uma atividade espontânea e imaginativa" (RCNEI, 1998, p. 29).

Sendo assim, os professores precisam enxergar no jogo algo além de um simples passatempo, visto que a educação infantil proporciona oportunidades que vão bem longe 
de um simples mundo de fantasias e imaginação. É no determinado período do jogo que a criança concentra o maior número de informações.

Pois é na Base Nacional Comum Curricular (BNCC) que a educação infantil é concernente, foi homologada em 2017 já no final, a base dela apresenta elementos fundamentais às aprendizagens da educação infantil sendo a primeira etapa da educação básica, e traz as mais importantes referências das práticas pedagógicas.

$\mathrm{O}$ documento pondera que esses direitos de aprendizagem são básicos para o desenvolvimento das crianças, bem como fortalecem a competência cognitiva e a captação do que ocorre ao redor, na BNCC que se estrutura essa base.

Os campos de experiências constituem um arranjo curricular que acolhe as situações e as experiências concretas da vida cotidiana das crianças e seus saberes, entrelaçando-os aos conhecimentos que fazem parte do patrimônio cultural. A definição e a denominação dos campos de experiências também se baseiam no que dispõem as DCNEI em relação aos saberes e conhecimentos fundamentais a ser propiciados às crianças e associados às suas experiências. (BRASIL, 2017, p. 38).

Os educadores devem harmonizar as qualidades necessárias para que as a crianças na educação infantil "aprendam em situações nas quais possam desempenhar um papel ativo em ambientes que as convidem a vivenciar desafios e a sentirem-se provocadas a resolvê-los, nas quais possam construir significados sobre si, os outros e o mundo social e natural" (BRASIL, 2017, p. 35).

Com embasamento neste referencial da BNCC apontado, podemos concluir que na educação infantil, a aprendizagem está fortemente anexa ao brincar e brincar. A brincadeira é a fase das crianças, onde são dois institutos essenciais. Nas brincadeiras as crianças estudam consecutivamente com os desafios que têm de confrontar-se.

O jogo pode tronar-se uma estratégia didática quando as situações são planejadas e orientadas pelo adulto visando a uma finalidade de aprendizagem, isto é, proporcionar à criança algum tipo de conhecimento, alguma relação ou atitude. Para que isso ocorra, é necessário haver uma intencionalidade educativa, o que implica planejamento e previsão de etapas pelo professor, para alcançar objetivos predeterminados e extrair do jogo atividades que lhe serão decorrentes (RCNEI, 1998, p. 212).

Por essa razão, a praxe didática em relação a jogos e brincadeiras é mais complexa do que demonstra a primeiro momento. 
Maluf (2003, p. 13) nos ajuda a compreender melhor a relevância do brincar dizendo: "é difícil alguém dizer que criança não precisa brincar, porém é difícil os adultos darem a importância que essa ocasião necessita (...) brincar livremente já causa resultados positivos para o desenvolvimento das crianças".

Requer desse modo melhor cautela e observação por parte dos professores. Rego (2004, p. 82) ressalta que a brincadeira caracteriza a perspectiva de "solução do impasse causado, de um lado pela necessidade de ação da criança e de outro, por sua impossibilidade de executar as operações exigidas por essas ações".

Deste modo, por meio do brinquedo, a criança copia o adulto buscando estar congruente com a função acolhida.

"O brincar sempre foi e sempre será uma atividade espontânea e muito prazerosa, acessível a todo ser humano, de qualquer faixa etária, classe social ou condição econômica" (MALUF, 2003, p. 17).

Porém, as brincadeiras não são só passatempo, é uma atividade prazerosa na aprendizagem das crianças, para as crianças brincar é um afazer, porque neste período em que brincam encontram habilidades e suas capacidades. A criança aprende de maneira espontânea, ela se envolve, cria e se desenvolve. Ficando assim bem claro que as brincadeiras vêm promover o acréscimo no procedimento de ensino e aprendizagem das crianças.

Sendo assim, observamos que os jogos e as brincadeiras na educação infantil, são um instrumento primordial na metodologia de ensino da criança.

\section{CONSIDERAÇÕES FINAIS}

Considera-se que a análise atingida propiciou conhecimento de como é importante o método de atividades lúdicas nas escolas de educação infantil. Ainda se tratou do valor das atividades lúdicas alcançadas com crianças, independentemente das idades, aceitando que essas atividades consentem um desenvolvimento do mesmo modo real das crianças.

As atividades lúdicas ajudam no descobrimento, na capacidade criadora, de forma que as crianças se expressem, critiquem, avaliem e modifiquem as coisa ao seu redor. Para a efetivação desse trabalho foi alcançada uma pesquisa bibliográfica, procurando 
autores de relevância nesse campo de informação. Autores esses que, a cada ideia defendida sobre a importância dos jogos e brincadeiras para o desenvolvimento da criança, nos mostra o quanto é essencial esse estudo e nos leva a querer aprofundar-se sempre mais nesse assunto.

Os autores em vários pontos mencionam a questão do jogo como algo "não sério", nesse ponto eles trazem a reflexão que isso não diverge que a brincadeira infantil não seja séria. Ao contrário, quando a criança brinca, ela se mostra muito concentrada. Quando o autor se refere a seriedade, ele quer relacionar a graça do jogo em si.

Definiu-se que não se carece esquecer de que os jogos e as brincadeiras ainda são adequadas de educar e permitir às crianças ser mais feliz, provendo-lhe uma estrutura emocional com habilidades para ampliar as suas diferentes aparências. É, portanto, essencial que os ambientes e, especialmente, o período escolar proposto ao brincar permaneça contido no hábito da educação infantil, não apenas em formato de estudo, mas assim como método constante de costume das diversas linguagens pelas crianças.

Dessa forma, o lúdico para as crianças possui um significado importante, onde elas passam a apresentar informação e inclusão no que arquitetam. Ficando portanto o lúdico com a cooperação do bem-estar corporal das crianças ajudando no aumento intelectual promovendo a convivência igualitária.

Os educadores que encontram-se preparados a trabalhar com a educação infantil, precisarão ter a consciência do exato significado das atividades lúdicas, harmonizando o brincar e constituindo o foco da sua sugestão pedagógica pois, seu papel vai além de tomar o tempo das crianças, necessitando que tudo seja desenvolvido com afetividade, cuidado e sensibilidade empregando, o lúdico a máxima esperteza do ensino da aprendizagem.

Como vimos, vários estudiosos confirmam quão importante é o lúdico no processo de desenvolvimento das crianças. Levando em consideração cada análise feita através desses estudiosos, podemos afirmar que o objetivo da pesquisa foi alcançado, visto que se levarmos o que foi estudado para rotina com as crianças veremos resultados já comprovados. Ter a consciência dessa relevância do brincar para o processo de aprendizagem nos torna pessoas mais qualificadas e empenhadas a ensinar. 


\section{REFERÊNCIAS}

ALMEIDA, P. N. de. Educação lúdica: Técnicas e jogos pedagógicos. São Paulo: Loyola, 1995.

BRASIL. Características do Referencial Nacional para a Educação Infantil. Ministério da Educação e do Desporto, Secretaria de Educação Fundamental. Brasília: MEC/SEF,1998 vol.3.

BRASIL. Base Nacional Comum Curricular. Brasília: MEC, 2017. Disponível em: <http://basenacionalcomum.mec.gov.br/images/BNC C_20dez_site.pdf >. Acesso em: 15 de jan. 2021.

BRASIL. Ministério da Educação e do Desporto. Secretaria de Educação Fundamental. Referencial curricular nacional para a educação infantil/Ministério da Educação* e do Desporto, Secretaria de Educação Fundamental. - Brasília: MEC/SEF, 1998, volume: 1 e 2 .

CARVALHO, A.M.C. et al. (Org.). Brincadeira e cultura: viajando pelo Brasil que brinca.São Paulo: Casa do Psicólogo, 1992.

GOMES, C. L. (org.). Dicionário Crítico do Lazer. Belo Horizonte: Autêntica, 2004.

Dispónivel em: <https://www.ipabrasil.org/post/o-direito-de-brincar>. Acesso em: 20 de jun. 2021.

HUIZINGA, J. Homo Ludens: O jogo como elemento de cultura. São Paulo, Perspectiva Editora da USP, 1971.

KISHIMOTO, T. M. Jogos infantis: o jogo, a criança e a educação. Petrópolis, RJ: Vozes, 1993.

KISHIMOTO, T. M. Jogo, brinquedo, brincadeira e a educação. São Paulo: Cortez, 1997.

KISHIMOTO, Tizuko Morchida. Jogos Infantis: O jogo, a Criança e a Educação. Rio de Janeiro: Vozes, 1993.

KISHIMOTO, Tizuko Morchida. Jogo, Brinquedo, Brincadeira e Educação. São Paulo: Cortez, $1996 . \quad$ Disponível em: <https://edisciplinas.usp.br/pluginfile.php/4386868/mod_resource/content/1/Jogo\%2C $\% 20$ brnquedo $\% 2 \mathrm{C} \% 20$ brincadeira $\% 20 \mathrm{e} \% 20$ educa $\% \mathrm{C} 3 \% \mathrm{~A} 7 \% \mathrm{C} 3 \% \mathrm{~A} 30 . \mathrm{pdf}>$. Acesso em:27 de out. 2020.

KISHIMOTO, T. M. jogo, brinquedo, brincadeira e a educação/ Tizuko M. Kishimoto (ORG); - 14. ed. - São Paulo: Cortez, 2011.

LEONTIEV, A. N. Os princípios psicológicos da brincadeira pré-escolar. In: VYGOTSKY, Lev. S.; Luria, A. R; Leontiev, A. N. Linguagem, desenvolvimento e aprendizagem. São Paulo: Ícone/Editora da Universidade de São Paulo, 1988.

LEONTIEV, A. N. Os Princípios Psicológicos da Brincadeira Pré-escolar. In: LEONTIEV, A. N., LURIA, A. R., VYGOTSKY, L. S. Linguagem, Desenvolvimento e Aprendizagem. São Paulo: Ícone/Edusp, 1991. Acesso em: 16 de jan. 2021.

MALUF, Ângela Cristina Munhoz, Brincar prazer e aprendizado. Petrópolis, RJ: Vozes, 2003. 
PIAGET, Jean. Seis estudos de psicologia. Tradução Maria Alice Magalhães D’ Amorim e Paulo Sergio Lima Silva. 24 eds. Rio de Janeiro: Forense Universitária, 2003. Disponível em: < http://atividadeparaeducacaoespecial.com/wpcontent/uploads/2015/01/SEIS-ESTUDOS-DE-PSICOLOGIA-JEAN-PIAGET.pdf> . Acesso em:27 de out. 2020.

PIAGET, J. A formação do símbolo na criança. $3^{\text {a }}$ ed. Rio de Janeiro: ed. Zahar, 1973. PIAGET, J.. Psicologia e Pedagogia. 4ª ed. Rio de Janeiro: Forense/ Universitária, 1976. RCNEI, BRASIL. Referencial Curricular Nacional para a Educação Infantil, Brasília: MEC/SEF, 1998.

REGO, Teresa Cristina. Vygotsky: uma perspectiva histórico-cultural da educação. Rio de Janeiro: Vozes, 2004.

RIBEIRO, Katiuce Lucio. Jogos na Educação Infantil. / Katiuce Lucio Ribeiro, Selma Pereira de Souza. Serra: Escola Superior de Ensino Anísio Teixeira, 2011.

SANTOS, Santa Marli Pires dos. Brinquedos e infância: um guia para pais e educadores. Rio de Janeiro: Vozes, 1999.

SANTOS, S. M. P. Brinquedoteca: A criança o adulto e o lúdico. Petrópolis, RJ: Vozes, 2000.

SMOLE, K. S. Brincadeiras infantis nas aulas de matemática. Porto Alegre: Armed, 2000.

VIGOTSKY, L.S. A formação social da mente. São Paulo: Martins Fontes, 1984.

VYGOTSKY, Lev S. Formação Social da mente: o desenvolvimento dos processos psicológicos superiores. São Paulo: Martins Fontes, 1994.

VYGOTSKY, L.S. Pensamento e Linguagem. São Paulo: Martins Fontes, 1994.

VYGOTSKY, L. S. A formação social da mente. São Paulo: Martins Fontes, 1999. $4^{\text {a }}$ ed. Disponível em: <http://www.egov.ufsc.br/portal/sites/default/files/vygotsky-aformac3a7c3a3o-social-da-mente.pdf>. Acesso em: 01 de dez. 2020.

VYGOTSKY, L.S. e LEONTIEV, ALEXIS. Linguagem, desenvolvimento e aprendizagem. São Paulo: Edusp,1998.

VYGOTSKI, L. S. Fundamentos da Defctologia: Obras Escogidas V. Madri: Visor, 1997.

Origens do pensamento na criança. São Paulo: Manda, 2004. 


\title{
CAPÍTULO XXIV
}

\section{LUDICIDADE COMO REQUISITO PARA UMA APRENDIZAGEM SIGNIFICATIVA NA EDUCAÇÃO INFANTIL}

\author{
Alcione Sousa Dos Santos Almeida ${ }^{92}$. \\ DOI-Capítulo: 10.47538/AC-2021.14-24
}

RESUMO: Ao analisar o panorama da educação mundial e brasileira, em especial da Educação Infantil, e após a realização de estudos desenvolvidos por grandes pensadores, foi possível averiguar a importância que os jogos e as brincadeiras apresentam para o processo de ensino / aprendizagem de crianças, principalmente, daquelas que se encontram na faixa etária de zero a cinco anos de idade. A utilização de jogos e brincadeiras como procedimentos metodológicos no contexto das salas de aula de Educação Infantil ajudam na formação de conhecimentos mais sólidos e significativos para as crianças. Diante de tal perspectiva, esta pesquisa foi desenvolvida, tendo como objetivo principal analisar a importância dos jogos e brincadeiras para o desenvolvimento intelectual e social das crianças que se encontram na modalidade de Educação Infantil. $\mathrm{O}$ trabalho tem como estratégia metodológica a pesquisa bibliográfica que, certamente, contribuirá para um melhor desenvolvimento, embasamento e credibilidade dos fatos verificados e constatados.

PALAVRAS-CHAVE: Ludicidade. Aprendizagem. Jogos. Brincadeiras. Conhecimento.

\section{LUDICITY AS A REQUIREMENT FOR SIGNIFICANT LEARNING IN EARLY CHILDHOOD EDUCATION}

\begin{abstract}
After analyzing the panorama of world and Brazilian education,especially in Early Childhood Education, and carrying out studies developed by great thinkers, it was possible to investigate how important games and plays are for the teaching / learning process of children, especially those aged from zero to five years old. The use of games and plays as methodological procedures in the context of the Early Childhood Education classrooms help in building stronger and more meaningful knowledge for children.In this perspective, the research was developed aiming to analyze the importance of games and plays to the social and intellectual development of children who are in Early Childhood Education. The study has the bibliographic research as methodological strategy, which will certainly contribute to a better development, theoretical background and credibility of the found and verified facts.
\end{abstract}

KEYWORDS: Ludicity. Learning. Games. Plays. Knowledge.

92 Pedagoga. Professora da Educação Básica. E-mail: alcioneveronilson@gmail.com 


\section{INTRODUÇÃO}

A criança é um ser em constante crescimento físico e psicológico, sendo assim, necessita de estratégias motivadoras que influenciam diretamente e positivamente nesse desenvolvimento. A escola por ser uma instituição voltada para o trabalho sistemático desse desenvolvimento deve buscar estratégias que potencializam tal crescimento, dessa forma, deve utilizar atividades lúdicas como ferramenta pedagógica, ou seja, deve criar ambientes prazerosos de aprendizagem utilizando como principal caminho as brincadeiras e os jogos infantis.

É importante ressaltar que, especialmente, os jogos e as brincadeiras na Educação Infantil é uma ou se não a principal forma de apresentar os conhecimentos para as crianças com significado onde, consequentemente, os alunos aprenderão com maior prazer.

Diante de tal importância que os jogos e as brincadeiras têm para educação das crianças pequenas foi que decidimos desenvolver o presente trabalho que tem como objetivo geral analisar a importância que os jogos e as brincadeiras tem para o desenvolvimento intelectual e social das crianças que se encontram na modalidade de Educação Infantil e como objetivos específicos conhecer os fatores que interferem positivamente no desenvolvimento intelectual e social das crianças e compreender qual o papel do profissional da Educação Infantil.

Para realização da pesquisa foi utilizado o procedimento metodológico de análise bibliográfica, que ressalta e enfatiza as ideias e pensamentos de autores renomados que tratam do tema. Esse procedimento foi selecionado com o objetivo de oferecer maior credibilidade ao trabalho, pois, dessa forma, haverá um verdadeiro embasamento teórico sobre o tema pesquisado.

Para desenvolvimento da pesquisa bibliográfica entraremos em diálogo com os pensamentos de autores como Vygotsky (1998), Piaget (1998), Gomes (2004), entre outros que ressaltam toda a importância que a ludicidade traz para o desenvolvimento psicológico e aprendizagem das crianças que estão na Educação Infantil.

\section{HISTÓRIA DOS JOGOS NA EDUCAÇÃO INFANTIL}


O ato de brincar é inato da criança, ou seja, faz parte de suas atividades diárias e está diretamente ligado ao seu desenvolvimento psicológico e social, portanto, é quase que inadmissível falar em educação de crianças sem relacioná-las com o brincar. Conforme Antunes (2005, p. 33) "as implicações da necessidade lúdica extrapolaram as demarcações do brincar espontâneo".

Mesmo diante dessa grande importância tanto para crianças, como para jovens, não é comum identificar nas escolas estratégias metodológicas planejadas e voltadas para o ato de brincar. De acordo com Neves (2009, p. 45), "a criança e mesmo o jovem opõe uma resistência à escola e ao ensino, porque acima de tudo ela não é lúdica, não costuma ser prazerosa".

A palavra lúdico tem sua origem na palavra latina "ludus" que significa "jogo", porém, essa definição deixou de ser simplesmente essa e passou, ao longo da história, a ser definido como traço essencial de psicofisiologia do comportamento humano, isto é, algo que faz parte do desenvolvimento humano. Nesse sentido, Carneiro (1995, p. 66) destaca que "todas as pessoas têm uma cultura lúdica, que é um conjunto de significações sobre o lúdico".

Nas comunidades primitivas o brincar se expressava através das danças, lutas e de todas as atividades recreativas desenvolvidas. Segundo Antunes (2005, p. 56) "na Grécia antiga, Platão afirmava que os primeiros anos de vida da criança deveriam ser ocupados por jogos".

Segundo Kishimoto (1995), Platão colocava a importância de a criança aprender brincando para combater a opressão e a violência, enquanto Aristóteles enfatizava a necessidade de se utilizar jogos "sérios" na educação de crianças pequenas, como forma de prepará-las para vida.

A importância do jogo na educação de crianças só surgiu a partir do século XVI, ou seja, foi a partir desse período que estudiosos começaram a perceber a valorizar atividades lúdicas no contexto de aprendizagem de crianças. Para o pensador norteamericano Dewey (1859-1952), “O jogo faz o ambiente natural da criança, ao passo que as referências abstratas e remotas não correspondem ao interesse da criança." (2005, p. 23). conforme as ideias do autor, o jogo é considerado algo que já faz parte do interesse 
natural da criança, é algo que tem a capacidade inata de despertar na criança o gosto e o prazer.

Jean Piaget (apud ANTUNES, 2005, p. 25) "retrata que os jogos não são apenas uma forma de entretenimento para gastar a energia das crianças, mas meios que enriquecem o desenvolvimento intelectual". Para o pensador, a ludicidade, além de despertar o prazer, consegue despertar ainda o interesse pela aprendizagem de conhecimentos abstratos.

Em outras palavras, são atividades que contribuem, diretamente e essencialmente, na aprendizagem cognitiva e social das pessoas.

\section{A INTRODUÇÃO DOS JOGOS NA EDUCAÇÃO INFANTIL}

Aprender por meio de atividades recreativas como jogos e brincadeiras provocam grandes contribuições para o desenvolvimento e assimilação de conhecimentos cognitivos tanto para crianças, quanto para jovens e adultos. Aprender através de atividades prazerosas faz com que esses sujeitos adquiram capacidades e habilidades que permitem o seu autoconhecimento, como também, conhecer e experimentar situações de aventura, exploração e ação. Como diz Marcellino (1997).

destaca que "ao tratar do lúdico foca a abordagem que se busca, o lúdico não como algo isolado ou associado a uma determinada atividade", dessa forma, deve ser visto como algo imprescindível ao desenvolvimento das capacidades e habilidades da criança, como algo inseparável do crescimento cognitivo e psicológico desses indivíduos. (MARCELLINO, 1997, p. 44).

Conforme menciona Marcellino (1997) a ludicidade deve ser vista como elemento constituinte do ser infantil e que diante das aprendizagens formais realizadas na sala de aula, é algo inseparável, ou seja, só é possível desenvolver uma aprendizagem significativa com a presença marcante das atividades lúdicas. Essas podem ser consideradas todas aquelas que envolvem o ato de desenhar, brincar espontaneamente, jogar e utilizar brinquedos.

Cadermartori (1991, p. 58) ressalta que a criança vê o mundo a sua volta antes mesmo de detê-lo e escrevê-lo, sendo assim, afirma que: 
A manipulação lúdica dos sons da língua pela criança, fruição do sonoro independente do significado, constitui-se em parte fundamental do desenvolvimento linguístico. Do modo que o conhecimento da realidade exterior não se dá sem a atividade de exploração dos objetos, o conhecimento linguístico não prescinde de uma atividade com a língua na qual está é tratada como objetivo material. Aceito este ponto de vista, o ludismo sonoro deixa de ser visto como uma inconsequência infantil, à qual se pode ser indiferente, para ser visto como parte específica da habilidade da espécie para aprender a língua (CADERMARTORI, 1991, p. 58).

De acordo com o pensamento do autor fica notória a importância que os diversos tipos de jogos têm para se alcançar o pleno desenvolvimento das capacidades das crianças, sendo assim, deve ser atribuído valor a todas as atividades lúdicas sejam elas primárias que se restringem ao ato de falar e ouvir, sejam elas linguísticas fundamentais como é caso daquelas que tratam do ato de trabalhar jogos verbais, leituras, dramatizações, entre outras.

O brinquedo é outro elemento de grande importância para o desenvolvimento das crianças, isto é, o brinquedo, quando bem selecionado, o melhor atendimento às características e necessidades infantis, porém, é fundamental enfatizar que o brinquedo deve ser selecionado de acordo com a idade e com o objetivo ao qual se pretende alcançar com a sua utilização.

É brincando que os indivíduos desenvolvem sua imaginação e executam suas forças, além do mais, é brincando que a crianças exercita seus músculos e constrói, gradativamente, seu raciocínio lógico, tão importante para se viver em sociedade.

Os estabelecimentos que atendem crianças na faixa etária de 0 a 6 anos de idade têm, na sua grande maioria, limitado as atividades infantis aos exercícios repetitivos, motora e, por meio dessa castração bloqueiam a organização independente das crianças para as brincadeiras, essas estratégias pedagógicas não estimulam a criatividade e o pensamento argumentativo e lógico dos educandos, tratam suas ações simbólicas como se servissem apenas para explorar e facilitar ao educador a transmissão de determinada visão do mundo, definida, a princípio, pela instituição infantil. Nessa perspectiva, Wajskop (1995) aponta que se as instituições fossem organizadas em torno do brincar infantil, elas poderiam cumprir suas funções pedagógicas, privilegiando a educação da criança em uma perspectiva criadora, voluntária e consciente. 
Cabe à escola desenvolver atividades que concebem o trato com os valores humanos essenciais para se viver em sociedade, dessa forma, o trabalho realizado pelos estabelecimentos educacionais deve ter uma visão global e ir além dos conhecimentos técnicos proporcionados pelas disciplinas escolares. É aí que entra a importância da aplicabilidade de atividades lúdicas no contexto de uma sala de aula.De acordo com Gomes. 2004.

a ludicidade é uma dimensão da linguagem humana, que possibilita a expressão do sujeito criador que se torna capaz de dar significado à sua existência, ressignificar e transformar o mundo". E mais na frente conclui: "Dessa forma, a ludicidade é uma possibilidade e uma capacidade de se brincar com a realidade, ressignificando o mundo (GOMES, 2004, p. 47).

Segundo a citação acima por meio da ludicidade o professor consegue fazer uma ponte entre o ato de brincar com a aprendizagem de conhecimentos científicos. É uma forma de aprender com prazer, sobretudo, com significado.

Este autor estabelece a premissa básica de nossa abordagem quando escreve:

Como expressão de significados que têm o brincar como referência, o lúdico representa uma oportunidade de (re) organizar a vivência e (re) elaborar valores, os quais se comprometem com determinado projeto de sociedade. Pode contribuir, por um lado, com a alienação das pessoas: reforçando estereótipos, instigando discriminações, incitando a evasão da realidade, estimulando a passividade, o conformismo e o consumismo; por outro, o lúdico pode colaborar com a emancipação dos sujeitos, por meio do diálogo, da reflexão crítica, da construção coletiva e da contestação e resistência à ordem social injusta e excludente que impera em nossa realidade (GOMES, 2004, p. 146).

De acordo com o pensamento do autor, jogar é uma necessidade humana que faz parte dos interesses dos indivíduos independentemente de sua idade e que o desenvolvimento do aspecto lúdico favorece, como citado anteriormente, ao desenvolvimento pessoal, social e psicológico das pessoas.

No processo educacional de pessoas, e principalmente, na modalidade de Educação Infantil, a execução de estratégias lúdicas pedagógicas deve ser tratada como essencial e prioritária, portanto, devem estar contidas no planejamento escolar realizado pelos professores e coordenadores. Essa inclusão visa, portanto, a flexibilização e dinamização das atividades realizadas ao longo de toda a prática docente, oportunizando a eficácia e significação da aprendizagem. 
Segundo Rau (2012a), a utilização de jogos como método pedagógico pode contribuir para a formação integral da criança. A ludicidade no contexto educacional é composta por atividades significativas que estão de acordo com as necessidades das crianças de forma integrada, associando-se à sua realidade sociocultural no processo de construção de conhecimento. Para Piaget, por meio da ludicidade a criança incorpora a sua própria realidade.

Nesse contexto, é por meio do desenvolvimento de atividades lúdicas que a criança, considerada ser em formação, se prepara para a vida, ou seja, através de uma prática contínua de atividades que priorizem o dinamismo e o prazer pela aprendizagem, a criança consegue uma melhor assimilação da cultura do meio na qual está inserida, adaptando-se às condições que a vida lhe oferece e aprendendo a competir, cooperar com seus semelhantes e conviver como um ser social. Sendo assim, cabe aos educadores adquirirem a posição de facilitadores e mediadores dos conhecimentos sistematizados, e criarem um ambiente que proporcione essas atividades e que oportunize, a todos, as melhores condições para que possam construir de forma autônoma e integral o seu próprio conhecimento.

\section{RELAÇÕES ENTRE JOGOS E A APRENDIZAGEM DAS CRIANÇAS}

Desenvolver uma educação que esteja focada no pleno desenvolvimento das capacidades e habilidades dos educandos requer do professor um planejamento voltado para a prática de estratégias metodológicas baseada nas principais necessidades e interesse dos alunos.

Outro ponto de fundamental importância é trabalhar esses conhecimentos de maneira que todos possam assimilá-los. É aí que está o maior desafio dos professores. A esse respeito, Friedmann (2003) expõe que no processo da Educação, o papel do educador é primordial, pois é ele quem cria espaços, oferece os materiais e participa das brincadeiras, ou seja, media a construção do conhecimento.

Dessa forma. Cabe ao professor selecionar e planejar atividades e materiais que estejam de acordo com a idade e, sobretudo, com os interesses que lhes são peculiares. Criar um ambiente dinâmico e prazeroso, onde a aprendizagem de conteúdos seja visto como algo atrativo aos alunos, é um grande desafio para os educadores. 
Outro ponto que deve ser levado em consideração ao planejar atividades pedagógicas é a diversidade cultural, social e pessoal que se encontra numa sala de aula. Com isso, Teixeira (1995) menciona que cabe ao educador oferecer inúmeras oportunidades para que se torne prazerosa a aprendizagem por meio dos jogos e brincadeiras.

Oferecer um contexto onde a aprendizagem seja desenvolvida de maneira prazerosa é, indiscutivelmente, um grande desafio, no entanto, é fundamental enfatizar que esse desafio é possível de ser vencido, ou melhor, através da aplicabilidade de jogos no ambiente da sala de aula o professor consegue transformar o processo ensino aprendizagem em algo prazeroso.

São muitas as estratégias que podem ser desenvolvidas numa sala de aula, principalmente, quando se refere à Educação Infantil. Os jogos e as brincadeiras são as principais formas onde o ludismo se manifesta.

Em se tratando dos jogos podem ser classificados de acordo com a idade e a área de interesse. Muitos pensadores focaram seus estudos na importância que o jogo tem para o desenvolvimento humano e, principalmente, o infantil, sendo assim, Piaget elaborou uma "classificação genética baseada na evolução das estruturas" (PIAGET apud RIZZI, 1997).

De acordo com o pensamento de Piaget (1975) os jogos são classificados em três grandes categorias que corresponde a rês fazer do desenvolvimento infantil: fase sensório motora (do nascimento até os 2 anos, aproximadamente), fase pré operatória (dos 2 aos 5 ou 6 anos aproximadamente) e fase das operações concretas. Portanto são assim classificados: jogos de exercício sensório motor, jogos simbólicos e jogos de educativos computadorizados.

Nos jogos de exercício sensório motor a finalidade é o próprio prazer do funcionamento. Estes exercícios consistem na repetição de gestos e movimentos simples como agitar os braços, sacudir objetos, emitir sons, caminhar, pular, correr, etc. embora esses jogos comecem na fase maternal e durem predominantemente até os 2 anos, eles se mantém durante toda a infância e até na fase adulta. Por exemplo, andar de bicicleta, moto ou carro (PIAGET apud RIZZI, 1997). 
Os jogos simbólicos aparecem, predominantemente, entre os 2 a 6 anos. A função desse tipo de atividade lúdica, de acordo com Piaget, "consiste em satisfazer o eu por meio de uma transformação do real em função dos desejos, ou seja, tem como função assimilar a realidade" PIAGET apud RIZZI, 1997).

A criança tende a reproduzir nesses jogos as relações predominantes no seu meio ambiente e assimilar dessa maneira a realidade é uma maneira de se auto expressar. Esse jogo-de-faz-de-conta possibilita à criança a realização de sonhos e fantasia e revela conflitos, medos e angústias, aliviando tensões e frustrações. (RIZZI, 1997) Piaget afirma que:

(...) é evidente que os jogos de construção não definem uma fase entre outras, mas ocupam, no segundo e, sobretudo no terceiro nível, uma posição situada a meio de caminho entre o jogo e o trabalho inteligente (PIAGET apud RIZZI 1997, p. 27).

O autor ressalta a importância dos jogos para despertar e estimular a inteligência cognitiva, ou melhor, enfatiza que através do desenvolvimento de jogos a criança adquire também a capacidade de construir sua inteligência.

Os jogos educativos computadorizados são criados com a finalidade dupla de entreter e possibilitar a aquisição de conhecimento. Nesse contexto, os jogos de computador educativos ou simplesmente jogos educativos devem tentar explorar o processo completo de ensino-aprendizagem. E eles são ótimas ferramentas de apoio ao professor na sua tarefa. (PIAGET apud RIZZI, 1997).

Para Antunes (2008), o jogo é um instrumento ideal para uma aprendizagem significativa, a partir dele estimula-se o interesse da criança. De acordo com o autor, muitos filósofos, sociólogos, teólogos e antropólogos concordam em:

Compreender o jogo como uma atividade que contém em si mesma o objetivo de decifrar os enigmas da vida e de construir um momento de entusiasmo e alegria na aridez da aprendizagem e da caminhada humana pela evolução biológica. [...] Em síntese, o jogo é o melhor caminho de iniciação ao prazer estético, à descoberta da individualidade e à meditação individual (ANTUNES, 2008, p. 38).

Por meio das palavras acima, Antunes mostra que o entusiasmo provocado pelos jogos na criança tem a capacidade de expor sentimentos individuais em contato direto com o outro. 
Segundo Rau (2012a), na perspectiva de Piaget sobre o lúdico, a criança brinca e descobre os objetos livremente e, portanto, desde cedo as crianças lidam com aspectos de prazer. Com isso, a aprendizagem não é um peso, mas um aspecto de satisfação e desenvolvimento. Para o autor (p. 110):

O lúdico como recurso pedagógico direcionado às áreas de desenvolvimento e aprendizagem pode ser muito significativo no sentido de encorajar as crianças a tomar consciência dos conhecimentos sociais que são desenvolvidos durante o jogo os quais podem ser usados para ajudá-las no desenvolvimento de compreensão positiva da sociedade e na aquisição de habilidades (RAU, 2012, p. 110).

Conforme pensamento do autor a aprendizagem ocorre por meio de um processo natural, prazeroso e dinâmico, portanto ganha uma roupagem significativa.

Já as brincadeiras podem ser desenvolvidas através da utilização de um brinquedo ou por meio da espontaneidade. Sejam elas dirigidas ou não devem ter o acompanhamento direto do professor, pois, ele deve considerar quais os objetivos a serem alcançados no momento de desenvolvimento dessas atividades.

É fundamental a criação de tempos espaços direcionados ao ato de brincar, uma vez que é por meio dessa metodologia que os professores da Educação Infantil alcançam melhores resultados de desenvolvimento cognitivo, cultural, social e até mesmo humano.

\section{A IMPORTÂNCIA DO BRINCAR PARA O DESENVOLVIMENTO DA APRENDIZAGEM}

$\mathrm{Na}$ infância o ser humano apresenta uma grande necessidade de brincar e é por meio dessa atividade que ele pode se desenvolver plenamente. Brincando, a criança desenvolve situação de interação social, "porque, brincando, a criança desenvolve a sociabilidade, faz amigos e aprende a conviver, respeitando o direito dos outros e as normas estabelecidas pelo grupo" (CUNHA, 1994, p. 11).

Oliveira (2010, p. 26) afirma que: Brincadeiras e jogos podem ser vistos como um grande laboratório, em que crianças e adolescentes experimentam novas formas de agir, de sentir e de pensar. Brincando, a criança busca se adaptar de forma ativa à realidade onde vive, mas também emite juízos de valor, inclusive sobre o que considera passível de melhora. 
A educação infantil é um período marcante no processo de formação do ser humano. Esta etapa da educação básica está dirigida para as crianças em fases iniciais, até aproximadamente cinco anos de idade (RODRIGUES; SILVA; PARIZ, 2003). Segundo a Lei de Diretrizes e Bases da Educação Nacional - LDBEN, n. 9.394 de 20 de dezembro de 1996, artigo 29:

a educação infantil, primeira etapa da educação básica, tem como finalidade o desenvolvimento integral da criança até cinco anos de idade, em seus aspectos físicos, psicológicos, intelectuais e sociais, completando a ação da família e da comunidade (BRASIL, 1996, p. 27833).

Diante da citação acima a Educação infantil é uma etapa de grande importância para o desenvolvimento do sujeito, o que requer dos profissionais que atuam com esse público toda uma atenção e dedicação para o atendimento com qualidade. A criança deve ter suas necessidades, particularidades e idades respeitadas, ou seja, o trabalho pedagógico na Educação Infantil deve ser voltado, impreterivelmente, para o ensinar e, consequentemente, o aprender com prazer.

As salas de aula que atendem o público infantil devem ser compostas por pessoas que compreendam as necessidades internas dos pequenos e proporcione um trabalho dinâmico por meio de jogos e brincadeiras.

A esse respeito, Fortuna (2011, p. 9) afirma que: A brincadeira é tão importante para o desenvolvimento humano que até mesmo quando ocorrem brigas ela contribui para o crescimento e a aprendizagem. Negociar perspectivas, convencer o opositor, conquistar adesões para uma causa, ceder, abrir mão, lutar por um ponto de vista - tudo isso ensina a viver.

Huizinga (apud RICHTER; FRONCKOWIAK, 2011, p. 40) mostra que o jogo é uma "função significante isto é, encerra um determinado sentido [...] que transcende as necessidades da vida e confere um significado à ação”. Richter e Fronckowiak (2011) argumentam que esse significado e essa ação surgiram do próprio conhecimento. Quando a criança brinca nota-se a satisfação, os sentimentos de alegria e o prazer em realizar essa atividade, o que torna uma aprendizagem significativa que tem sentido e que está na realidade da criança. 
Alcançar uma aprendizagem significativa em crianças pequenas requer do professor toda uma preparação técnica que se adquire através da formação acadêmica inicial e continuada, como também, por meio da identificação e compromisso com o trabalho a ser desenvolvido.

Na Educação Infantil o objetivo de alcançar uma aprendizagem significativa está atrelada diretamente com as estratégias metodológicas que os professores aplicam no contexto da sala de aula. A esse respeito, Friedmann (2003) expõe que no processo da Educação, o papel do educador é primordial, pois é ele quem cria espaços, oferece os materiais e participa das brincadeiras, ou seja, media a construção do conhecimento.

Dessa maneira, cabe ao professor selecionar e criar materiais pedagógicos adequados, como também, inserir em seu planejamento atividades lúdicas como jogos e brincadeiras que possam colaborar para uma aprendizagem prazerosa e significativa. Assim, na visão de Moyles (2002) as crianças sentem grande prazer em repetir jogos que conhecem bem, sentem-se seguros quando percebem que contam cada vez mais habilidades em responder ou executar o que é esperado pelos outros.

Teixeira (1995) menciona que cabe ao educador oferecer inúmeras oportunidades para que se torne prazerosa a aprendizagem por meio dos jogos e brincadeiras. Assim sendo, o educador deve assumir o papel de mediador do conhecimento para que a aprendizagem flua e se concretize de maneira eficiente e, sobretudo, prazerosa.

Brincar é um ato que faz parte da natureza da criança, ou seja, são atividades indispensáveis ao desenvolvimento físico, mental, intelectual e emocional da criança. Nesse sentido, Vygotsky (1998) ressalta que no brinquedo, a criança cria uma situação imaginária, isto é, é por meio do brinquedo que essa criança aprende a agir uma esfera cognitiva, é promove o seu próprio desenvolvimento no decorrer de todo o processo educativo.

Brincadeiras e jogos são atividades internas que fazem parte do cotidiano de todas as crianças de modo geral, sendo assim, o brinquedo assume um importante papel na vida delas, isto, contribui significativamente no desenvolvimento dos aspectos motor, nas habilidades do pensamento, imaginação, interpretação, criatividade, tomada de decisões, entre outros fatores de grande relevância para a criança. 
Segundo Piaget (1998, p. 62), “o brinquedo não pode ser visto apenas como divertimento ou brincadeira para desgastar energia, pois ele favorece o desenvolvimento físico, cognitivo, afetivo e moral".

Nessa perspectiva, o brinquedo não é simplesmente um objeto usado para distrair os alunos, ao contrário, ele assume um papel de crucial importância no trabalho pedagógico, pois, corresponde a uma profunda exigência do organismo e ocupa lugar de extraordinária relevância na educação escolar.

Além do mais estimula o crescimento e o desenvolvimento, a coordenação muscular, as faculdades intelectuais, a iniciativa individual, favorecendo o advento e o progresso da palavra. Estimula a observar e conhecer as pessoas e as coisas do ambiente em que se vive. Através do brinquedo a criança pode brincar naturalmente, testar hipóteses, explorar toda a sua espontaneidade criativa.

Assim, Campos (2011) destaca que os professores precisam estar cientes de que a brincadeira é necessária e que traz enormes contribuições para o desenvolvimento da habilidade de aprender e pensar.

O jogo é considerado uma atividade espontânea ou não realizada pelos professores de maneira organizada e com um objetivo a ser alcançado. Para realização dos jogos no contexto escolar, se faz necessário um ambiente adequado com espaços e tempos de forma a garantir o alcance dos objetivos propostos.

Santos (2008) destaca que enriquecer e valorizar os jogos realizados pelas crianças é outra função do educador, uma observação atenta pode indicar os professores que sua participação seria interessante para enriquecer a atividade desenvolvida introduzindo novos personagens ou novas situações que torne o jogo mais rico e interessante para as crianças, interessando-se por elas, animando-as pelo esforço.

Negrini (1994), ao se referir a jogos, acrescenta: o jogo se apresenta para a criança como uma atividade dinâmica, no sentido de satisfazer uma necessidade. Dessa forma, os jogos e brincadeiras ajudam as crianças na resolução dos seus próprios problemas.

Segundo Antunes (2005, p. 11) “A palavra jogo provém de jocu, substantivo masculino de origem latina que significa gracejo. Em seu sentido etimológico, portanto, expressa um divertimento, uma brincadeira, um passatempo, sujeito a regras que devem 
ser observadas quando se joga. Significa também balanço, oscilação, astúcia, ardil, manobra. Não parece ser difícil concluir que todo jogo verdadeiro é uma metáfora da vida".

Ao unir as estratégias facilitadoras de ensino promovidas pelo professor mediador com a busca pelo conhecimento dos alunos surge o conhecimento, considerado o principal objetivo da educação. "Assim, brincar significa extrair da vida outra finalidade que não seja ela mesma. Em síntese, o jogo é o melhor caminho de iniciação ao prazer estético, à descoberta da individualidade e à meditação individual". (ANTUNES, 2005, p. 36).

Vygotsky (1998) afirma que o brincar é um espaço de aprendizagem onde a criança age além do seu comportamento humano. No brincar, ela age como se fosse maior do que é na realidade, realizando simbolicamente, o que mais tarde realizará na vida real. Embora aparentemente expresse apenas o que mais gosta, a criança quando brinca, aprende a se subordinar às regras das situações que reconstrói.

De modo geral as brincadeiras e os jogos direcionados ou não, assumem um importante papel no desenvolvimento global das crianças. São atividades que facilitam o processo ensino, permitindo assim, uma aprendizagem significativa, prazerosa e eficiente para as crianças em geral.

\section{O PAPEL DO EDUCADOR NA MEDIAÇÃO PEDAGÓGICA DOS JOGOS}

A atuação do professor na Educação Infantil é um fator de suma importância para o desenvolvimento de um bom trabalho, como também, para o alcance dos objetivos propostos para essa etapa tão importante na vida educacional dos indivíduos de modo geral.

No entanto, a qualificação profissional de pessoas para atuarem nessa modalidade de ensino, ainda é um grande problema que as escolas enfrentam atualmente. De acordo com a Lei de Diretrizes e Bases da Educação Brasileira - LDB - (BRASIL, 1996), para atuar nesta primeira etapa da educação básica, a formação mínima do professor é aquela oferecida em nível médio, na modalidade normal (Art. 62). A própria lei que ampara a educação brasileira reforça a ideia de uma qualificação baixa para o professor dessa modalidade de ensino. 
Diante das grandes transformações e necessidades que a sociedade contemporânea exige às funções desse profissional, vem passando por determinadas reformulações. Nessa perspectiva, o Referencial Curricular (BRASIL, 1998, p. 41) ressalta que:

Faz-se necessário que os profissionais, nas instituições de Educação Infantil, tenham ou venham a ter uma formação inicial sólida e consistente, acompanhada de adequada e permanente atualização em serviço. Assim, o diálogo, no interior da categoria, tanto quanto os investimentos na carreira e formação do profissional pelas redes de ensino, são hoje, desafios presentes, com vistas a profissionalização do docente da educação infantil.

Essa afirmação demonstra a exigência que a realidade vem exigindo para que os profissionais que atuam na Educação Infantil, se atualizam continuamente e, sobretudo, tenham uma formação inicial sólida e adequada, demonstrando, dessa forma, que devem ingressar em cursos de nível superior, pois, esse tipo de formação só pode ser adquirido no âmbito das instituições de ensino superior, sejam elas públicas ou privadas. Diante de tal exigência o Referencial Curricular (BRASIL, 1998) continua enfatizando que:

O trabalho direto com as crianças pequenas exige que o educador tenha uma competência polivalente. Ser polivalente significa que ao educador cabe trabalhar com conteúdos de matérias diversas que abrangem desde cuidados básicos essenciais até conhecimentos específicos provenientes das diversas áreas do conhecimento. Este caráter polivalente demanda, por sua vez, uma formação bastante ampla e profissional que deve tornar-se, ele também, um aprendiz, refletindo constantemente sobre sua prática, debatendo com seus pares, dialogando com as famílias e a comunidade e buscando informações necessárias para o trabalho que desenvolve. São instrumentos essenciais para reflexão sobre a prática direta com as crianças a observação, o registro, o planejamento e a avaliação (BRASIL, 1998, p. 41).

Diante de tais necessidades impostas pela realidade é que surge a exigência de um profissional mais capacitado e preparado para atuar nas salas de aulas da Educação Infantil. Cabe a esse professor buscar uma formação mais consistente e acadêmica, uma vez que, essa formação só é alcançada através dos cursos de formação superior.

A atual sociedade exige um profissional mais preparado, sendo assim, o agir pedagógico do educador deve buscar alcançar as necessidades que essa sociedade impõe, portanto, deve ter uma postura criativa e flexível, a fim de, atender essas exigências, sejam elas coletivas ou individuais. 
Pensar sobre essas questões implica na elaboração e execução de diferentes estratégias metodológicas para serem aplicadas nos contextos das salas de aula por todo o Brasil, ou seja, reinventar o ambiente, para neles possam ocorrer interações entre o mundo físico e o social, oportunizando vivências e situações de troca de experiências, promovendo assim, a autonomia e a cooperação, elementos fundamentais para formação do cidadão mais atuante na sociedade. Para o RCNEI (1998):

Educar significa, portanto, propiciar situações de cuidado, brincadeiras e aprendizagens orientadas de forma integrada e que possam contribuir para o desenvolvimento das capacidades infantis de relação interpessoal, de ser e estar com os outros em uma atitude básica de aceitação, respeito e confiança, e o acesso, pelas crianças, ao conhecimento mais amplo da realidade social e cultural. (RCNEI, 1998, p. 21).

A capacitação profissional promove uma prática pedagógica que possibilita a ampliação dos conhecimentos dos educandos sobre as diversas esferas da sociedade. Além disso, permite ao próprio professor rever suas práticas no sentido de avaliar seu fazer e analisar os resultados obtidos com seu trabalho.

Aprende ainda a respeitar os estágios de desenvolvimento das crianças e compreendem que a aprendizagem é um processo que exige diferentes níveis de maturidade nas crianças. Por meio dessa formação, adquire a capacidade de perceber as dificuldades inerentes ao educando, como também, de buscar estratégias que possam superá-las da melhor forma possível.

Aprender a conhecer e respeitar a criança na sua realidade social, cultural, religiosa e pessoal. Esse fato, proporciona uma melhor interação entre as partes e possibilita o desenvolvimento através da exploração de objetos, atividades lúdicas, desenvolvimento motor, físico, psicológico, intelectual, social e emocional.

Para Vygotsky (1991, p. 7) a função do educador é:

[...] desenvolver não uma única capacidade de pensar, mas muitas capacidades particulares de pensar em campos diferentes, não em reforçar a nossa capacidade geral de prestar atenção, mas de desenvolver diferentes faculdades de concentra a atenção sobre diferentes matérias (VYGOTSKY, 1991, p. 7).

O papel do profissional da Educação Infantil, e atualmente, desenvolver uma prática pedagógica que promova uma ampliação do conhecimento sobre as diversas 
esferas da sociedade. Sendo assim, o Referencial Curricular para Educação Infantil (1998, p. 33) afirma que:

É função do professor considerar, como ponto de partida para sua ação educativa, os conhecimentos que as crianças possuem, advindo das mais variadas experiências sociais, afetivas e cognitivas a que estão expostas. Detectar os conhecimentos prévios das crianças não é uma tarefa fácil, implica que o professor estabeleça didáticas para fazê-lo.

Segundo ideias elencadas nos documentos acima mencionados, cabe ao professor mediador, considerar os conhecimentos prévios dos alunos no processo ensino aprendizagem e a partir deles construir o conhecimento científico é necessário a formação integral dos pequenos educandos.

O professor deve ter a capacidade de ser um guia no atendimento, alguém que, segundo Bruner (2001), ajuda o aluno a descobrir por conta própria. Cabe ao professor ver na criança alguém com capacidade de aprendizagem e desenvolvimento, mesmo que não ocorra em tempos e níveis iguais em todas.

O bom professor deve respeitar as diferenças impostas pela realidade e descobrir diferentes estratégias para que todos os alunos aprendam e possam ter as mesmas oportunidades de atuação na sociedade.

\section{LÚDICO E A CONSTRUÇÃO DO SABER}

Numa educação em que se busca uma preparação para a vida, deve-se levar em consideração as necessidades humanas, dessa forma, deve-se usar a ludicidade como estratégia metodológica.

Brincar é algo vital para o desenvolvimento do corpo e da mente, sendo assim, utilizar jogos no processo de ensino contribui para o desenvolvimento de uma educação integral que motive as crianças e leve-as a uma aprendizagem prazerosa e significativa. Os jogos, em especial, favorecem para que crianças se convertam em adultos maduros, com grande imaginação e autoconfiança, mesmo aqueles que apresentam alguma dificuldade na sua aprendizagem ou na aquisição do conhecimento.

É fundamental dar ênfase nas metodologias que se alicerçam no ato de brincar, no facilitar as coisas do aprender através do jogo, da brincadeira, da fantasia, do encantamento. A arte-magia do ensinar-aprender (ROJAS, 1997), permite que o outro 
construa por meio da alegria e do prazer de querer fazer. Os jogos estão presentes em todas as fases da vida dos seres humanos, tornando especial a sua existência.

Além de proporcionar uma aprendizagem significativa e prazerosa, os jogos, também contribuem para reforçar as relações interpessoais, ou seja, permite que as pessoas se aproximem e mostrem o melhor de si.

As crianças aprendem enquanto brincam, sendo assim, é imprescindível estimular atividades como a dramatização, a contação de histórias formais e informais, a construção de brinquedos e a criação de uma espaço lúdico. Quando se utiliza jogos no processo ensino aprendizagem se consegue, sem grandes esforços, encontrar respostas a várias indagações, podendo assim, sanar dificuldades, bem como interagir com os semelhantes.

Os jogos despertam o interesse para a aprendizagem, desenvolvem a mente, a sociabilidade, a coordenação motora e deixa qualquer criança ou adulto felizes, além do mais instiga as potencialidades, provoca o funcionamento da criatividade e cultiva a sensibilidade, portanto, ocorre o desenvolvimento intelectual, social e, sobretudo, emocional. Tudo isso num processo natural, sem estresse e sem medo.

Através do desenvolvimento dos jogos as crianças envolvem-se no dinamismo da atividade e sente a necessidade de partilhar com o outro, mesmo que em postura de adversário, a parceria é um estabelecimento de relação. Esta relação expõe as potencialidades dos participantes, afeta as emoções e põe à prova as aptidões testando limites.

Ao jogar, as crianças terão a oportunidade de desenvolver capacidades indispensáveis a sua futura atuação profissional, tais como atenção, afetividade, o hábito de permanecer concentrado e outras habilidades perceptuais psicomotoras.

\section{CONSIDERAÇÕES FINAIS}

A Educação Infantil, considerada primeira etapa de educação básica, é o alicerce de toda trajetória educacional formal dos indivíduos que ingressam nas instituições de ensino, sejam elas públicas ou privadas de todo o território nacional brasileiro.

Diante de tal importância, a aplicação de jogos e brincadeiras no contexto escolar se apresenta como uma ferramenta imprescindível de aprendizagem para os educandos 
que fazem parte da Educação Infantil, ou seja, por meio dessas atividades lúdicas as crianças aprendem de maneira mais eficaz e prazerosa, além de dar maior significado aos conhecimentos assimilados pelos pequenos aprendentes.

Essa afirmação nos levou a decidir sobre a realização da pesquisa ora apresentada, portanto, nos levou a pesquisar sobre a importância do trabalho desenvolvido nas salas de aula da educação Infantil, onde atende, especificamente, crianças de zero a cinco ou seis anos de idade.

Os conhecimentos assimilados por meio da pesquisa bibliográfica nos fez entender que os jogos e as brincadeiras são ferramentas pedagógicas indispensáveis ao trabalho na Educação Infantil, ou melhor, não se pode tratar de crianças na faixa etária acima citada sem que esses instrumentos estimuladores e incentivadores estejam presentes, pois com o uso contínuo desses recursos a aprendizagem além de se tornar prazerosa, se torna também significativa.

Quanto aos professores dessa modalidade de ensino tão importante para o desenvolvimento humano, devem ser suficientemente capacitados para entender que a ludicidade deve ser o carro chefe do seu trabalho pedagógico. Devem ser criativos e dinâmicos para despertar nas crianças o interesse pelo ato de aprender brincando.

Muitas foram às contribuições da pesquisa para o crescimento acadêmico e profissional do pesquisador. Esse trabalho servirá para que futuros pesquisadores percebam a importância da ludicidade no processo ensino aprendizagem de crianças, como também, para que os professores de sala de aula que se apropriem do conteúdo da pesquisa possam fazer uma autoanálise de suas práticas e possam perceber pontos positivos e negativos, a fim, de aprimorar cada vez mais as estratégias metodológicas aplicadas em sala.

\section{REFERÊNCIAS}

ANTUNES, C. Jogos para a estimulação das múltiplas inteligências: os jogos e os parâmetros curriculares nacionais. Campinas: Papirus, 2005.

ANTUNES, Celso. O jogo e o brinquedo na escola. In: SANTOS, Santa Marli Pires dos. (Org.). Brinquedoteca: a criança, o adulto e o lúdico. 6. ed. Petrópolis: Vozes, 2008. Cap. 4, p. 37-42. 
BRASIL. Lei de Diretrizes e Bases da Educação infantil (LDBEN), n. 9.394, de 20 dezembro de 1996. Estabelece as diretrizes e bases da educação nacional. Brasília, Diário Oficial, 23 dez. 1996, p. 27833.

BRASIL/SEF/MEC. Referencial Curricular Nacional para Educação Infantil. Brasília, 1998.

BRUNER, J. A cultura da educação. Porto Alegre: Artmed, 2001.

CAMPOS, M. C. R. M. A importância do jogo no processo de aprendizagem. Disponívelem: $<$ http://www.psicopedagogia.com.br/entrevistas/entrevista.asp?entrIDAc essono dia 11 de junho de 2017.

CANDERMARTORI., Ligia. O que é literatura infantil. 5 ed. São Paulo: Brasiliense, 1991.

CARNEIRO, M. A. B. Aprendendo através da brincadeira. Ande, Revista da Associação Nacional de Educação, ao 13, no 21, Cortez Editores, 1995.

CUNHA, Nylse Helena Silva. Brinquedoteca: um mergulho no brincar. 2. ed. São Paulo: Maltese, 1994.

FRIEDMANN, A. A Importância de Brincar. Diário do Grande ABC, 26 de setembro de 2003, Santo André, SP.

GOMES, C. L. (org.). Dicionário Crítico do Lazer. Belo Horizonte: Autêntica, 2004.

KISHIMOTO, Tizuko M. O jogo e a Educação Infantil. São Paulo: Pioneira, 1994.

MARCELlinO, N. C. Pedagogia da animação. 2. edição, Campinas, São PauloSP, Editora Papirus, 1997.

MOYLES, J. R. Só Brincar? O papel do Brincar na Educação Infantil. Porto Alegre: Artmed, 2002.

NEGRINE, A.Aprendizagem e desenvolvimento infantil. Porto Alegre: Propil, 1994.

OLIVEIRA, Vera Barros de. Brincar: caminho de saúde e felicidade. In: OLIVEIRA, Vera Barros de; SOLÉ, María Borja i, Fortuna, Tânia Ramos. Brincar com o outro: caminho de saúde e bem estar. Petrópolis: Vozes, 2010. Cap.1, p. 13-46

PIAGET, Jean. A formação do Símbolo na criança: imitação, jogo e sonho. Rio de Janeiro: Zanar, 1978.

PIAGET, J. A psicologia da criança. Ed. Rio de Janeiro. Bertrand Brasil, 1998.

RAU, Maria Cristina Trois Dorneles. A ludicidade na educação: uma atitude pedagógica. Curitiba: Inter Saberes, 2012a.

RICHTER, Sandra; FRONCKOWIAK, Ângela. A tensão lúdica entre brincar e aprender na infância. Revista Pátio Educação Infantil, ano IX, n. 27, p. 39-41, abr./jun. 2011.

RIZZI, Leonor e Haydt, Régina Célia. Atividades lúdicas na educação da criança. Ed. Ática, $6^{\text {a }}$ edição, série educação, 1997.

RODRIGUES, Almir Sandro; SILVA, Ana Tereza Reis; PARIZ, Josiane Domingues Bertoja. Teorias da Aprendizagem. Curitiba: IESDE, 2003. 
SANTOS, S. M. P. dos. Brinquedoteca: sucata vira brinquedo. 2.ed. Porto Alegre: Artmed, 2008.

TEIXEIRA, C. E. J. A ludicidade na escola. São Paulo: Loyola, 1995.

VYGOTSKY, L. S. O Papel do Brinquedo no Desenvolvimento. In: VYGOTSKY. A Formação Social da Mente. São Paulo>Icone-Editora da Universidade de São Paulo, 1991.

VYGOTSKY, L. S. Aprendizagem, desenvolvimento e linguagem. 2. ed. São Paulo: Ícone, 1998

WAJSKOP, G. Brincar na Pré-Escola. São Paulo: Cortez, 1995 


\title{
CAPÍTULO XXV
}

\section{O CURRÍCULO NA PERSPECTIVA DA INCLUSÃO E DA DIVERSIDADE}

\author{
Juliane Claudia Rossi Silva ${ }^{93}$; Lucilene Cardoso de Miranda ${ }^{94}$; \\ Maria de Lourdes Reche Borges ${ }^{95}$; Sonia Maria Reche ${ }^{96}$. \\ DOI-Capítulo: 10.47538/AC-2021.14-25
}

RESUMO: O objetivo deste artigo é analisar estudos bibliográficos feitos nos últimos anos, no que se refere a inclusão do que tange ao currículo. Sabe-se que integrar é diferente de "incluir", na medida em que na integração há a inserção parcial do sujeito aprendiz, e na inclusão a inserção deve ser total. Sendo assim, numa perspectiva de educação inclusiva, é preciso assegurar condições para que as diferenças não sejam vistas como obstáculos a serem vencidos ou superados, e sim como uma dimensão constitutiva da prática pedagógica, que precisa ser considerada em todos os momentos: no planejamento, na realização das intervenções pedagógicas, nos processos avaliativos. Nesse sentido, através de uma metodologia baseada em estudos bibliográficos estaremos abordando algumas referências teóricas que discutem acerca do currículo para Educação Especial.

PALAVRAS-CHAVE: Educação Especial. Currículo. Inclusão.

\section{THE CURRICULUM FROM THE PERSPECTIVE OF INCLUSION AND DIVERSITY}

ABSTRACT: The aim of this article is to analyze bibliographic studies carried out in recent years, regarding the inclusion of curriculum. It is known that integrating is different from "including", as in integration there is a partial insertion of the apprentice subject, and in inclusion the insertion must be total. Therefore, from an inclusive education perspective, it is necessary to ensure conditions so that differences are not seen as obstacles to be overcome or overcome, but as a constitutive dimension of pedagogical practice, which needs to be considered at all times: in planning, in carrying out the pedagogical interventions, in the evaluation processes. In this sense, through a methodology based on bibliographic studies, we will be approaching some theoretical references that discuss about the curriculum for Special Education.

KEYWORDS: Special Education. Resume. Inclusion.

\section{INTRODUÇÃO}

O currículo não possui apenas uma definição que englobe todas as ideias relacionadas à estruturação, à organização, à realização e à avaliação das atividades

\footnotetext{
${ }^{93}$ Graduada em Pedagogia. E-mail: juliane_claudia@hotmail.com

${ }^{94}$ Graduada em Pedagogia. E-mail: lucinhamirandabbu@hotmail.com

${ }^{95}$ Graduada em Pedagogia. E-mail: crislen_reche@ hotmail.com

${ }^{96}$ Graduada em Pedagogia. E-mail: soniareche29@hotmail.com
} 
educativas, admitir-se-á que o currículo se define, essencialmente, pela sua complexidade, em que tudo é tecido junto o tempo todo.

Ou seja, trata-se de um conceito que não tem um sentido unívoco, pois se situa na diversidade de relações de forças e de conceitos em função das noções que se adotam, o que implica, por vezes, alguma imprecisão acerca da natureza e do âmbito do currículo.

Assim, mesmo que assumamos sua dimensão de complexidade, a discussão sobre as práticas curriculares requer, na maioria das vezes em que é realizada, uma tomada de posição em relação ao que estamos entendendo por currículo. Se partimos, a princípio, da etimologia, encontramos em Goodson (1995) que "currículo" vem da palavra latina Scurrere, que se refere a curso ou pista de corrida.

As implicações etimológicas são que, com isso, o currículo é definido como um curso a ser seguido ou, mais especificamente, apresentado, sendo impossível, nesse caso, separar currículo de "conteúdo a ser apresentado para estudo".

O Currículo não pode ser considerado uma pista de corrida, ficamos limitados a uma visão de currículo que o toma como trajetória, curso a ser realizado, pressupondo etapas, sequências, estágios e comportamentos necessários de serem garantidos no desenvolvimento das metodologias e conteúdos propostos.

Estaremos discorrendo um pouco sobre o Currículo na perspectiva da Educação Inclusiva com base nos teóricos que estão sendo mencionados de acordo com sua relevância. A proposta de currículo inclusivo defende que todas as crianças têm direito a aprender. Consequentemente, pelo viés desse currículo, é dever da escola garantir condições favoráveis de aprendizagem, considerando as diferentes trajetórias de vida dos estudantes. Nessa perspectiva, a avaliação é vista como intrinsecamente ligada às ações de ensino, servindo como ponto de partida para o planejamento didático, rompendo com a concepção excludente de avaliação para reprovação.

\section{ACERCA DO CURRÍCULO ESCOLAR}

Como observa Pacheco (2005, p. 35), “[...] o lexema currículo encerra duas ideias principais: uma de sequência ordenada, outra de noção de totalidade de estudos”. Mesmo 
sabendo que as prescrições oficiais, isto é, os textos escritos das propostas dos órgãos oficiais constituem elementos importantes do currículo.

Queremos analisar o contexto em que o Currículo tem a intenção de tirar o foco da ideia de um currículo como documento oficial e colocá-lo na de currículo como conhecimentos em redes, tecidos nos cotidianos das escolas, tendo fios e nós que não se limitam aos espaços físicos destas, mas se prolongam para além delas, enredando os diferentes contextos vividos pelos sujeitos praticantes, isto é, por todos aqueles que vivem e praticam esses cotidianos escolares.

Pacheco (2005), defende que, ao participarem da experiência curricular cotidiana, mesmo que supostamente seguindo materiais curriculares preestabelecidos, professores e alunos tecem alternativas práticas com os fios que as redes das quais fazem parte, dentro e fora da escola, lhes fornecem. Sendo assim, podemos dizer que existem muitos currículos em ação nas escolas, apesar dos diferentes mecanismos homogeneizadores.

Nas palavras do autor, boa parte de nossas propostas curriculares tem sido incapaz de incorporar essas experiências, pretendendo pairar acima da atividade prática diária dos sujeitos que constituem a escola. Inverter o eixo desse processo significa entender a tessitura curricular como um processo de fazer aparecer as alternativas construídas cotidianamente e já em curso.

Oliveira (2003), ao discutir os processos de criação de currículos nos cotidianos das escolas pelas práticas de professores e alunos, ajuda-nos a argumentar sobre a importância de evidenciarmos as "artes de fazer" daqueles a quem foi reservado o lugar da reprodução e/ou de implementação dos programas, projetos e propostas curriculares prescritivas.

Assumindo, de modo contrário, uma perspectiva para pensar o currículo também a partir do que, de fato, acontece nas escolas, a referida autora argumenta que o cotidiano [...] aparece como espaço privilegiado de produção curricular, para além do previsto nas propostas oficiais. Especificamente no que diz respeito aos processos de ensino e aprendizagem, as formas criativas e particulares através das quais professoras e professores buscam o aprendizado de seus alunos avançam muito além daquilo que 
poderíamos captar ou compreender pela via dos textos que definem e explicam as propostas em curso.

Cada forma nova de ensinar, cada conteúdo trabalhado, cada experiência particular só pode ser entendida junto ao conjunto de vida dos sujeitos em interação, sua formação e a realidade local específica, com experiências e saberes anteriores de todos, entre outros elementos da vida cotidiana.

De acordo com Oliveira 2003:

Em nossa proposta de pensar o currículo como conhecimentos em redes, faz-se necessário não assumir uma contraposição dicotômica entre "prescrições curriculares formais oficiais" e "currículos realizados nos cotidianos das escolas". De fato, entendemos que, nos cotidianos escolares, os currículos realizados, ou praticados ou em redes se expressam como possibilidades potentes para a problematização-ampliação dos discursos sobre currículo, incluindo as propostas prescritivas oficiais, entre tantos outros fatores que são determinantes na tessitura dessas redes. (OLIVEIRA, 2003, p. 68-69).

O mesmo autor ora mencionado ajuda-nos nessa defesa ao dizer que, muito embora a distinção entre "currículo formal" e "currículo vivido" tenha surgido para ampliar o sentido dado ao currículo, trazendo para ele a cultura vivida na escola, a forma como a articulação vem sendo feita tem implicações políticas que precisam ser consideradas.

Como problematiza a autora, dentre as consequências estão o fortalecimento da lógica do currículo como prescrição e o privilégio de uma concepção linear de poder. Nesse sentido, de acordo com uma abordagem alternativa, Macedo (2006, p. 98) propõe que "o currículo seja pensado como arena de produção cultural, para além das distinções entre produção e implementação, entre formal e vivido, entre cultura escolar e cultura da escola".

O argumento da autora, com o qual concordamos, é o de que o currículo é um espaço-tempo de fronteira, no qual as questões de poder precisam ser tratadas de uma perspectiva de poder menos hierárquica e vertical. Isso implica pensar outra forma de agência, capaz de dar conta de hegemonias provisórias e da superação da lógica da prescrição nos estudos sobre política curricular. 
De acordo com Oliveira (2003), é preciso que se assuma uma dimensão políticoepistemológica dos currículos em redes tecidas nos cotidianos das escolas, entendendo que justiça global não é possível sem justiça cognitiva. Segundo a autora, isso significa que, se desejamos trabalhar por e reconhecer as experiências de emancipação social, precisamos associá-las à crítica e à possível formulação de novas premissas epistemológicas que incorporem a validade e a legitimidade de diferentes saberes, práticas e modos de estar no mundo, superando a hierarquização hoje dominante entre uns e outros e viabilizando processos interativos entre os diferentes que não os tornam desiguais.

Assim, problematizar os currículos das escolas, tendo em vista a elaboração de outros discursos para o campo do currículo, implica em buscar caminhos que nos possibilitem compreender a existência cotidiana sem exigir nossa renúncia diante do que ela nos oferece, e, além disso, reconsiderar a necessidade de um retorno à existência e à linguagem de todo dia, buscando reavivar o contato com aquilo que, na vida comum, irrigado pelo fluxo de narrativas, passa despercebido de tão evidente, ou então só se deixa ver na remissão incessante de um texto a outro, de uma narrativa a outra.

Contudo, em um mesmo processo, vão aplicando o que lhes é imposto pela cultura dominante, com os produtos técnicos colocados à disposição para consumo e, em contrapartida, vão criando modos de usar e conhecer o invento técnico, fazendo surgir tecnologias e possibilidades de mudanças tanto dos artefatos técnicos, como das técnicas de uso.

A visão de currículo aqui observada e analisada defende a ideia de escutar e valorizar o comum, dar atenção às práticas cotidianas dos sujeitos das escolas, buscando pensar com eles e não para eles as diferentes situações vividas nos processos de ensinoaprendizagem. Compreendendo dessa forma a vida social dos alunos em suas diferentes manifestações significantes.

\section{A QUESTÃO DO CURRÍCULO E A INCLUSÃO}

Como afirma Rodrigues (2003), é por intermédio do currículo que as coisas acontecem na escola, que é através dele (ou com ele) que são sistematizados nossos esforços pedagógicos. Mas, não podemos esquecer, somos os responsáveis por sua 
elaboração e os currículos que mais recentemente temos elaborado nos conduzem a uma perspectiva multicultural: o Brasil é signatário de Tratados e Convenções Internacionais que asseguram a inclusão, o combate a discriminação e sustentam a implementação de políticas educacionais de Educação Ambiental, Educação em Direitos Humanos, Educação Especial, do Campo, Escolar Indígena, Quilombola e Educação para as relações Étnico-Raciais.

Quando se fala em Educação Inclusiva, nossas ideias sobre o currículo se tornam ainda mais centrais, e a questão da cultura e do que nós professores entendemos por diversidade cultural deve ser levado em conta para o desenvolvimento das práticas inclusivas na escola. Mas, presos que são às nossas velhas práticas e nossos hábitos, o currículo acaba desempenhando o papel de fornecer justificativas para manter a escola como está, não possibilitando as mudanças necessárias para que se possa atender as necessidades dos alunos, dos professores e da própria escola.

Mas, é como se essa nossa criação, o currículo, ganhasse vida própria, transformando-se no Sr. Currículo, que nos dita ordens e diz o que devemos ou não fazer! É preciso, já de início, abrir mão daquela velha ideia que circula entre os professores de que o currículo se resume aos tópicos de conteúdo que devem ser ensinados; quem pensa assim não percebe que antes de existirem estes tópicos eles foram escolhidos, selecionados, organizados em uma determinada ordem... e por quem? Quem pensa apenas na "lista de conteúdos" não percebe que para cada tópico há uma escolha metodológica, há exemplos, há facilidades didáticas... e para quem? De modo que nós, professores, devemos ter clareza em relação ao fato de que o currículo não se resume a uma listagem de conteúdos.

Rodrigues (2003) declara que a escola é parte de uma sociedade complexa, regulada por leis, e tem sido a legislação "externa à Escola” que vem fornecendo garantias dos direitos dos alunos, em particular daqueles com deficiências, transtornos globais e altas habilidades/superdotação. Os professores, devemos entender como estas coisas acontecem: a escola já se encontra organizada de modo não-inclusivo, promovendo diferenciações entre disciplinas (algumas mais valorizadas, outras menos), entre professores (alguns considerados melhores que os outros por razões vagas como obter mais ou menos aprovações) e entre alunos. 
Quando se começa a discutir a inclusão, a conversa frequentemente gira em torno da eliminação e empobrecimento de conteúdos básicos, com a proposta de currículos alternativos ou até de sistemas paralelos de ensino. Ora, não é disso que trata a inclusão! (Se isso é o que acontece na escola, não é apropriado referir-se a isso como "inclusão" tal como estamos apresentando aqui.

Essa é a "inclusão" que apenas coloca um determinado tipo de aluno dentro de uma sala de aula, mas nada promove em termos de mudança no modo de pensar daqueles que participam do processo. Devemos pensar, inventar e promover um currículo no qual a diferença seja considerada um ponto de partida para a elaboração de propostas pedagógicas que contemplem as necessidades dos alunos que temos.

Rodrigues (2003) assim declara:

[...] não se separam os alunos com base em determinadas categorias, mas em que se educam os alunos em conjunto, procurando aproveitar o potencial educativo das suas diferenças, em suma, uma diferenciação na classe assumida como um grupo heterogêneo. Os professores, às vezes, agem como se todas as crianças fossem aprender a contar até dez ao mesmo tempo, com a mesma idade e com o mesmo ritmo (RODRIGUES, 2003, p. 92).

Não transferem sua própria condição de "diferentes" em relação a seus pares, quando fazem cursos de formação inicial ou continuada, e lidam com as próprias dificuldades de aprendizagem e de tempo, seja para estudar, seja para amadurecer algumas ideias.

Quando seus professores "aceleravam a matéria", frequentemente reclamavam e resmungavam por estar "em atraso" ... mas não acham, agora que são professores, que devam pensar em qualquer estratégia diferente para lidar com seus alunos que passam pelas mesmas dificuldades que passaram, em geral pensam: eu passei por isso e sobrevivi... Pois bem, trata-se de um equívoco pensar na homogeneidade como sinônimo de "qualidade" na escola, como muitas vezes é concebido pela comunidade escolar.

Novamente citamos o pesquisador, professor David Rodrigues (2003), que nos diz que parece muito sedutor pensar que todos os alunos aprendem através da mesma metodologia e estratégias pedagógicas; que a aprendizagem vai se efetivar igualmente em todos os alunos; que a escola vai possibilitar a todos os mesmos conhecimentos acadêmicos como herança cultural, que os alunos possuem o mesmo "nível cognitivo". 
A questão é: será que as turmas assim existem? E escolas desse tipo existem? Você já viu alguma turma assim? Pensar em práticas pedagógicas tendo como princípio a homogeneização é oferecer a hospitalidade da escola para hospedar o outro e depois colocá-lo sob o efeito perverso de práticas excludentes e de segregação.

Assim, as diferenças são importantes no sentido inverso daquele que usualmente a escola as toma, elas são importantes não para "separar" os alunos, e sim para promover a inclusão, elas são importantes para promover o convívio, não para justificar a segregação. Por fim, para esta reflexão, é necessário viver a inclusão educacional como uma proposta da sociedade e da escola e não como imposta por uma pessoa ou por um governo.

Não estamos falando de um professor especialista que assume o ensino do aluno com deficiência, transtorno global do desenvolvimento e altas habilidades/ superdotação, estamos falando de um currículo e de um sistema educacional inclusivo e isso tem uma abrangência muito maior: as ações no interior da escola devem envolver todos os profissionais, alunos e a comunidade escolar; mudando a cultura da escola, mudando os modos de ser e estar, os ritos e práticas existentes nesses espaços.

Insistimos em dizer que a escola inclusiva propõe uma ruptura não só com as práticas, mas principalmente com os valores da escola tradicional. Essa escola inclusiva rompe com a ideia de um desenvolvimento curricular único, com a ideia de aluno padrão, com a ideia de ensino como transmissão e com o modelo de escola como estrutura de reprodução.

Em todos esses aspectos, tanto professores como a comunidade podem e devem se valer do aparato legal. Entretanto, por incrível que pareça, há municípios, escolas e professores que alegam não ter conhecimento dessas leis. E há aqueles que, tendo conhecimento das leis, alegam não terem condições de as colocar em prática. Destes assuntos é que trata o próximo texto.

\section{CONSIDERAÇÕES FINAIS}

Os novos tempos pedagógicos e curriculares, construídos a partir da organização em ciclos, realizam-se em espaços escolares e sociais redimensionados. A sala de aula 
deixa de ser o único local de aprendizagem e sociabilidade. Outros espaços, tanto internos como externos à escola, passam a ser privilegiados pelo seu potencial de dinamização das interações e mobilização da vontade de conhecer das crianças.

A reflexão sobre diferentes problemas, questões e especificidades presentes na comunidade circundante à escola é, nesse sentido, uma possibilidade política e pedagógica privilegiada. Circular, observar e intervir criticamente nas situações e espaços sociais, culturais, ambientais, etc., aparentemente já “conhecidos" pelos estudantes, pode levá-los a uma percepção mais aprofundada e diferenciada de fenômenos variados de seu cotidiano, fortalecendo vínculos com sua comunidade, bem como desta com a escola.

\section{REFERÊNCIAS}

BRASIL. Secretaria de Educação. Conjunto de materiais para a capacitação de professores: necessidades na sala de aula/ Secretaria de Educação Especial; tradução, Ana Maria Isabel Lopes da Silva. Brasil: MEC/ SEESP, 1998.

BRASIL. Secretaria de Educação Fundamental. Parâmetros Curriculares Nacionais: Adaptação Curricular/Secretaria de Educação Fundamental. Secretaria de Educação Especial. - Brasil: MEC/SEF/SESSP.

CARVALHO, Erenice N. S. (Org.) (1997). Deficiência Mental. Brasília: SEESP.

RODRIGUES, D. Dez idéias (mal) feitas sobre a educação inclusiva. In: RODRIGUES, D. (Org.). Inclusão e educação: doze olhares sobre a educação inclusiva. São Paulo: Summus, 2006. p. 299-318.

Educação inclusiva: as boas e as más notícias. In: RODRIGUES, D. (Org.). Perspectivas sobre a inclusão: da educação à sociedade. Porto: Editora Porto, 2003. p. 91 92.

SANTOS, K. R. Educação especial e escola: reflexões sobre os projetos educacionais para surdos. In: FERNANDES, E. (Org.). Surdez e bilinguismo. Porto Alegre: Mediação, 2005. p. 51-64.

SARTORETTO, M. L.; BERSCH, R. C. R. Educação especial na perspectiva da educação inclusiva: recursos pedagógicos acessíveis e comunicação aumentativa e alternativa. Brasília: MEC/SEESP, 2010. 


\title{
CAPÍTULO XXVI
}

\section{O LÚDICO COMO FERRAMENTA PARA A EDUCAÇÃO INCLUSIVA}

\author{
Tamires Aline de Amorim ${ }^{97}$; Maria Aparecida Teixeira ${ }^{98}$; \\ Luana Teixeira Alves ${ }^{99}$; Ana Paula de Sousa Xavier ${ }^{100}$; \\ Claudiane Teixeira ${ }^{101}$. \\ DOI-Capítulo: 10.47538/AC-2021.14-26
}

\begin{abstract}
RESUMO: A inclusão é um assunto cada vez mais recorrente nas mídias e um direito constitucional das pessoas com deficiência. Esse processo exige grandes mudanças nas estruturas físicas e na mentalidade das pessoas, pois, falando de uma maneira ampla, a sociedade não aprendeu a pensar, olhar e valorizar as diferenças, sendo o ambiente sócio - cultural de nossa realidade, inclusive a escola, pouco propício a compreender e cooperar com o outro. As atividades recreativas adaptadas caracterizam-se como uma grande oportunidade para que o indivíduo com necessidades especiais possa desenvolver uma atividade física, deixando de lado o sedentarismo e o isolamento social. Um aspecto importante a ser abordado, é que além das limitações impostas pela deficiência, o indivíduo com necessidades especiais pode sofrer ainda, com outros problemas decorrentes da falta de estruturas físicas dos centros urbanos não adaptados para as condições individuais básicas de mobilidade necessárias para vida cotidiana, onde muitas vezes dificultam ou impedem a realização da prática de exercícios físicos. Para essa pesquisa utilizaremos teóricos como Heil (2014) e Negrine (1994).
\end{abstract}

PALAVRAS-CHAVE: Lúdico. Educação Inclusiva. Escola.

\section{PLAYING AS A TOOL FOR INCLUSIVE EDUCATION}

ABSTRACT: Inclusion is an increasingly recurrent subject in the media and a constitutional right of people with disabilities. This process requires major changes in people's physical structures and mentality, because, broadly speaking, society has not learned to think, look at and value differences, and the socio-cultural environment of our reality, including school, has little conducive to understanding and cooperating with each other. Adapted recreational activities are characterized as a great opportunity for individuals with special needs to develop physical activity, leaving sedentary lifestyles and social isolation aside. An important aspect to be addressed is that, in addition to the limitations imposed by the disability, the individual with special needs can also suffer from other problems arising from the lack of physical structures in urban centers not adapted to the basic individual mobility conditions necessary for everyday life, where they often make it difficult or prevent the performance of physical exercise. For this research we will use theorists such as Heil (2014) and Negrine (1994).

KEYWORDS: Playful. Inclusive education. School.

\footnotetext{
${ }^{97}$ Graduada em Pedagogia. E-mail: tamiresalinedeamorim@gmail.com

${ }^{98}$ Graduada em Pedagogia. E-mail: maria.bbu18@gmail.com

99 Graduada em Pedagogia. E-mail: luana.teixeira@ gmail.com

${ }^{100}$ Graduada em Pedagogia. E-mail:aniinhaxavier@ hotmail.com

${ }^{101}$ Graduada em Pedagogia. E-mail: claudiane.teixeira@gmail.com
} 


\section{INTRODUÇÃO}

A Educação inclusiva está sendo atualmente muito discutido no cenário educacional, em que diversos autores buscam refletir despertando nos leitores mudanças de ensino para uma melhor aprendizagem aos alunos especiais, fazendo com que eles se sintam incluídos dentro do contexto educacional.

Para muitos, o lúdico é uma das principais formas de inclusão dos alunos com algum tipo de deficiência. Outros acreditam que por meio do esporte, somos capazes de diminuir consideravelmente os índices de exclusão.

A inclusão social dos alunados tem se tornado uma realidade através da prática de atividades recreativas. Nessa perspectiva, o presente projeto é voltado para o ensino fundamental I, onde os alunos necessitam de uma maior capacidade de entendimento das ideias inclusivas, a fim de se tornarem adultos conscientes. A aplicação das atividades recreativas adaptadas nesse projeto nos permite refletir sobre o potencial da escola em unir pessoas de diferentes condições físicas.

Dessa forma, as práticas recreativas adaptadas são capazes de dar um sentido para a vida, assim como alunos que possuem dificuldade de se inserir dentro do contexto escolar. Nessa perspectiva, visa desempenhar o papel de incluir a percepção de competência e identidade pessoal, identidade esta como aluno do contexto escolar e não como deficiente físico.

Assim, destaca-se que o esporte para pessoas com algum tipo de deficiência teve início com uma tentativa de colaborar no processo terapêutico delas e logo cresceu e ganhou muitos adeptos, chegando a extrapolar o meio de recuperação e passou a se tornar uma grande alternativa no processo de inclusão social e escolar.

Atualmente mais do que terapia, o esporte para esta população caminha para o alto rendimento e o nível técnico dos atletas impressiona cada vez mais o público e os estudiosos da educação.

Nesse sentido, observou-se a relevância em elaborar uma pesquisa bibliográfica envolvendo a recreação de atividades adaptadas e pessoas com deficiência física, promovendo uma melhor qualidade de vida em seu cotidiano. 


\section{REFERENCIAL TEÓRICO}

As práticas recreativas adaptadas devem ser trabalhadas de forma única e de forma integrada, em indivíduos com ou sem limitações físicas, ou seja, com ou sem deficiência, ou de forma segregada, em que as pessoas com deficiência praticam e competem separadamente daqueles sem deficiência.

Heil (2008) explica que é uma prática recorrente da sociedade fazer uma associação da pessoa com deficiência a falta de produtividade, ou seja, que a possibilidade do fracasso é facilmente apontado e o sucesso é pouco percebido e quando percebido é atribuído com mérito, não sendo valorizado o esforço depositado para tal proeza. $\mathrm{O}$ esporte adaptado exerce um papel importante na sociedade porque ele combate este tipo de preconceito e estereótipo em torno das pessoas com deficiência, ajuda na promoção social e financeira daqueles que buscam nele uma alternativa de vida.

Corroborando com o supracitado, Moura (2006) evidencia que a Paraolimpíada é dos grandes exemplos de importância atribuído ao esporte adaptado, e da perspectiva que ele oferece de crescimento multifatorial dos para atletas, onde se podem ver exemplos de adaptação e superação de atletas deficientes.

Para Costa e Silvia (2013) o esporte pode ser entendido como um fenômeno sociocultural com formas de manifestações mais distintas do que podemos observar. $\mathrm{O}$ esporte adaptado se coloca como uma destas possibilidades sendo um objeto complexo com raízes na reabilitação de soldados que perderam membros inferiores ou superiores durante a Segunda Guerra Mundial.

Nessa perspectiva, o conceito de inclusão é dado por meio do processo pelo qual a pessoa com deficiência de qualquer tipo de necessidade especial se preparam para assumir papéis ativos na sociedade e como resposta, a sociedade se adapta para atender as necessidades de todas as pessoas, respeitando os seus limites e aceitando-os como eles realmente são.

Costa e Silva (2013) entende que o processo de inclusão social através do esporte adaptado encontra-se na sociedade atual como um importante pilar e crescimento de pessoas com deficiência, porém o componente competitivo lhe confere uma face de exclusão, onde os sujeitos são selecionados e comparados frente sua capacidade física, deixando de lado aquelas que estão em níveis inferiores, desta forma, o crescimento da 
importância social e do profissionalismo presente no esporte lhe confere um papel paradoxal frente à inclusão de pessoas com deficiência física.

Quando se fala em esportes adaptados dentro do contexto escolar, e em consequência disso da Educação Física, Winnick (2004), entende que a Educação Física Adaptada é uma área da Educação Física escolar, onde podemos desenvolver diversas atividades, tais como brincadeiras, danças e esportes são adaptados às necessidades dos alunos deficientes, visando superar a exclusão que comumente ocorre nas aulas ou tendo por objetivo atingir uma participação satisfatória de todos os alunos.

Nas escolas contemporâneas, todos os alunos possuem o mesmo direito de participar das práticas pedagógicas, de modo que possam aprender o mesmo conteúdo e exercer sua cidadania de maneira igualitária sem nenhuma forma de exclusão. Nesse sentido, a Educação Física visa garantir este direito por meio dos esportes adaptados, onde professor irá adaptar suas atividades de modo que todos os alunos, inclusive os deficientes, possam fazer parte do processo de ensino-aprendizagem.

Quando se fala em Esportes Adaptados, ou em Educação Física Adaptada é comum nos remetermos às aulas aplicadas em escolas especiais ou turmas cuja a escola recebe alunos com deficiência. A maioria dos trabalhos acadêmicos, dentre pesquisas artigos e relatos de experiência, trata o Esporte Adaptado como um meio facilitador e democrático para os deficientes praticarem as modalidades esportivas. Concordamos com essa finalidade dos Esportes Adaptados, porém entendemos que a discussão sobre deficiência é muito importante e necessária também para os alunos que não são deficientes.

Dessa forma, o esporte adaptado se dá por meio do entendimento de que há relação estreita entre esporte e educação física, principalmente se considerar a escola como principal palco das atividades educacionais desenvolvidas. Primeiramente, esclarecemos que o esporte e a educação física têm se apoiado mutuamente, mesmo tendo aspectos que os diferenciam em termos de objetivos, revelando suas identidades.

Para Almeida (1995), entende que o esporte não é somente educação física, assim como educação física não é basicamente esporte. Ambos andam sim, no mesmo caminho e estão inseridos no estudo do movimento humano. Este autor acrescenta ainda que a falta 
de reflexão neste sentido tem nos levado cada vez mais a criar distâncias entre esporte e educação física e, consequentemente, a temer uma interposição entre estes.

As atividades lúdicas abrangem inúmeras capacidades de criação e desenvolvimento de metodologias diferenciadas, as quais contribuem de maneira significativa em variados pontos, como por exemplo, no desenvolvimento dos aspectos cognitivos, motores, sociais e afetivos, e, sobre isso Negrine (1994, p. 34), complementa dizendo que,

As contribuições das atividades lúdicas no desenvolvimento integral indicam que elas contribuem poderosamente no desenvolvimento global da criança e que todas as dimensões estão intrinsecamente vinculadas: a inteligência, a afetividade, a motricidade e a sociabilidade são inseparáveis, sendo a afetividade a que constitui a energia necessária para a progressão psíquica, moral, intelectual e motriz da criança.

Partindo do pressuposto das inúmeras significações evidenciadas pelas atividades lúdicas, nota-se que nestas estão impregnadas muitas riquezas, e disso decorre a necessidade da efetivação de práticas e ações que as envolvam. Almeida (2003, p. 57), ressalta que,

(...) a educação lúdica, além de contribuir e influenciar na formação da criança e do adolescente, possibilitando um crescimento sadio, um enriquecimento permanente, integra-se ao mais alto espírito de uma prática democrática enquanto investe em uma produção séria do conhecimento. Sua prática exige a participação franca, criativa, livre, crítica, promovendo a interação social e tendo em vista o forte compromisso de transformação e modificação do meio.

Corroborando com a fala de Almeida, enfatizamos que o lúdico é um importante aliado no processo de ensino-aprendizagem, haja vista que as atividades contribuem nos estímulos e no desenvolvimento de bons resultados no processo educativo. As dinâmicas das aulas transbordam diversão e prazer, além de muitos conhecimentos, despertando nos sujeitos a sensação de aulas significativas e inesquecíveis. Essas atividades apresentam auxílios na evolução da autoestima, estimulação da criatividade, desejo de aprender, fomentados através de práticas leves e descontraídas. Geralmente, quando nos remetemos a lembrar do processo histórico escolar, e escolhemos especificamente um momento, uma aula, um professor, etc., sempre nos lembramos de momentos/conteúdos/atividades transmitidas de maneira lúdica. Tal afirmação pressupõe o quanto as atividades lúdicas deixam resultados positivos e significativos para a vida dos sujeitos. 
Contudo, é válido ressaltar que os docentes, na realização de seu plano de aula diário e/ou planejamento semanal/mensal, não devem minimizar o ensino dos conteúdos necessários, em troca de aulas alegres e prazerosas, todavia, sem apresentar conhecimentos relevantes. Esses momentos devem ser utilizados para a pesquisa da sua própria prática docente, bem como, na busca por informações específicas sobre a identidade dos educandos, e assim potencializar suas aulas, em torno dos diferentes níveis de aprendizagens, das preferências de aprendizagem, entre tantas outras abordagens que devem ser analisadas e (re)pensadas, para que assim as ações possam ser redirecionadas. Essas observações podem ser realizadas até mesmo no dia-a-dia dos docentes, haja vista que, "[...] em todo lugar temos crianças à nossa volta, e o desenvolvimento do conhecimento lógico, matemático, do conhecimento físico, e assim por diante não podemos estudar em nenhum lugar melhor do que em crianças. " (PIAGET, 1978. p. 21).

De acordo com Almeida e Cipriano (2016, p. 08):

(...) o brincar, partindo do universo lúdico e acontecendo na forma de brincadeira e/ou do jogo, tendo o brinquedo como o suporte material, traduz-se como recurso, estratégia, instrumento, ação, possibilidade e intervenção propriamente dita junto a crianças que se encontram dentro do Espectro do Autismo.

Face ao exposto, evidencia-se a importância das atividades lúdicas para o desenvolvimento da criança autista, uma vez que possibilita uma gama de benefícios, como a interação, a diversão e o espírito de colaboração entre as crianças.

É notório que quanto maior o nível econômico das famílias, mais larga será a possibilidade de uma educação de qualidade. Portanto, as crianças que não possuem esse poderio financeiro, necessitam de estímulos maiores para aprender, e, se estes não lhe forem dados, maior será o índice de evasão escolar. Nessa perspectiva, surge o lúdico, que está em todas as atividades que despertam o prazer, a felicidade. Através destas, o educando terá um maior desejo em aprender, e assim, a escola deixará de ser um espaço onde se ministram aulas "chatas", e passará a ser um espaço atrativo e divertido para as crianças.

A ludicidade se trata de um importante instrumento pedagógico, que vem contribuindo com inúmeras alternativas de auxílio ao trabalho docente, como por exemplo: jogos, música, brincadeiras, etc. Cabe salientar que, o espaço da sala de aula é 
reservado para brincadeiras, desde que os professores consigam aliar os objetivos específicos propostos para a aula, com o desejo dos alunos. Esses momentos necessitam apresentar planejamentos direcionados, com orientações e objetivos pré-definidos, uma vez que, se as brincadeiras forem apresentadas sem fundamentos e intencionalidades, os professores acabam perdendo o rumo das lições, e permitindo que suas aulas se tornem insignificantes e sem desígnios claros.

A educação é um item básico para formar uma vida ativa do ser humano. Com uma boa educação a sociedade terá cidadãos que irão contribuir para o crescimento do mundo.

Em 1988 a Constituição, Leia 7853 de 1989 teve o apoio das pessoas com deficiência e sua integração social, Estatuto da Criança e Adolescente de 1990. Capitulo da LDB 1996, sobre educação Decreto 3298 e3 1999 regulamenta na Lei 7853 de 24 de outubro de 1989, dispõe sobre a Política Nacional, para integração da Pessoa portadora de deficiência.

A inclusão de pessoas com necessidades especiais tem que ser feita nas escolas e na sociedade, como este presente na lei, os professores, os familiares e a sociedade, todos devem estar dispostos e empenhados para que essa inclusão aconteça, de maneira mais natural e tranquila possível. Na educação, muitas das vezes o aluno com alguma deficiência é visto como "diferente. " Com base em pesquisa bibliográfica, sobre o tema educação inclusiva, há muita contradição entre discurso e ação.

Vários professores relatam sobre a dificuldade encontrada no ambiente de trabalho, com falta de infraestrutura para que a inclusão aconteça, dentre essas dificuldades o número elevado de alunos em sala de aula e a angústia de ensinar as crianças que necessitam de uma atenção especial.

Lembrando que nas salas de aulas muitas das vezes há somente um professor com turma de até 20 alunos, compostos por crianças que não tem nenhum tipo de deficiência e crianças com alguma síndrome.

Com essas perspectivas, a questão norteadora é identificar e fazer valer a inclusão social das crianças. O curso de Pedagogia foi crescendo cada vez mais, os professores já podiam trabalhar em outros lugares, como fábricas, ruas, projetos sociais, igrejas, 
hospitais, entre outros. O pedagogo também exerce o papel de Gestor e Supervisor, em diversos segmentos diferentes.

E seja qual for o local onde trabalhamos, vivemos sempre nos deparamos com pessoas com algum tipo de necessidade especial e temos como dever fazer com que essas pessoas se sintam acolhidas e incluídas, em tudo o que for fazer. $\mathrm{O}$ professor tem que estar capacitado para saber lidar com as diferenças do seu dia a dia, cabe a escola dar esse suporte para seus professores, para que a inclusão seja bem-feita, de modo que todos os colaboradores possam participar e exercer a inclusão.

\section{CONSIDERAÇÕES FINAIS}

Evidencia-se a partir desse projeto que foi possível identificar como os alunos precisam evoluir nas questões referentes aos deficientes, tendo uma tomada de consciência, percebendo que não são doentes e incapacitados. Conclui-se, portanto, que se houver respeito, ajuda, solidariedade e cooperação, todas as crianças podem brincar juntas e se divertirem.

Identificaram a importância de pensarmos nos deficientes, respeitando-os e pensando a importância de pensarmos os espaços públicos para todos. Confirmamos a importância de refletirmos sobre os deficientes nas escolas regulares. Toda criança tem direito à educação com excelência, direito à inclusão, ao respeito.

A família deve assegurar o direito de suas crianças, e apoiar sempre que independente da dificuldade da criança, ela tem direito a fazer o que quiser.

Que poderá estudar, trabalhar, constituir sua família, direito de ir e vir. E que a escola tem o dever de aceitar e fazer a inclusão dessas crianças, sempre abordando o tema com amor e dedicação.

A inclusão é um dos princípios garantidos pela Lei de Diretrizes e Base da Educação e a educação é um direito garantido na Constituição Brasileira de 1988 e que deve zelar pela qualidade do ensino e pela equidade entre os estudantes. Pautados nessa igualdade, pensamos num projeto em que a inclusão fosse evidenciada de forma contundente. 


\section{REFERÊNCIAS}

COSTA, Roberto Hernandez; SILVA, Carlos Fernadez; Metodologia de pesquisa. Porto Alegre: Penso, 2013. p. 624.

FREIRE, Paulo. Pedagogia da autonomia: Saberes necessários à prática educativa. São Paulo: Paz e terra, 1996.

LIRA, Natali Alves Barros; RUBIO, Juliana de Alcântara Silveira. A Importância do Brincar na Educação Infantil. 2014. Disponível em:

<http://www.uninove.br/marketing/fac/publicacoes_pdf/educacao/v5_n1_2014/Natali.p df>. Acesso em: 03 ago. 2021.

HEIL, E. (2008) A percepção de atletas com deficiência visual sobre o esporte adaptado. Disponível em: Acesso em: 10 de junho de 2014. Disponível em: $<$ http://siaibib01.univali.br/pdf/Edineia\%20Benvenutti\%20Heil.pdfm $\geq$. Acesso em: 03 ago. 2021.

Moura, W.L.; Benda, R. N.; Novaes, J. S.; Tubino, M. J. G. (2006). O Atletismo no desenvolvimento de crianças portadoras de necessidades especiais. Motricidade 2 (1): 53-61

NEGRINE, A. Aprendizagem e desenvolvimento infantil: Simbolismo e Jogo. Porto Alegre: PRODIL, 1994. 


\title{
CAPÍTULO XXVII
}

\section{OS DESAFIOS DA EDUCAÇÃO FRENTE ÀS NOVAS TECNOLOGIAS}

\author{
Maria Aldeni de Oliveira Andrade ${ }^{102}$; Alyson Matheus da Silva Rodrigues ${ }^{103}$; \\ Geonar do Nascimento Silva ${ }^{104}$. \\ DOI-Capítulo: 10.47538/AC-2021.14-27
}

RESUMO: O trabalho se propõe a pesquisar sobre a tecnologias e os desafios na educação e como elas estão sendo integradas à prática pedagógica da escola, pois as novas tecnologias do conhecimento está se tornando cada vez mais ativas e inovadoras para a educação, pois as instituições que utilizam as ferramentas tecnológicas no processo ensino-aprendizagem estão se tornando cada vez mais procuradas pelos pais. O professor hoje tem como desafio alfabetizar-se nas tecnologias inovadoras e descobrir-se no processo educacional, reinventando um conjunto de ações didático-pedagógicas, pois as novas tecnologias do ensino estão inovando a cada dia mais, não podemos discutir sobre acerca da realidade em que os docentes estão inseridos, especialmente na sua prática pedagógica, formação e experiências. Esses elementos poderão ser determinantes para modificar a ação docente. A escola, enquanto espaço físico, precisa reunir as condições materiais para a implantação de equipamentos e programas. As novas tecnologias, aliadas à práxis do ensino, aprimoram e dinamizam o processo educacional tanto do aluno como do professor. Para alcançar o objetivo proposto foi realizado um estudo bibliográfico com base em Aranha (2006), Oliveira (2009), Medeiros (2009), dentre outros. Sugere-se, por fim, a busca por uma formação reflexiva sobre o uso de mídias no processo de ensino e aprendizagem no sentido que estas possam transformar as aulas em um espaço de interatividade, contextualizado, à realidade que os alunos vivenciam.

PALAVRAS-CHAVE: Práticas inovadoras. Tecnologia. Educação.

\section{THE CHALLENGES OF EDUCATION FACING NEW TECHNOLOGIES}

ABSTRACT: The work proposes to research the technologies and challenges in education and how they are being integrated into the pedagogical practice of the school, as the new knowledge technologies are becoming increasingly active and innovative for education, as the institutions who use technological tools in the teaching-learning process are becoming increasingly sought after by parents. The challenge of the teacher today is to become literate in innovative technologies and discover himself in the educational process, reinventing a set of didactic-pedagogical actions, as new teaching technologies are innovating more and more, we cannot discuss about the reality in that teachers are included, especially in their pedagogical practice, training and experiences. These

\footnotetext{
${ }^{102}$ Graduada em Pedagogia e Geografia -UFRN. Pós-graduada em Psicopedagogía - FIP. Mestranda em Ciências da Educação - FACEM. E-mail: aldeniandrade24@gmail.com

${ }^{103}$ Graduação em Licenciatura em Biologia -IFRN. Pós-graduação em formação Psicopedagogía - FAVINI. Mestrando em Ciências da Educação - World University Ecumenica dos EUA. Professor do município de Pendências e Porto do Mangue. E-mail: matheusdemariaoutlook.com.br

${ }^{104}$ Licenciatura em História - UERN. Pós-graduação em Especialização em História do Brasil República - UERN. Especialização em Psicopedagogia - UNINTA. Mestrado em Ciências da Educação (em andamento) - FACEM. Email: geonar.nasci@gmail
} 
elements may be decisive in modifying the teaching action. The school, as a physical space, needs to gather the material conditions for the implementation of equipment and programs. New technologies, combined with the praxis of teaching, improve and streamline the educational process for both the student and the teacher. To achieve the proposed objective, a bibliographical study was carried out based on Aranha (2006), Oliveira (2009), Medeiros (2009), among others. Finally, the search for a reflective training on the use of media in the teaching and learning process is suggested in the sense that they can transform classes into a space of interactivity, contextualized to the reality that students experience.

KEYWORDS: Innovative practices. Technology. Education.

\section{INTRODUÇÃO}

Diante das mudanças do novo paradigma da educação deve ser entendida e colocada em prática pelos profissionais não somente professores, mas pela gestão pedagógica da escola colaborando com os novos desafios enfrentados neste novo cenário. É de suma importância a gestão promover formação que contribuir com o conhecimento de todos que estão passando por este processo de mudanças, tanto o professor como o educando, preparados para os desafios com as novas tecnologias, pode ser concretizada.

$\mathrm{Na}$ chamada era da informação, a temática das tecnologias digitais se consolida no discurso pedagógico e nas pesquisas em educação, pelos quais perpassa a denúncia da necessidade de paradigmas educacionais que dialoguem com as inovações tecnológicas de nosso tempo.

Frente ao avanço das tecnologias em nossa sociedade, os meios acessíveis para seu uso tornaram-se um meio eficaz para o professor introduzir em suas práticas pedagógicas, pois o uso das tecnologias digitais na educação, permite novas formas para a construção dos conhecimentos do alunado promovendo cada vez mais um novo olhar para esse paradigma da educação.

Contudo, percebe-se uma lacuna quanto às indagações sobre o que se entende por tecnologia no âmbito educacional e sobre de que maneira esse entendimento influencia o campo de aprendizagem.

Por isso, este trabalho propõe identificar e analisar as percepções de tecnologia e a incorporação das novas tecnologias ao ensino, não podemos descuidar da investigação acerca da realidade em que estes sujeitos, os docentes, estão inseridos, especialmente sua prática pedagógica, formação e experiências. 
Esses elementos poderão ser determinantes para modificar a ação docente. A escola, enquanto espaço físico, precisa reunir as condições materiais para a implantação de equipamentos e programas que dê suporte neste novo processo de ensino, na verdade é que as novas tecnologias, aliadas à práxis do ensino, aprimoram e dinamizam o processo educacional.

As principais evidências, a esse respeito, são: as inovações tecnológicas potencializam o ensino-aprendizagem; as instituições de ensino não podem prescindir delas; o docente precisa ser estimulado ao uso dos novos recursos. Propõem-se duas categorias de análise sobre as percepções de tecnologia: artefato técnico e artefato sociocultural.

A responsabilidade de facilitar a relação professor-tecnologia é majoritariamente das escolas, que devem buscar investir no aperfeiçoamento dos conhecimentos desses profissionais.

Considera-se, por fim, que, embora haja apontamentos em direção a perspectivas socioculturais quanto à tecnologia no âmbito educacional, a percepção preponderante se relaciona mais fortemente aos aspectos da tecnologia como artefato técnico.

\section{DIFICULDADES COM A TECNOLOGIA ENFRENTADA POR EDUCADORES}

Aplicar a tecnologia para auxiliar o ensino na sala de aula, já é algo existente que precisa ser trabalhado entre a escola e os profissionais da educação. A capacitação profissional deve ser aplicada para a melhoria do processo de ensino.

Com as potencialidades digitais, o professor poderá desenvolver metodologias que beneficiem o processo de construção do conhecimento a partir do suporte dos recursos tecnológicos.

Segundo Peixoto e Araújo (2012), o computador é uma tecnologia compreendida como um instrumento pedagógico que procura melhorar a qualidade do processo de ensino-aprendizagem.

O papel exercido pelas tecnologias e a valorização cada vez maior da inovação excedem no processo de aprendizagem e no uso excessivo das tecnologias como redes sociais e demais recursos digitais que mostram o novo diante das mudanças. 
Em sintonia com este mesmo pensamento, respeitando a pluralidade da educação, Carvalho (2008, p. 19) afirma:

Em qualquer nível em que se exerça, a educação deve empenhar-se em concentrar esforços sintonizados na construção de saberes universalistas que não neguem nenhuma forma de diversidade, na formação de pensadores indisciplinados, capazes de enfrentar os desafios do conhecimento e criar formas de entendimento do mundo a serem viabilizadas e planejadas para a incerteza dos tempos futuros.

Mediante circunstância e não tendo o apoio necessário, o professor se põe inseguro em suas produções, e que profissionais da educação não se acomodam às competências exigidas, havendo a não assistência das instituições escolares, às leis que regem o sistema de ensino nacional para formação dos profissionais da Educação.

Procurar superar a fragmentação para ampliar a complexidade no desenvolvimento do indivíduo, enfim a educação auxilia a pensar no tipo de pessoa que gostaria de se tornar e mais do que isso, constitui e legitima o ser. "Isso significa que a educação não deve ser separada da vida nem é a preparação para a vida, mas é a vida mesma" (ARANHA, 2006, p. 32).

As dificuldades encontradas pelos professores são extremamente desafiadoras, pois requer uma visão de aprendizado. De acordo com Castells (1999), a sociedade como um todo necessita da tecnologia para acompanhar as informações obtidas, sendo que nos dias atuais, a informatização aborda as diversas áreas do conhecimento e está mais presente no cotidiano das pessoas.

\section{A FORMAÇÃO DOS DOCENTES NAS TECNOLOGIAS}

Nos cursos de formação inicial evidencia-se a distância que separa o currículo da realidade das escolas e da sociedade em geral. Em função de uma formação inicial muitas vezes insuficiente e desajustada da realidade, o professor inicia sua vida profissional sem âncora para que responda às necessidades apresentadas pela sua profissão. A formação dos professores que atuam neste século continua a mesma de décadas anteriores, ignorando a maioria dos avanços científicos sucedidos na história, assim como, no desenvolvimento das tecnologias que podem ser usadas na melhoria da educação. 
Há um extenso caminho para a formação de professores que consideram todas as possibilidades de uso da tecnologia na educação. Sobre esse assunto. Coombs assegura:

O professor, na maioria das vezes, é preparado para o ensino de ontem e não para o de amanhã, e se por acaso for preparado para o ensino de amanhã, logo se verá impedido de utilizar o seu preparo ao deparar-se com a realidade de seu primeiro emprego. A partir de então seu crescimento profissional é, na melhor das hipóteses, problemático. (...) É claro que os sistemas não se modernizarão sem que todo o modo de formação de professores passe por uma completa revisão, dinamizado pela pesquisa pedagógica, torne-se intelectualmente mais rico e estimulante, e vá além da formação pré-serviço, para tornar-se uma contínua renovação profissional para todos os professores (COOMBS, 1976, p. 238).

Sabemos das dificuldades através da realidade encontrada nas instituições escolares diante do ensino tecnológico, pois há a necessidade de preparar professores para o uso adequado das novas tecnologias. Assim sendo, é preciso aperfeiçoá-los para essa nova realidade educacional, pois as novas tecnologias e seu impacto na sociedade são aspectos pouco desenvolvidos nos cursos de formação de professores, e as oportunidades que se atualizam nem sempre são ou estão adequadas à realidade ou necessidade.

\section{OS DESAFIOS DO PROFESSOR NO ENSINO REMOTO}

Em virtude da prevenção ao contágio da COVID-19, houve a necessidade de suspensão das aulas presenciais desde março de 2020, isso trouxe muitos desafios para os educadores de todo país. Todos os profissionais da educação precisaram adaptar-se a um novo formato de ensino e os alunos ao novo formato de aprendizagem. Torna-se complicado determinar as lacunas que as atividades não presenciais estão deixando no processo de aprendizagem, no entanto, têm sido a única alternativa viável para a continuidade da garantia dos direitos de aprendizagem estabelecidos pela Base Nacional Comum Curricular (BNCC, 2017).

Com os avanços das novas tecnologias vivenciados ultimamente, os docentes de todo Brasil têm enfrentado muitos desafios em virtude das aulas remotas. Tornando assim muito difícil o desenvolvimento das práticas pedagógicas do professor neste novo cenário que todos o país passou a viver, tivemos que receber um novo direcionamento e serem flexibilizadas para o momento que estávamos passando. Isso porque as atividades 
tiveram que ser aplicadas em um formato remoto que muitos nem tinham conhecimento de como aplicar para seus alunos.

No uso direto com as tecnologias surgiram muitas dúvidas e inquietações e angústias para adaptação dos educadores para se adequar à nova realidade de compartilhar o conhecimento.

Porém, os recursos tecnológicos que possibilitaram tamanha façanha, como computadores, dispositivos móveis e internet não se fazem presente nas moradias de vários educandos brasileiros, como também a praticar de manusear essas ferramentas, como se é notável que alguns profissionais da educação não se adequam ao modelo de ensino mediante as dificuldades do uso destas ferramentas que dão suporte para as aulas a distância usando como por exemplo, a utilização das redes sociais em larga escala pela sociedade e a agilidade na velocidade de transmissão da informação através de aplicativos advindos do uso da internet, provocaram uma progressiva difusão da tecnologia dentro da sociedade, e isso vem trazendo profundas mudanças na forma de comunicação, e principalmente em todos os aspectos e dimensões do ambiente escolar.

Em função disso, a sociedade vive um período de grandes transformações que têm impactado e modificado de forma definitiva, o processo educacional em todo o mundo.

Atualmente a educação básica da rede pública brasileira conta com aproximadamente dois milhões de professores em atuação no ensino e também conta com uma demanda educacional exigente na expansão qualitativa capaz de mudar significativamente os resultados de escolarização. Mas uma parcela significativa desses professores mesmo possuindo a formação docente inicial, os mesmos precisam de constante atualização de suas práticas de modo a atender as perspectivas dos desafios contemporâneos (MEDEIROS, 2009 apud OLIVEIRA, 2009).

As tecnologias digitais podem ser vistas como uma grande aliada para proporcionar um ambiente mais interativo, atrativo e rico de em informações relevantes ao aprendizado, mas, nada adianta ficar repetindo o que o professor deve ou não fazer, que recursos devem ou não utilizar, é preciso perguntar aos educadores quais são os seus maiores desafios enfrentados para inserir no seu dia-a-dia a tecnologia digital, bem como 
descobrir quais são as suas limitações, pois muitos professores sofrem até hoje com essas ferramentas tecnológicas .

Diante de todas circunstâncias, os profissionais da educação estão sobrecarregados, sofrendo com cresce de ansiedade e receio quanto ao futuro, quando as aulas retornarão presenciais, as incertezas quanto a continuar nas aulas remotas, modos de avaliação da aprendizagem dos alunos durante a pandemia. Além disso, a carga excessiva de trabalho imposta pelo ensino remoto tem afetado a saúde mental dos professores e isso tem contribuído diretamente na qualidade de vida destes profissionais.

A prática de aulas remotas deixou ainda mais evidente a desigualdade que existe no nosso país, principalmente a desigualdade social, cultural e educacional. Pois para que esse método de ensino possa acontecer há a necessidade do acesso à internet e aos recursos necessários para esse tipo de ensino, sendo óbvio que os alunos das escolas públicas, principalmente os mais carentes das zonas rurais não possuem esse recurso ou se possui é de baixa qualidade.

\section{DESAFIOS NO USO DAS TECNOLOGIAS EM SALA DE AULA}

Utilizar a tecnologia ainda é um desafio em muitas escolas brasileiras, não só pela falta de infraestrutura, mas também porque nem todos os profissionais estão preparados para implantar essa metodologia em suas aulas. Essa falta de preparo acarreta no uso desequilibrado da tecnologia em sala, seja pela sua limitação ou pelo uso demasiado.

A responsabilidade de facilitar a relação professor-tecnologia é majoritariamente das escolas, que devem buscar investir no aperfeiçoamento dos conhecimentos desses profissionais.

Os professores, por sua vez, devem buscar manter-se atualizados quanto às novas oportunidades que o ambiente digital proporciona. Dessa forma, podem colocar em prática essas novidades em suas aulas da maneira mais qualificada possível.

É importante entender que a tecnologia não deve ser utilizada como forma de entretenimento e distração, e sim para auxiliar no desenvolvimento dos jovens de maneira natural, sendo um recurso produtivo. É preciso ressaltar que a relação entre professor e aluno continua sendo essencial no processo de educação, assim como o desenvolvimento 
da empatia e convívio entre toda a turma. Por mais que as redes sociais e os recursos de interação tenham um papel fundamental para fomentar debates, o contato real ainda é importante. Em cursos à distância, por exemplo, é preciso estar comprometido em fazer todas as disciplinas, mesmo sem o incentivo constante de colegas e professores. Claro, tudo depende de como a aula é conduzida. Muitos professores acreditam que os smartphones e tablets podem ser apenas uma fonte de distração para os alunos. Em alguns casos, essa afirmação é verdadeira.

Os jovens se distraem com muita facilidade e os gadgets podem tornar a rotina da sala de aula estressante. Cabe ao educador usar os recursos ao seu favor para tornar a aula motivadora e manter o foco. Se mal utilizada, a tecnologia pode facilitar em excesso as tarefas dos estudantes. Usar aplicativos que fornecem respostas rápidas em vez de aprender determinado exercício em profundidade é um exemplo de como a tecnologia, se mal utilizada, presta um desserviço à educação. Gestores e professores devem encontrar o ponto de equilíbrio entre a utilização correta dos aplicativos e o uso desregrado

\section{CONCLUSÃO}

O processo de ensino-aprendizagem não é estático. Estamos vivenciando um período de mudança de paradigmas. O modelo tradicional de ensino tem sido posto à prova diante dos avanços das tecnologias de informação e comunicação. As tecnologias eletrônicas têm definido, em boa parte, o nosso modo de pensar e de agir. A escola é um espaço formal de educação e está sendo cobrada quanto à inserção dos recursos tecnológicos na prática pedagógica e sabemos que as mídias estão presentes em muitas escolas de rede pública em nosso país. Diante de tantas novidades que chegam ao conhecimento dos alunos, surge a necessidade dos professores se atualizarem e inserirem o uso de mídias em seus planos pedagógicos, sendo assim, incorporando-as aos recursos metodológicos e contemplando os alunos com uma aprendizagem efetiva e de qualidade.

O que defendemos com o texto é a ideia de que a inserção dos recursos tecnológicos nas escolas depende em boa parte da atuação dos docentes. Para que o professor se sinta preparado para trabalhar com as novas tecnologias é necessário qualificação. Por meio da qualificação o docente poderá se descobrir como parceiro do estudante e um facilitador do processo de ensino aprendizagem. 
Quanto à realidade e os desafios dos docentes no cenário das novas tecnologias de informação, percebemos que estes têm conhecimento do contexto evolutivo da pedagogia educacional e vêm buscando experimentar e se apropriar desses instrumentos tecnológicos em suas aulas. Todavia, a utilização de novas formas de transmissão e troca de conhecimentos entre educadores e educandos têm apresentado também novos desafios, uma vez que em suas experiências ainda há uma prática voltada para às pesquisas na internet ou em atividades de caráter lúdico. Portanto, percebe-se que o maior desafio para esses docentes é encontrar meios, usando metodologias adequadas, as quais envolvam as NTICs para a construção do conhecimento.

O aluno de hoje é um nativo digital, parece possuir habilidades natas para lidar com as tecnologias. As escolas que entenderam esse cenário e criaram condições para incorporar as conquistas tecnológicas à educação dinamizaram a didática e a metodologia e tem contribuído para formar cidadãos críticos, éticos, autônomos e emancipados. Embora os limites para a incorporação dos recursos tecnológicos à educação sejam de toda ordem, como visto, tudo indica que o caminho do ensino passa pelo universo tecnológico.

Enfim, sugere-se a busca por uma formação reflexiva sobre o uso de mídias no processo de ensino e aprendizagem no sentido que estas possam transformar as aulas em um espaço de interatividade, contextualizando à realidade que os alunos vivenciam.

\section{BIBLIOGRAFIA}

ARANHA, Maria Lúcia de Arruda. Filosofia da Educação. São Paulo. Moderna, 2006. CASTELLS, M. Fim de milênio: economia, sociedade e cultura. Trad. Roneide Venâncio Major. 6. ed. v. 1. São Paulo: Paz e Terra, 1999.

COOMB, Philip. A crise mundial da educação. São Paulo: Perspectiva, 1976.

QUARTIERO, E. M. As tecnologias da Informação e Comunicação e a Educação. Revista Brasileira de Informática na Educação, n.4, 1999. Disponível em: http://ceiesbc.educacao.ws/pub/index.php/rbie/article/view/2294/2056> Acesso em 25 jul. 2013.

PEIXOTO, M. de A. P. ; BRANDÃO, M. A. G. B.; SANTOS, G. dos. Metacognição e Tecnologia Educacional Simbólica. Revista Brasileira de Educação Médica, Rio de Janeiro, v.29, n. 1, p. 67-80, jan. 2007. 
CHAVES, E. Tecnologia na educação. 2004. Disponível em: < http://chaves.com.br/T EXTS ELF/EDTECH/tecned2.htm\#II. Tecnologia na Educação>

PEIXOTO, J; ARAÚJO, C. H. dos. S. Tecnologia e educação: algumas considerações sobre o discurso pedagógico contemporâneo. Educ. Soc, v. 33, n. 118, p. 253-268, 2012.

VALENTE, J. A. Diferentes usos do Computador na Educação. 2008. Disponível em: <http://www.nied.unicamp.br/publicacoes/separatas/Sep1.pdf> Acesso em 23 agosto. 2021.

BRASIL. Base Nacional Comum Curricular (BNCC). Educação é a Base. Brasília, MEC/CONSED/UNDIME, 2017. Disponível em: < 568 http://

http://basenacionalcomum.mec.gov.br

OLIVEIRA. Fátima Bayma. Desafios da educação. Rio de Janeiro: e-papers: Fundação Getúlio Vargas, 2009. 


\title{
CAPÍTULO XXVIII
}

\section{PERCEPÇÃO DOCENTE SOBRE OS ENTRAVES E OS DESAFIOS DA EDUCAÇÃO NO CONTEXTO DA PANDEMIA EM UMA ESCOLA DA ZONA OESTE DO MUNICÍPIO DE BOA VISTA- RR}

\author{
Rosana Cléia de Carvalho Chaves ${ }^{105}$; Cristiane Pereira Ferreira ${ }^{106}$; \\ Paula Roberta dos Prazeres Santos ${ }^{107}$; Lyres Luiza de Souza Cruz Silva ${ }^{108}$; \\ Julio Roque de Oliveira ${ }^{109}$. \\ DOI-Capítulo: 10.47538/AC-2021.14-28
}

RESUMO: Este artigo, traz um recorte do Projeto Pedagógico "Protagonismos: Nossas histórias na Pandemia", projeto este em andamento, que objetiva analisar as principais contribuições das intervenções pedagógicas quanto ao processo de ensino e aprendizagem da leitura e da escrita de estudantes da Escola Municipal Prof. Amazona de Oliveira Monteiro. Neste aspecto, partimos do seguinte questionamento: Como a relação entre as intervenções pedagógicas frente aos desafios da Educação no contexto da Pandemia podem contribuir para minimizar os problemas de baixo rendimento escolar e promover a aprendizagem dos Estudantes? Para tanto, a referida pesquisa configurou-se em uma abordagem qualitativa, envolvendo pesquisa participante, bibliográfica e de campo. Para tanto foram aplicados questionários a 16 docentes dos Anos Iniciais do Ensino Fundamental, cujo parâmetro de discussão refere-se a compreensão e percepção destes professores sobre a importância da utilização das tecnologias digitais informação e comunicação - TDIC's e o papel do professor frente aos desafios e entraves no processo de ensino e no acompanhamento da aprendizagem dos alunos no contexto da pandemia. Com isso, vimos que se faz necessário uma reflexão quanto a formação do professor, uma vez que este profissional necessita fundamentar sua prática com metodologias, que possibilitem e oportunizem o diálogo, experiências, problematização e a aproximação da realidade cotidiana bem como a mediação e a interação entre o ensino e a aprendizagem. PALAVRAS-CHAVE: Intervenções. Professor. Desafios. Ensino. Aprendizagem.

\section{TEACHERS' PERCEPTION ABOUT THE OBSTACLES AND CHALLENGES OF EDUCATION IN THE CONTEXT OF THE PANDEMICS IN A SCHOOL IN THE WEST ZONE OF THE MUNICIPALITY OF BOA VISTA-RR}

\footnotetext{
${ }^{105}$ Universidade Estadual de Roraima; http://lattes.cnpq.br/6070758877844357; https://orcid.org/0000-0002-75917070. E-mail: rosanacleia@gmail.com

${ }^{106}$ Universidade Três Fronteiras - PY (UnInter - PY); http://lattes.cnpq.br/4188516460383461; https://orcid.org/00000002-5782-4217. E-mail: crisjesusfamilia@ hotmail.com

107 Gestora da Escola Municipal Prof. Amazona de Oliveira Monteiro em Boa Vista-RR; http://lattes.cnpq.br/5220800253352058; $\quad$ https://orcid.org/0000-0002-9467-0800. E-mail: ppaulinhadosprazeres@hotmail.com

108 FARES - Faculdade Roraimense De Ensino Superior; ;http://lattes.cnpq.br/8205759429975275; https://orcid.org/0000-0002-2569-0226. E-mail: lyrescruz.trabalho@gmail.com

${ }^{109}$ Universidade Estadual de Roraima - UERR; http://lattes.cnpq.br/1145311585547477; https://orcid.org/0000-00022569-0226. E-mail: roquejulio292@gmail.com
} 
ABSTRACT: This article brings an excerpt from the Pedagogical Project "Protagonisms: Our stories in the Pandemic", this project is in progress, which aims to analyze the main contributions of pedagogical interventions in the teaching and learning process of reading and writing by students at the School Municipal Prof. Amazon of Oliveira Monteiro. In this regard, we start with the following question: How can the relationship between pedagogical interventions in the face of Educational challenges in the context of the Pandemic contribute to minimizing the problems of low school performance and promoting student learning? Therefore, this research was configured in a qualitative approach, involving participant, bibliographical and field research. For this purpose, questionnaires were applied to 16 teachers from the Initial Years of Elementary School, whose discussion parameter refers to the understanding and perception of these teachers about the importance of using digital information and communication technologies TDIC's and the teacher's role in the face of challenges and obstacles in the teaching process and in the monitoring of student learning in the context of the pandemic. Thus, we saw that it is necessary to reflect on teacher education, since these professionals need to base their practice on methodologies that enable and provide opportunities for dialogue, experiences, problematization and the approximation of everyday reality as well as mediation and interaction between teaching and learning.

KEYWORDS: Interventions. Teacher. Challenges. Teaching. Learning

\section{INTRODUÇÃO}

Considerando a Pandemia do Covid-19, doença causada pelo novo coronavírus (Sars-Cov-2), gerou rápidas transformações sociais, o que nos obrigou a desacelerar a nossa vida e, tem nos feito refletir, sobre como concebemos nossa existência, as relações de trabalho, o sistema vigente e nossas relações sociais (BEZERRA et al 2021).

Com isso é notório perceber os desafios para a maioria dos professores para trabalhar com uma nova realidade, nunca antes imaginados, bem como as exigências e mudanças radicais nas formas de processar as aulas por meio do ensino remoto, pois ao nosso ver necessita uma nova postura para ensinar e aprender.

Neste caso, esta pandemia vem modificando a vida e a rotina de todos os indivíduos, contudo na educação a pandemia trouxe consigo vários desafios e sem dúvida, a necessidade de mudanças: de comportamento, compreensão do atual contexto social, financeiro, educacional e emocional.

Dessa forma, percebe-se que várias mudanças ocorreram no panorama das práticas educativas, bem como, o repensar, recriar e reinventar na educação novas formas de ver, viver e experienciar o mundo. 
Neste contexto, vimos que os desafios de toda a comunidade escolar: alunos, pais, professores e demais profissionais, durante a quarentena têm sido desafiadores, tendo em vista que abrange os grandes desafios e consequências e impactos na educação em tempos de pandemia.

Contudo, a situação provocada pela pandemia expôs ainda mais as mazelas educacionais. Claro que nenhum profissional, professor ou não, estava preparado para lidar com as dificuldades surgidas, no entanto, barreiras no desenvolvimento de aulas remotas nos leva, a visualizar o baixo investimento educacional, bem como a falta de políticas efetivas de formação e valorização docente (BEZERRA et al, 2021).

Diante desse cenário, as escolas tiveram que se adaptar à nova realidade e a utilizar as tecnologias digitais informação e comunicação - TDIC's, cuja ação foi decisiva nesse momento.

Desse modo, através do processo permanente de reflexão no qual permeia nossa prática docente no processo de ensino aprendizagem no contexto da pandemia, elaborouse o projeto - Protagonismos: Nossas histórias na pandemia, cuja ações, reflexões e perspectivas culminam com a busca pelo aperfeiçoamento da leitura e da escrita.

Dessa forma, a proposta de pesquisa apresentada, visa investigar, quanto aos desafios e os fatores que interferem na aprendizagem e no desenvolvimento pelo hábito pela leitura e os impactos no processo de escolarização das crianças, assim como também promover uma reflexão sobre prática pedagógica de ensino e aprendizagem para a promoção da leitura e escrita no contexto da pandemia.

Em linhas, a partir da atividade de acolhimento e o devido suporte a comunidade escolar, com problemas emocionais, bem como, possibilitar o exercício e a sensibilização da empatia, cooperação, auxiliar por meio da escuta e do diálogo, a resolução de conflitos e a cooperação, promovendo o respeito e a valorização a diversidade dos indivíduos de seus saberes e estratégias que promovam inferências diversificando e adaptando as estratégias pedagógicas às dificuldades individuais do aluno para fortalecer o processo de ensino-aprendizagem da leitura e escrita. 


\section{TECNOLOGIAS DIGITAIS DE INFORMAÇÃO E COMUNICAÇÃO (TDIC's) NO CONTEXTO EDUCATIVO}

Como sabemos as crianças desde muito cedo estão em constante contato com as Tecnologias Digitais de Informação e Comunicação (TDIC's), dessa forma, as crianças nos primeiros anos escolares já utilizam e demonstram uma aproximação junto aos vários recursos tecnológicos como: celular, computador, tablete, vídeo games entre outros elementos indicadores da cultura digital.

Para Moran (2000, p. 37),

A criança também é educada pela mídia, principalmente pela televisão. Aprende a informar-se, a conhecer - os outros, o mundo, a si mesma-, a sentir, a fantasiar, a relaxar, vendo, ouvindo, "tocando" as pessoas na tela, pessoas estas que lhe mostram como viver, ser feliz e infeliz, amar e odiar.

Neste foco, compreende-se a importância das TDIC's como um conjunto de recursos presente no nosso cotidiano e que a cada momento está evoluindo, trazendo vários benefícios para a vida e assumindo uma função de grande relevância na vida social e escolar do indivíduo.

A este respeito, Haetinger (2005, p. 39) declara: “A escola jamais poderia ser indiferente, pois se constitui um lugar de posturas e mudanças sociais. É na escola onde se encontra o âmago das modificações de origem social".

Assim torna-se indispensável à utilização TDIC's tendo em vista que, tais recursos auxilia a dinâmica do processo de ensino e aprendizagem, amplia a interatividade entre aluno e professor, levando um mundo de conhecimento para dentro da sala de aula, através de várias formas tem uma colaboração na mudança de paradigmas tradicionais em relação ao processo de ensino e aprendizagem, ou seja, elas se apresentam como uma nova maneira de ensinar e aprender.

As evidências das TDIC's têm influenciado a aprendizagem dos alunos de forma significativa, pois tais recursos oportunizam o diálogo, fortalece a interação com colegas não somente no ambiente escolar, mas também fora da escola, garantindo uma mudança significativa e desafiadora, integrando-as e aproximando o aluno da aprendizagem.

Partindo desse pressuposto, entendemos que, a utilização das TDIC's, merece ter seu lugar de destaque no processo educativo, por aguçar e estimular cada vez mais a 
capacidade de inquirir, pesquisar e descobrir de maneira que os alunos aprendam e prove de outras experiências. Em linhas gerais vimos que o professor é o mediador desse processo, portanto tem um papel significativo, tendo em vista que, é dele a missão de buscar alternativas para verificar, acompanhar e sanar as possíveis dificuldades de aprendizagem dos estudantes.

\section{O PAPEL DO PROFESSOR E OS DESAFIOS DA INSERÇÃO DAS TECNOLOGIAS DIGITAIS DE INFORMAÇÃO E COMUNICAÇÃO (TDIC's) NO PROCESSO DE ENSINO E APRENDIZAGEM}

Considerando que a escola é um espaço que proporciona oportunidades de experiência de aprendizagem do conhecimento sistematizado, essa é uma das razões pela qual é considerada um lugar privilegiado para a aprendizagem, assumindo o compromisso de capacitar os indivíduos para serem autores e atores do projeto de sociedade em que vivem.

Nesta perspectiva, as TDIC's, na pandemia no contexto educativo foram incorporadas na escola como suporte e auxílio de integração às atividades escolares, dessa forma, adentraram no contexto diário por meio das aulas em sistema de ensino remoto.

Neste sentido, $[\ldots]$ o processo ensino-aprendizagem deve incorporar cada vez mais o uso das tecnologias digitais para que os alunos e os educadores possam manipular e aprender a ler, escrever e expressar-se usando essas novas modalidades e meios de comunicação, procurando atingir o nível de letramento (VALENTE, 2007, p. 38).

Conforme os autores Almeida e Valente (2009, p. 2-3):

É importante utilizar as TDIC's para [...] potencializar as práticas pedagógicas que favoreçam um currículo voltado ao desenvolvimento da autonomia do aluno na busca e geração de informações significativas para compreender o mundo $\mathrm{e}$ atuar em sua reconstrução, no desenvolvimento do pensamento crítico e auto-reflexivo do aluno, de modo que ele tenha capacidade de julgamento, autorealização e possa atuar na defesa dos ideais de liberdade responsável, emancipação social e democracia.

Tais atividades levaram à compreensão de que o uso das tecnologias de informação e comunicação - TDIC's na escola, principalmente com o acesso à Internet, contribui para expandir o acesso à informação atualizada e, principalmente, para promover a criação de comunidades colaborativas que privilegiam a comunicação, 
permitem estabelecer novas relações com o saber que ultrapassam os limites dos materiais instrucionais tradicionais e rompem com os muros da escola, articulando-os com outros espaços produtores do conhecimento, o que poderá resultar em mudanças substanciais em seu interior.

A análise da realidade educacional e social deixa evidente a necessidade do professor, o sentido e relevância do seu papel para com a sociedade, exigindo assim, uma maior exigência na sua atividade e na postura profissional em conhecimentos imbuídos na formação do professor. Essa análise é feita por vários educadores.

De acordo com Perrenoud (2000, p. 38) "o professor é um profissional do ensino, praticante reflexivo, essa dinâmica é orientada e mediatizada pela percepção do seu papel, da sua atuação ligadas ao investimento de toda formação".

Compreende-se então que, a esse profissional cabe assumir o "investimento" de responsabilidade pessoal, na tentativa de realizar uma prática profissional transformadora, ou seja, que possa atender às necessidades educacionais do "mundo globalizado - contemporâneo" e assim contribuir para uma sociedade mais digna, criando espaços de possibilidades para a construção do conhecimento e de autonomia.

Neste foco, a formação do professor deve basear-se em estabelecer estratégias de pensamento, de percepção, de estímulos e centrar-se na tomada de decisões para processar, sistematizar e comunicar a informação numa perspectiva e de prática pedagógica inovadora.

A este respeito, cabe ao professor buscar em sua formação continuada mecanismos que fundamentam teoricamente sua prática. É importante salientar que a formação assume um papel que transcende o ensino, como enfatiza Ibernon (2002):

A formação não é uma mera atualização científica, pedagógica e didática, e sim possibilidades de criar espaços de participação, reflexão e transformação, para que as pessoas aprendam, adaptem para poder conviver com as mudanças e as incertezas.

Portanto, a formação também servirá de estímulo crítico ao constatar as enormes contradições da profissão e ao tentar trazer elementos para superar as situações perpetuadoras - alienação profissional e comodismo, isto é, ter uma postura de um 
"profissional" competente que desenvolva um trabalho voltado a gerenciar a sala de aula, comprometendo-se e objetivando o exercício de sua função.

\section{ASPECTOS METODOLÓGICOS}

A trajetória metodológica desta pesquisa com abordagem qualitativa envolvendo pesquisa participante, bibliográfica e de campo, que se configurou em um recorte do Projeto Pedagógico "Protagonismos: Nossas histórias na Pandemia".

Dessa forma, objetivou analisar as principais contribuições das intervenções pedagógicas quanto ao processo de ensino e aprendizagem da leitura e da escrita de estudantes da Escola Municipal Prof. Amazona de Oliveira Monteiro, localizada na Zona Oeste de Boa Vista-RR.

Neste contexto, foi elaborado questionário contendo 11 questões, sendo: 05 questões abertas e 06 questões fechadas através da plataforma virtual Google forms, que foram aplicados a 16 docentes dos Anos Iniciais do Ensino Fundamental de forma anônima e voluntária, teve como propósito traçar o perfil destes professores e identificar sua percepção frente cujo parâmetro de discussão refere-se a compreensão e percepção destes professores sobre a importância da utilização das tecnologias digitais informação e comunicação - TDIC's e o papel do professor frente aos desafios e entraves no processo de ensino e no acompanhamento da aprendizagem dos alunos no contexto da pandemia.

Desse modo, objetiva-se promover reflexões acerca de limite desafios e possibilidade mediante a experiência indicada por estes a pesquisa exploratória e descritiva reflete um estudo que busca observar e descrever documentos as características regiões atitudes e crenças determinada população ou fenômeno proporcionado maior familiaridade com o problema, objetivando tornar mais compreensível sugestivo a hipóteses (GIL, 2002).

Portanto, tais evidências visam uma discussão e reflexão quanto a formação do professor, uma vez que este profissional necessita fundamentar sua prática com metodologias, que possibilitem e oportunizem o diálogo, experiências, problematização e a aproximação da realidade cotidiana bem como a mediação e a interação entre o ensino e a aprendizagem. 


\section{RESULTADO E DISCUSSÃO}

Na perspectiva didática e diante do atual cenário educacional provocado pela pandemia do COVID 19, em que docentes e discentes tiveram que, por decretos Federais, Estaduais e Municipais, manter o distanciamento social como proposta de segurança para a saúde, com isso, para que os alunos não ficassem tão prejudicados no processo de ensino aprendizagem, foi necessário repensar sobre que estratégias poderiam ser utilizadas para que fosse dado continuidade ao ano letivo.

Foi então que surgiu a proposta por meio de documentos oficiais para o ensino remoto. Com isso, devem ser usadas ferramentas que estimulam ainda processos de tomada de decisão, negociação de significados e o uso de ferramentas de comunicação que promovam ou facilitem a aprendizagem colaborativa enquanto durar a pandemia. (SALMON, 2004).

Assim, ainda sobre ensino remoto, Garcia, Morais, Zaros e Rêgo (2021) destacam:

A utilização do Ensino Remoto envolve os princípios gerais da Didática em atenção a decisões quanto à escolha do método de apresentação do conteúdo, à manutenção da atenção, ao interesse e à motivação do aluno e aos resultados da aprendizagem, como já destacado. Desse modo, o desafio está em escolher e propor o design instrucional que o professor quer ou decidiu adotar.

Nesse sentido, o Ensino remoto no contexto da docência na respectiva escola, foi evidenciado pela busca de ferramentas diversificadas, uma vez que, percebe-se a necessidade de fundamentar a prática pedagógica com metodologias, que possibilitem a mediação e a interação entre o ensino e a aprendizagem, de tal modo que oportunize o diálogo, experiências, problematização e a aproximação da realidade cotidiana.

Desse modo, elaborou-se o Projeto Pedagógico, "Protagonismos: Nossas histórias na Pandemia", a fim de tentar sanar dificuldades enfrentadas na escola, a saber, problemas de baixo rendimento escolar, o impacto emocional e promover a aprendizagem da leitura e escrita dos Estudantes.

A partir do projeto em andamento, foi proposto o acolhimento, com atividades voltadas ao momento de escuta e atividade diferenciadas, na qual exponham suas angústias e expectativas, como forma também de trabalhar a escrita, leitura, produção de texto e desenho, com produção de um livro de cada turma. 
Em se tratando da Produção de texto, foi desenvolvido um texto, no formato de relato pessoal falando de acontecimentos marcantes na sua vida enquanto precisou estudar em casa no período de pandemia, isolamento social, exposição das dificuldades, quem ajudou nas tarefas em casa, como foi falar com a professora só pelo WhatsApp.

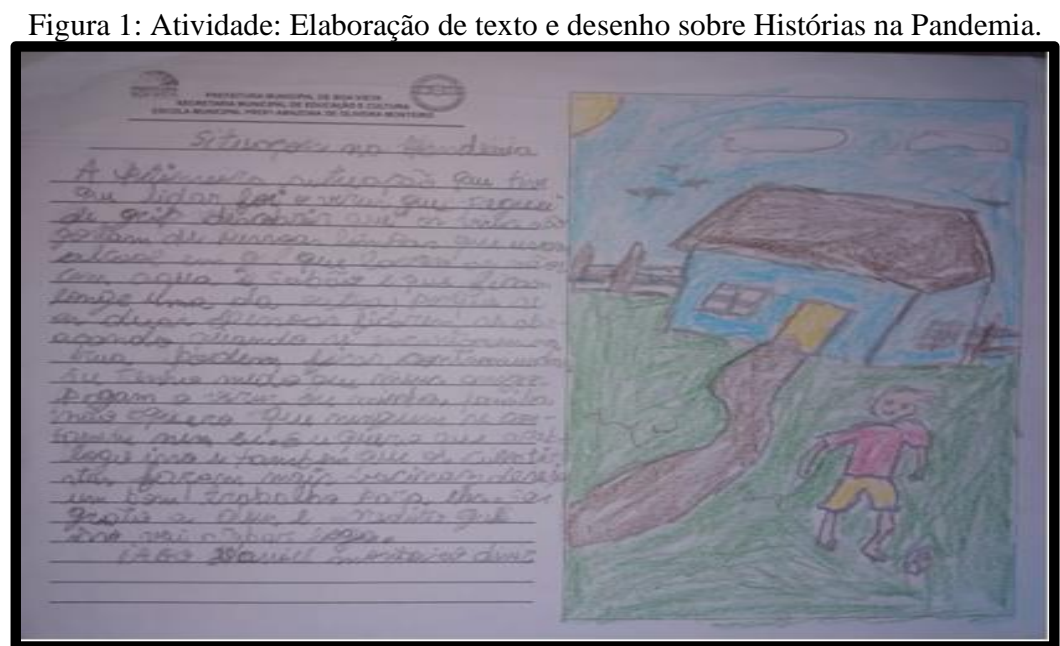

Fonte: Arquivo docente da Escola Municipal Prof. Amazona de Oliveira Monteiro, 4 ano "A" (C.P.F, 2021).

Quando entrevistados sobre os entraves e desafios no processo de ensino e no acompanhamento da aprendizagem dos alunos durante a pandemia, tais profissionais, evidenciaram a ausência de aparelho celular e a falta de acesso à internet de alguns alunos ocasionaram e fortaleceram a falta da participação de muitos alunos nas aulas. Neste foco, o distanciamento social, ocasionou muitos prejuízos, principalmente para os alunos em processo de alfabetização.

Desta forma, como é visível que a maioria da população atendida nas escolas municipais, mesmo de baixa renda, possui pelo menos um celular por família, optou-se por utilizar esse recurso tecnológico com uso do aplicativo WhatsApp para manter a corrente de comunicação entre escola e comunidade.

Desse modo, o maior desafio destacado pelos docentes, trata da ausência dos estudantes nas aulas e manter a produtividade destes. Eis a razão de que nem todos os alunos disponibilizam de recursos tecnológicos, nem todos os pais possuem aparelho celular e/ou disponibilizam tempo para acompanhar a vida escolar dos filhos. Com isso, percebe-se que se perpetua a ausência quanto aos incentivos do país e o acompanhamento rigoroso dos mesmos em contribuir para não se perder o ritmo de estudos. 
Neste contexto, os docentes colaboradores, apontaram que, para tentar amenizar os impactos causados pela falta de internet para os menos favorecidos, foi elaborado um roteiro de atividades com plantão tira dúvidas, via telefone celular no número da professora , assim, embora não pudessem ter acesso ao grupo do WhatsApp da turma para acompanhar as videoaulas explicativas de sua turma ou não puderam fazer uma chamada de vídeo para sua professora para receber uma melhor explicação ou tirar a dúvida existente sobre alguma atividade, tentou-se alcançá-los com estes roteiros impressos e uso do livro didático, foi a forma encontrada para que se sentissem incluídos nas aulas planejadas por seus professores, pois ao terem acesso aos materiais de estudos por meio destes recursos esperou-se que estes discentes se sentissem parte da sua escola de alguma forma, também a necessidade da vacinação para todos, foram algumas possíveis soluções destacadas para o enfrentamento das dificuldades impostas pela pandemia no processo de ensino e de aprendizagem.

No caso dos alunos que possuem recursos tecnológicos: celular, tablet, computador, ambos engajaram-se no grupo de aula do WhatsApp, os quais foram disponibilizados videoaulas e chamadas de vídeos para tirar possíveis dúvidas sobre os conteúdos.

Vale aqui ressaltar, todo o esforço e empenho dos docentes desta instituição, consolidou-se na busca para reelaborar projetos já existentes de intervenção pedagógica para o modo remoto, com o intuito de estreitar os laços com a família dos alunos e os alunos inseridos na classe.

A este respeito, aos discentes com a defasagem de aprendizagem, foi pensado e elaboradas atividades para um acompanhamento específico de alfabetização, por meio de apostilamento impresso. Em relação ao acesso ao meio de comunicação, foi solicitado pelos professores por meio da gestão da escola a melhoria da internet na escola para os professores.

Neste caso, vale destacar que para apoiar o trabalho escolar, a equipe técnica de suporte pedagógico da SMEC, elaborou projeto: Aprendendo em casa, e disponibilizando atividades complementares trabalhadas nos sábados letivos por meio de reposição de dias letivos, para que os docentes aplicassem aos seus alunos por meio do grupo de aula no WhatsApp. 
Neste caso, um dos aspectos fundamentais foi pensado pela equipe técnica da Secretaria Municipal de Educação (SMEC) do município de Boa Vista - RR, que mesmo diante das dificuldades, fez aquisição de tablets e enviou às escolas para dar suporte ao ensino remoto. Contudo, posteriormente fez a doação aos professores de Chromebook, com isso disponibilizou tais recursos tecnológicos mais acessíveis para todos os professores, coordenadores e gestores da rede regidas por esta secretaria.

Desse modo, para obter informações e promover um momento de reflexão e compreensão da percepção docente sobre a importância da utilização das tecnologias digitais informação e comunicação - TDIC's e o papel do professor frente aos desafios e entraves no processo de ensino e no acompanhamento da aprendizagem dos alunos no contexto da pandemia, foi elaborado e aplicado um questionário contendo 11 questões, por meio da plataforma virtual Google forms, cuja a participação conta com 16 docentes dos Anos Iniciais do Ensino Fundamental.

Neste caso, quando mencionado os resultados das aulas remotas, os entrevistados responderam que é necessário além do empenho e compromisso por parte da família, uma plataforma que atenda com mais facilidade pais, alunos e professores.

Neste caso, percebe-se a necessidade de políticas públicas de investimento na educação com foco no reforço escolar para todos os alunos que não conseguiram desenvolver pelo menos $50 \%$ da aprendizagem dos conteúdos propostos, bem como apoio psicológico e acolhimento para todos os profissionais envolvidos no processo escolar.

Assim, acredita-se que a busca ativa da família, o diálogo com os pais, a assinatura de termos de compromisso quanto a aprendizagem de seus filhos, flexibilização dos conteúdos do programa estruturado segundo a realidade de cada escola/turma, acesso à internet de qualidade na escola e formação continuada para os professores podem favorecer maior envolvimento entre os sujeitos e o processo de ensino e aprendizagem.

Dessa forma, também percebe-se que a SMEC, têm demonstrado preocupação em proporcionar momentos de reestruturação e acolhimento sócio emocional tantos dos professores quanto dos alunos, por meio do Programa Compasso, que tem como um de seus objetivos contribuir para que, por meios dos encontros virtuais os profissionais possam ter acesso a atividades que contribuam para entender como é importante 
identificar sentimentos, falar sobre eles, se acalmar e buscar uma estratégia positiva para saber lidar com os sentimentos e superar aquele momento considerado conflitante e assim por meio das atividades que aplicam aos seus alunos transmitir tais informações.

No que se refere a Importância das tecnologias e o papel do professor, frente aos desafios da Educação no contexto da Pandemia, obtivemos diversas as respostas, como: "nesse tempo de Pandemia as tecnologias foram e continuam sendo fundamentais, mas a carências que muitos têm pela falta da mesma é o desafio maior” (C.P.F - 2021).

No que se refere ao desempenho das atividades, vimos que, o uso das ferramentas tecnológicas tem sido fundamental, haja vista que tem sido a ferramenta que utilizamos como principal canal de comunicação entre professor - aluno e professor -família, foi de fundamental importância e de reinventar novas formas de ensinar. A tecnologia é de suma importância pois foi o único meio seguro tanto para os educandos quanto para os educadores no processo de ensino e aprendizagem durante a pandemia.

Como respostas também obtivemos que a internet é a maior e melhor ferramenta para o ensino remoto, pois hoje estamos todos interligados por essa rede, que nesse momento de Pandemia transmite segurança no sentido de ser contaminado pelo novo vírus que provoca o COVID 19. É também uma ferramenta de suma importância para transmitir o conhecimento aos discentes.

Vale enfatizar que os professores entrevistados também deixaram claro que, foi de grande importância o uso das diversas ferramentas utilizadas no decorrer desse processo, ainda destacaram que o professor teve um papel de grande relevância e responsabilidade, pois além das aulas aplicadas, tiveram que conversar e acalmar os alunos e os pais, pois muitos discentes tiveram perdas de parentes e amigos e ficaram emocionalmente muito abalados.

Foi dito ainda que as TDIC's são de extrema relevância frente ao processo de ensino e aprendizagem, ainda mais em uma sociedade contemporânea onde a Ciência e Tecnologia fazem parte do cotidiano dos alunos, é preciso investir e possibilitar o acesso aos recursos tecnológicos como imprescindíveis no cotidiano das escolas.

Nesta perspectiva, o papel do professor é de mediador, e acima de tudo de agente que constrói pontes e contribui para a formação de cidadãos críticos e reflexivos em nossa 
sociedade. Sendo assim, a tecnologia é de suma importância contudo essas tecnologias digitais ainda não estão acessíveis a todos os alunos, temos uma conectividade precária e os professores nem sempre conseguem usufruir dessa ferramenta para ajudar no ensino dos alunos.

Diante dessa afirmação, os docentes ainda apontaram que, as TDIC's são de extrema importância, para desenvolver as aulas remotas, com isso, utilizaram algumas mídias e aplicativos digitais, dentre quais puderam citar o WhatsApp como o mais utilizado, pois foi a principal ferramenta de comunicação entre eles, os alunos e seus responsáveis. Utilizaram também o Google sala de aula, Canvas, Google class, gravação de tela, Meet, Xrecord e outros, conforme registros abaixo:

Figura 2: Utilização do App Canvas na sala de aula.

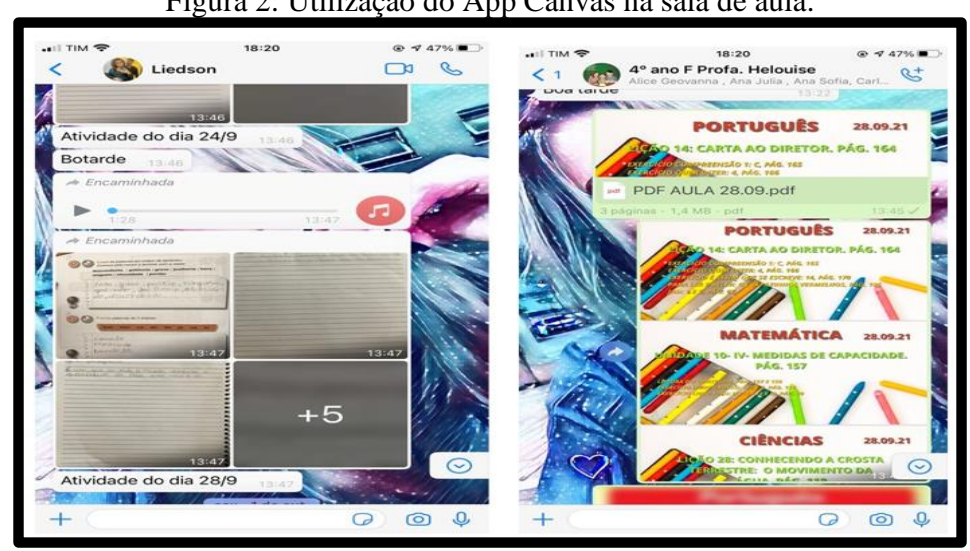

Fonte: Arquivo docente da Escola Municipal Prof. Amazona de Oliveira Monteiro,4 Ano F (H.P, 2021).

Diante da ilustração acima, percebemos que o App CANVAS foi o recurso tecnológico utilizado pela docente, desse modo, elaborou seu roteiro de aula. A docente em entrevista afirmou: “Eu fiz alguns cursos on-line com ferramentas digitais, pois sabia que acabaríamos voltando e utilizando o meios digitais, num desses cursos eu conheci o Canvas e gostei muito e resolvi usar" (H.P, 2021). Neste aspecto, fica evidente que esta professora se preocupou e procurou investir na sua formação. 
Figura 3: Aulas Ministradas no grupo de WhatsApp

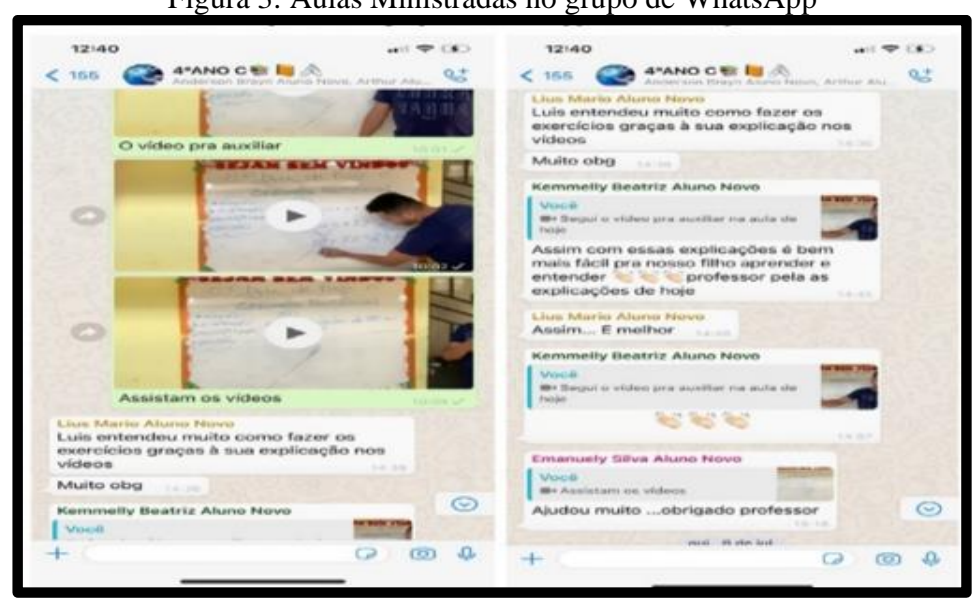

Fonte: Arquivo docente da Escola Municipal Prof. Amazona de Oliveira Monteiro, 4 Ano C, (E. R, 2021).

$\mathrm{Na}$ imagem acima podemos perceber a preocupação por parte do professor em fornecer recursos que contribua para o melhor entendimento de seus alunos do conteúdo aplicado, pois dedica tempo em gravar vídeos explicativos sobre a atividade a ser desenvolvida pela turma, verificamos ainda a satisfação dos alunos e responsáveis confirmando que com o vídeo explicativo enviado ficou bem melhor de entender o conteúdo ali transmitido.

Contudo vale ressaltar que durante esse período de pandemia $100 \%$ dos professores participantes da pesquisa, fizeram aquisição de algum equipamento tecnológico para preparar ou utilizar nas aulas e que acreditam que a educação no contexto da pandemia é uma reflexão necessária.

Figura 4: Apoio diante do desenvolvimento do Ensino Remoto.

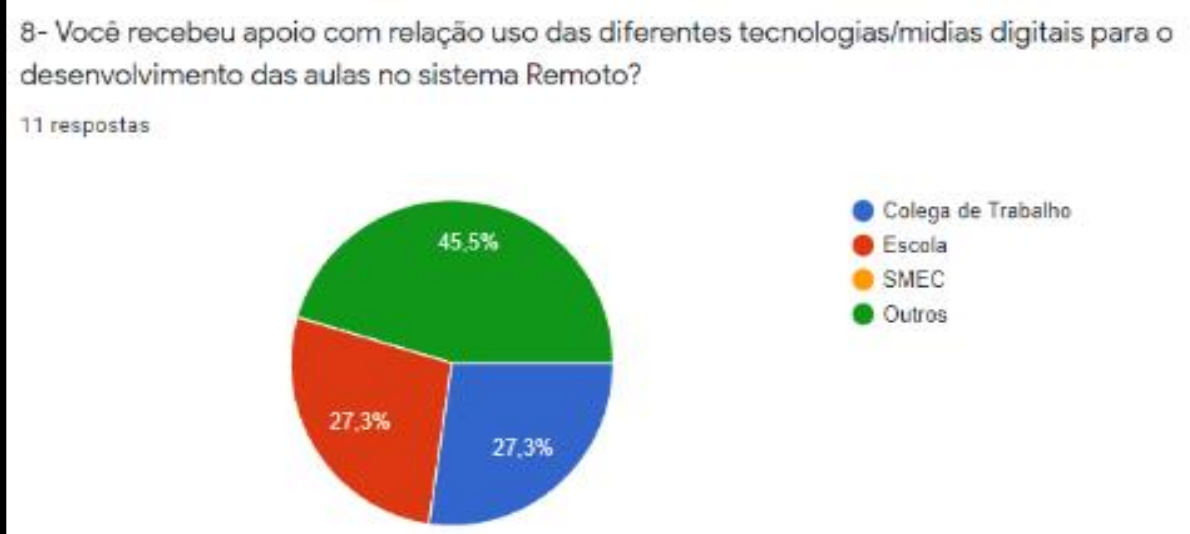

Fonte: Arquivo dos pesquisadores (2021).

Ao serem questionados sobre o apoio pedagógico referente ao uso das diferentes tecnologias recebidos nesse período, o gráfico nos mostra que $27,3 \%$ dos entrevistados 
disseram que tiveram apoio de colega de trabalho, 27,3\% de um profissional da escola, $45,5 \%$ dos entrevistados disseram que tiveram apoio de outras pessoas fora do rol de trabalho.

Conforme ilustração do resultado da pesquisa realizada que consta no gráfico abaixo, 43,8\% disseram que encontraram dificuldades para ministrar aulas remotas e fazer uso das diferentes tecnologias digitais e 56,3\% não tiveram essas dificuldades.

Figura 5: Ensino Remoto.

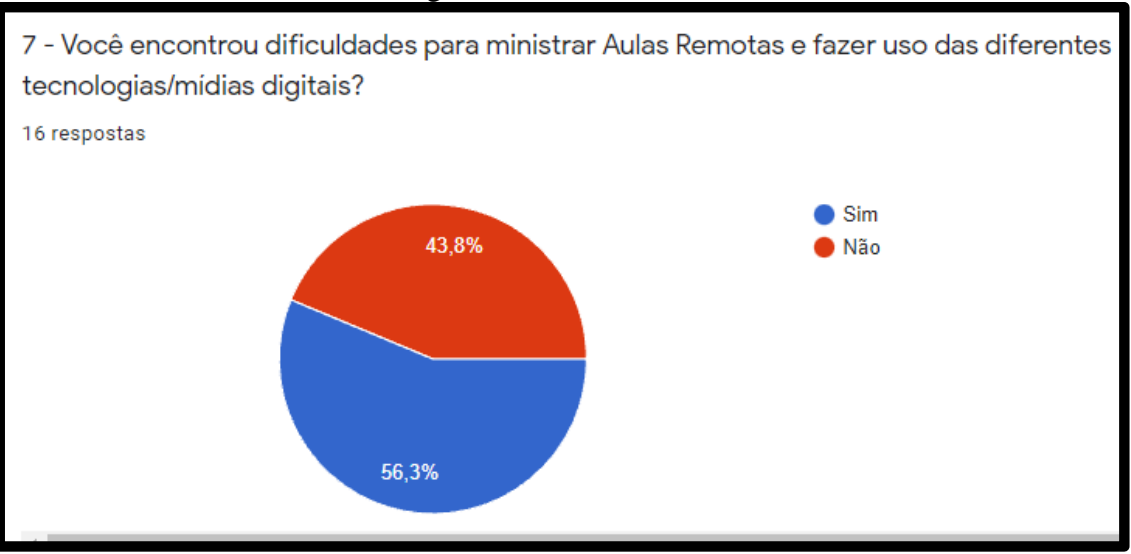

Fonte: Arquivo dos pesquisadores (2021).

Diante dos dados apresentados, vimos que se faz necessário uma reflexão quanto a formação do professor, uma vez que este profissional necessita fundamentar sua prática com metodologias, que possibilitem e oportunizem o diálogo, experiências, problematização e a aproximação da realidade cotidiana bem como a mediação e a interação entre o ensino e a aprendizagem.

\section{CONSIDERAÇÕES FINAIS}

Ao refletirmos sobre uma nova postura docente na educação no período de pandemia e pós-pandemia, reconhecemos que embora tenha deixado marcas irreparáveis na sociedade que atingiu diretamente o processo de ensino aprendizagem dos alunos da escola pública, para termos saúde emocional precisamos focar na ideia que ela deixará algo positivo e que, mesmo diante de tantas dificuldades, a educação poderá ser inovada e transformada por meio da formação continuada dos profissionais inseridos o âmbito educacional escolar para a exploração do uso adequado das Tecnologias Digitais de Informação e Comunicação (TDIC's), que o sistema educacional ofertar formação 
continuada nessa área e momentos para discutir quais fatores influenciam a utilização da tecnologia. para assim favorecer o aprendizado dos alunos.

Desse modo, constatou-se, dentre outros aspectos, que há uma grande dificuldade de manuseio, acesso e compreensão das várias ferramentas tecnológicas. Contudo, o foco desta pesquisa está pautado nos reflexos das ações desenvolvidas por meio do uso das diversas ferramentas tecnológicas e também analisar as principais contribuições das intervenções pedagógicas quanto ao processo de ensino e aprendizagem da leitura e da escrita de estudantes da Escola Municipal Prof. Amazona de Oliveira Monteiro.

Portanto, essa pesquisa foi de grande relevância para a educação, pois ficou evidente que é de extrema necessidade a aplicação de recursos públicos para a formação continuada dos discentes para o aperfeiçoamento do quanto ao uso das diversas ferramentas tecnológicas digitais para a eficácia de uma aula de qualidade, para justificar essa fala podemos concordar com o que diz Bezerra et al, (2021), que nenhum profissional ou docente, estava preparado para lidar as dificuldades surgidas com Pandemia do COVID 19, contudo as barreiras no desenvolvimento de aulas remotas têm nos levado a refletir na importância de investir na formação desses profissionais.

\section{REFERÊNCIAS}

ALMEIDA et al. Ensino remoto e tecnologia: uma nova postura docente na educação pós-pandemia, VII Congresso Nacional de Educação - CONEDU. 2020.

BEZERRA, N.P.X et, Al. Ressignificando a prática docente: experiências em tempos de pandemia. Práticas Educativas, Memórias e Oralidades. Rev. Pemo -Revista do PEMO, Fortaleza, v.3,n.2, e323917, 2021.

GARCIA, T.C. M, et. Al, Ensino remoto emergencial: proposta de design para organização de aulas. UFRN: SEDIS, 2020. Disponível em: https://repositorio.ufrn.br. Acesso em 02 de maio de 2021.

GIL, A. C. Como elaborar projeto de pesquisa. 4. Ed. São Paulo: Atlas. 2002.

HAETINGER, M. G. 2005. O Universo Criativo da Criança na educação. (www.maxcriar.com.br/) Acesso em: 19/09/2015.

IMBERNÓN, F. Formação docente e profissional. Forma-se para a mudança e a incerteza. 3 Ed. São Paulo: Cortez, 2002.

MORAN, José. Ensino e aprendizagem inovadores com tecnologias audiovisuais e telemáticas, In: MORAN, J., MASETTO, M. e BEHRENS, M. Novas tecnologias e mediação pedagógica. Campinas, SP: Papirus, 2000. 
PERRENOUD, P. PAQUAY, L. Formando professores profissionais. Quais estratégias? Quais competências. 2 Ed. Porto Alegre: Artmed, 2000.

SALMON, G. E-actividades. El factor clave para uan formación en línea activa. Barcelona: Editorial UOC, 2004.

VALENTE, José. O uso inteligente do computador na educação, Pátio, ano 1, n. 1, p. 19-21, Porto Alegre, mai/jul. 1997. Informática na Educação: uma questão técnica ou pedagógica? Pátio, ano 3, n. 9, p. 20-23, Porto Alegre, mai/jul., 2007. 


\title{
CAPÍTULO XXIX
}

\section{PONTOS CANTADOS DE UMBANDA E SEU POSSÍVEL USO COMO FERRAMENTA PEDAGÓGICA PARA O ENSINO DE HISTÓRIA DA ÁFRICA \\ E CULTURA AFRO-BRASILEIRA}

\author{
Paula Roberta Libanori Haenisch ${ }^{110}$. \\ DOI-Capítulo: 10.47538/AC-2021.14-29
}

\begin{abstract}
RESUMO: O presente capítulo tem por objetivo trazer à tona reflexões que relacionem o campo de Ensino de História e suas abordagens acerca dos povos africanos e afrobrasileiros, por meio da utilização dos Pontos Cantados de Umbanda que são as canções sagradas entoadas durante os rituais da referida religião e que carregam em si temáticas diversas que se entrecruzam, de diversas maneiras, com determinados objetos de estudos abordados nas aulas de História. Pretende-se, portanto, apresentar em que consistem os tais Pontos Cantados e por quais motivos eles são utilizados nos rituais umbandistas para, posteriormente, trazer a tona reflexões sobre como a utilização dos tais Pontos Cantados em sala de aula pode consistir em uma ferramenta não somente pedagógica no sentido do conhecimento conteudista, mas, também, uma estratégia de valorização da cultura religiosa de matriz africana presente em nosso país para que se faça, inclusive, cumprir a lei 10.639/03.
\end{abstract}

PALAVRAS-CHAVE: Ensino de História. Lei 10.639/03. Umbanda. Pontos Cantados.

\section{SUNG POINTS OF UMBANDA AND THEIR POSSIBLE USE AS A PEDAGOGICAL TOOL FOR TEACHING AFRICAN HISTORY AND AFRO- BRAZILIAN CULTURE}

ABSTRACT: This chapter aims to bring up reflections that relate the field of History Teaching and its approaches to African and Afro-Brazilian peoples, through the use of Umbanda Sung Points, which are the sacred songs sung during the aforementioned rituals. religion and that carry in them diverse themes that intersect, in different ways, with certain objects of study addressed in History classes. It is intended, therefore, to present what these Sung Points consist of and why they are used in Umbanda rituals, to later bring up reflections on how the use of such Sung Points in the classroom can be a non-tool. only pedagogical in the sense of content knowledge, but also a strategy of valuing the African-based religious culture present in our country so that the law 10.639/03 can even be complied with.

KEYWORDS: Teaching History. Law 10.639/03. Umbanda. Sung Points.

\section{INTRODUÇÃO}

\footnotetext{
${ }^{110}$ Mestranda em História Pública pela UNESPAR - Universidade Estadual do Paraná - campus de Campo Mourão; http://lattes.cnpq.br/4312579445143769; 0000-0002-6263-0556. E-mail: paulahaenisch2020@ gmail.com
} 
A História, enquanto disciplina no Brasil passou por inúmeros processos de institucionalização e ainda vem sofrendo frequentes alterações em sua carga programática, na atualidade, visto que tal disciplina, muitas vezes, é formulada e utilizada para atender interesses específicos dentro de períodos e contextos históricos carregados de particularidades.

Ao longo do século XIX, por exemplo, quando ela começou a ser institucionalizada, o Colégio Dom Pedro II era considerado o modelo de História nacional a ser seguido em todo o Brasil Imperial e tal processo de institucionalização da História, com o dito colégio como centro de referência, era encaminhado pelo Estado e pela Igreja (TOLEDO, 2005). Recém-formada no início do século XIX, o ideal de nação brasileira precisava ser formulado pela elite, esta, por sua vez, tinha raízes europeias bastante fincadas, sendo o próprio Imperador Dom Pedro I um homem de origem lusa. Esse processo de criação de uma identidade nacional foi, inclusive, bastante complexo e lento, se estendendo por muitas décadas ao longo do século retrasado. Deste modo, Toledo (2005, p. 3) evidencia que:

Nesse processo de criar a imagem de Nação tornou-se necessário construir um saber sobre o passado nacional, pois se um conhecimento sobre as nações apresentava-se necessário àqueles sujeitos que de maneira ativa viviam o momento de consolidação do Império brasileiro, da mesma forma construir um saber sobre o passado nacional era um dos caminhos considerados mais acertados para que se reconhecesse o país como uno.

Neste sentido, a História passa a ser consolidada enquanto disciplina escolar tendo o Colégio Dom Pedro II como ponto central desse processo, conforme fora mencionado anteriormente, desde a sua fundação, em 1838. E foi da referida instituição que "saiu a principal produção da historiografia didática do período" (TOLEDO, 2005, p. 5). Todavia, por conta da ausência de autores nacionais que servissem como referencial teórico para a produção desses materiais, a influência estrangeira na produção deles e na organização dos conteúdos programáticos se fez muito marcante. Deste modo, a história do Brasil foi sendo escrita sob as perspectivas sociais, culturais e historiográficas europeias, sobretudo, com forte influência francesa (TOLEDO, 2005).

Em seus primórdios, portanto, a disciplina de História visava destacar uma história nacional com narrativas não inclusivas e incoerentes com a realidade brasileira, uma vez 
que setores de nossa população eram negligenciados, como era o caso dos indígenas, dos africanos, dos afrodescendentes e, até mesmo, das mulheres (BITTENCOURT, 2018). Havia um processo de construção de narrativas históricas que dava destaque aos chamados 'grandes homens da história' e esse processo não se findou no Brasil Imperial, sendo reproduzido por anos a fio, posteriormente, no Brasil Republicano. Ou seja, as narrativas históricas oficiais seguiram enaltecendo, por muito tempo, o homem branco como único modelo possível de mártir - ou herói - na história do Brasil. (ORIÁ, 2018) e, arrisco-me a dizer, que ainda seguem enaltecendo esse modelo de 'herói' nos dias de hoje.

Mesmo após muitas reflexões terem sido realizadas acerca dessas perspectivas eurocêntricas existentes em inúmeras narrativas históricas sobre o nosso país, ainda é necessário que, constantemente, estejamos atentos em relação à quais os modelos de narrativas costumam ser propagados aos estudantes nas aulas de História em pleno século XXI. Apenas assim, por meio de reflexões incessantes, poderemos trazer a tona visões diversas e respeitosas, colocando em prática, inclusive, aquilo que determina a Lei 10.639/03 tão conhecida, mas, ao mesmo tempo, ainda tão descurada nas salas de aula Brasil afora.

\section{DOS DESCASOS E DAS POSSIBILIDADES QUANTO À LEI 10.639/03}

A Lei 10.639/03 foi aprovada no dia 09 de Janeiro do ano de 2003 visando incluir no currículo oficial da Rede de Ensino brasileira a obrigatoriedade quanto à abordagem de objetos de estudos sobre História e Cultura Afro-Brasileira, conforme consta nas informações oficiais disponíveis no site do Planalto do governo brasileiro.

Embora exista há quase duas décadas, a lei em questão é tratada com enorme desdém em muitas instituições de ensino do nosso país, sejam elas públicas, privadas, de Educação Básica ou do Ensino Superior. Esse tipo de descaso, entretanto, não é exclusivo da Lei 10639/03, pois ele se fez presente diante de inúmeras leis relacionadas às temáticas e problemáticas dos povos negros em nosso país, por motivos variados, conforme nos mostra Silva (2007, p. 41): A legislação voltada às questões étnico-raciais no Brasil não é nova, embora sua aplicabilidade tenha sido prejudicada por uma série de percalços, que 
vão do histórico preconceito que impera na sociedade brasileira a impedimentos de natureza jurídica e afins.

Especificamente em relação à Lei 10.639/03, a sua aplicação voltada à Educação Básica - Ensinos Fundamental e Médio - prevê a valorização do legado dos sujeitos afrodescendentes para a formação da identidade nacional e da história brasileira (SILVA, 2005), em diversos aspectos como, por exemplo, nos campos da cultura, relações étnicas, religiosidade e resistências. Quanto ao Ensino Superior, por sua vez, tal lei aborda a necessidade de se pensar em estratégias que visem a formação e a capacitação contínua de professores para que eles estejam aptos a tratarem dessas temáticas com seus alunos. No entanto, é visível que essas estratégias estão bastante longe de serem aplicadas em quantidade e em formatos suficientes, principalmente nas instituições privadas do Ensino Superior (SILVA, 2005).

Conforme afirma Silva (2005, p. 233) sobre as potencialidades e, simultaneamente, sobre as limitações da Lei 10.639/03, averígua-se que:

Apesar desse importante aporte legal anti-racista e de uma volumosa produção científica, percebe-se a falta de uma iniciativa conjunta dos pesquisadores, dos movimentos sociais, dos educadores e das instâncias governamentais com vistas à efetiva implementação da legislação em questão.

Apesar de difícil, não é impossível fazer cumprir a Lei 10.639/03, afinal existe um leque de assuntos que podem e, mais do que isso, devem ser tratados em sala de aula para a valorização dos povos afrodescendentes. Assuntos, estes, que possam, inclusive, trazer novos olhares à história do povo negro em nosso país, fugindo dos velhos padrões que colocam sob tal povo visões exclusivamente distorcidas que, ora escarnecem, ora menosprezam a história desses sujeitos, além de perpetuar ideias equivocadas de submissão totalmente passiva deles em relação aos brancos nas relações escravistas, por exemplo. Silva (2007, p. 46), inclusive, sugere vários tópicos interdisciplinares que podem ser discutidos nas aulas de História, bem como nas aulas de Literatura e Língua Portuguesa. Vejamos:

O ensino da literatura africana de língua portuguesa deve pressupor, a nosso ver, a abordagem de três tópicos ligados à cultura africana: os estudos da história sociopolítica da África, da língua portuguesa no continente africano e da literatura africana de expressão portuguesa, todos eles, num primeiro momento [...] analisados de modo 
independente, mas, numa segunda etapa, estabelecendo dois tipos de relações: a interdisciplinar, em que história, língua e literatura interajam de forma mais dinâmica e abrangente, e a intercultural, em que essas áreas do conhecimento humano estabeleçam conexão com a realidade nacional.

Indo mais além, creio eu que sejam bastante plausíveis as reflexões sobre a relação da História com a religiosidade de matrizes africanas. Na Educação Básica, esse tipo de abordagem é possível tanto nas aulas de Ensino Religioso, como nas aulas de História, durante as quais o professor trabalha com questões sobre a história dos africanos ou sobre a história nacional que, certamente, podem ser entrecruzadas com o universo da religiosidade. Pois, tomando o pensamento de Certeau (1998) sobre táticas e resistências, assimilo o fato de que boa parte dos processos de resistência e manutenção da cultura e da identidade dos povos afro, em nosso país, perpassam - e ainda perpassam - as vivências experienciada por eles nas religiões de matrizes africanas. Logo, falar dessas religiões é uma maneira de falar sobre a ancestralidade e a força de resistência dos povos negros, africanos e afrodescendentes.

\section{O QUE CARACTERIZA A UMBANDA COMO RELIGIÃO DE MATRIZES AFRICANAS}

A Umbanda é uma religião de matrizes africanas praticada no Brasil, cuja origem exata não é possível ser apontada. Sabe-se, no entanto, que ela era praticada desde meados do século XIX, principalmente nos morros cariocas, muitas vezes se apresentando com nomenclaturas e grafias diversas, conforme consta nas informações de inúmeros estudos, como: As religiões africanas no Brasil (BASTIDE, 1971), Candomblé e Umbanda: caminhos da devoção (SILVA, 2005), Macumba de Branco (ISAIA, 2006), Da `Nbandla à Umbanda: Transformações na Cultura Afro-Brasileira (BARBOSA, 2008), dentre outros. Não intenciono, todavia, tratar da 'história da Umbanda' ou dos conflitos ideológicos que existem a partir das distintas narrativas acerca de sua origem. O que pretendo, de fato, é evidenciar as raízes africanas que constituem a base da Umbanda para, então, justificar a questão central aqui apresentada: o uso dos Pontos Cantados de Umbanda como ferramentas pedagógicas no Ensino de História para abordagem da História Africana e da Cultura Afro-Brasileira, conforme previsto na Lei 10.639/03. 
Em algumas casas de Umbanda - geralmente chamadas de terreiros, expressão que será priorizada aqui - é possível encontrar imagens de santos católicos, bem como elementos do kardecismo em sua ritualística. Porém, esses elementos que podem, ou não, aparecer em certos terreiros e que são revelados pelo fenômeno do Sincretismo Religioso, como define Valente (1996), não devem ser utilizados para diminuir e, muito menos, anular as inegáveis raízes africanas da Umbanda. Pelo contrário, é necessário que apesar do fenômeno sincrético ainda acontecer, a Umbanda seja pensada nas salas de aula a partir de suas matrizes africanas para que, deste modo, se estabeleçam diálogos honestos sobre a cultura religiosa africana praticada em nosso país. Afinal, pretende-se que, para além de perpassarem as atribuições da Lei 10.639/03, os diálogos levantados em sala de aula e as abordagens pedagógicas no Ensino de História sejam capazes de promover o respeito e a tolerância religiosa, por meio de uma educação antirracista.

Seguindo essa linha de raciocínio acerca da valorização das raízes religiosas africanas presentes na Umbanda, penso que é fundamental destacar a existência da crença nos Orixás como parte da ritualística e da cosmovisão umbandista, pois é justamente a crença nos Orixás que reforça as raízes africanas que formam as bases de tal religião.

Eles - os Orixás - são seres divinos ancestrais que carregam a missão de criar, de governar e de zelar o mundo e amparar os seres humanos (AZAMBUJA, 2010) e que aparecem tanto na Umbanda quanto em outras religiões de matrizes africanas como, por exemplo, no Candomblé, embora em cada uma dessas religiões eles tenham particularidades a serem consideradas.

No que diz respeito à Umbanda, especificamente, os Orixás são seres divinos cujos médiuns - ou filhos de santo - não os incorporam, diferentemente do que é visto no Candomblé, religião na qual ocorre, sim, a incorporação desses seres divinos. Ao comparar as especificidades acerca dos Orixás, de acordo com as cosmovisões umbandista e candomblecista, Silva (2005, p. 120) explica que na Umbanda os Orixás "são entendidos e cultuados com outras características". Sendo considerados espíritos muito evoluídos, de luz [...] só ocasionalmente descem à Terra e mesmo assim apenas na forma de "vibração".

Se os filhos de santo nos terreiros de Umbanda não incorporam Orixás, quem, então, eles incorporam? Ora, os seres cultuados e contatados por meio da incorporação 
mediúnica nos terreiros de Umbanda são os chamados Guias ou Entidades e eles se apresentam com arquétipos diversificados a partir das linhas de atuação existentes nos trabalhos espirituais de cada terreiro.

Os tais Guias de Umbanda carregam consigo, por meio de seus arquétipos, trejeitos, linguajares e indumentárias, representações que vão muito além de sujeitos isolados que mesmo estando no plano espiritual segue realizando trabalhos de caridade. Mais do que isso, as Entidades em questão trazem a tona referências geralmente concebidas a setores e sujeitos da sociedade muitas vezes marginalizados (MAGGIE, 2001), mas que, nos trabalhos umbandistas, são cultuados e valorizados por sua força espiritual de modo que, embora representem “[...] figuras desprestigiadas pela sociedade mais ampla transformam-se, no ritual, não só em figuras de prestígio, mas [...] o inverso do que seriam na vida cotidiana, não sagrada" (2001, p. 118).

Por fim, é válido destacar a presença das canções sagradas nos rituais umbandistas, afinal, é com o auxílio dessas canções - ou seja, os Pontos Cantados - que os filhos de santo incorporam as Entidades e realizam todo o trabalho mediúnico. Quem 'puxa o Ponto' é chamado de ogan - também denominados curimbeiros ou atabaqueiros - que deve cantar e tocar os atabaques ao mesmo tempo (ALMEIDA; SOUZA, 2011) e, por isso, em geral, eles não entram em transe mediúnico. Assim como os ogans, na organização dos terreiros há os cambones que também não entram em transe, pois, no caso deles, trabalham auxiliando os irmãos de santo que estão incorporados com os Guias e os visitantes do terreiro, mantendo o equilíbrio da casa durante as sessões de trabalho (AZEVEDO, 2008) que são frequentemente chamadas de Giras.

\section{DEFININDO EM QUE CONSISTEM OS PONTOS CANTADOS DE UMBANDA E REFLETINDO AS POSSIBILIDADES DE UTILIZAÇÃO DELES COMO FERRAMENTAS PEDAGÓGICAS}

Os Pontos Cantados de Umbanda são canções sagradas entoadas, em vias de regra, pelos ogans, durante os rituais, conforme as explicações prévias aqui expostas. Além dos Pontos Cantados, menciono - ainda que brevemente - a existência dos Pontos Riscados que consistem em uma espécie de assinatura dos tais Guias ou Entidades (AZEVEDO, 2008). Quando eles pegam o giz sagrado, conhecido como pemba, e riscam o tal ponto 
em uma tabuleta de madeira, ou no chão dependendo do terreiro, do Guia ou da ocasião em si, é sinal de que estão se apresentando, formalmente, digamos assim, para aquele agrupamento de filhos de santo.

Além do Ponto Riscado, nesses momentos, os tais Guias costumam mencionar seus respectivos nomes podendo, inclusive, mencionar o nome do(s) Orixá(s) cuja linha vibratória eles trabalham. Entretanto, outra maneira dos Guias se apresentarem é executando o seu Ponto Cantado que, depois, deverá ser reproduzido pelos tais ogans nos próximos trabalhos em que o Guia se fizer presente.

Daí, portanto, a importância deles, os ogans, estarem sempre atentos nas letras dos Pontos Cantados e, também, na natureza dos Pontos, afinal, não existem apenas Pontos Cantados para apresentação de Entidades (AZEVEDO, 2008). Existem diversas naturezas deles, dentre as quais menciono a título de conhecimento: Pontos de defumação, Pontos de abertura dos trabalhos mediúnicos e, por suposto, Pontos de encerramento dos trabalhos, assim como, Pontos para quebra de demandas, Pontos para chegada - e para partida - das Entidades, Pontos fúnebres, Pontos de consagração dos filhos que adentram ao terreiro e tantos outros. Além de terem letras distintas entre si e de haver momentos específicos e exatos em que cada tipo de Ponto deve ser entoado, cada um deles apresenta, também, seu próprio ritmo e "[...] uma maneira certa de ser tocado, pois a vibração combinada com a entoação das palavras conduz ao transe que permite a incorporação do médium" (AZEVEDO, 2008, p. 29).

Essas particularidades sobre os Pontos - tanto os Riscados, como os Cantados pode, inclusive, ser trabalhada em sala de aula para que os estudantes se familiarizem e criem empatia com as religiões de matrizes africanas a partir de uma melhor compreensão acerca da cosmovisão e da ritualística existentes nessas manifestações religiosas.

Para além dos apontamentos sobre em que consistem e quais são os diversos tipos de Pontos Cantados entoados nos rituais de Umbanda, é válido destacar que muitos deles trazem a história dos Guias carregadas de elementos históricos nacionais. Partindo desse pressuposto, focarei, nesta discussão, nos Pontos Cantados de Pretos Velhos, pensando, justamente, na questão de como eles podem ser utilizados em sala de aula para colaborar com o Ensino de História voltado às questões afro. 
Seguem, portanto, as análises de _ Pontos Cantados de Pretos Velhos e de Pretas Velhas dentro das perspectivas aqui declaradas:

\author{
Figura 1: Primeiro Ponto a ser analisado (Ponto de Pretos Velhos) \\ Um navio negreiro, vem beirando o mar \\ Trazendo os africanos para trabalhar, \\ Oh saravá povo de Congo, \\ Sua gira é formosa em qualquer lugar \\ Fonte: BLOG Baiano Juvenal (online)
}

Figura 2: Segundo Ponto a ser analisado (Ponto de Preta Velha)

Vovó não quer casca de côco no terreiro.

Vovó não quer casca de côco no terreiro.

É para não lembrar dos tempos do cativeiro,

É para não lembrar dos tempos do cativeiro,

Fonte: BLOG Baiano Juvenal (online)

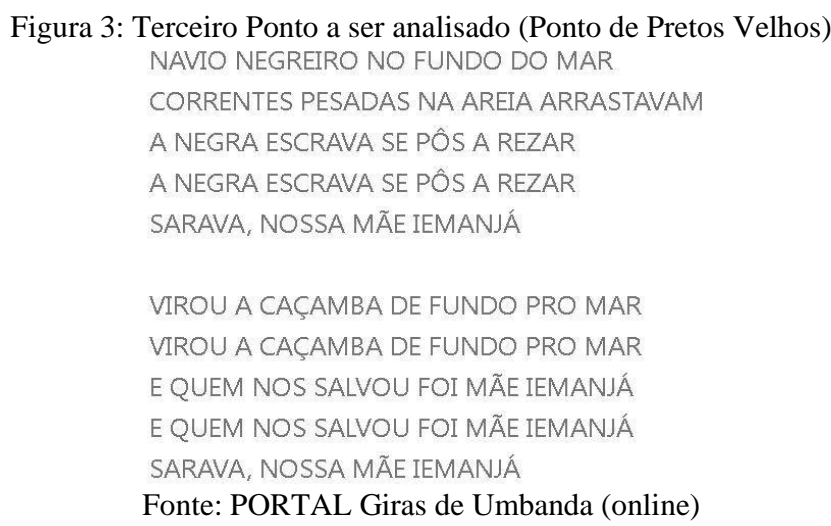

Evidentemente, o Ponto Cantado apresentado na Figura 1 estabelece relação entre a história das Entidades da linha dos Pretos Velhos com a realidade escravocrata existente no Brasil até o século XIX, legalmente falando, ao abordar a chegada de povos africanos da região do Congo trazidos em um navio negreiro. Já o trecho 'trazendo os africanos para trabalhar' pode ser interpretado com duplo sentido, referindo-se não apenas ao trabalho dos sujeitos escravizados em vida, mas, se tratando de uma canção religiosa umbandista, esse 'trabalhar', igualmente, pode ser interpretado no âmbito da imaterialidade religiosa fazendo alusão aos trabalhos espirituais desses Guias nos rituais da Umbanda. 
No Ponto Cantado presente na Figura 2, também há uma relação explícita entre as vivências da 'Vovó' - que simboliza, de forma genérica, as Pretas Velhas - com a realidade escravocrata dando a entender que a Preta Velha em questão já não se encontra mais na situação de escravidão e, portanto, passou a trabalhar apenas no sentido espiritual. Essa interpretação se torna possível quando se lê com atenção o ponto e se nota que a Vovó está no terreiro, mas não quer que tenha nele cascas de coco 'para não lembrar dos tempos do cativeiro'.

No caso da Figura 3, o Ponto apresentado tem uma relação não apenas com um relato de tragédia ocorrido em um navio negreiro cuja caçamba 'virou de fundo pro mar', mas, igualmente, a explícita conexão entre os sujeitos africanos com sua religiosidade e ancestralidade. Pois esses, de acordo com o que se nota no Ponto, ao estarem afundando juntamente do navio passam a rogar pela Mãe Iemanjá que, por sua vez, salva seus filhos: 'e quem nos salvou foi Mãe Iemanjá, Sarava nossa Mãe Iemanjá'. Ademais, caso o professor queira fazer um exercício mais profundo e abstrato de interpretação, nota-se que o trecho 'quem nos salvou foi Mãe Iemanjá' pode gerar discussões interessantes quanto a essa tal salvação, se ela se concretizou no plano físico ou no plano espiritual, visto que Iemanjá e a Orixá das águas salgadas que recolhe as almas que ali atravessam para o mundo imaterial pós vida terrena. Sendo assim, por meio desses Pontos aqui expostos, se abrem precedentes para discussão de temáticas históricas - como a escravidão em si - e de temáticas histórico-culturais que se interligam ao universo afro religiosos, valorizando as manifestações de fé permeadas por matrizes africanas. 
Figura 4: Quarto Ponto a ser analisado (Ponto do Preto Velho José de Aruanda)

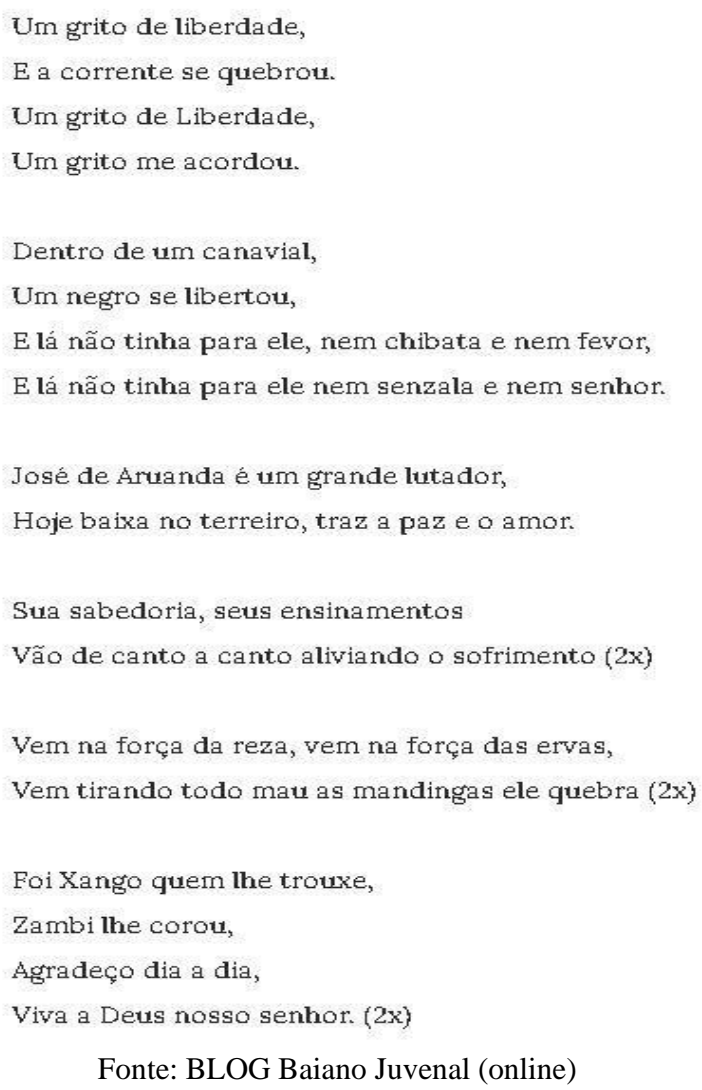

Fonte: BLOG Baiano Juvenal (online)

O Ponto Cantado expresso na Figura 4, por sua vez, traz uma visão de empoderamento do sujeito negro, contemplando as premissas de valorização da cultura negra e suas formas de resistência ao longo do tempo, levando em consideração os princípios desejados no momento de colocar em prática a Lei $10.639 / 03$. Por meio do Ponto em questão, o professor pode discutir não somente a religiosidade ao analisar os termos 'Aruanda', 'Xangô' e 'Zambi' que aparecem na letra da canção sacra, como, igualmente, pensar na questão sincrética, visto que a palavra 'Deus' também aparece na letra. Ademais, seria possível e importante abordar a temática abolicionista ao contrapor narrativas que, desde muito tempo e até os dias atuais, costumam atribuir à Princesa Isabel - mulher branca da elite Imperial - os méritos da abolição, bem como a outros personagens brancos. Essas abordagens tão frequentemente propagadas acabam por manter muitas as vozes e memórias subterrâneas (POLLAK, 1989) esvaziando o papel e apagando o protagonismo negro em momentos de rememorações nacionais como, por exemplo, as que ocorrem no dia 13 de Maio. 


\section{CONSIDERAÇÕES FINAIS}

A partir das reflexões realizadas, nota-se que o Ensino de História em nosso país, apesar dos avanços vivenciados, ainda apresenta muitas lacunas que precisam ser preenchidas e problemáticas que necessitam ser repensadas, assim como narrativas que devem ser (des)construídas e reformuladas. Deste modo, a aplicação da Lei 10.639/03 se faz extremamente importante e é justamente por isso que o descaso existente em relação a ela, ainda nos dias de hoje, assim como o despreparo dos professores, seja pensado como um problema que precisa ser discutido.

Por motivos diversos, como fora discutido anteriormente, tal lei tem sido desprezada, ignorada ou, então, tem sido colocada em prática de forma insuficiente, apenas para dizer que 'ela se fez cumprir'. Todavia, cabe à comunidade - não somente a comunidade escolar e universitária, inclusive - repensar estratégias para amenizar e melhorar essa situação.

Por isso, intencionando somar a valorização da história dos povos negros e afrodescendentes no Brasil e na África, bem como suas manifestações de cultura, religião e resistência é que elenco os Pontos Cantados de Umbanda como uma possível ferramenta pedagógica utilizada no Ensino de História (mas que, certamente, poderia ser utilizada em outros componentes curriculares, como Ensino Religioso ou, no caso do Ensino Médio, por exemplo, pelos professores de Sociologia). A intenção na presente reflexão não é impor vieses interpretativos acerca dos Pontos Cantados, mas, sim, sugerir possibilidades de discussão a partir deles, lembrando que os Pontos Cantados aqui apresentados são apenas uma pequena parte em relação à vasta quantidade existente das ditas canções sagradas, basta que o educador - ou qualquer sujeito interessado no assunto - tenha a boa vontade em procurá-lo para conhecer mais a fundo o universo religioso de matriz africana presente em diversas manifestações de fé em nosso país.

\section{REFERÊNCIAS}

ALMEIDA, André \& SOUZA Ana. Ogans: Músicos de Religiões Afro-Brasileiras. Identidades e Representações de Poder. In Anais do II Simpósio Nacional de Musicologia (EMAC/UFG) \& IV Encontro de Musicologia Histórica (UFRJ), 2011, p. 78-83. 
AZAMBUJA, Márcio Passos. Uma visada sobre a presença dos orixás em João do Rio, de Mário de Andrade e Jorge Amado. Monografia [Licenciatura] - Universidade Federal do Rio Grande do Sul, Faculdade de Letras, Porto Alegre, 2010, 58p.

AZEVEDO, Janaina. Tudo o que você precisa saber sobre Umbanda. / Janaina Azevedo -- São Paulo: Universo dos Livros, 2008. 144p. ISBN: 978.85.99187.91.3

BARBOSA, Wilson do Nascimento. Da 'Nbandla à Umbanda: Transformações na Cultura Afro-Brasileira. In: Sankofa. Revista de História da África e de Estudos da Diáspora Africana. São Paulo, nº 1 jun./2008, p. 7 - 19.

BASTIDE, Roger. As religiões africanas no Brasil. 2 v. São Paulo: Pioneira, 1971.

BITTENCOURT, Circe Fernandes. Reflexões sobre o Ensino de História. Revista Ensino de Humanidades. Estudos Avançados. On-line, São Paulo, n. 32. p. 127 - 149, mai-ago. 2018. DOI: https://doi.org/10.5935/0103-4014.20180035. Disponível em < https://www.scielo.br/j/ea/a/WYqvqrhmppwbWpGVY47wWtp/?format=pdf\&lang=pt > Acesso em 29.nov.2021.

CERTEAU, Michel de. A invenção do cotidiano: Artes de fazer. Petrópolis, Editora Vozes, 1998. $3^{\text {a }}$ edição. 352p. ISBN: 85.326.1148-6

ISAIA, Artur Cesar. Macumba de Branco. Nossa História. São Paulo. (36), 2006. p. 28 $-32$

MAGGIE, Yvonne. Guerra de Orixá: um estudo de ritual e conflito. / Yvonne Maggie

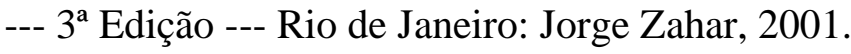

ORIÁ, Ricardo. História Pública e monumentos: a narrativa social do passado nacional. História Pública em debate: patrimônio, educação e mediações do passado / Juniele Rabêlo de Almeida e Sônia Meneses, (organização) -- São Paulo (SP): Letra e Voz, 2018. 240p. : 16x23cm. ISBN: 978-85-93467-11-0.

POLLAK, Michael. Memória, Esquecimento, Silêncio. Estudos Históricos, Rio de Janeiro, vol. 2, n. 3, 1989, p. 3-15.

SILVA, Marilena da. O Ensino de História da África e cultura afro-brasileira em Goiânia. Negro e Educação: escola, identidades, cultura e políticas públicas. / organizado por Iolanda de Oliveira, Petronilha Beatriz Gonçalves e Silva e Regina Pahim Pinto - São Paulo: Ação Educativa, ANPEd, 2005. 264p. ISBN 85-86382-06-X.

SILVA, Maurício Pedro. Novas diretrizes curriculares para o estudo da História e da Cultura afro-brasileira e africana: a Lei 10.639/03. In: EccoS Revista Científica, Online. vol. 9, núm. 1, janeiro-junho, 2007, p. 39-52 Universidade Nove de Julho São Paulo, Brasil. ISSN: $\quad 1517.1949 . \quad$ Disponível em: http://www.redalyc.org/articulo.oa?id=71590103> Acesso em 30.nov.2021.

SILVA, Vagner Gonçalves da. Candomblé e Umbanda: caminhos da devoção brasileira / Vagner Gonçalves da Silva; [ilustrações Olavo Cavalcanti]. - 5 a Ed. - São Paulo: Selo Negro, 2005.

TOLEDO, Maria Aparecida Leopoldino Tursi. A disciplina de história no Império Brasileiro. Revista HISTEDBR On-line, Campinas, n.17, p. 1 - 10, mar. 2005 - ISSN: 1676-2584 1. Disponível em: < https://www.fe.unicamp.br/pffe/publicacao/5238/art01_17.pdf > Acesso em 29.nov.2021. 
VALENTE, Waldemar. Sincretismo religioso afro-brasileiro. 2. ed. São Paulo: Companhia Editora Nacional, 1976.

\section{FONTES:}

BLOG, Baiano Juvenal On-line. Disponível em: < http://baianojuvenal.blogspot.com/2015/08/pontos-cantados-de-preto-velho-na.html > Acesso em: 01.dez.2021

PLANALTO, do Governo Brasileiro. On-line: Disponível em: < http://www.planalto.gov.br/ccivil_03/leis/2003/110.639.htm\#: :text=LEI\%20No\%2010. 639\%2C\%20DE\%209\%20DE\%20JANEIRO\%20DE\%202003.\&text=Altera\%20a\%20 Lei\%20no,\%22\%2C\%20e\%20d\%C3\%A1\%20outras\%20provid\%C3\%AAncias. Acesso em: 30.nov.2021.

PORTAL, Giras de Umbanda. On-line: Disponível em: < https://www.girasdeumbanda.com.br/materia/197/pontos-de-pretos-e-pretas-velhas.html $>$ Acesso em: 01.dez.2021. 


\title{
CAPÍTULO XXX
}

\section{ENSINO DE CIÊNCIAS: ESTRATÉGIAS DIDÁTICAS PARA A PREVENÇÃO AO USO DE DROGAS}

\author{
Dayana Lúcia Rodrigues de Freitas ${ }^{111}$. \\ DOI -Capítulo: 10.47538/AC-2021.14-30
}

RESUMO: As drogas são um problema encontrado em todos os âmbitos da sociedade, inclusive no ambiente escolar. Essa triste realidade faz com seja necessário pensar em políticas e estratégias educacionais voltadas para a prevenção das drogas entre escolares, visando amenizar os impactos na sociedade. Pensando nas dificuldades de se elaborar estratégias e ações preventivas ao uso de drogas que este trabalho foi elaborado. Trata-se de um relato de experiência da atividade docente, que detalhará o uso de estratégias didáticas, na disciplina de Ciências, quanto ao tema drogas. Tais estratégias foram aplicadas com alunos do $8^{\circ}$ ano do Ensino Fundamental, da Escola Municipal Professora Maria Madalena da Silva, Distrito de Baixa do Meio (Guamaré/RN); durante o mês de agosto de 2017. Desta forma, este estudo tem como principal objetivo apontar o uso de sequências didáticas como forma eficaz de ensino-aprendizagem. O procedimento metodológico utilizado foi analisar, sob a ótica do ensino-aprendizado, a eficácia das estratégias didáticas utilizadas nas aulas de ciências sobre o tema drogas. Essa análise ocorreu com base em todas as ações realizadas pelo professor, bem como pelo feedback dos alunos, através das atividades propostas. Percebeu-se então que este conjunto de atividades diversificadas foi eficaz quanto aos resultados esperados para as aulas, pois permitiram o desenvolvimento do aluno e a reflexão crítica quanto ao tema drogas. Por fim, recomenda-se a realização de mais pesquisa sobre o tema, e principalmente, o aumento/inovação do uso de ações metodológicas que engrandeçam e ajudem os discentes quanto à prevenção do só de drogas.

PALAVRAS-CHAVE: Estratégias didáticas. Ensino de Ciências. Drogas.

\section{SCIENCE TEACHING: TEACHING STRATEGIES FOR PREVENTING DRUG}

\section{USE}

ABSTRACT: Drugs are a problem found in all spheres of society, including the school environment. This sad reality makes it necessary to think about educational policies and strategies aimed at the prevention of drugs among students, aiming to alleviate the impacts on society. Thinking about the difficulties of developing strategies and preventive actions against drug use that this work was developed. This is an experience report of the teaching activity, which will detail the use of didactic strategies, in the Science discipline, on the topic of drugs. Such strategies were applied with students from the 8th year of Elementary School, from the Municipal School Teacher Maria Madalena da Silva, District of Baixa do Meio (Guamaré/RN); during the month of August 2017.

111 Doutoranda em Ciências da Educação (CECAP). Docente nos Município de Macau/RN e Guamaré/RN. Orcid: https://orcid.org/0000-0001-5355-3547. Lattes: http://lattes.cnpq.br/5122671799874415.

E-mail: dayannaproducoes@gmail.com. 
Thus, this study aims to point out the use of didactic sequences as an effective way of teaching and learning. The methodological procedure used was to analyze, from the perspective of teaching-learning, the effectiveness of the didactic strategies used in science classes on the subject of drugs. This analysis was based on all actions taken by the teacher, as well as the feedback from students, through the proposed activities. It was then noticed that this set of diversified activities was effective in terms of the expected results for the classes, as they allowed the student's development and critical reflection on the topic of drugs. Finally, it is recommended that more research be carried out on the topic, and especially, the increase/innovation in the use of methodological actions that enhance and help students with regard to the prevention of drugs alone.

KEYWORDS: Didactic strategies. Science teaching. Drugs.

\section{INTRODUÇÃO}

As drogas são um problema encontrado em todos os âmbitos da sociedade, inclusive no ambiente escolar. Essa triste realidade faz com seja necessário pensar em estratégias educacionais voltadas para a prevenção das drogas entre escolares, visando amenizar os impactos educacionais e na saúde da sociedade.

Alguns autores afirmam que "a escola tem sido considerada um espaço privilegiado para o desenvolvimento da prevenção e auxilia a promoção da saúde" (MOREIRA; VÓVIO; MICHELI, 2015, p. 1); exatamente pelo contato que os professorem tem com os alunos diariamente, o que permite o desenvolvimento de ações educacionais preventivas, inclusive as de prevenção às drogas. Como forma de orientação para as ações docentes, Os Parâmetros Curriculares Nacionais de Ciências (PCNs), do terceiro e quarto ciclo; preconizam sobre os eixos temáticos que devem ser abordados no ensino de Ciências. Os PCNs afirmam que "o tema transversal Saúde aborda as relações entre os problemas de saúde e fatores econômicos, políticos, sociais e históricos" (BRASIL, 1998, p. 46). Entre os assuntos que devem ser abordados no Eixo Ser Humano e Saúde estão:

O funcionamento normal do organismo e suas alterações em situações de risco (abuso de drogas, sexo sem preservativos, violência, automedicação e alimentação inadequada) devem ser explicados pelos estudantes, utilizando conhecimentos sobre as funções de nutrição, de regulação e reprodutivas (BRASIL, 1998, p. 113).

Assim, cabe ao professor à escolha e organização de como determinadas temáticas serão abordadas em sala de aula. Desta forma, para que se tenha um ensino de forma que realmente agregue valor é preciso que o professor, como sendo um mediador do 
conhecimento, se utilize de métodos e técnicas adequadas que tenham base não apenas no contexto geral como o local (FREITAS, 2016).

Pensando nas dificuldades de se elaborar estratégias e ações preventivas ao uso de drogas que este trabalho foi elaborado. Trata-se de um relato de experiência da atividade docente, que detalhará o uso de estratégias didáticas, na disciplina de Ciências, quanto a temática drogas. Tais estratégias foram aplicadas com alunos do $8^{\circ}$ ano do Ensino Fundamental, da Escola Municipal Professora Maria Madalena da Silva, Distrito de Baixa do Meio (Guamaré/RN); durante o mês de agosto de 2017. Desta forma, este estudo tem como principal objetivo apontar o uso de sequências didáticas como forma eficaz de ensino-aprendizagem.

\section{JUSTIFICATIVA}

Devido à importância da temática "drogas", sua abordagem transversal e interdisciplinar, muitos autores pesquisaram sobre seu contexto em ambientes escolares, tais como: Silva et. al. (2006); Monteiro, Vargas e Rebello (2003); Moreira, Silveira e Andreoli (2006). No entanto, pouco se relata sobre os detalhamentos de como as ações e estratégias didáticas foram realizadas.

Segundo Moraes (2016, p. 98) “as estratégias didáticas inovadoras desenvolvidas e aplicadas colaboram com aspectos de visualização e compreensão de conteúdos, funcionando como importante recurso para o aprendizado". Desta forma, a elaboração e aplicação de estratégias didáticas se tornam importantes para a melhoria do ensino e para a aprendizagem significativa, visando a internalização dos conteúdos para a vida.

Por tudo isso, esta pesquisa se justifica pela importância do detalhamento das estratégias didáticas de prevenção às drogas, como proposta de orientação e auxílio para professores de Ciências do ensino Fundamental, na construção de atividades preventivas e abordagem sobre as drogas, visando à eficiência do processo de ensino-aprendizagem.

\section{A IMPORTÂNCIA DAS ESTRATÉGIAS DIDÁTICAS PARA O ENSINO DE CIÊNCIAS}


O processo de ensinar é um conjunto de atividades organizadas do professor e dos alunos, visando alcançar determinados resultados, tendo como ponto de partida o nível atual de conhecimentos, experiências e desenvolvimento mental dos alunos (LIBÂNEO, 1994, p. 84). O mesmo concorda Freire (1996) ao dizer que "ensinar não é transferir conhecimento, mas criar as possibilidades para a sua produção ou a sua construção".

Fazer essa "construção" utilizando aulas dinâmicas e interativas permite aguçar a curiosidade do aluno, fazendo com que o mesmo tenha mais vontade de aprender (RODRIGUES et. al., 2015). Além disso, para haja uma aprendizagem eficaz são necessário inúmeros fatores, dentre os quais, os mais pertinentes são: o talento do professor, o tipo intelectual do aluno, as oportunidades oferecidas pelo ambiente imediato da escola e as perspectivas futuras de vida do aluno (MOTA; PEREIRA, 1998).

Tratando da disciplina de Ciências, ensiná-la não se resume apenas a transmissão de informações, mas sim, ajudar o aluno a tomar consciência de si mesmo, dos outros e da sociedade (KNECHTEL; BRANCALHÃO, 2009). Os Parâmetros Curriculares Nacionais (PCN's) retratam sobre a importância do Ensino de Ciências, afirmando que a mesma deve estar inclusa no currículo desde as primeiras séries da Educação Básica; pois é nesse período que a criança constrói e reconstrói seus conceitos e apreende de modo significativo sobre o ambiente (BRASIL, 1997).

Desta forma, identificar o modo de funcionamento cognitivo durante a aquisição de um novo conteúdo seria muito útil na elaboração das estratégias pedagógicas. No entanto, o funcionamento cognitivo está longe de ser simples e a grande quantidade de variáveis que ele traz nos incita à elaboração e à prática de diferentes métodos de ensino (BRAGA, 2012). Por isso, para auxiliar na escolha de estratégia didática que se adeque a realidade sala de aula, o professor pode recorrer as Teoria de aprendizagem; que é uma construção humana para interpretar sistematicamente a área de conhecimento que chamamos aprendizagem (MOREIRA, 1999). Ainda, segundo Carvalho (2003), "as teorias da aprendizagem apresentam contribuições à compreensão do processo de ensino e aprendizagem, considerando o desenvolvimento, a faixa etária e os aspectos psicossociais e cognitivos".

A utilização da estratégia didática correta irá favorecer todo o processo de ensinoaprendizado, tornando a aula produtiva e marcante. Os PCN's, por exemplo, apontam 
sobre a aprendizagem significativa; onde "os alunos são convidados a praticar os procedimentos, no início a partir de modelos oferecidos pelo professor e, aos poucos, tornando-se autônomos" (BRASIL, 1998, p. 29). Estas características de estratégias de ensino-aprendizagem se enquadram na teoria da assimilação ou teoria da aprendizagem significativa que foi construída por Ausubel; esta teoria procura explicar os mecanismos internos que ocorrem na mente humana com relação ao aprendizado e a estruturação do conhecimento (PRASS, 2012). Neste modelo, as estratégias didáticas devem ser voltadas para aulas dinâmicas e experiências práticas.

Vale salientar que tanto a escolha dos conteúdos é importante como o modo de aplicá-los; para Imbernón (2002), o professor não deve fazer tal escolha apenas no âmbito técnico, mas deve buscar meios que facilitem o aprender tornando-se provocador da interação entre o alunado. Segundo Rodrigues et. al. (2015) as ações pedagógicas que usam diversificação de metodologias, pautadas em novas perspectivas e tecnologias de ensino, tem papel significativo na conquista de uma pedagogia da autonomia. Sendo assim, podemos considerar a utilização de estratégias didáticas fundamental para que realmente haja um processo de ensino-aprendizado de qualidade na disciplina de ciências, cabendo ao professor à escolha correta da mesma.

\section{A IMPORTÂNCIA DAS ABORDAGENS DIDÁTICAS NO ENSINO DE CIÊNCIAS SOBRE O TEMA DROGAS}

As drogas se constituem como uma das principais preocupações da sociedade atual, passando a fazer com que o ambiente escolar se torne um espeço propício para o desenvolvimento de estratégias preventivas (MOREIRA; VÓVIO; MICHELI, 2015). O tema "prevenção às drogas" é um assunto que deve ser abordado constantemente nos ambientes escolares; devido à importância do tema e a necessidade imediata de prevenção em todos os grupos sociais. Para Imbernón (2002, p. 8), o professor deve ensinar não apenas os conteúdos curriculares, mas, deve ensinar entre outras coisas, sob "as diversas instâncias em que se materializa: democrática, social, solidária, igualitária, intercultural e ambiental".

Porem existe uma complexidade em se trabalhar com a temática "prevenção ao uso de drogas". Segundo Ribeiro (2001), para esse tipo de abordagem vários fatores 
devem ser observados, tais como: o contexto social, histórico, cultural, psicológico e biológico dos sujeitos envolvidos. Devendo assim o tema ser abordado em caráter interdisciplinar e multidimensional.

Em relação às possíveis estratégias preventivas ao uso de drogas Moreira, Silveira e Andreoli (2006, p. 808) definem-nas em três grupos: 1) diminuir a oferta do produto (ações de repressão, voltadas para a redução da disponibilidade dessas substâncias); 2) diminuir a demanda por parte do usuário (ação educativa por meio de intervenções de caráter pedagógico); e 3) influir sobre as circunstâncias favorecedoras da oferta e da procura (medidas visando minimizar ou neutralizar o impacto dos fatores relacionados ao risco ou à proteção). Seguindo essa linha de pensamento, a escola deveria utilizar estratégias didáticas pensando principalmente na conscientização dos efeitos colaterais que as drogas provocam no corpo. Essa abordagem drogas-efeito colateral, se enquadra dentro dos conteúdos da disciplina de Ciências, podendo o professor diversificar a abordagem desse conteúdo.

Outro tipo de abordagem didática é apontado por Placco (2011, p. 50), que define as estratégias preventivas em duas abordagens: a primeira conhecida como "Guerra contra as drogas" (de caráter proibicionista); e a segunda conhecida como "Prevenção Baseada na Redução de Danos” (de caráter educativo). Esta segunda opção está fundamentada na ampliação e aprofundamento de conhecimentos e informações sobre as drogas e seu consumo, no fortalecimento afetivo dos sujeitos, no desenvolvimento da capacidade de escolha com base em suas possíveis consequências. Neste modelo citado por Placco (2011) a abordagem na escola deve focar sobre "os malefícios do uso de drogas, discutindo os problemas biológicos decorrentes deste consumo e suas danosas consequências no corpo humano".

Em todos os exemplos citados, observa-se que a escola deveria se aprofundaria em estratégias e abordagens "voltadas para a prevenção ao uso" (exemplo 1); e nas abordagens de "Prevenção Baseada na Redução de Danos" (exemplo 2). Ambos com enfoque na redução da demanda pelo consumo de substâncias ilegais de forma educativa.

Para que tais ações preventivas sejam realizadas de forma eficiente se faz necessário maior planejamento da parte docente; utilização e recursos e métodos variados e o respeito ao ritmo de aprendizagem dos alunos (NASCIMENTO; DUARTE, 2004). 
Franco (2016, p. 17) aponta que existe diversas metodologias e estratégias voltadas para a prevenção ao uso de drogas, todas elas com o mesmo objetivo: "modificar a postura do professor, transmitir valores éticos e fazer com que os estudantes tomem decisões mais responsáveis acerca do consumo de drogas".

Por fim, podemos afirmar que, as abordagens didáticas voltadas para o ensino de Ciências, com ações preventivas nas escolas, favorecem a internalização de intervenções com significado real na vida dos alunos (RIBEIRO, 2001); sendo, as mesmas, de extrema necessidade para a redução dos índices de drogas nos ambientes escolares e conseguintemente, nos grupos sociais.

\section{METODOLOGIA}

O presente trabalho se constitui em um Relato de experiência docente, com aplicação de estratégias didáticas no ensino de Ciências, sobre o tema drogas. Esta pesquisa foi realizada com alunos do $8^{\circ}$ ano do Ensino Fundamental, da Escola Municipal Professora Maria Madalena da Silva, situada a Rua Manoel Ribeiro, s/n, CEP 59598-000, Distrito de Baixa do Meio (Guamaré/RN); sendo a mesma de caráter descritivo.

Este trabalho teve como procedimento metodológico analisar, sob a ótica do ensino-aprendizado, a eficácia das estratégias didáticas utilizadas nas aulas de ciências sobre o tema drogas. Essa análise ocorreu com base em todas as ações realizadas pelo professor, bem como pelo feedback dos alunos, através das atividades propostas.

\section{A APLICAÇÃO DAS ESTRATÉGIAS DIDÁTICAS NAS AULAS DE CIÊNCIAS SOBRE O TEMA DROGAS}

Em relação às estratégias didáticas, foram realizadas as seguintes ações: aula expositiva; entrevista com profissionais da área da saúde ou com ex-usuários; confecção de cartazes; pesquisa bibliográfica e socialização dos resultados entre os alunos. Este conjunto de ações abrangeu todas as turmas do $8^{\circ}$ ano do turno vespertino, 4 (quatro) turmas no total; contando com a participação de 108 (cento e oito) alunos, de idade entre 14 (quatorze) e 16 (dezesseis) anos, oriundos da zona rural e assentamento de Guamaré/RN. A avaliação da aprendizagem e eficácia das estratégias didáticas aplicadas 
sobre as drogas ocorreu através da análise dos materiais produzidos, bem como da participação e socialização de todo processo didático.

As estratégias didáticas ocorreram ao longo do mês de agosto de 2017; com a realização de ações específicas ao longo das semanas. As atividades foram realizadas em sala, durante o horário regular das aulas de disciplina de Ciências; bem como extraclasse, onde os alunos foram previamente orientados.

Em relação à execução das estratégias didáticas em sala de aula, aconteceram da seguinte forma:

A $1^{\circ}$ fase: "aula expositiva e dialogada sobre o sistema nervoso e sua interação como às drogas"; foram destinadas 4 (quatro) hora/aulas, onde ocorram as explanações sobre a interação do Sistema Nervoso e de como as drogas o afeta. O espaço físico utilizado para este momento foi o laboratório de ciências da escola. Como principal recurso utilizou-se o livro didático. O livro em questão se trata do exemplar do $8^{\circ}$ ano aprovado no PNLD (Plano Nacional Do Livro Didático), da coleção Ciências Naturais: aprendendo com o cotidiano, do autor Eduardo Leite do Canto, $5^{\circ}$ Edição- São Paulo, Moderna, 2015. Esse livro didático possui uma linguagem de fácil compreensão para os alunos e aborda o tema drogas fazendo sua assimilação com doenças e efeitos colaterais oriundos do uso contínuo de drogas lícitas e ilícitas; o efeito sobre as sinapses e a dependência química. Ainda apresenta um quadro expondo o nome da droga, modo de uso, efeitos e riscos a saúde.

Estas aulas ocorreram satisfatoriamente, com o principal intuito de apresentar aos alunos os efeitos das drogas no organismo. Nesses encontros os discentes puderam relatar fatos do dia-a-dia e demostrar os conhecimentos prévios sobre a temática em questão. Os Parâmetros Curriculares Nacionais de Ciências enfatizam e importância dessa assimilação dos conteúdos do sistema nervos e as drogas, o mesmo cita:

Ao explicar a ação de algumas drogas no nível das sinapses nervosas, os estudantes também organizam, com ajuda do professor, as relações entre estímulos do meio externo, as reações e o desenvolvimento do ser humano, inclusive no delicado equilíbrio entre estado de saúde e estado de doença, discutindo-se valores e atitudes envolvidos. Também é necessário sistematizar a noção do corpo como totalidade e que qualquer desequilíbrio localizado em um ponto abala todo o conjunto (BRASIL, 1997, p. 104). 
A $2^{\circ}$ fase: "Entrevista com um profissional da saúde ou com ex-usuário"; se subdividiu em duas partes: a elaboração das questões para a entrevista (em sala) e a realização da entrevista (extraclasse). Inicialmente a turma se dividiu em grupos (entre 6 e 8 alunos por turma); onde cada grupo ficou designado a elaborar todas as suas atividades relacionadas a um tipo de droga específica, foram elas: álcool, cigarro (tabaco), LSD, êxtase, maconha, crack, cocaína, anfetamina.

Após a definição dos temas, cada grupo decidiu com quem realizaria a entrevistar: um profissional da área de saúde (médico ou enfermeiro) ou se entrevistaria algum exusuário. Na sequência, elaboraram 15 (quinze) perguntas sobre a droga em questão. As perguntas foram elaboradas em sala de aula para que o professor pudesse orientá-los e auxilia-los em qualquer dúvida. Posteriormente, os alunos realizaram as entrevistas (extraclasse), de acordo com à disponibilidade pessoal de cada grupo ou entrevistado (ver figura 02). Os PCN's (BRASIL, 1997) retratam a relevância da utilização de "entrevista com agentes de saúde" nas temáticas direcionas ao eixo Ser Humana e Saúde, ajudando a integrar temas de forma transversal.

Como resultado deste momento, as respostas obtidas nas entrevistas foram registradas e os alunos elaborara um relatório contendo todas as explicações dadas pelos entrevistados.

$3^{\circ}$ fase: "Pesquisa bibliográfica para os alunos". Houve o aproveitamento dos mesmos grupos e temas; foi solicitada a realização de uma pesquisa bibliográfica, onde deveria contar as principais informações sobre a droga; índices de tráfico, introdução da droga no Brasil; consumo e dependência; tratamentos para dependentes; etc. Essa pesquisa teve como finalidade o embasamento teórico, para que os alunos tivessem um conhecimento aprofundado sobre o assunto. Quando o aluno realiza uma pesquisa, ele compreende que as informações não são restritas apenas ao professor; podendo utilizar vários meios, como biblioteca, livros, internet. Além disso, a pesquisa permite que os alunos amadureçam, compreendendo a realidade, tomando decisões, apresentando suas próprias opiniões (CARDOSO, 2009).

$4^{\circ}$ fase: "Elaboração de cartazes". Ainda utilizando os mesmo grupos e temas, cada equipe ficou responsável pela confecção de um cartaz preventivo sobre a droga tema de seu trabalho. Eles tinham que fazê-lo manualmente, podendo utilizar como base 
alguma propaganda pré-existente. Nascimento e Duarte (2014) apresentam em seu trabalho um destaque quanto ao uso da análise de desenhos, onde o aluno tem a oportunidade de demostrar através da arte, sua visão sobre determinado assunto, gerando resultados produtivos. Essa atividade teve como finalidade aguçar o sentimento de prevenção às drogas através da arte e da criatividade. Fazendo com que os alunos demostrassem de forma artística seu sentimento de combate às drogas.

$5^{\circ}$ fase: "socialização dos trabalhos". A socialização dos trabalhos de cada turma aconteceu individualmente, por falta de um espaço adequado que suportasse todos os alunos ao mesmo tempo. Desta forma, houve 4 (quatro) socializações, cada uma num dia e horário específicos. Nesse momento cada grupo expôs seu cartaz, relatou sobre a entrevista e os conhecimentos/curiosidades da pesquisa bibliográfica. $\mathrm{Na}$ exposição dos cartazes todos os grupos apresentaram satisfatoriamente os trabalhos, usaram bastante criatividade e demonstraram assimilar os conhecimentos acerca da prevenção às drogas. Utilizaram réplicas de folders já existentes e desenhos criados por eles próprios; com frases de prevenção.

Por fim, todos os trabalhos foram expostos na área de convivência da escola, ficando em amostrar durante uma semana. Nesse período toda escola teve contato com o material produzido pelos alunos do $8^{\circ}$ ano, podendo assim apreciar e se beneficiar das informações ali contidas.

\section{ANÁLISE E DISCUSSÕES}

Fazendo uma análise de todos os procedimentos e ações didáticas utilizadas durante estas aulas de ciências, para a abordagem do tema drogas, percebemos vários pontos positivos relacionados ao ensino-aprendizado. Na fase 01 , realização das aulas teóricas correlacionando os malefícios físicos causados pelas drogas com o sistema nervoso, pode-se perceber que este tipo de procedimento didático fez com que os alunos compreendessem os efeitos colaterais das drogas no organismo, alertando-os para o não uso de substâncias ilegais.

Na fase 02 , em relação às entrevistas, essa foi à atividade a mais surpreendente, pois a maioria dos alunos optou por entrevistar usuários e ex-usuários, sendo estes parentes dos próprios. Além das respostas obtidas através das perguntas do questionário, 
eles compartilharam com os colegas situações familiares e problemas que as famílias enfrentam/enfrentaram com aquele usuário. Os relatos foram os mais diversos, desde parentes que morreram por causa das drogas até mesmo histórias de superação de quem superou o vício. Em alguns casos, os entrevistados falaram que iniciaram nas drogas ainda na adolescência; que tiveram problemas com a polícia; que venderam objetos de dentro de casa; que se arrependem de fazer uso das drogas. Esta estratégia didática pode proporcionar uma reflexão da realidade vivida por vários alunos, mostrando-os o efeito que as drogas causam a nível familiar e social na vida real, alertando-os sobre os malefícios do consumo destas substâncias.

$\mathrm{Na}$ fase 03, no tocante a pesquisa bibliográfica realizada pelos alunos, os resultados também foram extremamente satisfatórios. Os discentes coletaram dados e curiosidades específicas de cada tipo de droga; cumprido as metas exigidas para a elaboração do material escrito. Este tipo de estratégia didática ajuda o aluno a desenvolver a curiosidade e assimilação do tema; fazendo com que ele mesmo descubra novos saberes.

$\mathrm{Na}$ fase 04, Elaboração de cartazes, este tipo de ação didática permite que os alunos agucem seu lado artístico e criativo, diversificando o aprendizado e possibilitando que o aluno mostre, através da arte, sua compreensão sobre o tema abordado.

Na fase 05, socialização de todos os trabalhos realizados; este é um tipo de estratégia didática é super eficiente, pois permite que os alunos exponham suas experiências, relatando o que aprenderam e o que internalizaram, através de suas palavras e ações. Além disso, o passo-a-passo das ações fizeram com que os alunos se aprofundassem no tema, nas discussões e nas curiosidades inerente ao assunto, ampliando seus conhecimentos.

Após a realização de todas as aulas, analisando os procedimentos didáticos utilizados pode-se perceber que os alunos conseguiram compreender os conhecimentos e informações sobre a prevenção as drogas. Silva, Mota e Leite (2014) defendem à variedade de atividades, segundo os autores o pluralismo metodológico para trabalhar o tema drogas no ensino de Ciências, visto que a variabilidade metodológica pode ser interessante para despertar o interesse do aluno e permitir uma melhor aprendizagem. Esse tipo de estratégia plural é defendido pelos PCN's (BRASIL, 1997), já que a 
diversidade de ações ajuda a promover o aprendizado da maioria, uma vez que os déficits de uma atividade podem ser sanados pela realização de outra que a complete.

\section{CONCLUSÃO}

Após a análise de todos os dados e observações realizadas durante esta pesquisa percebeu-se que o uso de estratégias diversificadas é mais eficientes no processo de ensino-aprendizagem, neste caso, relacionadas ao tema drogas. As atividades em sala possibilitaram um maior entrosamento com o tema, auxiliando os alunos quanto às dúvidas, e possibilitando a compreensão dos conceitos necessários. Já as atividades extraclasses permitiram que os discentes tivessem autonomia e buscassem o conhecimento por conta própria, ampliando as possibilidades de aprendizagem e facilitando o trabalho em grupo.

Percebeu-se então que este conjunto de atividades diversificadas foi eficaz quanto aos resultados esperados para as aulas, pois permitiram o desenvolvimento do aluno e a reflexão crítica quanto ao tema drogas. Esta pesquisa trata-se de um relato de experiência, seus resultados estão baseados na análise de um determinado grupo, todavia, os mesmo resultados positivos são esperados em outros grupos de estudantes, visto que a aplicação destas estratégias metodológicas variadas só tem a facilitar o aprendizado dos alunos quanto à disciplina de Ciências, em como as demais disciplinas. É importante ressaltar que todas as temáticas citadas nos PCN's (BRASIL, 1997) quanto ao eixo Ser Humano e Saúde devem ser abordadas de forma interdisciplinar ao longo do ano letivo, não apenas em ações pontuais; pois assim seus resultados serão melhor percebidos.

Por fim, é notório que este conjunto de ações didáticas variadas exige uma maior dedicação e disponibilização de tempo por parte do professor, para poder acompanhar o passo-a-passo de todo o processo. Contudo, se faz necessário a dedicação do professor, para que os resultados do projeto venham a ser satisfatórios. Recomenda-se a realização de mais pesquisa sobre o tema, e principalmente, o aumento/inovação do uso de ações metodológicas que engrandeçam e ajudem os discentes quanto ao processo de aprendizagem significativa. 


\section{REFERÊNCIAS}

ANASTASIOU, Léa das Graças; ALVES, Leonir Pessate. Processos de ensinagem na universidade: Pressupostos para as estratégias de trabalho em aula. Editora Univille. $9^{\circ}$ Edição. Joinville, 2010.

ARAÚJO, Paullyanne Leal de; YOSHIDA, Sônia Maria Pinheiro Ferro. Professor: Desafios da prática pedagógica na atualidade. In: Anais do Instituto Cuiabano de Educação. 2009

BRAGA, E.M. Os elementos do processo de ensino-aprendizagem: Da sala de aula à educação mediada pelas tecnologias digitais da informação e da comunicação (TDICs). Revista Vozes dos Vales da UFVJM: Publicações Acadêmicas - MG - Brasil - $\mathrm{N}^{\circ} 02$ Ano I - Outubro de 2012. Disponível em:

$<$ http://site.ufvjm.edu.br/revistamultidisciplinar/ files/2011/09/os-elementos-doprocesso-de-ensino-aprendizagem-da-sala-de-aula-\%c3\%80-educa\%c3\%87\%c3\%83omediada-pelas-tecnologias-digitais-da-informa\%c3\%87\%c3\%83o-e-dacomunica\%c3\%87\%c3\%83o-tdics_elayn.pdf>. acesso em 27 de agosto de 2017.

BRASIL. Secretaria de Educação Fundamental. Parâmetros Curriculares Nacionais. p.167-242, Brasília, 1997.

Lei $\mathbf{n}^{\circ}$ 9.394/1996. Estabelece as diretrizes e bases da educação nacional. Brasília/DF: 1996.

CARVALHO, D. C. As contribuições da psicologia para a formação de professores: algumas questões para debate. In: MARASCHIN, Cleci; FREITAS, Lia; CARVALHO, Diana Carvalho de. Psicologia e Educação: multiversos sentidos, olhares e experiências. Porto Alegre: Ed. UFRGS, 2003.

FRANCO, M.L. Programas e projetos de prevenção ao uso de drogas: uma revisão integrativa da literatura dos anos 2000 a 2016. Brasília: Universidade de Brasília, 2016.

FREIRE, Paulo. Pedagogia da autonomia: saberes necessários à prática educativa. Editora Paz e Terra. $38^{\circ}$ edição. São Paulo, 1996.

1997.

Pedagogia do Oprimido. $62^{\circ}$ edição. Editora Paz e Terra. Rio de Janeiro,

FREITAS, S.R.P.C. O Processo De Ensino E Aprendizagem: A Importância Da Didática. In anais de VII FIPED. Acesso em 27 de agosto de 2017.

IMBERNÓN, Francisco. Formação docente e profissional: Forma-se para a mudança e a incerteza. Editora Cortez Editora. $3^{\circ}$ Edição. São Paulo, 2002.

KNECHTEL, C. M.; BRANCALHÃO, R. M. C. Estratégias Lúdicas No Ensino De Ciências. In: Portal da secretaria de Educação do Estado do Paraná. 2009. Disponível em: <http://www.diaadiaeducacao.pr.gov.br/portals/pde/arquivos/2354-8.pdf>. Acesso em 07 de novembro de 2017.

LEPIENSKI, L.M.; PINHO, K.E.P. Recursos Didáticos No Ensino De Biologia E Ciências. Instituto Paranaense de Desenvolvimento Educacional - Fundepar.

Secretaria da Educação do Paraná. 2008. Disponível em: <http://www.diadiaeducacao.pr.gov.br/portals/pde/arquivos/400-2.pdf> . Acesso em 15 de setembro de 2017. 
LIBÂNEO, J.C. A Didática e as exigências do processo de escolarização: formação cultural e científica e demandas das práticas socioculturais. São Paulo: Cortez, 1994.

MONTEIRO, S. S.; VARGAS, E. P.; REBELLO, S, M.. Educação, prevenção e drogas: resultados e desdobramentos da avaliação de um jogo educativo. Educ. Soc., Campinas, vol. 24, n. 83, p. 659-678, agosto 2003. Disponível em <http://www.cedes.unicamp.br.> Acesso em 07 de novembro de 2017.

MORAES, T. D. S. Estratégias inovadoras no uso de recursos didáticos para o ensino de Ciências e Biologia. Dissertação (Mestrado) - Universidade do Estado da Bahia. Programa de Pós-Graduação Gestão e Tecnologias Aplicadas à Educação (GESTEC). Salvador, 2016.

MOREIRA, Marco Antonio. Teorias de aprendizagem. - 2. ed. ampl. - São Paulo: EPU, 2011.

MOREIRA, F.G.; SILVEIRA, D.X.; ANDREOLI, S.B. Redução de danos do uso indevido de drogas no contexto da escola promotora de saúde. Ciência \& Saúde Coletiva, vol. 11, núm. 3, julho-setembro. Associação Brasileira de Pós-Graduação em Saúde Coletiva. Rio de Janeiro, 2006. Disponível em:

<http://www.redalyc.org/articulo.oa?id=63011328>. Acesso em 10 de novembro de 2017.

MOREIRA, A.; VÓVIO, C. L.; MICHELI, D. Prevenção ao consumo abusivo de drogas na escola: desafios e possibilidades para a atuação do educador. Revista Educação e Pesquisa, São Paulo, v. 41, n. 1, p. 119-135, jan./mar. 2015. Disponível em: <http://dx.doi.org/10.1590/S1517-97022015011670>. Acesso em 07 de novembro de 2017.

MOTA, M.S.G.; PEREIRA, F.E.L. Desenvolvimento e aprendizagem. Processo de construção do conhecimento e desenvolvimento mental do indivíduo. 1998. Disponível em: http://portal.mec.gov.br/setec/arquivos/pdf3/tcc_desenvolvimento.pdf . Acesso em 27 de agosto de 2017.

NASCIMENTO, T.A.; DUARTE, A.C.S. Estratégias pedagógicas do ensino de ciências no fundamental I: Uma análise a partir de dissertações. Revista SBEnBIO, número 7, outubro, 2014. Disponível em: <www.sbenbio.org.br/wordpress/wpcontent/uploads/2014/11/R0946-2.pdf>. Acesso em 10 de novembro de 2017.

PRASS, A.R. Teorias De Aprendizagem. ScriniaLibris.com. Maio de 2012. Disponível em: http://www.fisica.net/monografias/Teorias_de_Aprendizagem.pdf. Acesso em 27 de agosto de 2017.

PLACCO, V.M.N.S. Modelos de prevenção do uso de drogas para adolescentes: concepções e ações de professores. Em: SILVA, Eroy Aparecida da; MICHELI, Denise De (Orgs.) Adolescência, uso e abuso de drogas: uma visão integrativa. São Paulo: FAP-Unifesp, 2011.

RIBEIRO, W.A. Abordagens pedagógicas de prevenção do uso indevido de drogas por adolescentes: da prática da opressão à "prática da liberdade". Dissertação (mestrado) - Pontifícia Universidade Católica de Minas Gerais. Belo Horizonte, 2001.

RODRIGUES, A.M.S.; OLIVEIRA, E. S. F.; LIRA, E. F. S.; NUNES, J. T. F.; LIMA, J. K. A. Uso de estratégias didáticas no ensino de Ciências: uma análise da utilização 
de jogos em uma Escola Pública de Arapiraca, AL. In: anais de II CONEDU, Congresso Nacional de Educação. Campina Grande, PB, 2015. Disponível em:

<http://www.editorarealize.com.br/revistas/conedu/trabalhos/

trabalho_ev045_md1_sa18_id5758_09092015102000.pdf>. acesso em 07 de novembro de 2017.

SANTOMOURO, B. O que ensinar em Ciências. Revista eletrônica Nova Escola. 2009. Disponível em: <https://novaescola.org.br/conteudo/48/o-que-ensinar-emciencias>. Acesso em 07 de novembro de 2017.

SILVA; L. V. R.; MALBERGIER, A.; STEMPLIUK, V. A.; ANDRADE, A. G. Fatores associados ao consumo de álcool e drogas entre estudantes universitários. Revista de Saúde Pública, vol. 40, núm. 2, abril, 2006, pp. 280-288. Disponível em: <http://www.redalyc.org/articulo.oa?id=67240152014>. Acesso em 07 de nov. de 2017.

SILVA, R. B.; MOTA, M. D. A.; LEITE, R. C. M. Estratégias Didáticas Para Abordagem Sobre Drogas No Ensino De Ciências Naturais. EdUECE- Livro 2. In: Anais XVII Encontro Nacional de Prática de Ensino - ENDIPE. 2014. Disponível em: <http://www.uece.br/endipe2014/ebooks/livro2/ESTRAT\%C3\%89GIAS\%20DID\%C3 $\% 81$ TICAS\%20PARA\%20ABORDAGEM\%20SOBRE\%20DROGAS\%20NO\%20EN SINO\%20DE\%20CI\%C3\%8ANCIAS\%20NATURAIS.pdf.> Acesso em 15 de setembro de 2017. 


\section{CAPÍTULO XXXI}

\section{A UTILIZAÇÃO DAS TIC'S NO ENSINO DE HISTÓRIA}

\section{Caroline Rodrigues de Freitas Fernandes ${ }^{112}$. \\ DOI-Capítulo: 10.47538/AC-2021.14-31}

RESUMO: As tecnologias digitais já não são novidade para a sociedade contemporânea. De modo geral, a população tende a se adaptar e/ou acostumar-se, em menor ou maior grau com a tecnologia em seu cotidiano. A tendência é de que a adoção de TICs ocorra largamente em todas as áreas de automatização da ação humana, indo além das fronteiras da educação. A utilização de TICs cresce a cada dia em diversas vertentes, seja na indústria, segurança, educação e comunicação social. A presente pesquisa consiste em um revisão bibliográfica, a partir de fontes já publicadas dentro da temática abordada, como artigos em periódicos científicos, livros, teses, dissertações, além de embasamento em autores como: Capobianco (2010), kenski (2008), Lévy (2010), Moran (2012), Pischetola e Heinsfeld (2018), entre outros. Assim, o uso das TIC's de maneira apropriada durante o ensino da história pode contribuir para incorporação de novas abordagens, novos objetos, novos problemas e novos sujeitos, reconstruindo a história na perspectiva crítico-dialética, contribuindo para o desenvolvimento de uma nova concepção de construir e ensinar história, que por sua vez rompe com os pressupostos da história tradicional.

PALAVRAS-CHAVE: História. Tecnologia. Educação.

\section{THE USE OF TIC'S IN HISTORY TEACHING}

ABSTRACT: Digital technologies are no longer new to contemporary society. In general, the population tends to adapt and/or get used, to a lesser or greater degree, to technology in their daily lives. The trend is that the adoption of ICTs occurs widely in all areas of automation of human action, going beyond the borders of education. The use of ICTs grows every day in different areas, whether in industry, security, education and social communication. This research consists of a literature review, from sources already published within the theme addressed, such as articles in scientific journals, books, theses, dissertations, in addition to being supported by authors such as: Capobianco (2010), kenski (2008), Lévy (2010), Moran (2012), Pischetola and Heinsfeld (2018), among others. Thus, the appropriate use of ICTs during the teaching of history can contribute to the incorporation of new approaches, new objects, new problems and new subjects, reconstructing history in a critical-dialectical perspective, contributing to the development of a new conception of building and teaching history, which in turn breaks the assumptions of traditional history.

KEYWORDS: History. Technology. Education.

112Pós-Graduada em Mídias na Educação (UERN). Docente no Município de Macau/RN. Orcid: https://orcid.org/0000-0002-9198-6746. Lattes: http://lattes.cnpq.br/5956672837215695. E-mail: caroline_brum2005@hotmail.com. 


\section{INTRODUÇÃO}

Com o acentuado desenvolvimento tecnológico ocorrido em todo o mundo nos últimos anos, as tecnologias de informação e comunicação (TIC's) tornaram-se um aliado importante para auxiliar em praticamente todos as atividades humanas, nas mais diversas formas e em diferentes áreas, adquirindo relevância também no cenário educacional. Nos últimos anos, o advento de novas ferramentas no ambiente da Internet e de tecnologias tem possibilitado o incremento de recursos que podem ser utilizados também na educação.

O uso das tecnologias de informação e comunicação na educação deve ocorrer de forma contextualizada, contando, por exemplo, com a criação de um projeto curricular, planos de aula e novos métodos destinados a desenvolver nos alunos a capacidade de aprender novos conhecimentos a partir de seus próprios pensamentos e criatividade, visto que estas tecnologias já estão interligadas ao nosso cotidiano e ao cotidiano da maioria dos alunos.

As mudanças causadas pelo avanço tecnológico e, consequentemente, pelo surgimento e inserção das Tecnologias da Informação e Comunicação (TIC), na educação estão configurando e atribuindo novas denominações e novos significados as relações, inter-relações e a maneira de se comunicar, adquirir e produzir conhecimentos, dentro e fora do ambiente escolar, mas que trazem consequências direta para o desenvolvimento do indivíduo.

Sendo assim, para buscar entender melhor sobre o uso das tecnologias em sala de aula, especificamente na disciplina de história surge a problemática desta pesquisa: Quais as principais contribuições do uso de Tecnologias de informação e comunicação no ambiente escolar na mediação do ensino de história?

Desta forma, a presente pesquisa tem como objetivo geral constatar as principais contribuições advindas do uso das tecnologias na disciplina de História. Como objetivos específicos: Identificar os tipos de tecnologia digital utilizadas na escola; apresentar as dificuldades encontradas pelos docentes; Comparar a realidade tecnológica dos alunos e professores; refletir sobre as possibilidades de utilização das tecnologias em sala de aula.

Este trabalho se justifica pela relevância do tema que se aplica à conjuntura da sociedade contemporânea e ao universo das escolas públicas. Debater sobre tecnologia 
dentro do ambiente escolar permite que os envolvidos possam refletir sobre suas práticas, ideias e perspectivas.

A presente pesquisa consiste em uma revisão bibliográfica, a partir de fontes já publicadas dentro da temática abordada, como artigos em periódicos científicos, livros, teses, dissertações, além de embasamento em autores como: Capobianco (2010), kenski (2008), Lévy (2010), Moran (2012), Pischetola e Heinsfeld (2018), entre outros.

\section{DESENVOLVIMENTO}

O que são TIC's?

A partir do século XX, através da evolução das telecomunicações, começou a destacar-se as tecnologias de informação e comunicação, sendo percebidas em diversos fatores, tais como, na utilização cotidiana dos computadores, no desenvolvimento da internet e ainda, com o aparecimento de tecnologias mais avançadas, como a utilização de Energia Nuclear, Nanotecnologia, Biotecnologia, entre outros.

A partir do momento que a tecnologia e seus produtos se tornaram mais acessíveis e populares, eles se fizeram cada vez mais presentes em todas as atividades humanas. Assim, a cada dia são apresentadas à sociedade novas tecnologias, resultantes desse um contínuo processo de transformação, inovação e superação de obstáculos e limites científicos e tecnológicos.

[...] para todas as atividades que realizamos, precisamos de produtos e equipamentos resultantes de estudos, planejamentos e construções específicas, na busca de melhores formas de viver. Ao conjunto de conhecimentos e princípios científicos que se aplicam ao planejamento, à construção e à utilização de um equipamento em um determinado tipo de atividade nós chamamos de "tecnologia" (KENSKI, 2008, p. 18).

A partir desse conceito podemos entender que o papel das TIC's consiste em servir como meio de comunicação entre as pessoas, possibilitando o compartilhamento de conhecimentos, concepções e opiniões, permitindo um paralelo de diferentes visões de mundo em relação a um mesmo objeto. É fato que a sociedade sempre esteve em constante evolução, porém, é evidente que essas mudanças estão ocorrendo de maneira cada vez mais veloz e o principal responsável são as Tecnologias de Informação e Comunicação (TICs). 
As TIC's enquanto recursos associados a informática, têm se destacado por oferecerem infinitas possibilidades de acesso a variadas fontes de conhecimento e informação nos mais diversos formatos (texto, aúdio, vídeo...), disponíveis e armazenados em computadores de todo o mundo, contribuindo para quebrar as barreiras, temporal e geográfica, em uma fração de segundo, com apenas alguns toques, e, consequentemente, favorecendo o desenvolvimento do conhecimento, da comunicação, da leitura, da escrita, e fatores gerais que promovem aumento do conhecimento de seus usuários.

Segundo Pischetola e Heinsfeld (2018, p. 04):

No mundo on-line, convergem informação e entretenimento, trabalho e lazer, local e global, público e privado. Diante dessa convergência, os sujeitos precisam desenvolver habilidades muito além das que já possuem em relação às dinâmicas de colaboração, acesso à informação em múltiplos formatos, produção de conteúdos e comunicação nos diferentes espaços de mediação.

Diante do reconhecimento das possibilidades das TIC's, se faz necessário um processo de adaptação, para que as pessoas comecem a vislumbrar as formas e possibilidades de ampliação do conhecimento com o auxílio de uma ferramenta tão importante e habitual quanto à internet e suas ramificações.

\section{O USO DAS TIC'S NA ESCOLA}

Hoje, as novas tecnologias ou, como ficou conhecida, Tecnologias da Informação e Comunicação e/ou Tecnologia Digital, já que são oriundas da união da informática com as telecomunicações e as mídias eletrônicas, são capazes de proporcionaram no contexto educacional um envolvimento tão significativo que rompeu as barreiras físicas e geográficas, disponibilizando por meio de seus recursos a formação de teias de comunicação mais dinâmicas, democráticas e interativas que reduziram a ideia de tempo, espaço e distância e uniram diferentes culturas, povos, classes e indivíduos.

O uso das tecnologias de informação e comunicação na educação deve ocorrer de forma contextualizada, contando, por exemplo, com a criação de um projeto curricular, planos de aula e novos métodos destinados a desenvolver nos alunos a capacidade de aprender novos conhecimentos a partir de seus próprios pensamentos e criatividade, visto 
que estas tecnologias já estão interligadas ao nosso cotidiano e ao cotidiano da maioria dos alunos.

Inicialmente é preciso considerar e ressaltar a existência de um enorme potencial no desenvolvimento de habilidades através do uso das tecnologias, tanto no ambiente escolar, quanto em sala de aula, e até mesmo fora dela. Por essa razão, os educadores precisam compreender a importância da utilização dos recursos tecnológicos como aliados no processo de desenvolvimento do ensino, cuidando para que seja feito o uso correto dessa tecnologia e assim obtenha-se os resultados esperados.

Entretanto, esse potencial só poderá se concretizar de forma proveitosa se houver um plano pedagógico tanto por parte da instituição, quanto por parte do próprio docente. Assim, é essencial ao professor, independente da área e faixa etária em que atua, saber utilizar a tecnologia, e a partir dela produzir meios para o desenvolvimento cognitivo dos alunos. Portanto, além da modernização gerada no ambiente escolar, o uso das tecnologias precisa propiciar mudanças de paradigmas resultante dos benefícios que a tecnologia e suas ferramentas proporcionam para o processo de ensino-aprendizagem.

Pierre Lévy (2010) em seu trabalho denominado Cibercultura, aponta que as teias de comunicação que se estabelecem a partir de uma rede de computadores é capaz de criar ambientes que permitem as pessoas conectadas construir e compartilhar inteligência coletiva, sem sofrer nenhuma restrição de caráter político-ideológico, ou seja, a internet passa a se constituir em uma grande ferramenta humanizadora, onde é possível democratizar a informação, permitindo a valorização das competências individuais dos seus usuários e a defesa dos interesses das minorias/maiorias.

Inicialmente, o uso das tecnologias na educação brasileira esteve voltado exclusivamente para o ensino a distância $(\mathrm{EaD})$. No entanto, a escola contemporânea precisa considerar a introdução das novas TICs em suas práticas pedagógicas, visto que estas são atualmente essenciais para o desenvolvimento integral do indivíduo, nessa sociedade altamente tecnológica e globalizada. Em síntese, as formas de ensino, seus métodos e metodologias precisam acompanhar a evolução da sociedade.

Hoje, portanto, as Novas Tecnologias ou tal qual as identificamos no momento atual como Tecnologias da Informação e Comunicação e/ou Tecnologia Digital, após se constituírem da união da informática com as telecomunicações e as mídias eletrônicas, elas proporcionaram no 
contexto educacional um envolvimento de tal forma que rompeu as barreiras físicas, outrora distantes há quilômetros, viabilizando, por meio de seus recursos, a formação de teias de comunicação eletrônicas mais dinâmicas, democráticas e interativas que, ao introduzirem o conceito de simultaneidade, reduziram a ideia de tempo, espaço e distância (TODAKA; SILVA, 2018, p. 18).

Segundo Capobianco (2010), as Tecnologias de Informação e Comunicação (TIC) fornecem recursos capazes de favorecer e enriquecer as aplicações e os processos, principalmente na área de educação. Pois, a adoção destes recursos abre um leque de grandes e novas possibilidades para complementar e aperfeiçoar a educação formal.

O uso das TIC na escola auxilia na promoção social da cultura, das normas e tradições do grupo, ao mesmo tempo, é desenvolvido um processo pessoal que envolve estilo, aptidão, motivação. A exploração das imagens, sons e movimentos simultâneos ensejam aos alunos e professores oportunidades de interação e produção de saberes (MORAN, 2012, p. 13).

As mudanças causadas pelo avanço tecnológico e, consequentemente, pelo surgimento e inserção das Tecnologias da Informação e Comunicação (TIC), na educação estão configurando e atribuindo novas denominações e novos significados as relações, inter-relações e a maneira de se comunicar, adquirir e produzir conhecimentos, dentro e fora do ambiente escolar, mas que trazem consequências direta para o desenvolvimento do indivíduo.

Por essas razões, a educação precisa acompanhar e adequar-se às novas concepções trazidas pelas transformações tecnológicas, culturais e morais, procedentes dos avanços tecnológicos. Pois, assim, estará apta a preparar seus alunos para um mundo de ilimitadas possibilidades que podem surgir da integração da escola, alunos e professores com o uso destas tecnologias no processo de ensino-aprendizagem.

A introdução das TIC's na Educação necessita de reflexões e avaliações que busquem identificar elementos capazes de suscitar subsídios necessários para estabelecer diálogos enriquecedores e que potencializem as demandas sociais e tecnológicas oriundas da relação desses dois elementos, tecnologia e educação.

Observando o ambiente escolar na atualidade verifica-se que muitos estudantes chegam às escolas dispondo de uma variedade de dispositivos tecnológicos (celulares, tabletes, notebooks) que já fazem parte do seu cotidiano. E a escola, como principal instituição responsável pela preparação dos alunos para a participação da vida em 
sociedade, fazendo deles cidadãos ativos, deve usar essas tecnologias como ferramenta educacional em favor do ensino, sabendo que resultarão em grandes possibilidades de interação e desenvolvimento pessoal, social e cognitivo.

Além disso, o uso das TIC's contribui para democratizar o acesso ao conhecimento, agora mais acessível a toda população, e para o desenvolvimento do processo ensino-aprendizagem, e de busca e construção de novos conhecimentos.

De acordo com Moran (2010, p. 27), o uso das tecnologias ajuda a realizar o que já fazemos ou desejamos fazer em nosso dia a dia. Se somos pessoas abertas, elas nos ajudam a ampliar a nossa comunicação; se somos fechados, ajudam a nos controlar mais. Se temos propostas inovadoras, elas facilitam a mudança.

Considerando as ideias de Moran (2010), compreendemos que as mudanças advindas da introdução das tecnologias na educação são muito importantes para suplantar o modelo de educação tradicional, há muito tempo ultrapassado, que limita a busca e transmissão de conhecimentos. Assim, a união entre as tecnologias e a educação poderá criar um ambiente propício para construção de novas propostas teórico-metodológicas que enriquecerão o processo de ensino e aprendizagem no universo escolar, trazendo avanços no modelo, qualidade e resultados da educação.

As Tecnologias Digitais e as diversas abordagens pedagógicas que as utilizam podem contribuir para a personalização do ensino e para a autonomia e o engajamento dos estudantes, tornando-os mais ativos e mais responsáveis pela sua aprendizagem (BARCELOS; BATISTA, 2019, p. 61).

É necessário ter em mente que os alunos do século XXI, considerados nativos digitais, passam a maior parte do tempo envolvidos em um mundo virtual criado a partir da tecnologia. Então, aderir ou não ao uso das tecnologias nos processos educativos vai além de seguir uma moda, diz respeito a avaliar e saber como empregar estes recursos nas práticas docentes e no cotidiano escolar de forma a contribuir para o melhoramento do processo de ensino-aprendizagem, modificando e colocando fim definitivamente nos conceitos do antigo sistema tradicional de ensino.

Moran (2010) mostra como as tecnologias ampliam o leque de opções em uma aula, começando pelo fato de que ela não mais se restringe as quatro paredes da sala de aula física, pois o momento de produção do conhecimento pode ser feito em qualquer 
lugar e a qualquer momento, sem limites de tempo e espaço, indo muito além dos muros da escola. Além disso, é possível atrair e manter a atenção e concentração dos alunos por mais tempo, com as possibilidades de melhoria na comunicação, no uso de audiovisuais mais atrativos, maximizando o conceito de aula.

É preciso salientar que o aumento no acesso ao computador e internet, seja na escola ou em casa, significa um aumento no acesso à informação; no entanto, a simples disponibilidade de informação na internet não gera aprendizagem, ou seja, o aumento do uso de computadores em sala de aula, não implica necessariamente em uma maior aprendizagem por parte dos alunos e nem em uma educação de melhor qualidade.

[...] a presença das Tecnologias da Informação e Comunicação (TIC) na educação, hoje com computadores portáteis, smartphone, tablets e uma enorme parafernália tecnológica que, presente na escola, não está conseguindo, em linhas gerais, promover as tão necessárias radicais transformações da educação em nosso país e, sem medo de errar, no mundo (PRETTO, 2013, p. 23).

Assim, as tecnologias só serão capazes de auxiliar no processo de ensinoaprendizagem, se o seu uso ocorrer de forma correta, consciente e produtiva, sendo necessário atenção e acompanhamento para que os alunos não se percam diante da infinidade de informações que recebem de forma tão rápida e dispersem seu foco e atenção para outras finalidades, ficando alheios ao que de fato é importante para o seu desenvolvimento.

É possível afirmar que a tecnologia ao inserir-se no cenário educacional desempenha uma função primordial na construção de novas estruturas e maneiras de produção e de elaboração de novos saberes. Dentro do contexto de evolução, o processo educativo terá um papel altamente significativo nessas transformações, levando todos que estão direta ou indiretamente envolvidos, a um novo e elevado patamar do processo de ensino-aprendizagem.

Se analisarmos a situação tecnológica atual das instituições de ensino brasileiras, temos diversos tipos de defasagens entre as públicas e as privadas, além de também estarmos em estágios diferentes se nos compararmos a países estrangeiros. No entanto, parece que o fator "tecnologia da informação" em si não é definitivo para a educação na era digital - ele só é diferencial positivo se contar com a participação efetiva do professor e dos planos pedagógicos. O professor deve deixar de ser um informador para ser um formador; caso contrário, o uso da 
tecnologia da informação terá apenas aparência de modernidade (GABRIEL, 2013, p. 109).

O fato de simplesmente disponibilizar a tecnologia ou o acesso a redes sociais em sala de aula não significa que elas serão usadas como recurso para um maior aproveitamento nas aulas, é preciso, primeiramente, conhecer quais as limitações e dificuldades que os docentes encontram para poder conseguir inserir de maneira eficiente essas novas tecnologias no ambiente escolar, gerando frutos para a aprendizagem.

A partir do momento em que as escolas se dispuserem a rever seus processos e currículos pedagógicos e a mudar suas ações, metodologias e métodos de ensino, abrirão as portas para o crescimento de cidadãos mais ativos e participativos, que atuem de forma autônoma, crítica e responsável dentro da sociedade em que está inserido.

De nada adianta ter uma escola visivelmente bonita, bem estruturada e equipada, seguindo padrões de organização, se não houver a atualização do currículo pedagógico, a inserção das tecnologias na dinâmica escolar, principalmente em sala de aula, a capacitação e formação de professores para atuar com essas tecnologias, entre outros.

\section{O USO DAS TIC'S NO ENSINO DE HISTÓRIA}

Compreender o processo de inserção e uso das TIC na educação, mais precisamente, no Ensino de História, requer uma análise criteriosa das possíveis construções de atitudes e mentalidades que poderão surgir a partir das interações entre indivíduos e tecnologia, as quais implicaram em mudanças no processo ensino aprendizagem.

É imprescindível inovar no que diz respeito ao processo de ensino-aprendizagem, principalmente cientes que essa nova geração de estudantes já vem com uma bagagem grande de conhecimento de tecnologias, que, portanto, devem ser aproveitados para auxiliar no desejo de aprender, mudando a visão que os alunos possuem do aprendizado de História que foi construído e mantido ao longo dos anos.

Nesse sentido, o educador de História deve estar atento às dessa nova realidade social e cultural das escolas e dos alunos, substituindo aquele velho modo de ensinar, no qual o aluno é mero expectador e o professor o transmissor de conhecimentos, pela visão onde o professor é o problematizador, que auxilia na formação do aluno, suscitando nele 
a capacidade de compreender, opinar, criticar, formando um cidadão pleno em suas responsabilidades.

O professor de História precisa compreender o processo inovador do uso de recursos tecnológicos em sala de aula como uma evolução no processo educacional. E como conhecedor das evoluções ao longo da história, não deve mostrar resistência a essas inovações, sob o risco de se tornar obsoleto e perder seu espaço no mercado de trabalho e sua função de orientador do processo de aprendizagem dos alunos.

É necessário ainda ao docente buscar conhecimento e se preparar para escolher as ferramentas corretas para utilizar na sala de aula enquanto estiver ministrando suas aulas. Assim ele estará apto a contribuir para um maior interesse pelo aprendizado por parte do aluno, pois as TIC's trazem o mundo para o ambiente educativo, de forma interativa.

Caberá ao educador investigar, dentre os vários recursos da rede virtual, quais deles possam ter um valor consideravelmente eficaz no processo de ensino e de aprendizagem. Quais deles melhor contribuem para que os alunos passem da passividade para a atividade. Mais do que utilizar os recursos disponíveis no panorama sociomundial, ou se apropriar das ferramentas tecnológicas, um dos principais objetivos do ensino é o de conseguir que os professores estabeleçam entendimento e reflexão no que concerne às mudanças tecnológicas. Isso transita pelo papel do professor investigador-colaborador (VASCONCELOS, 2010, p. 30).

É notório observar que no contexto educacional atual, o aluno ganha um novo papel, pois deixa de ser um mero aprendiz e se torna participante ativo no processo de ensino-aprendizagem, tendo em suas mãos os meios vitais para buscar as respostas aos seus questionamentos na prática, e a partir do resultado encontrado analisar situações e problemas, levantar hipóteses e soluções, construir teses e assim desenvolver o seu cognitivo.

Contudo, cabe ao docente possibilitar as condições didáticas possíveis a esse processo, baseado em um planejamento consciente, criando as condições para que essa aprendizagem ocorra de forma significativa, gerando resultando que cooperem para melhor compreensão da disciplina de história por parte dos alunos.

Especificamente no ensino da História, é muito importante que as TIC's sejam utilizadas não apenas como máquinas para ensinar ou aprender, mas como ferramentas pedagógicas para criar um ambiente interativo que proporcione ao aprendiz, diante de 
uma situação problema, investigar, levantar hipóteses, testá-las e refinar suas ideias iniciais, construindo assim seu próprio conhecimento.

Essas mudanças almejadas a partir do uso das TIC's envolvem não somente a prática docente e o objeto de aprendizagem, isto é, o conteúdo de história em suas múltiplas linguagens, mas, todo o universo do processo de aprendizagem, ou seja, a escola e a sala de aula enquanto espaços privilegiados para o desenvolvimento do fazer docente, alunos, professores, o ensino como um todo e suas várias dimensões.

Leite e Radetzke (2017, p. 281) afirma que:

O professor precisa construir metodologias que tomem como ponto de partida as compreensões dos alunos acerca da temática e estimular neles novas compreensões e novos significados que favoreçam a compreensão do mundo, tanto no âmbito social, político, natural ou econômico, visualizando possibilidades de transformação desse mundo. [...] o papel dos professores é de propor estratégias de ensino que se projetem para o mundo.

Assim, outra contribuição do uso das TIC's no ensino de História é a diminuição da distância, permitindo ao aluno se conectar a outros lugares que antes eram desconhecidos ou conhecidos limitadamente, é possível ainda visualizar mapas e espaços geográficos em tempo real, criar inúmeras oportunidades de poder discutir e construir conhecimentos coletivamente com alunos distantes, com outras culturas e sociedades.

Outra ferramenta que pode ser utilizada no contexto de ampliação das TIC's na disciplina de história é a grande oferta de produções cinematográficas (filmes, documentários, relatos reais), que aumentou o leque de opções que trazem possibilidade de enriquecimento da prática docente e agregam grande valor ao ensino em sala de aula.

Para tanto, o profissional do ensino de história, precisa possuir uma proposta de trabalho, aliada às TIC, para desenvolvê-la com os alunos, ou seja, o profissional do ensino de história deverá criar condições para os alunos refletirem acerca das diversas possibilidades de reconstruir a história a partir das produções cinematográficas (SILVA, PORTO, 2012).

Por muito tempo, o único recurso do professor nas aulas de História foi o quadronegro e o livro didático, com isso as aulas foram se tornando entediantes e abordando apenas as concepções teóricas, cobrando dos alunos que os fatos históricos fossem memorizados e não aprendidos. Deste modo, professores e alunos não refletiam e nem 
discutiam os fatos históricos, suas razões e contribuições para a história, apenas abordavam as temáticas de modo sistemático com foco na memorização.

Com o passar do tempo, muitas mudanças foram sendo implantadas no Ensino de História, principalmente ideológicas, gerando a liberdade de expressão dos alunos e a oportunidade de debates reflexivos sobre os fatos abordados em sala. Associar tais mudanças às possibilidades das TICs é permitir que o aluno possa pesquisar novas fontes e poder integrar novos saberes aos textos dos livros didáticos, além de confrontar opiniões de diferentes autores sobre um fato histórico, tornando cada vez mais enriquecedor para o processo de construção do conhecimento.

Existem vários recursos tecnológicos que servem para compartilhar experiência com grupos de estudos e construir conhecimentos em redes colaborativas de aprendizagem e que hoje estão acessíveis a qualquer pessoa, e, portanto, podem tornam o ensino de história mais atraente, dinâmico e criativo, contribuindo para a construção de um processo ensino-aprendizagem que estimule neles o desejo em querer aprender, conhecer e fazer descobertas.

Atualmente, as informações circulam cada vez mais rápido e se atualizam constantemente, e isso está acessível quase que imediatamente em qualquer lugar que você esteja no mundo, além do que um mesmo fato é relatado por inúmeros jornais, revistas e sites que apresentam diferentes pontos de vistas, o que permite considerar vários fatores diferentes na análise dos acontecimentos.

Nesse ponto de vista, as TIC's contribuem, pois, os alunos podem estudar um fato histórico acessando diferentes fontes e formatos, pois além do texto, o aluno pode assistir vídeos, imagens e aprofundar-se nos assuntos. O que garante ao aluno a possibilidade de estudar o passado por meio dos aparatos tecnológicos atuais e relacionar o passado com o presente por meio de reflexões promovidas pelos professores.

Além disso, a utilização das TIC's na mediação do ensino de história contribui para viabilizar o acesso a espaços sociais antes inacessíveis, como arquivos, museus e bibliotecas virtuais. É possível perceber que tal procedimento, além de favorecer no processo ensino aprendizagem, exerce influência na transformação do ensino de História e na concepção do mesmo enquanto disciplina voltada para o passado, o presente e o 
futuro, haja visto que, a mediação tecnológica no referido ensino abre ao aluno a perspectiva da pesquisa, procedimento considerado indispensável para produção do conhecimento histórico e para formação do discente enquanto sujeito.

Com isso, cria-se condições, não somente para o aluno ser capaz de questionar e buscar suplantar a ordem já estabelecida, mas, de sugerir mudanças que prime pela tolerância e o respeito as diferenças das minorias historicamente desrespeitadas tanto no aspecto tecnologicamente falando, quanto no aspecto educacional e escolar.

\section{CONCLUSÃO}

Os conceitos, metodologias e recursos relacionados à educação, ao longo da história, modificam-se ou reinventam-se a partir dos desafios e necessidades que se colocam por diferentes motivos. Assim, o uso das TIC's de maneira apropriada durante o ensino da história pode contribuir para incorporação de novas abordagens, novos objetos, novos problemas e novos sujeitos, reconstruindo a história na perspectiva críticodialética, contribuindo para o desenvolvimento de uma nova concepção de construir e ensinar história, que por sua vez rompe com os pressupostos da história tradicional.

A mudança de modelo ou padrão no processo de ensino-aprendizagem constitui um dos grande desafios da escola e do professor dentro dessa sociedade tecnológica da atualidade, pois exige um repensar sobre as práticas pedagógicas, a formação docente, as condições físicas e estruturais da escola e o verdadeiro papel da educação, para que possamos caminhar em direção a uma educação e um ensino de história inclusivo e de qualidade que valorize os conhecimentos dos homens que constroem cotidianamente a história vivida e ensinada nos diferentes contextos educacionais. Dentro deste contexto as TIC's se mostram como excelentes aliadas trazendo grandes benefícios ao ensino de história e a educação como um todo.

\section{REFERÊNCIAS}

BARCELOS, Gilmara Teixeira. BATISTA, Silvia Cristina Freitas. Ensino Híbrido: aspectos teóricos e análise de duas experiências pedagógicas com Sala de Aula Invertida. Revista Novas Tecnologias na Educação. V. 17 No 2, agosto, 2019. 
CAPOBIANCO, L. Comunicação e Literacia Digital na Internet - Estudo etnográfico e análise exploratória de dados do Programa de Inclusão Digital Acessa SP - PONLINE. Dissertação (Mestrado em Ciências da Comunicação). Escola de Comunicação e Artes, Universidade de São Paulo, 2010.

GABRIEL, M. Educar - A (r) evolução digital na educação. São Paulo: Saraiva, 2013. KENSKI, V. M. Tecnologias e ensino presencial e a distância. Campinas, SP: Papirus, 2008 .

LEITE, Fabiane De Andrade; RADETZKE, Franciele Siqueira. Contextualização no ensino de ciências: compreensões de professores da educação básica. VIDYA, v. 37, n. 1, p. 273-286, jan./jun., 2017 - Santa Maria, 2017.

LEVY, Pierre. Cibercultura. São Paulo. Ed.34, 2010.

MORAN, J. M., MASSETTO, M. T., BEHRENS, M. A Novas tecnologias e mediações pedagógicas. Campinas, SP: Papirus. 2012.

MORAN, José Manuel. Ensino e aprendizagem inovadores com tecnologias audiovisuais e telemáticas. In Moran, J. M. Novas Tecnologias e mediação pedagógica. Campinas, SP: Papirus, $17^{\mathrm{a}}$ Ed, 2010.

PISCHETOLA, Magda. HEINSFELD, Bruna Damiana. Eles já nascem sabendo!: desmistificando o conceito de nativos digitais no contexto educacional. Revista Novas Tecnologias na Educação. V. 16 No 1, julho, 2018.

PRETTO, N. L. Uma escola sem/com futuro. Educação e multimídia. 8. ed. rev. e atual. Salvador/BA: EDUFBA, 2013.

SILVA, Marco Antônio; PORTO, Amélia. Nas trilhas do ensino de história: teoria e prática. Belo Horizonte: Rona, 2012.

TODAKA, Antonio Jerry Da Silva; SILVA, Orinaldo Jorge Monteiro Da. O ensino de história mediado pelas TIC em uma escola pública do município de Belém-PA: caminhos e desafios. 2018.

VASCONCELOS, Z. B. das C. Uso do microblog Twitter como recurso didático na visão docente. Dissertação de Mestrado. Fortaleza, 2010. Disponível em www.uece.br/mpcomp/index.php/arquivos/doc.../225-dissertacao-66. Acesso: 22/08/2009 


\title{
CAPÍTULO XXXII
}

\section{A IMPORTÂNCIA DO SENSO COMUM PARA O ENSINO DE CIÊNCIAS}

\author{
Dayana Lúcia Rodrigues de Freitas ${ }^{113}$. \\ DOI -Capítulo: 10.47538/AC-2021.14-32
}

RESUMO: O presente ensaio teórico versa sobre a importância dos saberes relacionados ao senso comum e da sua importância para o conhecimento científico. Trata-se de uma revisão de três textos que discutem sobre o tema em questão, baseado nos autores: Figueiredo Neto, Macêdo e Rosa (2010); Souza (2006); Silva (2011). O principal objetivo deste estudo é demostrar que o senso comum também possui relevância e deveriam ser valorizadas mediante a comunidade científica; bem como do seu aproveitamento para o ensino de ciências naturais.

PALAVRAS-CHAVE: Senso comum. Conhecimento científico. Ensaio teórico. Revisão bibliográfica.

\section{THE IMPORTANCE OF COMMON SENSE FOR SCIENCE TEACHING}

ABSTRACT: This theoretical essay deals with the importance of knowledge related to common sense and its importance for scientific knowledge. It is a review of three texts that discuss the topic in question, based on the authors: Figueiredo Neto, Macêdo and Rosa (2010); Souza (2006); Silva (2011). The main objective of this study is to demonstrate that common sense is also relevant and should be valued by the scientific community; as well as its use for teaching natural sciences.

KEYWORDS: Common sense. Scientific knowledge. Theoretical essay. Literature review.

\section{INTRODUÇÃO}

A relação entre ciência e senso comum sempre foram polêmicas, havendo uma disputa de conhecimento e veracidade em cada um desses seguimentos. A comunidade científica sempre buscou inferiorizar o senso comum a ponto de muitas vezes inutilizálo.

Este ensaio teórico abordará a importância do senso comum para a ciência, com base no estudo de três textos e seus respectivos autores abaixo relacionados: A relação entre ciência e senso comum (Sandra Siqueira da Silva). As sete teses equivocadas sobre conhecimento científico: reflexões epistemológicas (Janara Sousa).

113 Doutoranda em Ciências da Educação (CECAP). Docente nos Município de Macau/RN e Guamaré/RN. Orcid: https://orcid.org/0000-0001-5355-3547. Lattes: http://lattes.cnpq.br/5122671799874415.

E-mail: dayannaproducoes@gmail.com. 
A aproximação entre a ciência e o senso comum: A ciência ensinada e a ciência em si (Manoel Valente Figueiredo Neto, Andreya Lorena Santos Macêdo, Lúcia Cristina dos Santos Rosa).

O principal objetivo deste estudo é demostrar, através de um estudo bibliográfico, a importância do senso comum para a comunidade científica e para a população em geral, enfatizando que o senso comum é relevante e não pode ser menosprezado e desvalorizado, visto que muitos conhecimentos científicos derivam do conhecimento popular.

\section{DESENVOLVIMENTO}

Para iniciarmos a compreensão do assunto é importante definimos os dois principais temos norteadores deste ensaio. Apresentaremos as definições do que é Ciências e do que é senso comum na visão dos autores estudados.

Figueira Neto, Macêdo e Rosa (2010) apresentam a definição de Ciência encontrada numa busca no dicionário HOUAISS, onde dizem que:

Substantivo feminino, 1 conhecimento atento e aprofundado de alguma coisa, 1.1 esse conhecimento como informação, noção precisa; consciência, 1.2 conhecimento amplo adquirido via reflexão ou experiência, 2 processo racional us. pelo homem para se relacionar com a natureza e assim obter resultados que lhe sejam úteis, 3 corpo de conhecimentos sistematizados que, adquiridos via observação, identificação, pesquisa e explicação de determinadas categorias de fenômenos e fatos, são formulados metódica e racionalmente, 4 Derivação: por metonímia, atividade, disciplina ou estudo voltado para qualquer ramo do conhecimento, 5 Derivação: por extensão de sentido, conjunto de conhecimentos teóricos, práticos ou técnicos voltados para determinado ramo de atividades; talento; mestria, 6 Derivação: por extensão de sentido, erudição, saber, 7 conhecimento puro independente da aplicação, 8 Rubrica: filosofia, conhecimento que, em constante interrogação de seu método, suas origens e seus fins, procura obedecer a princípios válidos e rigorosos, almejando esp. coerência interna e sistematicidade - substantivo feminino plural, 9 conhecimentos ou disciplinas que mantêm articulações, semelhanças ou conexões sistemáticas, tendo em vista o estudo de determinado tema, 10 disciplinas voltadas para o estudo sistemático da natureza ou para o cálculo matemático (HOUAISS, 2008, p. 189).

$\mathrm{Na}$ interpretação de Sousa (2006) o importante é "desendeusar" a Ciência tornando-a mais perto do homem, iniciando com uma abordagem de "nomenclatura 
correta", não chamando conhecimento científico de Ciência. A autora traz um aspecto interessante, onde diz que:

No fundo, claro, estamos falando da mesma coisa. Entretanto é dos vícios que o termo ciência criou que queremos nos livrar. Tratar esse fazer científico, que se iniciou especialmente depois da Idade Média na Europa, por conhecimento científico tem como principal intuito dar à produção científica o seu devido lugar. O lugar de mais um conhecimento, de mais uma possibilidade de explicação da realidade, dentre as várias que o homem criou.

Silva (2011) define o senso comum como: "um conhecimento prático, produzido em nosso cotidiano, e é por meio dele que orientamos as nossas ações”. A autora prossegue afirmando que: "O senso comum representa a realidade em que estamos inseridos, é um conhecimento fértil, representa as inquietações do sujeito".

Ao falarmos de senso comum, é fundamental deixamos claro sua importância e relevância no decorrer da história. Para Figueira Neto, Macêdo e Rosa (2010), “o senso comum talvez seja a primeira forma de conhecimento a ter surgido sobre a face da Terra, juntamente com o Homo sapiens, há cerca de 40 mil anos". Ainda segundo os autores "sem elas não poderíamos resolver os problemas mais simples do nosso dia-a-dia, pois em todos os instantes precisamos tomar decisões".

Silva (2011) diz que "o senso comum tende a ser um conhecimento mistificado e mistificador, mas, apesar disso e apesar de ser conservador, tem uma dimensão utópica e libertadora que pode ser ampliada através do diálogo com o conhecimento científico".

Figueira Neto, Macêdo e Rosa (2010) afirma que o senso comum também possui suas técnicas de verificação que se assemelham as técnicas de checagem do conhecimento científico, contudo, o diferencia é que não há um aprofundamento de estudos:

A relativa eficiência do senso comum deve-se ao fato de que ele também passou como o conhecimento científico, por um processo de aprendizagem e por ensaio e erro, mas limitou-se, na maioria das vezes, na tentativa de resolver problemas de ordem prática. Por outro lado, o conhecimento científico procura, sistematicamente, criticar uma hipótese, mesmo que ela resolva satisfatoriamente os problemas para os quais foi concebida.

Quando indagamos a validade e confiabilidade do senso comum, Sousa (2006) nos lembra que os conhecimentos científicos são tidos como absolutos pelo rigor metodológico utilizado, contudo esses métodos não são infalíveis, pois são uma 
construção humana. Desta forma "o conhecimento científico não é a única forma de conhecer o mundo e a realidade que nos rodeia”. Ainda, segundo colocação da autora:

Outros conhecimentos como o religioso, o filosófico e o senso comum trazem consigo explicações de mundo baseadas em seus próprios métodos de verificação e interpretação da realidade, que certamente não tomaram emprestados do conhecimento científico até porque eles vieram bem antes desse último.

Para Silva (2011), "cada modelo de produção de conhecimento tem suas particularidades no tocante à obtenção de suas verdades". Desta forma o senso comum também produz verdades.

Sousa (2006) traz à tona, em seu texto, algo que todos nós já sabemos: que "antes do surgimento do conhecimento científico existiam outras formas de interpretar a realidade". Essas outras formas de interpretações da realidade, oriundas do senso comum, religião, etc., também possuem seu grau de absolutismo e verdade.

Outro ponto abordado no estudo de Sousa (2006) é acreditar que o conhecimento científico é capaz de revelar a realidade como ela é. Para a autora este fato seria impossível, visto que "nenhum conhecimento é capaz dessa façanha! Toda vez que olhamos a realidade e tentamos explicá-la estamos fazendo um recorte baseados na nossa própria subjetividade".

Além disso, para Silva (2011), "sua crítica reside em se ter à ciência como produtora de verdades, pois, não se é possível ter a certeza nem mesmo do conhecimento que é produzido em nossas mentes".

Figueira Neto, Macêdo e Rosa (2010) defendem a união dos conhecimentos científicos com os conhecimentos oriundos do senso comum, onde retratam sobre um "Positivismo científico".

Tal positivismo científico tende a proporcionar oportunidades de "pensar a ciência como forma de aquisição de conhecimento, relacionando-a com o senso comum”.

Sousa (2006) afirma que "o conhecimento científico veio por uma demanda da humanidade na busca de explicações mais rigorosas sobre a realidade”. Porém, não surgiu para substituir o senso comum. Haja vista que, "o pensamento mágico e religioso ainda existe e é importante ressaltar que eles também gozam de respeito e autoridade". 
Em relação à importância do senso comum, Figueira Neto, Macêdo e Rosa (2010) traz em seu texto a seguinte frase: "conseguimos fazer uma aproximação entre a ciência e o senso comum. Tal aproximação repousa no fazer ciência e propõe que o que hoje não é parte da ciência, poderá vir a sê-lo amanhã". Desta forma, os autores rementem-se a importância do senso comum para a ciência e para a vida cotidiana.

Sousa (2006) apresenta em seu texto uma citação de (Demo 1995) que afirma a união do senso comum com a Ciência:

A ciência está cercada de ideologia e senso comum, não apenas como circunstâncias externas, mas como algo que está já dentro do próprio processo científico, que é incapaz de produzir conhecimento puro, historicamente não contextualizado (DEMO, 1995, 18).

Todavia, Silva (2011) defende que "o senso comum, e todos os conhecimentos provenientes deste campo do saber, são fundamentais para a compreensão do patrimônio cultural material e imaterial". Situações estas que a ciência não conseguiria explicar. A autora ainda enfatiza que:

O patrimônio imaterial é representado e catalogado através de saberes, crenças, práticas, e modos de fazer, originados a partir da prática cotidiana de uma determinada comunidade. O patrimônio imaterial é representado pelos conhecimentos resultantes da experiência cotidiana do senso comum, ou seja, são conhecimentos que são praticados e reproduzidos sem a necessidade de um contato prévio com o saber científico. Estes saberes pertencentes ao campo do senso comum são vivenciados, experienciados, e transmitidos de gerações em gerações, e durante toda a vida por um determinado grupo.

Finalizando sua pesquisa, Figueira Neto, Macêdo e Rosa (2010) concluem em seu texto a necessidade e importância da união desses dois saberes:

A ciência possui métodos e sistemas próprios, cujo objeto é uma natureza viva e dinâmica, diga-se cada vez mais viva e mais dinâmica com a pós modernidade, caracterizada pela acentuação da complexidade, do risco e da produção da diversidade em contraposição a racionalidade, ao consenso e a certeza, e por isso deve aliar-se inclusive ao senso comum buscando não uma única resposta absoluta, mas respostas menos obscuras e que levem em consideração o todo e ao mesmo tempo as singularidades e fragmentações.

Sousa (2006) finalizou sua pesquisa afirmando que:

Nossa pretensão foi colocar o conhecimento científico no lugar dele, considerando que ele não é a única forma de se conhecer a realidade do mundo e nem mesmo é o mais "verdadeiro". O conhecimento científico atende a uma demanda das sociedades contemporâneas que necessitam 
ampliar o conhecimento sobre a natureza, sobre o homem e sobre a vida em sociedade. Nesse sentido, submete-se a um rigor maior do que os outros conhecimentos. Contudo, esse rigor metodológico não é sinônimo de infalibilidade.

E por fim, Silva (2011) conclui que: Enfim, a ciência e o senso comum podem trazer no campo do patrimônio cultural muito mais que sua compreensão, tem também a função de se constituírem como vetores do desenvolvimento.

Como visto, todos os autores aqui apresentados defendem a relevância do senso comum, pois mesmo com todas as falhas quanto ao seu modelo metodológico o senso comum apresenta verdades indubitáveis e conclusões que, em diversos casos, podem ser comprovados cientificamente.

Além disso, os autores argumentam que o senso comum e baseado no conhecimento popular e que as verdades por ele produzidas servem, mesmo quando não comprovadas cientificamente, para a elucidação de dúvidas e inquietações da população menos esclarecidas, ressaltando que a verdade está relacionada com a fé (credibilidade) depositada na informação, e não apenas na comprovação cientifica.

\section{CONSIDERAÇÕES FINAIS}

Foi possível observar, atrás deste ensaio teórico, a importância do senso comum em conjunto ou separado do conhecimento científico. Todos os autores aqui estudados ressaltam a importância e a valorização do conhecimento popular ao longo da historio e nos dias atuais.

Conclui-se que a Ciência e os conhecimentos que dela deriva são de extrema relevância e necessidade para a humanidade, todavia, não podemos negar também o valor que há no senso comum e nas ideologias de outras formas de saberes.

Este estudo deixa claro que o senso comum e o conhecimento científico estão e são indissociáveis, sendo um complemento do outro; e muitas vezes a indagação/explicação que o ou outro necessita.

Por fim, considera-se, com base nas análises aqui obtidas, que o senso comum é indispensável ao mundo científico e que o mesmo não deveria ser rebaixado como muitos cientistas o fazem, e sim, compreendido, para que o conhecimento científico e o senso comum possam unir foças em busca de novos saberes. 


\section{REFERÊNCIAS}

FIGUEIREDO NETO, Manoel Valente; MACÊDO, Andreya Lorena Santos; ROSA, Lúcia Cristina dos Santos. A aproximação entre a ciência e o senso comum: A ciência ensinada e a ciência em si. In: Âmbito Jurídico, Rio Grande, XIII, n. 77, jun 2010. Disponível em: <http://www.ambito-juridico.com.br/site/index. php?n_link=revista_artigos_leitura\&artigo_id=7875>. Acesso em 05 de março 2017.

SILVA, Sandra Siqueira da. A relação entre ciência e senso comum. Revista Digital Porto Urbe, $\mathrm{n}^{\circ}$ 9, 2011. Disponível em: < https://pontourbe.revues.org/359>. Acesso em 05 de março 2017.

SOUSA, Janara. As sete teses equivocadas sobre conhecimento científico: reflexões epistemológicas. In: Ensaio; Periódico eletrônico em Psicológica; Revista Ciência e consignação, vol.8. Rio de Janeiro, 2006. Disponível em: < http://pepsic.bvsalud.org/scielo.php?script=sci_arttext\&pid=S1806-58212006 000200015\&lng=pt\&nrm=iso >. Acesso em 05 de março 2017. 


\title{
CAPÍTULO XXXIII
}

\section{DIREITO AO VOTO: A PARTICIPAÇÃO FEMININA NA VIDA POLÍTICA DO NOSSO PAÍS}

\author{
Caroline Rodrigues de Freitas Fernandes ${ }^{114}$. \\ DOI-Capítulo: 10.47538/AC-2021.14-33
}

\begin{abstract}
RESUMO: O sufrágio universal é primordial para a plenitude da democracia representativa, visto ser o meio pelo qual é exercida soberania popular. O voto é o que legitima o exercício do poder pelos governantes. Para que os direitos políticos fossem estendidos às mulheres, foram necessárias décadas de lutas, articulações feministas e intensos debates políticos. Nesse contexto, este trabalho tem o objetivo de compreender a luta pelo sufrágio feminino no Brasil, levando em conta os aspectos históricos, sociais e legais desse processo, bem como contextualizar o movimento brasileiro em relação à luta sufragista de outros países. A metodologia empregada é a de pesquisa bibliográfica e os dados secundários, retirados da literatura existente sobre a temática.
\end{abstract}

PALAVRAS-CHAVE: Sufrágio. Voto feminino. Igualdade.

\section{RIGHT TO VOTE: FEMALE PARTICIPATION IN THE POLITICAL LIFE OF OUR COUNTRY}

ABSTRACT: Universal suffrage is essential for the fullness of representative democracy, as it is the means by which popular sovereignty is exercised. The vote is what legitimizes the exercise of power by rulers. For political rights to be extended to women, decades of struggles, feminist articulations and intense political debates were necessary. In this context, this work aims to understand the struggle for women's suffrage in Brazil, taking into account the historical, social and legal aspects of this process, as well as contextualizing the Brazilian movement in relation to the suffrage struggle in other countries. The methodology used is that of bibliographic research and secondary data, taken from the existing literature on the subject.

KEYWORDS: Suffrage. Female vote. Equality.

\section{INTRODUÇÃO}

Quem acompanha a importância da luta das mulheres por direitos e o quanto essa discussão tem espaço nos dias atuais muitas vezes não imagina quão recentes são algumas das conquistas para o gênero feminino do ponto de vista histórico. Há apenas 88 anos, as mulheres nem sequer participavam da vida política do país, uma vez que eram proibidas

\footnotetext{
114Pós-Graduada em Mídias na Educação (UERN). Docente no Município de Macau/RN. Orcid: https://orcid.org/0000-0002-9198-6746. Lattes: http://lattes.cnpq.br/5956672837215695. E-mail: caroline_brum2005@hotmail.com.
} 
de votar. Somente em 24 de fevereiro de 1932, o Código Eleitoral passou a assegurar o voto feminino. E em 1934, o voto feminino passou a ser previsto na Constituição Federal.

Esse cenário não era exclusividade do Brasil. Na França, por exemplo, o voto feminino se tornou realidade em 1944 e, na Suíça, em 1971. No Brasil, no entanto, a bandeira das mulheres pelo direito de votar e de serem votadas teve início décadas antes, pelo menos desde 1891, quando foi apresentada proposta de emenda à Constituição brasileira que trazia essa prerrogativa. A proposta, contudo, foi rejeitada.

O tema ganhou ainda mais força no início do século XX, a partir da militância política feminina na Grã-Bretanha e nos Estados Unidos. Essa atuação organizada e estratégica inspirou outras mulheres no mundo todo. A internacionalização do movimento, conhecido como sufragista, favoreceu a conquista do voto feminino em diversos países.

Apesar dos avanços, a luta das mulheres por igualdade de direitos ainda é atual e se reflete nos espaços de poder, onde os homens ainda ocupam a maioria absoluta dos cargos. Elas representam quase 53\% de todo o eleitorado brasileiro, mas, ainda assim, são a minoria nos cargos eletivos.

A legislação eleitoral e a jurisprudência dos tribunais têm contribuído para mudar esse cenário, ainda que lentamente. Nesse sentido, alterações legislativas foram necessárias para deixar explícito aos partidos que é obrigatório o preenchimento de $30 \%$ e o máximo de $70 \%$ de candidatos de cada sexo. Antes, a regra era tida apenas como uma orientação, e, dessa forma, os partidos não se empenhavam para preencher as vagas com candidatas mulheres.

\section{HISTÓRIA DO VOTO FEMININO NO BRASIL}

$\mathrm{O}$ início do século XX foi marcado pelo surgimento de grupos organizados voltados para a reivindicação de direitos de mulheres em vários países da América Latina. O debate sobre o sufrágio feminino ganha força em vários países, motivando a criação de vários movimentos em diferentes países, como Argentina, Colômbia, Panamá, México e Chile. 
Neste aspecto podemos perceber que o Brasil esteve adiantado nos debates sobre o assunto entre seus países vizinhos. Visto que enquanto o início das discussões feministas da maior parte dos países latino-americanos ocorreu nas primeiras décadas do século XX, veremos que, no Brasil, essa questão já foi suscitada no século XIX.

O marco inicial das discussões parlamentares em torno do direito do voto feminino são os debates que antecederam a Constituição de 1824, outorgada por D. Pedro I. Essa Constituição não trazia qualquer impedimento ao exercício dos direitos políticos por mulheres, mas, por outro lado, também não era explícita quanto à possibilidade desse exercício.

A pesquisadora uruguaia María Laura Osta Vázquez, relata que ainda no Império foi elaborado um projeto de lei sobre direitos políticos das mulheres, datado de 1821, de autoria do deputado baiano Domingos Borges de Barros, apresentado nas Cortes de Lisboa. Segundo a pesquisadora, embora o projeto de lei em si não tenha sido encontrado em arquivos brasileiros ou portugueses, há referência a ele em três documentos: em um Parecer da Comissão de Legislação do Senado (de 12 de novembro de 1927); na obra "A reforma eleitoral" (1931), do jornalista Othelo Rosa; e em livro do próprio deputado, intitulado "Poesias oferecidas às mulheres brasileiras por um baiano" (1825).

Assim, vemos que a discussão sobre direitos políticos e civis das mulheres já havia sido suscitada em 1821, mesmo que provocada por um homem.

As ações das feministas, voltadas para conquistas de direitos políticos para a mulher, intensificaram-se em torno de 1918, quando Berta Lutz e um grupo de colaboradoras criaram, no Rio de Janeiro, uma organização chamada Liga para Emancipação Intelectual da Mulher, que, posteriormente, passou a denominar-se Liga pelo Progresso Feminino.

Em 1919, o senador Justo Chermont apresentou projeto de lei estendendo o direito de voto às mulheres, não conseguindo, porém, sua aprovação. Em 1922, devido a novas estratégias de luta, a Federação das Ligas pelo Progresso Feminino converteu-se na Federação Brasileira para o Progresso Feminino, que, neste mesmo ano, organizou o I Congresso Internacional Feminista, no Rio de Janeiro. 
Além do voto, as outras reivindicações eram igualdade entre os sexos e independência da mulher. Em 1932, Bertha foi uma das duas mulheres nomeadas para integrar a comissão para elaborar o anteprojeto da nova Constituição - a outra foi a advogada Natércia da Cunha Silveira (1905 - 1993). Em 1936, Bertha (que era suplente) assumiu o mandato na Câmara dos Deputados.

Deve-se salientar que a campanha pelo sufrágio feminino no Brasil não esteve ligada a nenhum partido político ou a qualquer outro movimento social, que não o liderado por Bertha Lutz.

Em 1831, ainda no Império, durante o período de Regências (após a abdicação de d. Pedro I), o assunto voltou a ser discutido na Assembleia Geral Legislativa. Nesse ano, os deputados José Bonifácio de Andrada e Silva e Manuel Alves Branco apresentaram um projeto de reformulação do sistema eleitoral, que previa o voto feminino em eleições locais.

Em 1930, Getúlio Vargas subiu ao poder e o regime provisório anunciou a decisão de criar um novo código eleitoral. O anteprojeto do código, liberado em 1931 pelo governo, contemplava o voto feminino, mas de forma limitada:

art. 7o - É eleitor todo cidadão de 21 anos, ou que tenha, por disposição da Lei civil, adquirido já a maioridade e que, não incorrendo em nenhuma das proibições do art. 11, se achar alistado no Registro Cívico. art. 80 - São admitidos a inscrever-se eleitoras, desde que preencham as demais condições legais: a) mulher solteira sui juris, que tenha economia própria e viva de seu trabalho honesto ou do que lhe rendam bens, empregos ou qualquer outra fonte de renda lícita; b) viúva em iguais condições; c) a mulher casada, que exerça efetivamente o comércio ou indústria por conta própria ou como chefe, gerente, empregada, ou simples operária de estabelecimento comercial ou industrial, e bem assim que exerça efetivamente qualquer lícita profissão, com escritório, consultório ou estabelecimento próprio ou em que tenha funções, devidamente autorizada pelo marido, na forma da lei civil. art. 9o - Ainda são alistáveis, nas condições do art. antecedente: a) a mulher separada por desquite amigável ou judicial, enquanto durar a separação; b) aquela que, em consequência da declaração judicial da ausência do marido, estiver testa dos bens do casal, ou na direção da família; c) aquela que foi deixada pelo marido durante mais de dois anos, embora esteja este em lugar sabido.

Assim, o Governo Vargas liberou um Código Provisório que concedia voto limitado às mulheres, ou seja, apenas a determinados grupos de mulheres. Neste somente as mulheres solteiras ou viúvas com renda próprias e casadas com a permissão dos 
maridos podiam votar. Mas, os grupos feministas protestaram e promoveram uma campanha para remoção das restrições antes que o mesmo fosse adotado.

Como se pode notar, os constituintes que defendiam o sufrágio feminino apoiavam a concessão do direito de voto apenas a determinadas mulheres e sempre de forma condicionada, principalmente à profissão e/ou ao estado civil, mas não de forma ampla.

Mas foi somente em 1932 que as mulheres obtiveram o direito de votar, o que veio a se concretizar nas eleições do ano seguinte. Isso ocorreu a partir da aprovação do Código Eleitoral de 1932, que, além dessa e de outras conquistas, instituiu a Justiça Eleitoral, que passou a regulamentar as eleições no País.

O artigo $2^{\circ}$ do Código Eleitoral continha a seguinte redação: "É eleitor o cidadão maior de 21 anos, sem distinção de sexo, alistado na forma deste Código". A aprovação do Código de 1932 deu-se por meio do Decreto n 21.076, durante o Governo Provisório de Getúlio Vargas.

Somente dois anos depois, em 1934, quando da inauguração de um novo Estado Democrático de Direito, por meio da segunda Constituição da República, esses direitos políticos conferidos às mulheres foram assentados em bases constitucionais. No entanto, a nova Constituição restringiu a votação feminina às mulheres que exerciam função pública remunerada.

Em 1910, foi fundado o Partido Republicano Feminino (PRF), presidido por Leolinda de Figueiredo Daltro. Leolinda Daltro, professora, se dirigia principalmente a outras professoras e a mulheres de classe média, e tinha como um de seus principais pleitos que os cargos públicos fossem abertos a todos os brasileiros, independentemente de sexo.134 Ela foi extremamente importante nos primeiros passos para um movimento feminista organizado no Brasil e para que a discussão sobre a emancipação feminina fosse difundida mais amplamente na sociedade.

O voto secreto garantia o livre exercício desse direito pelas mulheres: elas não precisariam prestar contas sobre seu voto aos maridos e pais. No entanto, somente as mulheres que trabalhavam (aquelas que recebiam alguma remuneração) eram obrigadas 
a votar. Isso só mudou em 1965, com a edição do Código Eleitoral que vigora até os dias de hoje.

Em 1937, com o golpe do Estado Novo, o Poder Legislativo foi extinto por quase 10 anos e os direitos políticos das mulheres novamente perderam força. Somente em 1945, com a volta da Democracia, que o avanço em prol dos direitos femininos continuou a ocorrer (RIBEIRO, 2004). A Constituição de 1946 concedeu novamente o direito de voto às mulheres e reconheceu a obrigatoriedade tanto para os homens quanto para as mulheres:

Artigo 131: São eleitores os brasileiros maiores de dezoito anos que se alistarem na forma da lei. Artigo 133: O alistamento e o voto são obrigatórios para os brasileiros de ambos os sexos, salvo as exceções previstas em lei. Artigo 134: O sufrágio é universal e direto; o voto é secreto; e fica assegurada a representação proporcional dos Partidos Políticos nacionais, na forma que a lei estabelecer (BRASIL, 1946).

Entretanto, em 1964, com o Golpe Militar e os atos institucionais outorgados por Castelo Branco em 1967 e pela Junta Militar em 1969, as mulheres novamente foram oprimidas. Foi somente com a abertura democrática da década de 80 que voltaram a ganhar espaço no contexto político. Com a promulgação da Constituição Federal de 1988, a igualdade em direitos e obrigações foi reconhecida para ambos os sexos, vedando distinção de qualquer natureza.

Art. 14. A soberania popular será exercida pelo sufrágio universal e pelo voto direto e secreto, com valor igual para todos, e, nos termos da lei (...). § $1^{\circ}$ - O alistamento eleitoral e o voto são: I - obrigatórios para os maiores de dezoito anos; II - facultativos para: a) os analfabetos; b) os maiores de setenta anos; c) os maiores de dezesseis e menores de dezoito anos (BRASIL, 1988).

$\mathrm{O}$ voto se tornou direto e secreto, com valor igual para todos, e obrigatório aos maiores de dezoito anos, porém facultativo aos maiores de setenta anos, aos analfabetos, e aos maiores de dezesseis e menores de dezoito anos.

Em 1985, outra barreira foi superada em relação aos direitos políticos das mulheres: o voto do analfabeto. Segundo dados do Instituto Brasileiro de Geografia e Estatística (IBGE), na década de 1980, 27,1\% das mulheres adultas eram analfabetas.

Depois de muitos anos de luta em função de adquirir seus direitos não apenas como eleitoras, mas também como cidadãs que participam de cargos políticos, as mulheres, atualmente, têm uma participação inquestionavelmente necessária na política 
do Brasil. Como se deu essa transição até os dias atuais é o que procuramos esclarecer neste trabalho, mostrando os principais fatores e pessoas que aderiram a causa e fizeram diferença para a modificação dos direitos das mulheres.

\section{A PARTICIPAÇÃO FEMININA DO RIO GRANDE DO NORTE NA HISTÓRIA DO VOTO}

Coube às mulheres do Rio Grande do Norte, o pioneirismo na conquista do direito de voto, onde ainda em 1927, o Rio Grande do Norte incluiu em sua Constituição Estadual, um artigo permitindo o voto feminino, que fez com que a mobilização para o sufrágio feminino se intensificasse ainda mais. Portanto, foi primeiro Estado brasileiro a conceder o voto às mulheres.

Em 25 de outubro de 1927, o movimento sufragista no Brasil alcançou sua primeira vitória: o reconhecimento do alistamento eleitoral feminino no estado do Rio Grande do Norte. O governador do estado na época - José Augusto Bezerra de Medeiros - sancionou a lei $n^{\circ} 660$, que determinou que pudessem votar e ser votados, sem distinção de sexo, todos os cidadãos que reunissem as condições exigidas.

Em 1927, o candidato ao governo do Rio Grande do Norte Juvenal Lamartine de Faria incluiu em sua plataforma a promessa de direitos políticos plenos às mulheres. Expressou "o desejo de contar com o concurso da mulher "não só na escolha daqueles que veem representar o povo" como também "entre os que elaboram e votam a lei que tiver de aplicar".

Defendia, portanto, o direito das mulheres de votar e ser votadas. No mesmo ano, foi elaborada a lei eleitoral do estado do Rio Grande do Norte, e Juvenal Lamartine solicitou a José Augusto Bezerra, então governador do estado, que incluísse emenda conferindo direito de voto às mulheres. Com isso, foi incluído o seguinte texto nas Disposições Transitórias da lei: “Art. 17 - No Rio Grande do Norte, poderão votar e ser votados, sem distinção de sexos, todos os cidadãos que reunirem as condições exigidas por esta lei".

Desse modo, o Rio Grande do Norte foi o primeiro Estado brasileiro a aprovar o sufrágio feminino. Com base nesse dispositivo, a professora Celina Guimarães Viana alistou-se como eleitora, obtendo decisão judicial que determinava sua inclusão na lista 
geral dos eleitores. O livro "Os Direitos Políticos da Mulher (Despachos)”, editado em

Natal em 1928, reúne decisões judiciais de três processos da Justiça do Rio Grande do Norte, que deferiram o pedido de inclusão no alistamento eleitoral de determinados municípios do referido estado a Julia Alves Barbosa, Maria de Lourdes Lamartine e Marta de Medeiros, todas professoras.

Celina Guimarães Viana, professora, foi a primeira eleitora a se registrar no Brasil e na América do Sul. Em 25 de novembro de 1927, aos 29 anos de idade, ela fez um requerimento para obter registro como eleitora da cidade de Mossoró (RN). Diversas mulheres e registraram no Rio Grande do Norte e votaram nas eleições municiais do dia 5 de abril de 1928, mas os votos foram anulados porque o Senado não reconheceu o direito de voto das mulheres. Mesmo assim, o movimento sufragista do Rio Grande do Norte ganhou repercussão internacional e entrou para a história.

\section{CONSIDERAÇÕES FINAIS}

A conquista do voto feminino representou, no Brasil e em outras democracias do mundo, um passo primordial na luta de mulheres por direitos políticos e de igualdade de gênero. Significou a reivindicação da participação no processo de tomada de decisão pública, espaço tradicionalmente ocupado apenas pelo sexo masculino.

As mulheres, como todos os cidadãos, também são sofrem as consequências das decisões tomadas pelos representantes do povo, no entanto, apesar disso, por muito tempo, não tinham voz no processo de escolha de tais representantes. Havia um grande desequilíbrio entre os direitos de homens e mulheres, pois apenas os homens tinham o direito de eleger aqueles que tomariam as decisões por todos.

A luta pelo direito ao sufrágio feminino se originou da conscientização das mulheres de sua situação de exclusão da vida política e social, e também de sujeição em relação aos homens. As sufragistas exigiam lugar no espaço público e no processo decisório democrático, como forma de conquistarem outros direitos, mas tudo isso só seria possível a partir do momento em que fossem ouvidas pelos governantes.

A conquista do sufrágio feminino foi essencial na luta por igualdade de direitos, sendo um relevante tema de estudo que, inclusive, nos permite realizar reflexões sobre a 
sociedade patriarcal em que vivemos, reflexões essas que continuam atuais mesmo em pleno século XXI.

\section{REFERÊNCIAS}

BRASIL, Constituição da República dos Estados Unidos do Brasil. Rio de Janeiro, 24 de fevereiro de 1891. Disponível em http://www.planalto.gov.br/. Acesso em $28 / 10 / 2021$

BRASIL, Constituição da República dos Estados Unidos do Brasil. Rio de Janeiro, 16 de julho de 1934. Disponível em http://www.planalto.gov.br/ . Acesso em $28 / 10 / 2021$

BRASIL, Constituição da República dos Estados Unidos do Brasil. Rio de Janeiro, 18 de setembro de 1946. Disponível em http://www.planalto.gov.br/ . Acesso em $28 / 10 / 2021$

BRASIL. Decreto no 21.076 de 24 de fevereiro de 1932. Disponível em http://www2.camara.leg.br/legin/fed/decret/1930-1939/decreto-21076-24-fevereiro1932-507583-publicacaooriginal-1-pe.html. Acesso em 26/10/2021

BRASIL, Constituição da República Federativa do Brasil. Brasília, 5 de outubro de 1988. Disponível em http://www.planalto.gov.br/. Acesso em 28/10/2021

BRASIL, Constituição Política do Império do Brazil. Rio de Janeiro, 25 de março de 1824. Disponível em http://www.planalto.gov.br/. Acesso em 28/10/2021

OSTA VÁZQUEZ, María Laura. Discussões feministas no século XIX. Revista NUPEM, v. 6, n. 11, p. 23-38, 2014. Disponível em < http://www.fecilcam.br/revista/index.php/nupem/article/viewFile/547/324>. Acesso em $30 / 10 / 2021$

Série Inclusão: a conquista do voto feminino no Brasil. Disponível em http://www.tse.jus.br/imprensa/noticias-tse/2013/Abril/serie-inclusao-a-conquista-dovoto-feminino-no-brasil. Acesso em 30/10/2021

Os Direitos Políticos da Mulher (Despachos). Natal: Edição da Imprensa Oficial, 1928. 30p. Disponível em http://www.stf.jus.br/bibliotecadigital/DominioPublico/45051/pdf/45051.pdf. Acesso em 30/10/2021 


\title{
CAPÍTULO XXXIV
}

\section{AULAS DE CIÊNCIAS NATURAIS: UTILIZAÇÃO DAS REDES SOCIAIS COMO ESPAÇO DE ENSINO-APRENDIZAGEM}

\author{
Dayana Lúcia Rodrigues de Freitas ${ }^{115}$. \\ DOI -Capítulo: 10.47538/AC-2021.14-34
}

RESUMO: Este trabalho trata da importância das tecnologias da comunicação visando sua incorporação no cotidiano da sala de aula, contribuindo para o processo de ensinoaprendizagem com o mundo virtual, através do uso das tecnologias pelo professor; como forma de tratar os conhecimentos atrativamente, despertando a curiosidade e interesse dos alunos. Tem como objetivo geral: Identificar possíveis metodologias para o ensino de ciências através do uso das redes sociais. E objetivos específicos são: Reconhecer, através dos alunos, as necessidades de implantação do uso das redes sociais no ensino de ciências; Apresentar estratégias com uso das TICs, que possam efetivamente ser utilizadas na escola; Ampliar as formas de processo de ensino-aprendizagem para a disciplina de ciências na escola. O público-alvo foram os alunos da Escola Municipal Professora Maria Madalena da Silva, localizada no distrito de Baixa do Meio (Guamaré/RN). Sendo entrevistados 40 alunos, formando assim um grupo amostral, 10 estudantes de cada série do ensino fundamental II ( $6^{\circ}$ ano, $7^{\circ}$ ano, $8^{\circ}$ ano e $9^{\circ}$ ano). À coleta dos dados, se deu através de entrevista estruturada realizada individualmente com os alunos, dentro da própria escola, contendo 10 perguntas subjetivas. Conclui-se que o uso das tecnologias e das redes sócias pelo professor como forma de extensão do conhecimento pode ser benéfico e atrair a curiosidade e o interesse dos alunos. Desta forma, os docentes devem investir nesse tipo de tecnologia para melhorar e ampliar o processo de ensinoaprendizagem.

PALAVRAS-CHAVE: Redes sociais. Ensino-aprendizagem. Ciências naturais.

\section{NATURAL SCIENCE CLASSES: USE OF SOCIAL NETWORKS AS A SPACE FOR TEACHING-LEARNING}

ABSTRACT: This work deals with the importance of communication technologies aiming at their incorporation in the daily life of the classroom, contributing to the teaching-learning process with the virtual world, through the use of technologies by the teacher; as a way of treating knowledge attractively, arousing students' curiosity and interest. Its general objective is to: Identify possible methodologies for teaching science through the use of social networks. And specific objectives are: Recognize, through students, the needs to implement the use of social networks in science education; Presenting strategies using ICTs, which can be effectively used at school; Expand the forms of teaching-learning process for the discipline of science at school. The target audience were students from the Professora Maria Madalena da Silva Municipal School,

115 Doutoranda em Ciências da Educação (CECAP). Docente nos Município de Macau/RN e Guamaré/RN. Orcid: https://orcid.org/0000-0001-5355-3547. Lattes: http://lattes.cnpq.br/5122671799874415.

E-mail: dayannaproducoes@gmail.com. 
located in the district of Baixa do Meio (Guamaré/RN). 40 students were interviewed, thus forming a sample group, 10 students from each grade of elementary school II (6th year, 7th year, 8th year and 9th year). Data collection was carried out through structured interviews carried out individually with students, within the school itself, containing 10 subjective questions. It is concluded that the use of technologies and social networks by the teacher as a way of extending knowledge can be beneficial and attract students' curiosity and interest. Thus, teachers must invest in this type of technology to improve and expand the teaching-learning process.

KEYWORDS: Social networks. Teaching-learning. Natural Sciences.

\section{INTRODUÇÃO}

A história da educação no Brasil percorreu diversos caminhos para chegar ao atual contexto educacional. Durante sua caminhada, a conquista da Lei de Diretrizes e Bases da Educação Nacional (Lei $n^{\circ}$ 9394/96) foi um dos maiores destaques para o desenvolvimento do progresso da educação, o que possibilitou várias mudanças positivas nessa área, proporcionada por diversos fatores, que contemplam transformações em todas as áreas do conhecimento e nos processos de ensino e aprendizagem de todos os níveis educacionais. Ações realizadas neste âmbito podem trazer benefício para a população, com estímulos para a capacitação do discernimento, da reflexão e criticidade, configurando as políticas educacionais dessas práticas como importantes instrumentos de mudanças sociais (LEÃO, 2005).

O sistema educacional, em nível mundial e nível nacional, está passando por diversas modificações no que diz respeito à implantação das novas tecnologias, sendo mais visíveis essas transformações nos últimos 10 (dez) anos (SERAFIM; SOUZA, 2011). Sabendo que os alunos são oriundos de uma sociedade com uma gama variada de tecnologia, como televisão, o rádio, o cinema e a internet; cabe às escolas se adequarem a esse novo sujeito tecnológico (JUCIEUDE et.al., 2016).

São inegáveis os avanços tecnológicos já ocorridos no ambiente escolar, contudo, muitas instituições ainda enxergam os meios de comunicação pelo aspecto técnico e não pelo aspecto cultural. Se ao entrar na escola o aluno já se encontra culturalmente inserido no universo midiático, como pode a mesma negar a cultura veiculado pelos meios de comunicação em massa?! (JUCIEUDE et.al., 2016). Desta forma, só restam aos sistemas educacionais à imersão definitiva na era tecnológica, dinamizando os processos de ensino-aprendizagem (SERAFIM; SOUZA, 2011). 
Com a ampliação e consolidação da era digital os professores devem mudar seus hábitos e incorporar o das tecnologias da informação no cotidiano de suas aulas. Desta forma $\mathrm{O}$ presente trabalho tem como objetivo analisar a inclusão das novas tecnologias sob a ótica educativa, bem como analisar a utilização das redes sociais como um canal educativo para os jovens, visto que os mesmos estão inseridos no mundo digital.

Este trabalho se justifica pela importância do estudo sobre as tecnologias da comunicação visando à incorporação dessas tecnologias no cotidiano da sala de aula, contribuindo para o processo de ensino-aprendizagem de uma sociedade conectada com o mundo virtual, através do uso das tecnologias e das redes sociais pelo professor como forma de extensão do conhecimento pode ser benéfico e atrair a curiosidade e o interesse dos alunos.

Sendo assim, este trabalho tem como objetivo geral: Identificar possíveis metodologias para o ensino de ciências através do uso das redes sociais. E seus objetivos específicos são: Reconhecer, através dos alunos, as necessidades de implantação do uso das redes sociais no ensino de ciências; Apresentar estratégias com uso das TICs, que possam efetivamente ser utilizadas na escola; Ampliar as formas de processo de ensinoaprendizagem para a disciplina de ciências na escola.

\section{A ESCOLA E A TECNOLOGIA}

A tecnologia já se encontra inserida na sociedade, contudo, entre os vários impasses que permeiam a implantação e o desenvolvimento das tecnologias dentro da escola está o fato da capacitação dos professores não acompanharem o mesmo ritmo dos avanços tecnológicos, resultando no uso inadequado dos recursos ou da não utilização dos mesmos (SERAFIM; SOUZA, 2011). Ainda segundo os autores é fundamental que o docente esteja apto a incluir as tecnologias digitais da informação e da comunicação em sua prática pedagógica.

Dentre as diversas possibilidades tecnológicas existentes hoje, o professor pode fazer uso das redes sócias como recurso didático para suas aulas, esta ferramenta é muito comum aos jovens de todo o mundo. Segundo Juliane et. al. (2012, p. 02), o termo redes sociais" significa: 
Ferramentas tecnológicas que permitem com que os relacionamentos sociais ocorram virtualmente, sem desconsiderar os indivíduos que as manipulam. São exemplos dessas ferramentas: MySpace, Twiter, Facebook, Orkut, Ebah, LinkIn, Google+, dentre outros.

Quanto às políticas públicas para a instalação das tecnologias na escola, bem como para a formação complementar dos professores, pode-se citar o programa Proinfo, implantando em todas as escolas públicas do país. Contudo, somente a instalação dos computadores não foi suficiente para uma mudança definitiva na prática pedagógica, a forma como o professor utiliza os recursos tecnológicos está ligada a sua relação de transformação, sendo uma percepção individual de como o mesmo se sente frente a esse processo (SERAFIM; SOUZA, 2011).

É importante ressaltar que o uso das tecnologias não altera a essência da relação pedagógica, uma vez que serve tanto para uma pedagogia conservadora quanto progressista (MORAN, 1995). Já que a comunicação e a escola não se separam, o professor deve utilizar a tecnologia "visando à transformação da informação em conhecimento" (SERAFIM; SOUZA, 2011). Entende-se que mesmo diante de tantos avanços, a tecnologia não substitui o professor, apenas transforma sua relação com o aluno; uma vez que as informações estão disponíveis por toda a parte (bancos de dados, livros, vídeos, programas em $\mathrm{CD}$, etc.) o docente passa a ter um papel de incentivador à curiosidade, orientando esse conhecimento e mediando o processo de ensino-aprendizado (MORAN, 1995).

A integração da escola com os meios multimídias proporciona diversos benefícios, segundo Serafim e Souza (2011, p. 22) esses benefícios são:

A dinamização e ampliação das habilidades cognitivas, devido à riqueza de objetos e sujeitos com os quais permitem interagir; a possibilidade de extensão da memória e de atuação em rede; ocorre a democratização de espaços e ferramentas, pois estas facilitam o compartilhamento de saberes, a vivência colaborativa, a Autoria, coautoria, edição e a publicação de informações, mensagens, obras e produções culturais tanto de docentes como discentes.

Apesar dos inegáveis benefícios quanto ao uso das tecnologias, muitas escolas não enxergam esse potencial, pois compreendem as mídias como improprias devido seu conteúdo de entretenimento (JUCIEUDE et al., 2016). 
Com os avanços tecnológicos pode-se perceber uma mudança dos "sistemas analógicos de produção e transmissão para os digitais". Os computadores antes utilizados apenas por grandes instituições agora encontram-se por toda parte, podendo ser utilizado como instrumento de trabalho, de comunicação e de lazer (MORAN, 1995). Nesse cenário as redes sociais ganham destaque, devido seu caráter de comunicação rápida e entretenimento.

Com tantas formas de comunicação, real e virtual, a língua apresenta diversas variedades. Segundo Souza (2018) “a Variação linguística é representada pela caracterização dos muitos modos de falar uma língua”. Onde cada variedade pode ser utilizada para uma comunicação ou meio social específico. Com relação à comunicação nas redes sociais, a autora fala:

O reconhecimento ou o não de determinadas práticas de escrita nas redes sociais faz com que o cidadão construa a imagem do senso comum, a imagem de transformação da linguagem, com consequente degradação da língua? Ao considerar a inserção do tema no campo de estudo das Ciências da Linguagem, a Comunicação Social e a Educação, se faz necessária uma visão discursiva no que se concebe a escrita como fonetizada, transcrição ou interferência da fala. E portanto, veicular a problematização do fenômeno do internetês no âmbito de uma avaliação distinta (SOUZA, 2018, p. 8).

Com todas essas mudanças e adaptações na comunicação, a escola não pode desconsiderar a variação linguística, pois seu uso é comum tanto na sociedade como na sala de aula. Desta forma, "as práticas de linguagem a serem tomadas no espaço da escola não se restringem à palavra escrita nem se filiam apenas aos padrões socioculturais hegemônicos" (SOUZA, 2018). Além disso, as escolas devem se apropriar do uso das redes sociais como espaço de aprendizagem, tornando mais atraente o processo de ensino aprendizagem.

Com tanta tecnologia, é possível o renascimento do encantamento da escola, ao expandir suas fronteiras e permitir que o estudante converse e pesquise com outros alunos, proporcionando a integração de conhecimentos da mesma cidade, país ou do exterior. Segundo Moran (1995, p. 6):

Alunos e professores encontram inúmeras bibliotecas eletrônicas, revistas online, com muitos textos, imagens e sons, que facilitam 
a tarefa de preparar as aulas, fazer trabalhos de pesquisa e ter materiais atraentes para apresentação. $O$ professor pode estar mais próximo do aluno. Pode receber mensagens com dúvidas, pode passar informações complementares para determinados alunos. Pode adaptar a sua aula para o ritmo de cada aluno. Pode procurar ajuda em outros colegas sobre problemas que surgem, novos programas para a sua área de conhecimento. $\mathrm{O}$ processo de ensino-aprendizagem pode ganhar assim um dinamismo, inovação e poder de comunicação inusitados.

Jucieude et.al. (2016) apontam que os meios de comunicação desempenham um papel socializador e formativo relevante, pois atuam como agentes de informação e entretenimento em todas as instancias da sociedade, como a família, a escola e a igreja. Portanto, entende-se que existem muitos ambientes de aprendizagem fora da sala de aula, que podem ocorrer através de espaços virtuais e do uso das redes sociais (SERAFIM; SOUZA, 2011).

Desta forma, cabem as escolas e ao professor a inclusão e afirmação das redes sociais como meio possível para a aprendizagem de uma sociedade altamente tecnológica e digital. Por vivermos em um mundo onde a tecnologia se faz presente em todas as áreas da nossa vida, modificando desde os aparelhos eletrônicos até mesmo as relações interpessoais e relacionamentos afetivos (MORAN, 1995). Segundo Kroetz, Ballejo e Lara (2015; p.08) o uso das redes sócias para as aulas de Ciências traz novas perspectivas, tais como:

Aulas que permitam um estudante mais ativo, com espaços para diálogos e socializações possibilitam que o estudante se sinta mais participante na construção do seu conhecimento. Além disso, se os saberes que ele possui puderem ser socializados e articulados aos conhecimentos da sala de aula, o estudante se sentirá mais valorizado e motivado a aprender.

Tais mudanças ocorridas na sociedade a partir do uso da tecnologia da informação faz-se necessário uma mudança nas instituições educacionais, não sendo mais aceito que a escola não se adeque a essa nova realidade digital, sendo necessária essa mudança para a "sobrevivência" das instituições de ensino (SERAFIM; SOUZA, 2011).

\section{METODOLOGIA}

A presente pesquisa tem natureza exploratória, que segundo Gil (2007, p. 27) é um tipo de pesquisa que tem como principal finalidade "desenvolver, esclarecer e 
modificar conceitos e ideias, tendo em vista a formulação de problemas mais precisos ou hipóteses pesquisáveis para estudos posteriores". Possui caráter descritivo, identificada por Matos e Raszl (2010, p. 23) como um estudo que "expõe características de determinada população ou de determinado fenômeno; pode também estabelecer correlações entre variáveis e definir sua natureza".

Para aprofundamento teórico, foi realizada pesquisa bibliográfica, caracterizada por Fonseca (2002) como uma pesquisa feita a partir do "levantamento de referências teóricas já analisadas, e publicadas por meios escritos e eletrônicos, como livros, artigos científicos, páginas de web sites" (FONSECA, 2002, p. 37).

O público-alvo foram os alunos da Escola Municipal Professora Maria Madalena da Silva, localizada no distrito de Baixa do Meio (Guamaré/RN). Sendo entrevistados 40 alunos, formando assim um grupo amostral, 10 estudantes de cada série do ensino fundamental II ( $6^{\circ}$ ano, $7^{\circ}$ ano, $8^{\circ}$ ano e $9^{\circ}$ ano $)$.

Em relação à coleta dos dados, se deu através de entrevista estruturada realizada individualmente com os alunos, dentro da própria escola. Gil (2007) define que a entrevista estruturada se desenvolve com base em perguntas fixa, seguindo a mesma ordem para todos os entrevistados. Durante a entrevista será utilizado um formulário contendo 10 perguntas subjetivas (ver apêndice), permitido que quaisquer outras informações fossem acrescentadas mediante relato dos entrevistados.

Quanto aos resultados, os mesmos estão apresentados em forma de gráficos com discussões quali-quantitativo (PRODANOV, FREITAS, 2013), mostrando possíveis metodologias para o ensino de ciências através do uso das redes sociais.

\section{ACHADOS DA PESQUISA: POSSIBILIDADES DAS REDES SOCIAIS PARA O ENSINO-APRENDIZAGEM}

Para que pudéssemos obter os dados necessários a este trabalho foi realizado entrevistas com os alunos da Escola Municipal Professora Maria Madalena da Silva, onde todos os alunos se dispuseram a responder voluntariamente. Após a coleta de dados, podese fazer o seguinte levantamento das informações: contatamos que a idade dos entrevistados variou de 12 a 19 anos, já que se tratou de séries diferentes. Contudo, percebemos uma variação idade/série, refletindo no seguinte resultado (ver gráfico 01): 
Gráfico 01: Idade/série dos alunos entrevistados

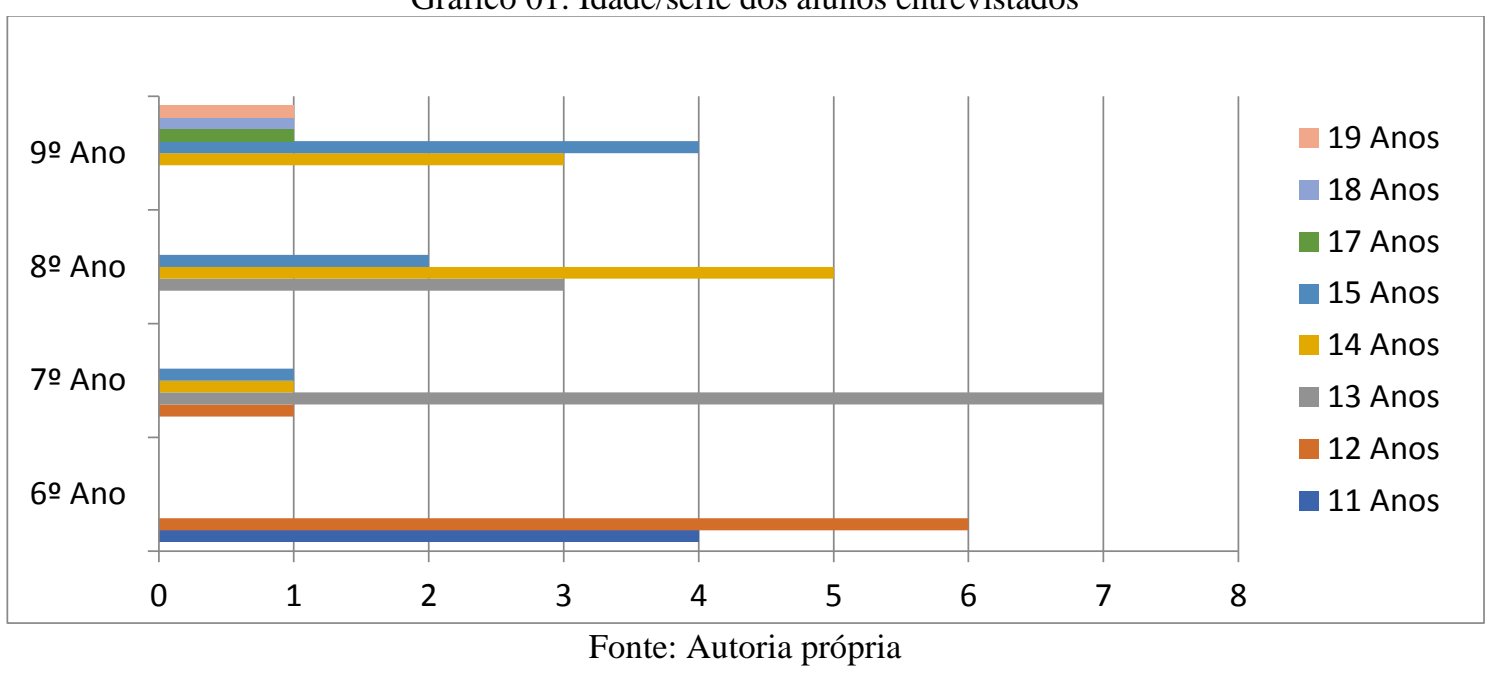

Iniciamos o questionário perguntando se os alunos tinham acesso às redes sociais e quais eles utilizavam. Todos afirmaram ter acesso, além disso, utilizam mais de um tipo de comunidade virtual, sendo as mais citadas: Facebook, YouTube, WhatsApp e Instagram.

De acordo com a jornalista Costa (2018), as redes sociais mais utilizadas pelos jovens no Brasil são (por ordem decrescente): Facebook, Whatsapp, YouTube, Instagram, Twitter, LinkedIn, Pinterest, Google+, Messenger e Snapchat. Pode-se perceber que os alunos entrevistados não fogem a essa realidade nacional.

Quando perguntados se algum professor faz/fez uso das redes sociais para ministrar aula ou algum conteúdo didático, a maioria respondeu "sim", contudo, existem variações entre as séries (ver gráfico 02). Os alunos do $7^{\circ}$ ano foram os que apresentaram maior percentual de negativas; enquanto $100 \%$ dos alunos do $6^{\circ}$ ano afirmaram que seus professores já utilizaram conteúdos on-line ou redes sociais para ministrar aulas.

Dentre as atividades realizadas pelos professores com utilização da internet ou de redes sociais, foram mencionadas: O programa Click ideia, pesquisas, desenhos, jogos, vídeos e app's. 
Gráfico 02: Utilização das redes sociais, por parte do professor, como ambiente de aprendizagem.

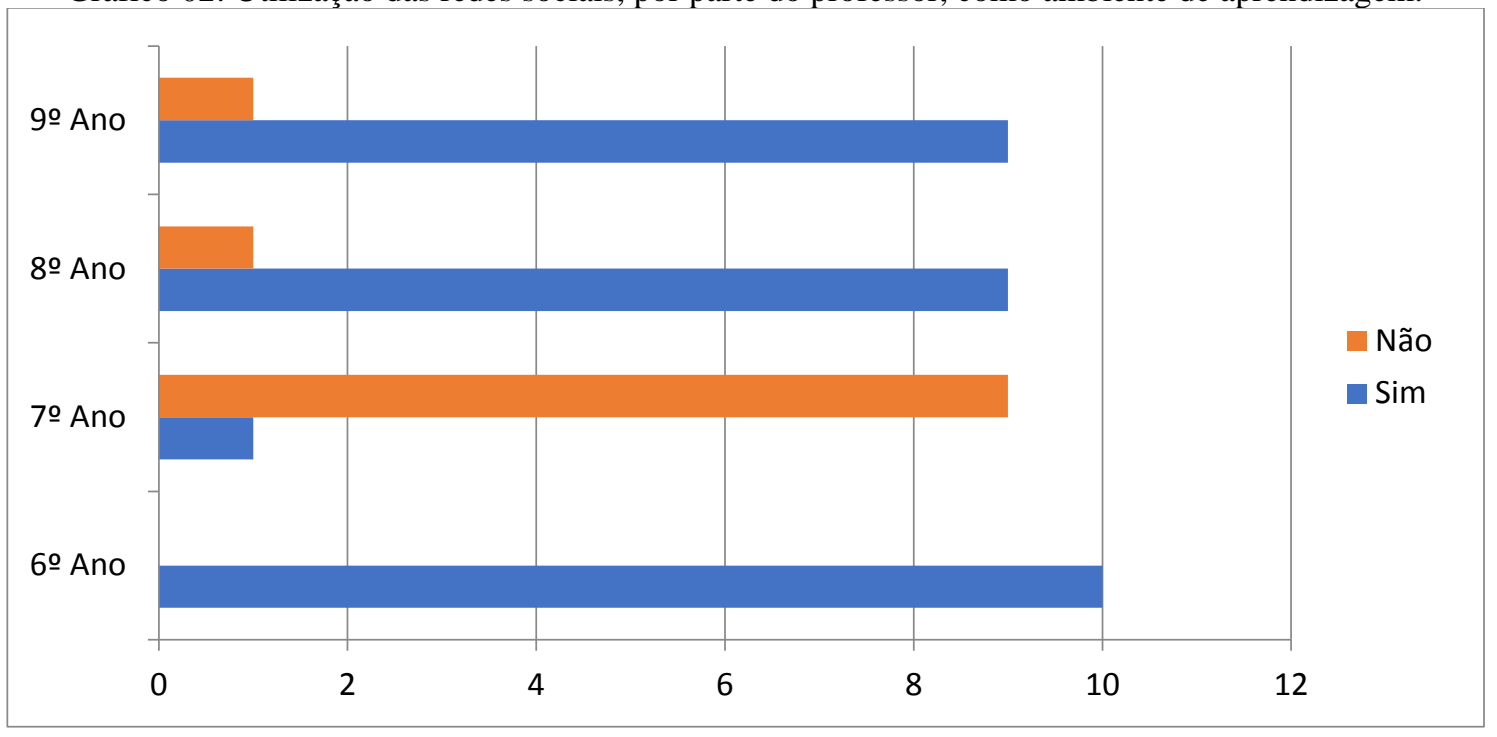

Fonte: Autoria própria

De acordo com o Portal da Prefeitura Municipal de Guamaré (2016) o Programa Click Ideia foi um projeto implantado no município de Guamaré, na rede municipal de ensino, no ano de 2016, que visava à inclusão digital de alunos e professores. Esse projeto capacitou professores e disponibilizou um site específico para que os mesmo pudessem utilizar com seus alunos. Atualmente o projeto encontrasse inativo.

A instalação desse projeto justifica o alto índice de professores utilizarem as TIC's em sala de aula.

Gráfico 03: Alunos que querem mais utilização das redes sociais como ambiente de aprendizagem.

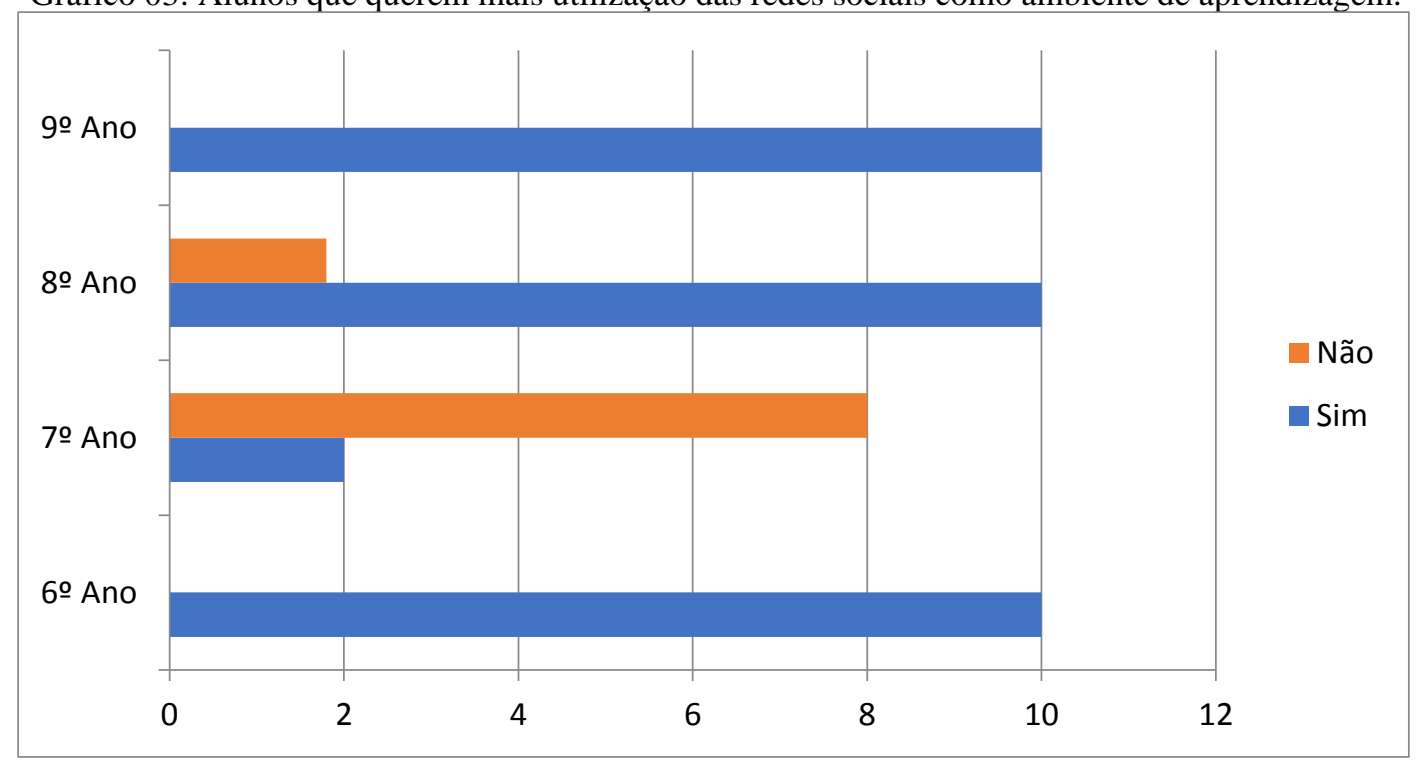

Fonte: Autoria própria 
Quando indagados se gostariam que houvesse mais utilização das redes sociais (como ambiente de aprendizagem) por parte dos professores, os alunos em grande maioria disseram sim (ver gráfico 03). Contudo, percebemos que 08 dos 10 alunos da turma de $7^{\circ}$ ano não gostariam da inserção das redes sociais como ambiente de aula, preferindo o ensino tradicional, segundo os próprios, o método presencial é melhor para o processo de aprendizagem.

Com relação, a qual maneira que o professor de ciências poderia usar as redes sociais como espaço de aprendizagem, os alunos responderam principalmente através de canal no YouTube. Citaram também: grupo no Whatsapp, página no Facebook e Blogs.

Segundo o site Escolaweb (2018) as 07 principais tendências em tecnologias educacionais são: Gamificação no ensino, Chatbots para esclarecer dúvidas de alunos, Armazenamento em nuvem para materiais didáticos, Realidade virtual e realidade aumentada em sala de aula, Dispositivos mobile como uma das tecnologias educacionais e Programação e robótica para estimular a criatividade. Percebe-se então que o desejo dos alunos para a utilização das tecnologias encontra-se dentro das tenências atuais, que representa o interesse dos jovens brasileiros.

Questionamos também, na opinião dos alunos, como se daria o processo de avaliação se o professor utilizasse as redes sociais como ambiente de aula. A sugestão mais apontada foi: A prova tradicional em sala de aula. Outras opiniões surgiram, tais como: através de postagens no próprio ambiente de aprendizagem, pesquisas, e exercícios no app. Pode-se perceber que os alunos ainda encontram-se ligados ao processo tradicional de ensino, onde escolhem a prova no papel como modo de avaliação. 
Gráfico 04: Tipo de conteúdo que o professor deveria abordar no ambiente virtual de aprendizagem.

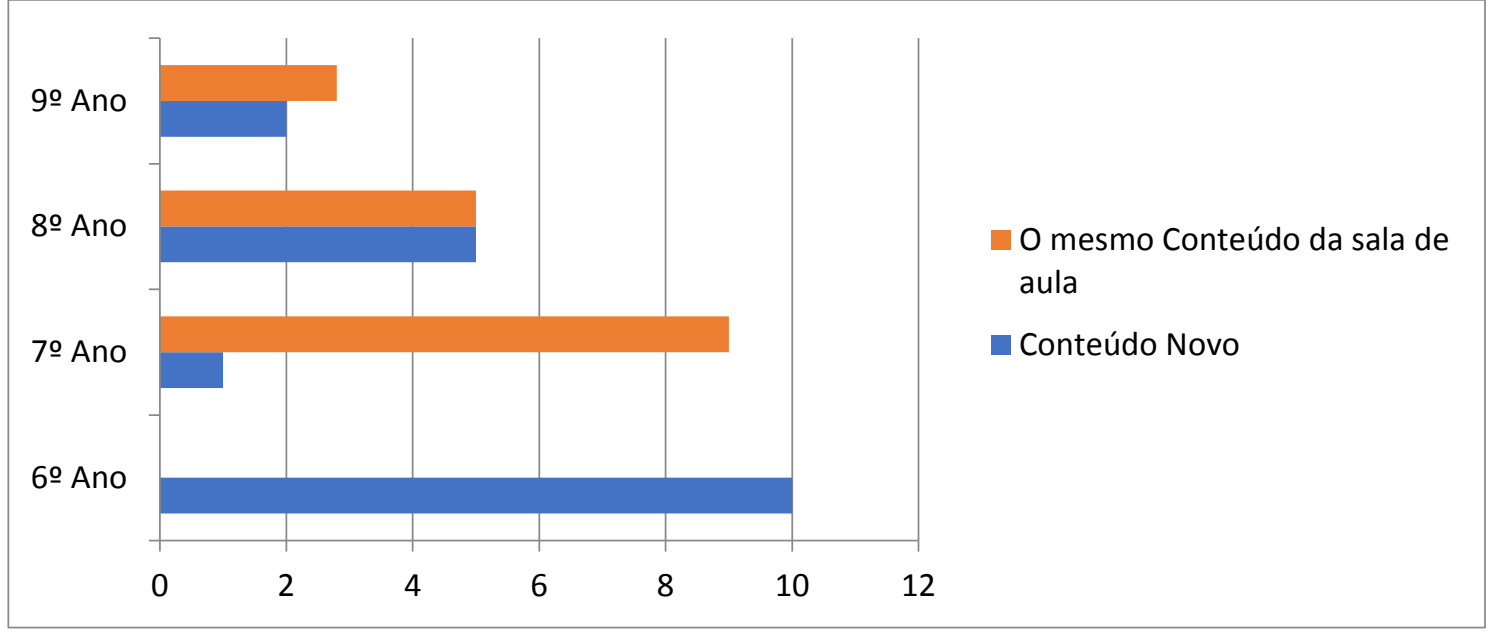

Fonte: Autoria própria

Após entender qual a preferência dos alunos em relação ao tipo de rede social e sua utilização, perguntamos qual seria o conteúdo abordado nesse ambiente virtual de aprendizagem (ver gráfico 04). Nesse caso, perguntamos se a preferência seria por dar continuidade ao mesmo tema explanado em sala de aula ou se gostariam de um assunto novo (diferente do explanado em sala de aula).

Os resultados apresentados foram parecidos, havendo um empate nas preferencias. Desta forma, o professor poderia alternar os conteúdos on line, entre temas curriculares e temas extracurriculares, despertando assim o interesse de todo o grupo.

Gráfico 05: Atração dos estudantes pelos estudos através das redes sócias.

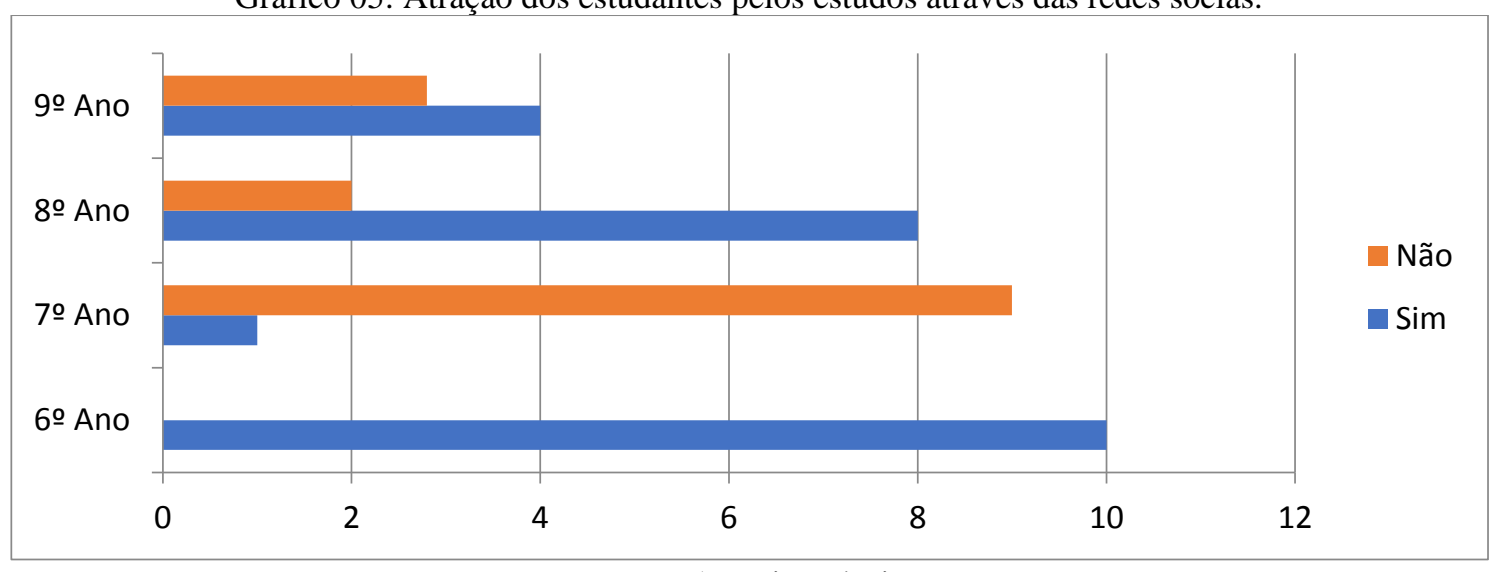

Fonte: Autoria própria

Sabendo que as redes sociais e o "mundo da internet" é algo fascinante, principalmente para os adolescentes, perguntamos se eles acham que "utilizando as redes 
sociais como ambiente de aprendizagem os alunos teriam mais interesse pelos estudos?" (ver gráfico 05).

Segundo o Programa Digital Inspira (2018, p. 01):

O uso da tecnologia favorece a interação entre alunos. Mesmo alunos considerados tímidos conseguem interagir por meio de ferramentas tecnológicas. Ao fazerem atividades em pares ou grupos, a internet permite que todos expressem seus conhecimentos e deem opiniões, o que traz à tona a experiência prévia dos alunos, o que os motiva ainda mais, pois sentem-se parte ativa e importante do processo de aprendizagem.

Percebemos que vários alunos afirmaram que a utilização das redes sociais seria um dos fatores-chave para atrai-los a estudar. Por outro lado, alguns alegam que a vontade de estudar independe de atrativos tecnológicos, ressaltando a preferência pelo ensino tradicional.

$\mathrm{Na}$ questão seguinte, perguntamos se os discentes se sentem preparados para estudar através de um ambiente virtual, sem a presença física de um professor durante os momentos de estudos (ver gráfico 06).

Gráfico 06: Nível de preparo dos alunos quanto aos estudos através de ambiente virtual.

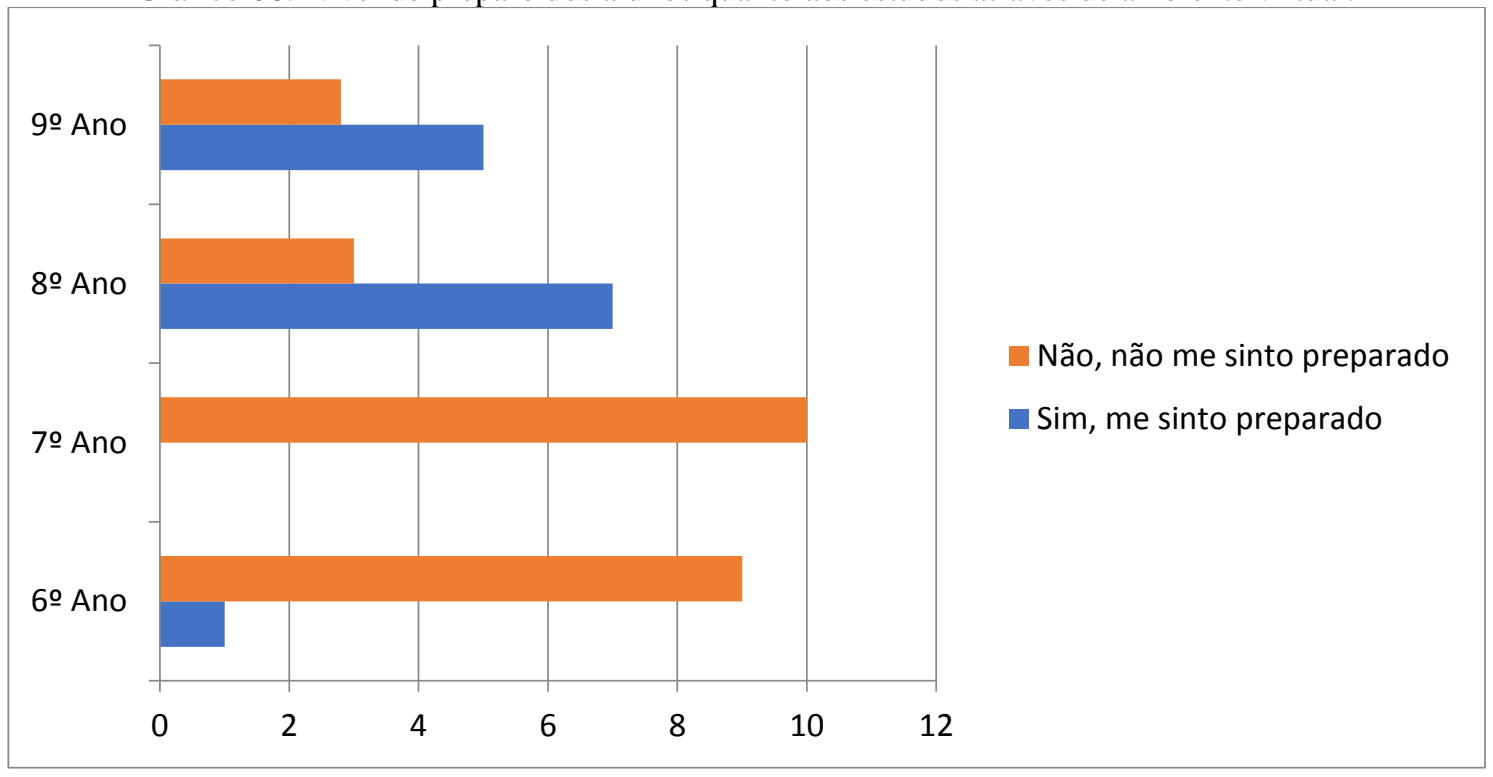

Fonte: Autoria própria

Constatamos que grande maioria dos entrevistados não se sente preparados para estudar através da internet. Como justificativa, os alunos alegaram que ao estudar pela internet iriam ser atraídos a acessarem outras coisas (como redes sociais) e não 
estudariam. Sentem que ainda não tem a maturidade necessária para esse tipo de compromisso.

Por fim, sabendo que a escola em questão, não oferece internet aos alunos; perguntamos se seria justo que o professor tornasse obrigatório as atividades realizadas na internet, já que a própria instituição não dá meios físicos para que o aluno tenha acesso a internet nem a computadores (ver gráfico 07).

Como resposta, alguns alunos não concordam com esse tipo de atitude, visto que a própria escola não tem laboratório de informática nem acesso livre a internet. Por outro lado, alguns alunos afirmam que, se o mesmo tem como acessa suas redes sociais para diversão teria como fazer o mesmo com finalidades educacionais, mesmo sem a escola conceder internet.

Gráfico 07: Opinião dos alunos quanto ao professor tornar obrigatório atividades na internet.

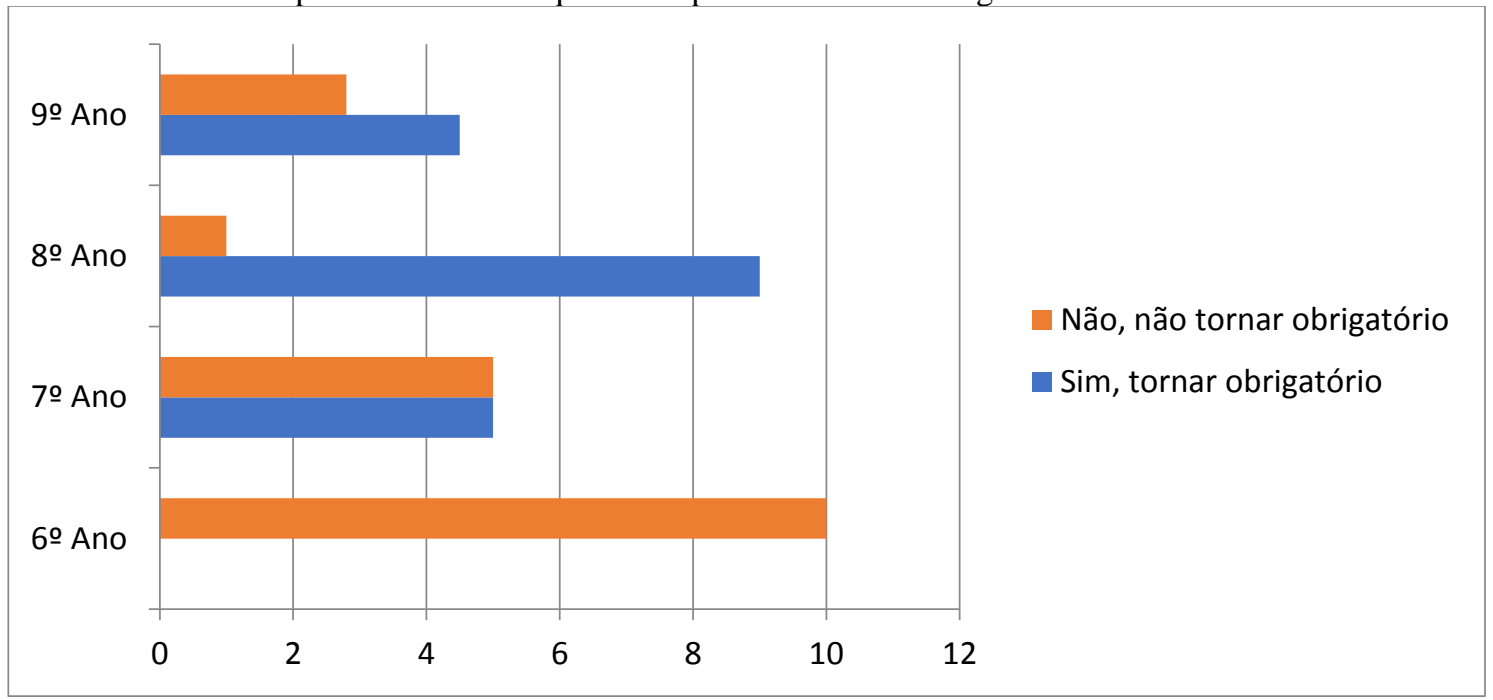

Fonte: Autoria própria

\section{CONCLUSÕES}

Após a leitura dos textos, bem como da análise dos dados, podemos compreender que as mudanças tecnológicas no ambiente escolar já começaram e que não existe possibilidade de regresso frente a uma sociedade completamente digital. Cabem as escolas, bem como aos professores a inclusão dessas mudanças na sua rotina em sala de aula.

Quanto as possíveis metodologias para o ensino de ciências através do uso das redes sociais, os alunos deram várias sugestões, desde grupos do Whatsapp até canal no 
YouTube; desta forma diversificando as possibilidades de transmissão do conteúdo.

Outro ponto importante é que para os alunos as aulas via internet devem ser complementos, não "a aula toda".

Desta forma, percebemos que há várias possibilidades do uso das redes sociais como ferramenta e espaço de aprendizagem, sendo um meio virtual de fácil acesso e de gosto popular entre os adolescentes, podendo ser bastante explorado pelos professores dentro e fora da escola.

Nota-se também que os próprios alunos são capazes para opinar e sugerir metodologias que possam ser utilizadas para o ensino das ciências naturais, bem como de outras disciplinas; podendo assim, o professor fazer seu planejamento junto ao alunado, adequando o tipo de metodologia de acordo com o perfil da turma. Entretanto, ainda é necessária uma atenção por parte do docente, visto que os estudantes ainda sentem que não tem maturidade suficiente para estudar pela internet sem a presença marcante de um professor para orientá-los e "cobra-los".

Podemos reconhecer, através da fala dos alunos, que se faz necessário a implantação do uso das redes sociais no ensino de ciências; para com isso estimular ainda mais o interesse pelos estudos; sobretudo, da disciplina de Ciências que apresenta muitos conceitos abstratos para os alunos.

Além disso, todas as estratégias apresentadas pelos alunos, em relação ao uso das TICs podem ser efetivamente utilizadas na escola, mesmo aquelas que possuem poucos recursos, visto que um celular com internet possibilita uma infinidade estratégias metodológicas. Porém, é importante que o professor análise até que ponto pode "exigir" o cumprimento das atividades on-line isto que muitas instituições públicas não disponibilizam de internet livre para os alunos.

Este estudo trata-se de uma análise inicial, sendo necessário um maior aprofundamento do tema para que o mesmo possa ser desmistificado e integrado ao cotidiano escolar.

Por fim, conclui-se que o uso das tecnologias e das redes sócias pelo professor pode ampliar as formas de processo de ensino-aprendizagem para a disciplina de ciências na escola, tornando-se uma extensão da sala de aula, favorecendo o conhecimento e 
atraindo a curiosidade dos alunos. Desta forma, os docentes devem investir nesse tipo de tecnologia para melhorar e ampliar o processo de ensino-aprendizagem.

\section{REFERÊNCIAS}

COSTA, T. Quais são as redes sociais mais usadas no Brasil?. Site Rockcontent. 2018. Disponível em: https://rockcontent.com/blog/redes-sociais-mais-usadas-no-brasil/. Acesso em 10 de fevereiro de 2019.

ESCOLAWEB. 7 tendências em tecnologias educacionais para 2018. Site Escolaweb. 2018. Disponível em: https://www.escolaweb.com.br/blog/tecnologias-para-educacao/7tendencias-em-tecnologias-educacionais-para-2018/ Acesso em 10 de fevereiro de 2019.

FONSECA, J. J. S. Metodologia da pesquisa científica. Fortaleza: UEC, 2002. Apostila. GIL, A. C. Como elaborar projetos de pesquisa. 4. ed. São Paulo: Atlas, 2007.

JUCIEUDE, L.E.; PAIVA, M.S.; SOUZA, K.C.A.; FONSECA, A.S.S. Meios de comunicação e escola na contemporaneidade: conflitos e diálogos possíveis. Educare Et. Educare Revista De Educação. Vol. 11, Número 23, Jul./Dez. 2016.

JULIANI, Douglas Paulesky et al. Utilização das redes sociais na educação: guia para o uso do Facebook em uma instituição de ensino superior. Renote, v. 10, n. 3, 2012.

KROETZ, K.; BALLEJO, C.C.; LARA, I.C.M. Internet e redes sociais no ensino de ciências e Matemática: percepções de docentes de um Programa de Pós-Graduação. In Anais III CIECITEC. 2015. Santo Ângelo/RS.

MATOS, K. H. O.; Raszl, S. M. (Org.). MATOS, Katherine Helena Oliveira. Metodologia para elaboração de projetos. Florianópolis: SENAI/SC, 2010.

MORAN, J.M. Novas tecnologias e o re-encantamento do mundo revista Tecnologia Educacional. Rio de Janeiro, vol. 23, n.126, setembro-outubro 1995, p. 24-26.

Prefeitura Municipal de Guamaré. Educacional alcança resultados expressivos em Guamaré. Portal. 2016. Disponível em: http://guamare.rn.gov.br/portal-educacionalalcanca-resultados-expressivos-em-guamare/. Acesso em 10 de fevereiro de 2019.

PRODANOV, C. C.; Freitas, E. C. Metodologia do trabalho científico [recurso eletrônico]: métodos e técnicas da pesquisa e do trabalho acadêmico. 2. ed. - Novo Hamburgo: Feevale, 2013.

SERAFIM, M.L., SOUSA, R.P. Multimídia na educação: o vídeo digital integrado ao contexto escolar. (ORG) SOUSA, RP., MIOTA, FMCSC., and CARVALHO, ABG. Campina Grande: EDUEPB, 2011.

SOUZA, F.V. Variação linguística e escrita veiculada na internet: a compreensão das operações sócio-discursivas. IN: Portal UERN moodle. 2018. 


\title{
CAPÍTULO XXXV
}

\section{LITERATURA POTIGUAR EM AÇÃO: UMA VISÃO PERSCRUTADORA PARA A OBRA O HORTO DE AUTA DE SOUZA}

\author{
Thatyane Santos e Silva da Penha ${ }^{116}$. \\ DOI -Capítulo: 10.47538/AC-2021.14-35
}

RESUMO: O presente artigo apresenta considerações acerca da Literatura Potiguar, evidenciando as relações, suas profundidades, e também uma visão perscrutadora para a obra O Horto da autora Auta de Souza. O estudo tem por objetivo refletir sobre a concepção e ensino de literatura que estimulam a leitura de textos da literatura local, mais precisamente os poemas de Auta de Souza, a fim de que possamos amenizar os entraves que norteiam as práticas com textos literários da literatura local em sala de aula. Reflete também a respeito dos estudos literários e de seus reflexos na escola; discute o ensino de literatura, observando suas práticas da tradição à atualidade e apreende aspectos relevantes quanto à tradição transmissiva com a finalidade de buscar algumas intervenções na prática educativa. $\mathrm{O}$ artigo contempla a Literatura Potiguar como foco; Auta de Souza como uma voz feminina dentro da Literatura; um olhar sobre os estudantes do Ensino Médio e uma leitura minuciosa dos poemas escolhidos. Através da pesquisa bibliográfica, o suporte teórico está ancorado nos conceitos dos autores: Oliveira (2003), Cosson (2011) e Arendt (2008) e os resultados evidenciam a relação das determinadas ações dispostas com a obra de Auta de Souza no processo de ensino aprendizagem juntamente com a aplicação da proposta de Cosson minimizando os entraves do trabalho com a Literatura Potiguar e com isso, ajudando a traçar um percurso que servirá de subsídio na melhoria da educação contextual. Assim, demonstrando o quanto esse contexto é perscrutador e, ao mesmo tempo essencial para que os envolvidos possam seguir, mostrar interesse e desenvolver-se de forma global, integrada.

PALAVRAS-CHAVE: Literatura Potiguar. Auta de Souza. Práticas.

\section{POTIGUAR LITERATURE IN ACTION: A PROSPECTING VISION FOR THE WORK THE HORTO DE AUTA DE SOUZA}

ABSTRACT: This article presents considerations about Potiguar Literature, highlighting the relationships, their depths, and also a scrutinizing vision for the work O Horto by author Auta de Souza. The study aims to reflect on the conception and teaching of literature that encourage the reading of texts from local literature, more precisely the poems by Auta de Souza, so that we can alleviate the obstacles that guide practices with literary texts from local literature in the classroom. It also reflects on literary studies and its effects on school; discusses the teaching of literature, observing its practices from

116 Graduada em Letras - Língua Portuguesa e Literaturas pela Universidade Federal do Rio Grande do Norte (UFRN); Docente no Governo do Estado do Rio Grande do Norte e Ministrante da Oficina Pedagógica "Entre saberes e fazeres: buscando práticas efetivamente alfabetizadoras na Modalidade de Educação de Jovens e Adultos”. E-mail: thatyane_santos@hotmail.com 
tradition to the present time, and apprehends relevant aspects regarding the transmissive tradition in order to seek some interventions in educational practice. The article focuses on Potiguar Literature; Auta de Souza as a female voice within Literature; a look at high school students and a thorough reading of the chosen poems. Through the bibliographical research, the theoretical support is anchored in the concepts of the authors: Oliveira (2003), Cosson (2011) and Arendt (2008) and the results show the relationship of certain actions arranged with the work of Auta de Souza in the teaching process learning along with the application of Cosson's proposal, minimizing the barriers of working with Potiguar Literature and, therefore, helping to trace a path that will serve as a subsidy in the improvement of contextual education. Thus, demonstrating how much this context is scrutinizing and, at the same time, essential for those involved to follow, show interest and develop in a global, integrated way.

KEYWORDS: Potiguar Literature. Auta de Souza. Practices.

\section{INTRODUÇÃO}

Com o objetivo de analisar e refletir acerca do interesse pela Literatura Potiguar, o estudo compreende a contribuição e a atuação desta literatura nas salas de aula do Ensino Médio e expõe as diferentes concepções e métodos baseados em como nortear o trabalho com a autora Auta de Souza, o livro Horto e o recorte dos poemas "Crepúsculo" e "Versos ligeiros" na perspectiva de Cosson, já que tais narrativas incentivam-nos a ter desejos e expressar o mundo por nós mesmos. Isso acontece porque elas refletem experiências que realizamos de uma forma mais reelaborada, propiciando a incorporação dos outros em nós sem que renunciemos a nossa própria identidade. Pretendo então, evidenciar as relações diretas e indiretas que esse meio tem com o interesse de imersão na literatura e refletir sobre a concepção e ensino que estimulam a leitura de textos da literatura local, mais precisamente os poemas de Auta de Souza, a fim de que possamos amenizar os entraves que norteiam as práticas com textos literários em sala de aula.

Desta forma, a motivação pela temática do projeto de pesquisa surgiu a partir da necessidade observada em quebrar paradigmas em relação à Literatura Potiguar em sala de aula e apontar alguns métodos pontuais baseados no estudo sobre as abordagens hermenêuticas, principalmente na permissão que o leitor tenha um papel mais ativo na interpretação dos textos e dá ao pesquisador, na área de literatura, mais liberdade para construir uma visão pessoal acerca da obra e do autor, bem como "quebrar alguns tabus" no que tange a Literatura Potiguar em sala de aula. A importância em desenvolver e 
trabalhar com uma prática de ensino mais real, próximo da realidade em ambos os contextos, ou seja, as transformações no campo social, político e cultural.

Por esses motivos, apresentarei Auta de Souza, o livro Horto e o recorte dado a sua obra como embasamento para meu projeto de pesquisa, na oportunidade de relativizar a ideia de que há alguma "interpretação verdadeira" alguma "leitura correta" da obra a ser descoberta pelo leitor.

Como metodologia para descrever esse interesse, temos uma abordagem qualitativa, segundo Oliveira (2003), a pesquisa qualitativa é realizada no contexto em que se pesquisa, ou seja, retratando a realidade de cunho social e da descoberta dos fatos. Portanto, ela enfatiza a interpretação em contexto, buscam retratar a realidade de forma completa e profunda, procuram representar os diferentes e às vezes conflitantes pontos de vista presentes numa situação social. Ou seja, para se possibilitar uma experiência mais real, é preciso estar inserido no contexto onde se realiza a ação. É compreendida a interpretação de fenômenos que não podem ser traduzidos em números. Segundo Silva e Menezes (2005), “ambiente natural é a fonte direta para coleta de dados e o pesquisador é o instrumento-chave" (SILVA; MENEZES, 2005, p. 20).

Através da pesquisa bibliográfica, o suporte teórico está ancorado nos conceitos dos autores: Oliveira (2003), Silva e Menezes (2005), Cândido (1995), Bakhtin (2006), Marcuschi (2002), Freire (1985), Foucault (1992), Maia (2007), Coelho (1997), Cosson (2011), Soares (2011), Arendt (2008), Vigotski (2000) e Gurgel (2001) e os resultados evidenciam a relação das determinadas ações dispostas com a obra de Auta de Souza no processo de ensino aprendizagem juntamente com a aplicação da proposta de Cosson minimizando os entraves do trabalho com a Literatura Potiguar e com isso, ajudando a traçar um percurso que servirá de subsídio na melhoria da educação contextual.

\section{LITERATURA POTIGUAR IN FOCO}

A Literatura é instrumento de realização de linguagem que rompe com o modelo oficial apregoado pelos estudos de gramática. Para Cândido (1995), a Literatura corresponde a uma necessidade cultural e universal. 
Dessa forma, refletindo sobre a concepção e ensino que estimula a leitura de textos da literatura local, podemos nos embasar mediante a concepção de literatura como forma de interação. Interação esta que denota o modo pelo qual os falantes se comunicam de forma contextualizada em relações sociais, gerando uma construção dialógica. Nessa concepção, não se consideram mais as explicações estruturais de uma frase, por exemplo, de como ocorriam os processos comunicativos da linguagem. Agora, os elementos aplicáveis a esses processos giram em torno de três: discurso, gênero e texto. Neste caso, consideramos que, ao interagirmos com o outro, fazemos uso da linguagem projetada em nosso discurso e esse discurso, por sua vez, concretiza-se por meio de textos e todo texto é estruturado em um determinado gênero discursivo.

Segundo Bakhtin (2006), essa construção dialógica depende das possibilidades tanto do ato de dizer que a língua nos oferece quanto ao que cada indivíduo realiza a partir dos gêneros discursivos. Conforme Marcuschi (2002), os enunciados são relativamente estáveis, inseridos em esferas comunicativas - ou seja, circulam socialmente em diversas áreas da atividade humana - são caracterizados pelo conteúdo temático, obedecem a uma construção composicional e pertencem a um estilo autoral. Atualmente, essa concepção é bastante utilizada nas escolas e é baseado nisso, a fim de estimular a leitura de textos da literatura local, mais precisamente os poemas de Auta de Souza que esta concepção de literatura surge como forma de amenizar os entraves que norteiam as práticas com textos literários em sala de aula, já que ao trazer a teoria bakhtiniana dos gêneros para o ensino da literatura, a concepção de literatura que irá se coadunar a uma proposta interacionista, é aquela em que a literatura seja um fenômeno, cultural, social e político. Nesse sentido, o ensino de literatura deve objetivar a formação de um leitor crítico e reflexivo, capaz de compreender, por meio da leitura literária, a realidade que o cerca; e, a partir dessa compreensão, ser capaz de intervir nessa realidade em que se insere.

Em sala de aula, o trabalho com esses textos são de fundamental importância para o desenvolvimento, para nossa formação social, contemplando os mais variados aspectos que vão desde a linguagem, passando pela sensibilidade, emoção até a criticidade e exercício da reflexão que são fundamentais para as diferentes aprendizagens. Através das leituras que realizamos, nos apropriamos de um vasto conhecimento sobre diferentes lugares, descobrimos um novo mundo de culturas e saberes. Nessa perspectiva, um dos 
autores que merece destaque é Tarcísio Gurgel em sua obra Informação da literatura potiguar (Natal: Editora Argos, 2001) onde o mesmo consegue fazer um mapeamento da produção literária do Estado, ressaltando os aspectos biográficos e temáticos dos autores julgados mais significativos no RN.

Desta forma, a literatura local pode ser utilizada tanto para escrita quanto para oralidade, isso requer do leitor conhecimentos que vem do seu repertório cultural, isto é, os saberes prévios, Freire (1985) ou memória discursiva Foucault (1992), que são todas as lembranças e saberes que os leitores recorrem ou evocam a fim de produzir os sentidos para as leituras que fazem. Nessa perspectiva, Maia (2007), explica que a experiência prévia, a visão de mundo e o conhecimento anterior são significativos para a produção dos significados acerca do que foi lido. Portanto, o ato de ler culmina num ato consciente que não se esgota nele mesmo para resultar em uma atividade que busca compreender o ser e estar no mundo. Sendo assim, não se sustenta apenas em bases psicológicas, mas também históricas e filosóficas, já que proporciona ao leitor em formação uma aventura dentro da literatura local que, certamente, afeta seu amadurecimento intelectual, proporcionando-lhe, além do prazer estético, um exercício mental. Assim, mesmo sem a intenção didática pedagógica, essa linha de pesquisa acaba sendo propulsora do ensino pela qualidade que apresenta ao ser levada e orientada no ambiente escolar.

A literatura, no caso a potiguar, sem sombra de dúvidas permite uma maior identificação do leitor com a realidade em que vive de forma a reconhecer-se com parte daquela localidade, reforçando a ideia de pertencimento e de consciência cidadã, ajudando na criação da identidade geo-social em mundo de realidades líquidas. Desta forma, a escolha pela temática do projeto de pesquisa deu-se pela necessidade observada em quebrar paradigmas em relação à Literatura Potiguar em sala de aula e apontar métodos a partir do estudo sobre as abordagens hermenêuticas, principalmente na permissão que o leitor tenha um papel mais ativo na interpretação dos textos e dá ao pesquisador, na área de literatura, mais liberdade para construir uma visão pessoal acerca da obra do autor ou dos autores que irei escolher para estudar, bem como "quebrar alguns tabus" no que tange a Literatura Potiguar em sala de aula. Por esse motivo, apresentarei Auta de Souza, o livro Horto e o recorte dado a sua obra como embasamento para meu projeto de pesquisa. 


\section{AUTA DE SOUZA: UMA VOZ FEMININA NA LITERATURA}

Auta de Souza nasceu em 1876 no município de Macaíba (RN), na época, principal centro comercial e político do Rio Grande do Norte. Faleceu em 1901, aos 25 anos de idade, vitimada pela tuberculose. Deixou alguns poemas publicados em jornais e revistas locais e regionais, dois manuscritos (Dhálias e Horto) e um único livro de poemas publicado: o Horto.

A mãe de Auta de Souza era Henriqueta Leopoldina Rodrigues de Souza e seu pai Eloy Castriciano de Souza. Como a maior parte das mulheres de origem humilde de seu tempo, era analfabeta, mas consta que sua filha tinha alguma instrução. Luís da Câmara Cascudo fala que ela era "lida em livros". Auta de Souza perdeu os pais muito cedo, a mãe aos três anos, o pai aos cinco. Após a morte dos pais, ela e seus quatro irmãos foram levados pelos avós maternos, de Macaíba para o Recife. O avô faleceu em 1882, ano seguinte à morte do pai de Auta, e todos os cinco irmãos ficaram sendo criados pela avó Silvina.

Mais uma morte veio tirar o sossego de Auta, então com doze anos, seu irmão mais novo, Irineu Leão Rodrigues de Souza. Marca de dor que parece ter levado para o resto da vida, inclusive em suas obras.

De Auta de Souza leitora, as informações foram colhidas basicamente nos textos de Henrique Castriciano, irmão da poetisa, e de Câmara Cascudo. As epígrafes existentes em seus manuscritos e no Horto são outra fonte considerada. Auta de Souza não o lia só para si, mas em voz alta, para "mulheres do povo e velhos escravos".

Segundo Câmara Cascudo, no Colégio teria conhecido um pouco da literatura francesa, tendo contato com escritos de Jacques-Bénigne Bossuet, François de Salignac Fenelon, François René Chateaubriand e "alguma coisa" de Alphonse de Lamartine. Desse último, o livro Horto traz alguns versos em epígrafe.

Excetuando-se a avó, Auta de Souza viveu entre rapazes, seus irmãos. Dois deles foram figuras prestigiadas no Rio Grande do Norte: Eloy Castriciano de Souza e Henrique Castriciano de Souza. 
Em 1899, Auta de Souza estava com o manuscrito Horto pronto para publicação.

Horto foi publicado em 20 de junho de 1900, trazendo o prefácio de Olavo Bilac. Compunha-se de 232 páginas, trazia 114 poemas, numa tiragem de mil exemplares.

Após o falecimento de Auta de Souza, em 1901, o Horto contou ainda com mais quatro edições (1910, 1936, 1970 e 2000). A segunda, organizada por Henrique Castriciano, trouxe uma Nota por ele escrita, que se transformou em espécie de emblema biográfico da poetisa. Além desse texto, ganhou também mais dezessete poemas, até então inéditos, retirados por seu irmão do manuscrito Dhálias. A terceira edição, de 1936, foi impressa no Rio de Janeiro, na Tipografia Batista de Souza. Contou com um prefácio novo, escrito por Alceu Amoroso Lima. Mas os poemas apresentados tanto na terceira como na quarta edições foram reproduzidos tal e qual aparecem na segunda edição, modificada somente a ordem de apresentação de alguns deles. O mesmo aconteceu com a quarta edição, publicada em 1970 pela Fundação José Augusto, em Natal. Em junho de 2000, em comemoração aos cem anos do Horto, foi publicada a quinta edição, agora pela Editora Auta de Souza, da Sociedade de Divulgação Espírita Auta de Souza, de Taguatinga (DF).

Na verdade, o livro Horto, de Auta de Souza, é a história de uma grande dor. Não se tratava apenas de um relato de vida em versos, tampouco de uma escritora feminina oitocentista, preparada apenas para amar Cristo sob todas as circunstâncias, ela também rompia as barreiras da escrita feminina, pois nessa época, a sociedade estava voltada em especial, para conferir visibilidade social ao homem, não à mulher, a figura feminina era preparada para "anjo do lar".

Um dos focos encontrados nesta pesquisa é o de justamente o quanto nossa autora, Auta de Souza, se mostrou despreocupada com qualquer engajamento literário, não se filiou a nenhuma escola. $\mathrm{O}$ gosto pelo individual em detrimento à objetividade da vida, mística de seus versos, permite o questionamento dos críticos literários em torno de seu estilo. Evidentemente o título do livro Horto, numa construção metafórica, faz menção ao local em que Jesus se refugiou para os seus últimos momentos de agonia na cruz e menção ao interior do eu-poético, marcando assim a religiosidade e o subjetivismo, tendo como elementos comuns à espiritualidade, a interiorização, o subjetivo, o vago, o misterioso, o ilógico, há sim um neo-romanatismo, até porque os dois em sua obra não se 
anulam, se complementam. Tratava-se antes de tudo, de uma jovem solitária que buscava em sua poesia a aceitação da existência, versos de sua alma e a razão de viver. Trata-se de uma poetisa do "sensível" e "invisível", que põe em seus versos o discurso de Jesus, num diálogo de confiança.

\section{UM OLHAR SOBRE OS ESTUDANTES DO ENSINO MÉDIO}

Se pararmos para analisar a prática de leitura existente no Ensino Médio, observamos que os estudantes que encontramos nesta etapa de ensino não estão relacionados apenas aos modelos teóricos que são preestabelecidos pelas instituições de ensino. Muitos alunos leem os títulos indicados pela escola apenas por mera exigência do professor. Entretanto, fora dessa esfera, muitos fazem leituras literárias de forma mais livre e por indicação de amigos, familiares e até mesmo por influência da mídia, embora não se possa negar a função das instituições de ensino como agenciadoras da formação de leitores proficientes.

A Literatura é uma área de conhecimento de suma importância para a formação e desenvolvimento humano, não somente pela gratuidade e entretenimento que a ficção proporciona, mas por possibilitar aos leitores refletirem, porque vivenciam situações que são da ficção, mas que tem inspiração na condição humana, isto é, é na vida real das pessoas que os autores recontam essas experiências, ora valendo-se apenas do realismo cotidiano, ora do mundo maravilhoso e fantástico, afirma Coelho (1997).

Segundo Cândido (1995), a Literatura desenvolve em nós a sensibilidade, e isso ocorre muito bem com nossos alunos no Ensino Médio tornando-nos mais compreensivos, reflexivos, críticos e abertos para novos olhares e possibilidades diante da nossa condição humana. A leitura literária permite-nos refletir sobre o mundo em nossa volta, abrindo nossos horizontes, ampliando os conhecimentos, possibilitando novas perspectivas. A leitura literária deixa em cada um de nós uma bagagem de experiências que nos define como leitores e que se refletem em nossa formação e ação frente às nossas interações sociais.

Enquanto docente, a partir das aulas de Literatura, percebo o quanto é importante para formação humana e profissional a leitura dos romances, da poesia, dos contos e de 
assistirmos, por deleite ou para estudo, as adaptações das narrativas literárias feitas para o cinema.

Dessa forma, sensibilidade, poder de observação diante de aspectos físicos e psíquicos que envolvem lugares e pessoas, perfil dos personagens e sentimentos de aceite e recusa dos mesmos, percepção da criatividade e estranhamento no uso da linguagem escrita e leitura do cotidiano com mais reflexão são algumas contribuições possibilitadas pela interação com essas narrativas literárias no Ensino Médio.

Com isso, é perceptível que embora a Literatura seja importante para a formação humana e faça parte do currículo escolar, as leituras literárias que acontecem em boa parte das escolas públicas de Ensino Médio, no Brasil, ainda ocorrem de forma fragmentada. Questões dessa natureza, por vezes, emperram a formação do gosto por esse tipo de texto, bem como inibe a proficiência dessa habilidade leitora, tão necessária quanto aquelas dos textos da vida ordinária a exemplo de e-mails, reportagens, notícias, receitas, postagens nas redes sociais entre outras.

Isso significa dizer que teórico-metodologicamente, em muitas escolas brasileiras, as pesquisas comprovam que não se tem uma preocupação com a palavra em estado de arte e a fruição que são próprios dos textos literários. Isto é, há uma ênfase maior na periodização das escolas literárias que se entrelaça entre estilos de época, cânone e dados biográficos, sendo, ainda, apresentados aos alunos-leitores, excertos de textos literários a fim de que sejam comprovadas as características dos períodos literários, afugentando, então, o prazer por esse tipo de leitura, Cosson (2011) que discute o panorama do ensino da Literatura nas escolas públicas brasileiras.

$\mathrm{Na}$ verdade, no Ensino Médio, esse aluno já deveria ser um aluno-leitor proficiente, gostando ou não das narrativas literárias que lhe são apresentadas e não algo que precisa ser estudado justamente pela demanda de um possível vestibular. Hoje, nos é disponibilizado, então: os Parâmetros Curriculares Nacionais para o Ensino Médio PCNEM Brasil (2000); as Orientações Educacionais Complementares aos Parâmetros Curriculares Nacionais - PCN + Brasil (2000) e as Orientações Curriculares Nacionais para o Ensino Médio - OCNEM, Brasil (2006) que destacam o caráter comunicativo no tocante à língua e humanizador em relação à Literatura. 
As competências e habilidades propostas pelos $\mathrm{PCN}+$, Parâmetros Curriculares Nacionais para o Ensino Médio (PCNEM) e pelas Orientações Curriculares Nacionais para o Ensino Médio permitem inferir que o ensino de Língua Portuguesa e de Literatura busque desenvolver no aluno-leitor seu potencial crítico, sua percepção das múltiplas possibilidades de expressão linguística, sua capacitação como leitor efetivo dos mais diversos textos representativos de nossa cultura com vistas a ampliar ou construir o letramento desses alunos-leitores, Soares (2011):

Para além da memorização mecânica de regras gramaticais ou das características de determinado movimento literário, o aluno deve ter meios para ampliar e articular conhecimentos e competências que possam ser mobilizadas nas inúmeras situações de uso da língua com que se depara na família, entre amigos, na escola, no mundo do trabalho (BRASIL, 2000, p. 55).

A formação do aluno leitor de Literatura é discutida nesses documentos de forma bastante ampla apontando as necessidades de letramento literário que leve aos jovens a não lerem apenas as obras literárias, mas que possam ir além, conhecendo textos que falem da Literatura. Tais documentos orientam os professores, apontando caminhos que devem trilhar para que alcancem seus objetivos, para cumprir com esses objetivos em relação à formação de leitores na escola.

Entretanto, segundo as orientações dadas por esses documentos oficiais publicados pelo Ministério da Educação e Cultura, não se deve sobrecarregar o alunoleitor com apenas informações sobre épocas, estilos, características de escolas literárias como até hoje tem ocorrido, apesar de os PCN, principalmente o (PCN++, 2002,p.55), alertarem para o caráter secundário de tais conteúdos para além da memorização mecânica de regras gramaticais ou das características de determinado movimento literário. O princípio teórico-metodológico é assegurar ao aluno o acesso aos meios para ampliar e articular conhecimentos, ou seja, tornar-se leitor proficiente e para isso ele precisa ler os textos de forma mais significativa e com mais intensidade e frequência, quer dizer precisa ler esses títulos e ter uma garantia de qualidades nessas leituras, coisa que não vem ocorrendo com tanta frequência em nossas salas de aulas.

Os PCNS insistem que a formação do leitor e escritor só será possível na medida em que o próprio professor se apresenta para o aluno como alguém que vive a experiência da leitura e da escrita. O professor, além de ser aquele que ensina conteúdos, é alguém que transmite o valor que a língua tem demonstrado para si. Se o professor tem relação prazerosa 
com a leitura e a escrita certamente poderá funcionar com medidas para seus alunos (ROJO, 2000, p. 66).

Infelizmente não é a escolarização da Literatura que tem que ser criticada, mas a inadequada e equivocada prática docente que se resume em uma pedagogização ou uma didatização imediatista e mal interpretada no que concerne ao trabalho com o texto literário e que o apresenta sempre como pretexto para se ensinar outras coisas, menos à especificidade das narrativas literárias em si mesmas.

Precisamos priorizar esse potencial do aluno - leitor, oferecer a ele diversos textos que estejam próximos ou distantes de sua realidade histórica e social no intuito de oferecer caminhos para construir sua identidade quanto leitor, colaborando para que possa se tornar um sujeito que age sobre o mundo para transformá-lo a partir da ação sobre si mesmo para firmar sua liberdade fugindo da alienação.

Nesse sentido, a Literatura tem uma atuação sobre nós por transmitir conhecimentos, resultando em aprendizados, mas vale ressaltar que ela não desempenha apenas esse papel quando se trata de produções literárias, pois o seu efeito ocorre devido à atuação que articula a relação da Literatura também com os direitos humanos por dois ângulos, segundo Cândido (1995).

E na perspectiva de Cosson, tais narrativas incentivam-nos a ter desejos e expressar o mundo por nós mesmos. Isso acontece porque elas refletem experiências que realizamos de uma forma mais reelaborada, propiciando a incorporação dos outros em nós sem que renunciemos a nossa própria identidade.

A escola precisa mostrar aos alunos a importância da leitura literária e o conhecimento dos aspectos que a envolvem, e, assim, apresentar narrativas interessantes e significativas, polêmicas, misteriosas, românticas, épicas, cuja leitura, se não realizada na escola, sob o olhar atento e orientador de um professor-leitor, muitas vezes jamais ocorrerá.

Caso o professor resolva fugir a esse programa restrito e ensinar leitura literária, ele tende a recusar os textos canônicos por considerá-los pouco atraente, seja pelo hermetismo do vocabulário e da sintaxe, seja pela temática antiga que pouco interessaria aos alunos de hoje (COSSON, 2007, p. 22). 
Riter (2009) afirma que a escola tema obrigação de dispor de instrumentos para efetuar as opções, mas as escolhas que contam são aquelas que ocorrem além dos muros da escola, de forma utilitarista com vistas apenas para o vestibular.

Os livros, como fatos, jamais falam por si mesmos. Quem os fazem falar são mecanismos de interpretação que usamos, e grande parte deles são aprendidos na escola. Depois a leitura literária que a escola objetiva processar visa mais que simplesmente ao entretenimento que a leitura de fruição proporcionam. No ambiente escolar, a literatura é um locus de conhecimento e, para que funcionasse como tal, convém ser explorada de maneira adequada (COSSON, 2011, p. 26-27).

Todorov afirma que:

O perigo que hoje ronda a Literatura não está, portanto, na escassez de bons poetas ou ficcionistas, no esgotamento da produção ou criação poética, mas na forma como a literatura tem sido oferecida aos jovens desde a escola primária até a faculdade: o perigo está no fato de que por uma estranha inversão, o estudante não entra em contato com a literatura mediante a leitura de textos literários propriamente ditos, mas com alguma forma de crítica, de teoria ou de história literária (TODOROV, 2009, p. 10).

A reflexão feita por esse estudioso é pertinente porque as práticas pedagógicas que trazem as ficções literárias como objeto de ensino têm provocado muito mais aversão do que contribuição para a formação de leitores desse tipo de texto. Para muitos jovens do Ensino Médio, a Literatura passa a ser muito mais uma matéria escolar a ser aprendida em sua periodização do que um bem cultural que proporciona conhecimento sobre o mundo, os homens, as paixões, a fantasia, o deleite, enfim, sobre sua vida íntima e pública. É nesse sentido que Todorov reivindica que o texto literário volte a ocupar o centro e não a periferia do processo educacional em especial nos cursos de Literatura. Muitos estudantes afirmam que gostam de ler e reconhecem a importância da leitura e Literatura, no entanto, a prática docente que a escola realiza frente aos livros literários termina afastando-os dos livros. Portanto, na escola fala-se muito sobre Literatura, em contrapartida, lê-se muito pouco os textos dessa natureza.

\section{UMA LEITURA DOS POEMAS}

Não podemos esquecer que o texto literário proporciona, a todo leitor, interpretações que conduzem o seu imaginário, a elaboração de imagens. Estas significam uma pluralidade de pensamentos que promovem a ampliação de horizontes, mediam 
ideologias, constroem e desconstroem culturas. As leituras de textos da literatura potiguar proporcionam ao leitor em formação uma aventura intelectual que, certamente, afetará seu amadurecimento intelectual, proporcionando-lhe, além do prazer estético, um exercício mental. Assim, mesmo sem a intenção didática pedagógica, esse gênero textual acaba sendo propulsor do ensino pela qualidade que apresenta ao ser levado e orientado no ambiente escolar. Acreditamos que a literatura comparada seja um canal que contribui para o entendimento dos diferentes ambientes políticos e sociais, pois, ao fazer uma análise dos poemas de Auta de Souza, propõe-se um estudo de interconexão interativo em literatura, cuja proposta cooperativa proporciona uma perspectiva alvissareira para todo leitor, por oferecer-lhe ideias em jogo dialético.

Se considerarmos o caráter místico e religioso de sua obra, revela-se o Simbolismo, a exemplo disso podemos perceber em um trecho da sua obra "Crepúsculo":

O Ângelus soa vagarosamente

A noite desce plácida e divina.

Ouço gemer meu coração doente.

chorando a tarde, a noiva peregrina.

Nos versos da poetisa pode-se estabelecer uma relação do sentimento de vida do eu poético comparando-os ao momento de sofrimento de Jesus na cruz, Auta de Souza sofreu unida à cruz do Salvador. E foi esse o grande e luminoso consolo, principalmente para familiares e amigos que viam a cada momento definhando uma jovem pela doença conhecida como mal do século (tuberculose).

Se considerarmos o poema "Versos ligeiros", percebemos a amplitude de uma escritora que não está emblemática a um tema, mas sim a um "devaneio cósmico que se insere em sua realidade", que ousa quebrar tabu e que não deve apenas ser reconhecida como poesia "católica", mesmo que seus textos sejam marcados com alusões aos cânones católicos e influência de formação da época. $\mathrm{Na}$ obra, eles são ressignificados como metáforas, numa busca do eu-poético em alcançar a plenitude em Jesus Cristo, independentemente de sua condição humana.

Ela deixou sim, uma mensagem espiritual, não apenas para igreja, mas para as crianças de sua terra, para a sua família, para os amigos, desnudando o seu cotidiano de 
forma sublime, poética e não divina. É possível perceber em Auta de Souza uma poesia simples, mas madura, que rompe a barreira de um Romantismo e navega na imaginação de uma realidade "dura", marcada muitas vezes pelo realismo que se projeta em temas do cotidiano.

Em se tratando de Auta de Souza a poesia foi, sem dúvida, um meio de sentir-se mulher, livre, e não somente um borrão das convenções sociais. Era vivida no seu cotidiano porque dele se nutria e a ele alimentava; era sua própria vida porque Auta não conseguia viver sem a poesia que escrevia; sua poesia era viva porque pulsava, gritava, denunciava, revelava, pedia escuta, imaginação, sensibilidade e liberdade cognitiva para ser entendida. É sabido, como afirma Bachelard (1990), que a poesia é a linguagem que é livre frente a si mesma. Talvez tenha sido por isso que Auta encontrou em sua escrita, um meio de liberação do seu psiquismo de "Mulher Selvagem", uma maneira de exercer a liberdade íntima e profunda.

Talvez Auta de Souza tenha percebido, em sua poesia, aquilo que Edgar Morin (2003) chama de "unidualidade do ser", as ambiguidades, contradições e polaridades complementares que nos fazem humanos, especialmente humanos. Como um olho que ver o que a razão não enxerga, a imaginação poética é capaz de perceber essa complexa unidualidade, marca da condição humana.

Em termos de dialogicidade, o poema Versos Ligeiros explicita uma estratégia para resolver a equação entre o pensar, o agir e o julgar. De acordo com Hannah Arendt (2008), o que nos faz pensar é o mesmo que nos faz ter vontade, o impulso dessas duas faculdades é semelhante em sua instância interna. Em outras palavras, o que move o pensar é a necessidade própria da racionalização: "o impulso interno dessa faculdade para se realizar na especulação (ARENDT, 2008, p. 87)". O mesmo pode ser dito da vontade, que tem sua independência em relação à razão e ao desejo: "nada além da vontade é a causa total da volição”, (ARENDT, 2008, p. 87). Isso também se dá em relação ao julgar, que se move como que por uma lei de si mesmo e para si mesmo, independente da regra universal que diz o que é belo, o que é feio, o que é certo, o que é errado.

Concluo, mais consciente, que os resultados das ações dispostas com a obra de Auta de Souza no processo de ensino aprendizagem juntamente com a aplicação da proposta de Cosson minimizará os entraves do trabalho com a Literatura Potiguar e com 
isso, ajudará a traçar um percurso que servirá de subsídio na melhoria da educação contextual.

\section{CONSIDERAÇÕES FINAIS}

A Literatura é uma área de conhecimento de suma importância para a formação e desenvolvimento humano. Por isso os textos literários deixam em cada um de nós uma bagagem de experiências que nos define como leitores e que se refletem em nossa formação humana e profissional, contribui para o desenvolvimento das pessoas em diferentes aspectos que começam no artístico e cultural e se estendem pelo social, político, cognitivo e sensorial. Nesse sentido, é preciso, pois, compreendermos sobre o que de fato significa e a que se propõe o trabalho com a leitura literária na escola. Foi nesse sentido que realizei um estudo exploratório e de cunho qualitativo que refletisse sobre as contribuições do ensino da Literatura para a formação do leitor no universo do Ensino Médio.

Compreendo que a escola, apesar de seus esforços, da criatividade dos professores e de sua formação continuada e da criação de projetos de leitura e de cultura, ainda não tem contribuído de forma eficaz para a formação de leitores proficientes, inclusive de textos literários devido às práticas que ainda estão muito fundamentadas na periodização das escolas literárias.

Ressaltamos, portanto, que o gosto pela leitura não está relacionado apenas aos modelos teóricos que são preestabelecidos pelas instituições de ensino. Muitos alunos leem os títulos indicados pela escola apenas por mera exigência do professor. Entretanto, fora dessa esfera, muitos fazem leituras literárias de forma mais livre e por indicação de amigos, familiares e até mesmo por influência da mídia.

Portanto, ensinar a Literatura não é apenas elencar uma série de textos ou autores e classificá-los num determinado período literário, mas sim revelar ao aluno o caráter atemporal, bem como a função simbólica e social da obra literária. Para ler de forma proficiente esse tipo de texto muito presente no Ensino Médio, o leitor precisa conhecer o repertório cultural e linguístico que constituem as narrativas e os poemas bem como os outros gêneros discursivos que tratam da Literatura. 
Cabe, então, à escola, repensar teórico-metodologicamente o Ensino da leitura literária no sentido de que a Literatura, inclusive a potiguar, possa se fazer presente como uma prática cultural no cotidiano desses jovens.

\section{REFERÊNCIAS}

ARENDT, Hannah. A vida do espírito. O pensar, o querer e o julgar. Rio de Janeiro: Civilização Brasileira, 2008.

BAKHTIN, M. M. Marxismo e filosofia da linguagem: problemas fundamentais no método sociológico na ciência da linguagem. 8. ed. Sao Paulo: Hucitec, 1996.

BRASIL. Parâmetros curriculares nacionais: ensino médio. Brasília: MEC/Semetec. 2000. http://portal.mec.gov./seb/arquivos//pdf/blegais.pdf.

CANDIDO, Antonio. Vários escritos. $3^{\mathrm{a}}$ ed.. revista e ampliada. São Paulo: Duas Cidades, 1995.

COELHO, N. N. Literatura Infantil: teoria - análise - didática. São Paulo: Ática, 1997.

COSSON, Rildo, Letramento literário: teoria e prática.2ed-São Paulo:

Contexto.2011 a.

FREIRE, Paulo,A importância do ato de ler: em três artigos que se completam. 23 ed. São Paulo: Cortez, 1989.

GURGEL, Tarcísio. Informação da Literatura Potiguar. Natal: Argos, 2001.

MAIA, Joseane Literatura na formação de leitores e professores São Paulo:

Paulinas, - Coleção literatura e ensino 2007.

MARCUSCHI, L. A. Produção textual, análise de gêneros e compreensão. São Paulo, SP: Parábola, 2008. p. 228 - 281.

ROJO, R. A prática de linguagem em sala de aula praticando os PCNs.São Paulo: Mercado de Letras, 2000.

SILVA, E. LUCIA; MENEZES, E. M. Metodologia da pesquisa e elaboração de dissertação. 4 ed. Florianópolis: UFSC, 2005.

TODOROV, Tzvetan, 1939-A literatura em perigo; tradução Caio Meira.-Rio de Janeiro: DIFEL, 2009.

VIGOTSKI, L. S. A construção do pensamento e da linguagem. São Paulo, Martins Fontes, 2000. 


\section{SOBRE OS ORGANIZADORES}

FREITAS, Dayana Lúcia Rodrigues de: Doutoranda em Ciências da Educação pelo Centro de Educação Continuada e Aperfeiçoamento Profissional (CECAP). Mestra em Ciências da Educação pelo Centro de Educação Continuada e Aperfeiçoamento Profissional (CECAP). Especialista em Mídias na Educação pela Universidade Estadual do Rio Grande do Norte (UERN). Especialista em Tecnologias Educacionais e Educação a Distância pelo Instituto Federal de Educação Ciências e Tecnologia do Rio Grande do Norte (IFRN). Especialista em Metodologia do ensino de Biologia e Química pelo Instituto Pedagógico de Minas Gerais (IPEMIG/MG). Especialista em Educação Ambiental e Geografia do semiárido pelo Instituto Federal de Educação Ciências e Tecnologia do Rio Grande do Norte (IFRN). Especialista em Ensino de Ciências Naturais e Matemática pelo Instituto Federal de educação Ciências e Tecnologia do Rio Grande do Norte (IFRN). Especialista em Língua Portuguesa, Matemática e Cidadania pelo Instituto Federal de Educação Ciências e Tecnologia do Rio Grande do Norte (IFRN). Graduada em Licenciatura Plena em Biologia pelo Instituto Federal de Educação Ciências e Tecnologia do Rio Grande do Norte (IFRN). Graduada em Pedagogia pela UNOPAR. Técnica em Meio Ambiente pelo Serviço Nacional de Aprendizagem Comercial (SENAC/RS). Palestrante. Pesquisadora. Professora e Orientadora de cursos de Pós-Graduação e Graduação em instituições da rede privada em Macau/RN. Professora; Orientadora de TCC e Orientadora de Estágio Curricular Supervisionado da Escola Técnica Fanex Rede de Ensino - Macau/RN. Professora da Educação Básica do município de Guamaré/RN. Orcid: https://orcid.org/0000-00015355-3547. Lattes: http://lattes.cnpq.br/5122671799874415. E-mail: dayannaproducoes@gmail.com.

PAIVA, Luciano Luan Gomes: Diretor de Arte na Editora Amplamente Cursos, coordenando toda a produção visual e ações de publicidade nas redes sociais e site da empresa. No campo da Educação, atua como Coach Educacional, Palestrante, Ministrante de Oficinas (presenciais e on-line), Tutor a Distância na Universidade do Estado do Rio Grande do Norte (UERN) e Professor de Música em múltiplos contextos. Como pesquisador, tem feito estudos sobre Aprendizagem mediada por Tecnologias Digitais sob a ótica da Complexidade; Formação Docente no âmbito das Tecnologias Digitais; e Mediação Pedagógica no Ciberespaço. Também é membro do Grupo de Estudos e Pesquisa em Música (GRUMUS-UFRN). Tem formação acadêmica, como Mestre em Música (com ênfase em Educação Musical) pela Universidade Federal do Rio Grande do Norte (UFRN). Especialista em Tecnologias Educacionais e Educação a Distância pelo Instituto Federal de Educação, Ciência e Tecnologia (IFRN). Licenciado em Música pela Universidade Federal do Rio Grande do Norte (UFRN). Orcid: https://orcid.org/0000-0001-6192-6075. Lattes: http://lattes.cnpq.br/0772088747598226. E-mail: luciano.90@hotmail.com. 
FERNANDES, Caroline Rodrigues de Freitas: Especialista em Mídias na Educação pela Universidade Estadual do Rio Grande do Norte (UERN). Pós-graduanda em Educação Inclusiva pelo Instituto Federal de Educação Ciências e Tecnologia do Rio Grande do Norte (IFRN). Graduada em Licenciatura em História pela Universidade Estadual do Rio Grande do Norte (UERN). Graduada em Licenciatura Plena em Pedagogia pela Faculdade UNOPAR. Técnica em Contabilidade pelo Centro de Educação Integrada Monsenhor Honório (CEIMH). Atua como professora da Rede Pública e Privada em Macau/RN. Atuou como professora da Escola Técnica Fanex Rede de Ensino - Macau/RN. Orcid: https://orcid.org/0000-0002-9198-6746. Lattes: http://lattes.cnpq.br/5956672837215695. E-mail: caroline_brum2005@ hotmail.com. Email: caroline_brum2005@hotmail.com. 


\section{SOBRE OS AUTORES}

ALMEIDA, Alcione Sousa Dos Santos: Pedagoga. Professora da Educação Básica. E-mail: alcioneveronilson@gmail.com

ALVES, Luana Teixeira: Graduada em Pedagogia. E-mail: luana.teixeira@gmail.com

AMORIM, Tamires Aline de: Graduada em Pedagogia. E-mail: tamiresalinedeamorim@gmail.com

ANDRADE, Maria Aldeni de Oliveira: Graduada em Pedagogia e Geografia UFRN. Pós-graduada em Psicopedagogía - FIP. Mestranda em Ciências da Educação FACEM. E-mail: aldeniandrade24@gmail.com

ANJOS, Josiane Guimarães dos: Graduação em pedagogia - UVA. Pósgraduação em Atendimento Educacional especializado (AEE) - Ipebras. Pós-graduação Educação Especial Inclusiva - Facuminas.

AQUINO, Liane Batista de: Pedagogia - ISEP. Pós-graduação em Educação Infantil E Ensino Fundamental -Faculdade de Maciço de Baturite. Pós-graduação em Neuropsicopedagogia - FAVED. E-mail: Liane.aquino123@gmail.com

ARAÚJO, Aldejane Leandro de: Doutoranda em Ciências da Educação pelo Instituto Superior de Educação do CECAP - Professora Me. em Ciências da Educação al-de-jane@ hotmail.com

ARAÚJO, Elisama da Silva: Graduação em pedagogia - ISEP, Pós-graduação em educação infantil e anos iniciais pela faculdade de Maciço de Baturité, Pós-graduação em gestão escolar e coordenação pedagógica - IPEBRAS, Pós-graduação em alfabetização e letramento - IPEBRAS, Pós-graduação em psicopedagogia institucional e clínica - IPEBRAS. Professora do município de Macau pela escola CEIMH, Professora do município de Guamaré.

ARAÚJO, Francisco Antônio Vieira de: Pós-Graduando em Educação Ambiental e Desenvolvimento Sustentável pela FAVENI. Professor do município de Macau/RN. E-mail: totusant@outlook.com 
ARAÚJO, Sara Maria Tomaz de Souza: Graduação em Letras-Língua - UERN.

Pós-graduação em Metodologia De Ensino Da Língua Portuguesa E Inglesa - Faculdade Futura. Pós-graduação em Metodologia Do Ensino Da Língua Inglesa -Faculdade Futura. Pós-graduação Em Literatura Em Língua Inglesa - FAEL. $2^{\circ}$ Graduação em Pedagogia Faculdade Futura (Cursando).

BARROS, Tiêgo Gonçalo de: Educação Física Licenciatura - UFRN. Professor Município de Pendência/RN. E-mail: tiegobarros@ hotmail.com

BEZERRA, Luciana Ivete Maciel: Graduação em Pedagogia - UVA. Professora Especialista em Psicopedagogia -Faculdade Integrada de Patos. Pós-graduada em Educação Infantil e Educação Especial - FAVENI. Pós-graduação em Gestão e Supervisão Escolar - Instituto Século XXI (em andamento). Professora Efetiva do Município de Guamaré/RN. E-mail: lucianaivete80573@gmail.com

BORGES, Maria de Lourdes Reche: Graduada em Pedagogia. E-mail: crislen_reche@hotmail.com

BREDER, Fernanda Aparecida: Graduada em Direito pela Faculdades Associadas de Ariquemes FAAR. nandabreder7@gmail.com

CHAVES, Rosana Cléia de Carvalho: Universidade Estadual de Roraima; http://lattes.cnpq.br/6070758877844357; https://orcid.org/0000-0002-7591-7070. Email: rosanacleia@gmail.com

COSTA, Ana Paula de Sousa: Graduada em Pedagogia. E-mail: aniinhaxavier@homail.com

CUNHA, Roberta Vasconcelos da: Advogada. Especialista em Direito do Consumidor com Ênfase nas relações de Consumo. Especialista em Direito Material e Processual Civil e Pós graduanda em Direito do Material e Processual do Trabalho.

FERNANDES, Caroline Rodrigues de Freitas: Pós-Graduada em Mídias na Educação (UERN). Docente no Município de Macau/RN. Orcid: https://orcid.org/00000002-9198-6746. Lattes: http://lattes.cnpq.br/5956672837215695. E-mail: caroline_brum2005@hotmail.com. 
FERREIRA, Adriano Cézar Dantas: Graduação em Letras com habilitação em Língua Portuguesa UERN. Pós-graduação em Libras - FACESA. Pós-graduação em Metodologia do Ensino de Língua Portuguesa, Literatura e Artes -Faculdade Futura. Pósgraduação em Educação Especial e EJA e Linguística e Formação de Leitores FACUMINAS. Professor do município de Guamaré/RN. E-mail: ferreira.adrianoufrn@outlook.com

FERREIRA, Cristiane Pereira: Universidade Três Fronteiras - PY (UnInter PY); http://lattes.cnpq.br/4188516460383461; https://orcid.org/0000-0002-5782-4217. E-mail: crisjesusfamilia@hotmail.com

FERREIRA, Rosenice Benedita: Graduada em Pedagogia. E-mail: rosenice2415@gmail.com

FIGUEREDO, Mirtes Pereira do Nascimento: Graduação em Pedagogia UVA. Pós-graduação em Psicopedagogia Clínica E Institucional - ISEP. Pós-graduação em Educação Infantil E Anos Iniciais - FAVENI. Professora e responsável escolar no Município de Guamaré-RN. E-mail: Mirtes_gmr@ hotmail.com

FREIRE, Wiziley de Queiroz: Graduação em Pedagogia - UVA. Graduação em Letras/português - UFRN. Pós-graduação em Processos Educacionais - Apoio Pedagógico - UNP. Pós-graduação em Educação Ambiental em Unidades de Conservação - UERN. Pós-graduação em Atendimento Educacional Especializado e Educação Especial pela Faculdade Única de Ipatinga - ÚNICA. Pós-graduação em Metodologias do Ensino de Língua Inglesa e Língua Portuguesa pela Universidade Única de Ipatinga - ÚNICA. Professor do município de Guamaré e professor efetivo do Estado do RN.

FREITAS, Dayana Lúcia Rodrigues de: Doutoranda em Educação (CECAP). Docente nos Município de Macau/RN e Guamaré/RN. Orcid: https://orcid.org/00000001-5355-3547. Lattes: http://lattes.cnpq.br/5122671799874415. E-mail: dayannaproducoes@gmail.com.

GONÇALVES, Adriana Aparecida: Graduada em Pedagogia. E-mail: adriana_ap01@hotmail.com 
HAENISCH, Paula Roberta Libanori: Mestranda em História Pública pela UNESPAR - Universidade Estadual do Paraná - campus de Campo Mourão; http://lattes.cnpq.br/4312579445143769; 0000-0002-6263-0556. E-mail: paulahaenisch2020@gmail.com

JÚNIOR, Elves França da Costa: Universidade Federal do Amazonas; http://lattes.cnpq.brq6074335965277066; https://orcid.org/0000-0001-9996-7024. Email: Elvesjr18@gmail.com

JUNIOR, João Paulo Roberti: Professor substituto da Universidade Federal de Roraima. Lattes: http://lattes.cnpq.br/2469361629650438. Orcid: https://orcid.org/00000002-1489-5330. E-mail: joao.roberti@ufrr.br

JÚNIOR, Juarez Ribeiro de Araújo: Pós-Graduado em Direito Tributário pela Faculdade de educação à distância de Coronel Fabriciano, Minas Gerais. juarezribeiroadv@gmail.com

LEMOS, Edna Maria de: Pedagoga. Professora da Educação Básica. E-mail: edna11302@gmail.com

LEMOS, Elizabete Maria: Pedagoga. Professora da Educação Básica. E-mail: elizabetelemos10@outlook.com

LIMA, Elcimar de Oliveira: Faculdade de Ciências Contábeis - FCC. Universidade Federal da Bahia - UFBA.

LIMA, Maria Gardênia dos Santos: Curso de Pedagogia, Licenciatura Plena, - UVA. Especialização em Psicopedagogia Institucional e Clínica pelo Instituto Superior de Educação de Pesqueira. Pós-Graduação Em Atendimento Educacional Especializado pela Faculdade Maciço De Baturité. Professora De Artesanato.

LOPES, Mayara da Silva: Graduada em Pedagogia. E-mail: mayara_lopes_may@hotmail.com

LUCAS, Ana Luisa Martinez Burguillo Mendonça: Mestranda do curso de pós graduação em Letras e Linguística da Faculdade de Letras da UFG; currículo lattes: http://lattes.cnpq.br/0629402700233426. E-mail: analu.mbmlucas@gmail.com 
LUNA, Daniele do Nascimento: Pedagogia - ISEP. Pós-graduação em AEE IPEBRAS. Pós-graduação em Alfabetização e Letramento - Faveni (em andamento). Pós-graduação em Anos Iniciais - Faceminas (em andamento). E-mail: darvindanny@gmail.com

MARTINS, Rosa de Lima: Graduação em Pedagogia UVA. Pós-graduação em Psicopedagogia Clínica E Institucional - FAIBRA. Pós-Graduação em Educação Infantil E Ensino Fundamental - Instituto Superior De Educação Elvira Dayrell. Professora no Município de Guamaré-RN. E-mail: rosalima87@gmail.com

MEDEIROS, Ana Maria Fonseca de Araújo: Pedagoga. Professora da Educação Básica. E-mail: Ana.medeirosgmr@gmail.com

MELO, Francisca da Conceição da Costa: Graduação em Pedagogia - UFRN. Pós-Graduação em Psicopedagogia -ISEP. Pós-graduação em Ludopedagogia na Educação Infantil - FETREMIS. Pós-graduação em Educação Infantil e Anos Iniciais Do Ensino Fundamental -FETREMIS. Professora no município de Guamaré/RN.

MIRANDA, Lucilene Cardoso de: Graduada em Pedagogia. E-mail: lucinhamirandabbu@hotmail.com

MONTEIRO, Sara Gabriele Alves: Graduada em Pedagogia. E-mail: sarapedagoga@gmail.com

NASCIMENTO, Patrícia Lima do: Pedagoga. Professora da Educação Básica. E-mail: patricialimapatricia3226@gmail.com

OLIVEIRA, Julio Roque de: Universidade Estadual de Roraima - UERR; http://lattes.cnpq.br/1145311585547477; https://orcid.org/0000-0002-2569-0226. Email: roquejulio292@gmail.com

OLIVEIRA, Ramiro Dias de: Universidade de Caxias do Sul. E-mail: Rdoliveira5@ucs.br

PADRE, Alexandra Lemos: Pedagoga. Professora da Educação Básica. E-mail: alexandralemospadre@outlook.com

PENHA, Thatyane Santos e Silva da: Graduada em Letras - Língua Portuguesa e Literaturas pela Universidade Federal do Rio Grande do Norte (UFRN); Docente no 
Governo do Estado do Rio Grande do Norte e Ministrante da Oficina Pedagógica "Entre saberes e fazeres: buscando práticas efetivamente alfabetizadoras na Modalidade de Educação de Jovens e Adultos”. E-mail: thatyane_santos@hotmail.com

PEREIRA, Érica Xavier Machado: Graduada em Pedagogia. E-mail: ericaxmp@hotmail.com

PEREIRA, Joyce Cristyane: Graduada em Pedagogia. E-mail: mj.joyce@hotmail.com

PEREIRA, Laura Nayara de Macêdo: Graduada em Pedagogia - Faculdade do Complexo Educacional Santo André. Pós-graduação em Educação Especial Inclusiva e Neuropsicopedagogia Institucional e Clínica (Cursando) - FAVENI. Professora no Município de Alto do Rodrigues-RN. E-mail: lauranayara17@gmail.com

PLÁCIDO, Rissa Soares: Graduada em Pedagogia - UEA. Licenciada Em Letras - Língua Portuguesa e Libras - UFRN. Pós-Graduada Em Educação Infantil - FACEL. Pós-Graduada Em Gestão Escolar E Coordenação Pedagógica - FAEL. Mestranda em Ciências da Educação - CECAP. E-mail: rissaplacido@hotmail.com

QUEIROZ, Jaqueline Fonseca de: Doutoranda em Ciências da Educação pelo Instituto Superior de Educação do CECAP - Professora Me. em Ciências da Educação jacfqueiroz@gmail.com

RECHE, Sonia Maria: Graduada em Pedagogia. E-mail: soniareche29@hotmail.com

RODRIGUES, Alyson Matheus da Silva: Graduação em Licenciatura em Biologia -IFRN. Pós-graduação em formação Psicopedagogía - FAVINI. Mestrando em Ciências da Educação - World University Ecumenica dos EUA. Professor do município de Pendências e Porto do Mangue. E-mail: matheusdemariaoutlook.com.br

RODRIGUES, Wustania Gaspar: Graduação em pedagogia - UVA. Pósgraduação em Educação infantil e anos iniciais - FIAVEC. Pós-graduação em Alfabetização e Letramento - Faculdade do Vale Elvira Dayrell. Pós-graduação em Educação Especial e Inclusiva - Faculdade do Vale Elvira Dayrell. Pós-graduação em Língua Brasileira de Sinais-LIBRAS - Faculdade do Vale Elvira Dayrell. Professora no município de Guamaré/RN. E-mail: wustaniaprofessora@ hotmail.com 
SANTANA, Maria Goretti silva de: Pedagoga. Professora da Educação Básica. E-mail: goretti.medeiros@ hotmail.com

SANTOS, Jorge Ribeiro Dias dos: Advogado. Especialista em Direito Imobiliário, Negócios, Administração e Direito. Pós - Graduando em Direito Material e Processual Civil e Especialista em Direito do Material e Processual do Trabalho.

SANTOS, Marcos Antônio Carlos dos: Doutorando em Ciências da Educação pelo Instituto Superior de Educação do CECAP - Professor Me. em Ciências da Educação, Escritor-marquinhosgmr@gmail.com

SANTOS, Paula Roberta dos Prazeres: Gestora da Escola Municipal Prof. Amazona de Oliveira Monteiro em Boa Vista-RR; http://lattes.cnpq.br/5220800253352058; https://orcid.org/0000-0002-9467-0800. Email: ppaulinhadosprazeres@ hotmail.com

SANTOS, Raisa Corlet: dos Graduação em educação física UFRN. Pósgraduação em Gestão De Programas E Projetos De Esporte E Lazer Na Escola - IFRN. Professora no Município de Macau-RN. E-mail: rayacorlet@gmail.com

SILVA, Ewerton Cardoso da: Graduação em Pedagogia - UVA. Pós-graduação em Formação de Docentes; Educação Infantil; Alfabetização e Educação EspecialFAVENI. Professora da Educação Básica. E-mail: ewertoncardosold@ hotmail.com

SILVA, Geonar do Nascimento: Licenciatura em História - UERN. Pósgraduação em Especialização em História do Brasil República - UERN. Especialização em Psicopedagogia - UNINTA. Mestrado em Ciências da Educação (em andamento) FACEM. E-mail: geonar.nasci@gmail

SILVA, Ingride Alane Cabral Câmara da: Técnica em Química - IFRN. Graduanda em Licenciatura da Computação pela UFERSA-RN. E-mail: ingridecamara@hotmail.com

SILVA, Lígia Maria da Conceição Santos: Graduada em pedagogia - UVA. Pós-graduação em psicopedagogia -FIP. Pós-graduada em Serviço Social no Campo (em andamento) - Universidade Dom Alberto. Professora do município de Guamaré rede privada. E-mail: mariaa.ligia@gmail.com 
SILVA, Lyres Luiza de Souza Cruz: FARES - Faculdade Roraimense De Ensino Superior; ;http://lattes.cnpq.br/8205759429975275; https://orcid.org/0000-00022569-0226. E-mail: lyrescruz.trabalho@gmail.com

SILVA, Maria Damiana da: Graduação em Pedagogia. Docente no Município de Guamaré/RN. E-mail: damianasilva1818@gmail.com

SILVA, Maria Zilma Batista da: Pedagoga. Professora da Educação Básica. Email: mariazilmagm@gmail.com

SILVA, Rosea Maria: Graduada em Pedagogia. E-mail: silvaroseamaria@gmail.com

SILVA; Juliane Claudia Rossi: Graduada em Pedagogia. E-mail: juliane_claudia@hotmail.com

SOARES, Maria das dores Barbosa: Pedagogia - ISEP. Pós-graduação em Educação Infantil e Ensino Fundamental - Faculdade de Maciço de Baubaturité. E-mail: Soaresb@gmail.com

SOUSA, Josélia Isídio Rodrigues de: Pedagogia - UFRN. Pós-graduação em Educação e Sustentabilidade em Unidade de Conservação - UFRN. Pós-graduação em Educação Infantil e Anos Iniciais - Faculdade Futura. Pós-graduação em Alfabetização e Letramento - FAVENI. E-mail: joseliaisidiorodrigues564@gmail.com

SOUSA, Vanúsia Silva de: Pedagogia - UVA. Pós-graduada em Educação Infantil e Anos Iniciais - FMB. Professora celetista do Município de Macau. E-mail: vanusiassousa@gmail.com

SOUZA, Francijânio Soares de: Graduação em educação física pela faculdade estadual do Rio Grande do Norte. Pós-graduação em exercícios físicos aplicados aos grupos especiais pela faculdade excelência. Professor do município de Guamaré.

SOUZA, Jaqueline Honorato de: Graduada em Pedagogia pela faculdade UNINTA - Centro Universitário.

SOUZA, Nilsa Araújo Silva de: Graduação em normal superior - Fundação Universidade do Tocantins. Pós-graduação em Psicopedagogo - UVA. Pós-graduação em Educação Infantil - UFRN. Professora do município do Alto do Rodrigues. 
SOUZA, Tiago Santana de: Graduado em pedagogia pela FACESA- Faculdade do Complexo Educacional Santo André. Pós-graduando em Alfabetização e Letramento pela FAVENI. Mestrando em Ciências da Educação pela FACEM. E-mail: tdetrabalho@hotmail.com

TEIXEIRA, Claudiane: Graduada em Pedagogia. E-mail: claudiane.teixeira@gmail.com

TEIXEIRA, Maria Aparecida: Graduada em Pedagogia. E-mail: maria.bbu18@gmail.com

XAVIER, Ana Paula de Sousa: Graduada em Pedagogia. Email:aniinhaxavier@hotmail.com 


\section{ÍNDICE REMISSIVO}

A

Acessibilidade, $\underline{232}$

Adversidade, 213

Alfabetização, 141

Anos iniciais, 225

Aprendizagem, 50, 100, $\underline{313}$

Arteterapia, $\underline{14}$

Auta de Souza, $\underline{453}$

Avanços tecnológicos, $\underline{251}$

B

Brincadeiras, 297, $\underline{313}$

C

Ciências naturais, $\underline{438}$

Competências docentes, 165

Conhecimento científico, $\underline{422}$

Contação de História, 32

Covid-19, 225

Currículo, 334

D

Direitos Trabalhistas, 261

Distúrbio de aprendizagem, 276

Docentes, 225

Donjuanismo, 110

Drogas, $\underline{393}$

$\mathbf{E}$

Educação, 213, 352, 40

Educação a distância, 232

Educação Especial, 334

Educação inclusiva, 288

Educação Inclusiva, 232, 242, 343

Educação Infantil, 14, $\underline{\text { 50, }}$ 125, 181, 225

Enfrentamento da covid-19, 156

Ensaio teórico, $\underline{422}$
Ensino de Ciências, 393

Ensino de História, 379

Ensino de Matemática, 92

Ensino Remoto Emergencial, 59

Ensino Superior, 194

Ensino-aprendizagem, 438

Escola, 242, 343

Escola cidadã, 141

Escrita, $\underline{50}$

Estratégias didáticas, 393

F

Formação Continuada, 14

Formação de professores, $\underline{59, \underline{251}}$

G

Gig economy, 261

H

História, $\underline{408}$

I

Igualdade, $\underline{429}$

Inclusão, $\underline{334}$

Intervenções, $\underline{362}$

J

Jogos, 2, $\underline{100}, \underline{125}, \underline{297}, \underline{313}$

$\mathbf{L}$

Leitura, $\underline{76}, \underline{141}$

Línguas Estrangeiras, $\underline{59}$

Literatura Infantil, $\underline{32}, \underline{76}$

Literatura Potiguar, $\underline{453}$

Livro infantil ilustrado, $\underline{32}$

Ludicidade, 100, 125, 297, 313

Lúdico, 181, $\underline{343}$ 
M

Mudança social, $\underline{288}$

$\mathbf{P}$

Pagamento de verbas contratuais, $\underline{156}$

Pandemia Covid-19, 59

Pandemia da COVID-19, 165

Patriarcado, 110

Pontos Cantados, $\underline{379}$

Prática cultural, $\underline{288}$

Práticas, $\underline{453}$

Práticas corporais, 181

Práticas inovadoras, $\underline{352}$

Processo de ensino-aprendizagem, 276

Processos de inclusão, 242

Professor, 76, 213, 362

Professor de Contabilidade, 165

Psicanálise, 14

Psicologia, 194

\section{$\mathbf{R}$}

Recursos Pedagógicos, $\underline{92}$
Redes sociais, 438

Relação trabalhista, $\underline{156}$

Revisão bibliográfica, $\underline{422}$

Revolta, $\underline{110}$

$\mathbf{S}$

Saberes pedagógicos, $\underline{165}$

Segurança jurídica, $\underline{156}$

Senso comum, $\underline{422}$

Sufrágio, $\underline{429}$

$\mathbf{T}$

Tecnologia, $\underline{352}, \underline{408}$

Tecnologias digitais, 251

$\mathbf{U}$

Umbanda, $\underline{379}$

V

Vínculo empregatício, 261

Violência, 213

Voto feminino, 429 


\section{E-BOOK}

\section{AMPLAMINTHE HDUCAÇÃO: NOVOS CAMINHOS PARA 0 ENSINO}

$1^{\text {a }}$ EDIÇÃO. VOLUME 01.

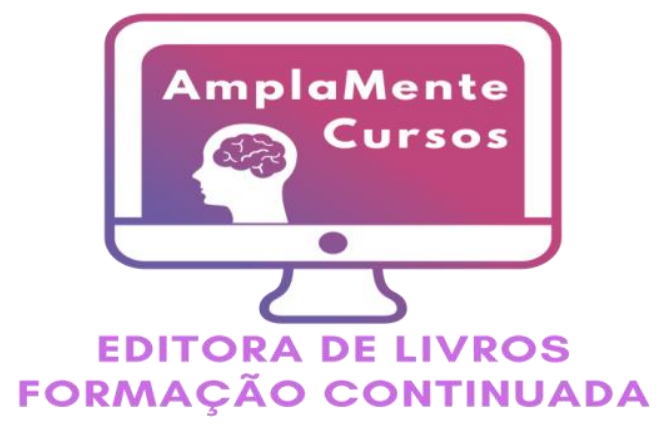

ORGANIZADORES

Dayana Lúcia Rodrigues de Freitas

Luciano Luan Gomes Paiva

Caroline Rodrigues de Freitas Fernandes

DOI: $10.47538 / A C-2021.14$

ISBN 978-65-89928-10-2

(84) 997072900

(ㄱ) @editoraamplamentecursos

$f$ amplamentecursos

Mpublicacoes@editoraamplamente.com.br

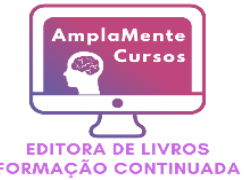

Ano 2021 